\title{
Atlas of the U.S. Exclusive Economic Zone Atlantic Continental Margin
}

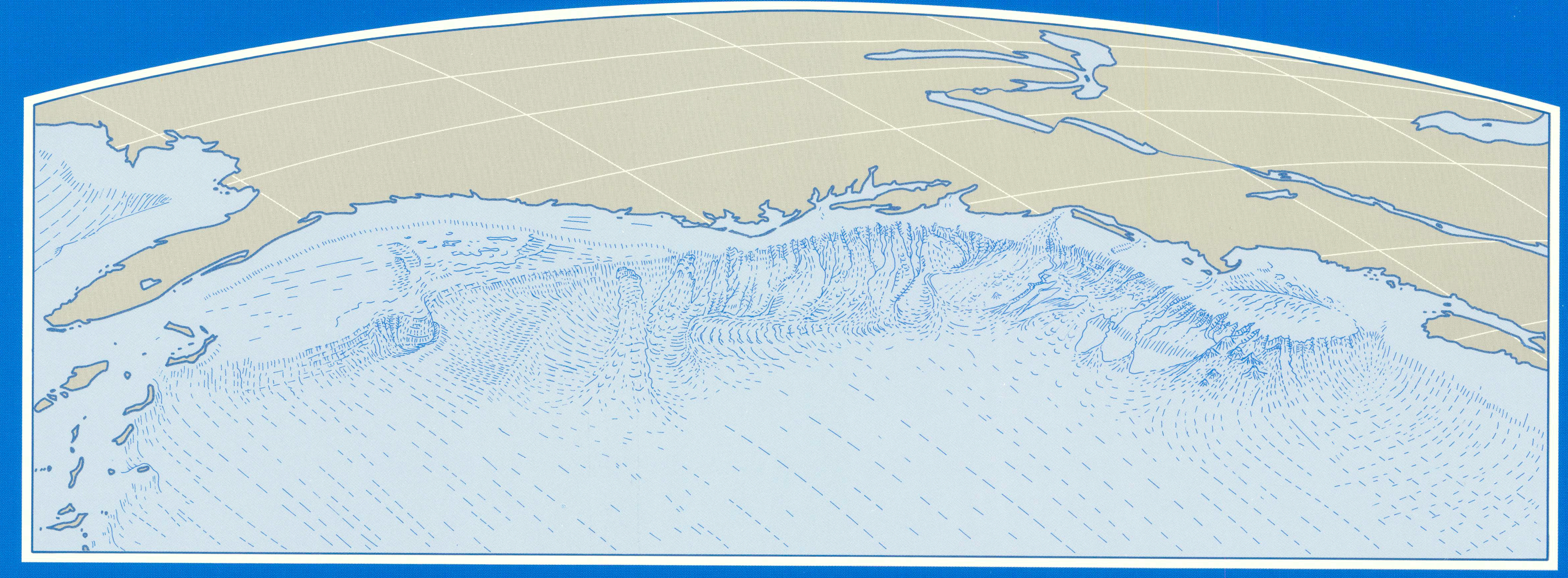

\author{
U.S. Geological Survey \\ Miscellaneous Investigations Series I-2054
}




\section{Atlas of the U.S. Exclusive Economic Zone, Atlantic Continental Margin}

By EEZ-SCAN 87 Scientific Staff

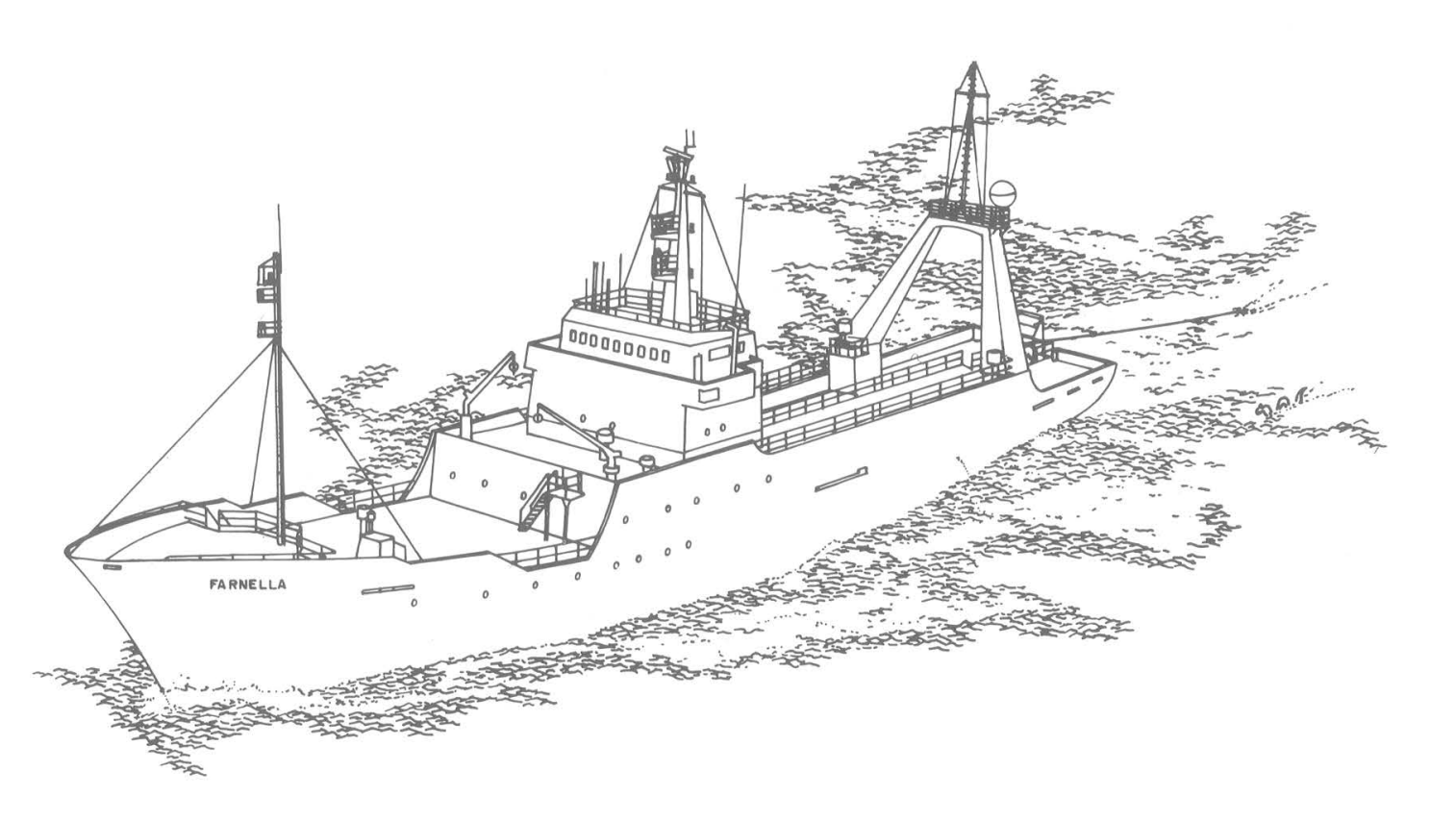

U.S. Geological Survey

Miscellaneous Investigations Series I-2054

1991 


\section{U.S. DEPARTMENT OF THE INTERIOR}

\section{MANUEL LUJAN, Jr., Secretary}

\section{U.S. GEOLOGICAL SURVEY}

\section{Dallas L. Peck, Director}

Any use of trade, product, or firm names in this publication is for descriptive

purposes only and does not imply endorsement by the U.S. Government

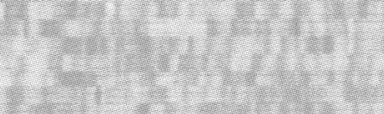

For sale by

U.S. Geological Survey

Map Distribution

Box 25286, Federal Center

Denver, CO 80225 


\section{FOREWORD}

Dallas L. Peck

Director, U.S. Geological Survey

An act of Congress in 1879 established the U.S. Geological Survey (USGS) as a scientific research organization and charged it to conduct an "examination of the geological structure, mineral resources, and products of the national domain." Not until 1962 however, were these examinations extended into the marine realm, when Congress first appropriated funds for offshore investigations by the USGS. During the late 1960's and 1970 's, offshore geologic surveys conducted by the USGS rapidly expanded as the resut of national and international events such as increased domestic oil and gas exploration and the oil embargo by the Organization of Petroleum Exporting Countries.

On March 10, 1983, President Reagan proclaimed that the ocean area out to 200 nautical miles off the coast of the United States-including the Commonwealths of Puerto Rico and the Northern Mariana Islands, and the island territories of the United States the Exclusive Economic Zone (EEZ) of this Nation. The proclamation increased the area offshore Federal lands to approximately 3.4 million square nautical miles, an area a a offshore Federal lands to approximately 3.4 million square nautical miles, an area about 30 percent larger than the total onshore area of the United States. As noted by the Nationa earth's natural resources on land and the potential that the oceans are believed to have for addition to our resource base, the significance of the EFZ to the future believed to have for addition to our resource base, the significance of the EEZ to the future of our country may well be greater than that of the Louisiana Purchase of 1803. That act (during the territorial and resource base on which the United States grew during the 19th century

In establishing the EFZ this which the United States grew during the 19 ch century. mineral resources that may lie on or below the surface of the sea floor. Accordingly, an mineral resources that mas lie on or below the surface of the sea floor. Accordingly, the resources of the EEZ are a potential means of ensuring national economic security by allowing the Nation to become more self-sufficient in strategic and critical minerals. However, the Unito States and development of the EEZ and provide sufficient information regarding the EEZ to allow rescos mineral ree aures and bed both by de mineral resources and by the provision of regulations that allow nomal competitive marke (fin managento of the Eez will also require adequa The EEZ, by companson to longst

The EEZ, by comparison to long-studied onshore areas, clearly is a new frontier. The exploration, charactenization, understanding, management, protection, and utilization of this frontior present including acadenta, industy, and govenment. In meetng this challenge, the USGS ha the impotant role of developing an integrated, comprehensive scientific understanding of the ELZ as a basis for formulation of Govenment, "The Deps State of the Union address of January 25, 1984, President Reayan said, "The Depatment of the Interior will encourage careful, selective exploration and production of our vital resources in an exclusive economic zone winh a 200 mile limit off our coasts.... Under the direction of the Secretary of the Interior and the Assistant Secretary for Water and Science, the USGS assumed responsibility for developing and coordinating an EEZ program of nationa scope. As part of this effort, the USGS marine program in the EEZ provides for the orderly exploration necessary to develop a geologic understanding of these new Federal lands. The EEZ program of the USGS serves the national need by developing or extending our understanding of where mineral or petroleum resources occur, the geologic framework in which such resources may exist, the geologic environmental conditions that may be encountered during their future exploitation, and how their formation in ocean areas can aid in the search for analogous onshore deposits of economic significance.

A logical first step in the exploration of a new frontier is to map it. In April 1984, the USGS, in cooperation with the Institute of Oceanographic Sciences (IOS) of the United Kingdom, initiated Program EEZ-SCAN as a first effort to expand our geologic understanding of the EEZ. This program was created to map the EEZ at a reconnaissance scale using a unique sidescan sonar system developed by 10 S. This revolutionary system, known as GLORIA (Geological LOng-Range Inclined Asdic), is capable of mapping large areas of the sea floor on a single pass of the ship. In 1984, GLORIA was used to map the EEZ of California, Oregon, and Washington with spectacular and significant results. Since then GLORIA has been used to map the EEZ in the Gulf of Mexico and eastern Caribbean, and off the Atlantic coast, Alaska, and most of the Hawaiian Islands. Over the next five years, surveys will be completed off Hawaii and will be extended to the EEZ of the other U.S. territories in the Pacific and the Commonwealth of the Northern Mariana Islands. We believe these surveys will provide the critical "road maps" for future EEZ research.

This publication provides a graphic overview of the EEZ off the Atlantic coast, but it represents only a fraction of the information that must be collected and analyzed in the exploration of the new frontiers. It illustrates how cooperative efforts between governments can successfully deal with the challenges of exploration. Most important, perhaps, the many discoveries illustrated in the atlas remind us that this is a beginning, not an end, to understanding our marine heritage.

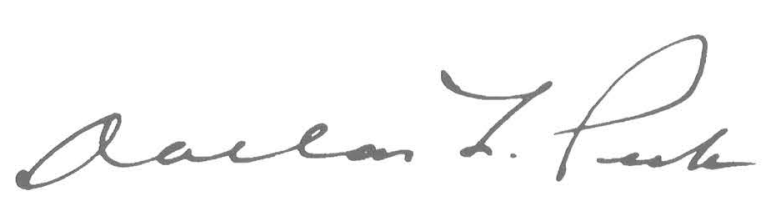


Discussion

Introduction 2

Data Collection 2

GLORIA Sidescan-Sonar System

Other Geophysical Data

Atlas Format and Kinds of Data Presented 2

Sonar-Imagery Mosaics

Seismic-Reflection Profile Data

Magnetic-Anomaly Data and Bathymetry

Digital Processing Techniques 3

Introduction

Geometric Corrections

Radiometric Corrections

Digital Mosaicking

Geologic Interpretation 3

Regional Perspective 3

The Region off Georges Bank and Southern New England 4

The Middle Atlantic Region 5

The Carolina Slope and Rise 6

The Hatteras Ridge, Lower Rise Hills, and Blake Ridge 6

The Blake Plateau 6

The Blake Escarpment 7

References Cited 8

Participants in U.S. Atlantic Margin Surveys 9

Trackline Map, Northern U.S. Atlantic Continental Margin 10

Trackline Map, Southern U.S. Atlantic Continental Margin 11

Bathymetric Map, U.S. Atlantic Continental Margin 12

Explanation for Geologic Interpretation of Sonar-Imagery Mosaics 12

Sonar-Imagery Mosaics with Geologic Interpretations and Bathymetry (Sheets 1-21)

Sonar-Imagery Mosaic of Northern U.S. Atlantic Continental Margin, Showing Area of Sheets 1-10 14

Sonar-Imagery Mosaic of Southern U.S. Atlantic Continental Margin, Showing Area of Sheets 11-21 15

Sheet 1 Imagery 16

Sheet 1 Imagery with Geologic Interpretation and Bathymetry 17

Sheet 2 Imagery 18

Sheet 2 Imagery with Geologic Interpretation and Bathymetry 19

Sheet 3 Imagery 20

Sheet 3 Imagery with Geologic Interpretation and Bathymetry 21

Sheet 4 Imagery 22

Sheet 4 Imagery with Geologic Interpretation and Bathymetry 23

Sheet 5 Imagery 24

Sheet 5 Imagery with Geologic Interpretation and Bathymetry 25

Sheet 6 Imagery 26
Sheet 6 Imagery with Geologic Interpretation and Bathymetry 27

Sheet 7 Imagery 28

Sheet 7 Imagery with Geologic Interpretation and Bathymetry 29

Sheet 8 Imagery 30

Sheet 8 Imagery with Geologic Interpretation and Bathymetry 31

Sheet 9 Imagery 32

Sheet 9 Imagery with Geologic Interpretation and Bathymetry 33

Sheet 10 Imagery 34

Sheet 10 Imagery with Geologic Interpretation and Bathymetry 35

Sheet 11 Imagery 36

Sheet 11 Imagery with Geologic Interpretation and Bathymetry 37

Sheet 12 Imagery 38

Sheet 12 Imagery with Geologic Interpretation and Bathymetry 39

Sheet 13 Imagery 40

Sheet 13 Imagery with Geologic Interpretation and Bathymetry 41

Sheet 14 Imagery 42

Sheet 14 Imagery with Geologic Interpretation and Bathymetry 43

Sheet 15 Imagery 44

Sheet 15 Imagery with Geologic Interpretation and Bathymetry 45

Sheet 16 Imagery 46

Sheet 16 Imagery with Geologic Interpretation and Bathymetry 47

Sheet 17 Imagery 48

Sheet 17 Imagery with Geologic Interpretation and Bathymetry 49

Sheet 18 Imagery $\mathbf{5 0}$

Sheet 18 Imagery with Geologic Interpretation and Bathymetry 51

Sheet 19 Imagery 52

Sheet 19 Imagery with Geologic Interpretation and Bathymetry 53

Sheet 20 Imagery 54

Sheet 20 Imagery with Geologic Interpretation and Bathymetry 55 Sheet 21 Imagery 56

Sheet 21 Imagery with Geologic Interpretation and Bathymetry 57

Seismic-Reflection Profiles

Profiles 60-142

Magnetic-Anomaly and Bathymetry Profiles

Profiles 144-174 
INTRODUCTION

This atlas is one in a series in which the U.S. Geological Survey (USGS) presents images of the sea floor and other geophysical data from the deepwater regions off the U.S. coasts. Containing the first comprehensive compilation of sea-floor imagery of the Atlantic continental margin, this volume provides the first broad-scale view of sea-floor features and the effects of systems of sedimentary processes that have been unknown or poorly known, until now. These data are a unique set of basic information that will support future
studies by government, academic and industry workers. The region covered is within the U.S. Exclusive studies by government, academic and industry workers. The region covered is within the U.S. Exclusive Economic Zone (EEZ) (fig. 1), which extends 200 nautical miles seaward from the shore, and which was
claimed by presidential proclamation in 1983 .

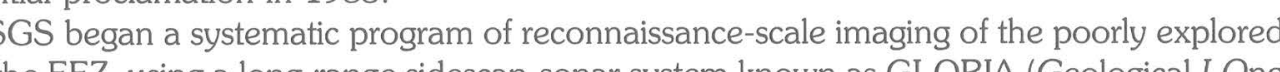
deepwater parts of the EEZ, using a long-range sidescan-sonar system known as GLORIA (Geological LOng Range Inclined Asdic). The instrument was designed, built, and operated by the United Kingdom's Institute system in existence and can be operated at fairly high speed it provides maximum possible data coverage system in existence and can be operated at fairly high speed, it provides maximum possible data coverage
and is the ideal tool for geologic reconnaissance mapping of large oceanic regions. A review of the history of imaging the ocean floor is presented by Vogt and Tucholke (1986b).

The eactict the Atlantic coast in 1979 (Teleki and others, 1981; Twichell and Roberts, 1982; Scanlon, 1984; Twichell, Gulf California, extending from the continental shelf edge (approximately 200 meters $(\mathrm{m})$ water depth) to the

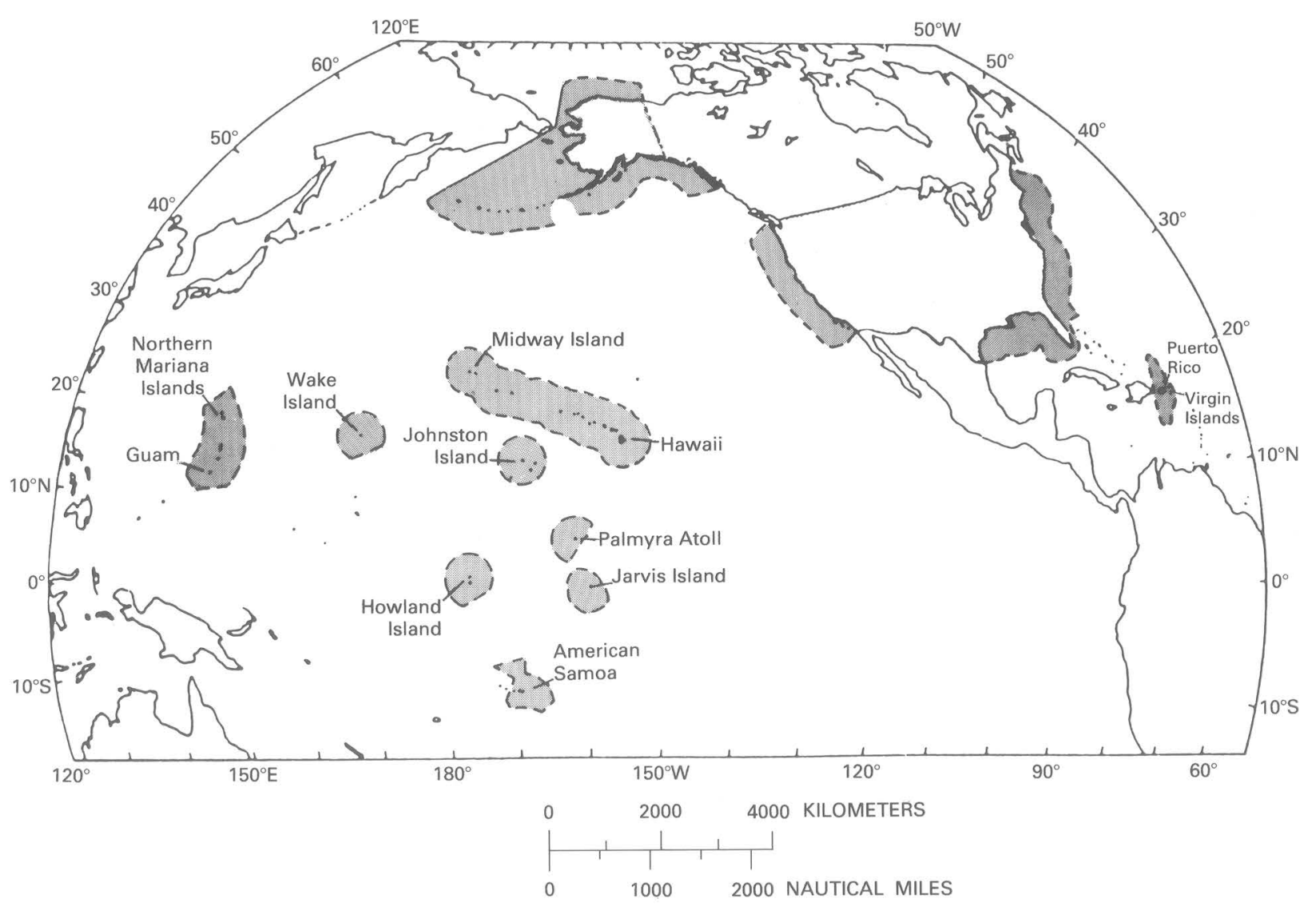
Figure 1-Exclusive Economic Zone (EEZ) of the United States, Commonwealth of Puerto Rico, Commonwealth of
the Northern Mariana Islands, and United States overseas territories and possessions (outlines on map are
approximate).

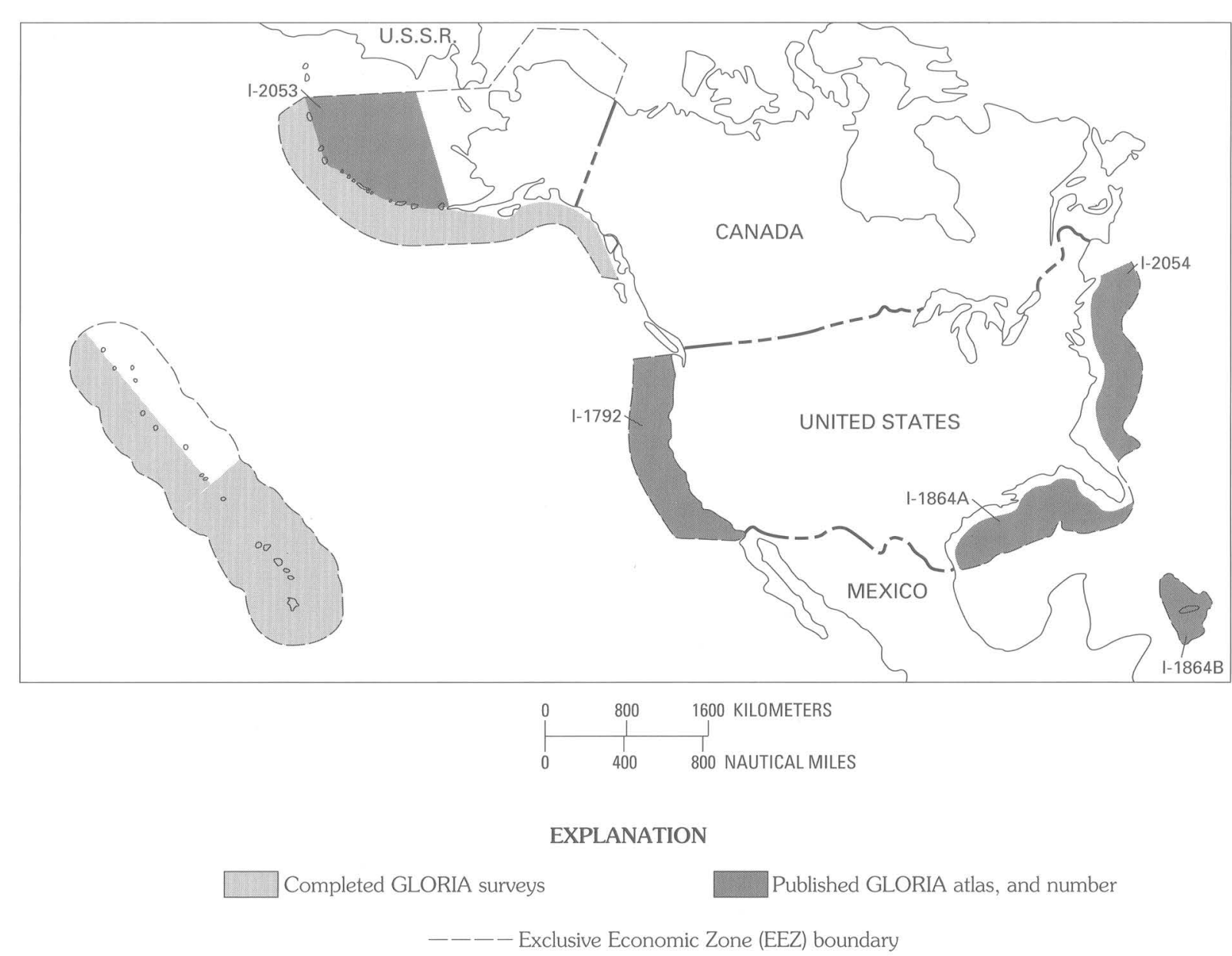

Figure 2-Status of the GLORIA mapping program as of October 1990

Zone, Western Conterminous United States (EEZ-SCAN 84 Scientific Staff, 1986) (fig. 2). Continuing the mapping effort in 1985, the USGS conducted surveys of the EEZ in the Gulf of Mexico and around Puerto Rico and the U.S. Virgin Islands. Results were published in the Atlas of the U.S. Exclusive Economic Zone, Gulf of Mexico and Eastern Caribbean Areas (EEZ-SCAN 85 Scientific Staff, 1987). Mapping for the present survey was undertaken in 1987. The status of the GLORIA mapping program as of October 1990
is shown in figure 2 .

\section{DATA COLLECTION}

Data collected in this survey of the U.S. Atlantic EEZ include GLORIA sidescan-sonar imagery shallow-penetration, medium-resolution seismic-reflection profiles; high-resolution seismic-reflection profiles; echo-sounder profiles; and measurements of total magnetic intensity. The field program, carried out during five cruises from February to May 1987, covered the Atlantic EEZ seaward of the continental shelf edge, from
the Canadian border southward to the northern Blake Plateau off Florida (figs. 26 and 27, p. 10 and 11). The the Canadian border southward to the northern Blake Plateau off Florida (figs. 26 and $27, \mathrm{p} .10$ and 11 ). The
innermost Blake Plateau north of lat $30^{\circ} \mathrm{N}$. and most of the plateau south of that latitude were not imaged during the 1987 cruses because of lack of time Survey lines had to be placed very close together in the relatively shallow water of the Blake Plateau (where surveyed, 700-1200 m) in order to obtain complete bottom coverage, thus requiring more ship time to cover an equivalent area compared to deeper-water regions.

Primary navigational control for this survey was by Loran-C. We estimate the positional accuracy of our fixes to be probably better than $50 \mathrm{~m}$. Data from the five cruises are annotated with Julian dates; on the Julia
Gloria Sidescan-Sonar System

GLORIA long-range sidescan sonar creates images (sonographs), which are a record of the acoustic backscatter from the ocean floor. These images are created by transmitting a series of sound pulses and recording their echoes from the sea floor as the collecting ship moves along a set course. The sound pulses are transmitted from two sets of transducers, aimed to port and starboard, which are mounted in a towed
vehicle. These transducers are tuned so that their beams form a narrow arc $\left(2.7^{\circ}\right)$ in the horizontal plane and vehicle. These transducers are tuned so that heir beams form a narow are (2.7\% in the horizontal plane and floor perpendicular to the ship's track. extending from directly beneath the towed vehicle to the maxise range on each side as indicated schematically by the white bands on the sea floor in figure 3 . The sound is reflected from the sea floor and travels back to the transducers on the towed vehicle where tis sensed and converted into electrical signals. The signals are transmitted along the tow cable to the ship where they are recorded digitally. As the ship moves, the pulses insonify successive bands of sea floor and thus record an acoustic map of the sea floor. In the GLORIA system, strong reflections appear as light areas on the image records appear more similar to black-and-white aerial photographs.

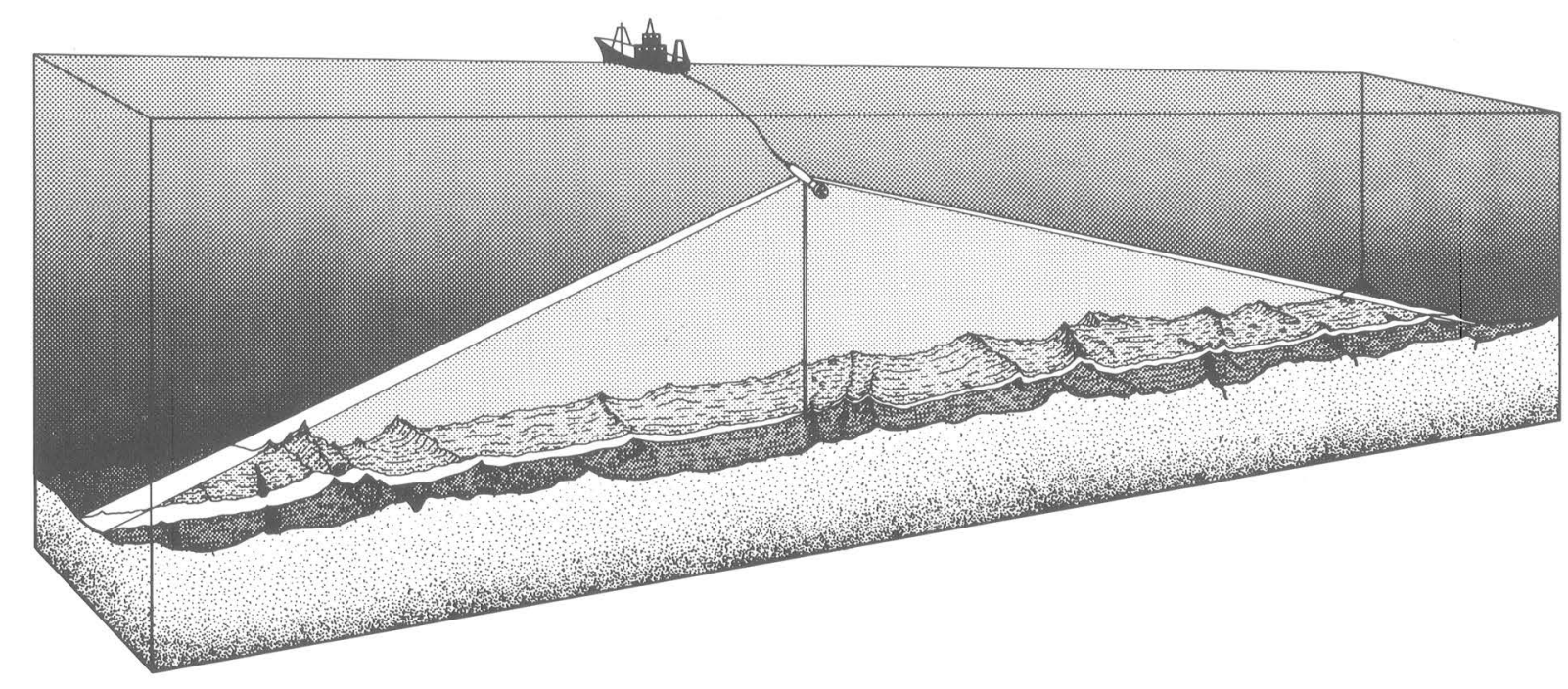

Figure 3-Diagram showing area of sea floor imaged by a single pulse from the GLORIA towed vehicle. A pulse

A few of the important technical features of the GLORIA system are provided here. For more detailed information and specifications, the reader is referred to Somers and others (1978). The towed sidescan vehicle is $8 \mathrm{~m}$ long and $0.7 \mathrm{~min}$ diameter, weighs 2.25 tons in air, and is nearly neutratly buoyant. The sonar arrays complise 120 lons $(\mathrm{cm})$ high a configuration that gives a a vertical beam width of $35^{\circ}$ between half-power points; considerable energy actually radiates outside these limits. The arrays are designed to confine the energy as nearly as possible to the plane perpendicular to the track and to fill the quadrant from nadir (the point on the sea floor directly beneath the towed vehicle) up to near horizontal. The vehicle is towed about $400 \mathrm{~m}$ behind the ship with no active depth control, but at the normal survey speed of 8 knots (kts), or 15 kilometers per hour $(\mathrm{km} / \mathrm{hr}$, the vehicle is stable at a depth about $50 \mathrm{~m}$ (ig. 4). Port and starboard transducers operate on slightly different frequencies in order to mine 62 k Because the pulse-repetition rate chosen for this survey was 30 seconds (s), the maximum swath of sea floor mapped was about $45 \mathrm{~km}$ wide ( $22.5 \mathrm{~km}$ on each side of the ship's track) under ideal conditions in water depths greater than $3000 \mathrm{~m}$. In shallower water the swath width was less. A longer pulse-repetition rate would have allowed a greater swath widh in deeper water, but would have reduced data density and, consequently, resolution. The resolution is determined by the size of the smallest building blocks or the mage,

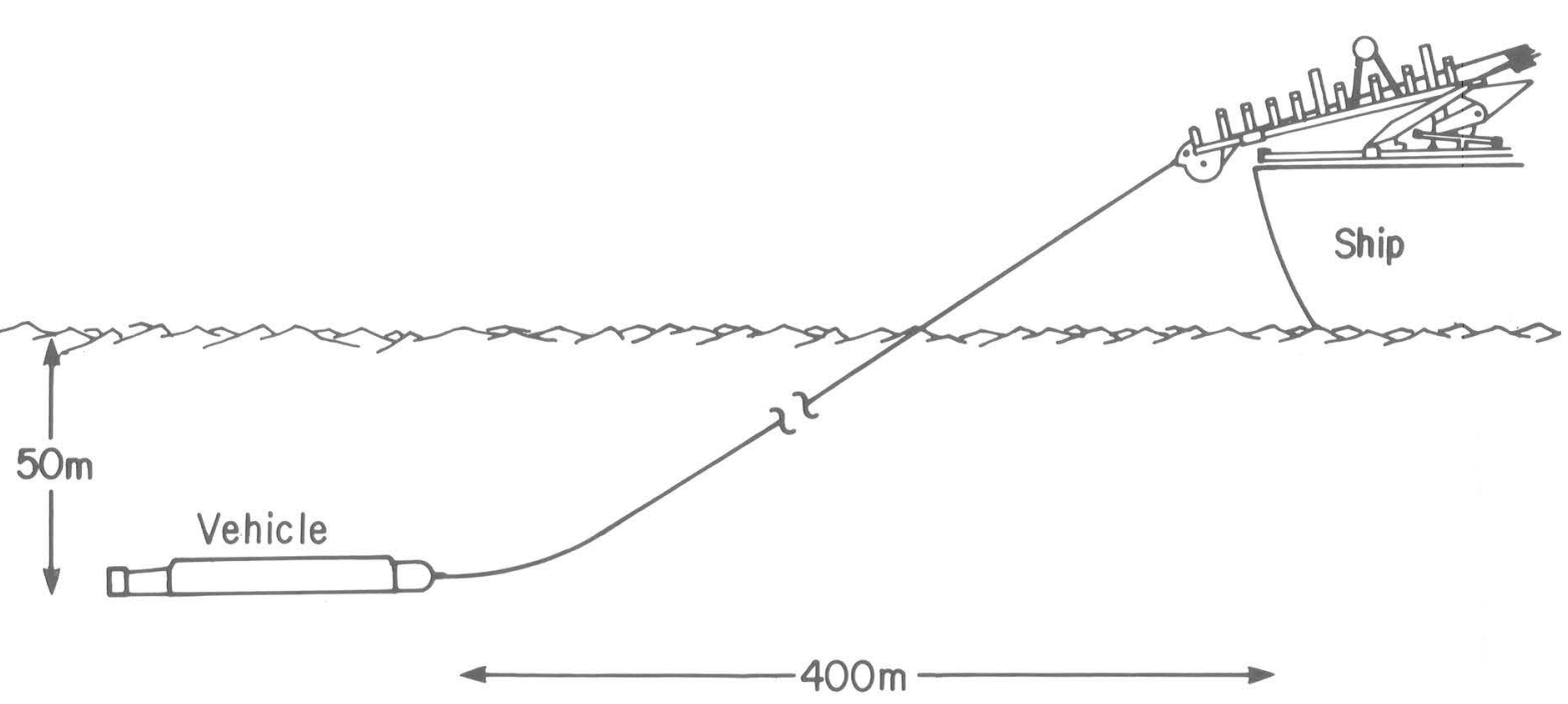

Figure 4-Diagram showing towing arrangement for the GLORIA towed vehicle. The gantry shown on the stern of
the ship is extended hydraulically for launch and retrieval of the 8 -m-long vehicle.

ependent on the number of subdivisions of an individual scan (1024), the width of the scan across the track, and the distance along the track between pulses (determined by the ship's speed and the pulse-repetition rate). The effective resolution in the original data amounts to a pixel size of about $125 \mathrm{~m}$ along track and about $50 \mathrm{~m}$ in the across-track direction. Thus it is clear that features on the sea floor that provide targets mus be several hundred meters in size, at least in one direction, in order to be interpreted. Of course, a reflection can come from a smaller target than the nonninal resolution size (pixel size). For example, a scarp that is only a few meters to a few tens of meters high can provide a reflection and, if several hundred meters long, can a large area, can collectively affect the echo and their extent can be mapped.

\section{Other Geophysical Data}

A suite of geophysical data was collected simultaneously with the sidescan-sonar data to aid in the geologic interpretation of the sonar imagery. Seismic-reflection profile data were collected along the ship's (the aing profile data also were recorded digitally. A proton-precession magnetometer measured the total intensity of the Earth's magnetic field.

\section{ATLAS FORMAT AND KINDS OF DATA PRESENTED}

This atlas comprises three data sections. The first consists of 21 pairs of facing pages; each left-hand page shows sidescan-sonar imagery and the facing right-hand page shows a screened (subdued) image of the samdata, oveprited whe

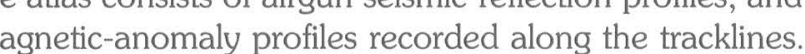

\section{Sonar Imagery Mosaics} The sidescan-sonar imagery maps are presented at a scale of 1:500,000 using an Albers equal-area 
by $1 \mathrm{~cm}$ on the map. Each of the 21 imagery sheets covers an area of $2^{\circ}$ of longitude by $2^{\circ}$ of latitude, except
for sheets 3 and 21 , which span less than $2^{\circ}$ of longitude.

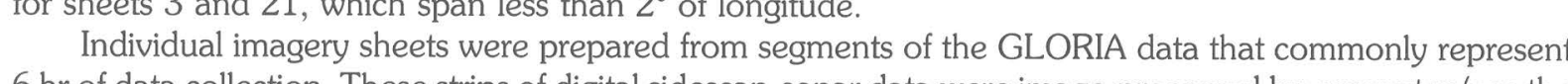
Individual imagery sheets were prepared from segments of the GLORIA data that commonly represent
$6 \mathrm{hr}$ of data collection. These strips of digital sidescan-sonar data were image-processed by computer (see the
section on digital processing techniques below) then assembled, also by computer, to create a mosaic sheet section on digital processing techniques below), then assembled, also by computer, to create a mosaic sheet.
Each mosaic sheet is a digitally halftoned black-and-white print of the acoustic reflectivity of the sea floor. Each mosaic sheet is a digitally halftoned black-and-white print of the acoustic reflectivity of the sea floor.
White represents the strongest acoustic reflectivity and black represents the weakest acoustic return. The darkness or lightness of a feature or an area on the mosaics is a function of how much sound is reflected from it. Reflectivity, in turn, is controlled by the slope of the sea floor, by the microtopography and roughness of
the sea floor (for example, sediment waves, or the blocky or rubbly surface of submarine landslide deposits), and by the physical properties of the sea floor (such as sediment type, compaction, and induration). When
viewed from the trackline, positive-relief features such as ridges and escarpments usually appear as bright
zones where the slope faces the trackline and therefore strongly reflects sound, and as dark zones where the zones where the slope faces the trackline and therefore strongly reflects sound, and as dark zones where the
slope faces away from the trackline. Depressions, such as canyons, show as dark zones nearest the track (the slope faces away from the trackline. Depressions, such as canyons, show as dark zones nearest the track (the
near wall is acoustically shadowed) and as bright zones farther away where the far wall (facing the trackline) near wall is acoustically shadowed) and as bright zones farther away where the far wall (facing the trackline)
is insonified. Brightness is also strongly controlled by the materials of the sea floor. Normally some materials, such as exposed eroded limestone or deposits of coarse sand that are commonly seen in the bottoms of canyons, provide very strong reflections, whereas others, such as soft, recently deposited muds, provide weak resulting from the major geometric corrections necessary in the area directly below the towed vehicle. The bathymetric contours (in meters) are printed in blue on each right-hand imagery sheet along with the geologic interpretation in red; a 250-m contour interval is used except in some areas where only 500-m contours were available. The bathymetry was digitized from 47 National Ocean Survey charts, which are
listed in the references cited (National Ocean Survey, 1972 to 1986 ). Bathymetric information varies greatly in accuracy and therefore the contours may not correlate with sea-floor features displayed in the im Under no circumstances should the bathymetric maps be used for undersea navigation; the bathymetry is under no circumstances should the bathymetric maps be used for undersea navigation; the bathymetry is
presented only as a general aid in the interpretation of the sidescan-sonar images. Geographic names
correspond to features identified on the airgun records in the seismic-profiles section of the atlas. Where correspond to features identified on the airgun records in the seismic-profiles section of the atlas. Where
possible, names are taken from the Gazetteer of Undersea Features (Defense Mapping Agency, 1981) possible, names are taken from the Gazetteer of Undersea Features (Defense Mapping Agency, 1981);
otherwise, names are taken from the scientific literature or chosen from other nearby geographic features.

\section{Seismic-Reflection Profile Data}

Three seismic-reflection profile systems were used: a 10-kHz echo sounder, a $3.5-\mathrm{kHz}$ high-resolution subbottom profiler, and an airgun system. Bathymetric profiles, tabulated from the $10 \mathrm{H} z$ echo sounder, are seismic-reflection information that was used to help interpret the sidescan-sonar data. Segments of the
$3.5-\mathrm{kHz}$ data a are shown to clarify features discussed in the geologic interpretation of the mosaics f(figs $6-8$ $3.5-\mathrm{kHz}$ data are shown to clarify features discussed in the geologic interpretation of the mosaics (figs. 6-8
and 10-14). Airgun system data are the basis for the seismic-reflection profiles shown on p. $60-142$ and introduced below.

The shallow subbottom structure of the continental-margin deposits was determined by using a profiling system that employed a small $\left(160\right.$ in $\left.^{3}\right)$ airgun. This seismic source was fired at $10-$ s intervals, and data were in the range of $15-300 \mathrm{~Hz}$. Vertical scale is given in two-way traveltime in seconds, with a scale of $2 \mathrm{~cm} / \mathrm{s}$ Assuming a sound velocity in water of $1500 \mathrm{~m} / \mathrm{s}$, each second of two-way traveltime represents $750 \mathrm{~m}$ o water depth, hence one vertical centimeter on the profile equals $375 \mathrm{~m}$. Because sound velocity generally
increases downward in the sediments, each second of traveltime in the sediments represents increasingly

The Julian day and time (Greenwich Mean Time) are annotated along the profiles, as are course
nges. The profiles are broken into segments at nearly all major course changes, to facilitate correlation with the track map and with the sidescan-sonar mosaics. Occasional gaps occur in the records at times when repairs to the airgun system were necessary; such gaps are identified with the words "no data". The airgun was secured and no seismic-profiling data gathered during part of the Blake Plateau survey in order to
increase the speed of GLORIA surveying and thus increase sidescan-sonar coverage. In calm weather, the increase the speed of GLORIA surveying and thus increase sidescan-sonar coverage. In calm weather, the
airgun was the limiting factor on ship speed, and, as we were restricted to a very narrow sidescan swath on the Blake Plateau because of the broad area of shallow water, we attempted to obtain greater coverage by
dispensing with the airgun. The handwritten annotations visible on some of the records represent information entered by watchstanders aboard ship.

\section{Magnetic-Anomaly Data and Bathymetry}

Total Earth's magnetic field values were collected continuously along the ship's track. These data were logged by computer and merged with the navigation and bathymetry information. Residual magnetic
anomaly values were calculated by subtracting the International Geomagnetic Reference Field updated to 1987 (IAGA, Division 1, Working Group I, 1986) from the measured values for the total Earth's magnetic field. These residual anomaly values are displayed in the magnetic anomaly profile section of the atlas as continuous profiles, plotted in nanoteslas (one nanotesla represents one gamma) against time. Water depth were tabulated from the 10-kHz echo sounder every 6 minutes (min). Additionally, depths to peaks, troughs,
and slope inflections were recorded. These depths were corrected for sound velocity in sea water, merged with the navigation data, and used during image processing to geometrically correct the sonographs. Depth
profiles are plotted with mangetic profiles on p. 144-174.

\section{DIGITAL PROCESSING TECHNIQUES}

Introduction

This section describes the techniques developed by the USGS to correct, enhance, and mosaic GLORIA digital sonar images. A more detailed explanation of the digital processing is given by Chavez (1986). Sonographs are a record of the acoustic backscattering properties of the sea floor. The four major factors
that control the strength of the acoustic backscatter are: (1) the slope angle of a feature relative to the incident sonar signal; (2) the sea-floor roughness (relief as small as $4 \mathrm{~cm}$ will affect the backscatter recorded by
GLORIA [Sabins, 1978]) (3) the variation in physical properties of the upper few meters of the sea floor and GLORIA [Sabins, 1978]); (3) the variation in physical properties of the upper few meters of the sea floor; and and we find that long travel paths also increase background noise). The intensity of the backscatter was
recorded as a digital number (DN) with a range of 0 to 255 discrete values $(0=$ black, $255=$ white), and
the arrival time of reflections also was recorded the arrival time of reflections also was recorded.
The raw GLORIA data contain geometric and radiometric distortions that had to be corrected before The raw GLORIA data contain geometric and radiometric distortions that had to be corrected before
they could be digitally mosaicked to generate the imagery presented in this atlas. Geometric distortions

\section{Geometric Corrections}

Two types of geometric distortion-slant-range error and aspect-ratio distortion-occur in the initial

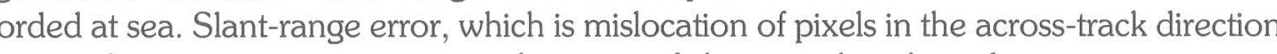
compared to their proper location on a map, occurs because of the way that the sidescan sonar senses
distance to a target. Aspect-ratio distortion-the shortening or extension of the image parallel to the ship's track-occurs because the distance scale across-track is not the same as the scale along-track; furthermore, the along-track scale varies constantly as ship speed changes. Both of these major distortions were eliminated
from the data presented in this atlas. Below is a brief explanation of the procedures used to correct for these from the data presentic distortions.

occurs because the range to reflection targets is measured as the direct distance from the towed vehicle near the surface diagonally to the target on the bottom, rather than as the horizontal distance between them (fig. 3). In order to create a map view, the horizontal distance from the target to the position on the sea floor directly below the vehicle is required. In trigonometric terms, GLORIA measures the length of the hypotenuse of a right triangle, but to create a map view we need to know the length of the base. Since the hypotenuse ts pixel in the across-track direction, if one assumes a flat sea floor

After the slant-range correction has been made, the across-track location of targets is accurate, but the shapes of objects are distorted because the along-track lengths are not equivalent to the across-track lengths in the image. This is the aspect-ratio distortion. The sampling interval for the 30-s pulse-repetition rate generates pixels that represent $45 \mathrm{~m}$ of distance in the across-track direction. The computer program that along-track direction is approximately $125 \mathrm{~m}$ at a speed of $8 \mathrm{kts}(15 \mathrm{~km} / \mathrm{hr}$ ). If we were to generate a plot using square pixels, this would create a distorted image that is compressed by a factor of about 2.5 in the along-track direction. Of course, any change in ship's speed while collecting the data, caused by winds, currents and other factors, will cause this compression factor to vary. During the surveys, the speed varied
from about 7 to $10 \mathrm{kts}(13$ to $19 \mathrm{~km} / \mathrm{hr}$ ), which caused the pixel size in the along-track direction to vary from from about 7 to $10 \mathrm{kts}(13$ to $19 \mathrm{~km} / \mathrm{hr}$ ), which caused the pixel size in the along-track direction to vary from
approximately 110 to $160 \mathrm{~m}$. This introduced an "accordion" effect into the geometry of the image in the approximately 110 to $160 \mathrm{~m}$. This introduced an "accordion" effect into the geometry of the image in the
along-track direction (Chavez, 1986). The aspect-ratio distortion was removed by using the navigation data compute the distance traveled by the ship every $30 \mathrm{~min}$ (unless a turn occurred, in which case the program
used a 10-min interval). Given the distance traveled, the number of pixels (each representing $50 \mathrm{~m}$ ) required along a particular 30-min segment was calculated. The original pixels were then duplicated the appropriate number of times to fill the along-track space with 50-m pixels and thus achieve a 1:1 ratio between along-track and across-track distances. The practice of duplication to create a square 50-m pixel size was
followed so that information in the across-track direction would not have to be omited -

\section{Radiometric Corrections}

Radiometric corrections change the digital number (DN) value (brightness) of a pixel rather than its location, as is the case with geometric corrections. Four different radiometric corrections were used to eliminate the following problems: (1) attenuation of the sonar energy in water as a function of range; (2) uneven energy output due to the slow power buildup of the acoustic pulse; (3) speckle noise; and (4) striping
noise. Removal of speckle and striping noise eliminates artifacts associated with the data acquisition and noise. Removal of speckle and striping noise eliminates artifacts associated with the data acquisition and
geometric correction. The corrections for power buildup and attenuation normalize all data so that pixel values everywhere in the image are more comparable.

The loss of power due to range attenuation and the delay in power buildup of the pulse were both colrected by using a two-pass algorithm. During the first pass through a batch of data (commonly data of the digital image in the along-track direction. These values were then normalized by the average of all the column averages (the overall average of the batch of data) to generate correction coefficients for each column. The correction coefficients were then applied to each pixel during the second pass through the data. The coefficients are nonlinear and are a function of range, so they effectively removed attenuation in the
across-track direction (Chavez, 1986). Speckle noise was removed by applying a small smoothing filter to the entire image, using a filter area of two pixels in the along-track direction by two pixels in the across-track direction. The smoothing fitter takes
the mean DN value of the four pixels in the filter area and replaces the pixel in the upper left corner with this mean value. The assumption justifying such a smoothing filter is that any very large changes in adjacent pixels probably represent noise. This filter minimized random speckle noise and also helped smooth the blocky appearance caused by pixel duplication in the along-track direction, which had been done to correct the Striping in the scan

Striping in the scan direction (perpendicular to the ship's track) is caused by small energy variations from
scan line to scan line In order te representing part of the original image with instrumental artifact, two separate pixel files are generated, each image. One pixel file represents the high-frequency components and the other the low-frequency
components. The high-frequency file is generated by taking the averege components. The high-frequency file is generated by taking the average of DN values in a 1- by 71-pixel area (referred to as a "boxcar") that is oriented normal to the trackline (along a scan line). This average value is
subtracted from the DN value at the center of the boxcar and the difference is assigned to the location of the center pixel This procedure is then applied to (centered on) each pixel to produce a field of values that describes only the high-frequency excursions in the original data. The low-frequency file is generated by
averaging the DN values in a 9- by 71-pixel boxcar, which also is aligned normal to the trackline, and by assigning this average value to the location of the center pixel. When applied to each pixel, this procedure file represents the high-frequency components of the image without the striping noise and the second file image very similar to the original but without the noise.

\section{Digital Mosaicking}

After the geometric and radiometric corrections, the data were ready for the digital mosaicking steps that resulted in the imagery sheets shown in this attas. The segments of processed data, each representing about where the ship's heading remained generally constant. The segments were tone-matched by adjusting the average brightness to minimize the tonal contrast at the seams where they were joined. Latitude, longitude, and heading were determined along the trackline of each continuous segment of
data at the start, end, and two intermediate points. These four control points, with eight additional points that were computed for the edges of the image segment, were used to position the segment within the map grid. The next step was to digitally stencil image segments to remove unwanted data. Interactively, a line was drawn on a video display outlining the part of each image segment to be retained while comparing it to
adjacent segments. Then all pixels outside the area enclosed by the line were converted to zero values thereby retaining only that part of the image desired. Finally, each stencilied segment was mosaicked to
adjacent segments, sequentially building the composite map. In this way a digital file having the desired map projection was created for each imagery sheet.

\section{GEOLOGIC INTERPRETATION}

\section{Regional Perspective}

The sidescan-sonar images in this atlas show a sea floor at a late stage in the evolution of a passive, or trailing-edge, continental margin. This sea floor is a result of tectonism, sediment deposition and erosion on the edge of a continental block undergoing subsidence and affected by complex sea-level fluctuations.
Recently, the geology and geologic history of the region were summarized in detail in three volumes edited Recently, the geology and geologic history of the region were summarized in detail in three volumes edited
by Poag (1985a), Vogt and Tucholke (1986a), and Sheridan and Grow (1988). Papers in these volumes - many of them review articles-represent the best way to enter the literature on the geology of the the geology of the entire U.S. Atlantic continental margin is provided in Emery and Uchupi (1972).
The U.S. Atlantic continental margin started to form in Late Triassic time (more than 200 million years
ago) as Africa and North America began to separate along an opening that would become the southern North ago) as Africa and North America began to separate along an opening that would become the southern North
Atlantic Ocean. Many fault basins formed (rift basins, fig 5) and ocean water invaded the central rift, where, Atlantic Ocean. Many fault basins formed (rift basins, fig. 5) and ocean water invaded the central rift, where,
in the dry climate at the middle of this very extensive land area, evaporation caused deposition of salt in the dry climate at the middle or
(Manspeizer and Cousminer, 1988)

Eventually, the gap forming between the separating continents was filled by molten mantle material that formed new oceanic crust, starting about 175 million years ago (Klitgord and Schouten, 1986; Klitgord and others, 1988; Poag and Valentine, 1988). Along most of the eastern continental margin of the United States magnetic anomaly known as the East Coast Magnetic Anomaly (fig. 5).

The newly rifted crust of the continental margin subsided because it was thinned by stretching and also because the adjoining, new oceanic crust, initially hot, cooled and became denser over time, and subsided
(Sawyer, 1988: Steckler and others, 1988). Irregularities in the amount of stretching along the margin created our basins (fig. 5) that are within the EEZ: the Georges Bank Basin (Schlee and Klitgord, 1988), the Baltimore Canyon Trough (Poag, 1985b; Grow and others, 1988), the Carolina Trough, and the Blake
Plateau Basin (Dillon and Popenee, 1988). As the basins subsided, they were continually filled with Plateau Basin (Dillon and Popenoe, 1988). As the basins subsided, they were continually filled with
lerrigenous sediments derived from the continent and with biogenic carbonate deposits (Poag and Valentine, terrigen

In the late stages of continental-margin development, during Tertiary and Quaternary time, margin mass movement, and depositional processes created complex sedimentary patterns (Mountain and Tucholke, 11985; Tucholke and Mountain, 1986; Riggs and Belknap, 1988). These patterns formed the
morphology of the eastern U.S. continental margin (fig. 28 and GLORIA images) (Shor and McClennen, 


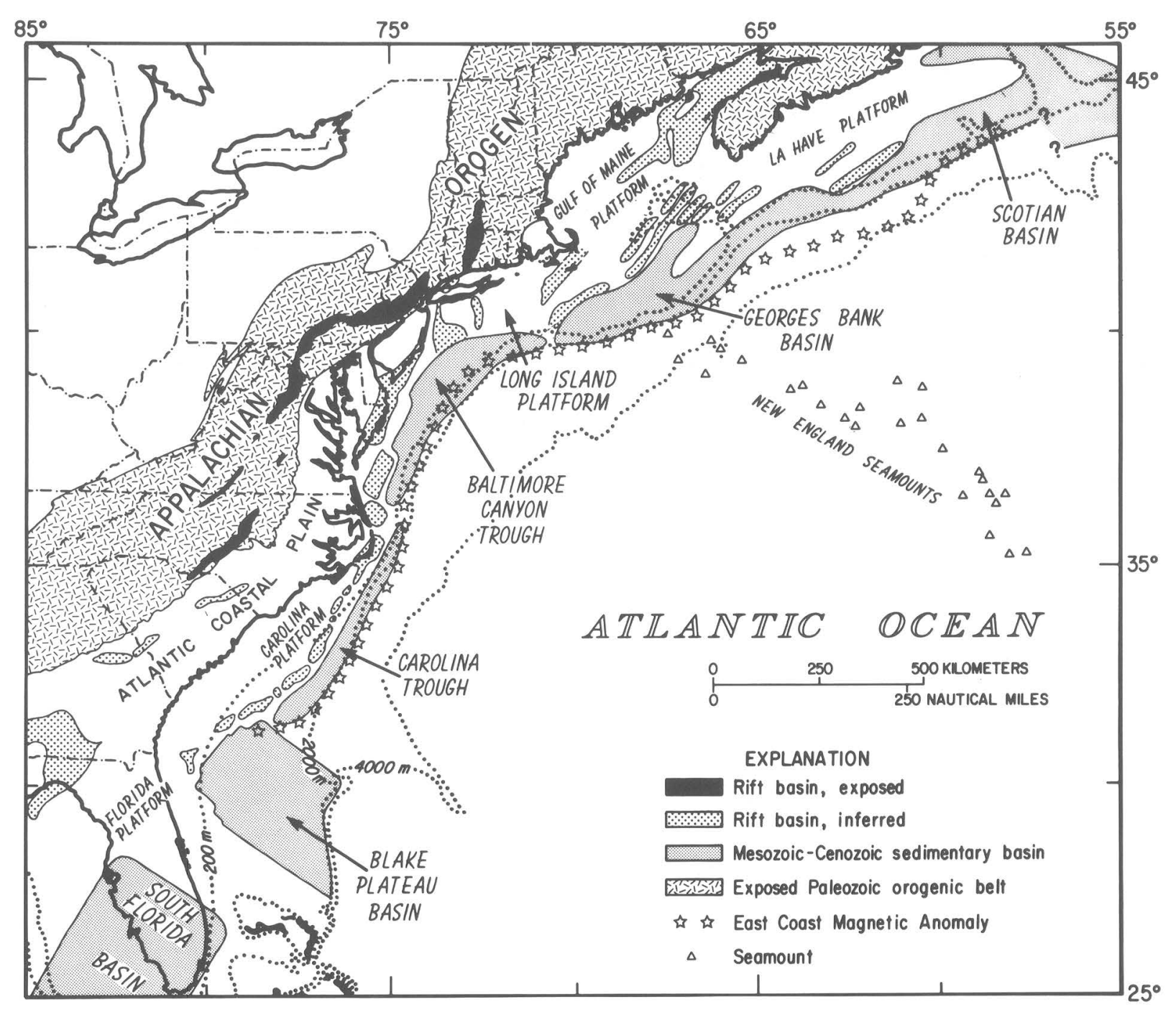

Figure $5-$ Gener
others (1988).

1988) and controlled the variations in reflection characteristics that also affect the picture presented by GLORIA (as well as by other acoustic methods of studying the sea floor; see Laine and others, 1986). The continental rise, which covers the major part of the GLORIA images, was formed by processes that transport sediments downslope, including turbidity currents (Pilkey and Cleary, 1986), slumps, slides and debris flows (Embley and Jacobi, 1986), and by processes that are controlled by contour currents, which flow in a slope-parallel direction (McCave and Tucholke, 1986). When sea level rises, as it has done during Holocene time, sediments initially are trapped in estuaries, but during lowered sea level, rivers debouch near
the edge of the continental shelf, and large sediment accumulations form on the shelf edge and upper slope. the edge of the continental shelf, and large sediment accumulations form on the shelf edge and upper slope.
These deposits become unstable and move downslope as slumps, slides and debris flows, leaving scars on the sea floor and the marks of downslope transportation and deposition of sediments. Slumping also can generate turbidity currents, which tend to flow down channels, helping to sculpt submarine canyons.

Southwest-directed contour currents, which occur along the eastern North American continental rise, are deepwater flows that are driven by densification of water by chilling in the Arctic (and to some extent in the Antarctic). The dense water flows parallel to the contour of the sea floor, sometimes depositing sediments,
and sometimes eroding them at locations where the sea-floor topography causes the current to be intensified.

\section{The Region off Georges Bank and Southern New England}

The continental slope off New England has different morphological characteristics east and west of long $70^{\circ} \mathrm{W}$. The eastern part (sheets 1,2 and 6 ) is built up by a thick (approximately $400 \mathrm{~m}$ ) wedge of prograde Pleistocene glacial outwash, located primantly along Georges Bank. The upper slope has a declivity of about 70 to 8 that flattens with depth so that the lower slope merges imperceptitlo the continental slope betwe long 100 . an abrupt contact with the upper rise at depths between 1800 and $2500 \mathrm{~m}$. Strata underlying this segment of the slope are more or less conformable with the sea floor.

The continental rise off New England is a very gently seaward sloping (about $0.5^{\circ}$ ) terrain built up by Cenozoic strata. The GLORIA data show that the rise is stratigraphically and morphologically complex and that the erosional and depositional features of the rise are largely related to the nature of the adjacen continental slope. Most canyon erosion and mass movement originated on the slope, which was the majo source of sediment delivered to the rise by mass wasting in late Pleistocene and Holocene time. The slope calch through them. The continued during the episode of mass movement: there is abundant evidence that mass movement has been

recurrent and has been active during the Holocene.
Six volcanic seamounts of the New England seamount chain are located off Georges Bank: Bear, Mytilus, Physalia, Picket, Retriever, and Buell (sheets 3, 7 and 10). All the seamounts except Bear have rugged, embayed slopes and crudely stellate perimeters, indicative of extensive collapse of the origin edifices. Seismic profle data suggest that much of the collapse occurred in Late Cretaceous or Paleogene Only Buell Seamount appears to have a slight moat presumably caused by erosion. Dredge samples from the seamounts have included holocrystalline to porphyritic and amygdaloidal alkaline-olivine basalts and
tuffs. $\mathrm{Ar}^{0} / \mathrm{Ar}^{39}$ values from the samples indicate that the seamounts range in age from about 100 to 85 million years (Duncan, 1984).

The GLORIA images show no forms or sea-floor markings indicative of along-contour scour or deposition within the New England part of the EEZ. However, the image-correlative seismic-reflection profiles (p. 108-111, between Julian days 106,0500 hours and 107,1200 hours approximately) show that the approximately $1^{\circ}$, beyond a water depth of about $3700 \mathrm{~m}$. Strata of the nearly flat lower rise onlap the base of this slope at a water depth of about $4200 \mathrm{~m}$. Stratigraphy recorded in seismic-reflection protiles suggest that this sediment accumulation may be a northward extension of the Neogene Chesapeake drift located southwest of Hudson Canyon (Tucholke and Mountain, 1986). The drift may have extended originally as far east as the New England seamounts; presently, the east end of the drift is eroded by Lydonia Canyon (sheet 7). The relief and slope of the difft seems to have deflected (to the east) and partly octluded flow of deb Veatch, and Hydrographer Canyons and Hudson and Carstens Valleys across the upper rise, as well as for their debouchment at about $4300 \mathrm{~m}$ water depth. This is because the sediment drift provides a significan gradient for channels extending to the $4300-\mathrm{m}$ isobath.

East of long $70^{\circ} \mathrm{W}$., the Neogene(?) and Pleistocene strata of the upper rise and lower slope are extensively eroded by canyons (sheets 1, 2, 3, 6, and 7). The larger canyons on the middle to lower slope attain erosional relief as great as $400 \mathrm{~m}$ and widths as great as $5 \mathrm{~km}$. West of long $70 W$., most of the (sheet 5). Canyons are few in this region, and canyon incision is restricted to the slope; excepting Hudson Canyon and Carstens Valley, the canyons debouch directly onto the upper rise.

Most of the canyons along the New England continental margin cont only six of 13 shelf-indenting canyons extend across the rise to the border of the EEZ. The six canyon (Nygren, Powell, Lydonia, Hydrographer, Veatch and Hudson) differ considerably from each other in overal aspect and in local channel characteristics. Veatch and Hydrographer Canyons extend for $150-200 \mathrm{~km}$ only half as wide as Veatch Canyon. Nygren Canyon shows slight if any, sinupsity, but does have acutely convergent triburies on the rise (sheets 2 and 3). Hudson Canyon and Valley (as well as Carstens Valley) the canyons have been conduits for sediment eroded from the slope, but the extent of transport and mode of delivery are varied. Hudson, Veatch and Hydrographer have carried sediment to the lower rise and abyssa

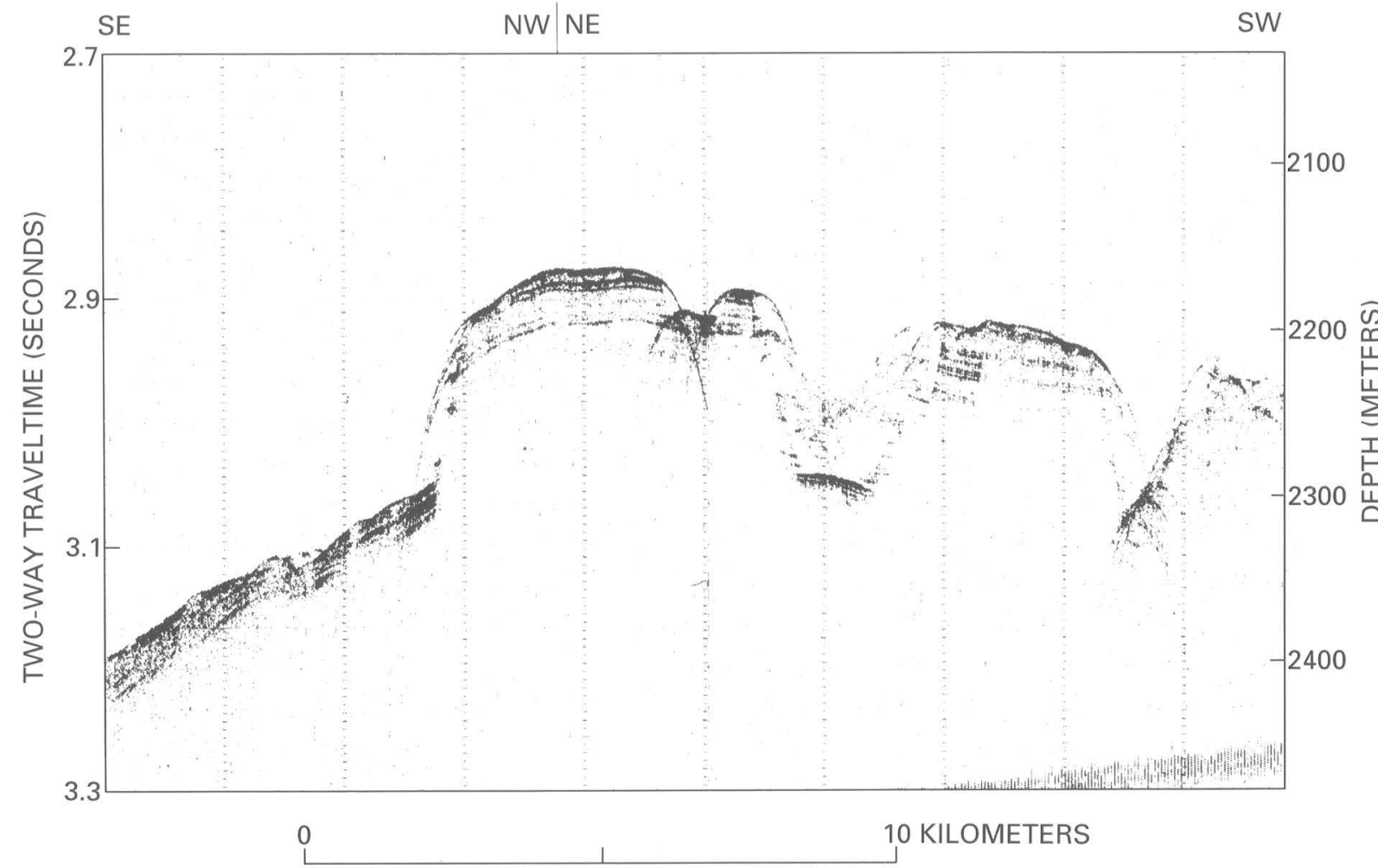

Figure 6-A 3.5-kHz high-resolution seismic profile showing butte-like promontories that are an aspect of the are located at about $2250 \mathrm{~m}$ water desth on the lower slope and upper rise (sheet 5 ). They have a relief of $113 \mathrm{~m}$.
The central gap is choked with debris and the two stacks to the right are partly overridden with debris. Vertical exaggeration
Time (GMT).

plain, whereas Lydonia and Powell debouch on the upper rise onto broad, fan-like deposits within which Mass movement was the dominant sediment distribution process on the New England continental rise In late Pleistocene to Holocene time. Most large mass movements originated on the lower slope at wate depths greater than $1000 \mathrm{~m}$, and have produced scarps having more than $100 \mathrm{~m}$ of relief (fig. 6). The area extent and rellef of slide scars indicates that mass movements were initially slabs with widh-to-thickness ratio rise as debris flows Debrisflow deposits show up in the GLORIA images as relatively bright, reflective areas of sea floor but individual flows are difficult to distinguish because mostlack well-defined edges (sheets 5 and 6). The debris deposits are generally less than $30 \mathrm{~m}$ thick (fig. 7); they typically thin to a feathered edge to a convex margin less than a meter thick. Individual deposits include large, flared sheets having wispy, distal borders, and elongate, linguloid bodies resembling mudflows or pahoehoe lava flows.

Mass movement is centered in two main areas of recurrent activity. The larger area is located west of long 690 . mixed with sediment funneled by the canyons. Several large slides (the Veatch Canyon slide, Nantucke Canyon slide, Atlantis Canyon slide and Block Canyon slide) coalesce to form a complex $220 \mathrm{~km}$ wide that extends at least $200 \mathrm{~km}$ downslope. The larger continental-slope canyons in this area, such as Babylon, Atlantis, and Alvin, are barely detectable on the rise; they are either flooded by debris or are chutes tha contributed debris to the total mass on the rise without forming distinct depositional borders (fig. 7). Considerable debris from this area moved soult, downslope, intercepting and partly filing Hudson Canyo the Veatch Canyon slide, overrode and partly filled Veatch Canyon. At about $3450 \mathrm{~m}$ water depth, the 2-km-wide Veatch Cnyon is nearly swampec by debris, as shown by the seismic-reflection profile (fig 8). The debris sheet crossed the canyon from the north, partly filling ilt, and continued for some uncertain distance to the south. The GLORIA image shows the debris as a bright area of sea floor. The image also shows that debris was not stuiced to the lower nise through the canyon and hat the channel was not re-incised following debris emplacement. In both areas of mass movement activity, the debris sheets were mobile enough for stabiling Some exceed $200 \mathrm{~km}$ in downstope extent Despite such apparent mobility, little, if any, debrits seems to have mod down the intercented canyons to the lower rise. In fact, there is evidence (sheet 5 ) that would seem, then, that most of the sediment debouched from the canyons to form the lower-rise fan deposit had been eroded from the middle to upper slope by the canyons before the major lower-slope slides

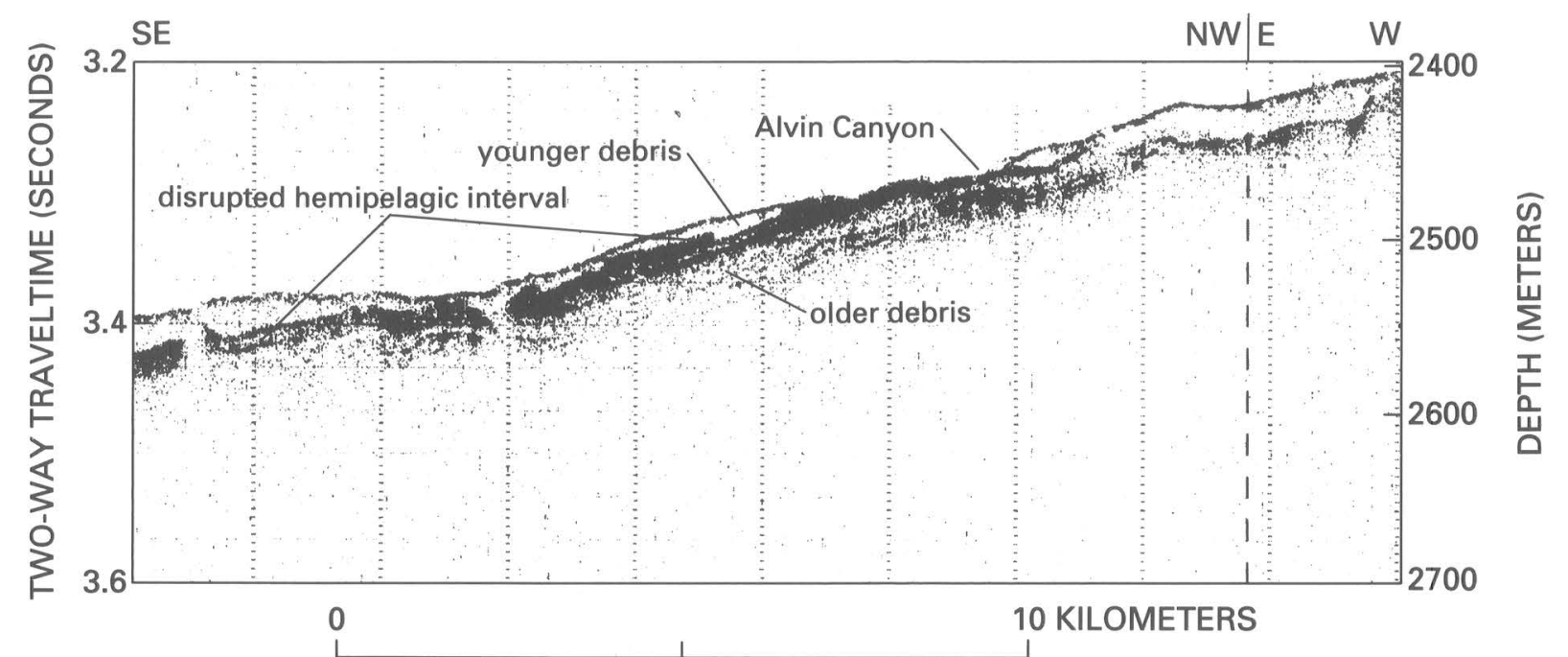

Figure 7-At a water depth of $2468 \mathrm{~m}$ on the upper continental rise, Alvin Canyon is simply a bare spot between
two masses of slide debris (sheet 55 . This $3.5-\mathrm{kHz}$ h high-resolution seismic profile shows a younger and an older debris deposit, each about $20 \mathrm{~m}$ thick, 2 eparated by a thin, disrupted hemipelagic interval. Alvin Canyon apparently
postdates the older mass movement. Vertical exaggeration 25:1. Profile location on figure 26 is at Julian day 110 ,
time $1430-1530$ hours GMT.

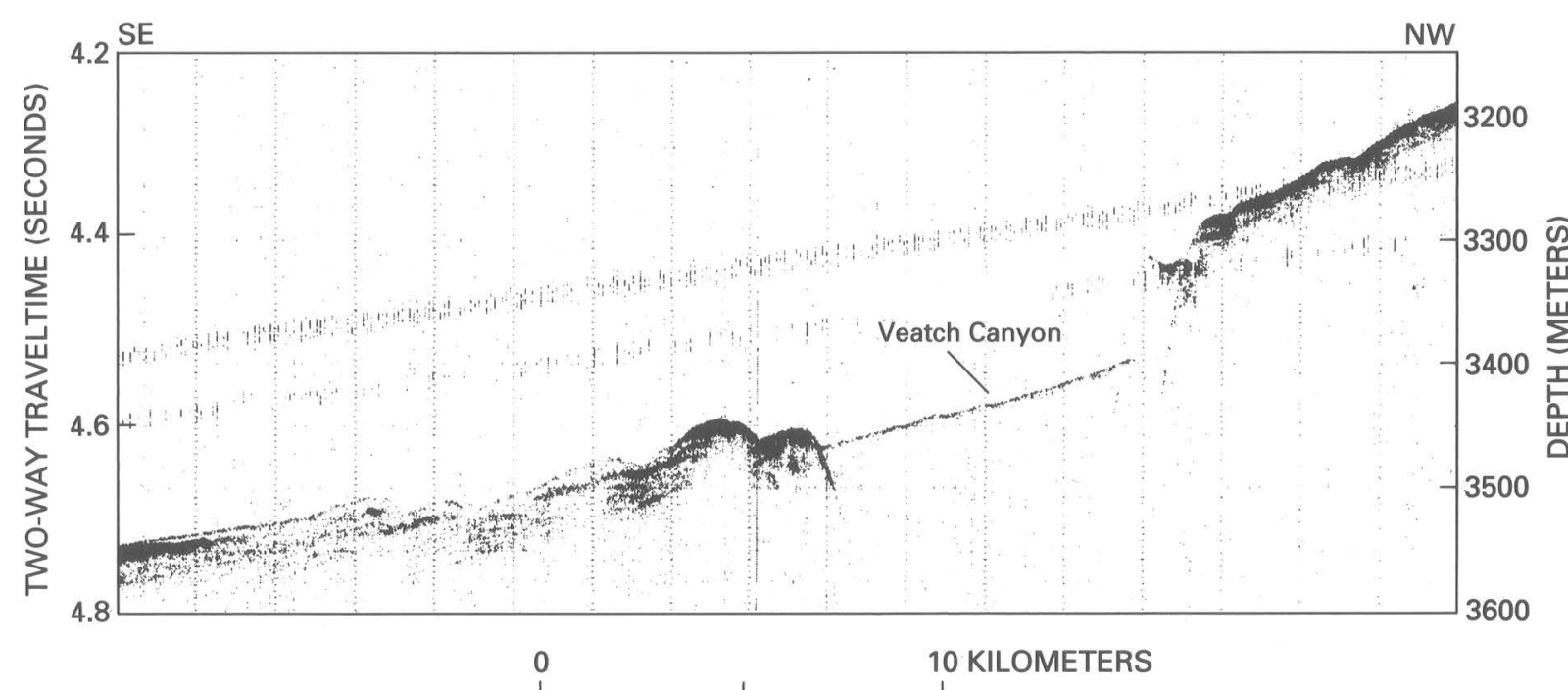

Figure 8-A 3.5-kHz high-resolution seismic profile crossing Veatch Canyon obliquely at a water depth of about $3450 \mathrm{~m}$ (sheet 6). The canyon is nearly filled with acoustically transparent slide debris. The continental rise
downslope (southi of the canyon is mantled by at least two generations of debris. Vertical exaggeration $31: 1$. Profile
location on figure 26 is at Julian day 109 , time 0018 - 0200 hours GMT. 


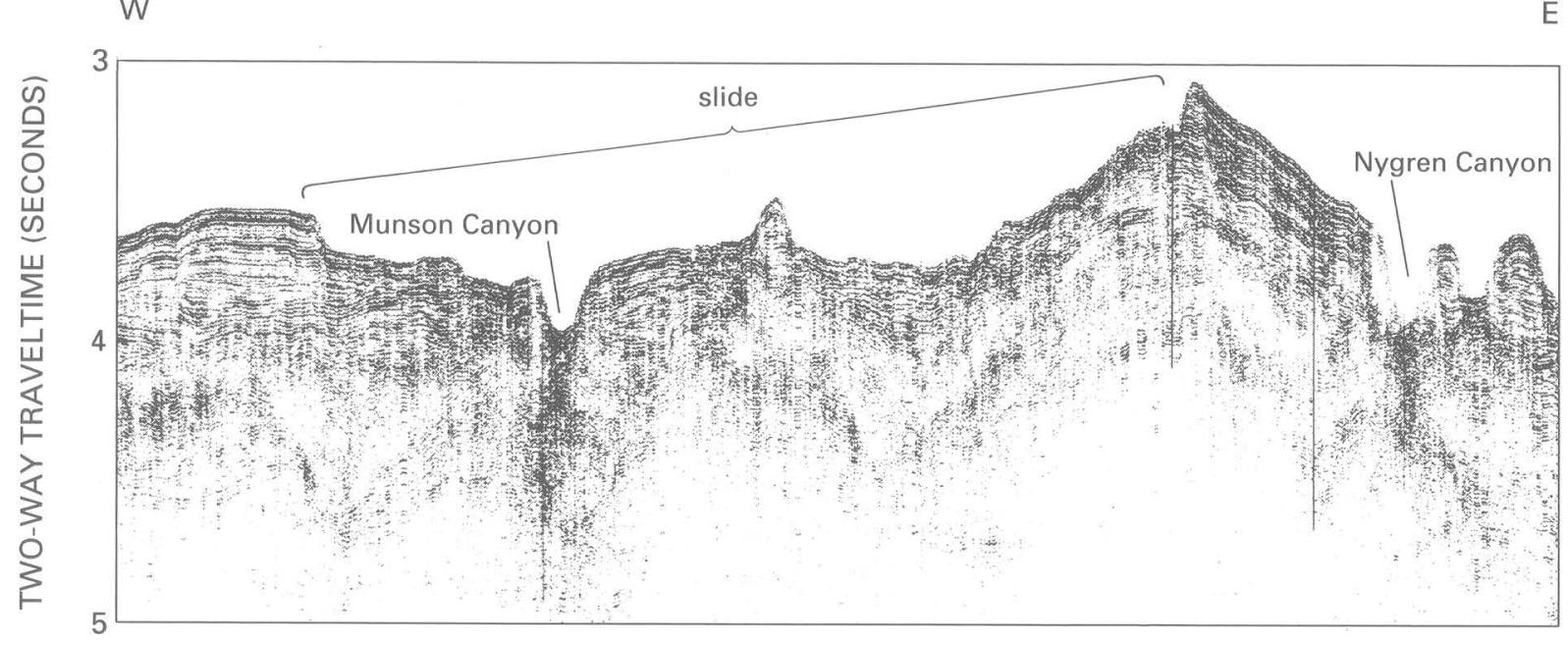

0

40 KILOMETERS

Figure 9-Airgun seismic profile across the head zone of the Munson-Nygren slide at about $2000 \mathrm{~m}$ water depth
on the lower continental slope (sheet 2). Scarp relief is about $150 \mathrm{~m}$. Munson Canyon appears to be partly filled with der the lower continental slope (sheet 2). Scarr relief is about $150 \mathrm{~m}$. Munson Canyon appears to be partly filled with
debris the older slide. Vertical exaggeration $22: 1$. Profile location on figure 26 is at Julian day 092-093, time
220055 hours GMT.

The Munson-Nygren slide and the younger, presumably related Retriever slide both head in the continental slope at a water depth of about 2,000 $\mathrm{m}$ (sheet 2). The Munson-Nygren slide has a scarp relief of at least $150 \mathrm{~m}$. Munson Canyon appears to be partly filled with debris from this older slide (fig. 9). Debris
from both slides has merged with sediment debouched from Powell Canyon and has spread around Picke from both slides has merged with 7 ediment debouched from Powell Canyon and has spread around Picket $120 \mathrm{~km}$.

\section{The Middle Atlantic Region}

The first detailed bathymetric maps of the continental slope and upper continental rise off the Middle Atlantic shelr were pulished in 1939 be veatch and Smith, who established most of the names of submarine rise based on character of echo-sounding profiles show the great complexity of the sea floor and its sediments (Laine and others, 1986; Pratson and Laine, 1988).

Sediments of the Middle Atlantic region within the EEZ are primarily terrigenous. During the Pleistocen glacial intervals, when the shoreline migrated back and forth across the present continental shelf, large areas of the continental rise, forming well-stratified, fine-grained hemipelagic deposits (fig 10) 10 cover appear on the mosaics as regions of uniform backscatter Transport of sediment across the sea floor by sediment-gravity flows is shown by the extensive systems of canyons on the slope and valleys on the rise (see especially sheets $4,5,8$ and 9 ). Large areas extending more than $100 \mathrm{~km}$ seaward of the con thental slope are covered by slide deposits, slumps, and debris flows (sheets 8 and 9), which produce high backscatter because of their hummocky topography in both macro and micro scale and because of local textural The

The surface of the upper rise shows dominance of downslope gravitational processes over longslope processes, but in the deeper-water areas east of Cape Hatteras a response to contour-following (southw The major feature of the Middle Atlantic EFZ is Hudson Canyon, which indents the continental shelf break for more than $30 \mathrm{~km}$ and is the largest submarine canyon on the eastern U.S. continental margin (sheets 4 and 5). It connects to the Hudson River via the Hudson Shelf Valley across the continental shelf.

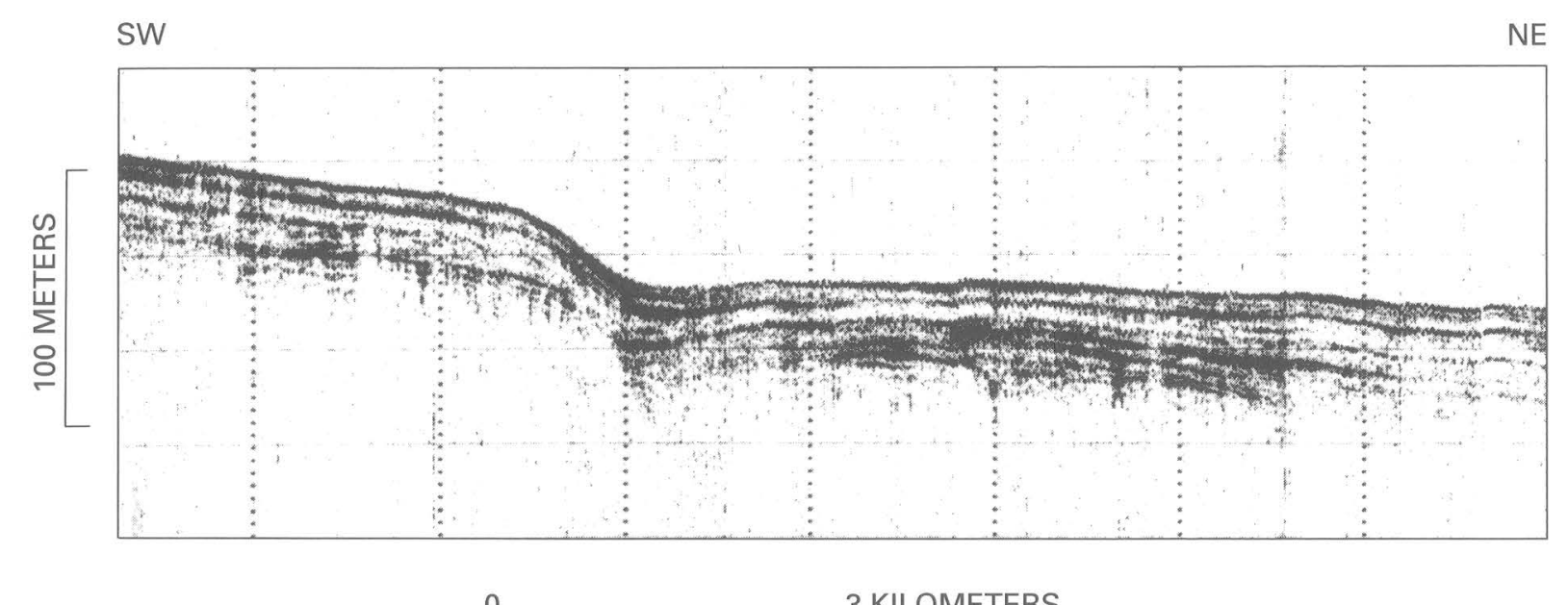

O 3 KILOMETERS

Figure $10-$ Seismic profile $(3.5 \mathrm{kHz}$ ) showing hemipelagic sediment cover on undisturbed parts of the continental
rise at about $2850 \mathrm{~m}$ water depth (sheet 8 , at approximately lat $377^{\circ} 5^{\prime} \mathrm{N}$. I long $73^{\circ} 5^{\prime}$ ' W.). Vertical exaggeration
$21: 1$. Profile location on figure 26 is at Julian day 74 , time $1055-1145$ hours GMT.

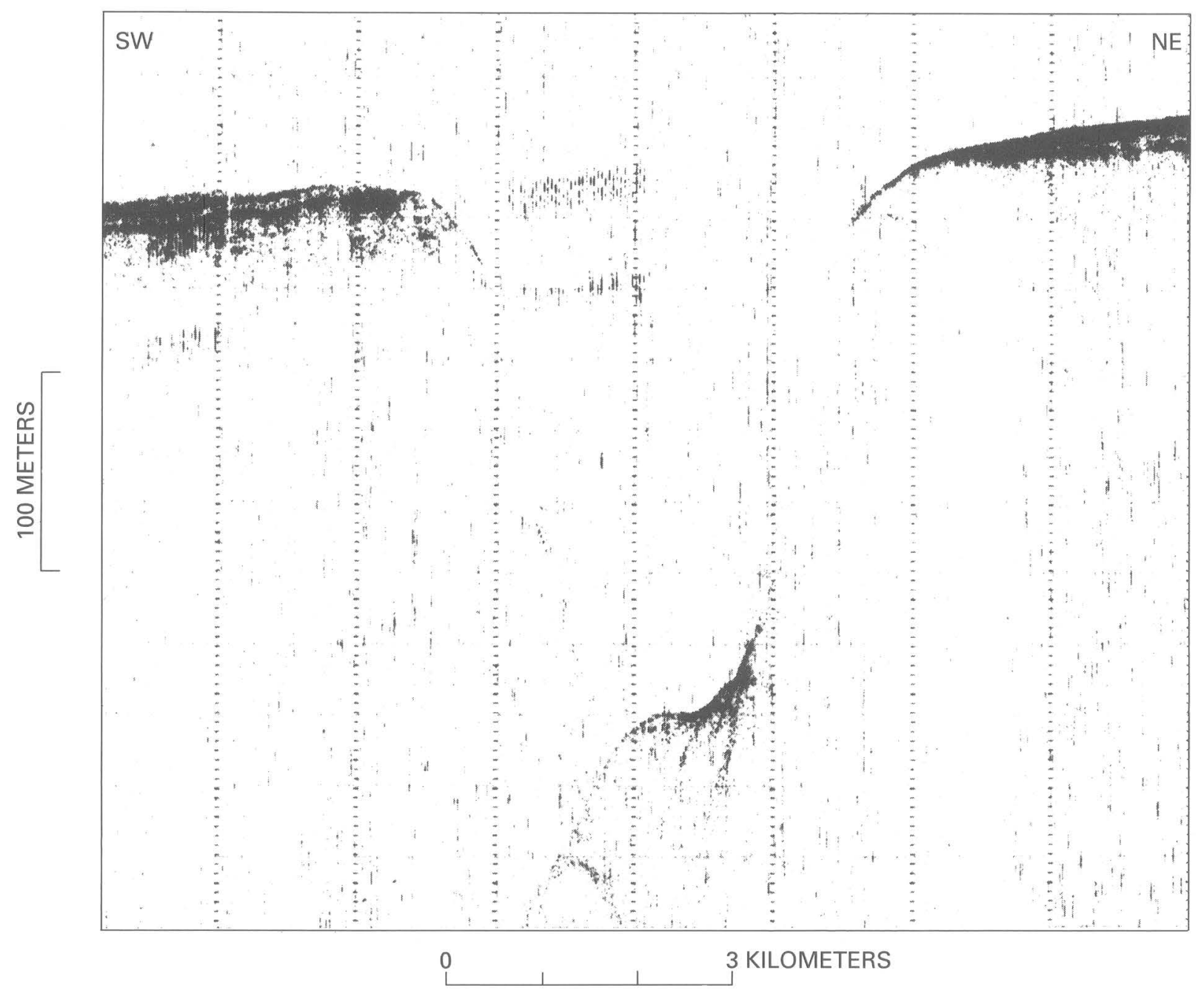

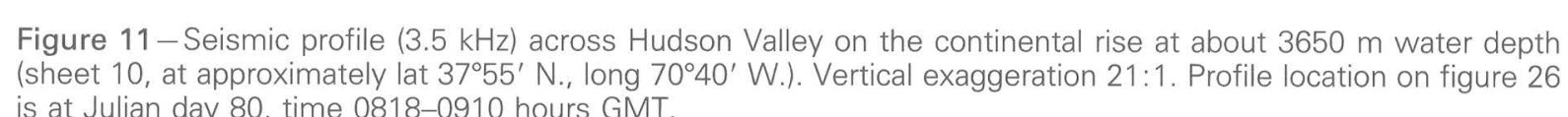

Seaward of the continental slope the canyon continues across the continental rise as Hudson Valley (fig. 11), where it displays meanders and low levees as it crosses the Hudson Cone (sheet 5). Sediment moves through
the Hudson system to the Hudson Fan, which is on the lower rise and is seaward of the area shown by the mosaic. Currently the Hudson Cone (sheet 5) appears to be a zone of transportation rather than of deposition. The GLORIA mosaic and seismic profiles across the Hudson Cone show a smooth surface that truncates slightly seaward-dipping strata in the seaward parts of the EEZ

Carstens Valley, located to the northeast of Hudson Valley (sheet 5), is a well-defined feature that heads about $100 \mathrm{~km}$ from the base of the slope and nearly parallels Hudson Valley. It is not traceable across the mass-wasting deposits. No buried valley appears in the seismic profiles, but this may just signify buried by acoustic contrast between the older and younger sediments. There is no clear present source of turbidity currents to create or maintain the valley, and it is probably relict. The parallel courses of Carstens and Hudson Valleys may have been caused by overbank deposits along Hudson Valley diverting the flows that had tormed Carstens Valley.

The GLORIA mosaics show evidence of changes in the depositional history of the continental rise. West of Hudson Valley are several narrow valleys that extend southward from the region of the debouchment of Hudson Canyon onto the rise (sheets 5 and 9). These valleys truncate subbottom reflectors and show no
levees. The GLORIA images show that parts of the upper-rise courses of these valleys have been covered by lobes of sediment that extend northwestward from a region of high backscatter deposits on the rise, fed by slope canyons of the Toms Canyon-Hendrickson Canyon complex. Significant increase in the flux of sediment through these canyons occurred during a glacial sea-level lowstand when sediment derived from subaerial Hudson River drainage was diverted south of the main Hudson Shelf Valley through a now-buried valley on the continental shelf and dumped into the Toms Canyon-Hendrickson Canyon complex (Knebel

The continental slope between Hendrickson Canyon and Baltimore Canyon is cut by many submarine
cnyons whose upper reaches on the slope are fed by a complex system of gullies (sheet 4 ). The mosaic shows that most of the canyons on the slope do not reach the continental shelf break, and, therefore, demonstrates that flows derived from terrestrial rivers or from shelf-originating processes $e g$, wave-induced turbidity currents) are unnecessary to canyon formation. Mass wasting on the continental slope and locally induced sediment gravity flows are now considered to be the primary agents creating the submarine canyons of the continental slope (Twichell and Roberts, 1982; Farre and others, 1983). However, well-developed continuous valleys on the continental rise have formed in only the few places where larger canyons have
breached the shelf break, and, presumably, have transported large volumes of shelf sediments (Farre and others, 1983)

The GLORIA images show fluvial-like features such as terraced and channeled flood plains and apparent crevasse-splay deposits (seen as high-backscatter lobes) where levee failure occurred and sediment gravity flows discharged at bends of Toms and Wilmington Canyons (sheets 4 and 9). Thus the long, continuous channels of the larger canyons have many of the erosional and depositional features of channelized sedimenterlacty low

Darine canyons form a system of valleys or shon to Baltimore Canyon, the seaward extensions of trending Wilmington Valley (sheets 4 and 9). Most of the apparent valleys on the rise appear as indistinct, discontinuous, high-backscatter bands on the GLORIA images. High-resolution echo-sounding profiles (3.5 $\mathrm{kHz}$ ) show that these high-backscatter bands correspond to shallow depressions with poorly defined banks, that are in regions having a hummocky bottom surface (fig. 12). Airgun seismic profiles show discontinuous others, 1988) Even Wilmington and Baltimore Canyons are shallow, porly defined and sediment choth in part of their course eastward from the base of the continental slope to their confluence and southward bend at the junction with valley traces of Hendrickson and Toms Canyons. Thus, many valleys of the upper rise,
visible on the GLORIA images, probably represent short-lived features. They are shallow channels that occupy lows between blocky debris accumulations and that transport sediment originating from mass wasting of the continental slope.

The concentration of valleys extending down the continental rise between Hendrickson and Baltimore Canyons (sheet 4) and the present eastward course of Baltimore and Wilmington Canyons (which
anomalous with respect to the southeastward regional inclination of the rise) may resulf from lons term lowe deposition rates relative to adjacent regions of the rise that have been supplied with sediments from the

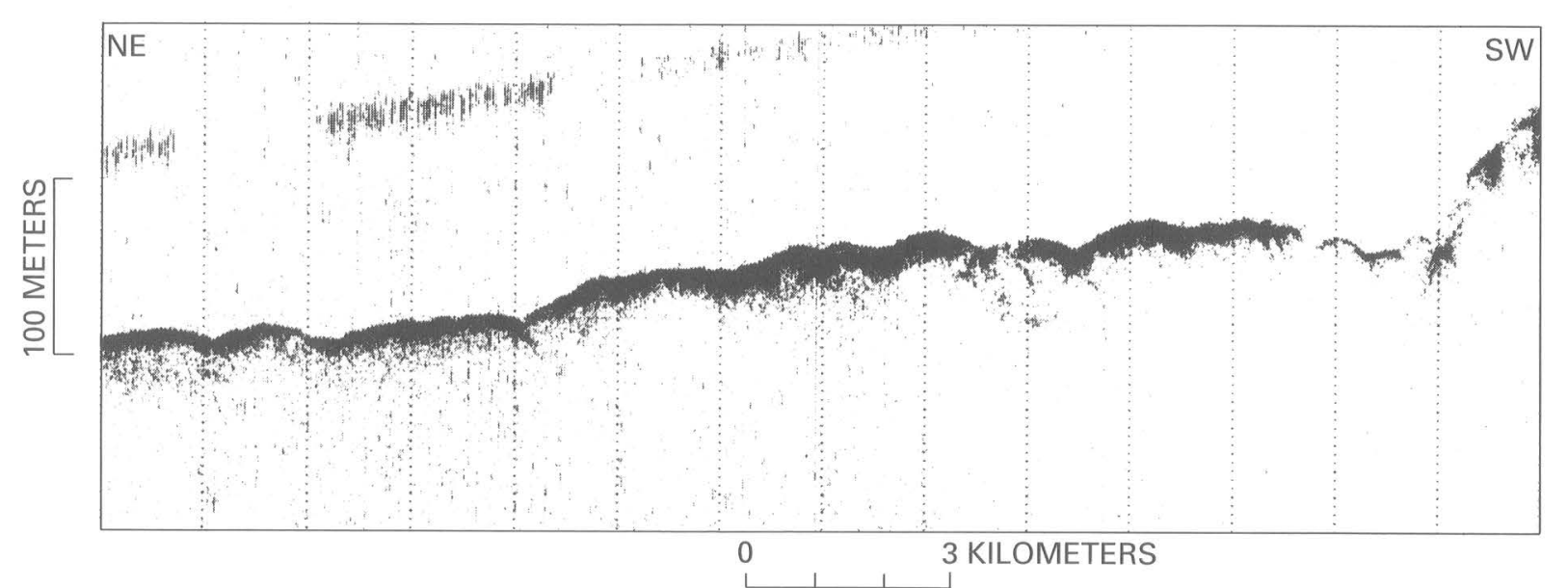

Figure 12 - Seismic profile (3.5 kHz) showing debris on surface of the upper continental rise at about $2880 \mathrm{~m}$ water depth, crossed by valleys that extend from Wilmington and Baltimore Canyons on the continental slope (sheet 4 ,
at approximately lat $38^{\circ} 05^{\prime} \mathrm{N}$., long $72^{\circ} 0^{\prime} 0^{\prime}$.). Vertical exaggeration 26:1. Profile location on figure 26 is at Julian
day $66-67$, time $2318-0048$ hours GMT.

Hudson River and Delaware River drainages. The eastward course of Baltimore and Wilmington Canyons may have been caused by piracy, whereby sediment gravity flows were diverted into the deeper region to the northeast, or by massive blocks of displaced continental-slope strata. There are southeast-trending canyons
visible in high-resolution bathymetric mass of the Baltimore Canyon-Washington Canyon slope-rise area that visible in high-resolution bathymetric maps of the Baltimore Canyon-Washington Canyon slope-rise area that could be former extensions of the Wilmington and Baltimore Canyon drainage (unpublished USGS
Sea-Beam data, personal commun. B. A. McGregor, 1988). Those canyons are blocked by topographic Sea-Beam data, personal commun., B. A. McGregor, 1988). Those canyons are blocked by topographic
highs that may be slide deposits, although the origin of these putative slide blocks is poorly understood highs that may be slide deposits, although the origin of these putative slide blocks is poorly
(McGregor, 1987; Twichell, 1987; Stubblefield and others, 1982; Twichell and Roberts, 1982).

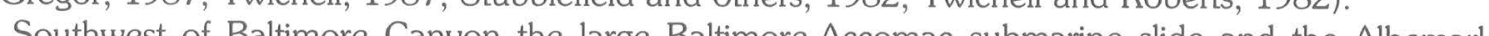
Currituck submarine slide are characterized by high backscatter in the GLORIA images (sheets 4 and 8 ) Echo-sounding profiles show hummocky topography (fig. 13) and inward-facing scarps that lie along the boundaries of the submarine slide areas in many places (fig. 14). The depression of the slide regions indicates displacement of rise sediments in addition to mass movenent of sediments that came from the continenta slope (Embley and Jacobi, 1977, 1986, Bunn and McGregor, 1980; Malahoff and others, 1980; Prior an the mass movements.

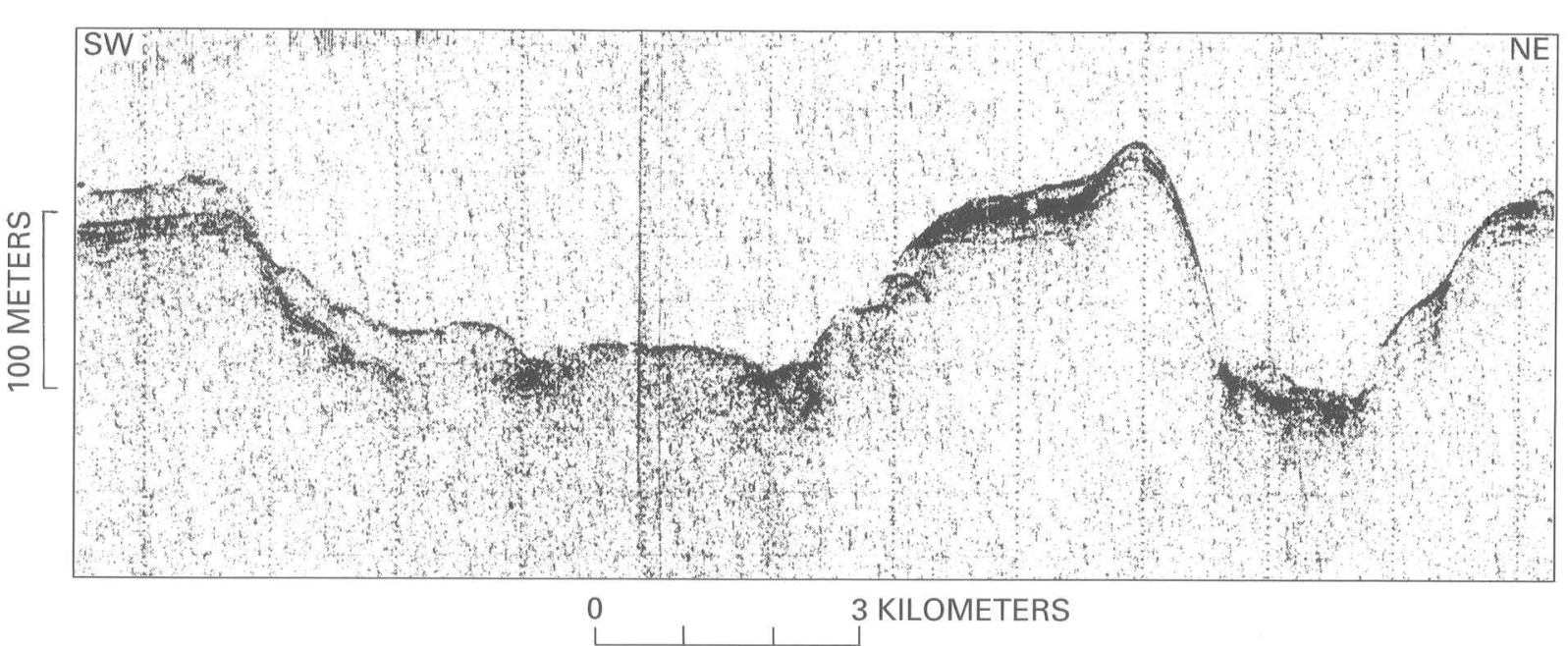

Figure 13 -Seismic profile $(3.5 \mathrm{kHz})$ showing hummocky surface of mass-wasting region on Baltimore-Accoma submarine slide, on the continental rise at about $2200 \mathrm{~m}$ water depth (sheet 8 , at approximately lat $37^{\circ} 45^{\prime} \mathrm{N}$., Iong
$73^{\circ} 25^{\prime}$ W.). Vertical exaggeration $20: 1$. Profile location on figure 26 is at Julian day 65 , time $2085-2156$ hours GMT. 


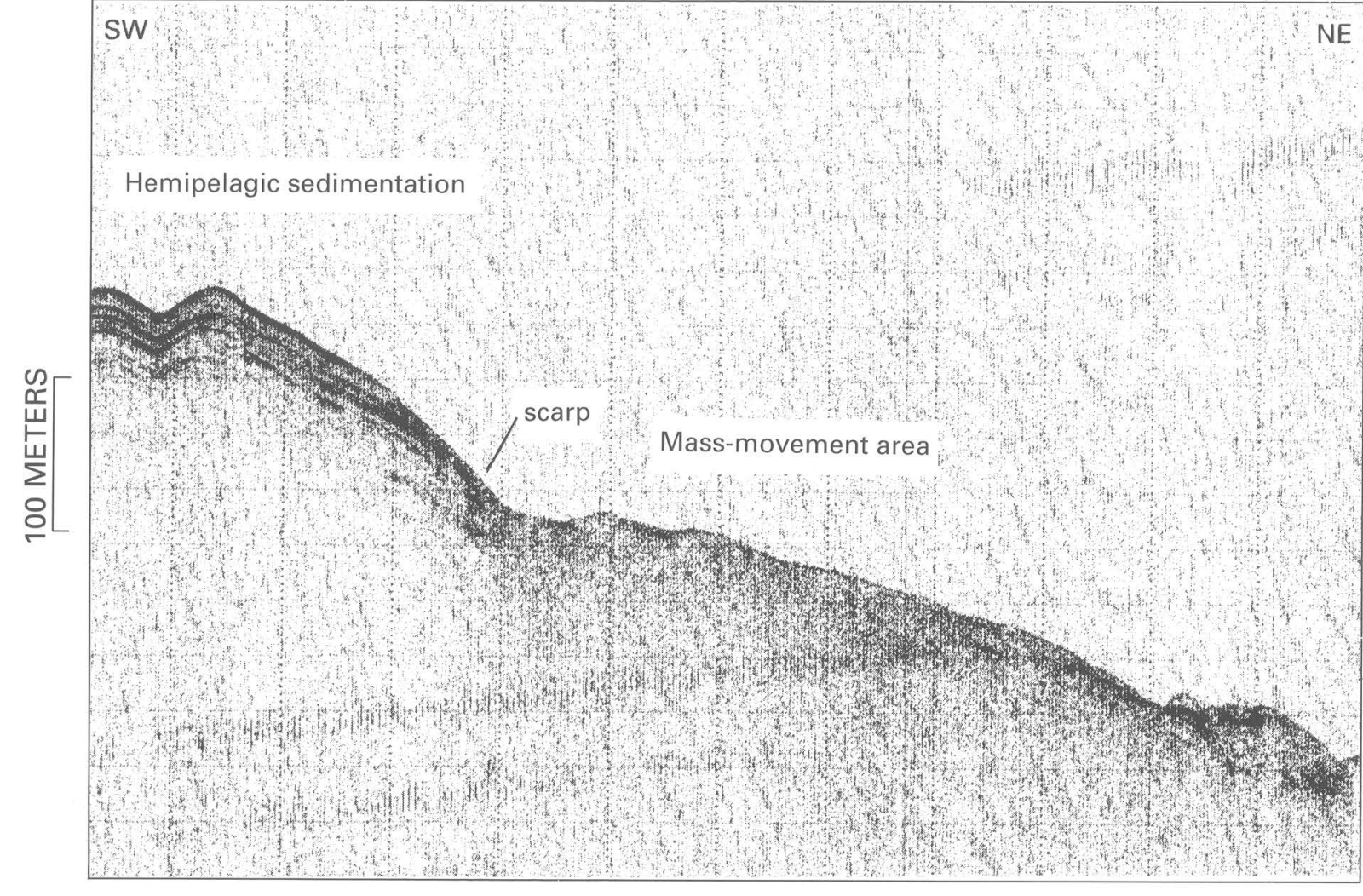

3 KILOMETERS

Figure $14-$ Seismic profile $(3.5 \mathrm{kHz})$ showing border of Baltimore-Accomac submarine slide region at about 2020
$\mathrm{~m}$ water depth (sheet 8 , at approximately lat $37^{\circ} 35^{\prime} \mathrm{N}$., long $73^{\circ} 45^{\prime} \mathrm{W}$.). Note that continental rise sediments are disturbed and that slide, is not a simple accumulation of material from the continental slope. Vertical exaggeration
$21: 1$. Profile location on figure 26 is at Julian day 65, time $1850-2000$ hours GMT.

Near the EEZ boundary is a small, isolated, sediment-covered seamount, Knauss Knoll (Lowrie and southwe contrasts with sediment drift (the Krause foredrift [Lowrie and Heezen, 1967]) to the notheast.

The Carolina Slope and Rise

The continental slope off North Carolina is generally steeper than the continental slope to the north because it is swept more strongly by the south-flowing Western Boundary Undercurrent. The slope declivity averages $7^{\circ}$, reaching a maximum of about $16^{\circ}$ off Cape Hatteras and decreasing to an inclination of only
about $3.5^{\circ}$ where it joins the Blake Ridge at about lat $32^{\circ} 30^{\prime} \mathrm{N}$. This change in slope angle is clearly evident in the GLORIA images because sedmentary processes action the slope are related to sea-floor inclination. highly dissected by canyons reflecting processes dominated by mass wasting (sheets 8,11 angle is steep, is canyons are steep chutes cut into Pleistocene clays and sands, and older rocks of Late Cretaceuse Paleogene age are exposed on the floors of many of them. East of anpe Her ras, the steep slope and stron currents also have caused older rocks to crop out on the sea floor between canyons. Both canyon walls and outcropping indurated strata that faced the GLORIA detector produced bright returns on the sonar image South of lat $34^{\circ} \mathrm{N}$., the continental slope is less steep and is not cut by canyons. However, slope failure evident in a large slump scar on the lower slope centered at lat $33^{\circ} \mathrm{N}$., long $76^{\circ} \mathrm{W}$. (Cape Fear slide, shee sedimentary process and the slope is mantled with a blanket of finely layered Pleistocen is the dominan (15):

Two major canyon systems, Hatteras Canyon and Pamlico Canyon, have cut deep valleys across the upper continental rise that terminate on the lower continental rise in depositional fans that are characterized
by transverse sediment waves (sheets 12 and 16). Between the canyons the bottom sediment consists chiefly of poorly reflective, layered hemipelagic ooze that drapes the bathymetric irregularities and produces a dark Non the sonar image.

Hrbidite fan that fills a broad on sheet 12 , another canyon system converges on the lower rise into a large Sediment flowing from the canyons and debris flows from adjacent slumps all merge on the lower rise into a turbidite debris apron that flows into and down the southwest-oriented Hatteras Transverse Canyon to terminate in a major fan, the Hatteras Cone (Cleary and Conolly, 1974), south of the Hatteras Ridge (sheets

The continental slope and upper rise off North Carolina exhibit some of the largest slope failures to be $22 \mathrm{~km}$ long. 7 to $12 \mathrm{~km}$ wide, and $300 \mathrm{~m}$ thick (Bunn and McGregor, 1980; Popenoe and others, 1982; and Prior and others, 1986). Debris flows from this slump can be clearly traced in the GLORIA images from the scar on the slope for $300 \mathrm{~km}$ across the rise (sheets 8,12 and 13) to where they merge with other debris flows and fan deposits that funnel into the Hatteras Transverse Canyon. The large debris flow from the Albemarle-Curntuck slide had earlier been traced by its seismic acoustc ches (Embley and Jacobi, 1977; Embley, 1980). The Cape Fear slide (sheet 15) involved sope thi

Can to $38 \mathrm{~km}$ wide and up 1980; Popenoe and others, 1982; Cashman and Popenoe, 1985; Embley and Jacobi, 1986) are clearly visible on the GLORIA image as a dark line. Failure of discrete layers of the upper continental slope above this complex (Embley, 1980, Carpenter, 1981; Popenoe and others, 1982) are also visible in the GLORIA image but less distinctly. Debris flows from the scar area can be traced across the continental rise for over 250
$\mathrm{~km}$ as a bright reflection return. At the eastern edge of the surveyed area (sheet 16), debris from the Cape

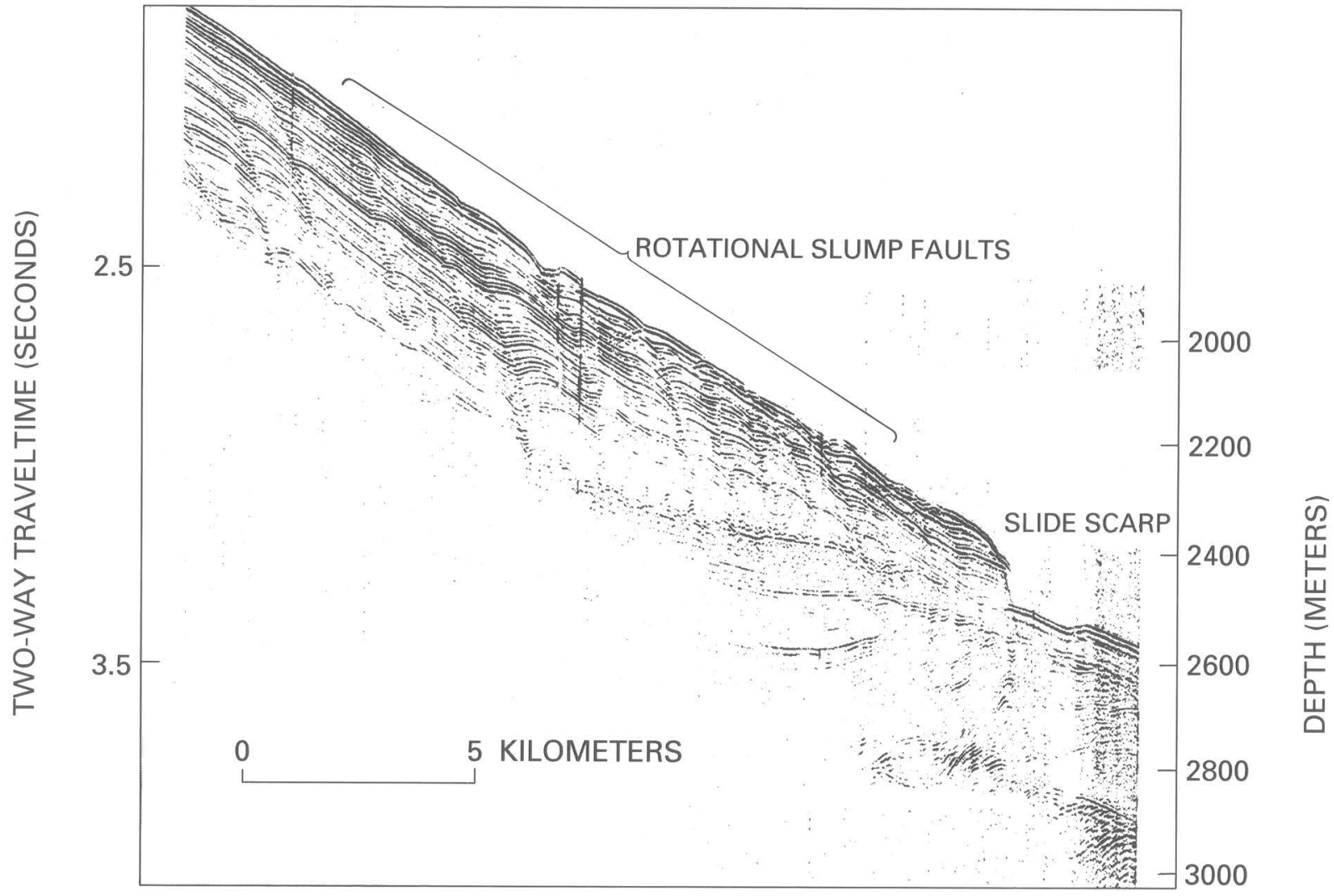

Figure 15 -Single-channel sismic-reflection profile (airgun) across the scarp of the Cape Fear slide off North
Carolina (sheet 15). The slide scarr at this crossing truncates $60 \mathrm{~m}$ of strata on the lower Carolina (sheet 15). The slide scarp at this crossing truncates $60 \mathrm{~m}$ of strata on the lower continental slope.
Rotational slump faults upslope of the scarp are probably caused by the removal of support at the base of the slope
by the slide. Vertical exaggeration 11:1. Illustration from Popenoe and others (1982).
Fear side flows across earlier debris from the Cape Lookout slide and other sources to the north, indicating

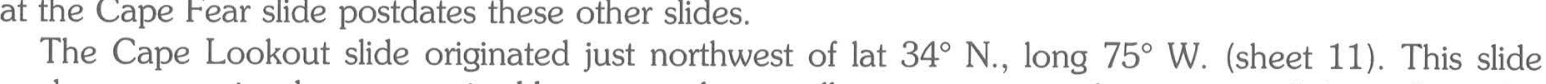
complex was previously unrecognized because only a small scarp occurs on the continental slope above the

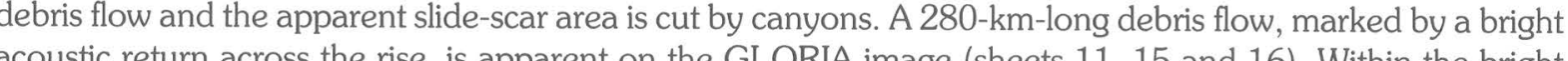
return area the bottom exhibits the fuzzy and transparent acoustic character that in $3.5-\mathrm{kH}$. Weismic profiles is characteristic of mass movement debris. The debris flow has cut a shallow trough that truncates hemipelagic 作 that the small upslope failure may have triggered the much larger, $36-\mathrm{km}$-wide failure on the upper rise (sheet A smaller slump scar and associated debris flow (the Hatteras slide) is present at lat $35^{\circ} 57.5^{\prime} \mathrm{N}$., long on the upper rise at the base of the continental slope.

The Hatteras Ridge, Lower Rise Hills, and Blake Ridge

The Hatteras Ridge, a major transverse barrier that deflects turbidity currents into the Hattera ransverse Canyon, is a prominent feature along the eastern margin of the surveyed area off North Carolin continental slope and is believed to be built of current-drifted sediments, chiefly muds and silts calle contourites, that became trapped in the shear zone between contour-following currents, the northeast-flowing Gulf Stream and the southwest-flowing abyssal Western Boundary Undercurrent (Tucholke and Laine, 1982). Large sediment waves, known as the Lower Rise Hills, characterize the southeast flank of the Hattera GLORIA image owing to the contrasting acoustic return of slopes facing toward and away from the don the A still larger sediment driff formed by the Western Boundary Undercurrent the Blake Ridge (Mark and hers, 1970; Markl and Bryan, 1983), occupies much of sheets 15, 19 and 20. The Blake Ridge is almo $2000 \mathrm{~m}$ high at its seaward end and forms a major bathymetric ramp on the rise that projects southeastwar from the conthental slope. Over much of its extent on the GLORIA image the Blake Ridge exhibits moncthe (1)

Scour-exposedic contrast is dependent on hardness and surface roughness, the acoustic return produced on the Blake Ridge (sheets 15, 19 and 20) differs considerably. For instance, there of sheet 19, and an area of alternating light and dark returns at the southwest corner of sheet 16 Seismic-reflection data show that both of these areas are underlain by outcropping erosion-resistant strat that have a rough surface expression. In contrast, outcropping strata on the ridgecrest and areas of smoothly reas of deposition on the Blake Ridge.

The Blake Plateau

The Blake Plateau lies off Florida, Georgia, South Carolina and North Carolina (sheets 14, 15, 18 an 21). The plateau is intermediate in water depth $(400$ to $1250 \mathrm{~m})$ between the Florida-Hatteras Shel generally 0 to $80 \mathrm{~m}$ in depth) and the upper continental rise (2000 to $4000 \mathrm{~m}$ ).

The Blake Plateau has formed since the early Tertiary when the strong Florida Current first began to flow through the Straits of Florida across what was then a deepwater continental shelf, thus cutting off the supply (a) continent-deitved sediment to the outer shelf (Paull arid Dillon, 1980). Since that time, sediment

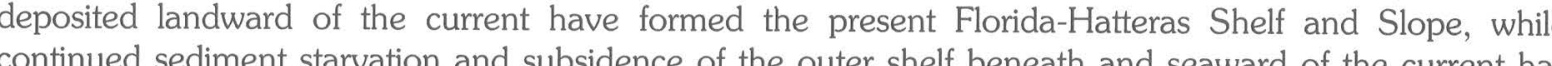
formed the Blake Plateau. Although some sediments were deposited on the outer Blake Plateau in the later Tertiary the combined flow of the Florida Current and the Antilles Current which merge over the souther Blake Plateau to form the Gulf Stream, have prevented most deposition over the plateau and have deeply scoured the bottom.

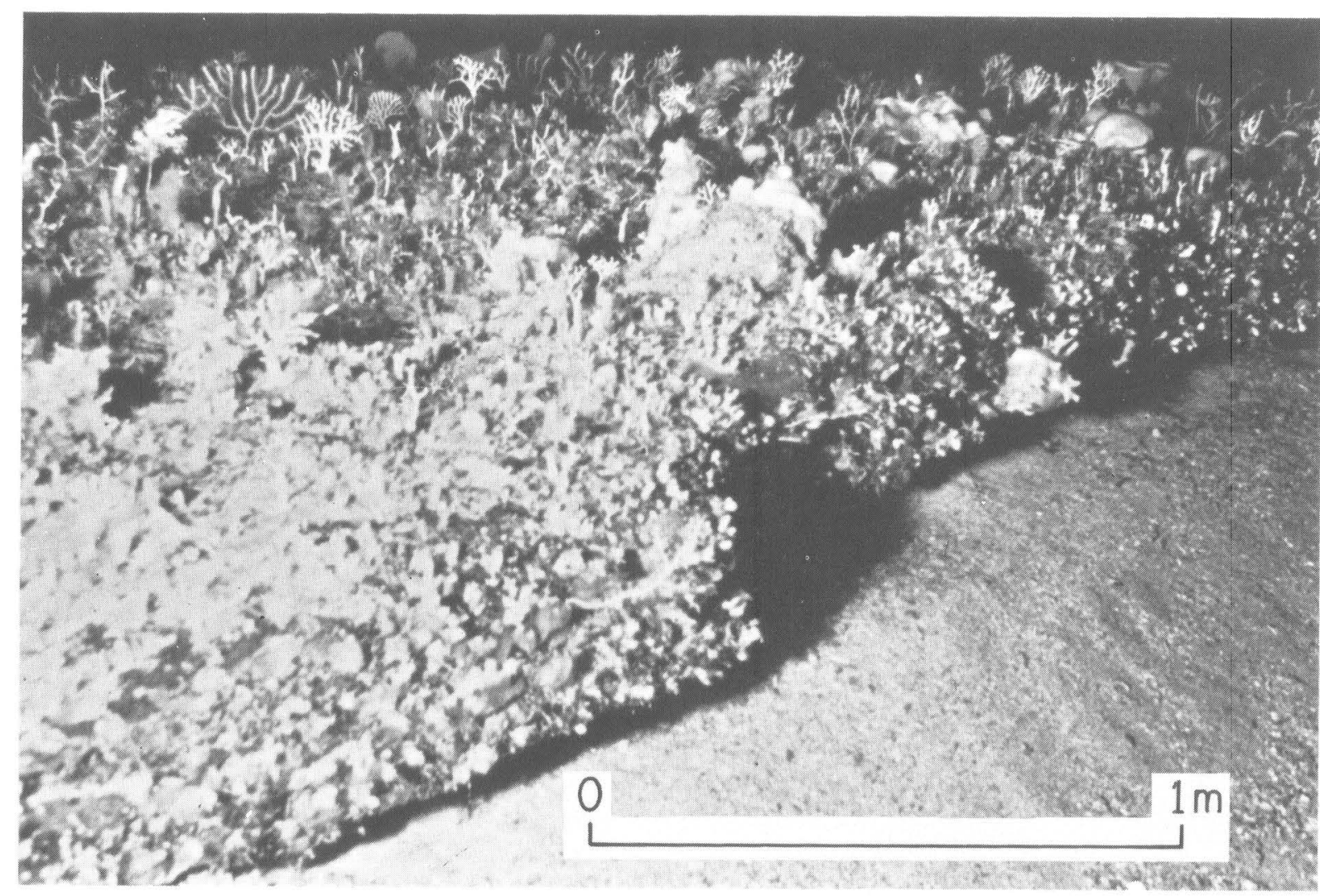

Figure 16-View of the sea floor at about $500 \mathrm{~m}$ depth on the northern Blake Plateau (sheet 18). A

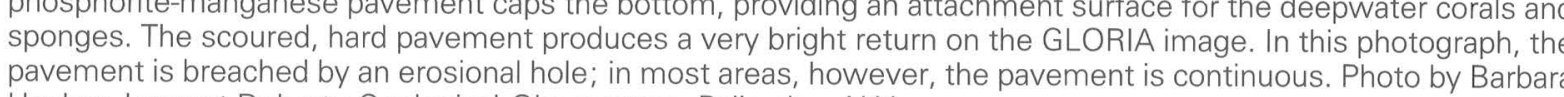

The northern Blake Plateau forms a prominent structural and bathymetric ramp known as the Charleston Bump (sheets 14 and 18) that developed over an offset in the original crustal rift along which the $1250 \mathrm{~m}$ but between $1031^{\circ} \mathrm{N}$ and $32^{\circ} \mathrm{N}$ ( $1250 \mathrm{~m}, \mathrm{bu}$ burent $\mathrm{s}$. Charleston Bump is a highly scoured area within which consolidated limestones and calcareous silsto the Cretaceous and Paleogene age are expsed by both erosion and nondeposition. The bottom is also capped in the scour area by a thin (less than $0.5 \mathrm{~m}$ ) layer of cemented phosphatic lag gravel (fig. 16) that has bee winnowed by currents from bottom sediments and impregnated and capped by a manganese oxide rind (Manheim and others, 1980). The GLORIA image shows this scoured, hard bottom as an extremely brigh return area. The pavement-capped area is broken only by linear bright streaks that represent slopes of large These valleys are not well mapped on the present bathymetric map of the plateau (sheets 14 and 18 ) and A). These holes, which lie on the flat sea floor at the base of the Charleston Bump, are over $150 \mathrm{~m}$ deep and resemble sinkholes, although they are probably related to bottom scour by current

deepwe deepwater corals and sponges attlach (fig. 16). Over most of the Blake Plateau, coral and sponge colonies are
associated with pavement and are not separately visible on the GLORIA images; however, much of the mottling apparent in the bright-reflectance areas may represent places where the corals and sponges are more abundant, because of bottom roughness, In some locations (for instance, around the large scour hole centered at lat $32^{\circ} \mathrm{N}$., long $77^{\circ} 30^{\prime} \mathrm{W}$. on sheets 14 and 18 , and crossed by the seismic profile shown in figure 


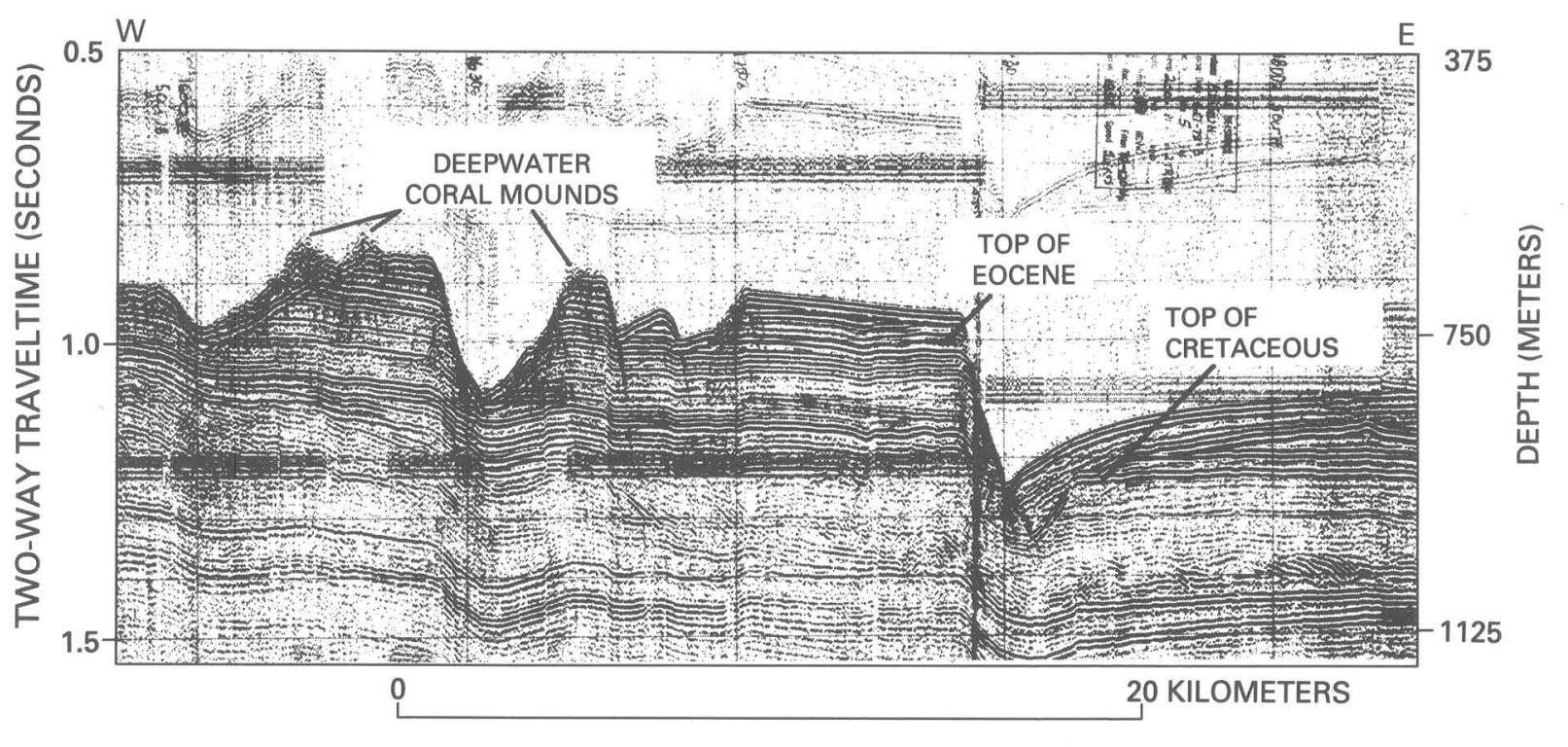

Figure 17 -Single-channel seismic-eflection profile across a part of the northern Blake Plateau, showing scouring
caused by Gulf Stream currents (also see sheeet 18 ). The deepest scour holes are about $200 \mathrm{~m}$ deep and are eroded
into gently eastward-dipping limestones of Paleogene age Vertical exalogation

17), long, linear coral banks as high as $150 \mathrm{~m}$ have developed in areas of water turbulence caused by the sea-floor irregularities. These coral banks are clearly visible on the GLORIA image as darker bands that partly
ring the edge of the scour feature. The turbulent water brings food to the coral polyps, cleans them, and flushes away metabolic waste, providing an ideal environment for their growth.

There are tonal variations on the GLORIA image over the Blake Plateau that relate to the composition produce the brightest returns. Slightly darker returns are produced by outcropping saleogene limestones induration. An example is a band of partly cemented calcareous sands of Miocene age that crosses the plateau in an east-west direction at about lat $30^{\circ} 30^{\prime} \mathrm{N}$. (sheet 18). On the same sheet, outcropping Cretaceous calcareous siltstone floors a deep valley that crosses the plateau at lat $31^{\circ} 45^{\prime} \mathrm{N}$. in an
east-northeast direction. The area of Cretaceous outcrop produces a slightly darker tone on the GLORIA image.
The darkest areas over the Blake Plateau on the GLORIA image are found where scour is less intense and where unconsolidated post-Miocene calcareous sands and ooze compose the bottom. These deposiseveral large north-south-oriented scour hols area is on sheet 18 north of lat $31^{\circ} \mathrm{N}$. at about long $77^{\circ} 30^{\prime}$ W. Unconsolidated sand is characteristic of the entire bottom north of lat. $33^{\circ} \mathrm{N}$., which lies downcurrent of and in the lee of the Charleston Bump. Here, reduced bottom-current intensity caused by both frictional loss and deflection of the Gulf Stream by the Bump allows some deposition to occur. The dark return areas on the deeper part of the plateau south of the
Charleston Bump (sheets 18 and 21 south of lat $30^{\circ} 30^{\prime}$ N.) are also produced by post-Miocene deposits.

\section{The Blake Escarpment}

Off the southern Blake Plateau, east of Florida, the transition from the plateau edge (about $1250 \mathrm{~m}$ deep) to oceanic depths $(5000 \mathrm{~m})$ is unusually abrupt. This rapid change from continental margin to deep-sea basin occurs at the undersea cliff known as the Blake Escarpment (fig. 28 on p. 12). The part of the Blake Escarpment that is within the U.S. EEZ consists of three main morphologic zones. The northern zone, which lies approximately between lat $29^{\circ} 45^{\prime}$ and $30^{\circ} 15^{\prime} \mathrm{N}$., forms the walls of the Blake Spur, a salient of the Blake Plateau that extends eastward of the rest of the plateau (sheets 19 and 21 ). The central morphologic zone
is the canyon-incised region that lies between about lat $29^{\circ} 45^{\prime}$ and $29^{\circ} 05^{\prime} \mathrm{N}$ ( (sheet 21), and the southern zone is an almost linear section that extends south to lat $27^{\circ} 50^{\prime} \mathrm{N}$. (sheet 21).

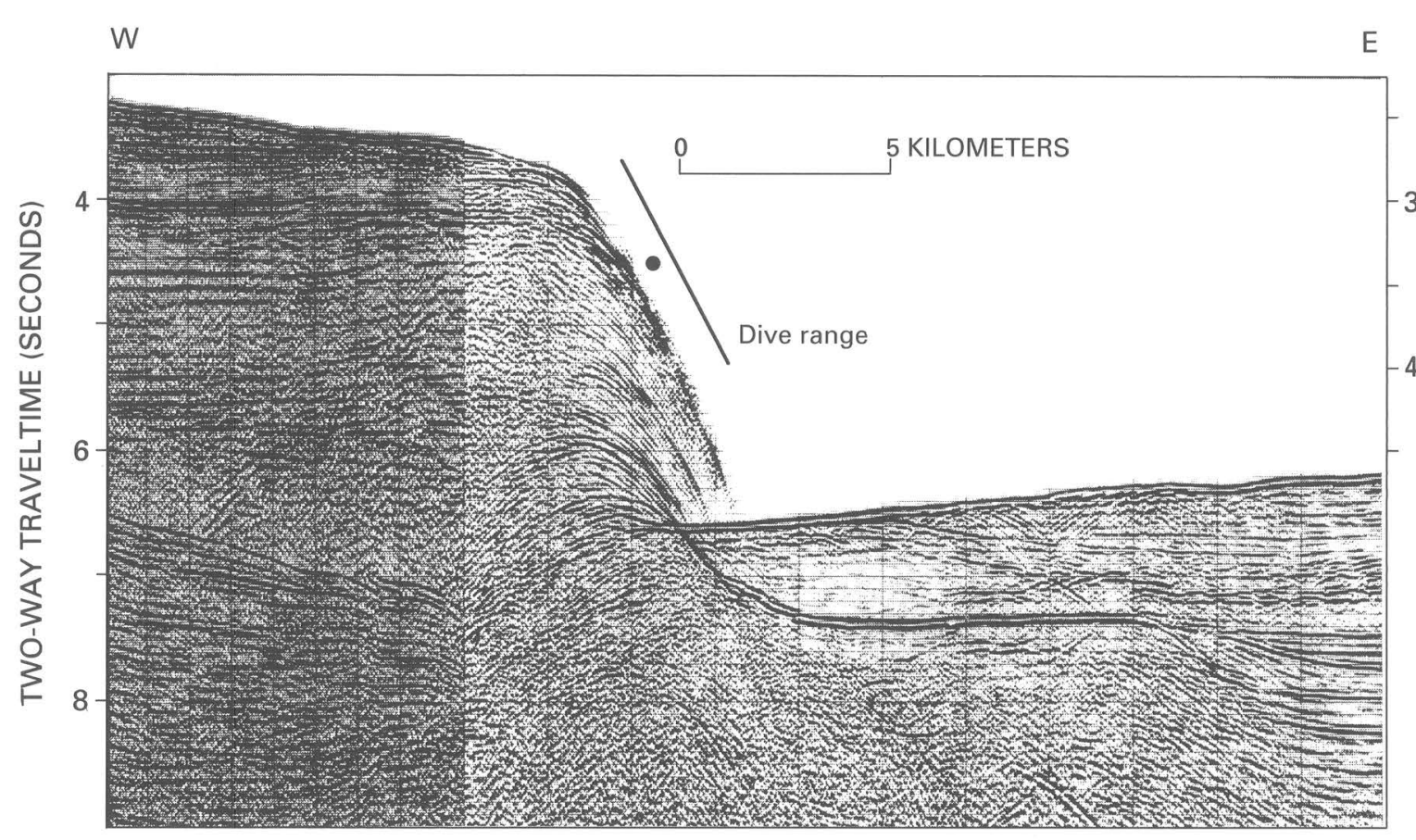

Figure 18-Multichannel seismic-reflection profile extending east from the Blake Spur to the Blake Basin (sheet
19). A buried eroded bench at $7.3-5$ two-way traveltime is continuous with an eroded unconformity that extends over much of the western North Atlantic basin (Dillon and others, 1985 ). The dive range covered by the research submersible A/vin is indicated and the depth of
dot. Alvin's maximum depth capability is $4 \mathrm{~km}$.

In the Blake Spur zone the escarpment is steepest, so that seismic-reflection profiles commonly show echo returns generated only near the top of the escarpment, because reflections from the lower part of the escarpment are covered by the reflections from the top (fig. 18). Dives made in the research submersible Alvin at he sprovith an indication that the clift has formed by erosion rather than by accumulation, because the front of a

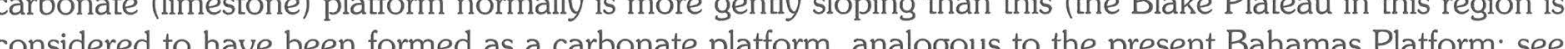
Dillon and Popenoe 1988. The strong subbottom retlector seawarc of the escarpment (tig 18) is considered to represent a buried bench that was formed during erosional retreat of the escarpment by more than $10 \mathrm{~km}$. The truncation of reflectors that represent strata near the sea floor in this profile also is evidence for a more recent episode of erosion that probably continues today. Figure 19 is a diagram summarizing the indications (sheet 21).
(shesion the In the central morphologic zone, south of the Blake Spur, the Blake Escarpment is extensively dissected by canyons and gullies (sheet 21 and fig. 20). These canyons are possibly relict from a time when the Blake Plateau surface was near sea level and large amounts of carbonate sediment were being created and passed
through these chutes to the deep-sea floor. This episode of a shallow-water Blake Plateau probably ended at the end of Early Cretaceous time, about 100 million years ago. Comparison of seismic profiles to the at the end of Early Cretaceous time, about 100 million years ago. Comparison of seismic profiles to the
GLORIA image (sheet 21) indicates that, particularly on the lower continental slope, bright reflections in the image are characteristic of canyon floors. This could be caused by relatively coarser sediments covering the floors-which would suggest that the canyons are sill somewhat active - or by bare limestone exposed on he floors.

A band of stronger reflections also extends along the uppermost part of the escarpment in the canyon-incised zone. This band represents a part of the escarpment that is steeper than that below, and where the limestone strata of the escarpment are exposed. The canyons do not extend into this sediment once collected on the plateau and spilled over the edge, the system that channeled them is gone, modified by Cenozoic erosion and deposition.

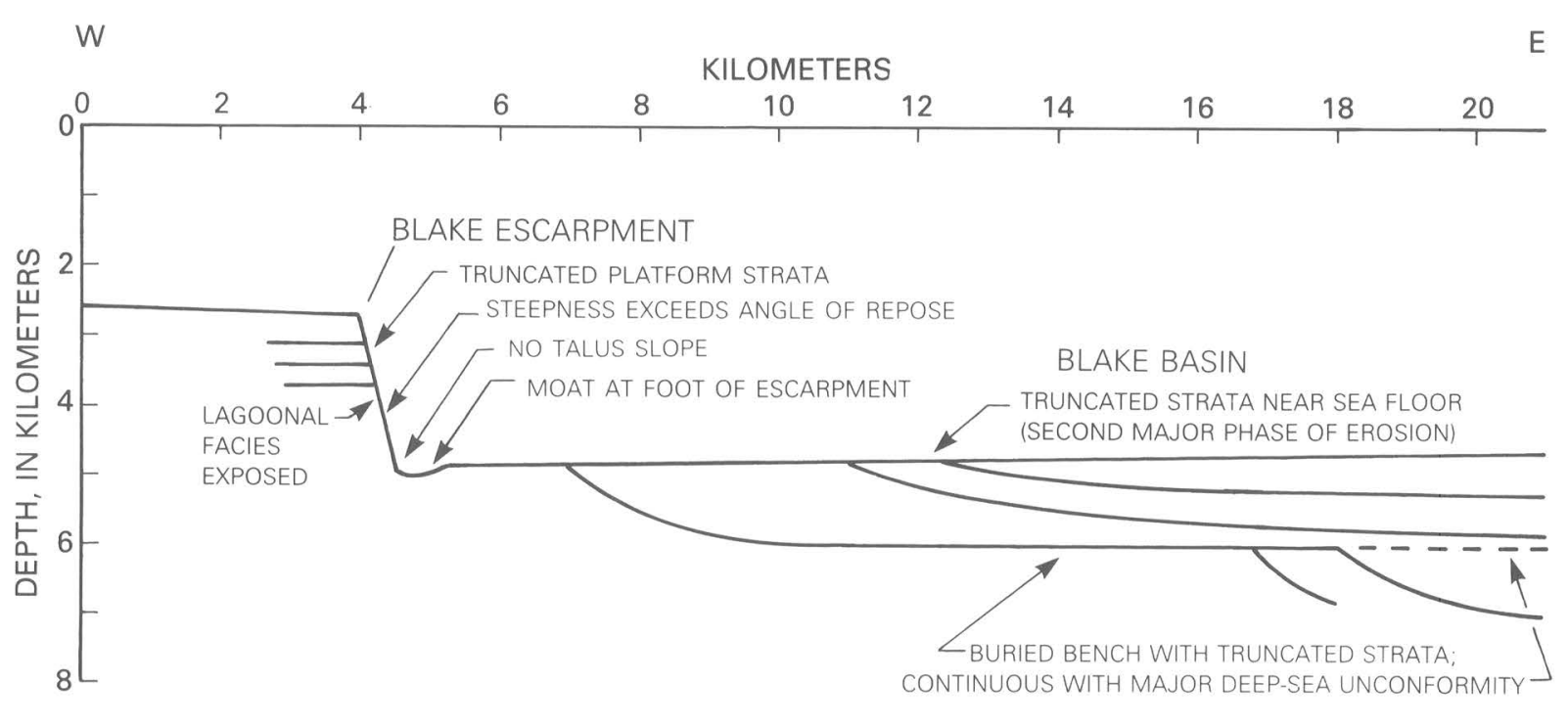

Figure 19-Diagram showing features of the Blake Escarpment and nearby Blake Basin that provide evidence for

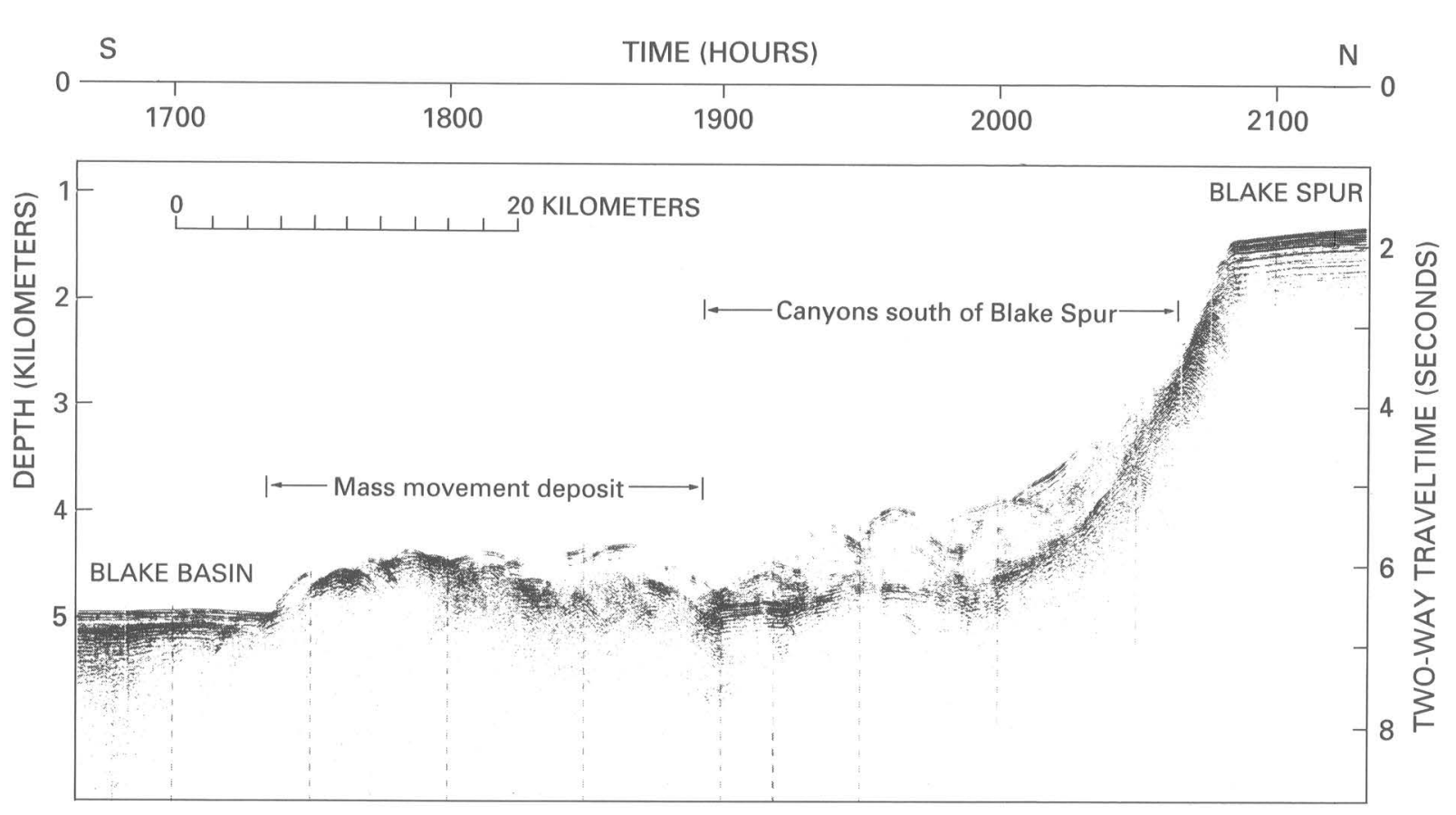

Figure 20 -Single-channel seismic-reflection profile extending south from the Blake Spur and crossing the canyons
south of the spur and a large mass-movement deposit before reaching the Blake Basin. The canyons display

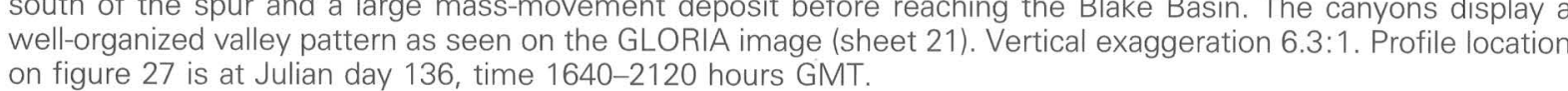

Within the central zone is a large collapse deposit located approximately between lat $29^{\circ} 10^{\prime} \mathrm{N}$. and 29. $25^{\prime} \mathrm{N}$. (sheet 21). Canyons seem to have formed around this deposit, suggesting that it predates then perhaps covered by pelagic deposits, except for one bright area that may mark the site of a more recent slump.

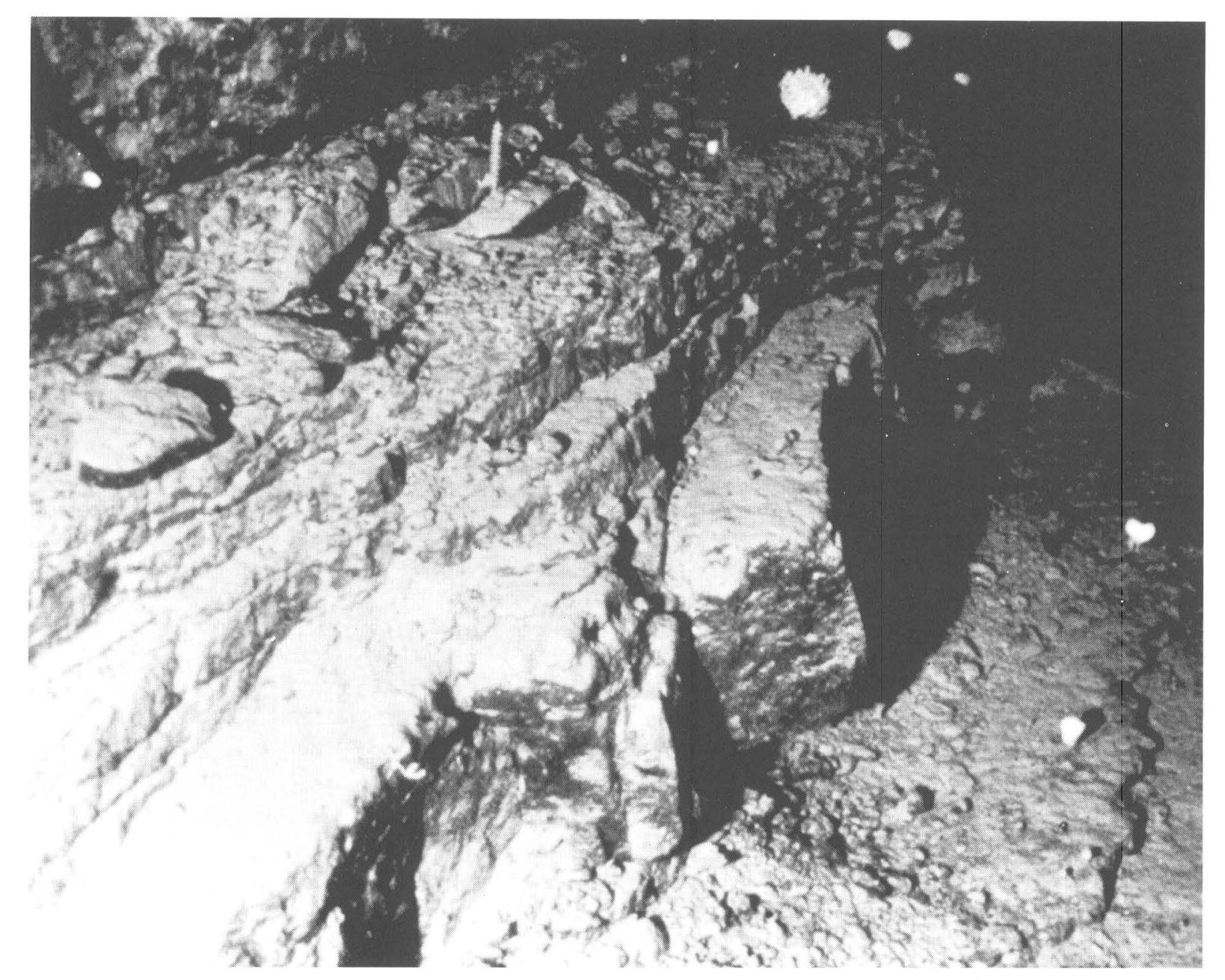

Figure 21-Face of the Blake Escarpment, photographed from the research submersible Alvin. The height of outcrop shown is about $2 \mathrm{~m}$. Such a stepped, eroded pattern to the escarpment is characteristic of the linear section
of the escarpment, south of the canyons. Steps on a very much larger scale appear on the GLORIA image (sheeet
21)
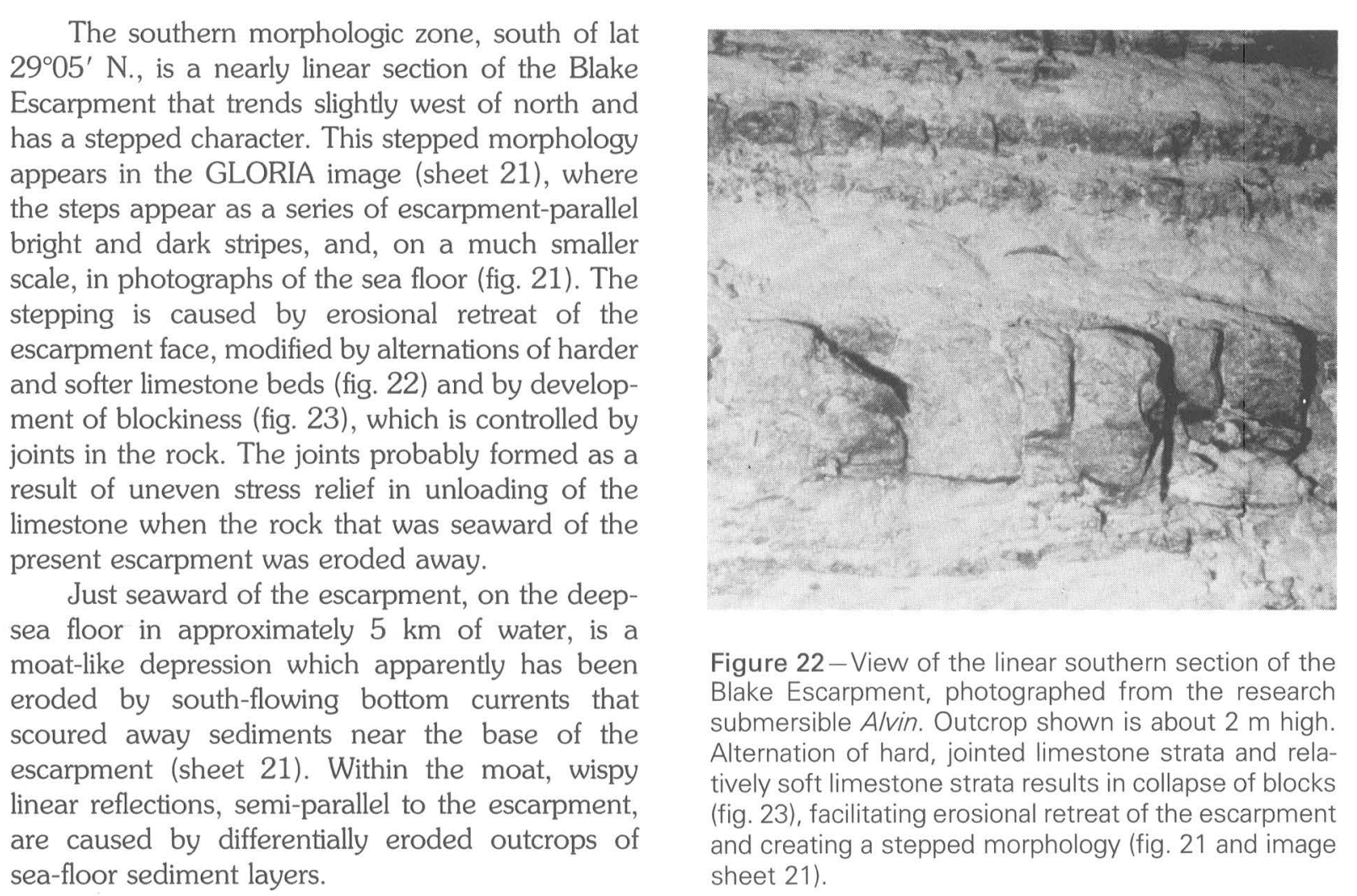

Figure $22-$ View of the linear southern section of the
Blake Escariment, photographed from the resear Blake Escarpment, photographed from the research
submersible A/vin. Outcrop shown is about $2 \mathrm{~m}$ high. Alternation of hard, jointed limestone strata and rela tively soft limestone strata results in collapse of blocks
(fig. 23), facilitating erosional retreat of the escarpment and creating a stepped morphology (fig. 21 and image
sheet 21 ) 


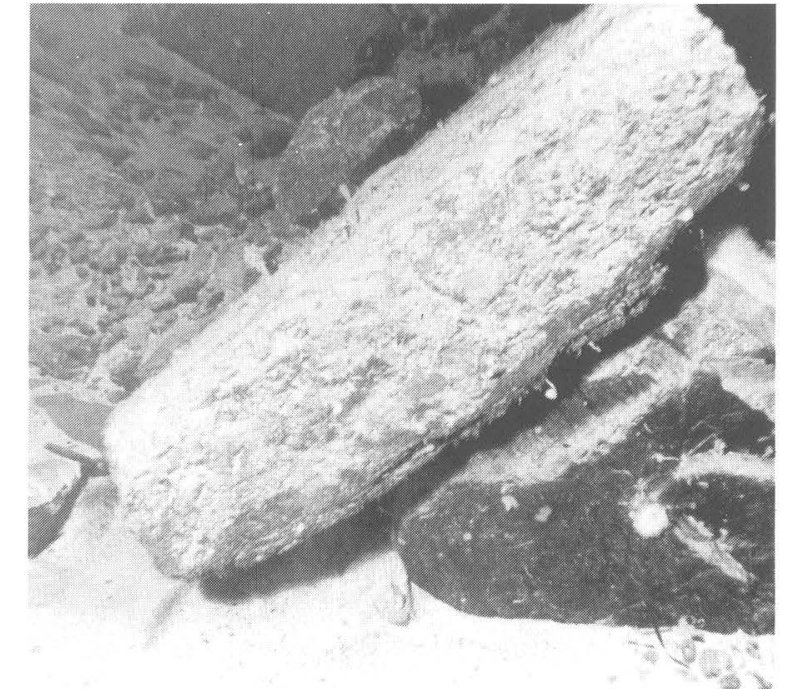

On top of the Blake Plateau, just landward of
the Blake Escarmment in the southern zone, broad northwest-trending lineations on the image appear to be caused by lange scale sedment dint deposits of varying thicknesses up to about $500 \mathrm{~m}$. Valleys (fig. 24 and sheet 21), are simply depressions between sediment accumulations and tend to appear dark in the GLORIA image. Farther north
the outermost plateau west of the canyon-incised the outermost plateau west fin the cantral zone) shows fine reflections paralle to the escarpment. They occur on the sloping outer margin of sediment-drift deposits and probably are
caused by erosion and minor slumping of the deposits. These Cenozoic pelagic sediments pre-
sumably are swept over the edge of the Blake
Plateau and provide the blanket of pelagic ooze that Plateau and provide the blanket of pelagic ooze that
partly covers the Blake Escarrment in some of its Figure 23 -Collapsed rubble resulting from erosion of
the Blake Escarmment. The block in center is about $1 \mathrm{~m}$ more gently sloping places (fig. 25)

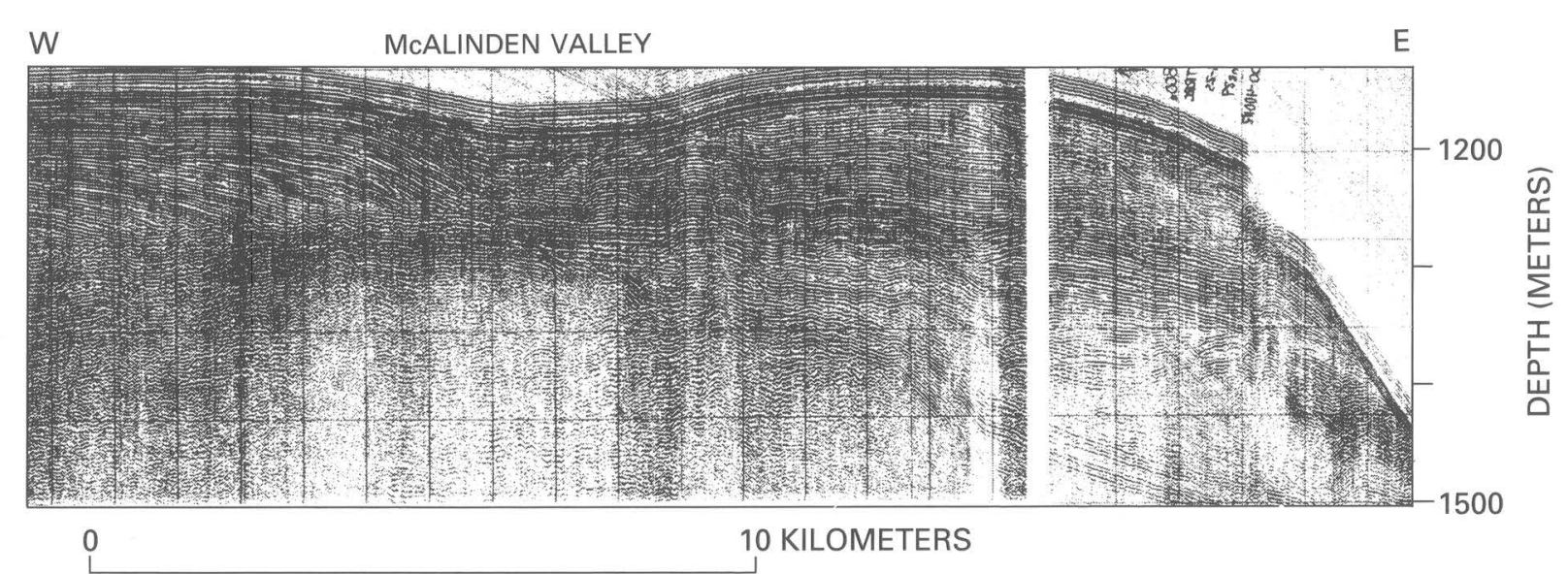

Figure $24-$ Sediment drift depsosits on the outer Blake Plateau result in valleys produced by accretion rather than
erosion, such as McAlinden Valley (sheet 211. The seismic source was a sparker. Vertical exaggeration 17:1.

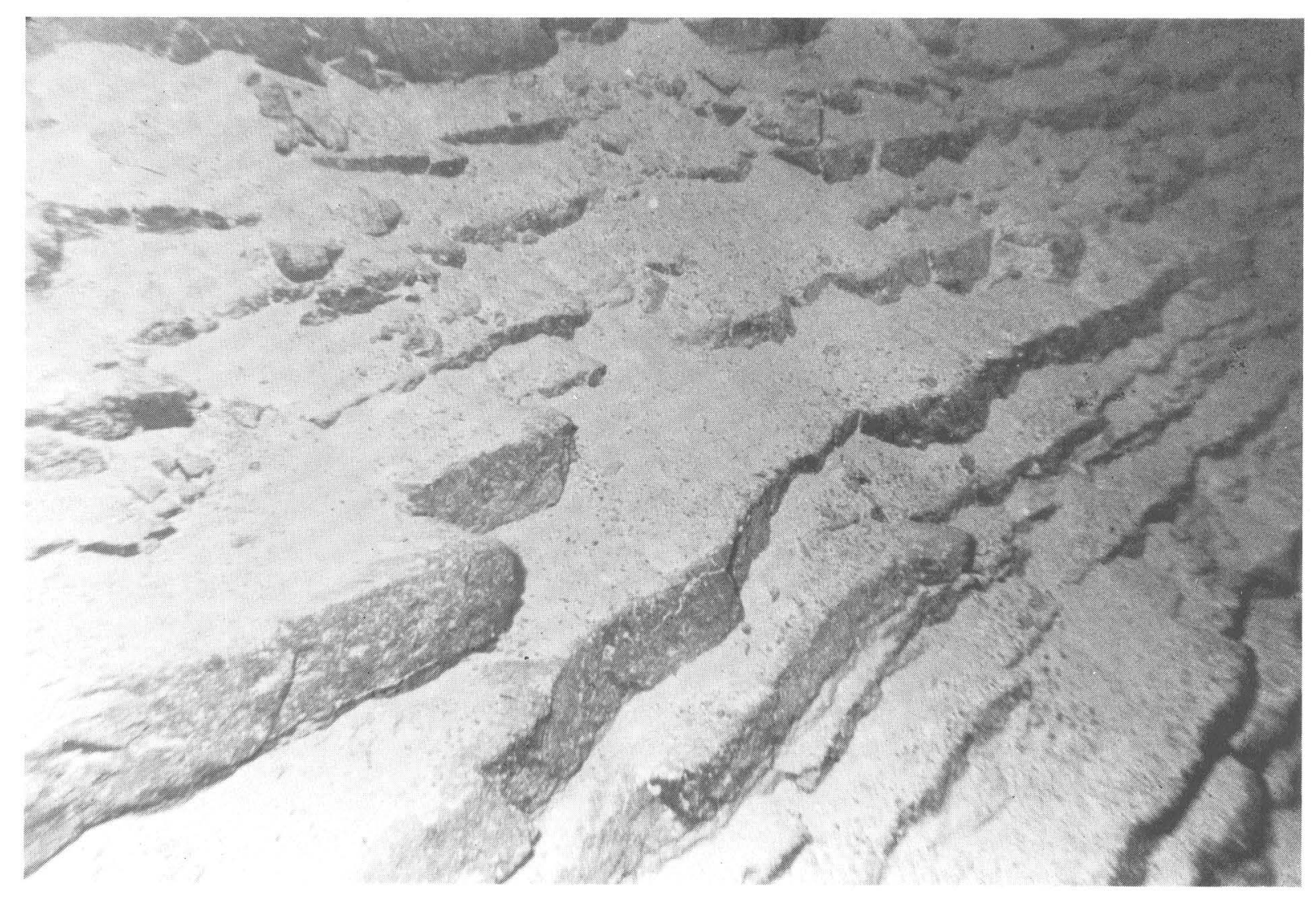

Figure 25 - Biogenic sediments, probably originally deposited on the Blake Plateau and carried over its edge, accumulate on the less-steep sections of the Blake Escarpment. Picked up by currents and swept along the face
of the escarament, they possibly aid in its erosion by grinding away the outcropping strata. The limestone steps are
perhaps $20-30 \mathrm{~cm}$ high. Photographed from research submersible A/vin.

\section{REFERENCES CITED} Bunn, A.R., and McGregor, B.A., 1980, Morphology of the North Carolina continental slope, western North
Atlantic, shaped by deltaic sedimentation and slumping: Marine Geology, v. 37, no. 3/4, p. 253-266.
Carpenter, George, 1981, Coincident sediment slump/clathrate complexes on the U.S. Atlantic continental

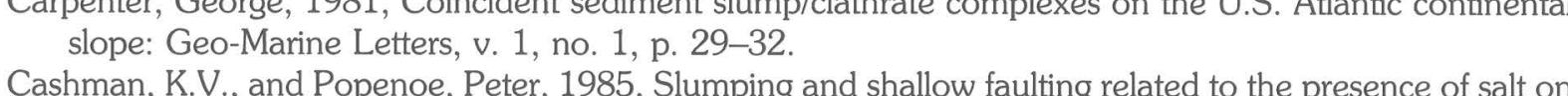
Cashman, K.V., and Popenoe, Peter, 1985, Slumping and shallow faulting related to the presence of salt on
the continental slope and rise off North Carolina: Marine and Petroleum Geology Chavez, P.S., Jr., 1986, Processing techniques for digital sonar images from GLORIA: Photogrammetric Engineering and Remote Sensing, v. 52 2, no. 8 , p. $1133-1145$.
Cleary, W.J., and Conolly, J.R., 1974, Hatteras deep-sea fan: Journal of Sedimentary Petrology, v. 44, no. 4, p. 1140-1154.

muth, J.E., Flood, R.D., Kowsmann, R.O., Belderson, R.H., and Gorini, M.A., 1988, Anatomy and growth pattern of Amazon deep-sea fan as revealed by long-range sidescan sonar (GLORIA) and
high-resolution seismic studies: American Association of Petroleum Geologists Bulletin, v. 72, no. 8, p. 885-911.

Dillon, W. P. Paull, Chey, 1981, Gazetteer of undersea features, 3rd edition: Washington, D.C. Blake. Paull, C.K., and Gilbert, L.E., 1985, History of the Atlantic continental margin off Florida-the Blake Plateau Basin, in Poag, C.W., ed., Geologic evolution of the United States Atlantic margin: New

lon, W.P., and Popenoe, Peter, 1988, The Blake Plateau Basin and Carolina Trough, in Sheridan, R.E., Boulder, Colo., Geological Society of America, p. 291-328, (The of The geology of North America: [DNAG] Project.)

Duncan, R.A., 1984, Age progressive volcanism in the New England Seamounts and the opening of the

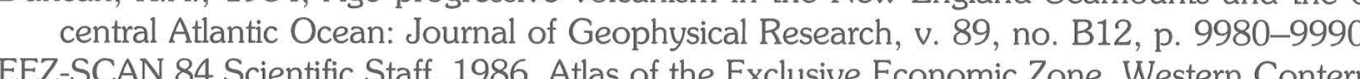

列 84 Scientific Staff, 1986, Atlas of the Exclusive Economic Zone, Western Conterminous United States: U.S. Geological Survey Miscellaneous Investigations Series I-1792, 152 p., scale 1:500,000.
EEZ-SCAN 85 Scientific Staff, 1987, Atlas of the U.S. Exclusive Economic Zone. Gulf of Mexico and Eastent Caribbean Areas: U.S. Geological Survey Miscellaneous Investigations Series I-1864-A,B, 162 p. scale 1:500,000.
1980, The role of mass transport in the distribution and character of deep-ocean sediment Embley, R.W., 1980, The role of mass transport in the distribution and character of deep-oce
with special reference to the North Atlantic: Marine Geology, v. 38, no. 1/3, p. 23-50

Embley, R.W., and Jacobi, R.D., 1977, Distribution and morphology of large submarine sediment slides on Atlantic continental margins: Marine Geotechnology, v. 2, p. 205-228. (Marine Slope Stability volume North Atlantic region, v. M of The geology of North America: Boulder. Colo, Geological Society of

America, p. 479-490. (The Decade of North American Geology [DNAG] Project.)
Emery, K.O., and Uchupi, Elazar, 1972, Western North Atlantic Ocean: Topography, rocks, structure, water

life, and sediments: American Association of Petroleum Geologists Memoir 17, 532 p.

Farre, J.A., McGregor, B.A., Ryan, W.B.F., and Robb, J.M., 1983, Breaching the shelffreak: passage from youthful to mature phase in submarine canyon evolution: Society of Economic Paleontologists and Garrison, L.E., Kenyon, N.H., and Bouma, A.H., 1982, Channel systems and lobe construction in the Mississippi fan: Geo-Marine Letters, v. 2, nos. 1 and 2, p. 31-39.

Grow, J.A., Klitgord, K.D., and Schlee, J.S., 1988, Structure and evolution of Baltimore Canyon Trough, in North America: Boulder. Colo. Geological Society of America, p. 269-290. (The Decade of North

American Geology [DNAG] Project.)
Hampson, J.C., Jr., and Robb, J.M., 1987, The Hudson River system as a migrating source for continental slope and rise deposits [abs.]: Society of Economic Paleontologists and Mineralogists Annual Midyea GA, Division 1, Working Gion

1986, International Geomagnetic Reference Field revision 1985: Eos (American Geophysical Union Transactions), v. 67, no. 24., p. 523

gord, K.D., Hutchinson, D.R., and Schouten, Hans, 1988, U.S. Atlantic continental margin-Structural and tectonic framework, in Sheridan, R.E., and Grow, J. A., eds., The Atlantic continental margin: U.S.,
v. I-2 of The geology of North America: Boulder, Colo., Geological Society of America, p. 19-55. (The Decade of North American Geology [DNAG] Project.)

Klitgord, K.D., and Schouten, Hans, 1986, Plate kinematics of the central Atlantic, in Vogt, P.R., and Tucholke, B.E., eds., The western North Atlantic region, v. M of The geology of North America: Boulder,

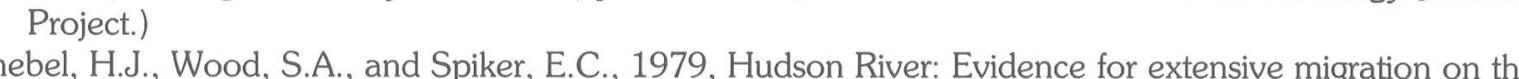
exposed continental shelf during Pleistocene time: Geology, v. 7, no. 5, p. 254-258

e, E.P., Damulh, J.E., and Jacobi, Robert, 1986, Surticial sedimentary processes revealed by echo-character mapping in the western North Atlantic Ocean, in Vogt, P. R., and Tucholke, B.E., eds. The western North Atlantic region, v. M of The geology of North America: Boulder, Colo., Geologic Lowrie, Allen, Jr., and Heezen, B.C., 1967, Knoll and sediment drift near Hudson Canyon: Science, v. 157, no. 3796, p. $1552-1553$

Malahoff, A., Embley, R.W., Perry, R.B., and Fefe, C., 1980, Submarine mass-wasting of sediments on the continental slope and upper rise south of Baltimore Canyon: Earth and Planetary Science Letters, v. 49 no. 1, p. 1-7.

Manheim, F.T., Pratt, R.M., and McFarlin, P.F., 1980, Composition and origin of phosphorite deposits of the Blake Plateau, in Bentor, Y.K., and Scripps Institution of Oceanography, eds., Marine phosphoritesgeochemistry, occurrence, genesis: a symposium held at the 10th International Congress on Sedimen-
tology, Jerusalem, Israel, July 9-14, 1978: Society of Economic Paleontologists and Mineralogists Special Publication no. 29, p. 117-137.

Manspeizer, Warren, and Cousminer, H.L., 1988, Late Triassic-Early Jurassic synnift basins of the U. S Atlantic margin, in Sheridan, R. E., and Grow, J.A., eds., The Atlantic continental margin: U.S., v. I-2
of The geology of North America: Boulder Colo, Geological Society of America, p. 197-216. (The Decade of North American Geology [DNAG] Project.) Markl, R.G., Bryan, G.M., and Ewing, J.I., 1970, Structure

Research, v. 75, no. 24, p, 4539-4555 Markl, R.G., and Bryan, G.M., 1983, Stratigraphic evolution of Blake Outer Ridge: American Association of Petroleum Geologists Bulletin, v. 67, no. 4, p. 666-688

McCave, I.N., and Tucholke, B.E., 1986, Deep current-controlled sedimentation in the western North of North America: Boulder. Colo., Geological Society of America, p. 451-468. (The Decade of North American Geology [DNAG] Project.)

McGregor, B.A., 1987, Diversity of processes and morphology on the U. S. Atlantic continental slope and rise, in Folger, D.W., and Hathaway, J.C., eds., Conference on continental margin mass wasting an Pleistocene sea-level changes, August 13-15, 1980: U.S. Geological Survey Circular 961, p. 21-35.

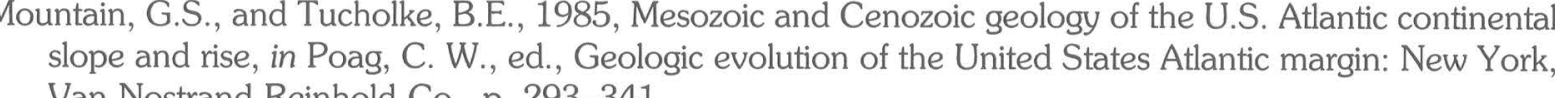
National Ocean Survey, 1972, Beaufort: Bathymetric Map NI 18-4, scale 1:250,000

1975, Hudson Canyon: Bathymetric Map NJ 18-3, scale 1:250,000 1976, Jacksonville: Bathymetric Map NH 17-5, scale 1:250,000. 1977, Wilsugton Canyon. Bathymetric Map NJ 18-6, scale 1:250,000 1978b, Soyt Hils. Bathyntic Map NH 17-3, scale 1:250,000. 1978c Harrington Hill. Bathymetric Map NH 18-1, scale 1:250,000 1978d, McAlinden Spur: Bathymetric Map NH 18-7, scale 1.250,000. 1978e, Chincoteague: Bathymetric Map NJ 18-8, scale 1:250,000. 978f, Currituck Sound: Bathymetric Map NJ 18-11, scale 1:250,000 1978g, Richardson Hills: Bathymetric Map NI 18-10, scale 1:250,000 1978i, Block Island Shelf: Bathymetric Map NK 19-10, 19ane 1.250. 1978; Hock 1978k Ludonia Canyon. Bathymetric Man NK 19-12 scale 1.250,000 1979a, Blake Spur: Bathymetric Map NH 18-4, scale 1:250,000. 1979b, Pillsbury: Bathymetric Map NH 17-12, scale 1:250,000. 1979c, James Island: Bathymetric Map N1 17-12, scale 1:250,000 1980a, Adams: Bathymetric Map NH 17-9, scale 1:250,000. Bathymetric Map NL 18-2, scale 1:250,000 1980b. Russell: Bathymetric Map NI 18-5, scale 1:250,000. 1.250 .000 1980c, Marmer: Bathymetric Map NI 18-8, Scale 1:250,000 980, Baltimore Rise: Bathymetric Map NJ 18-9, scale 1:250,000 980e, Hyman: Bathymetric Map NJ 18-12, scale 1:250,000. 1980, Veatch Canyon: Bathymetric Map NJ 19-2, scale 1:250,000. 1980, Heezen Plateau: Bathymetric Map NJ 19-4, scale 1:250,000 982a, Wraight: Bathymetric Map NI 18-3, scale 1:250,000. 982b, Wittman: Bathymetric Map NI 18-11, scale 1:250,000. 1982c, Bear Seamount: Bathymetric Map NJ 19-3, scale 1:250,00
982d, Powell: Bathymetric Map NJ 19-5, scale 1:250,000. 1982d, Powell: Bathymetric Map NJ 19-5, scale 1:250,000 1982f, Fundian Rise: Bathymetric Map NK 20-7, scale 1:250,000 1982, Fundian Rise: Bathymetric Map NK 20-7, scale 1:250,000.
Stewart: Bathymetric Map NK 20-10, scale 1:250,000. 984a, Daytona Beach: Bathymetric Map NH 17-8, scale 1:250,000 984b, Hatteras Ridge: Bathymetric Map NI 18-6, scale 1:250,000. 984c, Lanier: Bathymetric Map NI 18-9, scale 1:250,000. 984d, Tibbet: Bathymetric Map NI 18-12, scale 1:250,000 984e, Lippold: Bathymetric Map NI 19-1, scale 1:250,000. 1984G Muller: Bathymetric Map N.J 19-6, scale 1:250,000. 1984h, Uchupi: Bathymetric Map NJ 19-8, scale 1.250,000 984i, Wilmington Valley: Bathymetric Map NJ 19-10, scale 1:250,000 984j, Balanus Seamount: Bathymetric Map NJ 20-1, scale 1:250,000. 1984k, Baccaro Bank: Bathymetric Map NK 20-4, scale 1:250,000.

985, Northern United States regional map: Bathymetric map, scale 1:1,000,000. . Geology, v. 10, p. 87-92. Flood, R.D., Ginsburg. R.N., Gorsline, D.S., Hine, A.C. Sternberg, R.W. Swift, D.J.P., and Wright, L.D., 1988, Sedimentation on continental margins: an integrated program for innovative studies during the 1990's: Eos (American Geophysical Union Transactions), v. 69, no. 5, p. $58-59$ and $67-68$.

(19) Structure, stratigraphy, and geologic history of the Florida-Hatteras She p. $339-358$.

Pilkey, O.H., and Cleary, W.J., 1986, Turbidite sedimentation in the northwestern Atlantic Ocean basin, in

Vogt, P. M., and Tucholke, B.E., eds., The western North Atlantic region, v. M of The geology of North 
America: Boulder, Colo., Geological Society of America, p. 437-450. (The Decade of North American Geology [DNAG] Project,

(1985a, Geologic evolution of the United States Atlantic margin: New York, Van Nostrand oag, C.W., 1985b, Depositional history and stratigraphic reference section for central Baltimore Canyon Trough, in Poag, C.W., ed., Geologic evolution of the United States Atlantic margin: New York, Van Nostrand Reinhold Co., p. 217-264.

Poag, C.W., and Valentine, P.C., 1988, Mesozoic and Cenozoic stratigraphy of the United States Atlantic U.S., v. I- 2 of The geology of North America: Boulder Colo., Geological Society of America, p $67-85$ The Decade of North American Geology [DNAG] Project.

Popenoe, Peter, Coward, E.L., and Cashman, K.V., 1982, A regional assessment of potential environmental hazards to and limitations on petroleum development of the southeastern United States Atlantic Continental 82-136, 67 ., map scale 1:1,000,000.

sedimentation during the Quaternary along the midance of gravity-induced versus current-controlled 3.5-kHz echo character: Marine Geology, v. 89, p. 87-126.

Prior, D.B., Doyle, E.H., and Neurauter, Tom, 1986, The Currituck slide, mid-Atlantic continental slope-revisited: Marine Geology, v. 73, no. 1/2, p. 25-45

(1980, Upper Cenozoic processes and environments of continental margin margin. US, 2 of The gets of North America: Boulder, Colo., pins, F.F., J. 1978, Decade of North American Geology [DNAG] Project.

1978, Remote sensing-principles and interpretation: San Francisco, W.H. Freeman Co.

Sawyer, D.S., 1988, Thermal evolution, in Sheridan, R.E., and Grow, J.A., eds., The Atlantic continental margin: U.S., v. I-2 of The geology of North America: Boulder, Colo., Geological Society of America, .

scanlon, K.M., 1984, The continental slope off New England-A long-range sidescan-sonar perspective Schlee, J.S., and Klitgord, KD. 1988 , Georges Bank Basin -A regional synthesis, in Sheridan, R. E., and Grow, J.A., eds., The Atlantic continental margin: U.S., v. I-2 of The geology of North America: Boulder,

eridan, R.E., and Grow, J.A., eds., 1988, The Atlantic continental margin: U.S., v. I-2 of The geology of Geology [DNAG] Project

Geology [DNAG] Project.) . Boulder, Co A

Somers, M. L., Carson, R. M., Revie, J. A., Edge, R. H., Barrow, B. J., and Andrews, A.G., 1978, GLORIA II -an improved long range sidescan sonar, in Proceedings of the Institute of Electrical Engineering on
Offshore Instrumentation and Communications, Oceanology International Technical Session J: London, BPS Publications Ltd, $p$. 16-24.

Steckler, M.S., Watts, A.B., and Thorne, J.A., 1988, Subsidence and basin modeling at the U.S. Atlantic passive margin, in Sheridan, R.E., and Grow, J.A., eds., The Atlantic continental margin: U.S., v. I-2 of Decade of North American Geology [DNAG] Project.)

Stubblefield, W.L., McGregor, B.A., Forde, E.B., Lambert, D.N., and Merrill, G.F., 1982, Reconnaissance in DSRV Alvin of a "fluvial-like" meander system in Wilmington Canyon and slump features in South Wilmington Canyon: Geology, v. 10, no. 1, p. 31-36.

Teleki, P.G., Roberts, D.G., Chavez, P.S., Somers, M.L., and Twichell, D.C., 1981, Sonar survey of the U.S Atlantic continental slope: Acoustic characteristics and image processing techniques, Thirteenth Annual

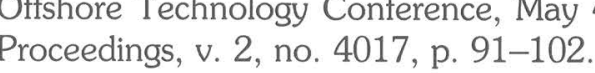

Tucholke, B.E., and Laine, E.P., 1982, Neogene and Quaternary development of the lower continental rise off the central U.S. East Coast, in Watkins, J.S., and Drake, C.L., eds., Studies in continental margin

geology: American Association of Petroleum Geologists, Memoir 34, p. 295-305.
ucholke, B.E., and Mountain, G.S., 1986, Tertiary paleoceanography of the western North Atlantic Ocean, Vogt, P.R., and Tucholke, B.E., eds., The western North Atlantic region, v. M of The geology of North

Geology [DNAG] Project.)
Twichell, D.C., 1987, Geomorphic map of the U. S. Atlantic continental margin and upper rise between Hudson and Baltimore Canyons, in Folger, D.W., and Hathaway, J. C., eds., Conference on continental margin mass wasting and Pleistocene sea-level changes, August 13-15, 1980: U.S. Geological Survey Circular 961, p. 14-21

on the no. 8, p. 408-412.

Uchupi, Elazar, 1965, Map showing relation of land and submarine topography, Nova Scotia to Florida: U.S Geological Survey Miscellaneous Geologic Investigations Series Map I-451, scale 1:1,000,000, 3 sheets.
Veatch, A.C., and Smith, P.A., 1939, Atlantic submarine valleys of the United States and the Congo submarine valley: Geological Society of America, Special Paper 7, 101 p., 16 plates

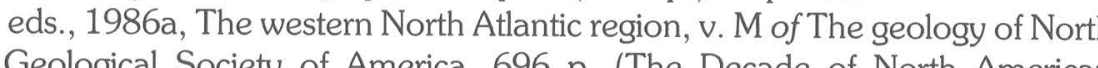
Geology [DNAG] Project)

vogt, P.R., and Tucholke, B.E., 1986b, Imaging the ocean floor - History and state of the art, in Vogt, P.R, and Tucholke, B.E., eds., The western North Atantic region, v. M of The geology of North America: Boulder, Colo., Geological Society of America, p. 19-44. (The Decade of North American Geology

It is recommended that reference to the atlas be made in the following form

ERy

\section{PARTICIPANTS IN U.S. ATLANTIC MARGIN SURVEYS}

SCIENTIFIC PERSONNEI

Mr. Peter Popenoe, USGS, co-chief scientist........
Dr. David C. Twichell, USGS, co-chief scientist.....

Dr. David C. Twichell, USGS, co-chief sciet.

Mr. Eric Darlington, IOS, GLORIA engineer

Mr. James M. Robb, USGS, co-chief scientist......

Dr. John S. Schlee, USGS, co-chief scientist.

Mr. Christopher F. Polloni, USGS, co-chiet scientist.

Dr. Stephen Williams, IOS, co-chief scientist ....
Mr. Malcolm Harris, IOS, GLORIA engineer...

Dr. Dennis W. O'Leary, USGS, co-nief scientit...

Dr. John Hughes-Clarke, GSC, co-chief scientist .....

Mr. Quentin Huggett, IOS, co-chief scientist

Mr. Derek Bishop, IOS, GLORIA engineer

Dr. William P. Dillon, USGS, co-chief scientist.........

Mr. Andrew Hari IOS, enging

Mr. Simon Cargill, USGS, geologist ....

Ms. Sarah Griscom, USGS, geologist....

Mr. Colin Jacobs, IOS, photo manager

M. Lawrence Kooker, USGS, electronics technician .....

Ms. Kay Potter, RVS, computer specias

Mr. Steve Whittle, IOS, mech

Mr. Robin Bonner, IOS, mechanical techniciai ....

Mr. Michael Boyle, USGS, electronics technician .....

Mr. Christopher Flewellen, RVS, engineer

Mr. David Gunn, IOS, photo manager.

.

Ms. Nancy Soderber USGS, data cr....

Mr. Linton Wedlock, RVS, computer specialis

Dr. Max Dobson, IOS-University of Wales, Aberystwyth,

geologist

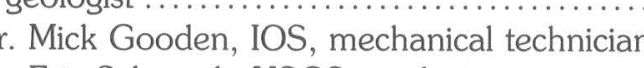

Mr. Eric Schmuck USGS, geologist....

Mr. Roy Sparkes, GSC, physical oceanographer.
Mr. James Vaughan USGS, electronics technician ....

Mr. Ross Walker, IOS, engineer

Ms. Doriel Jones, RVS, computer specialist .........

M. Lraham Lake, IOS, mechanical

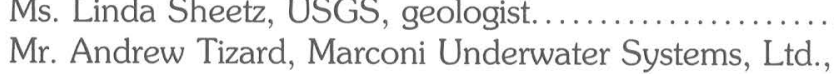

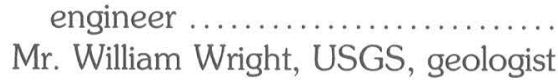

Ms. Emma Woodward, IOS, photo manage

Dr. Page C V Valentine, USGS, geolog.

CHS, Canadian Hydrographic Service
EPA, Environmental Protection Agene

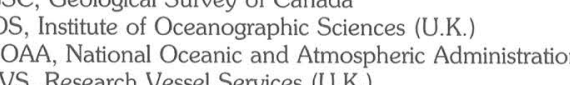

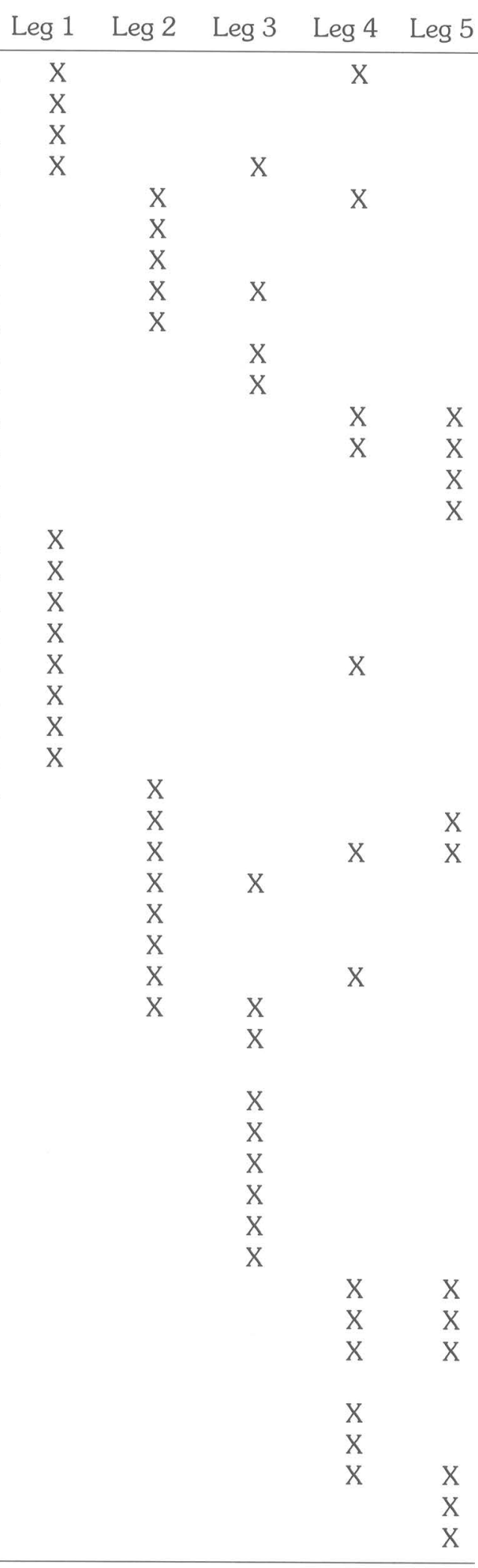

$x$
$X$
$x$ 


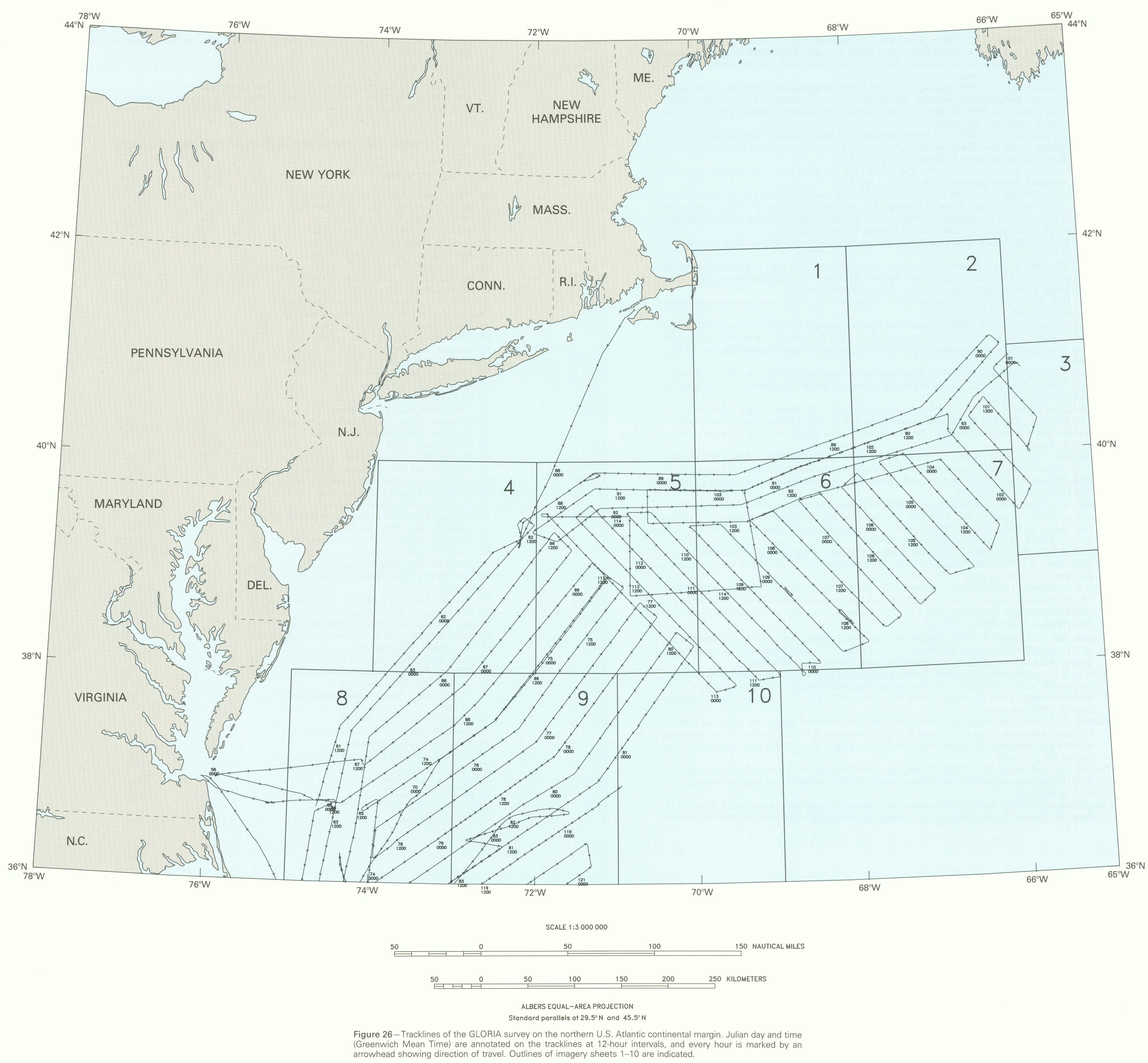




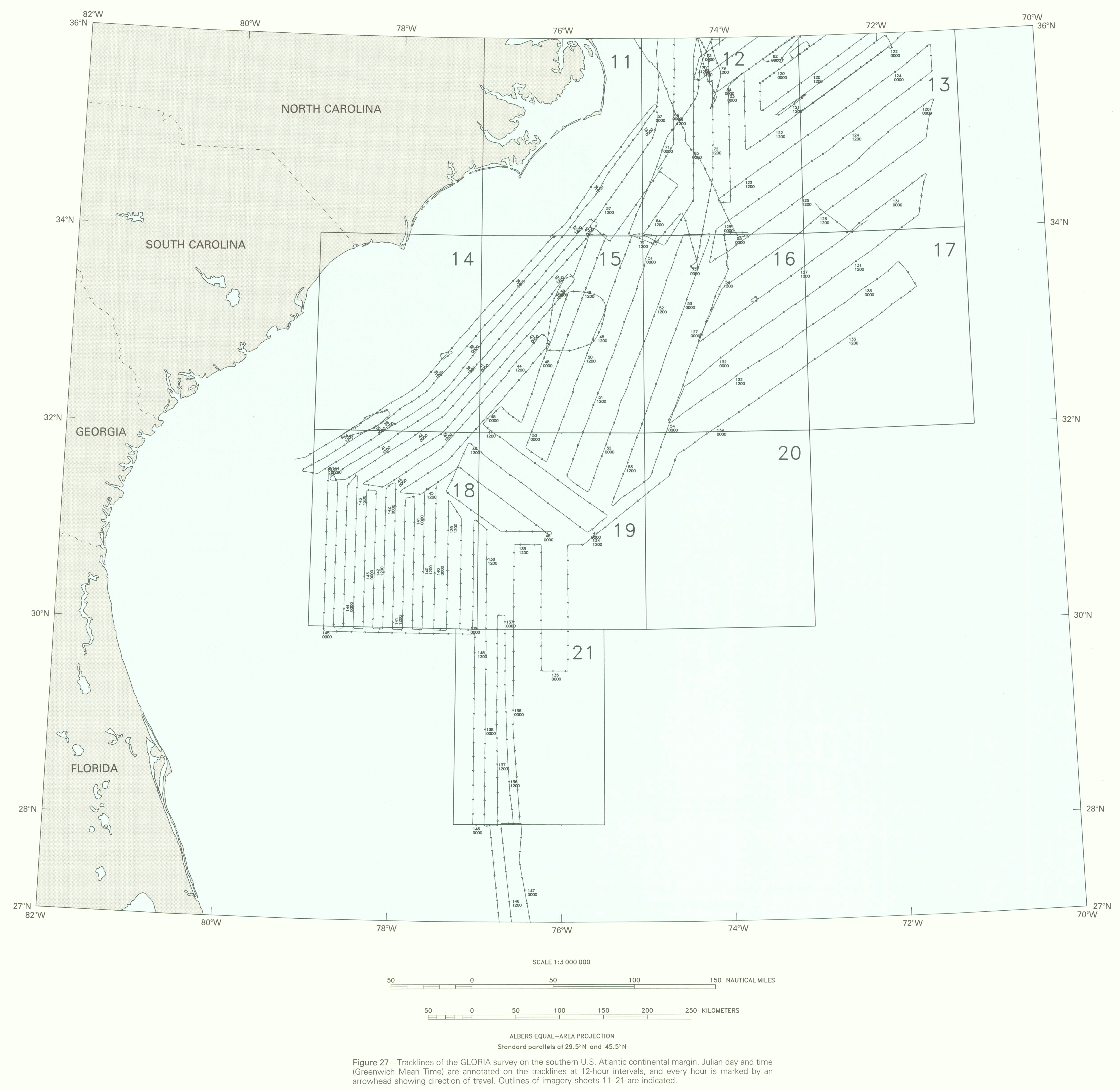




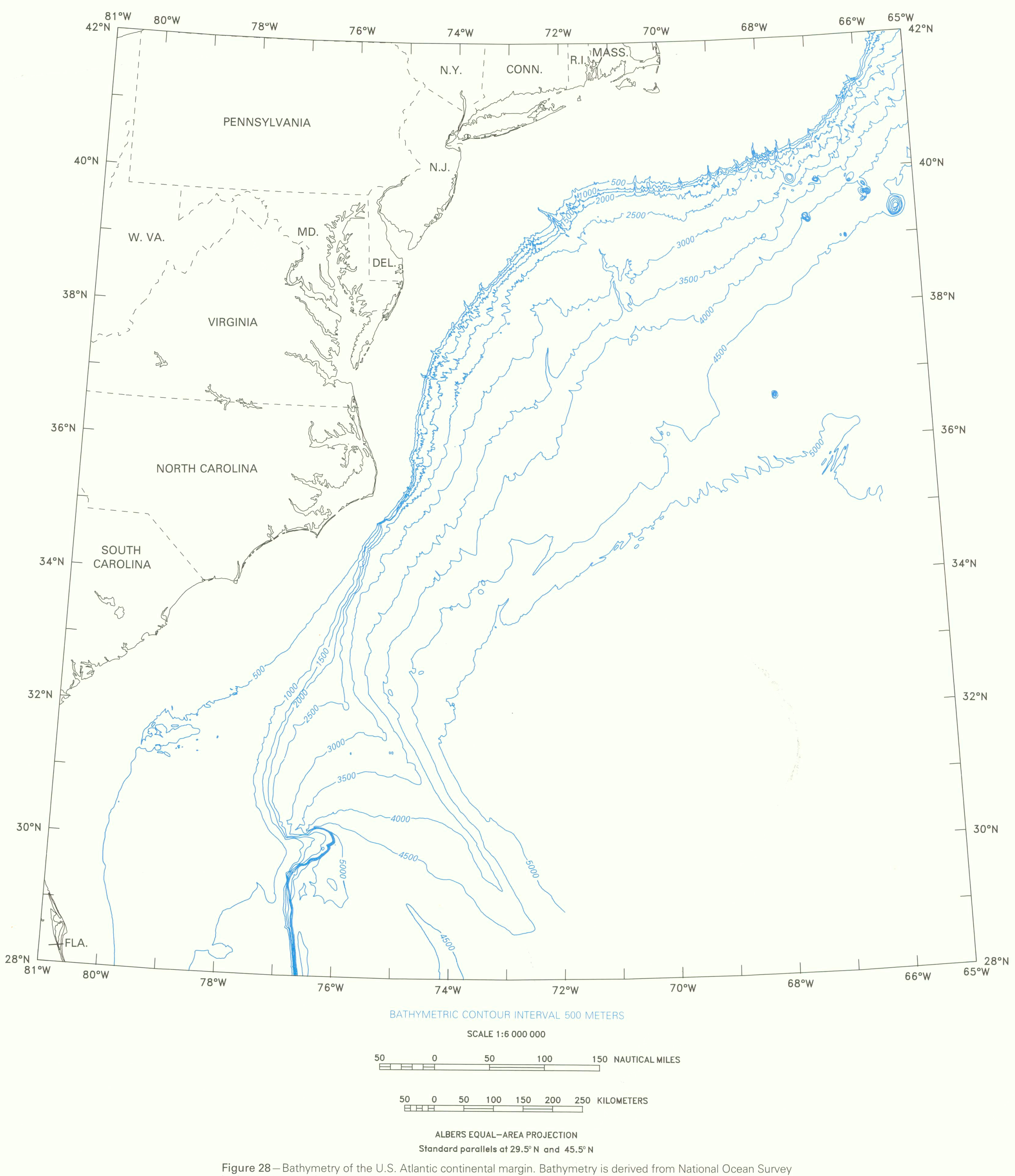

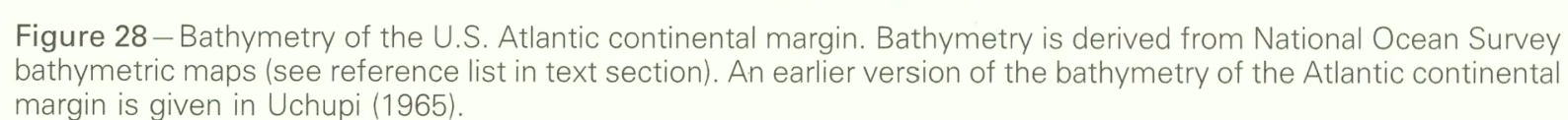

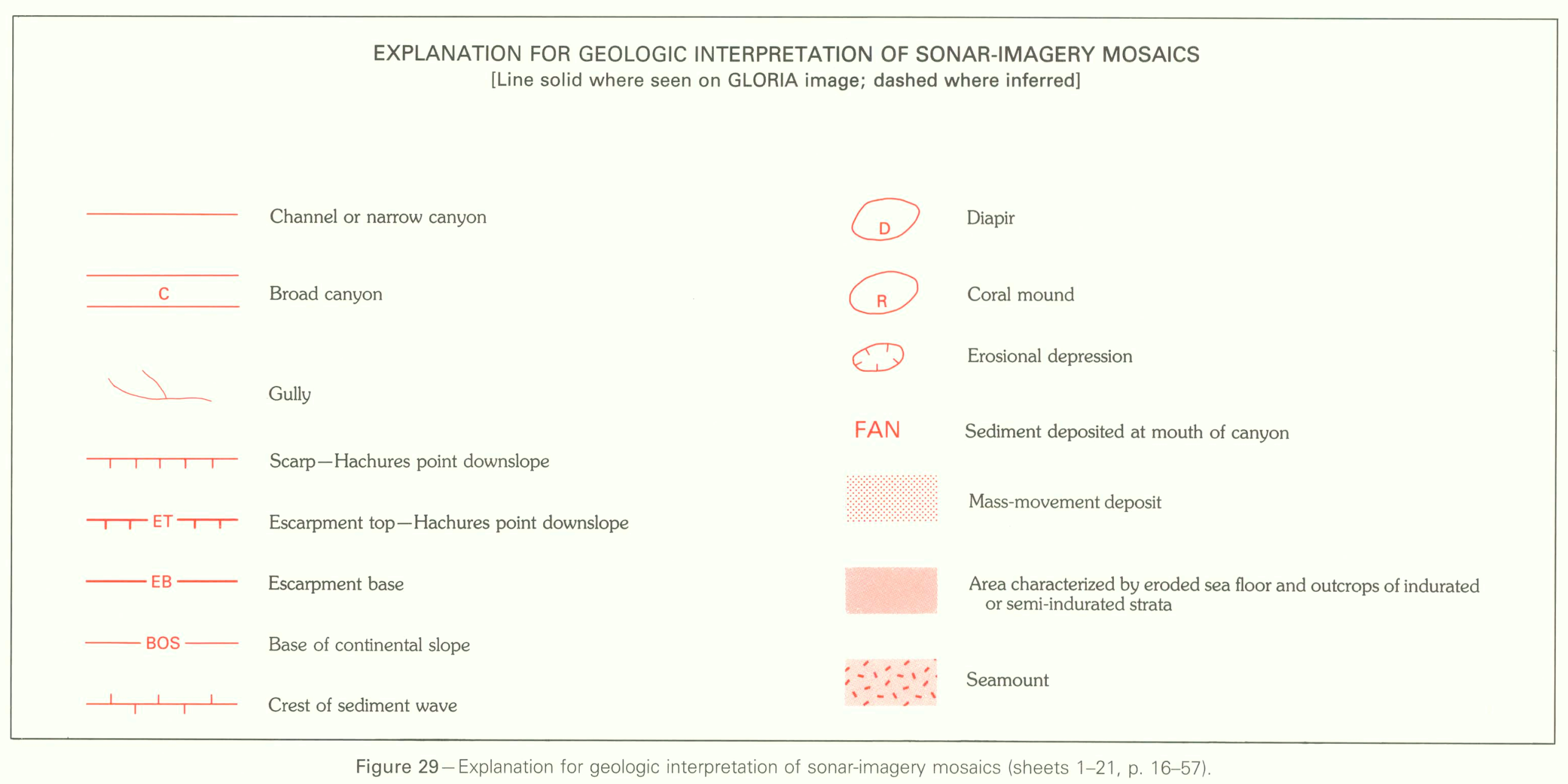

Figure 29-Explanation for geologic interpretation of sonar-imagery mosaics (sheets 1-21, p. 16-57) 
SONAR-IMAGERY MOSAICS

WITH GEOLOGIC INTERPRETATIONS

AND BATHYMETRY

(SHEETS 1-21) 


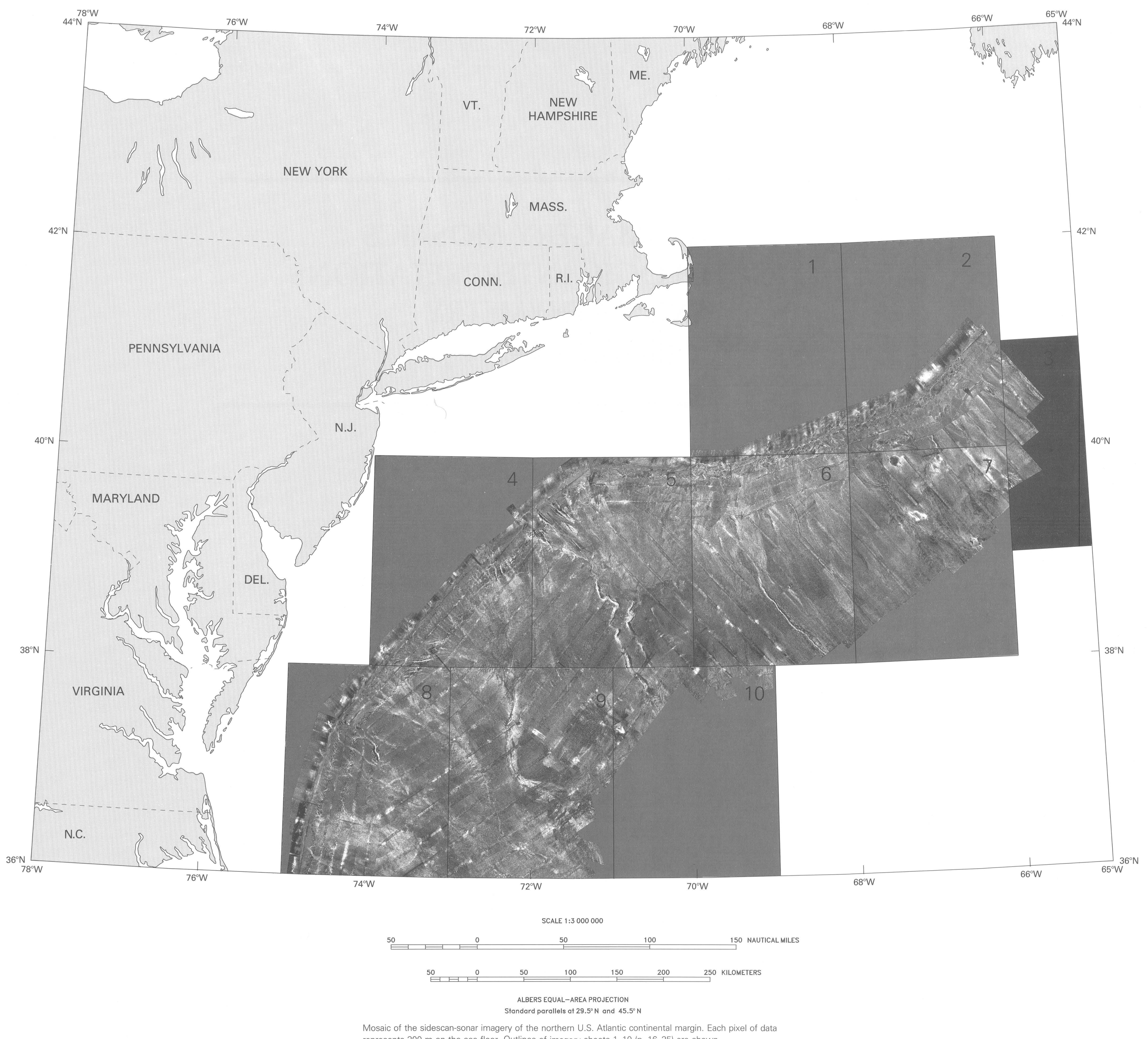

rgin. Each pixel of data 


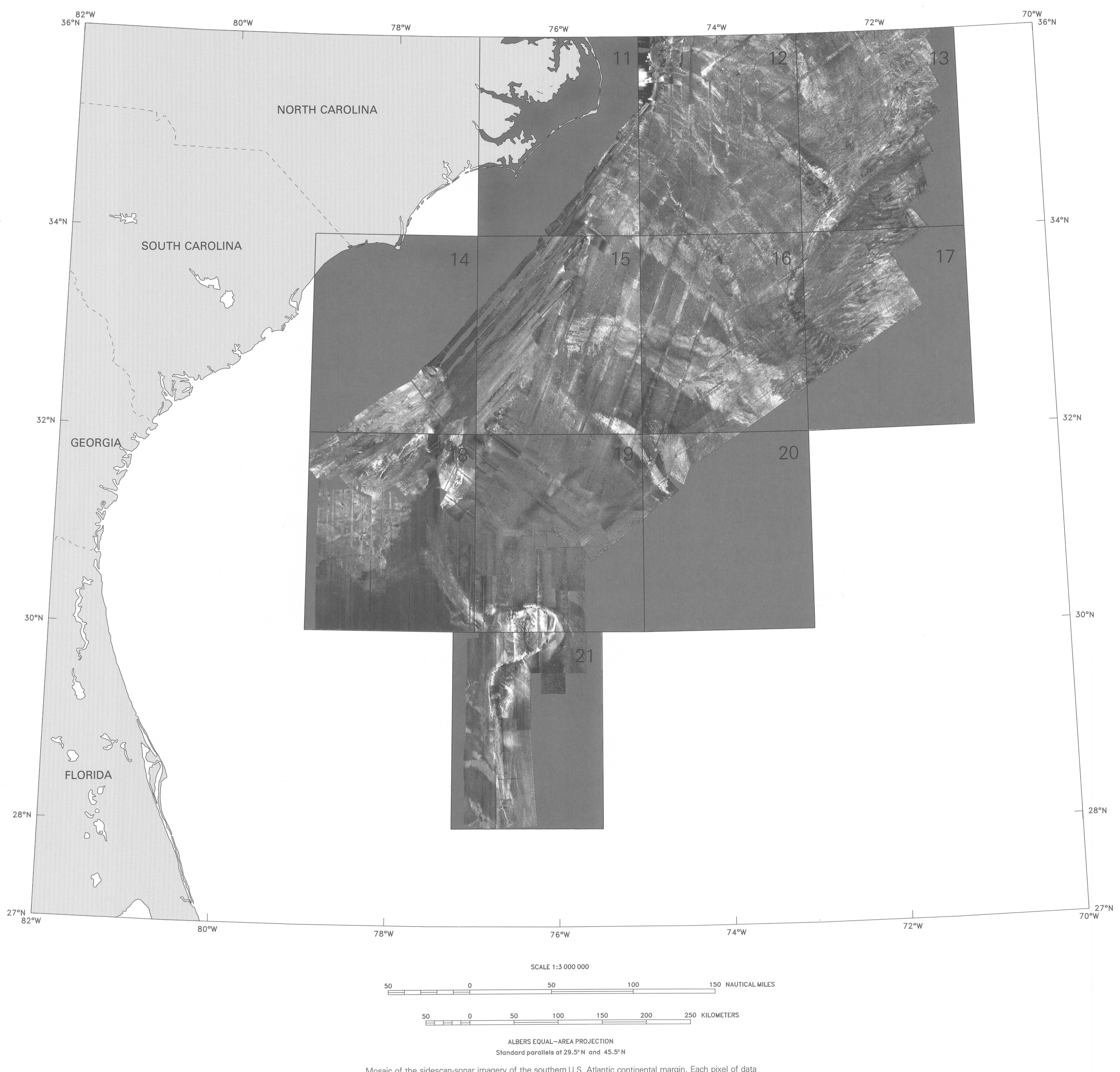

Mosaic of the sidescan-sonar imagery of the southern U.S. Atlantic continental margin. Each pixel of data 


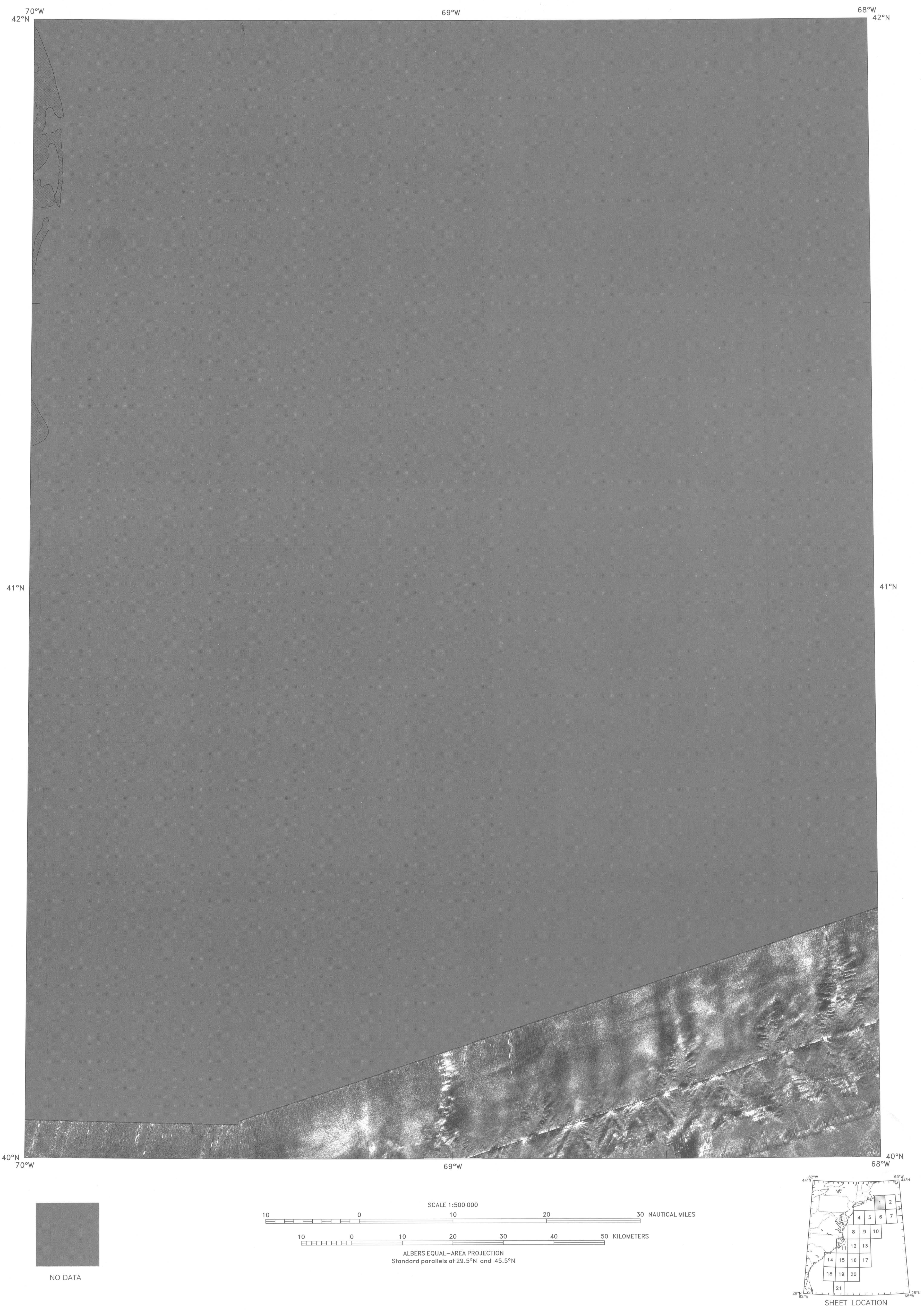




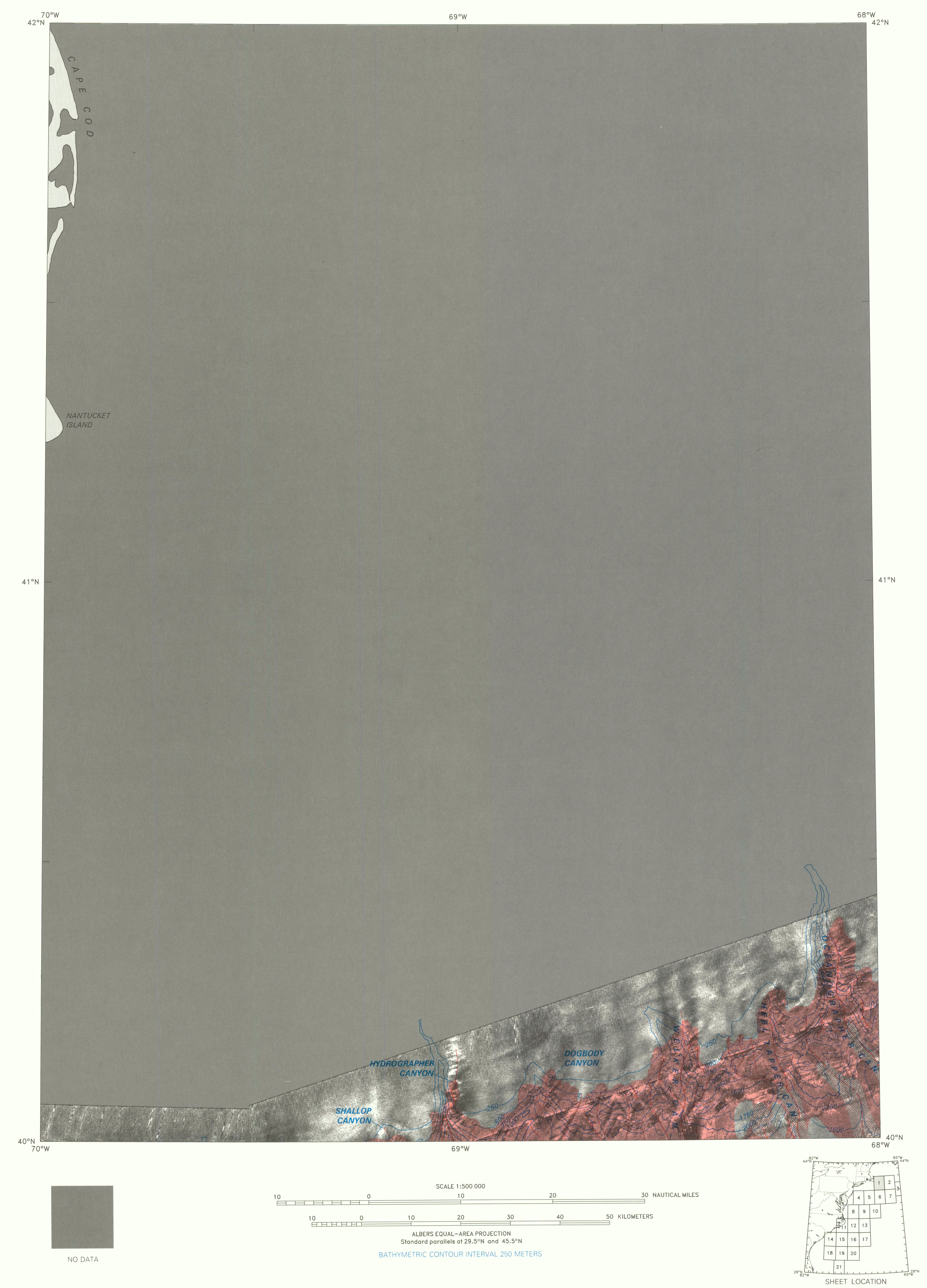




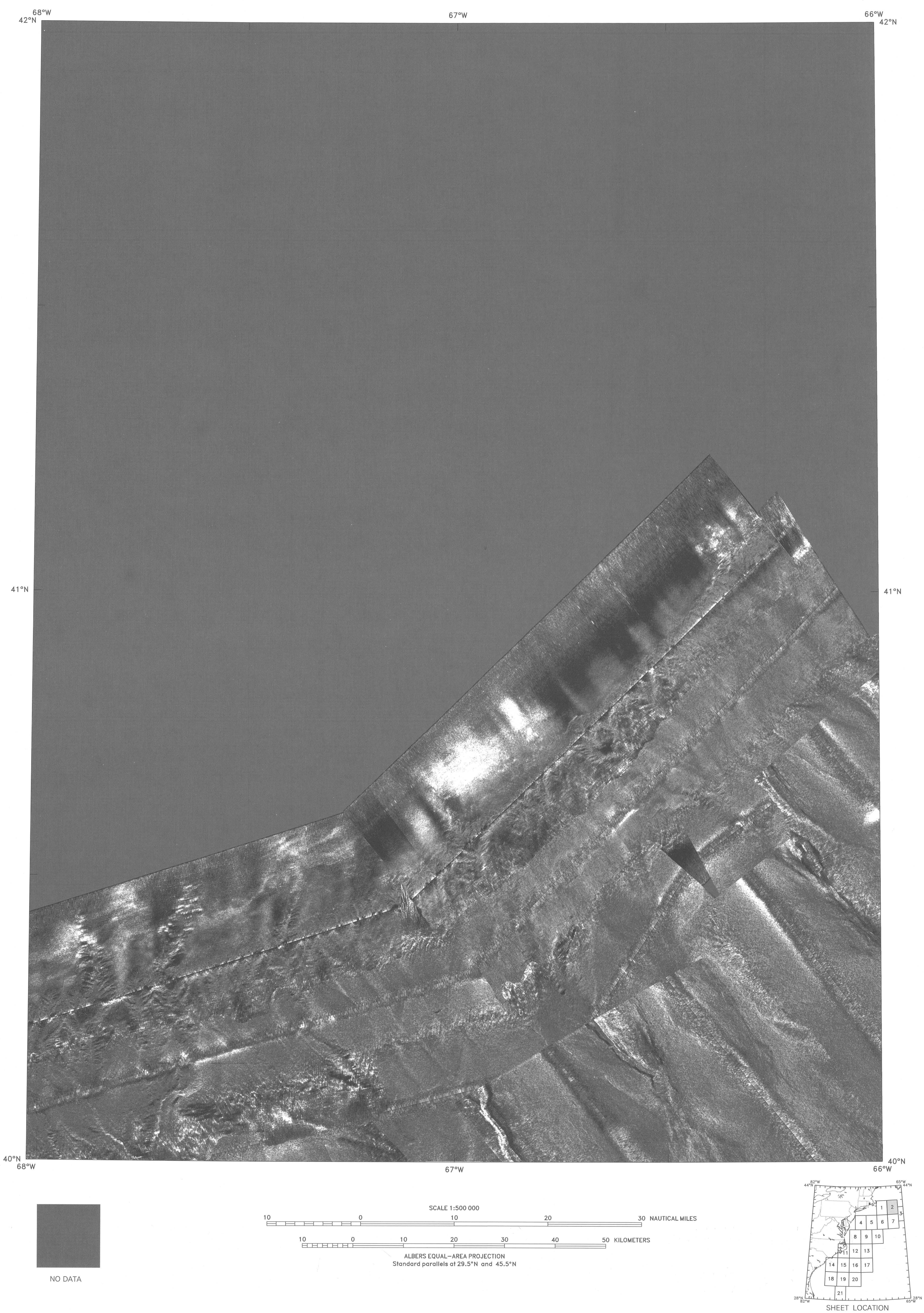




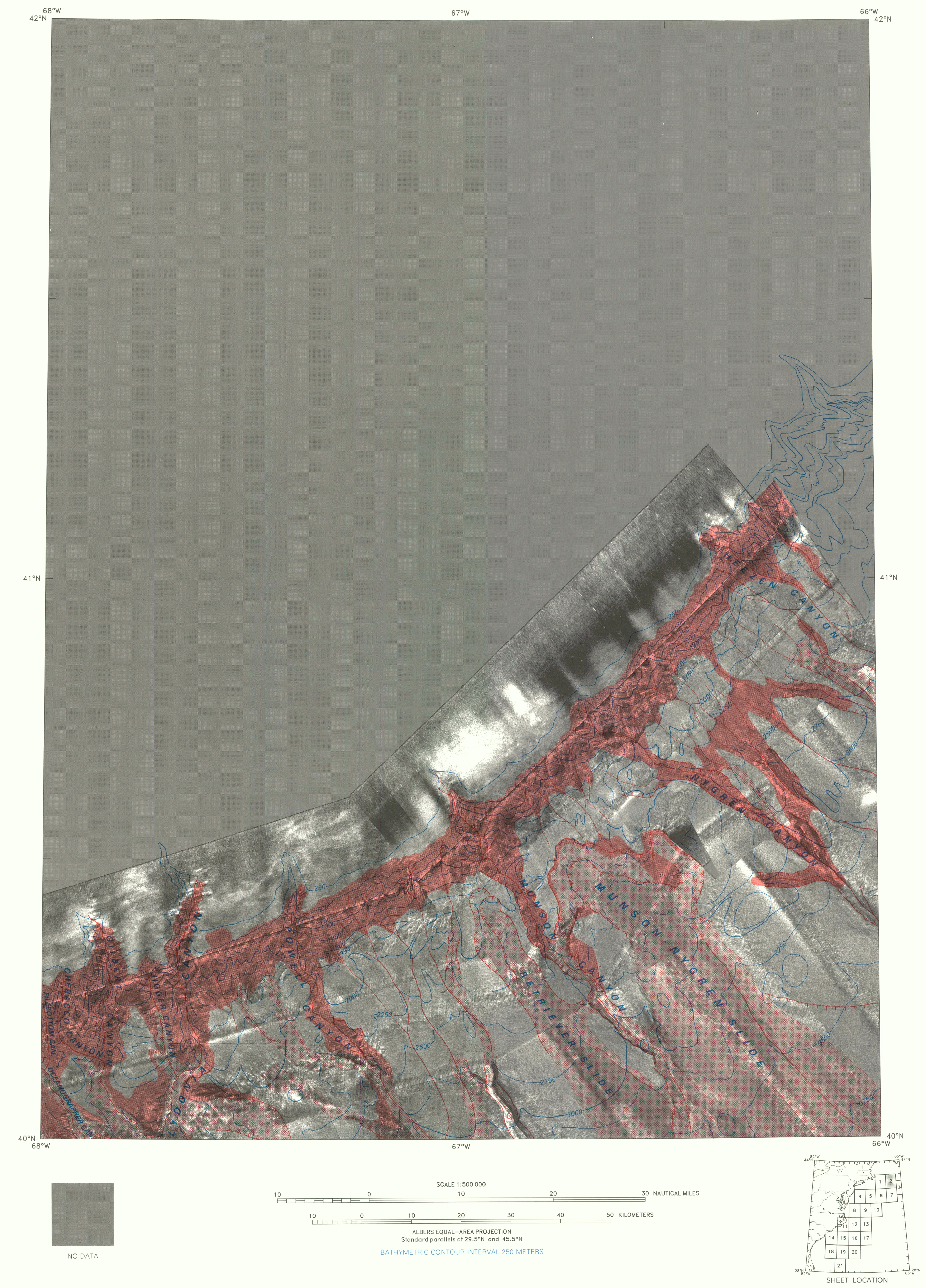



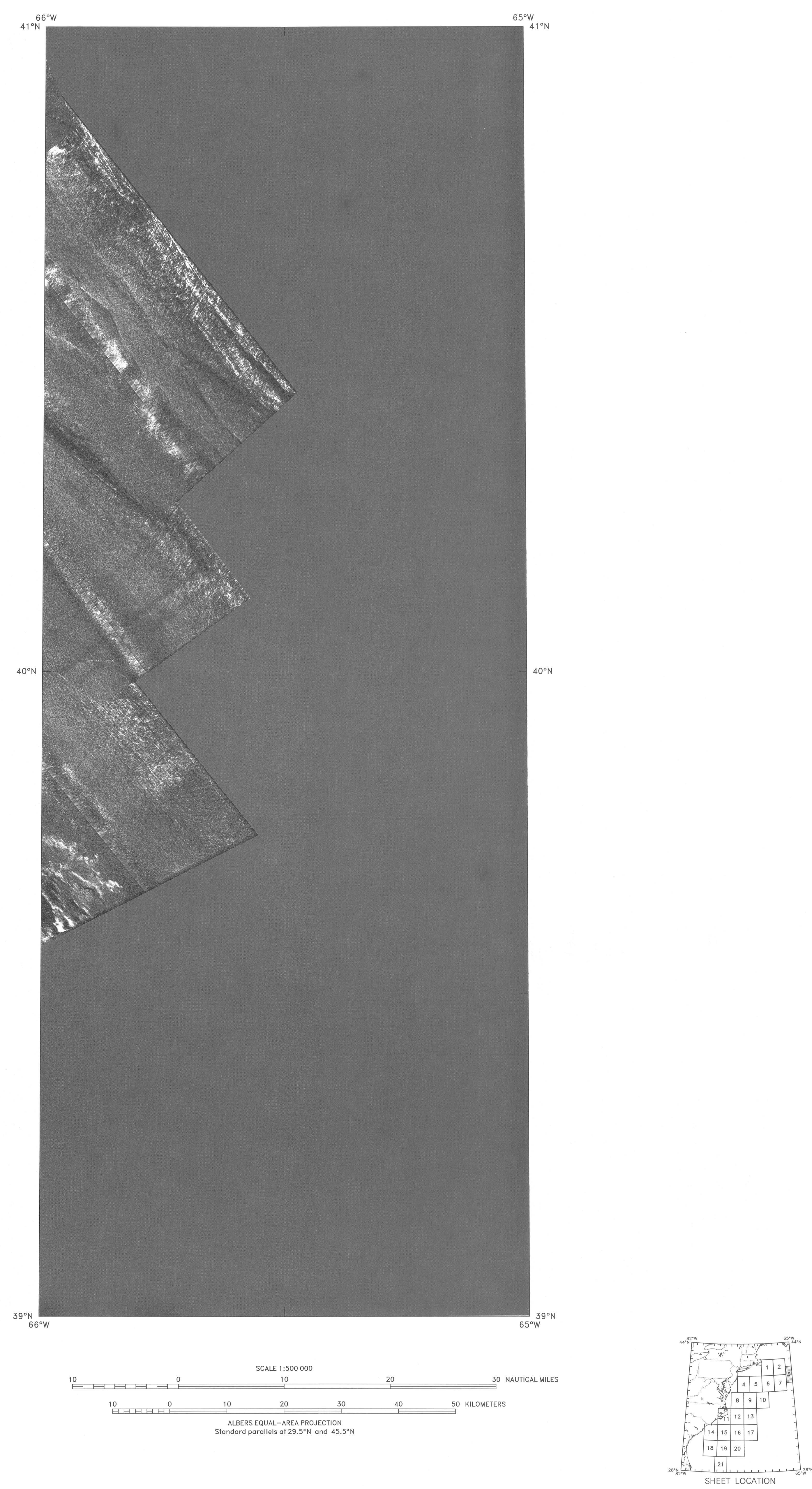

BATHYMETRY
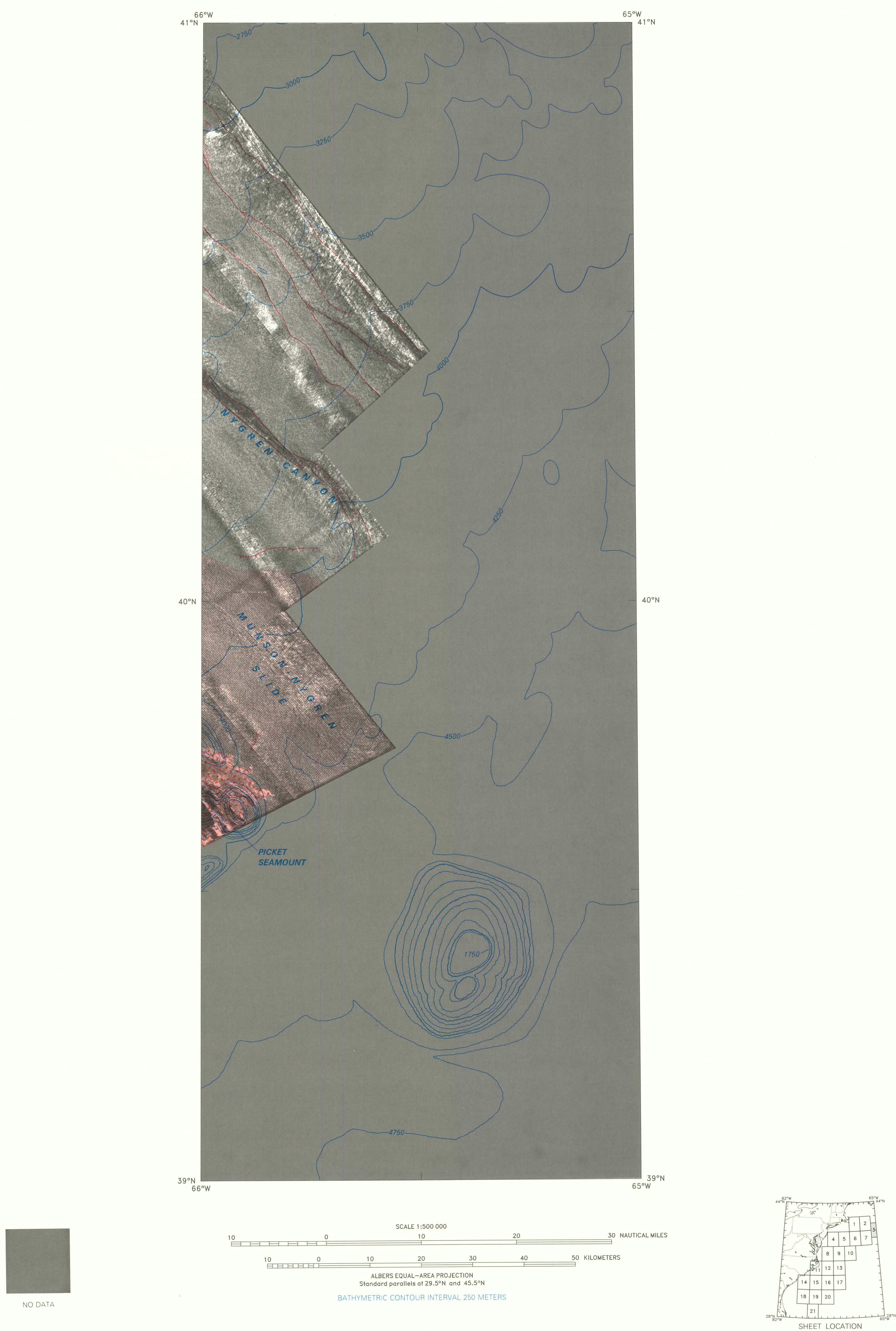


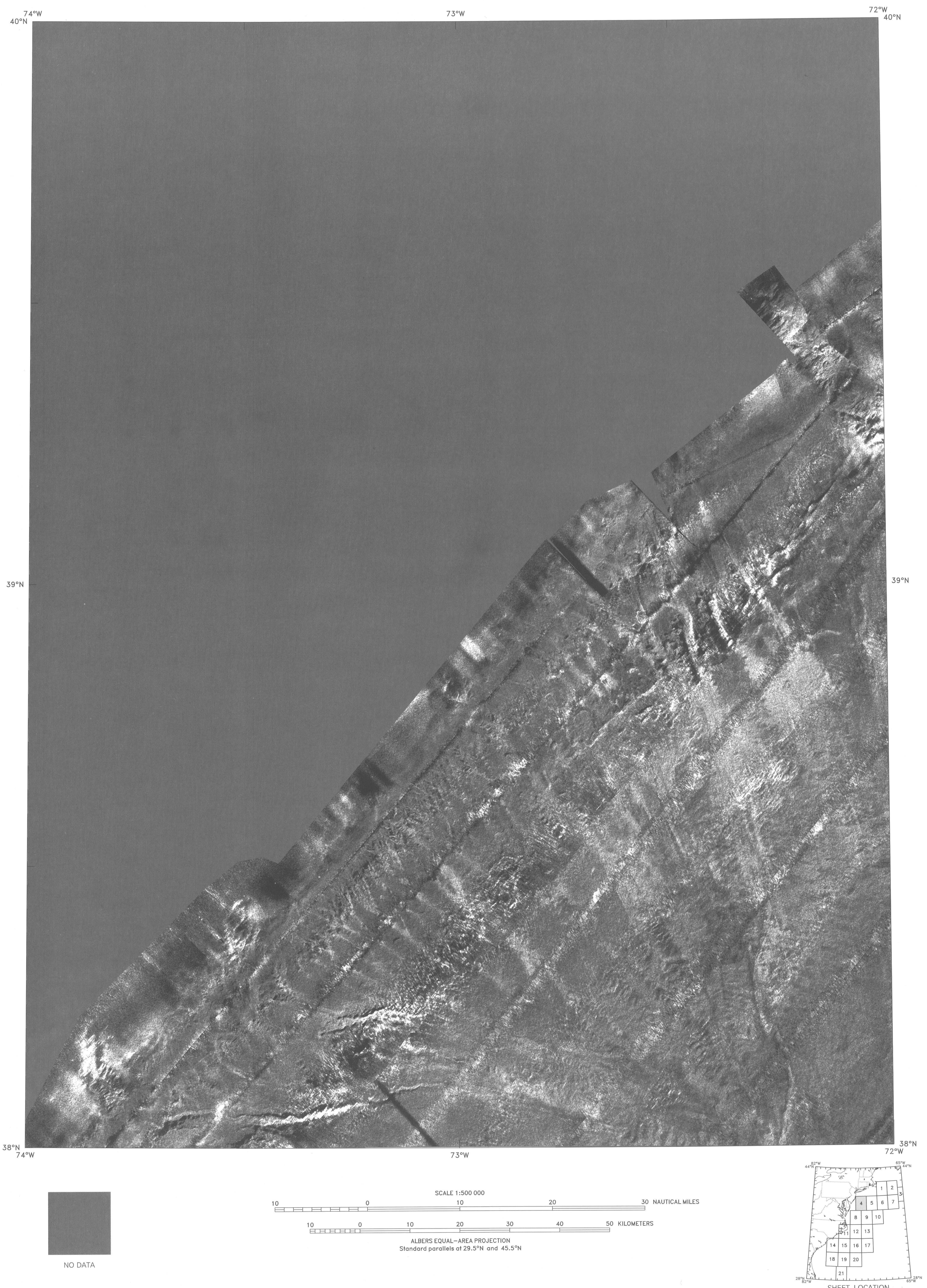




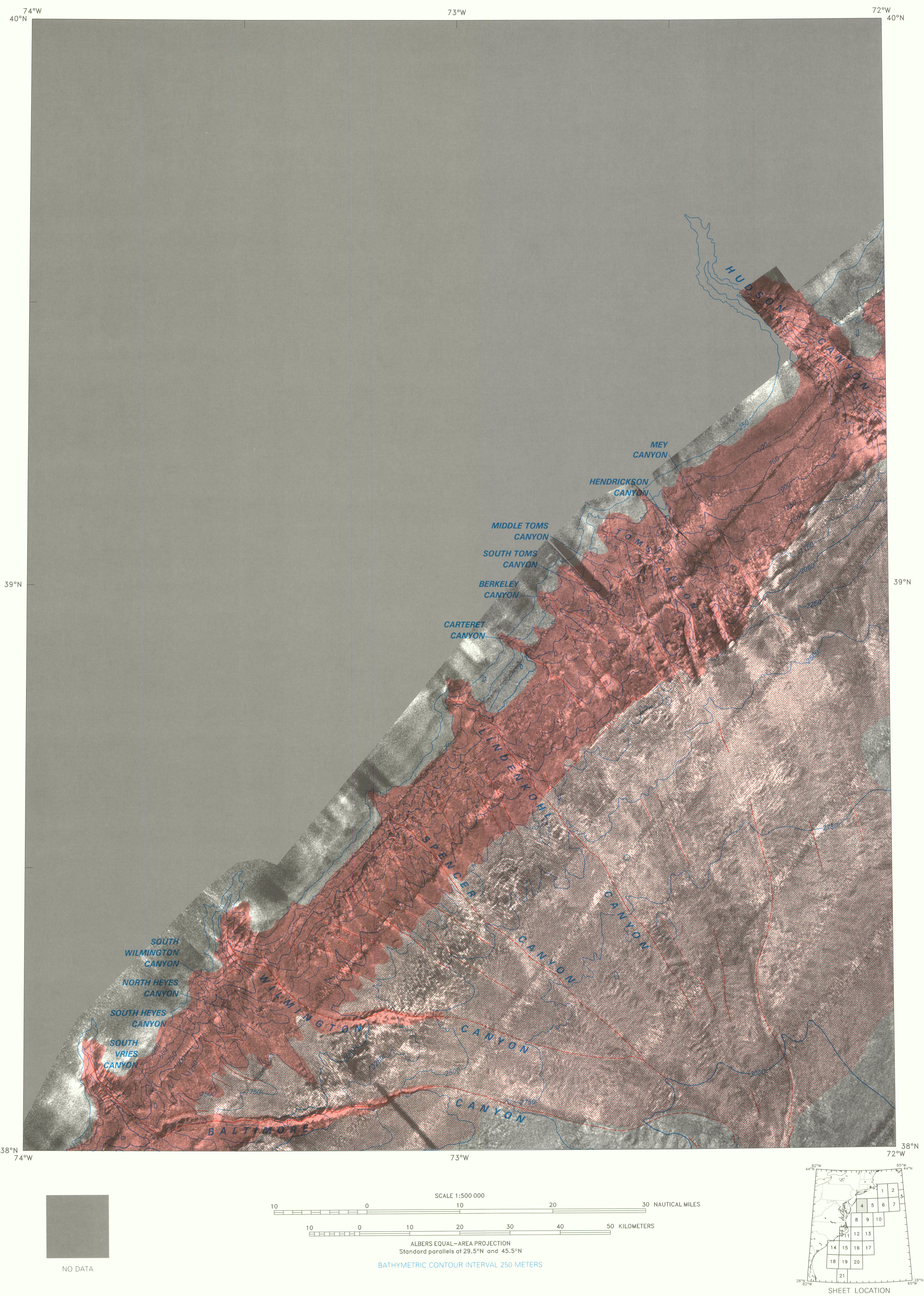




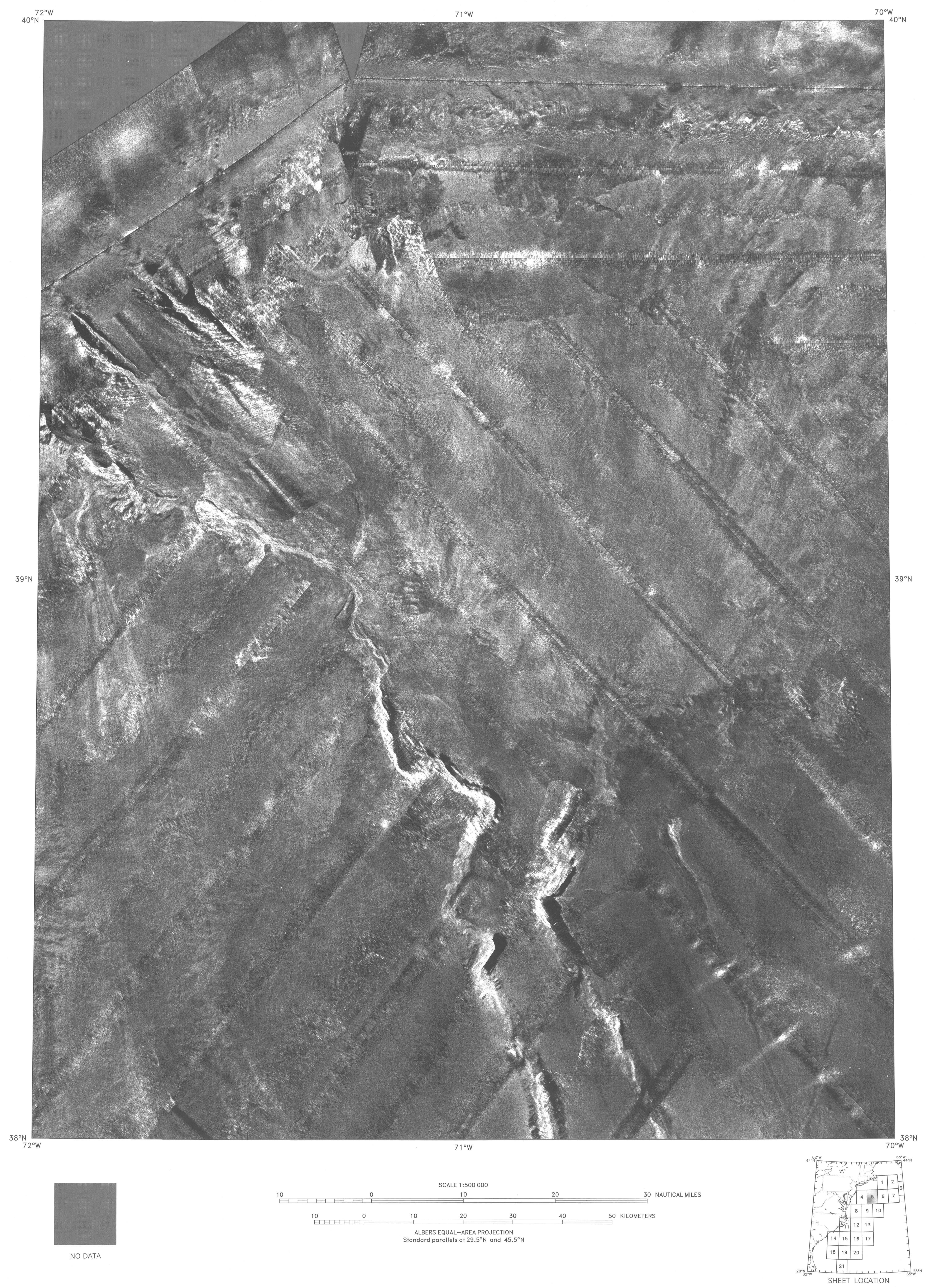




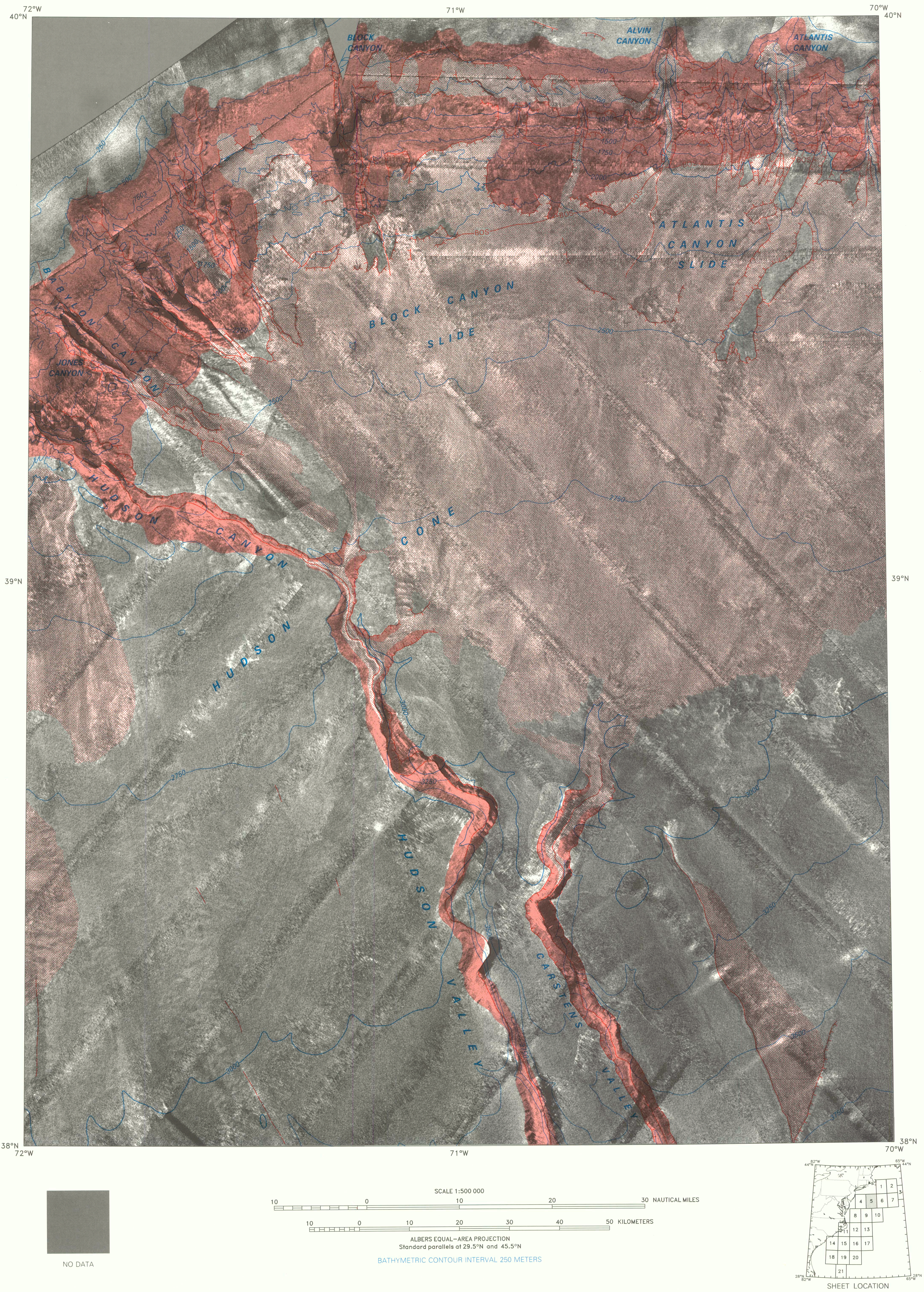




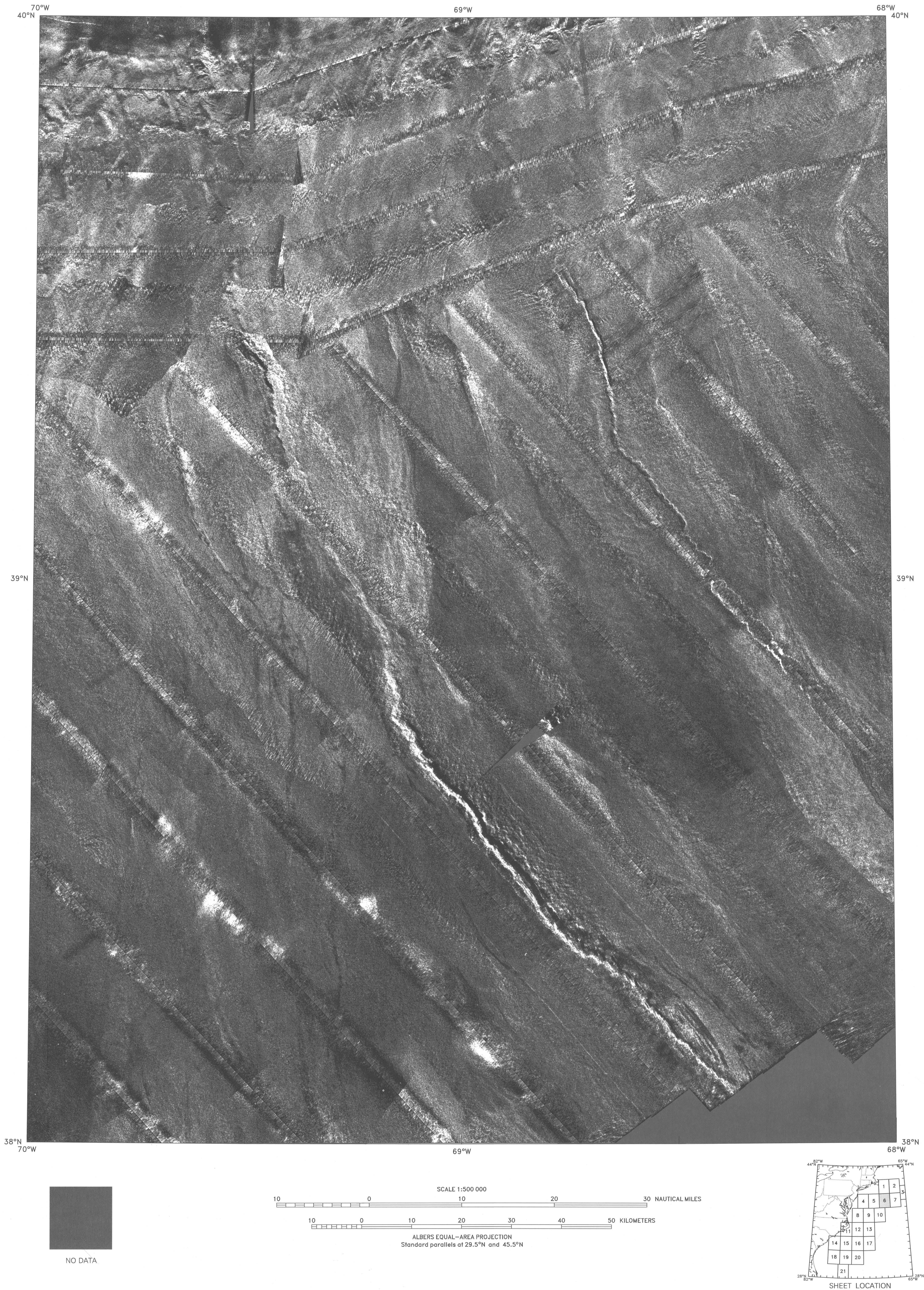




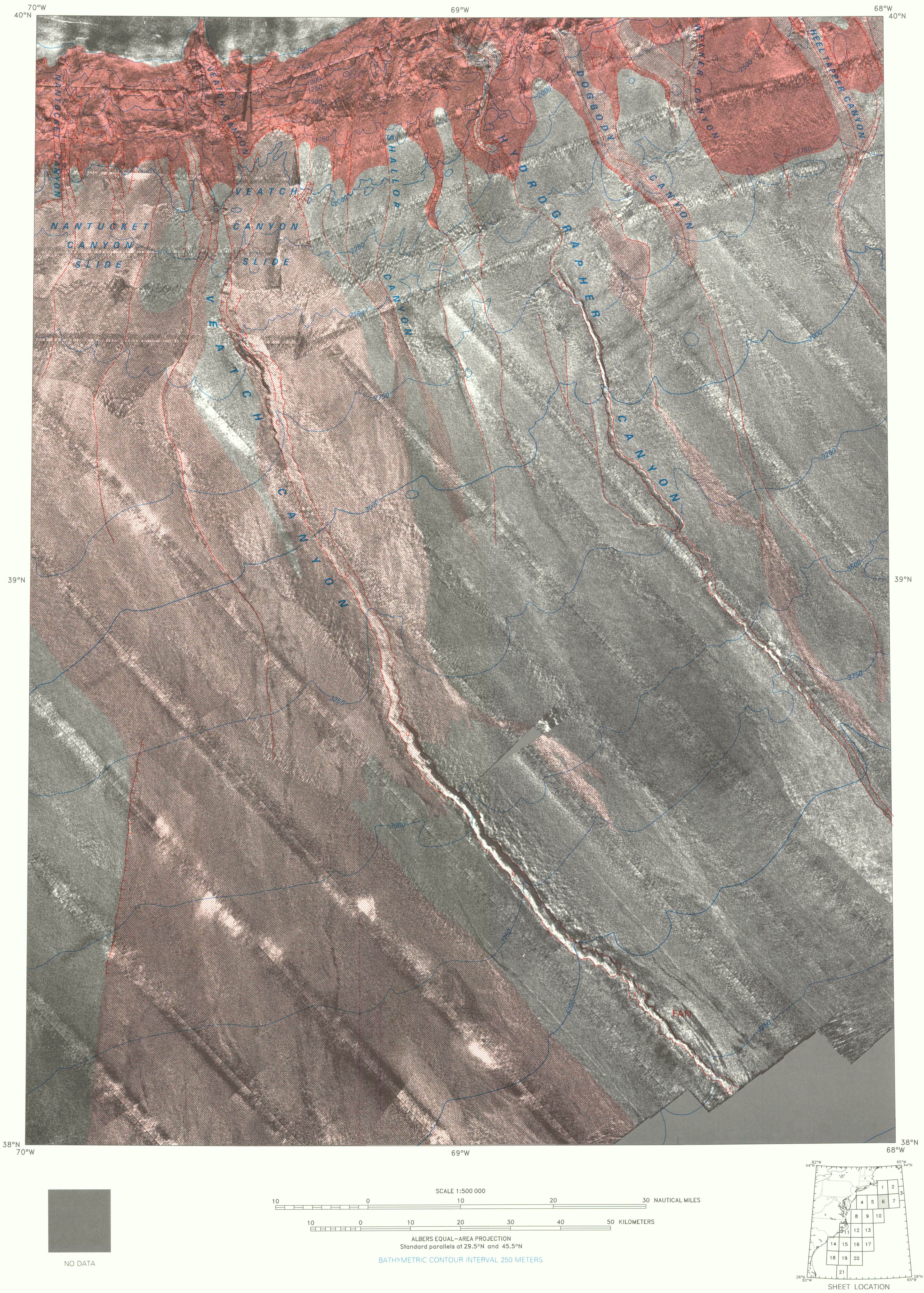




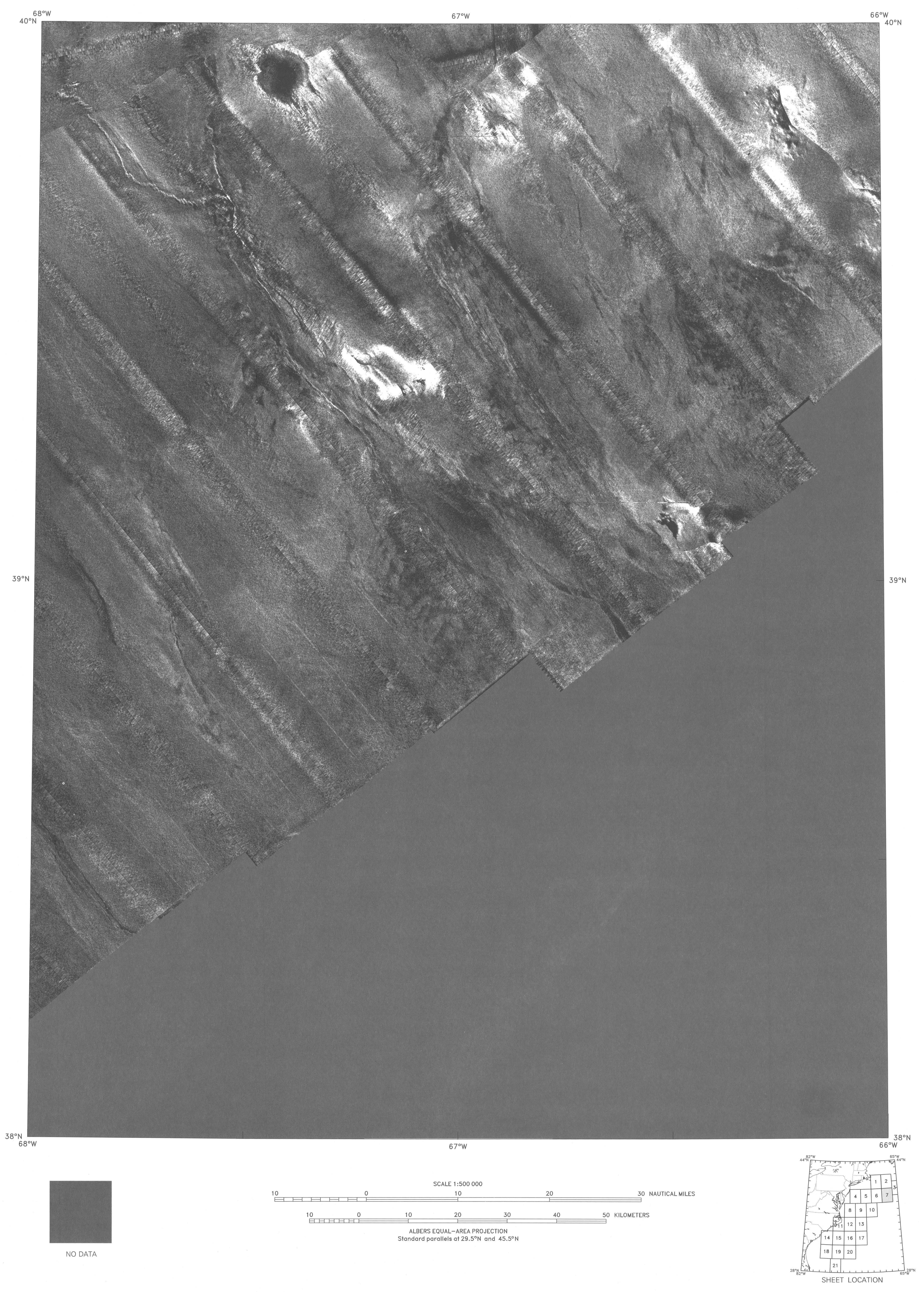




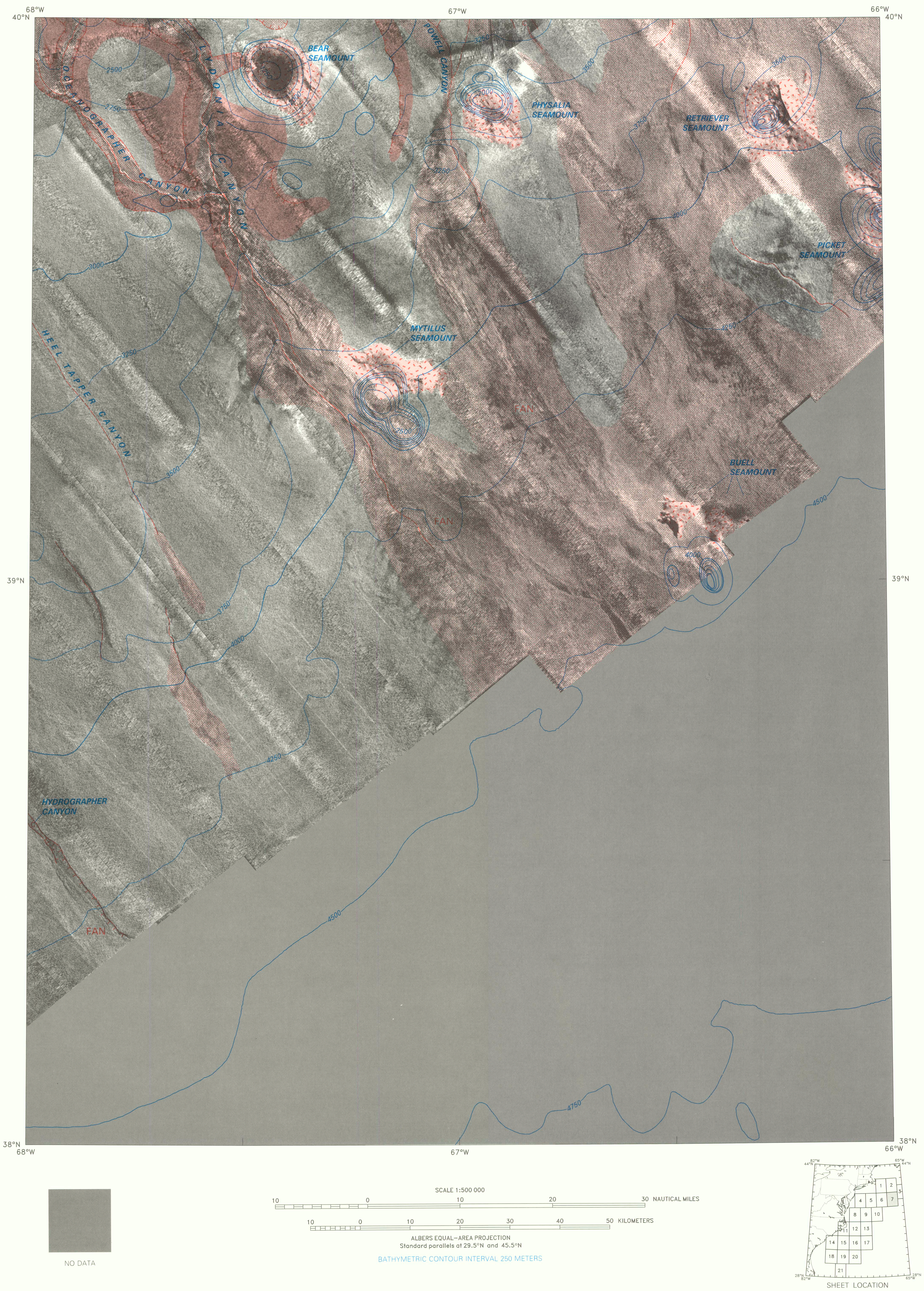




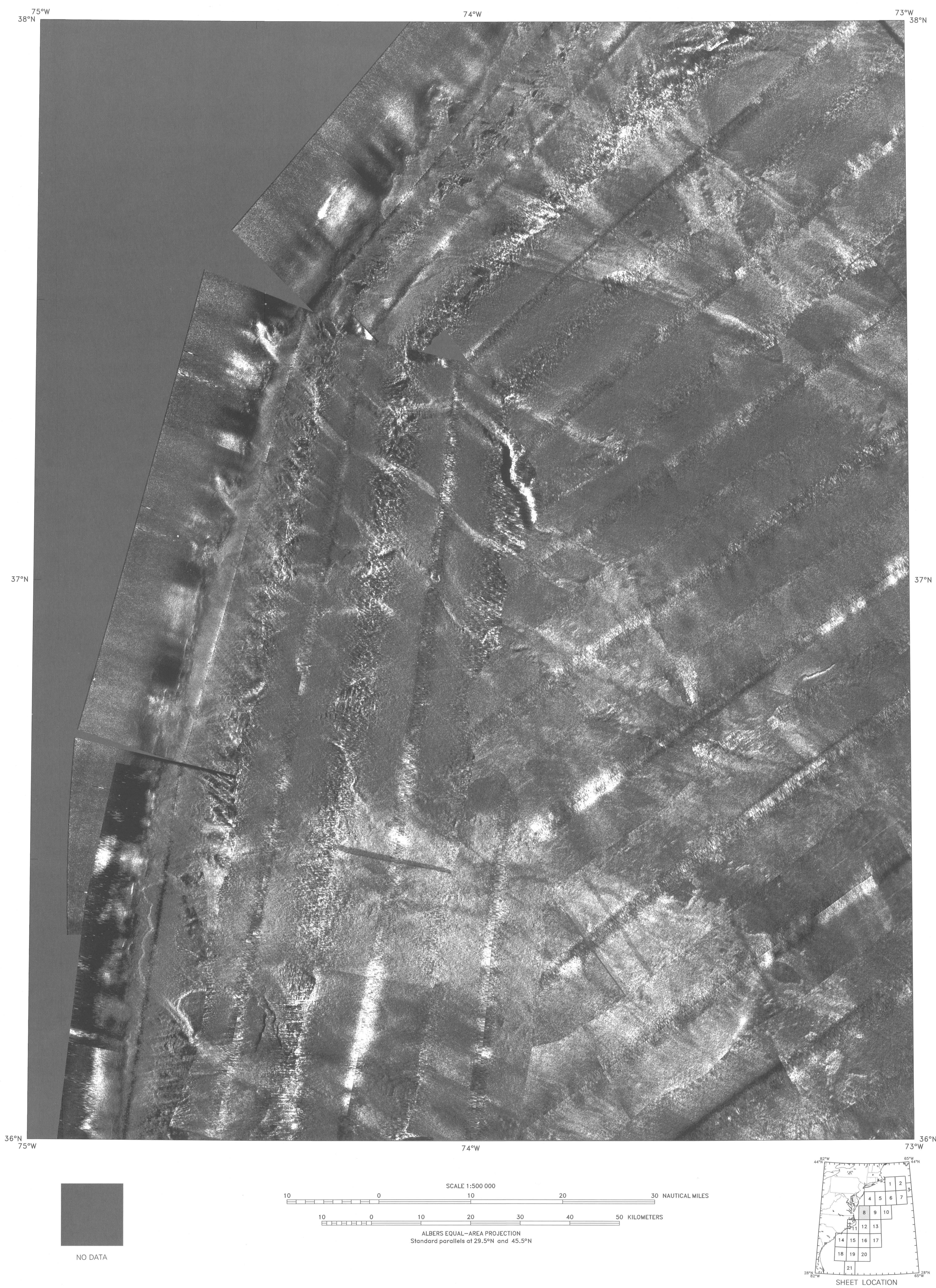




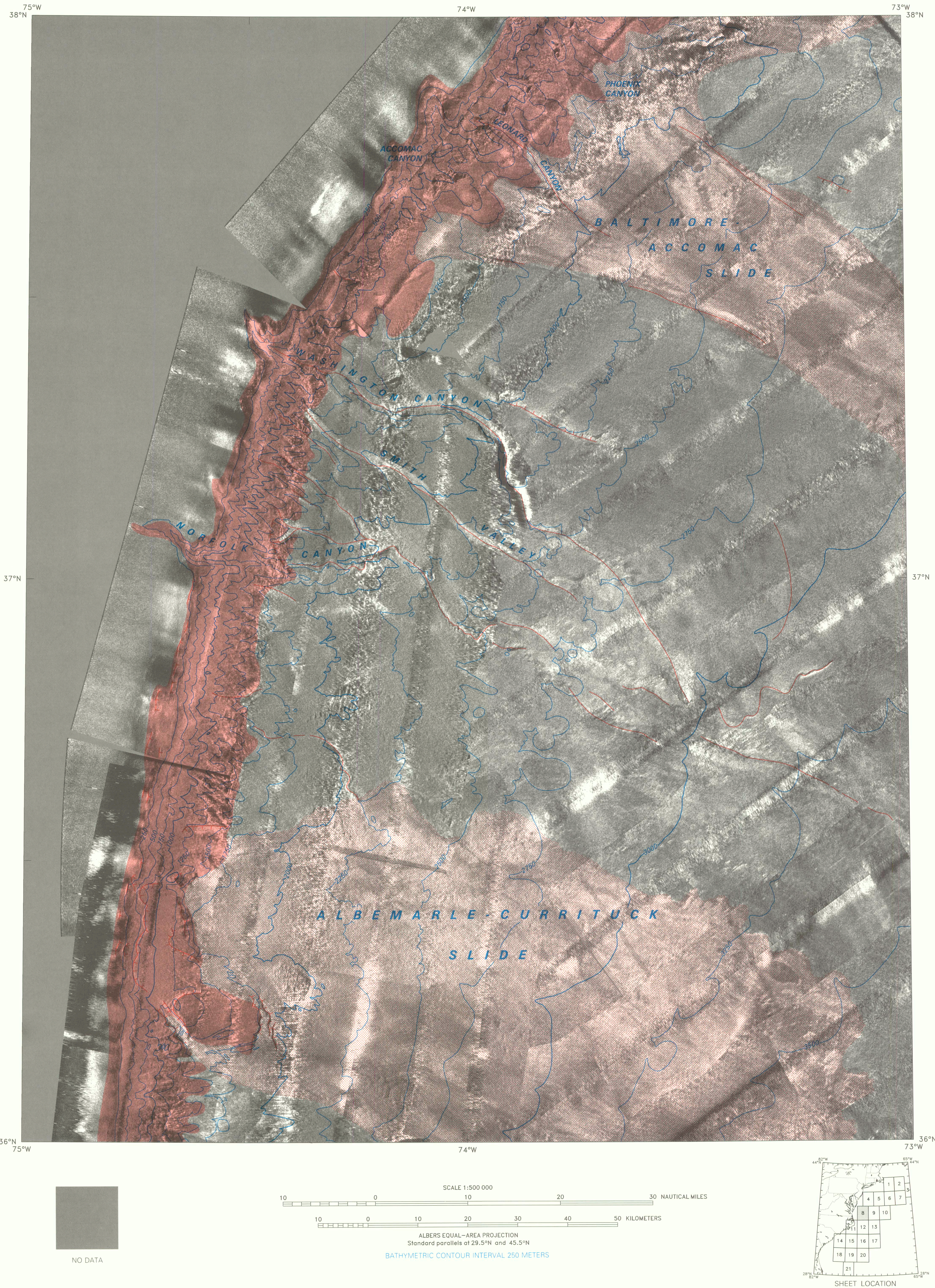




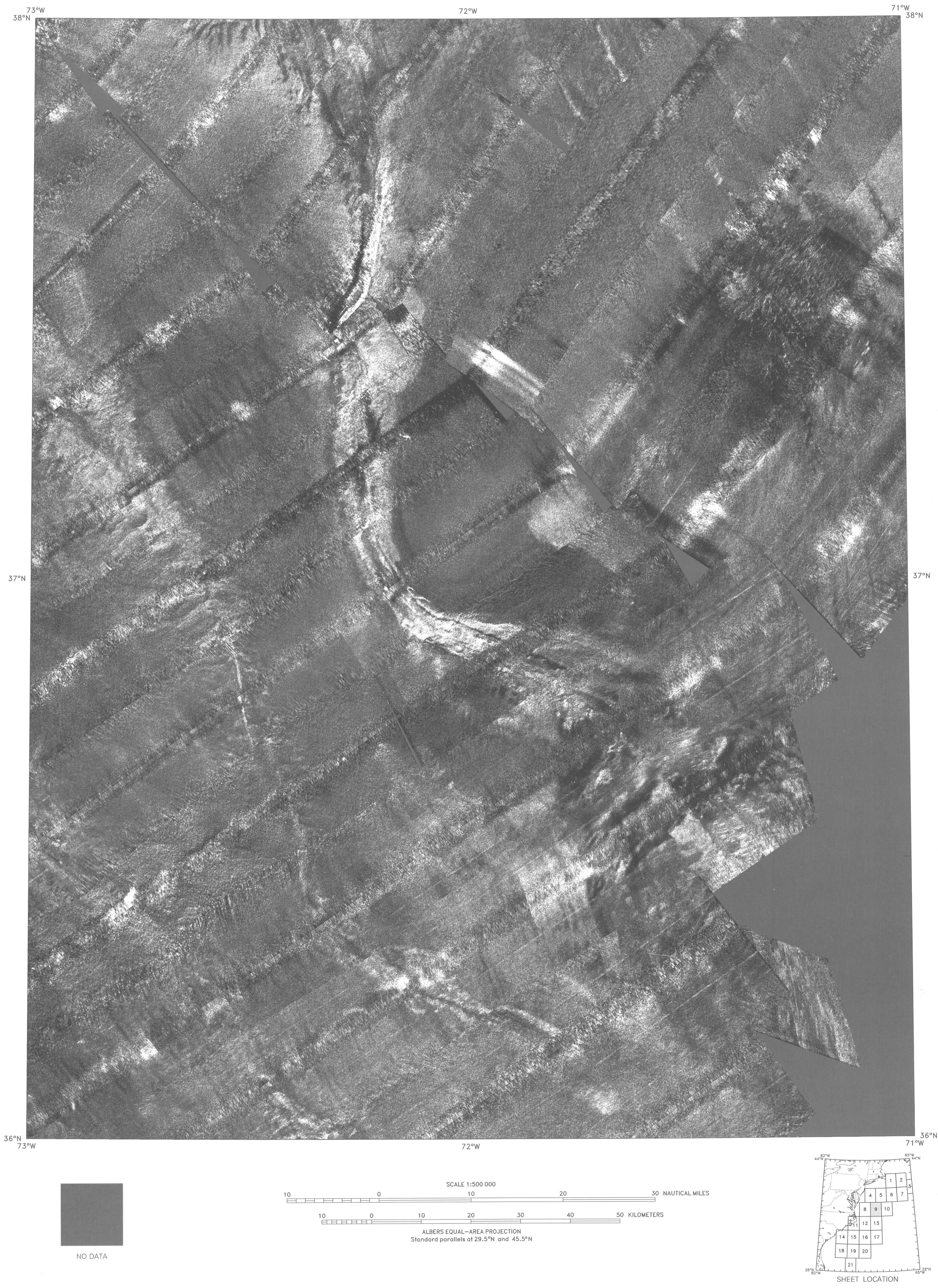




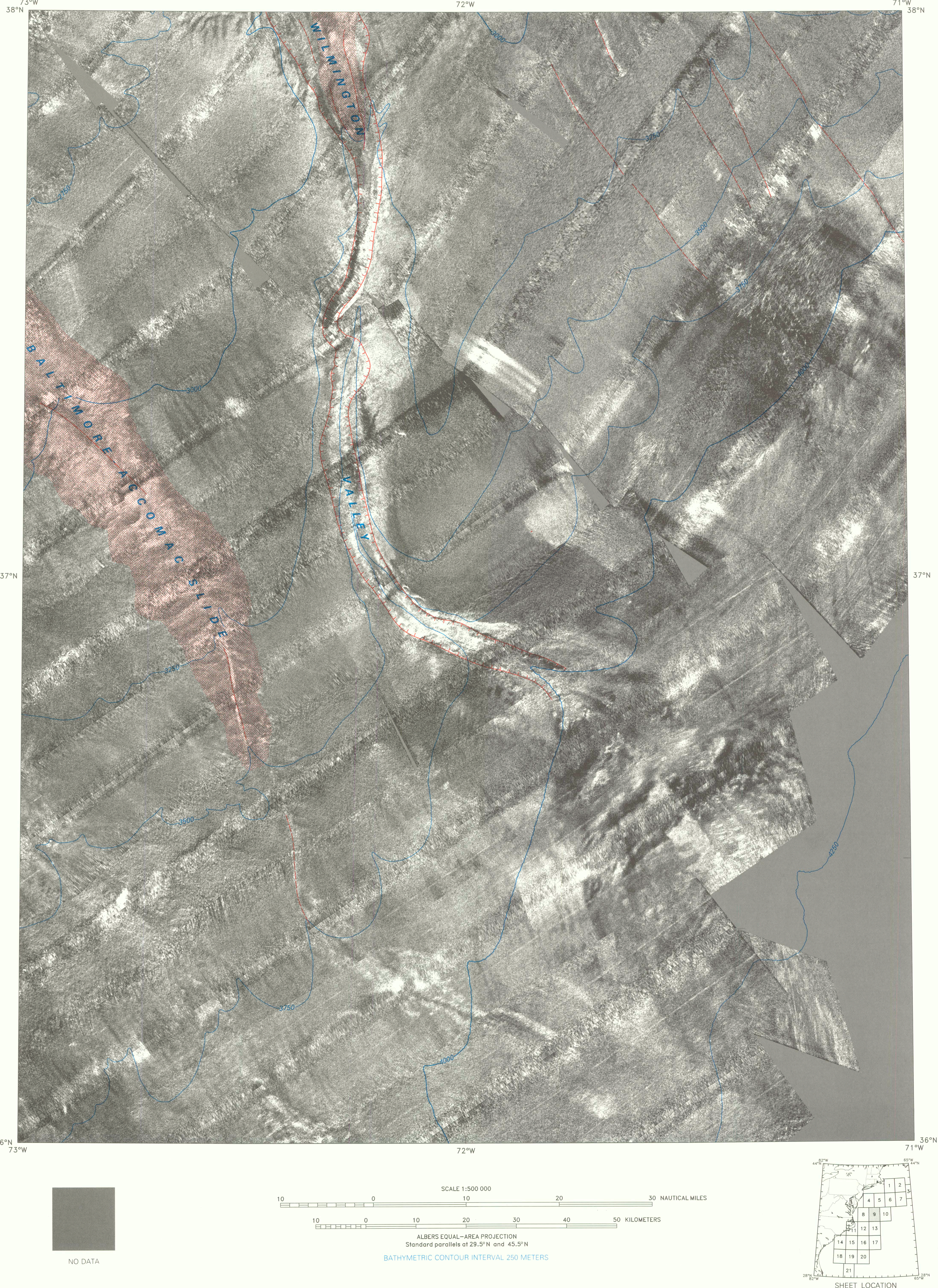


ATLAS OF THE U.S. EXCLUSIVE ECONOMIC ZONE ATLANTIC CONTINENTAL MARGIN

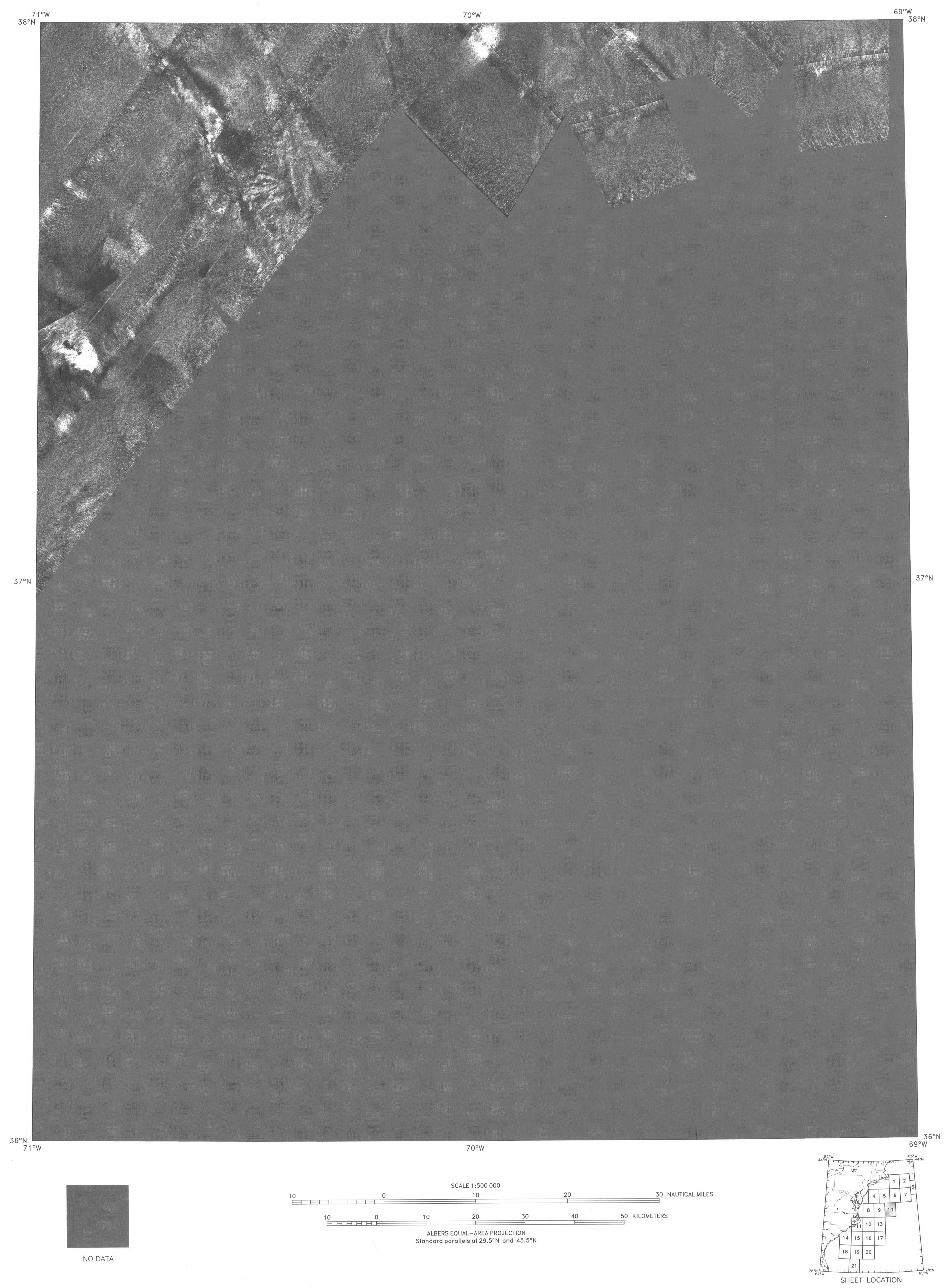



BATHYMETRY

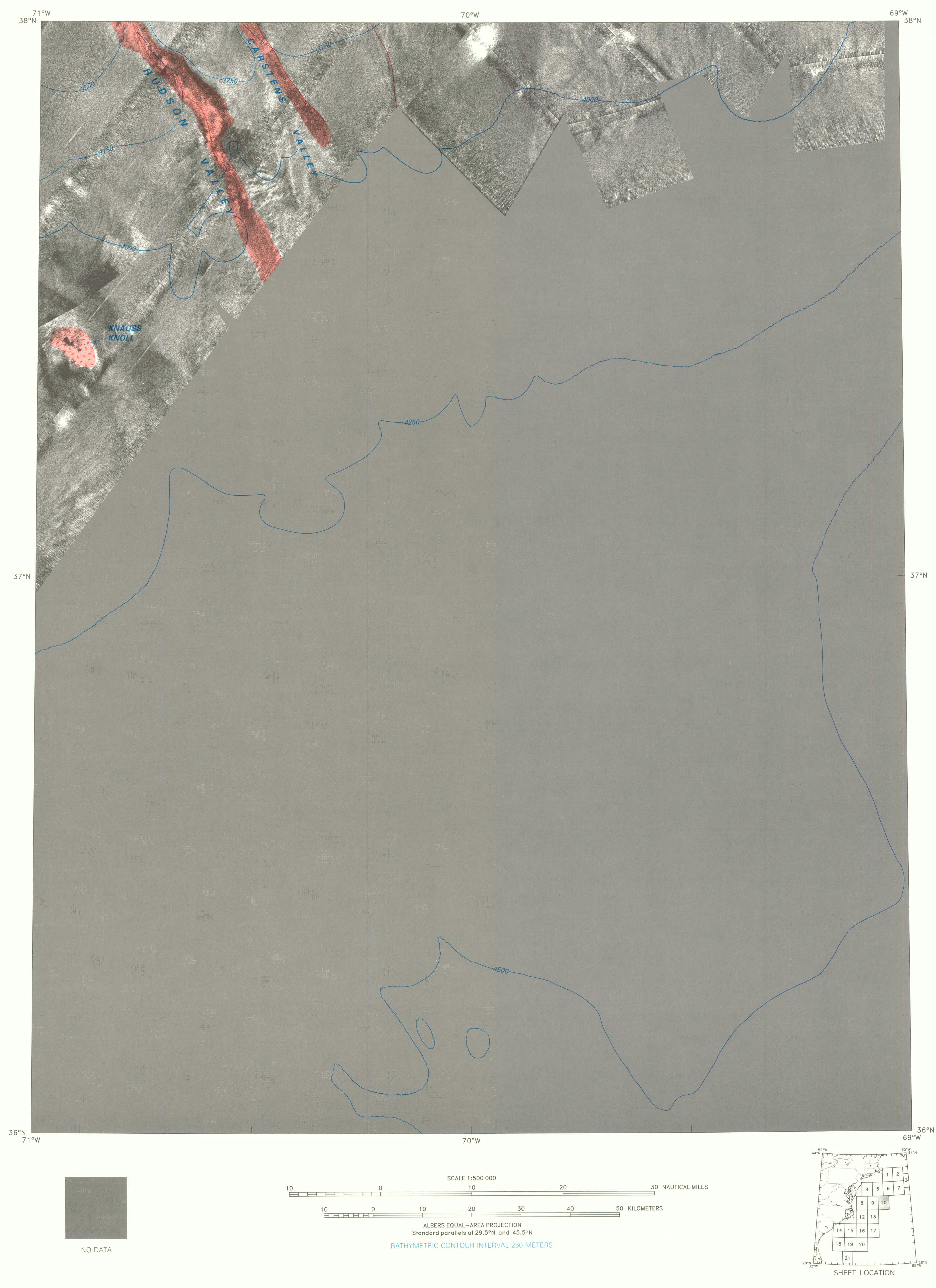




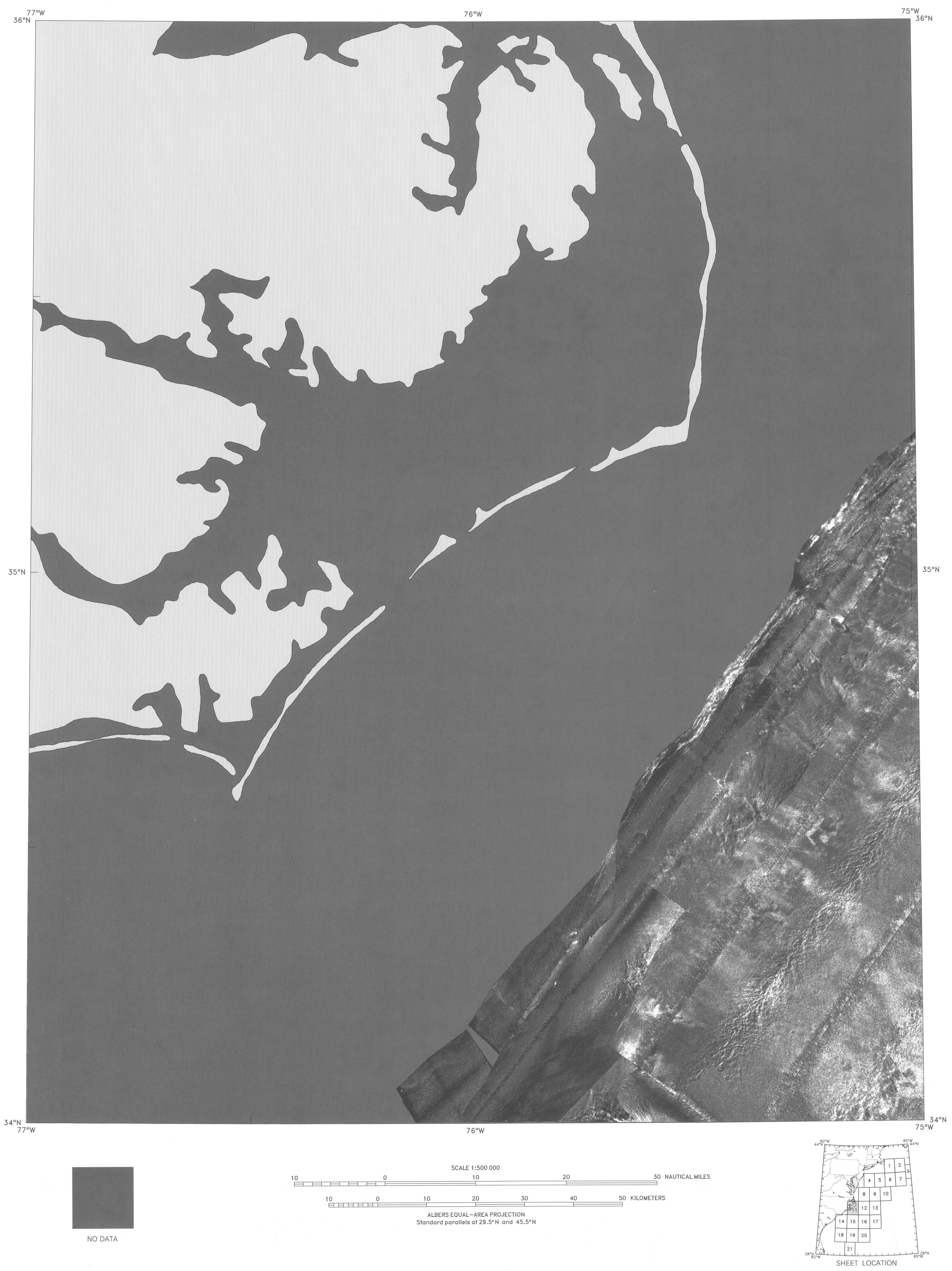



BATHYMETRY

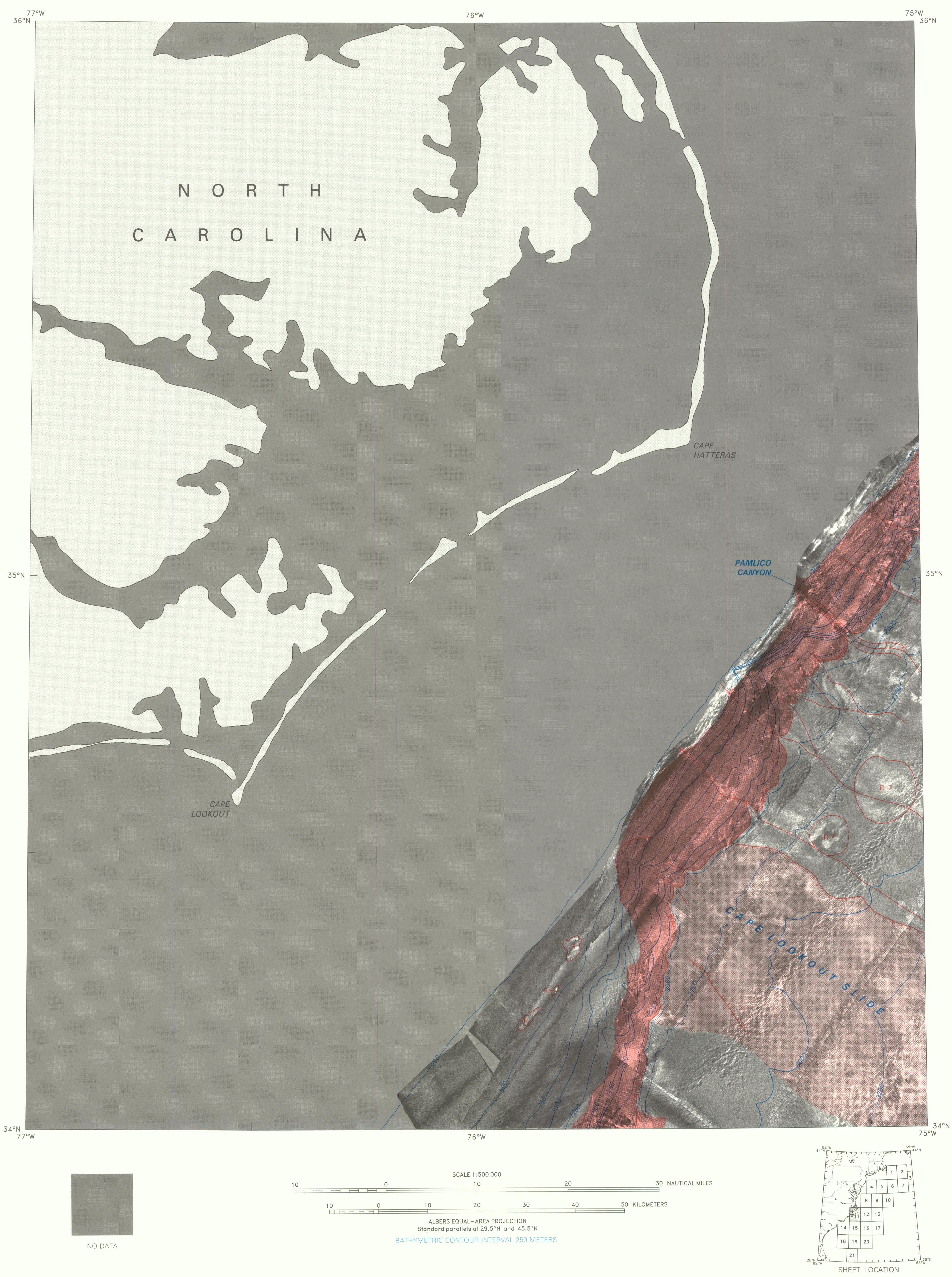




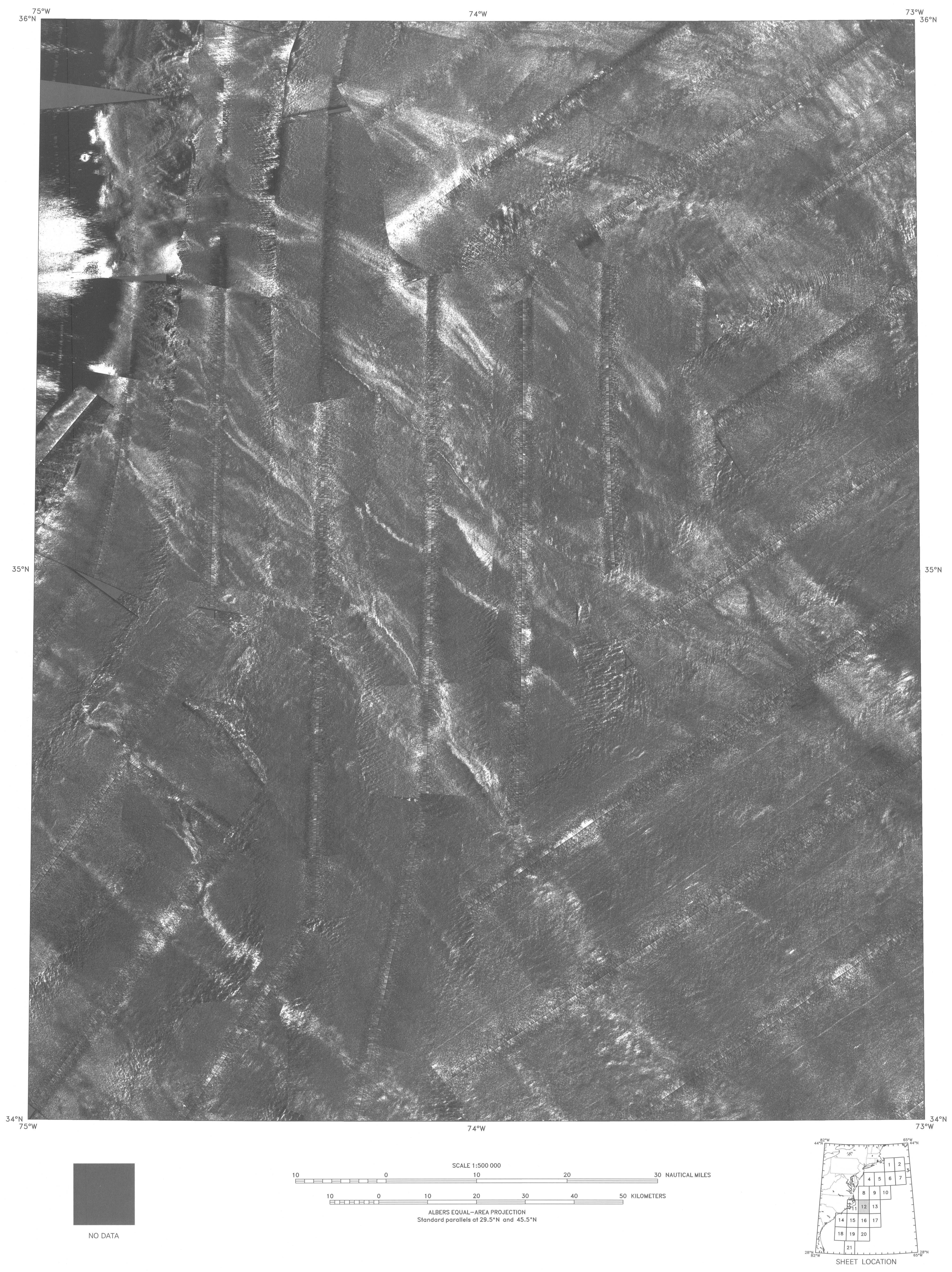




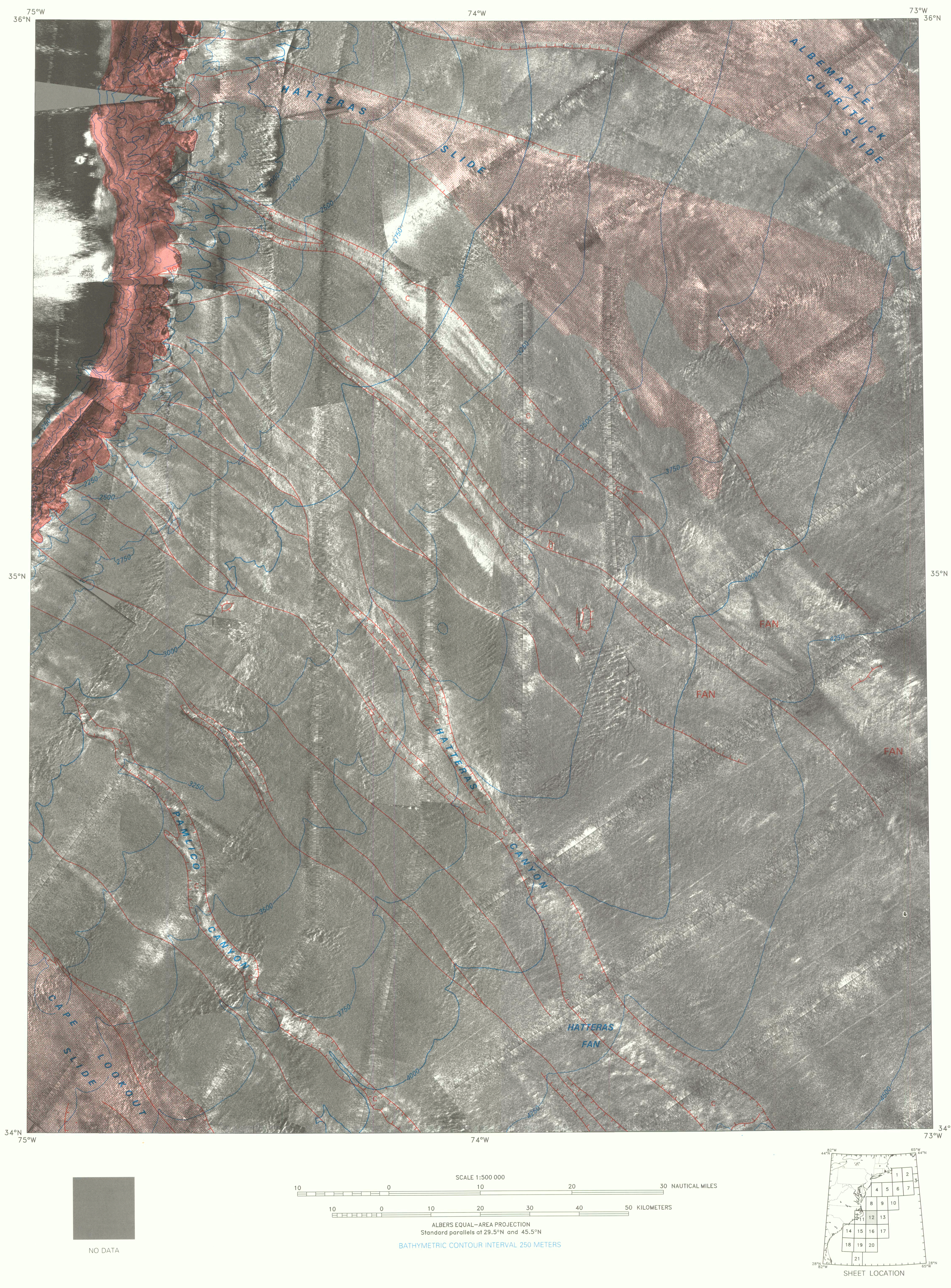




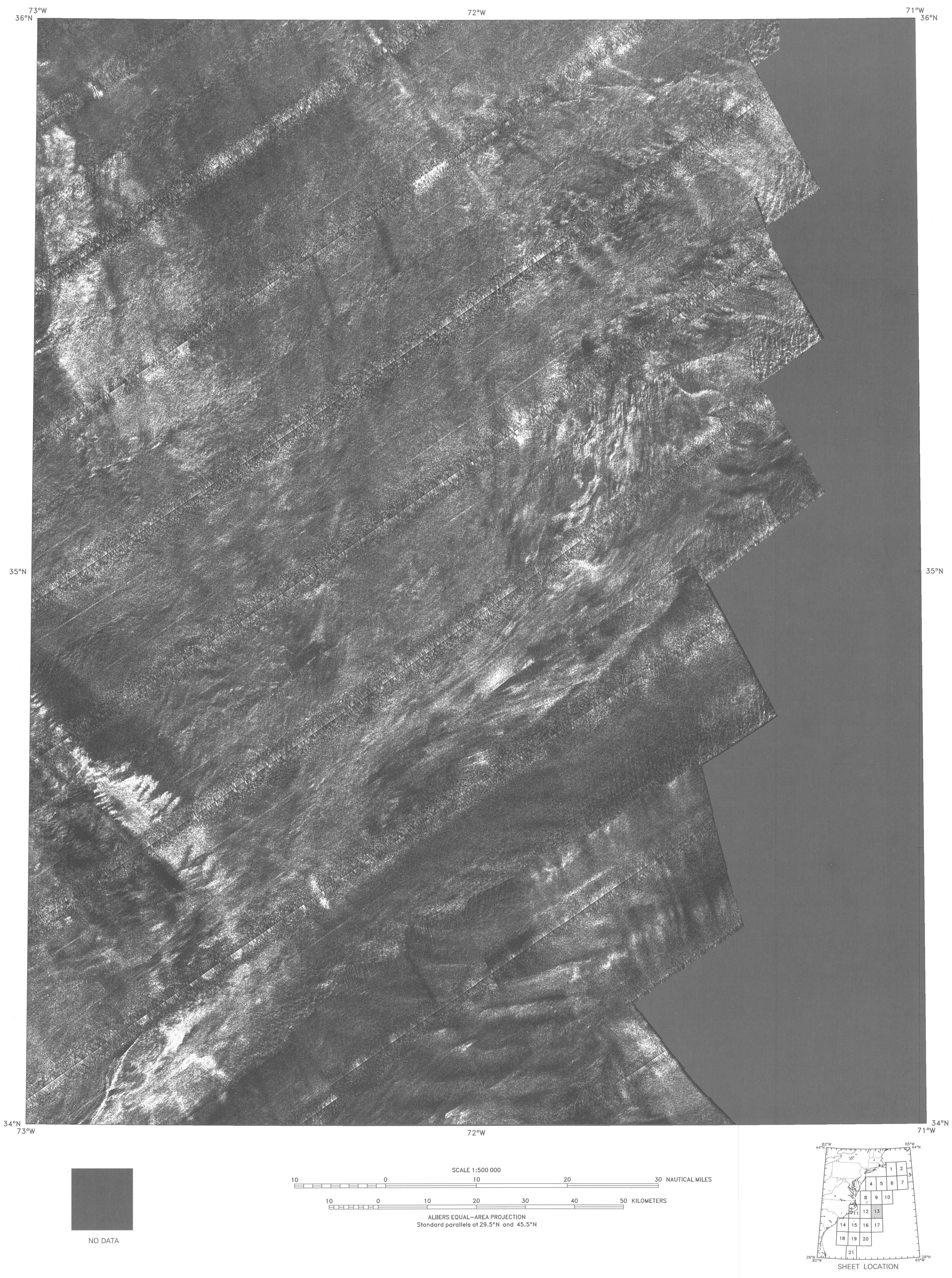




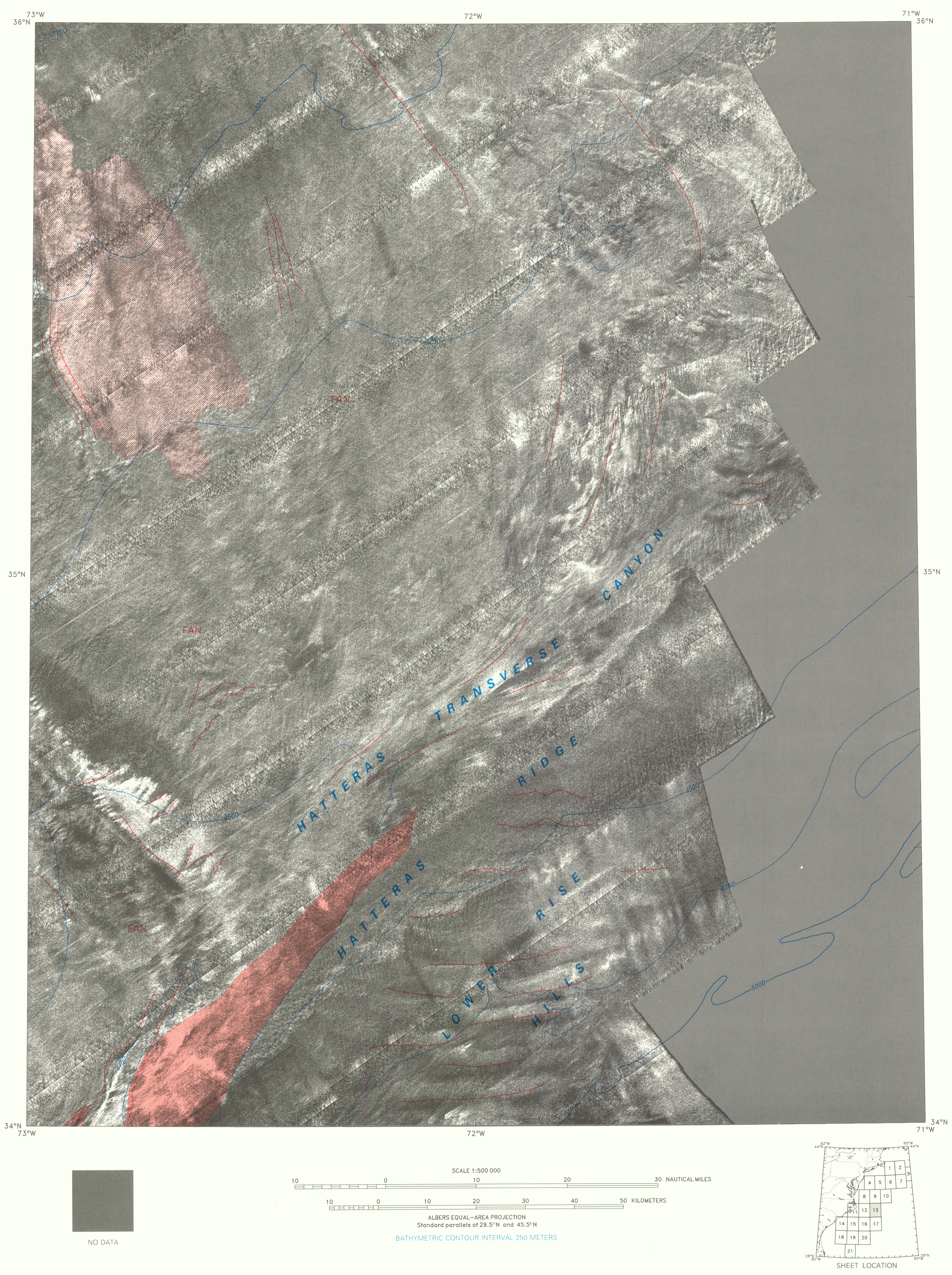




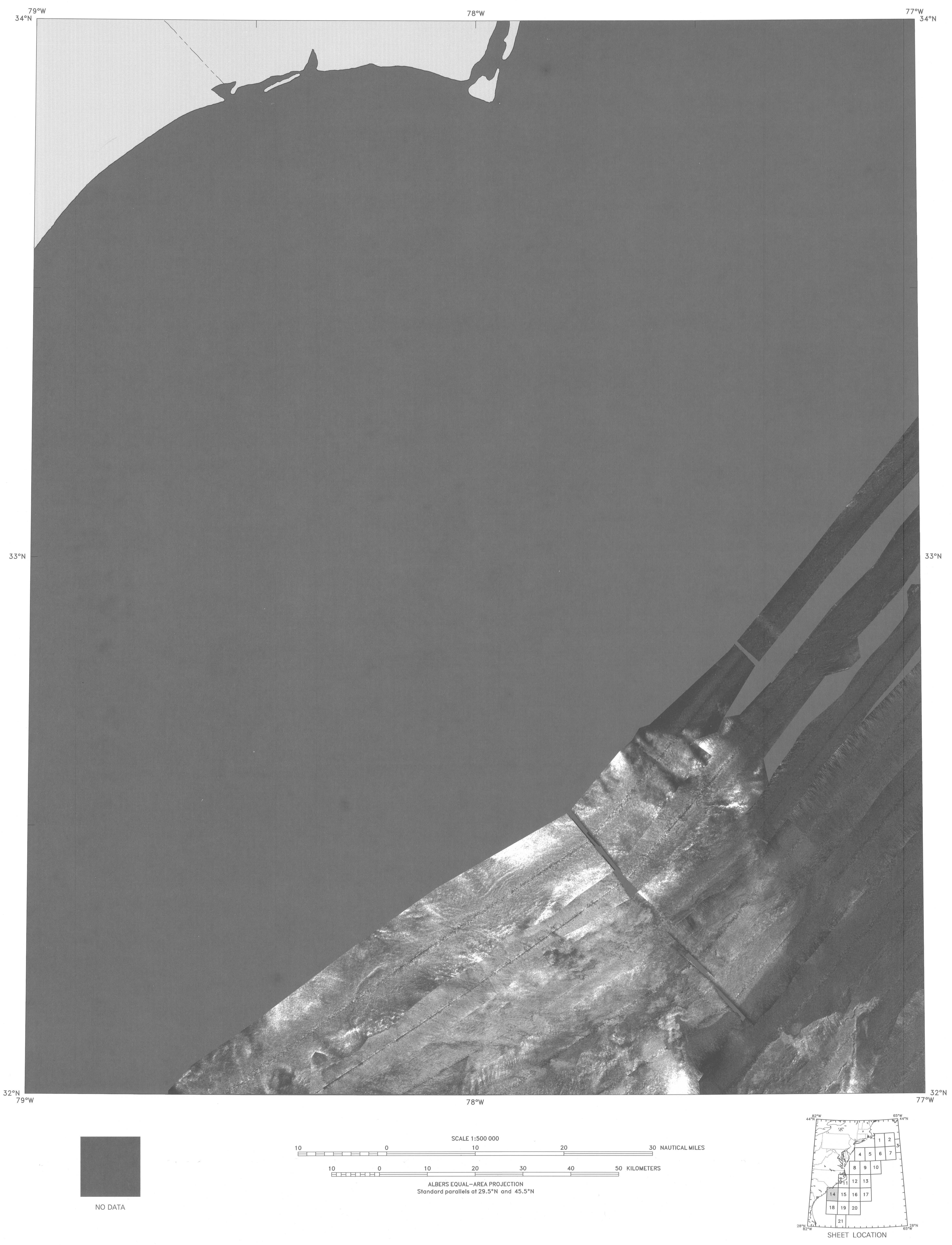




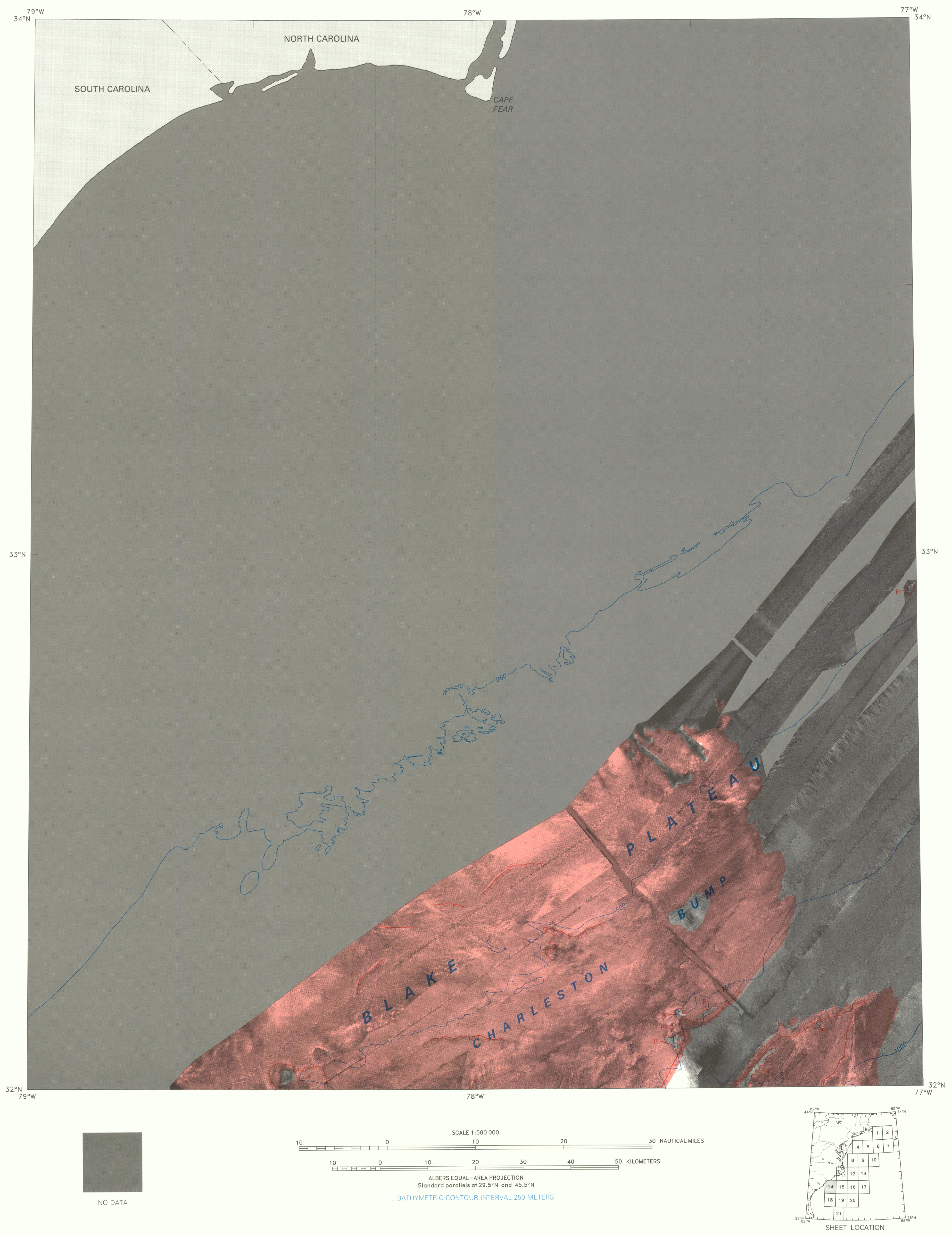




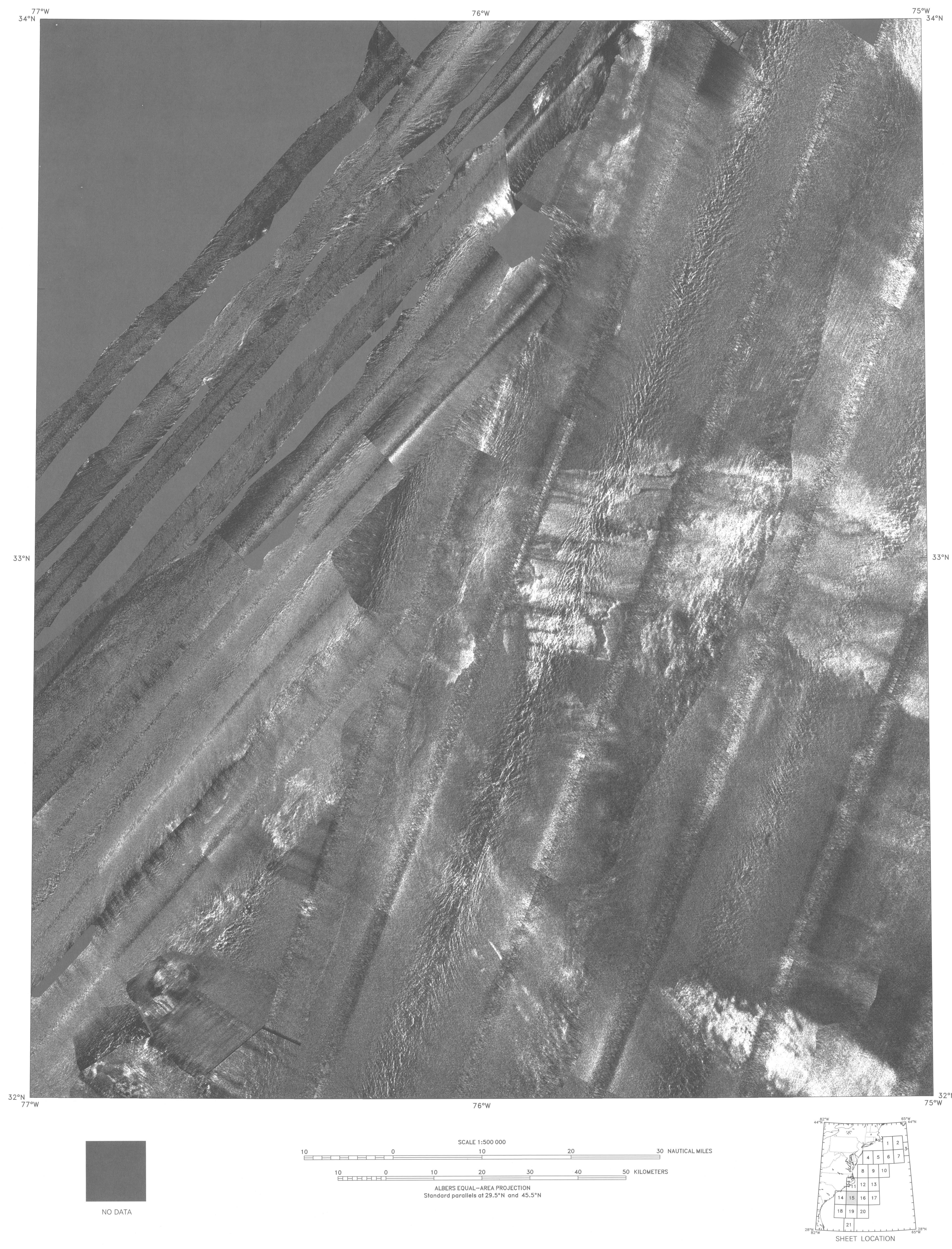




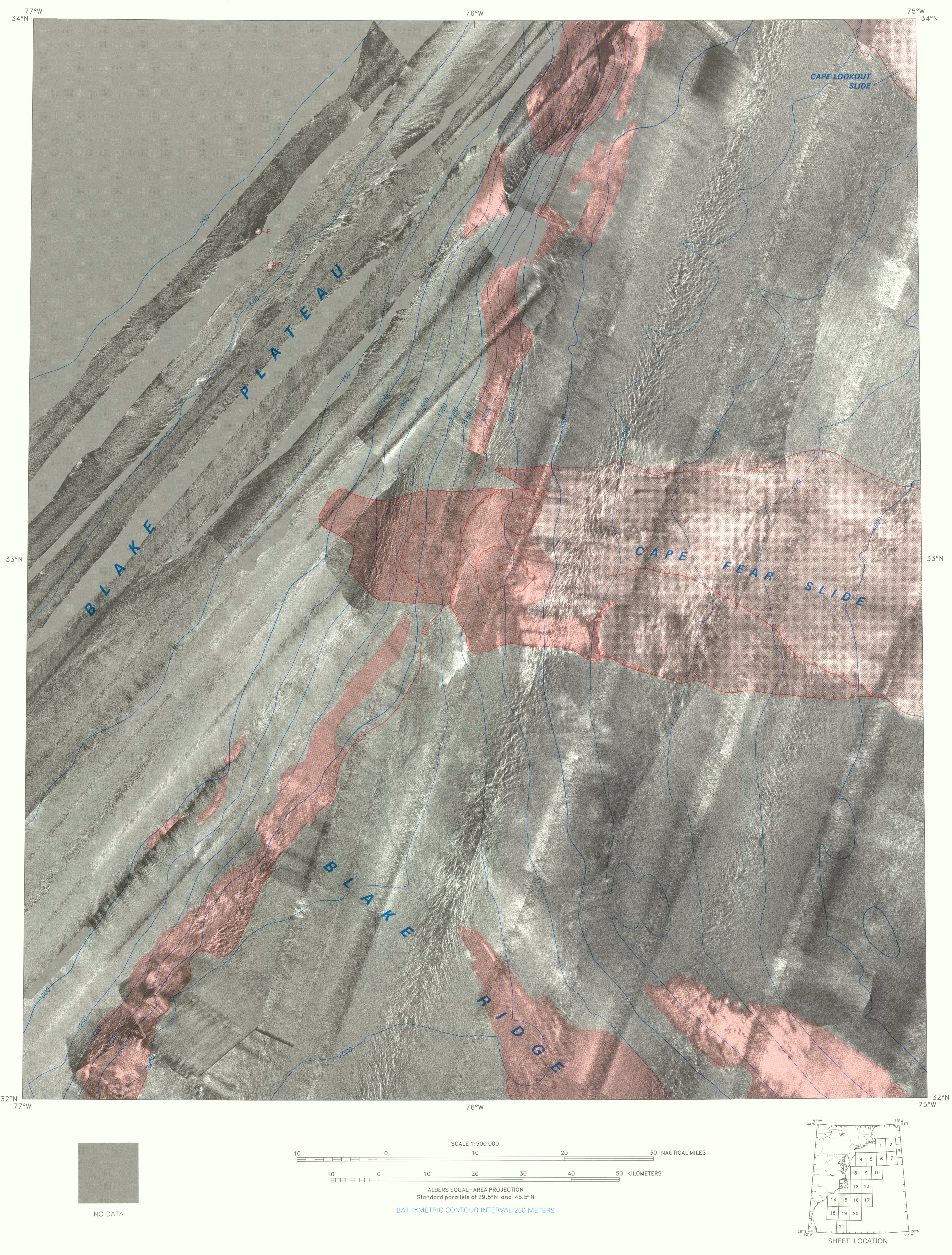




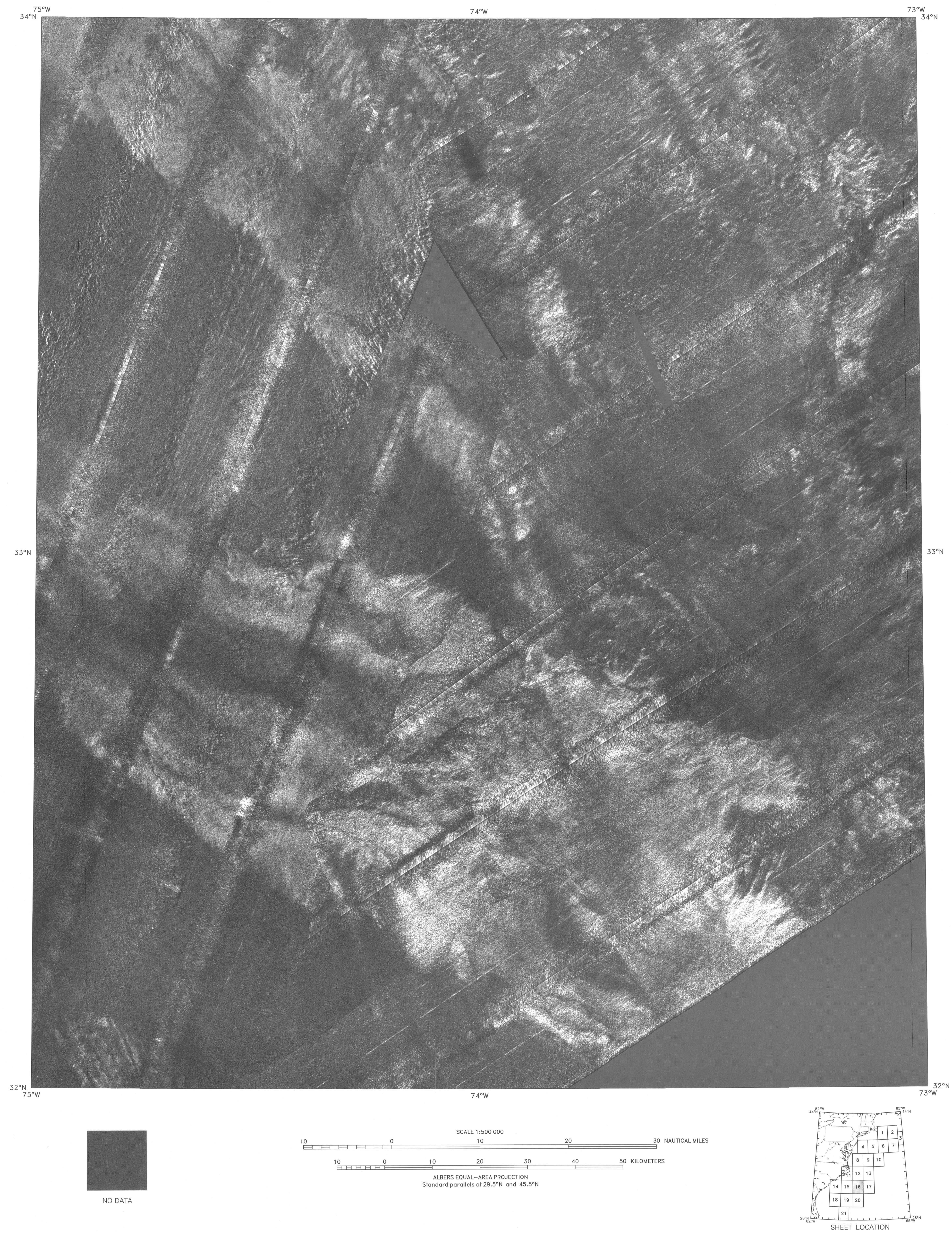



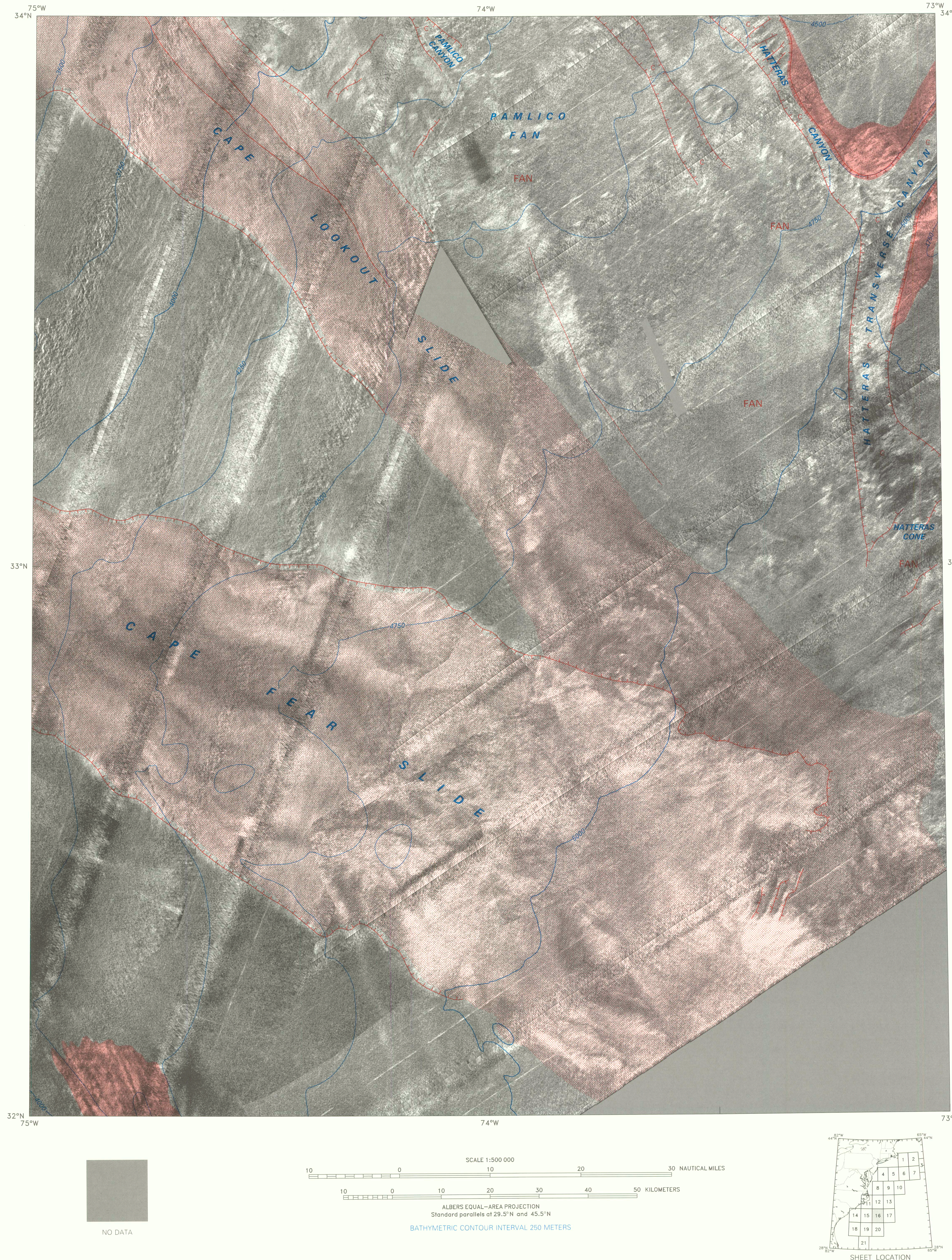


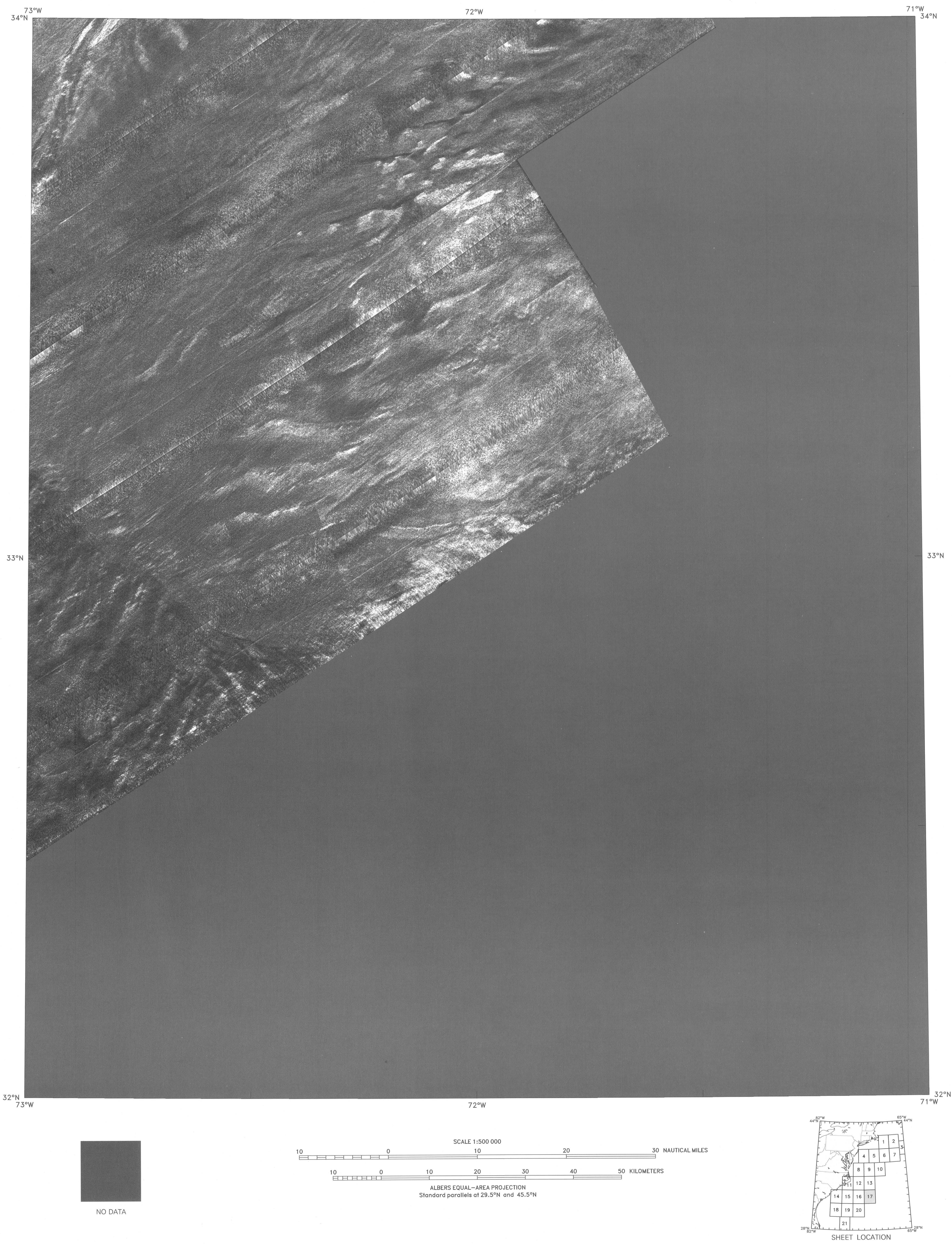




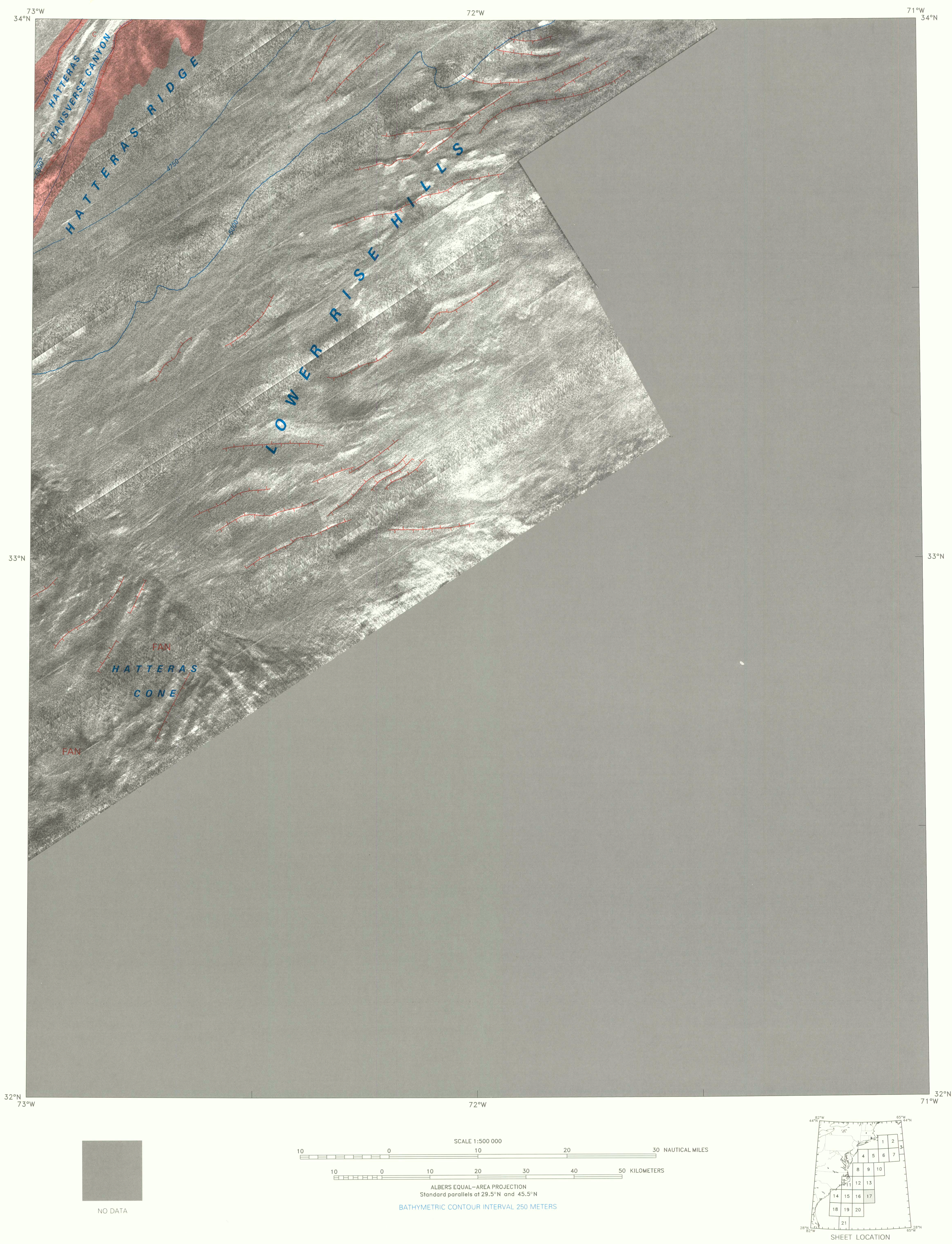




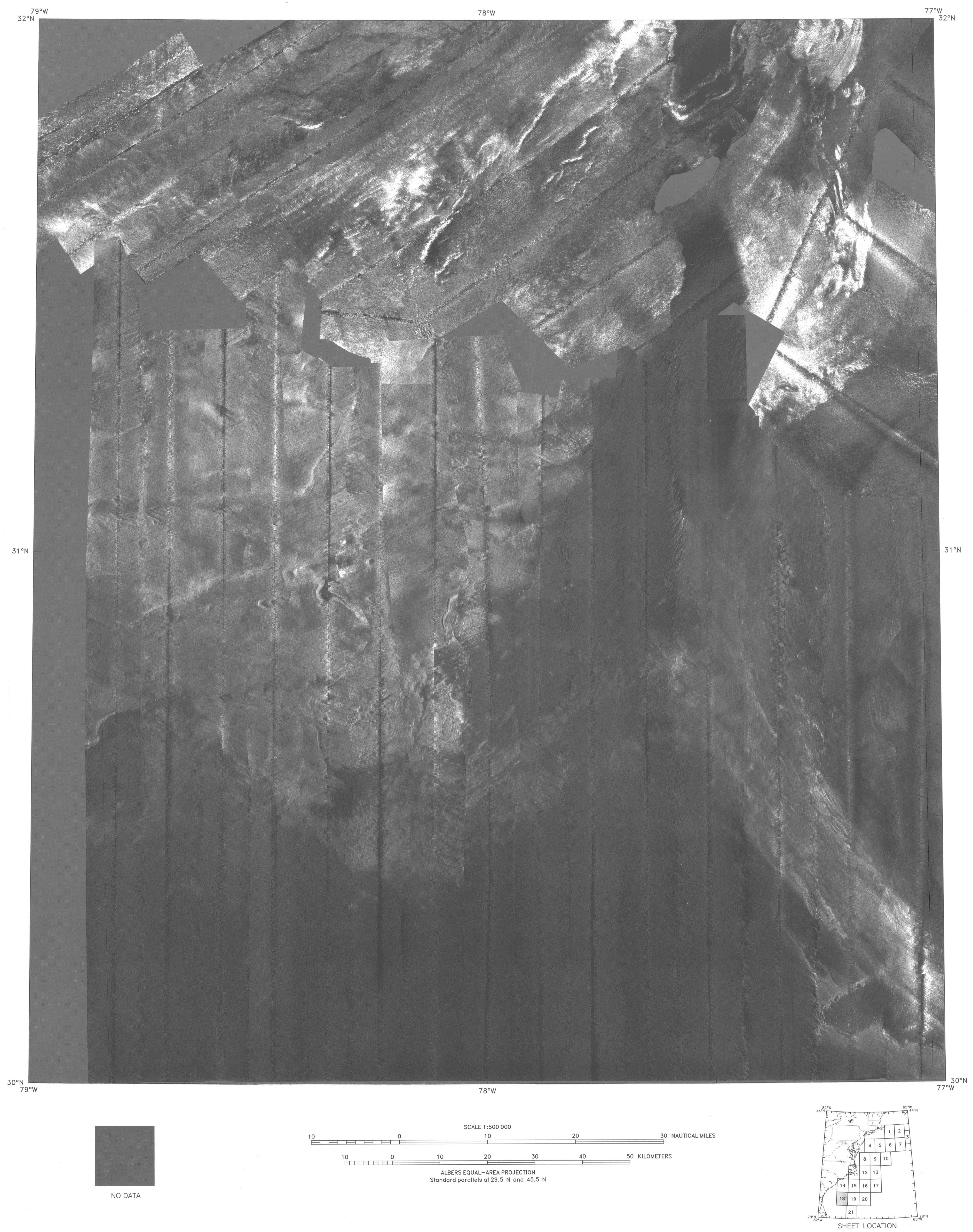




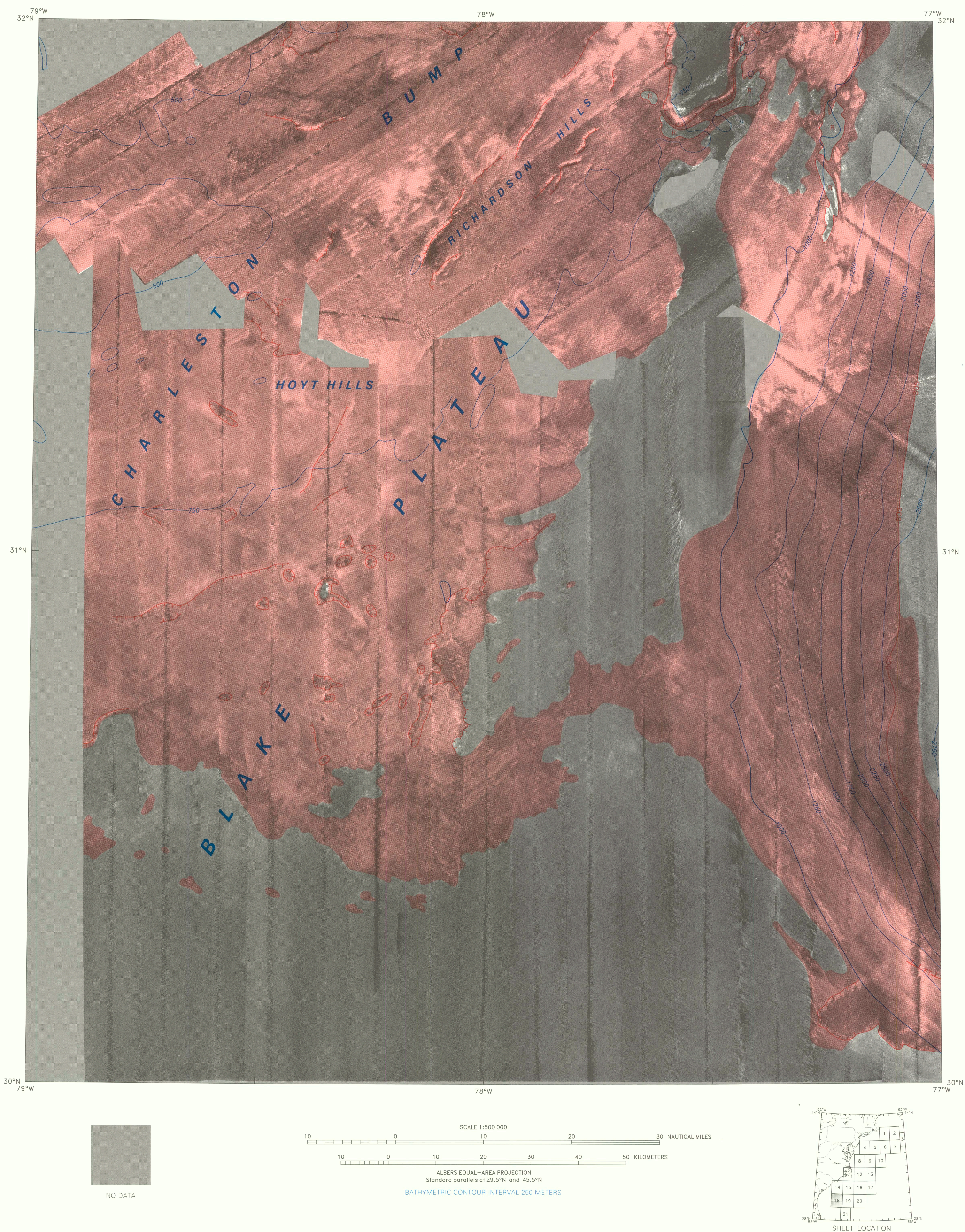




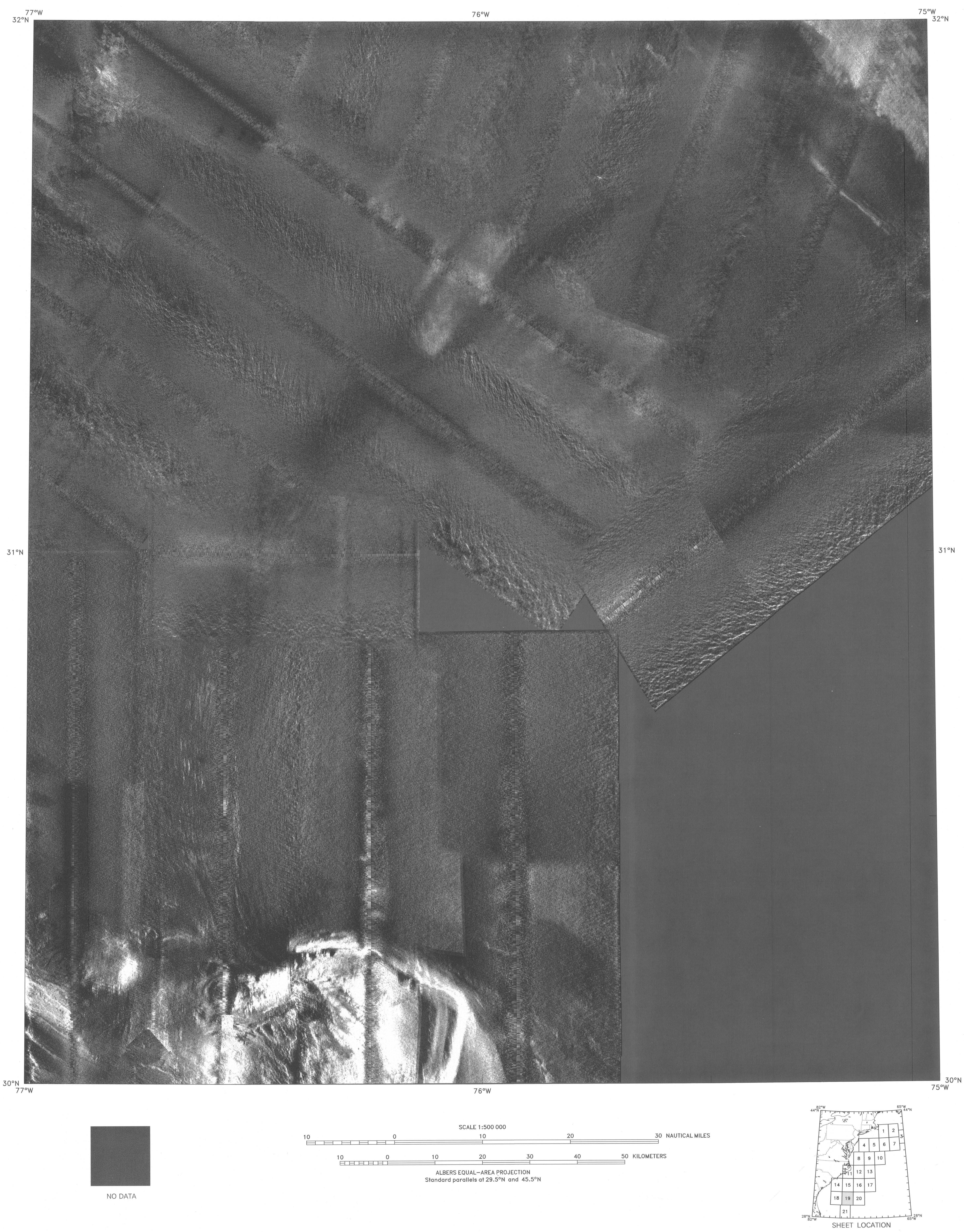




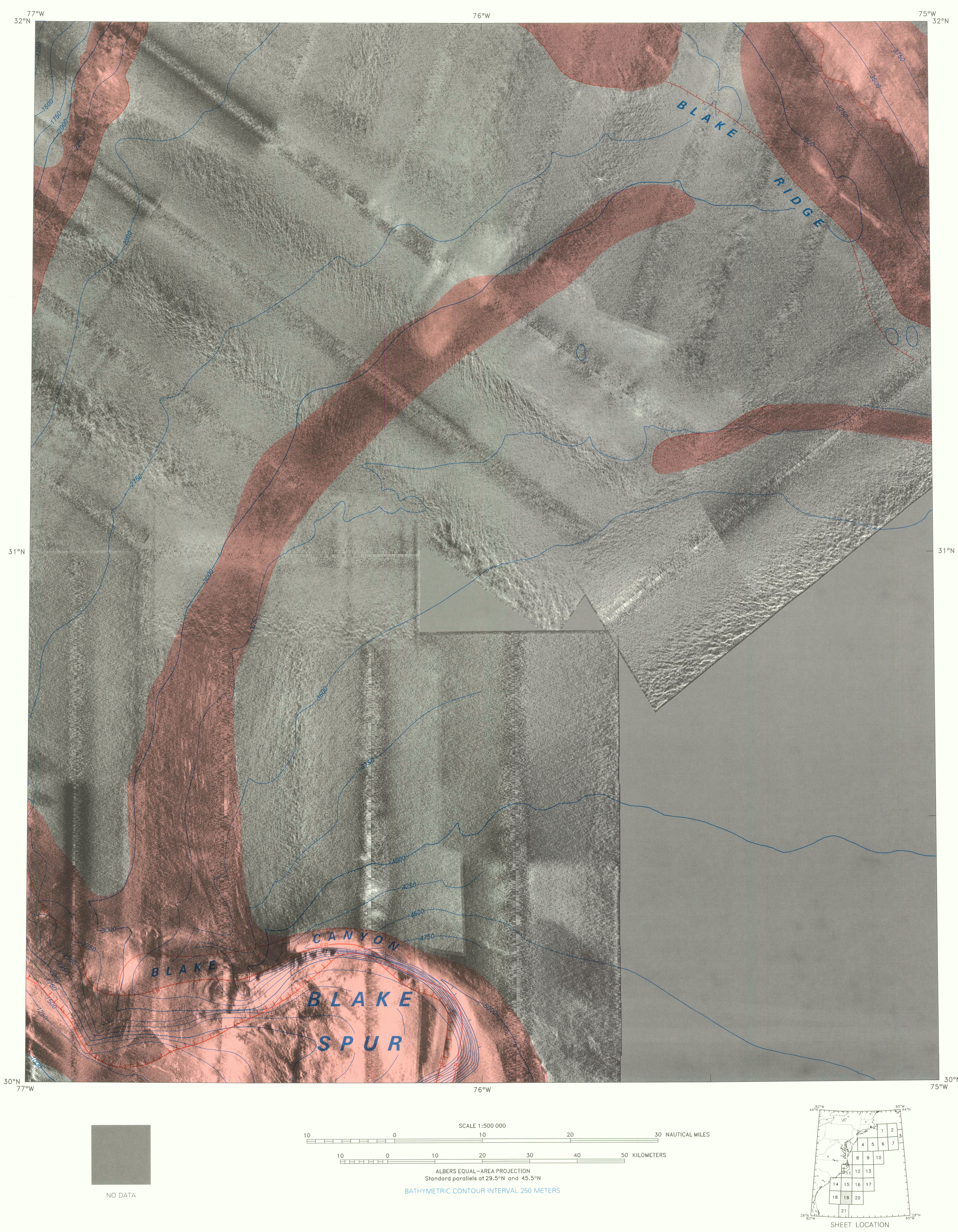




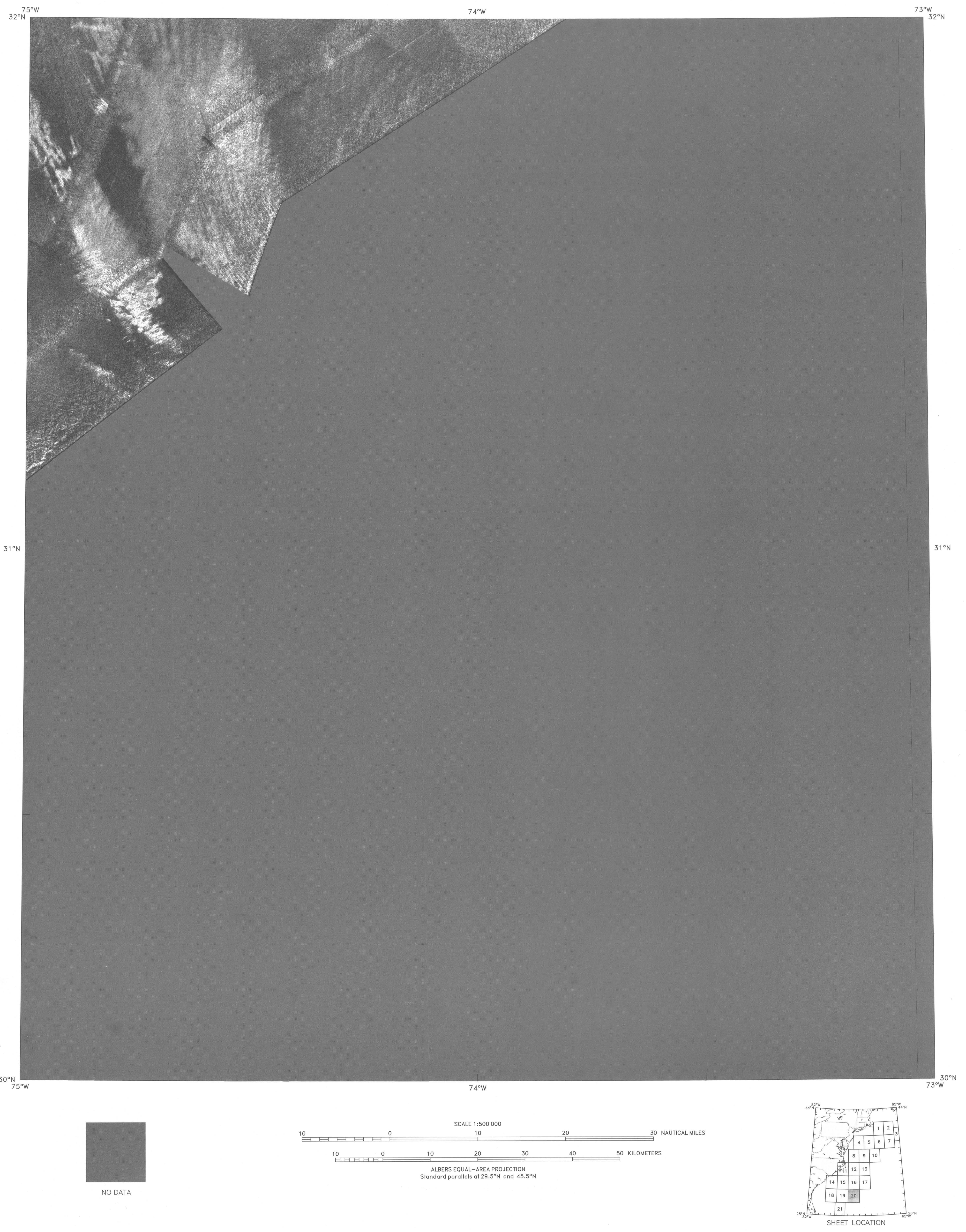




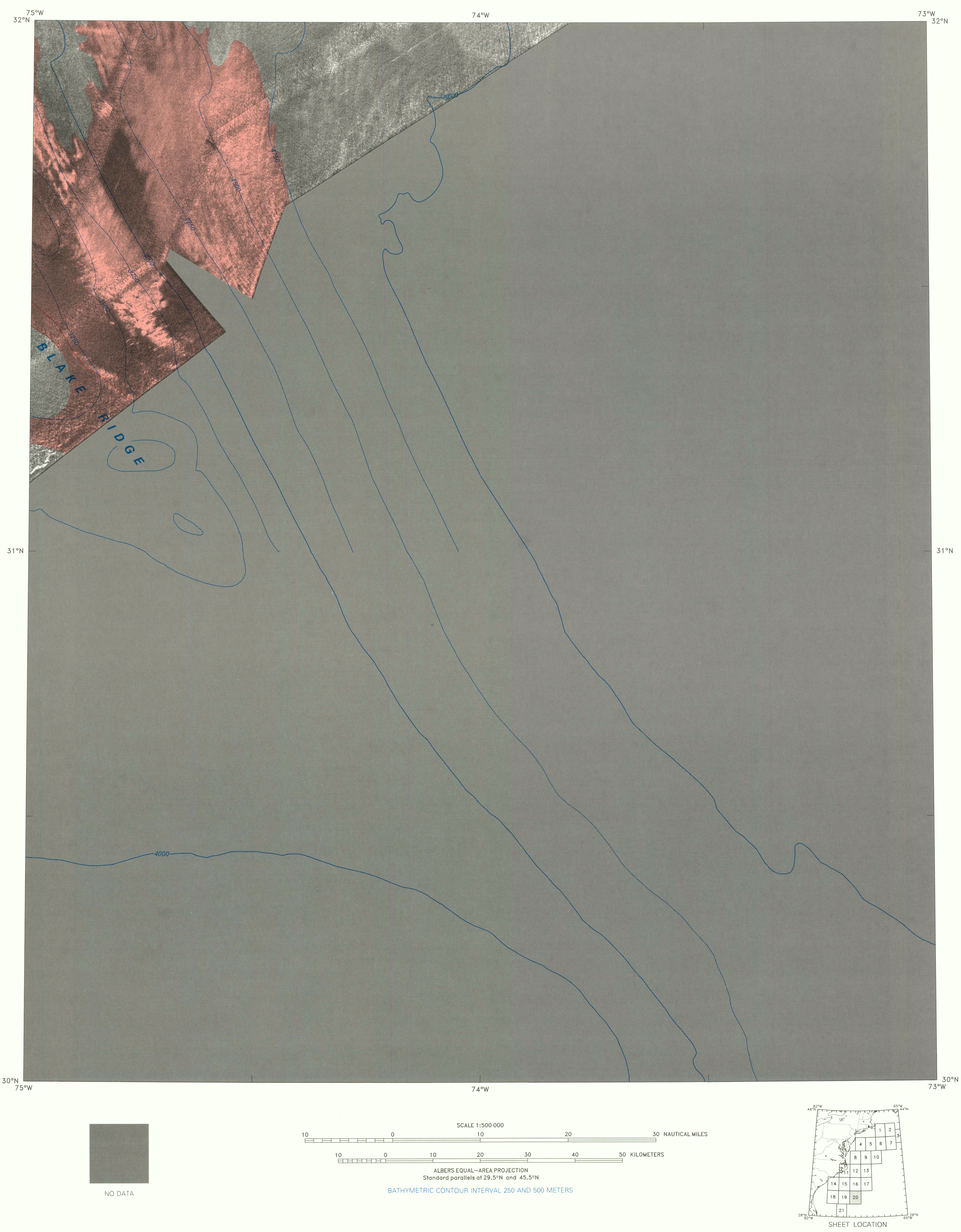




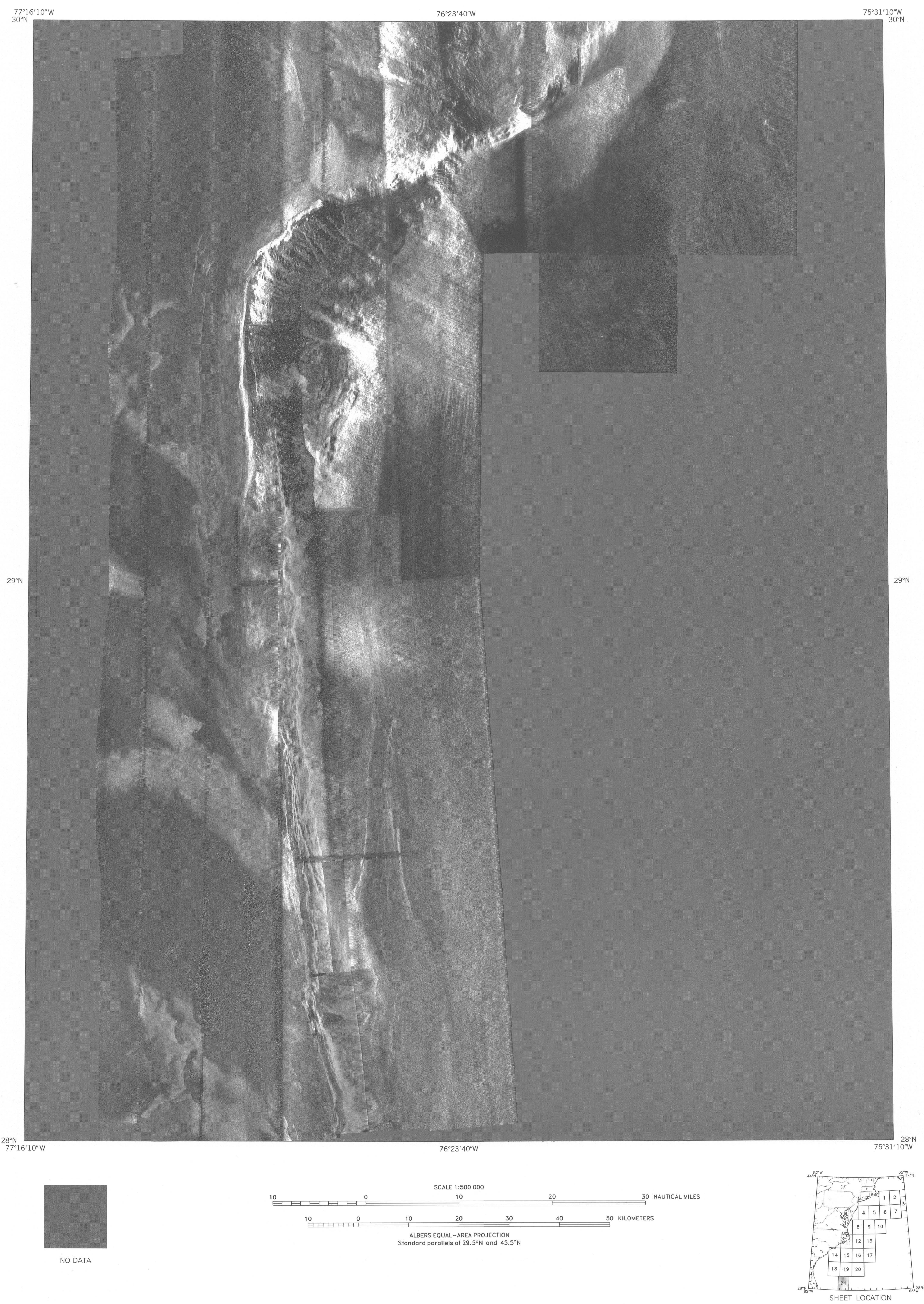



BATHYMETRY

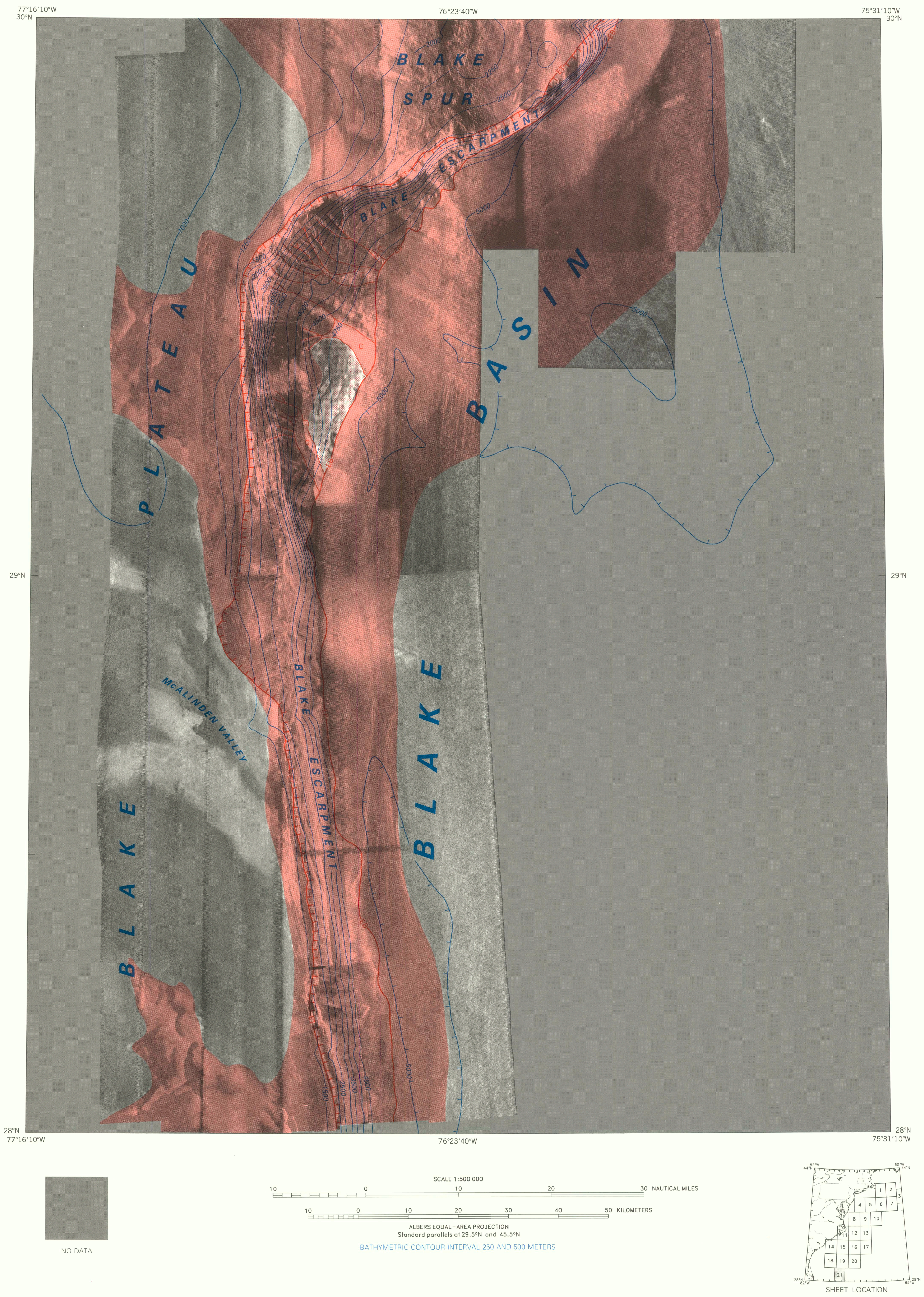


This page left intentionally blank. 
SEISMIC-REFLECTION PROFILES 

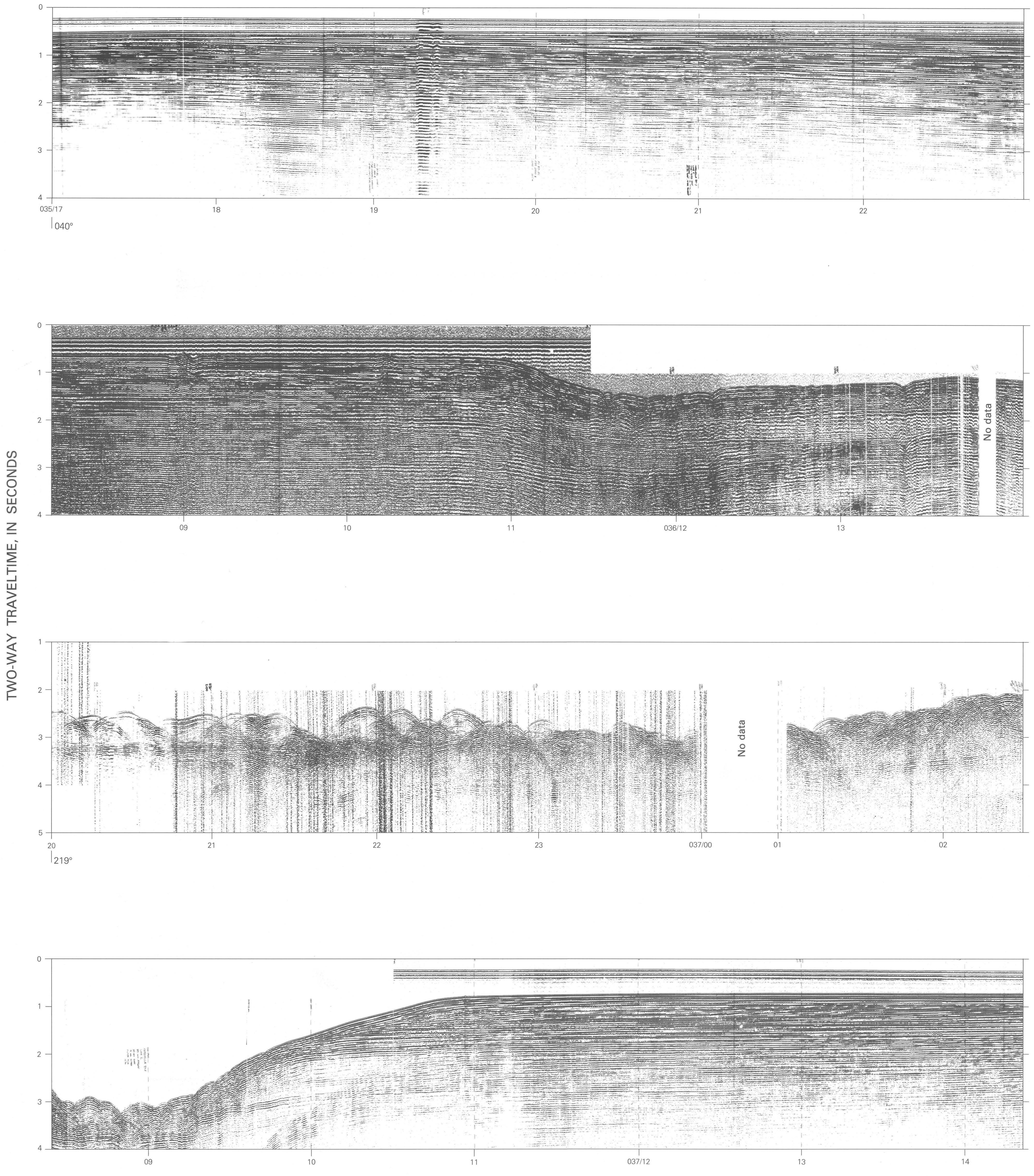

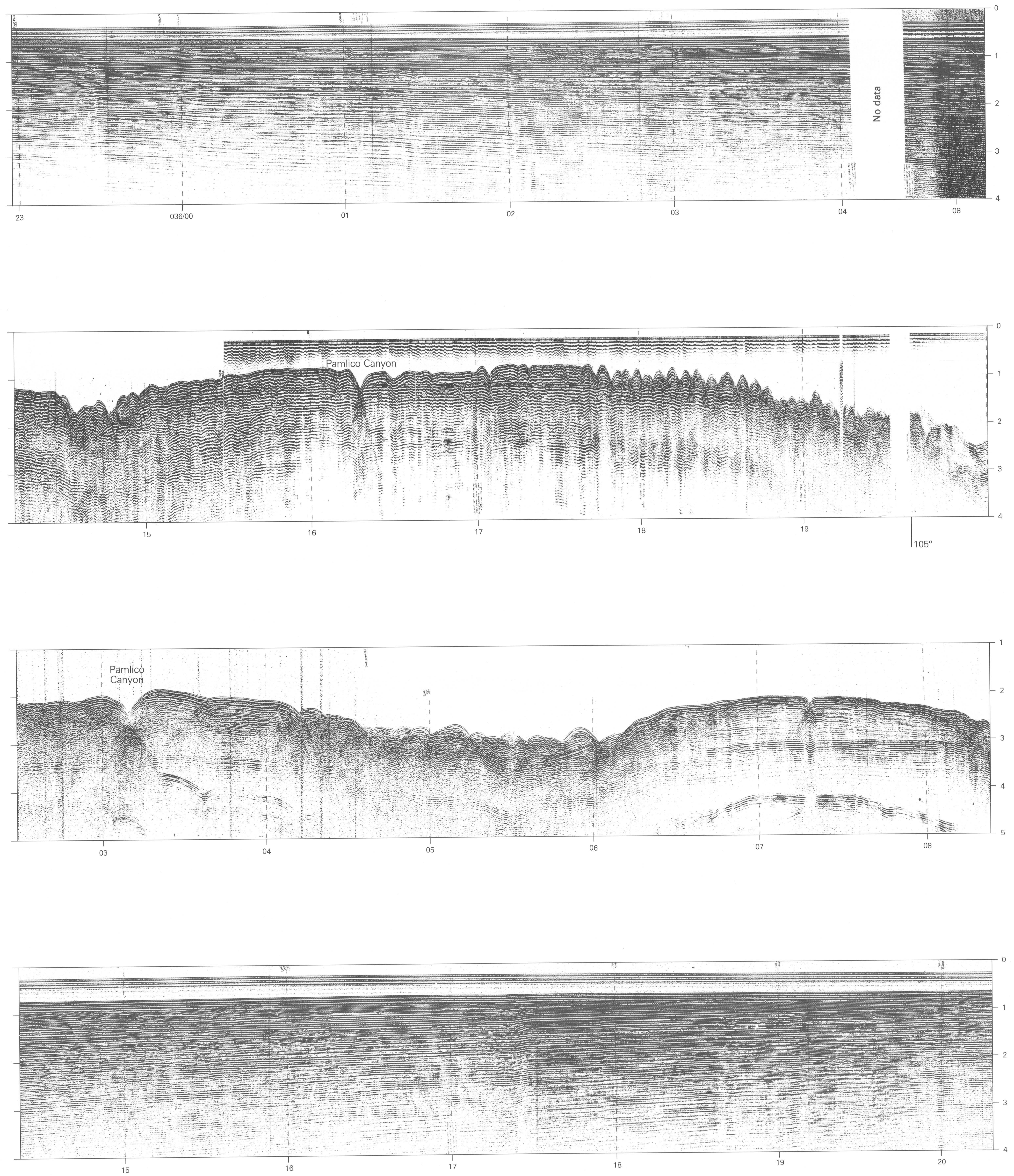

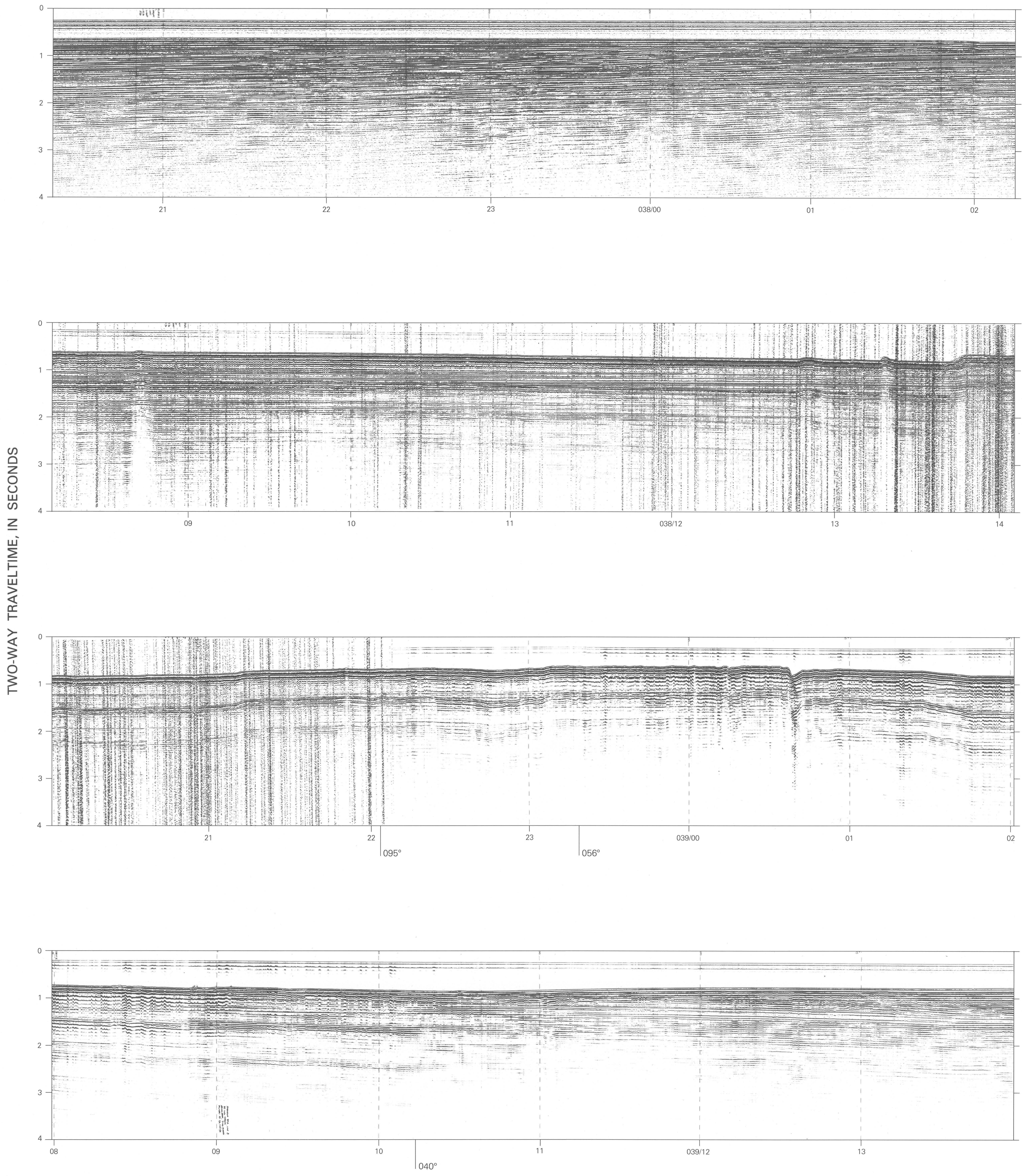

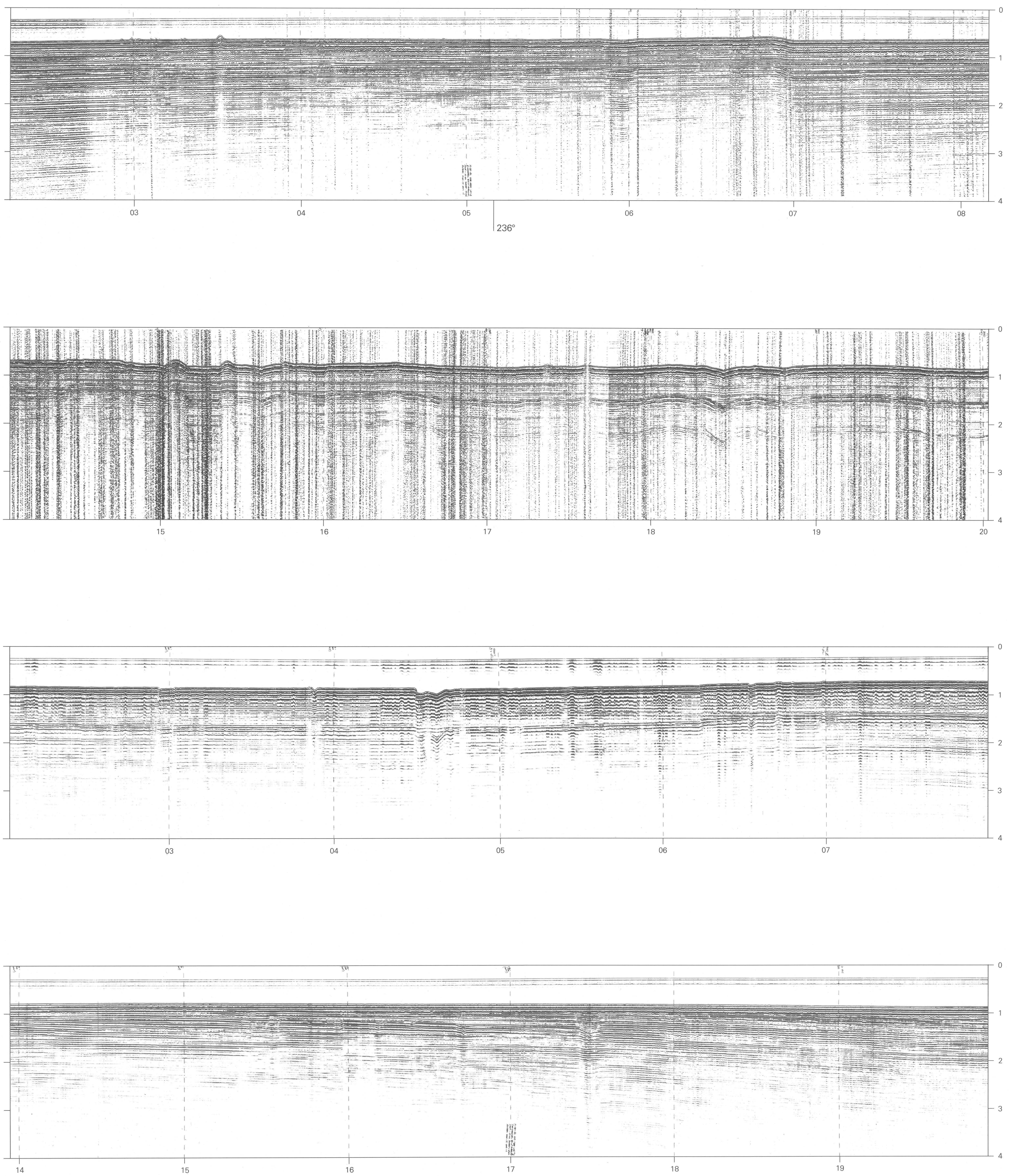

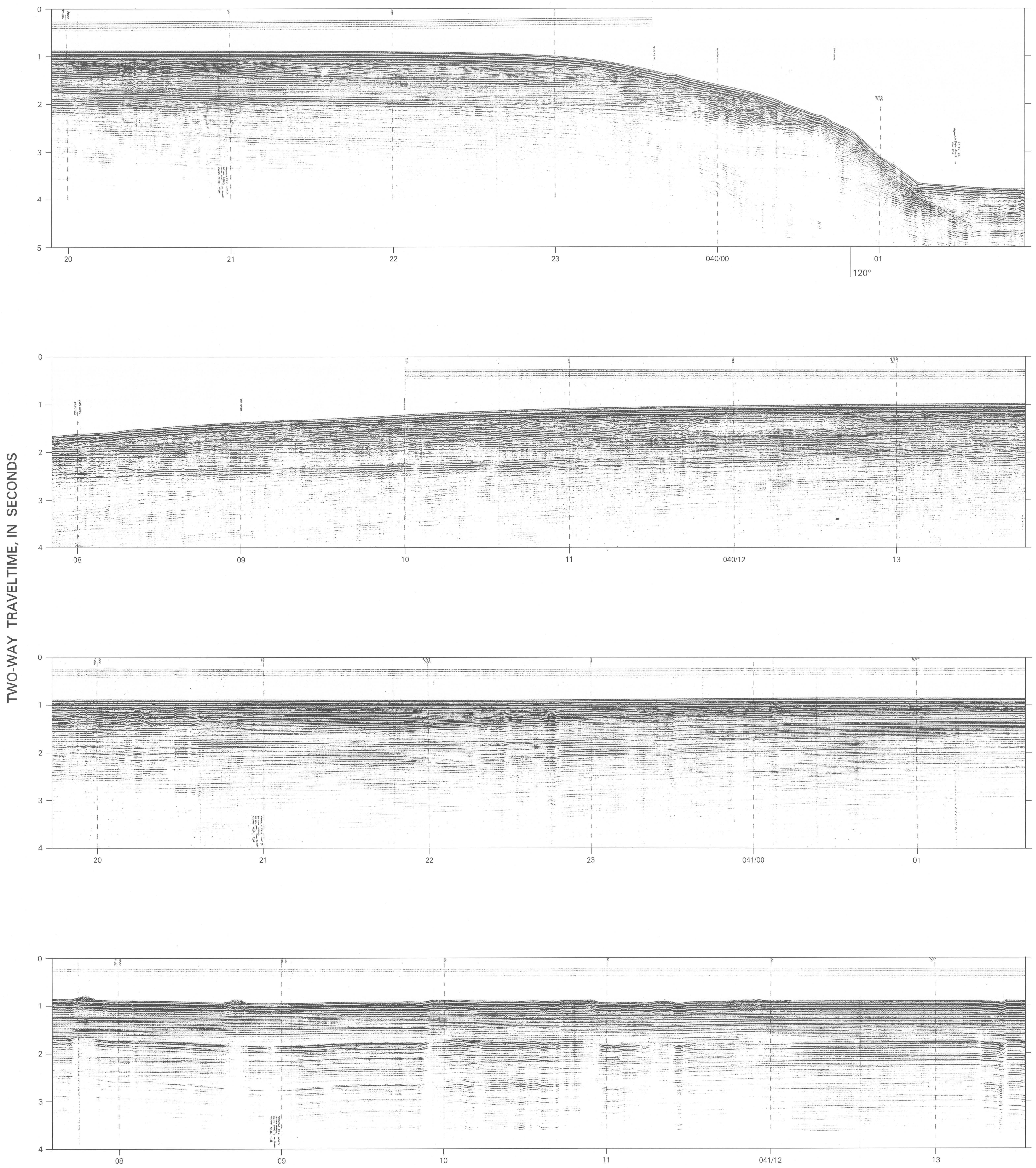

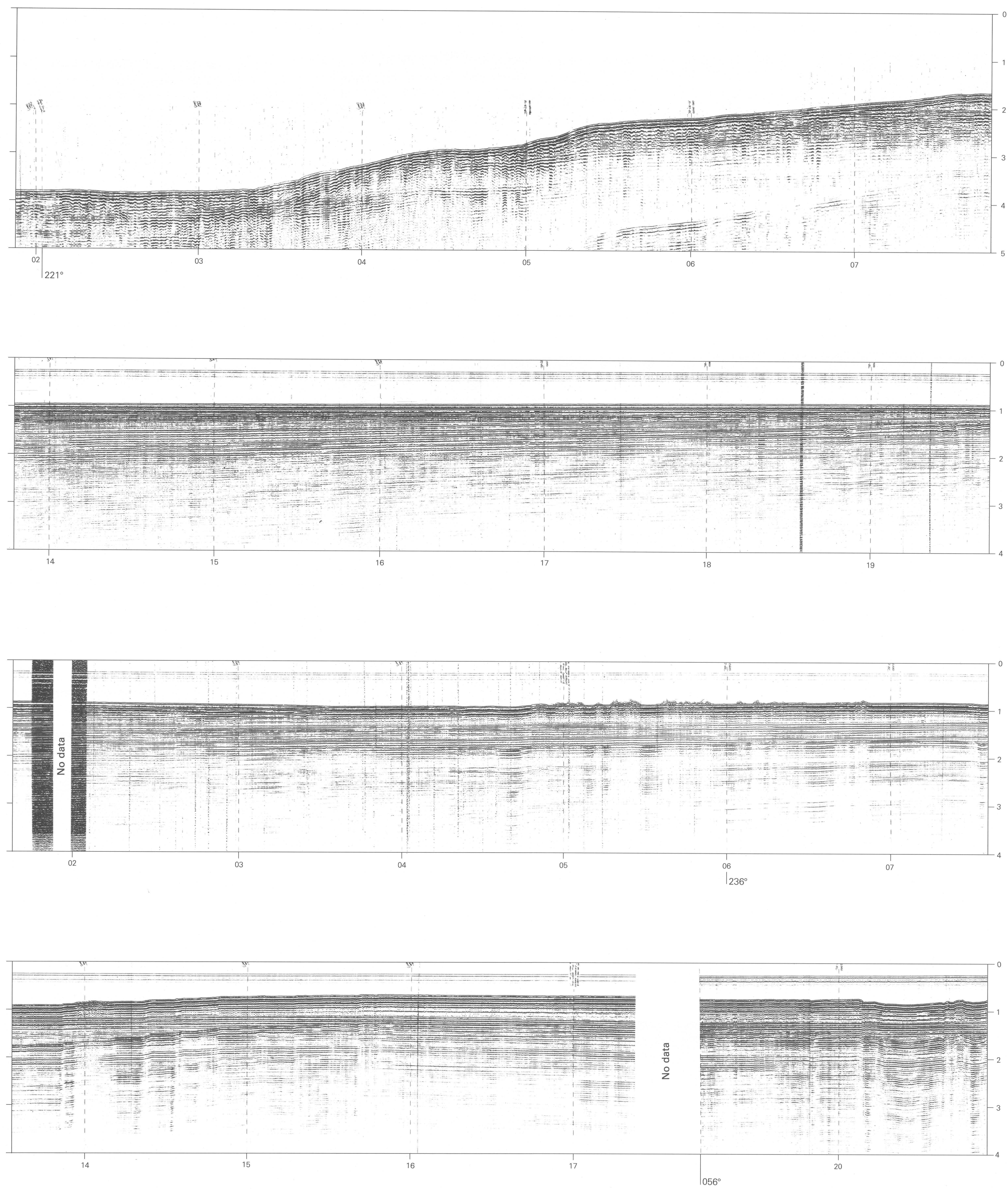

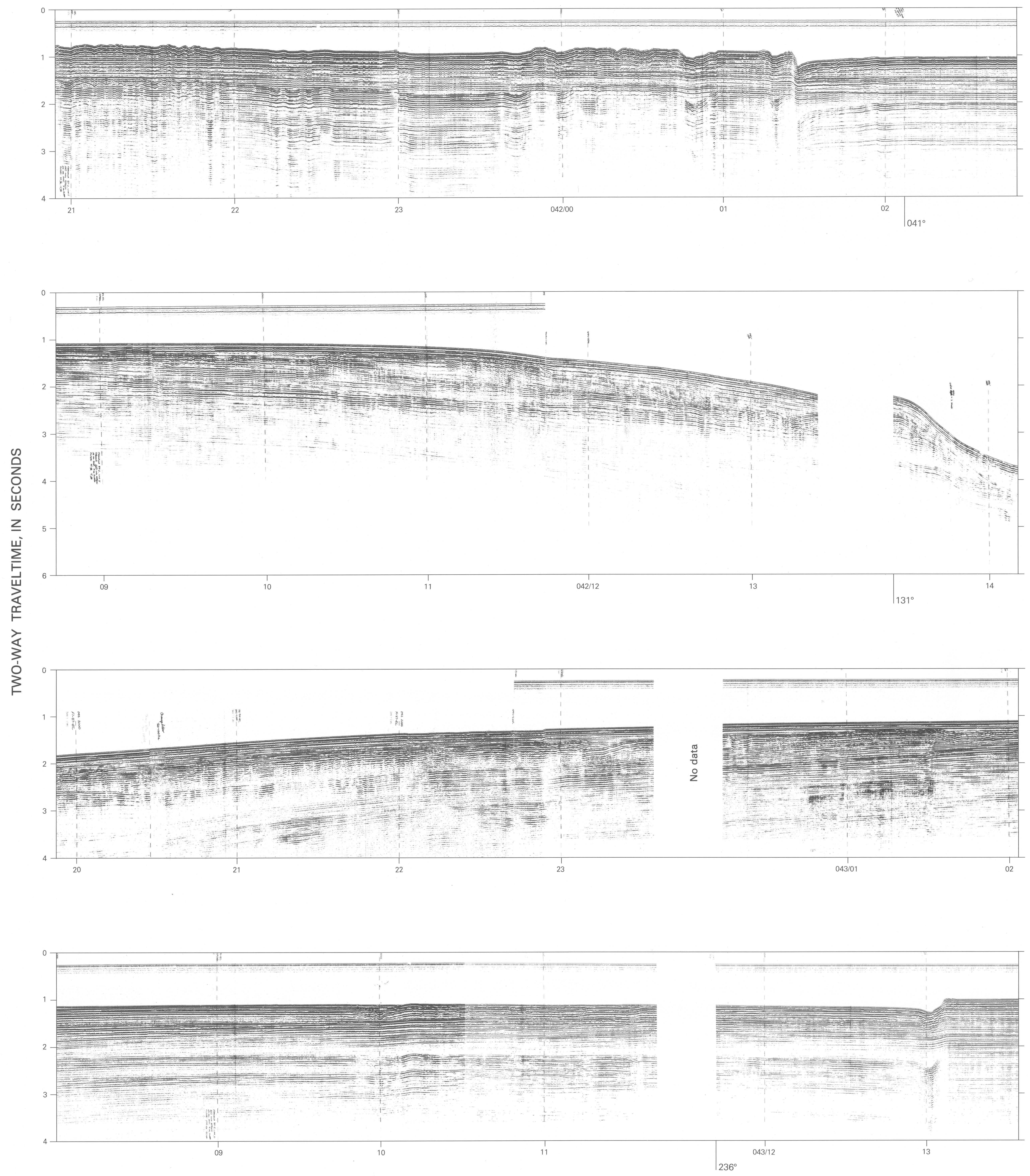

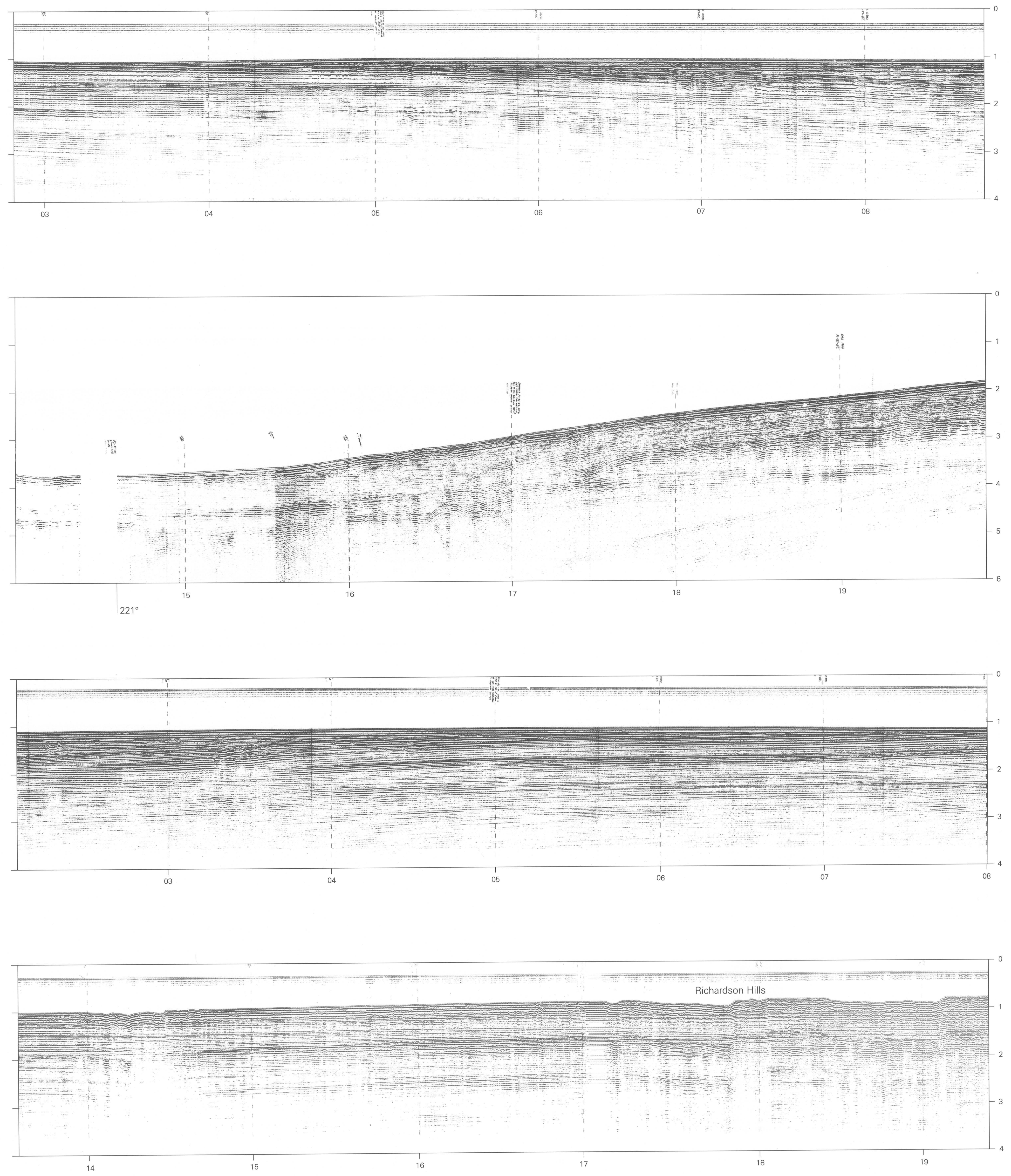

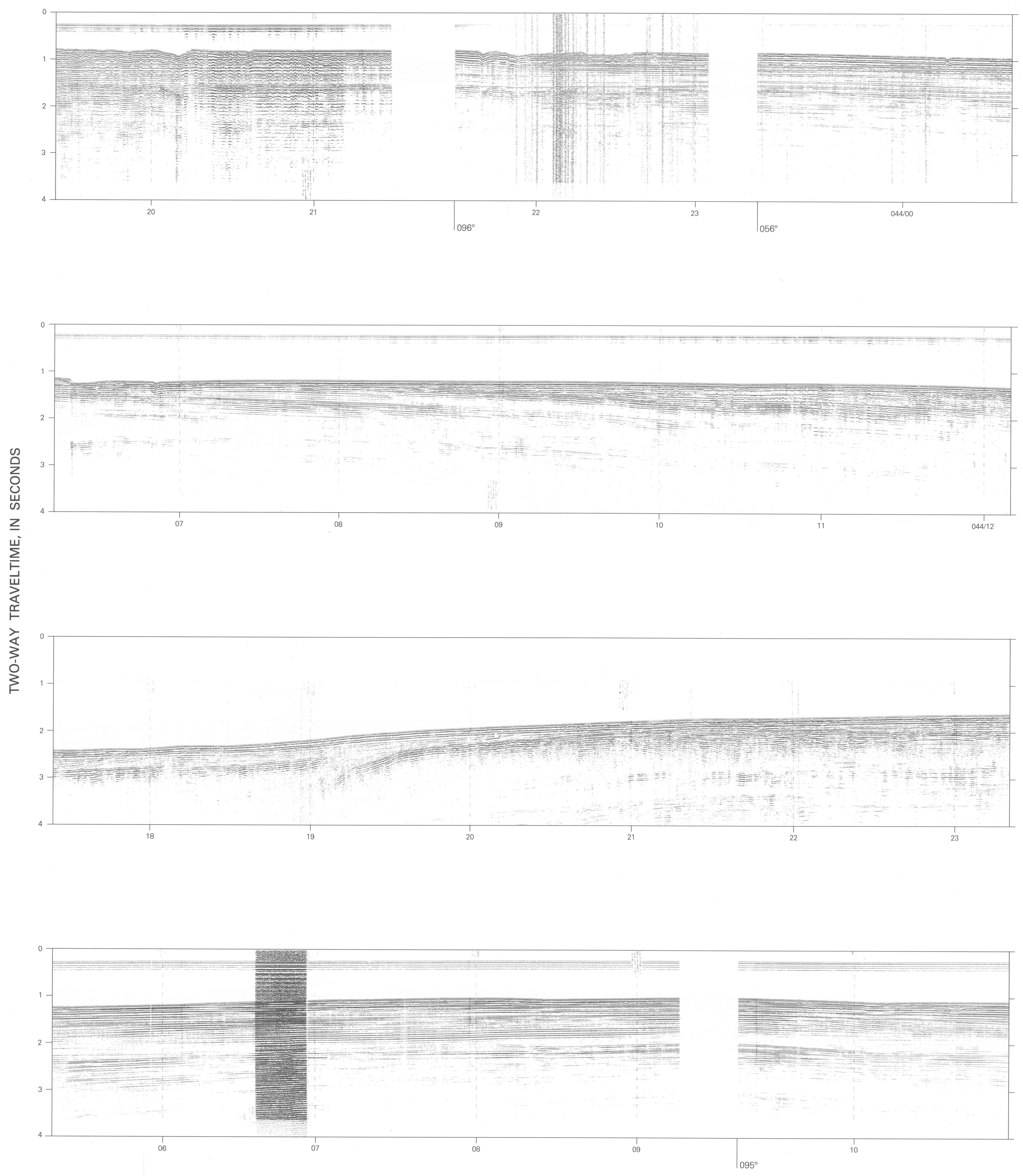

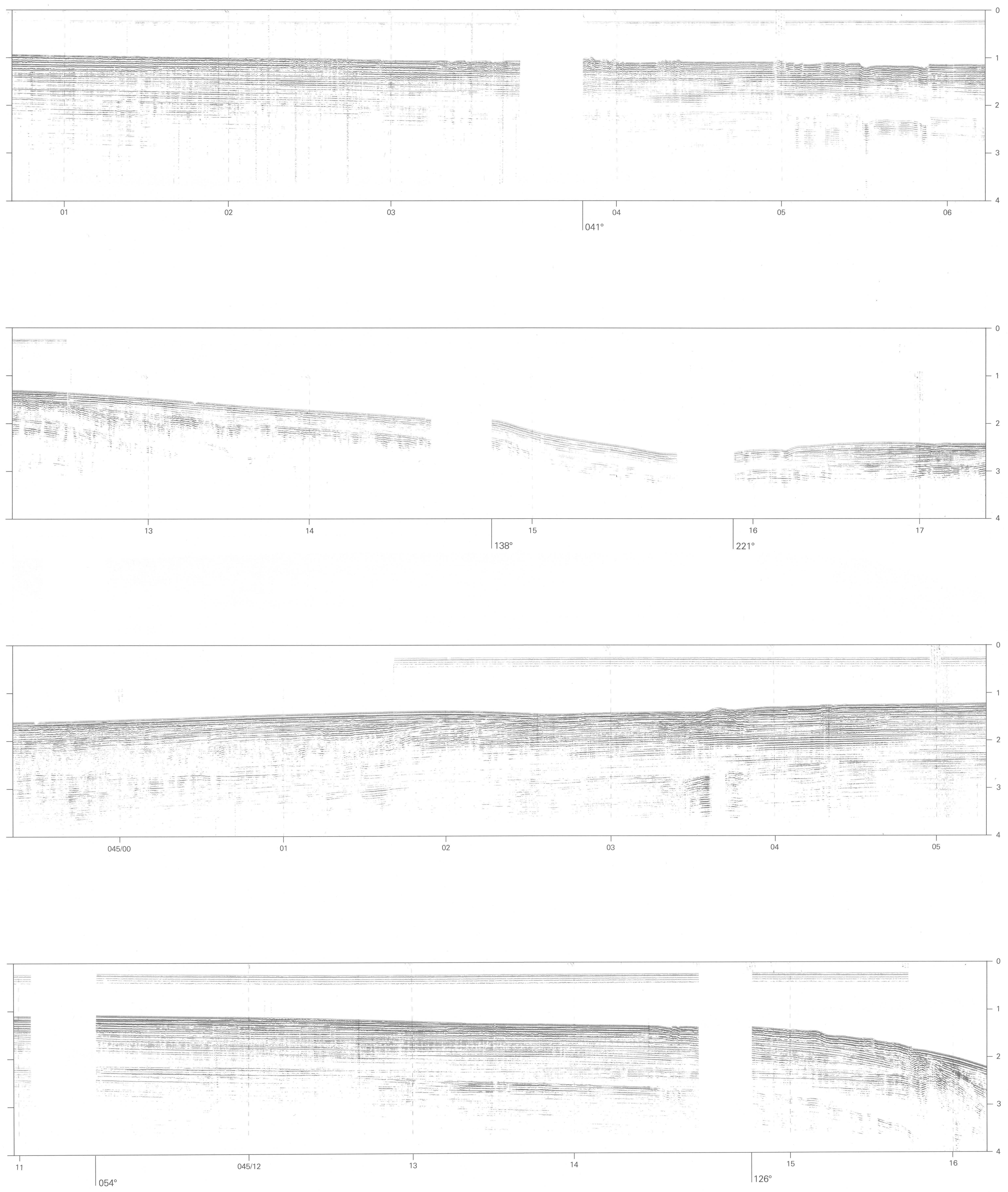

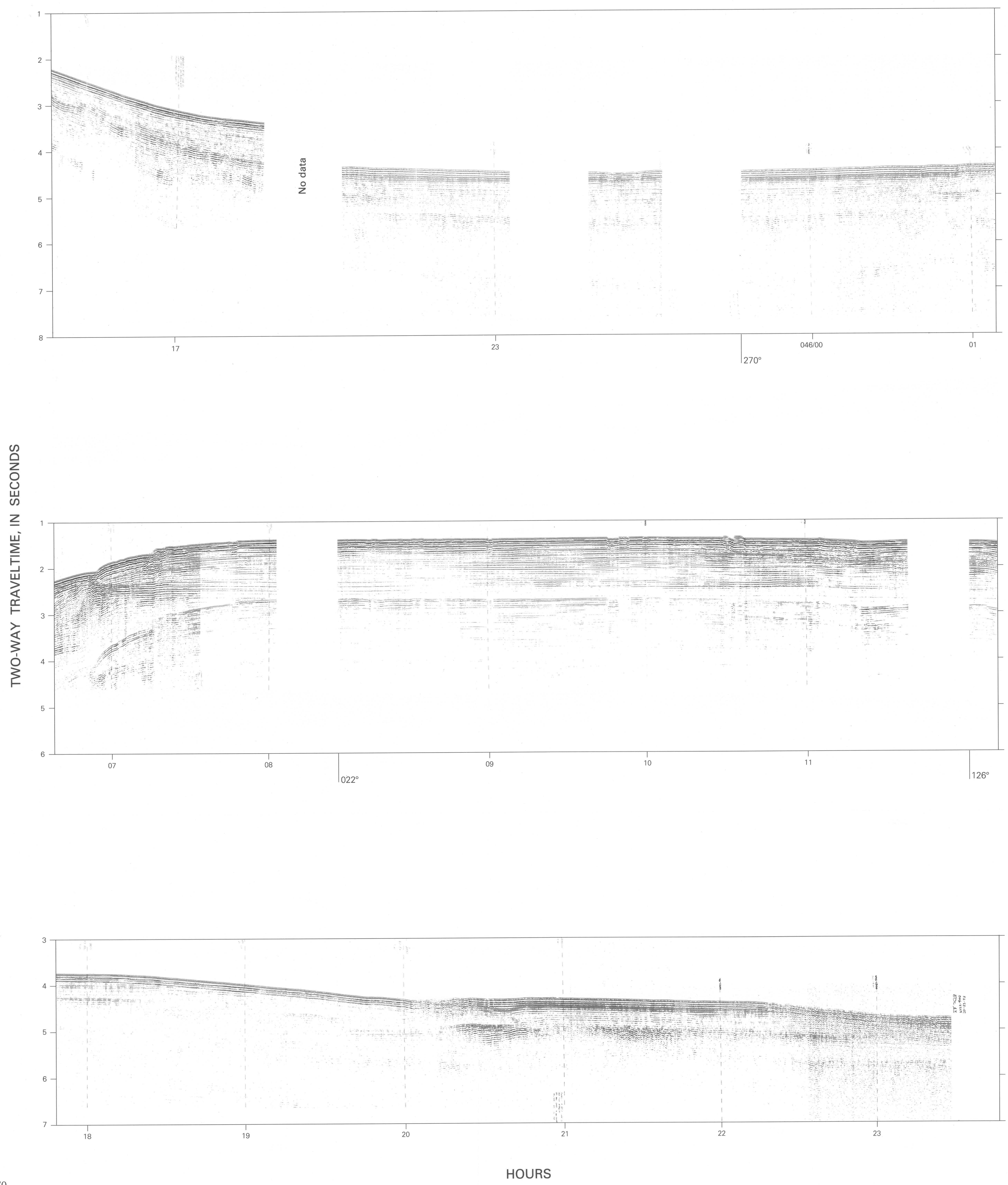

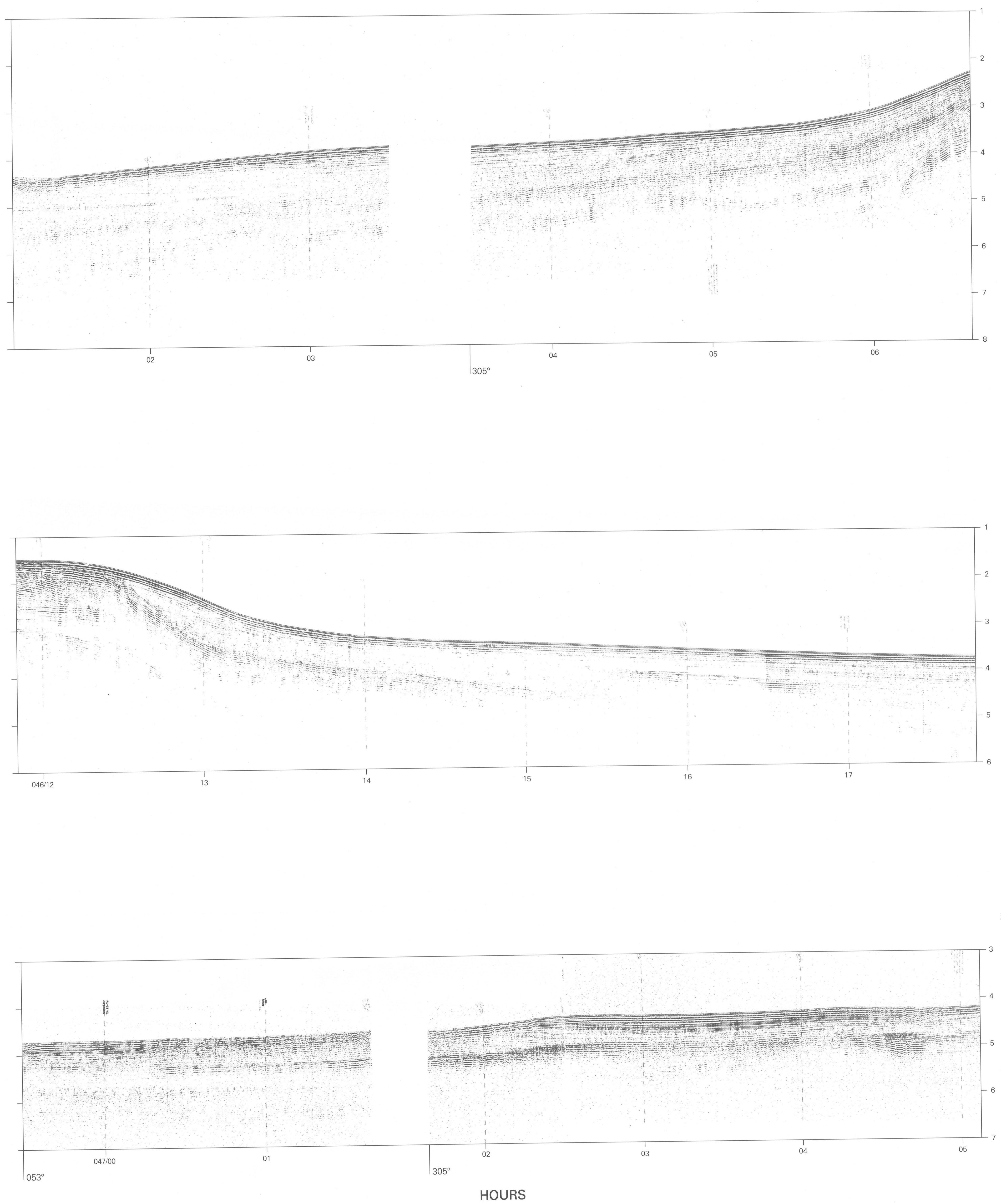
DEPARTMENT OF THE INTERIOR U.S. GEOLOGICAL SURVEY
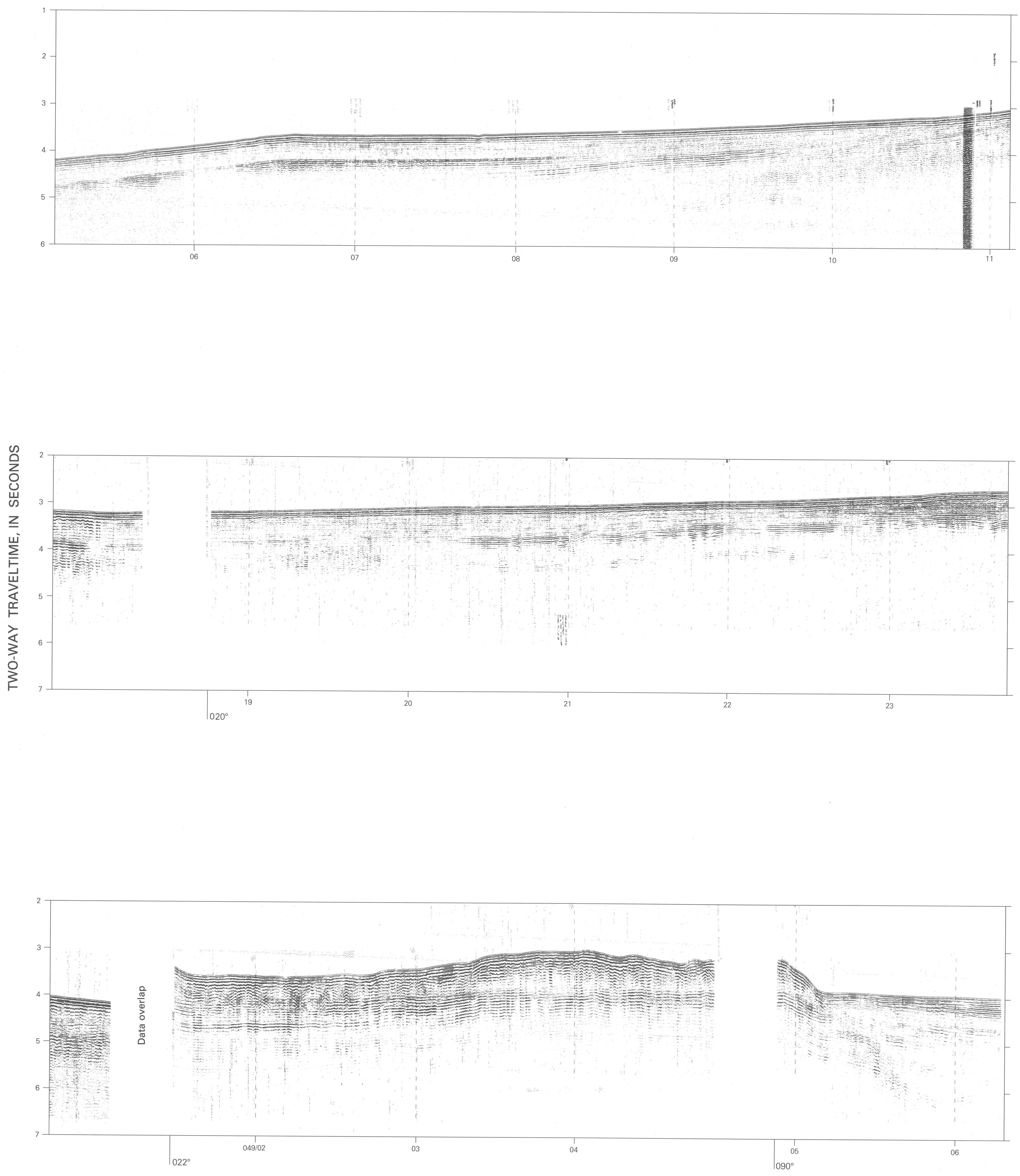

HOURS 

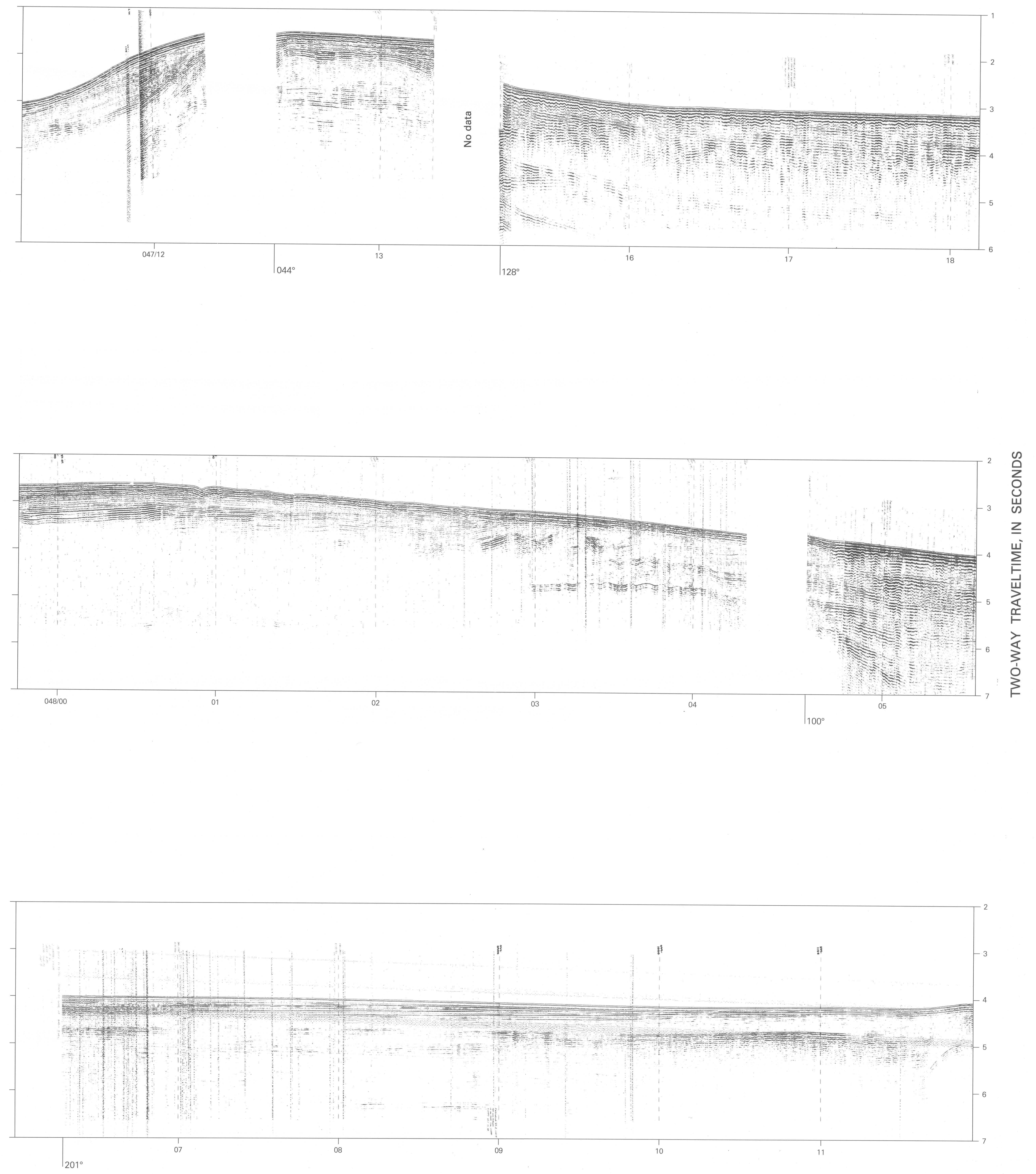

HOURS 
DEPARTMENT OF THE INTERIOR

U.S. GEOLOGICAL SURVEY
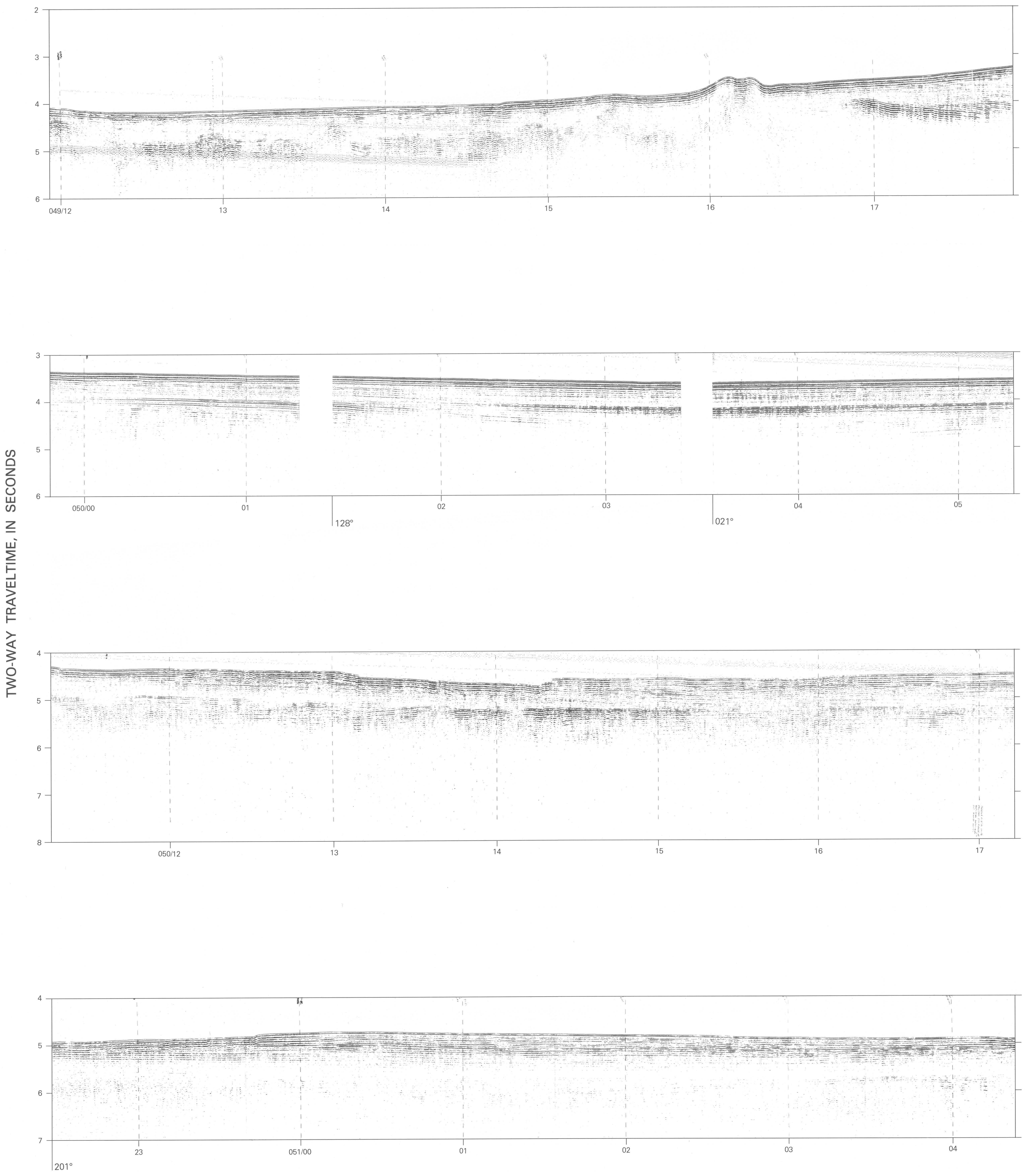

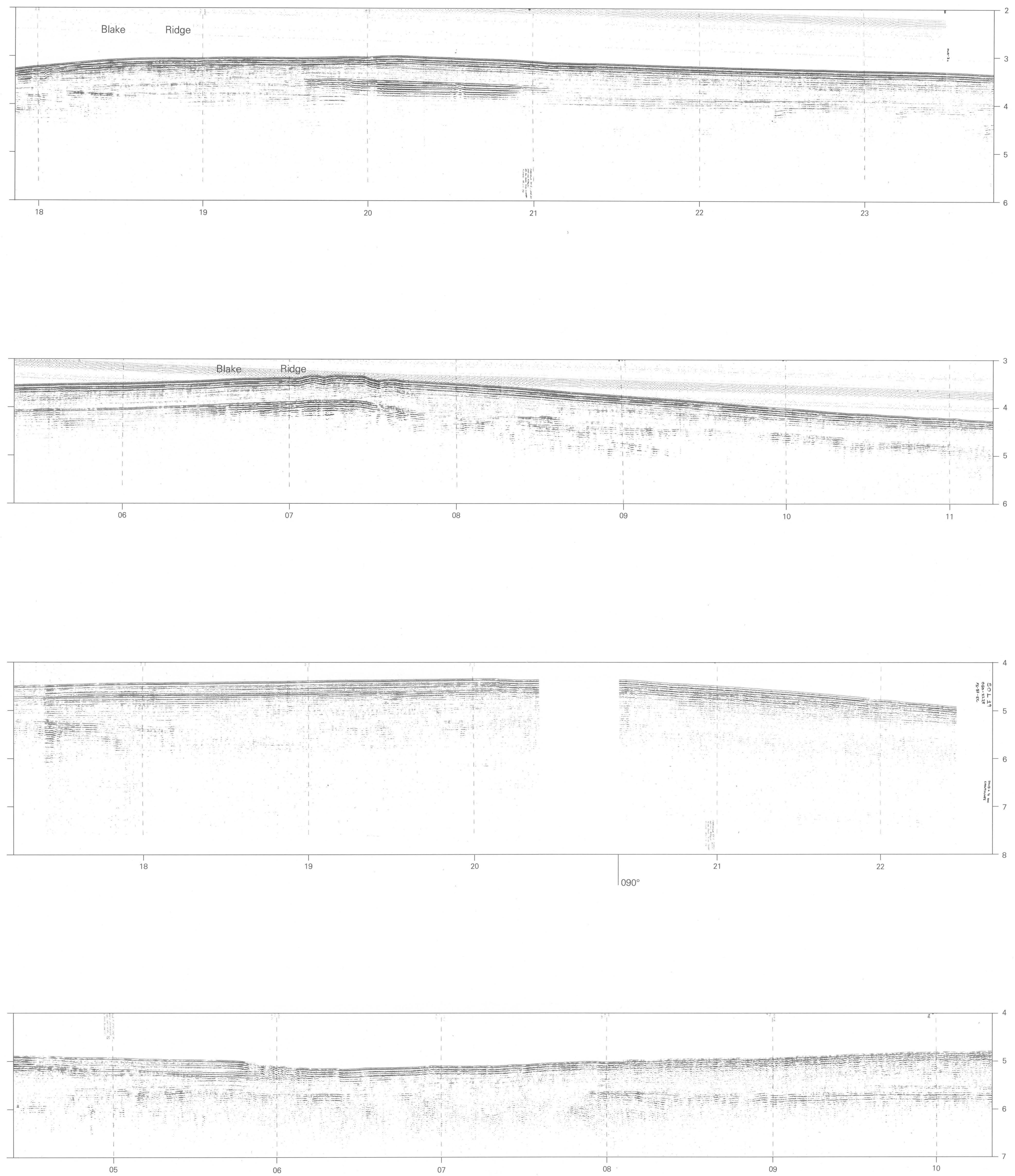

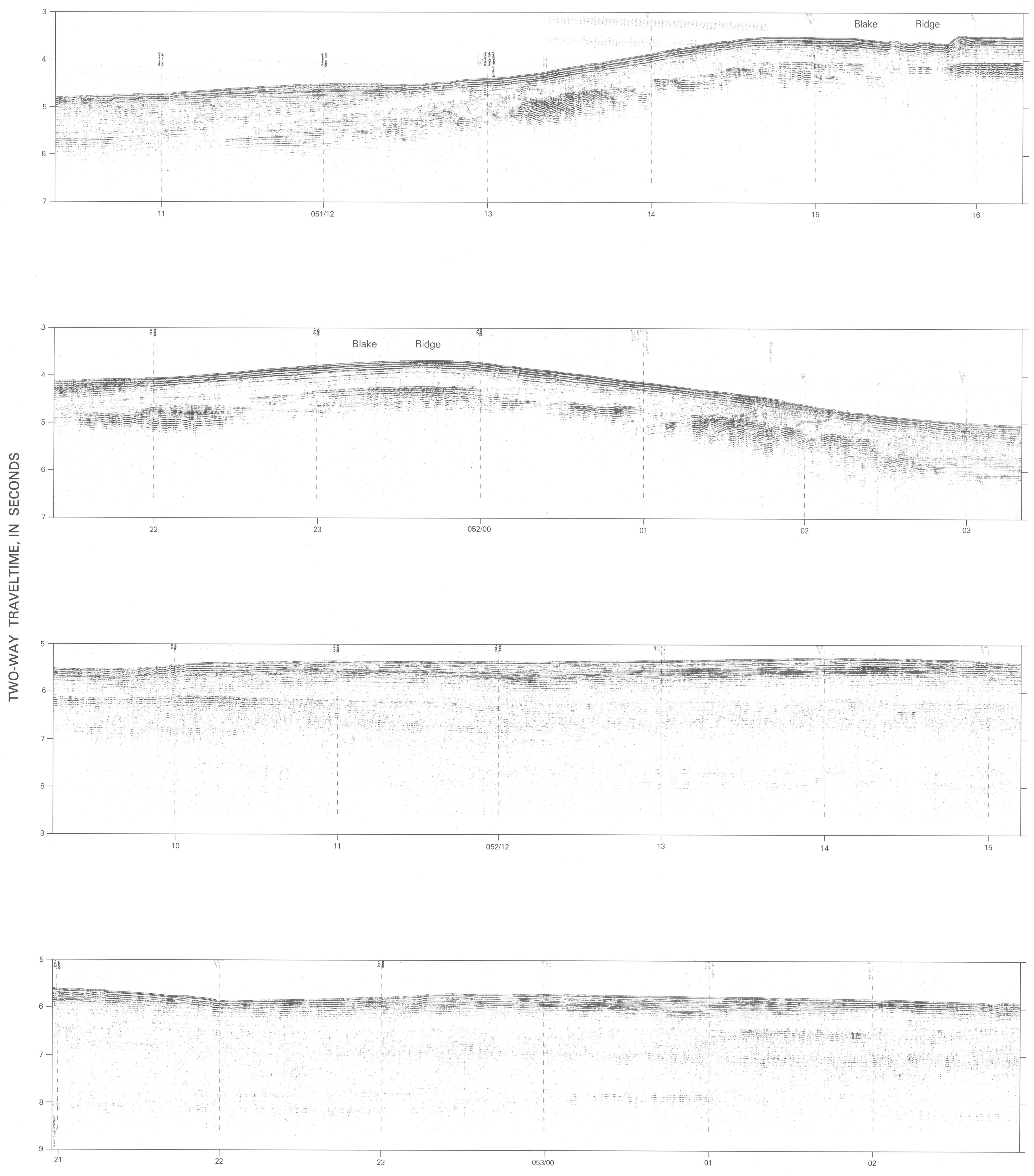
Blake Ridge

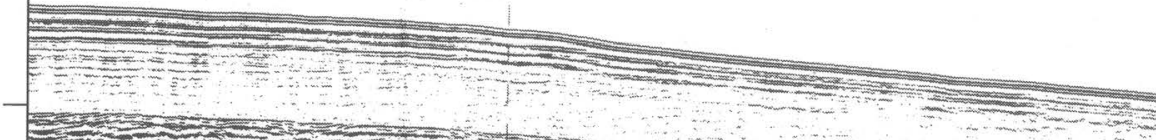

I

then
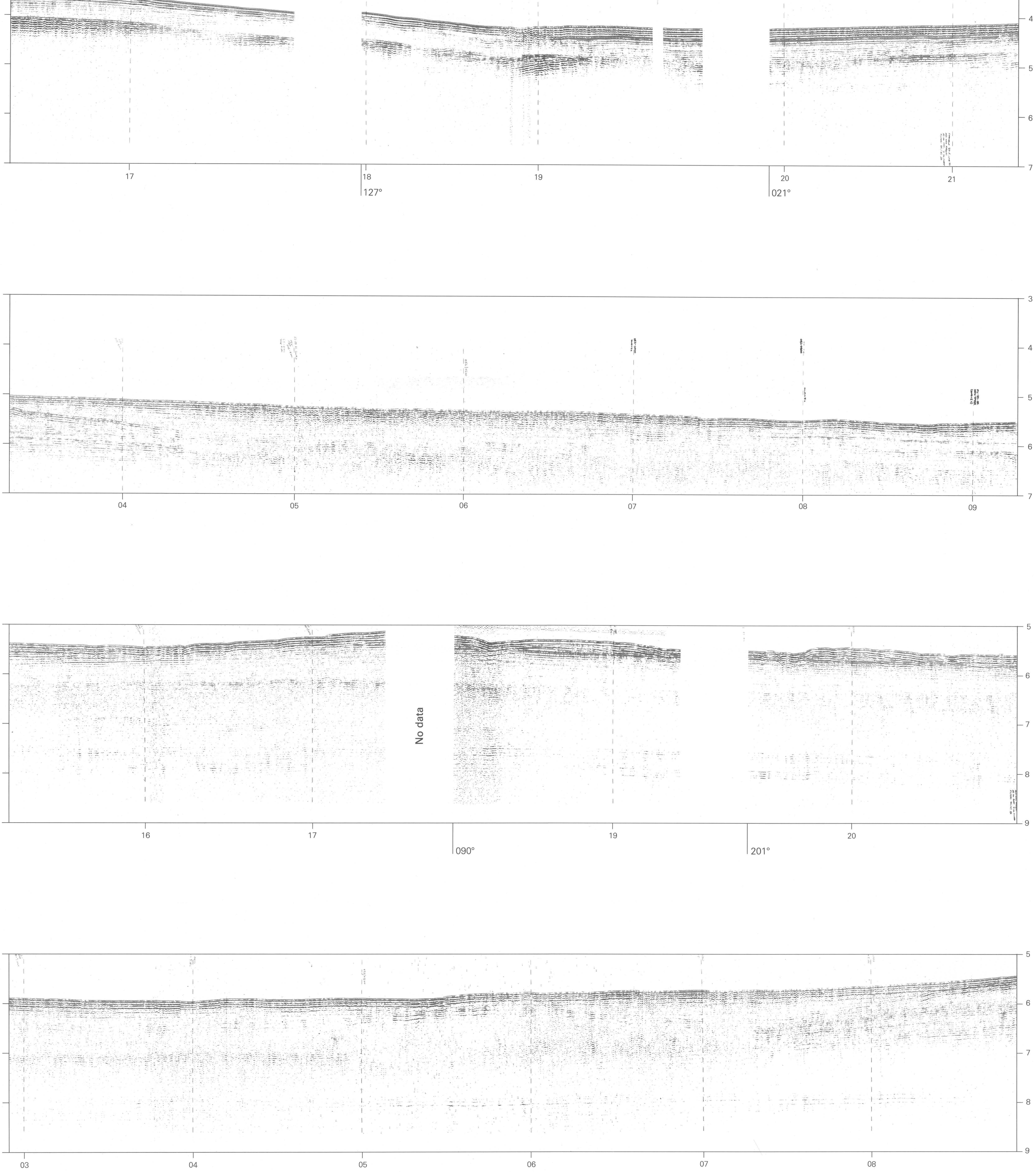

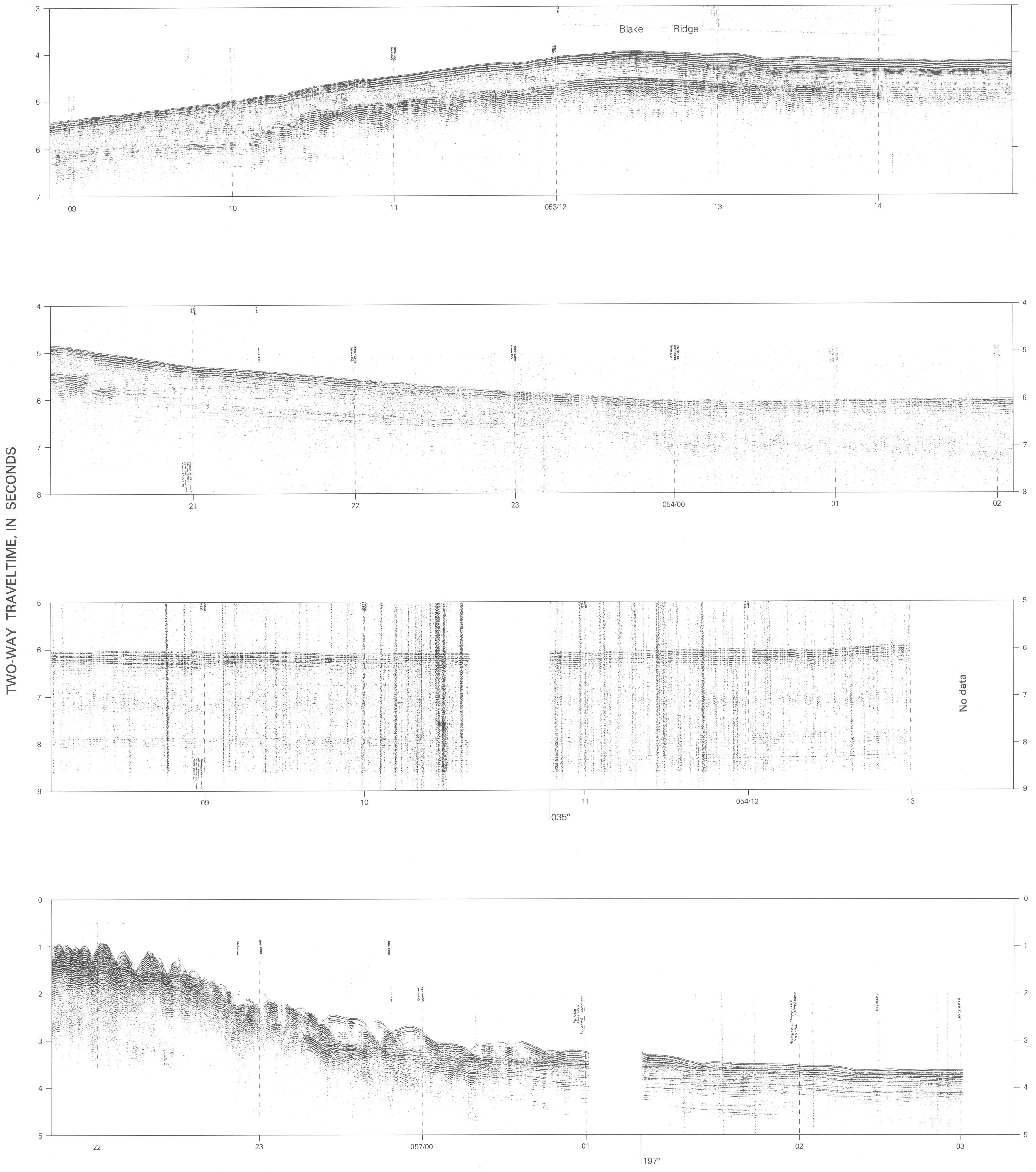

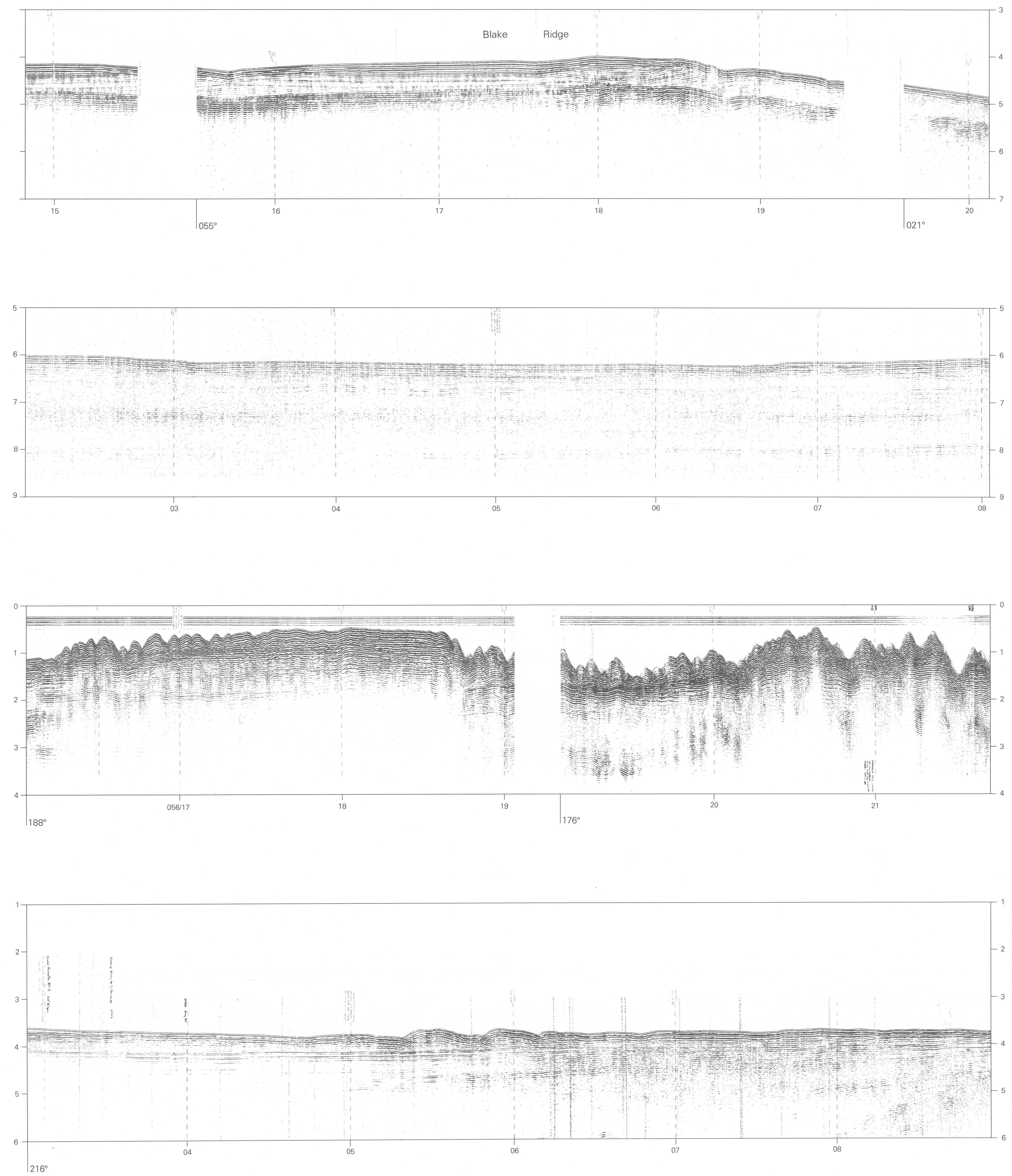

HOURS 
DEPARTMENT OF THE INTERIOR

U.S. GEOLOGICAL SURVEY
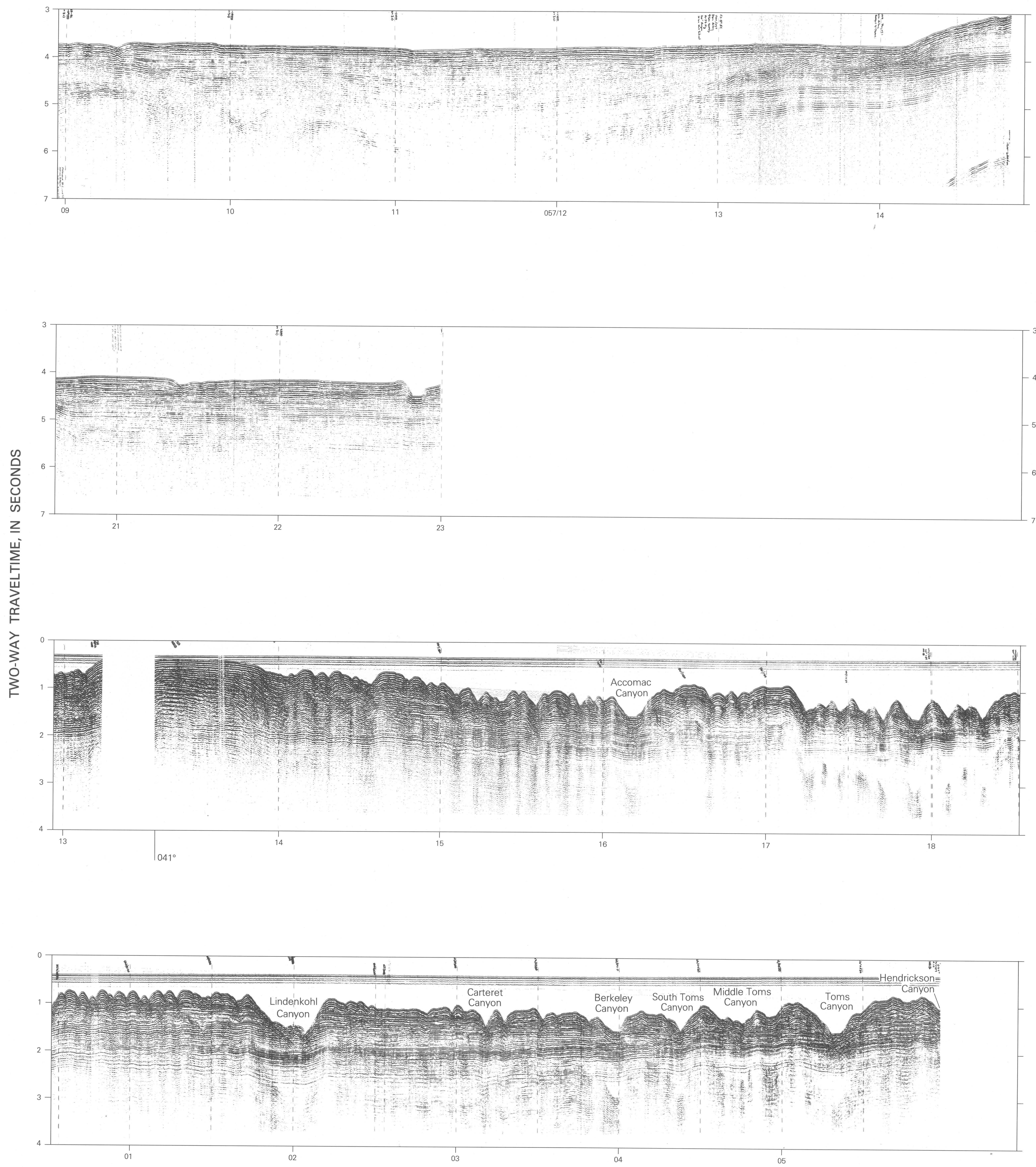

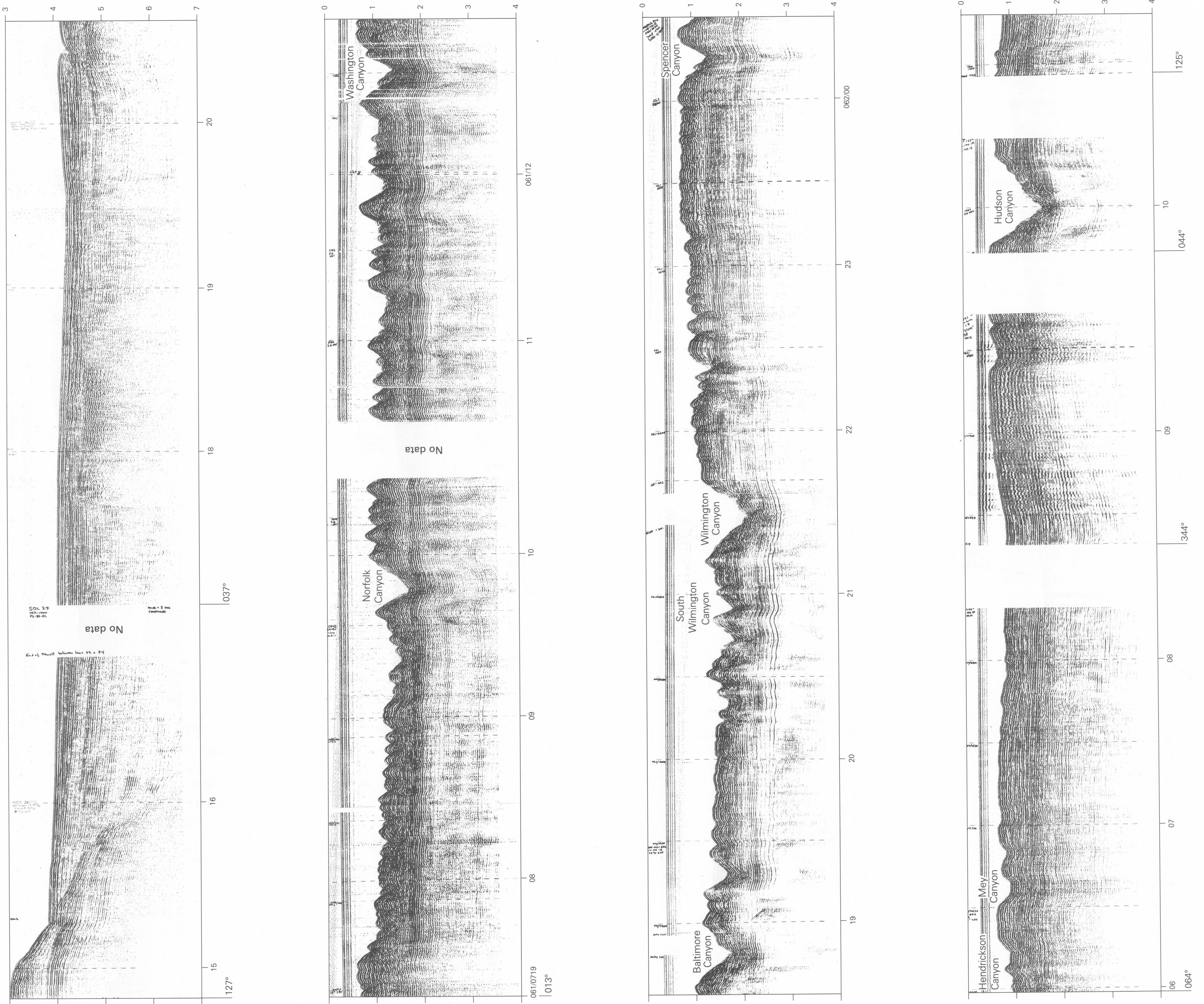

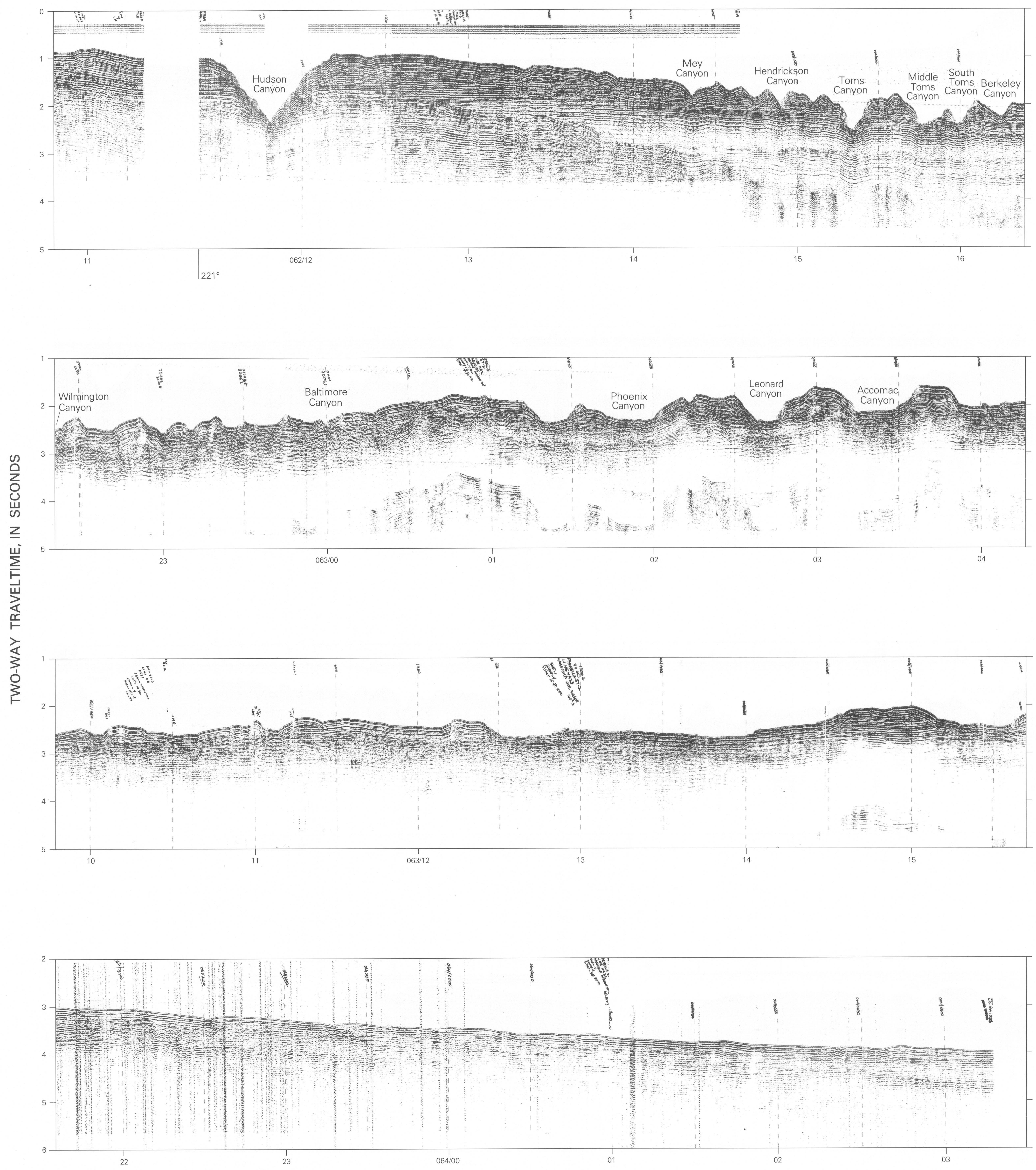

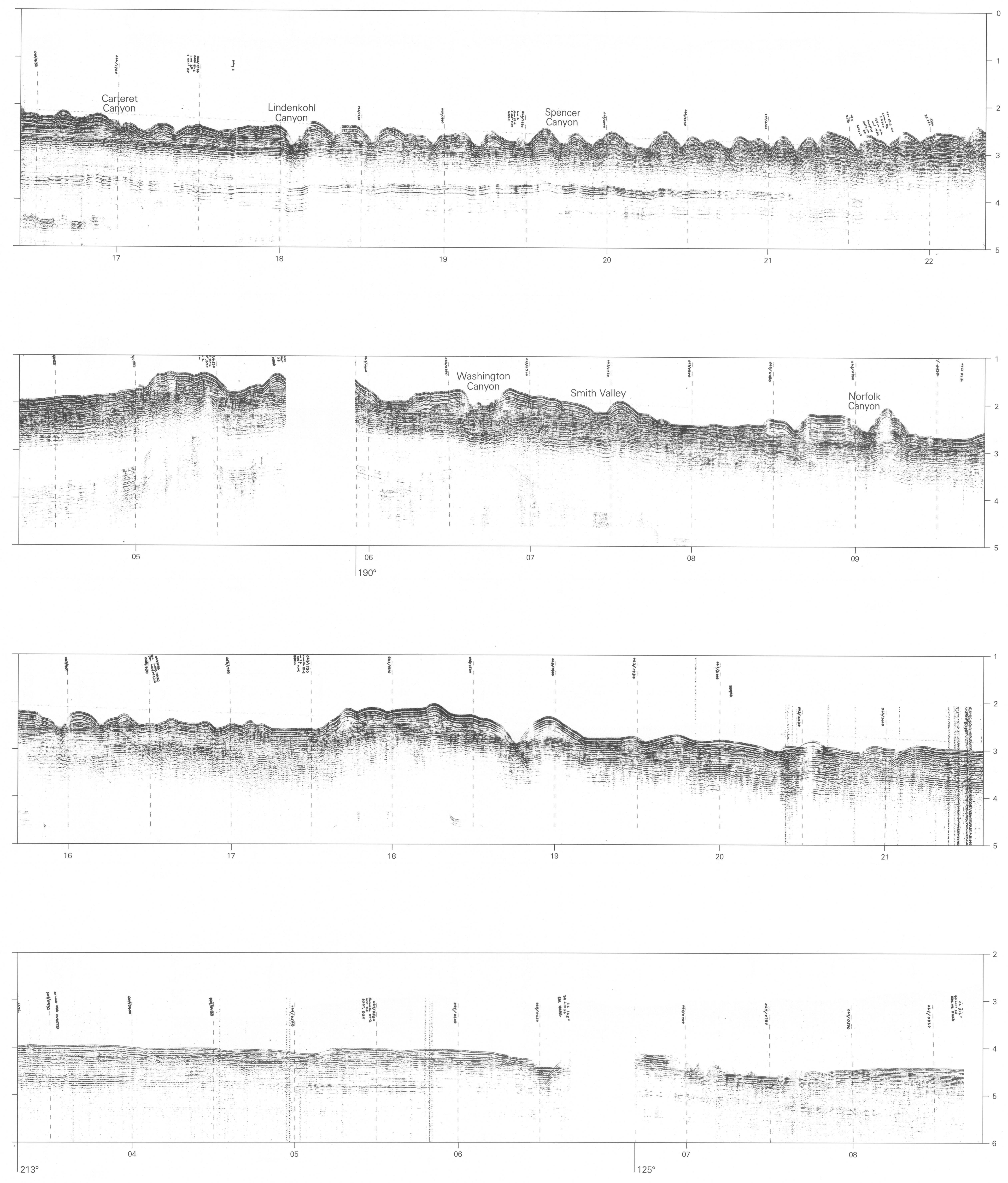
DEPARTMENT OF THE INTERIOR

U.S. GEOLOGICAL SURVEY
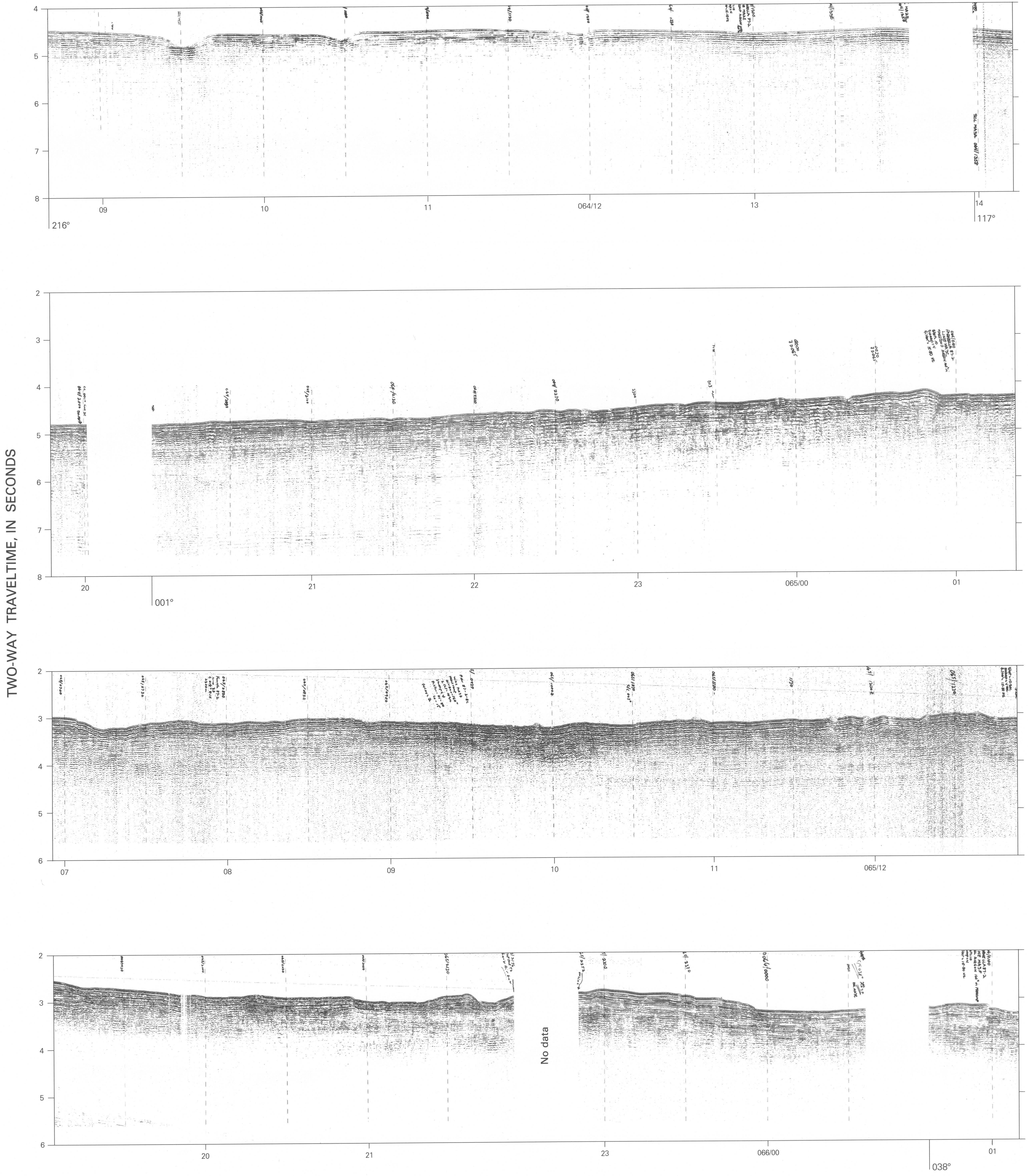

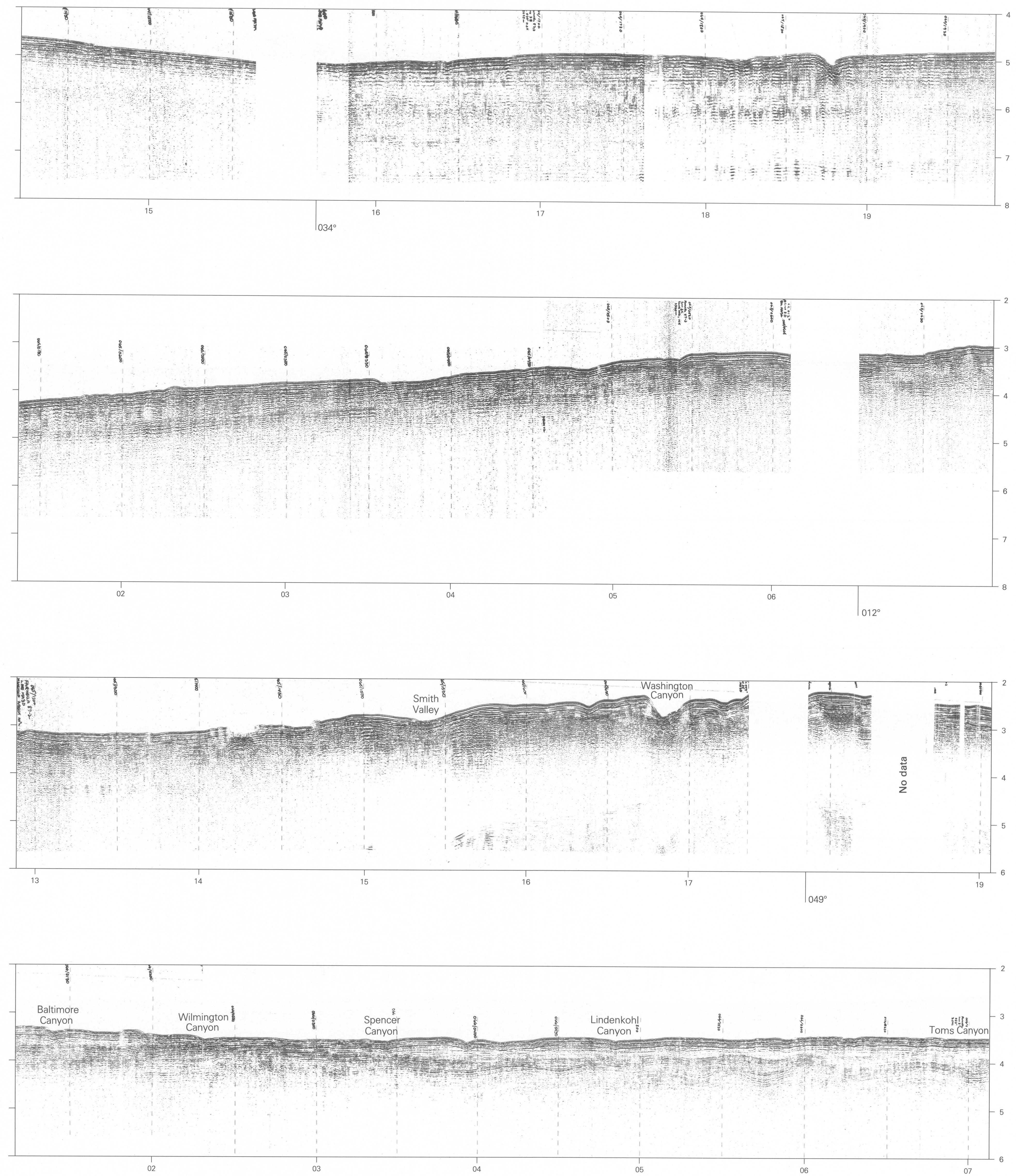

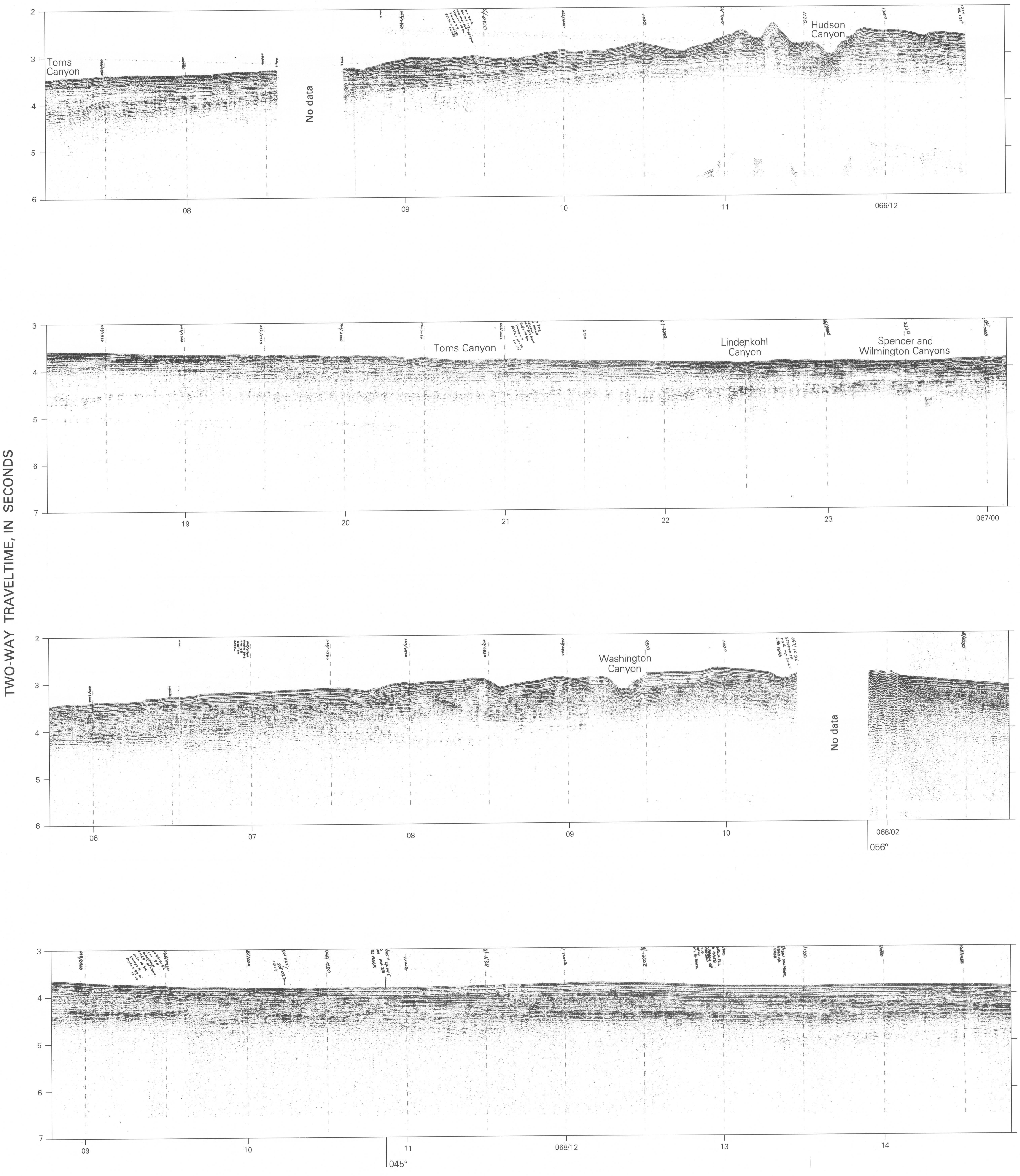

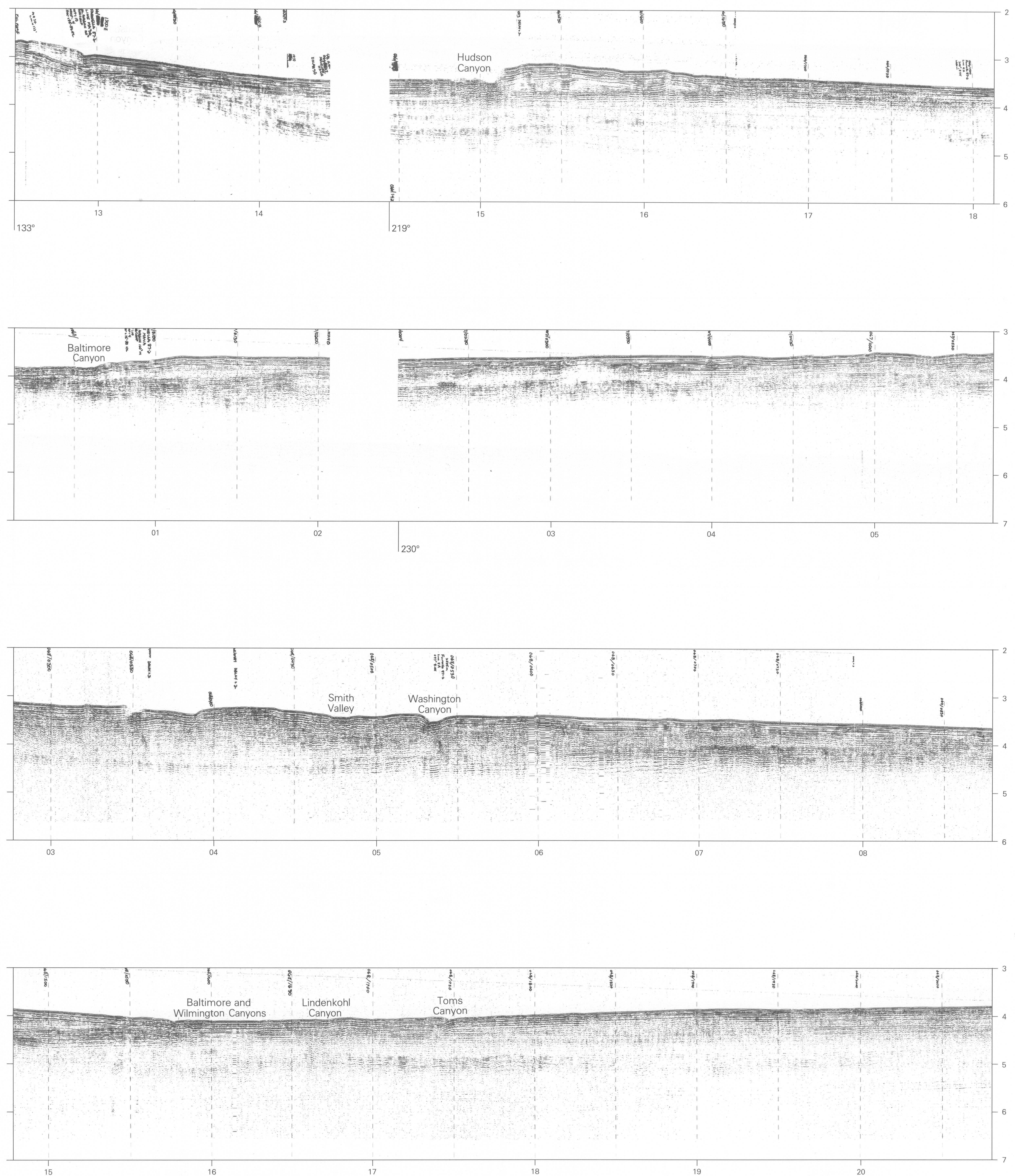
DEPARTMENT OF THE INTERIOR

U.S. GEOLOGICAL SURVEY
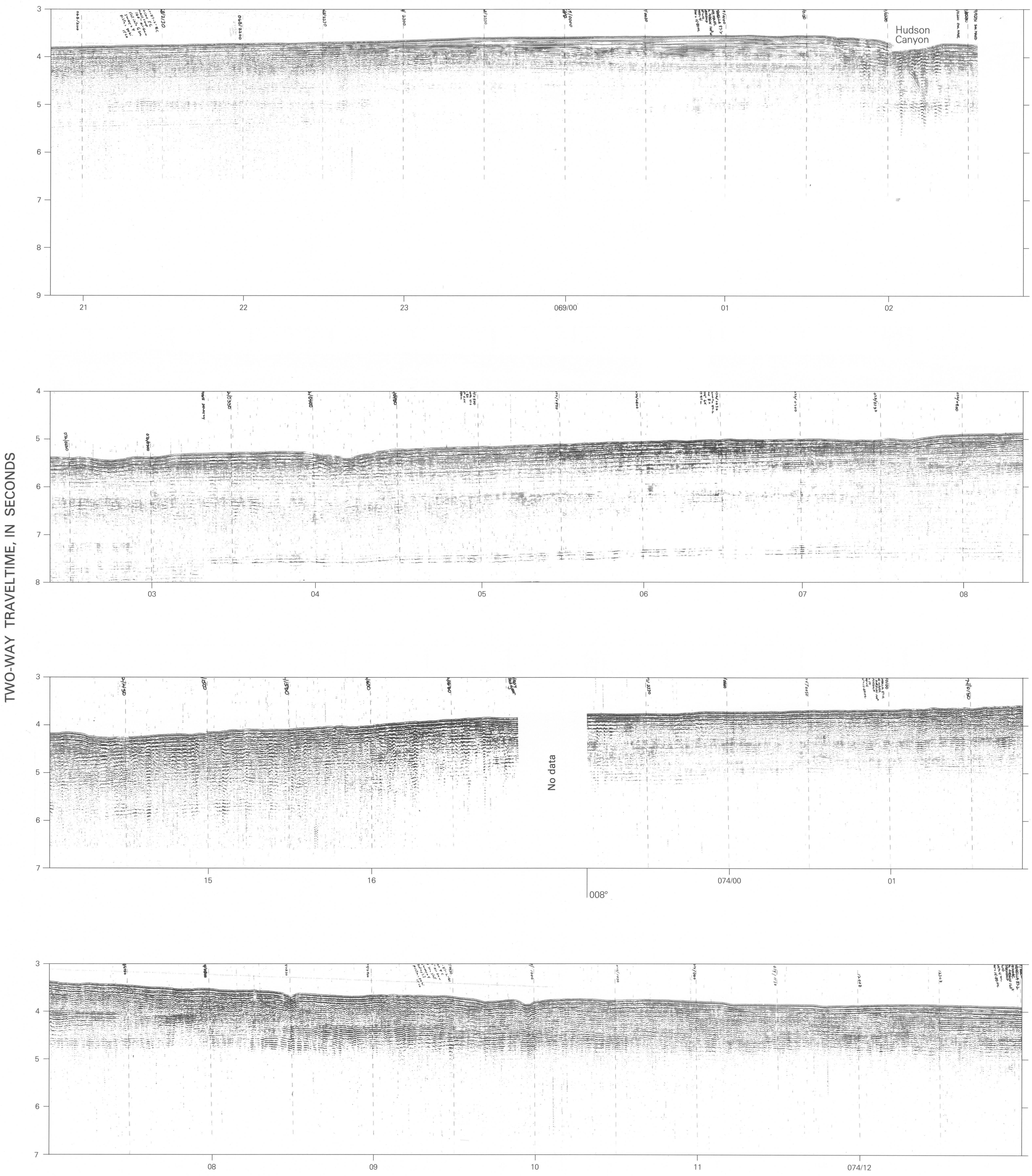

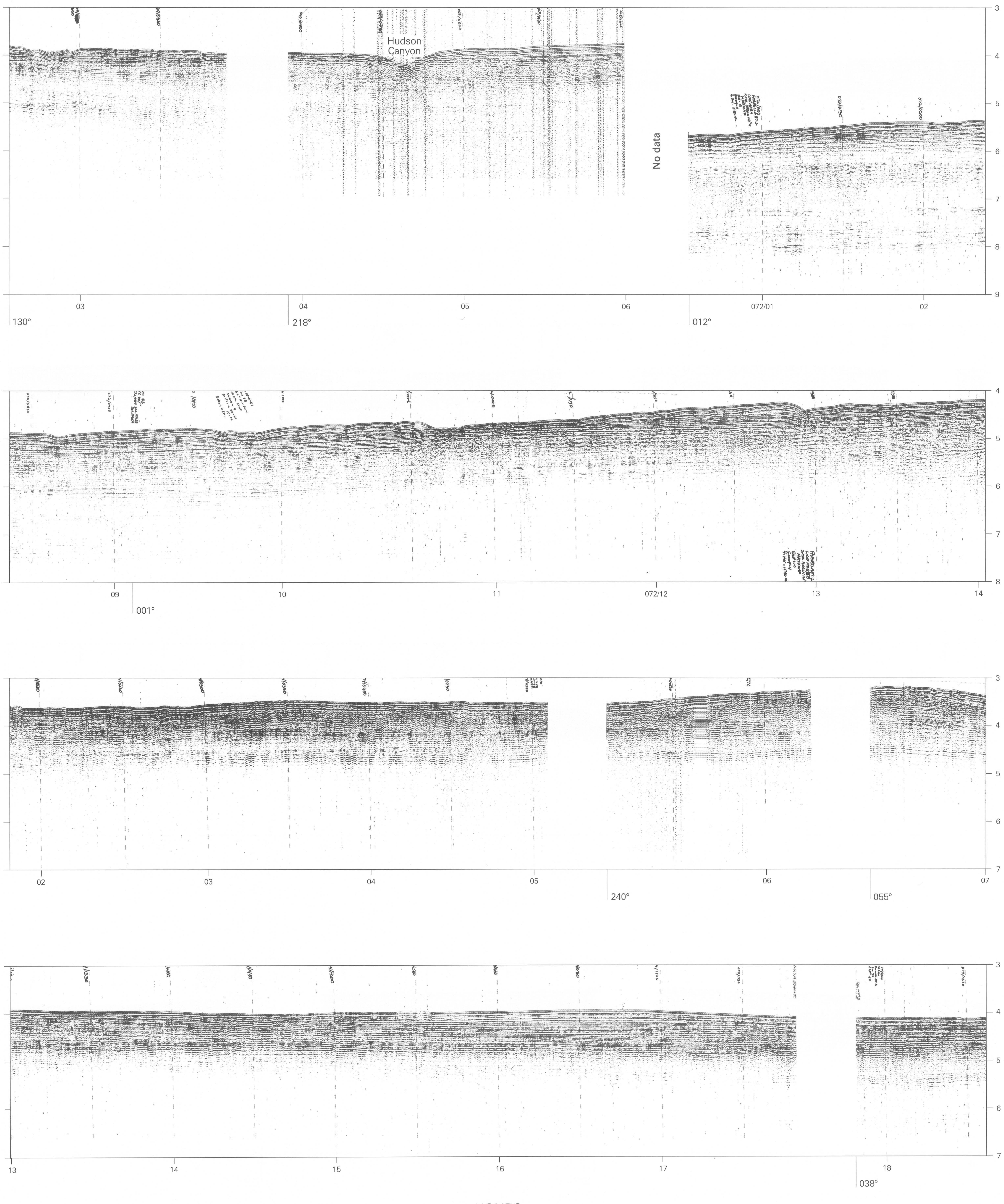

HOURS 

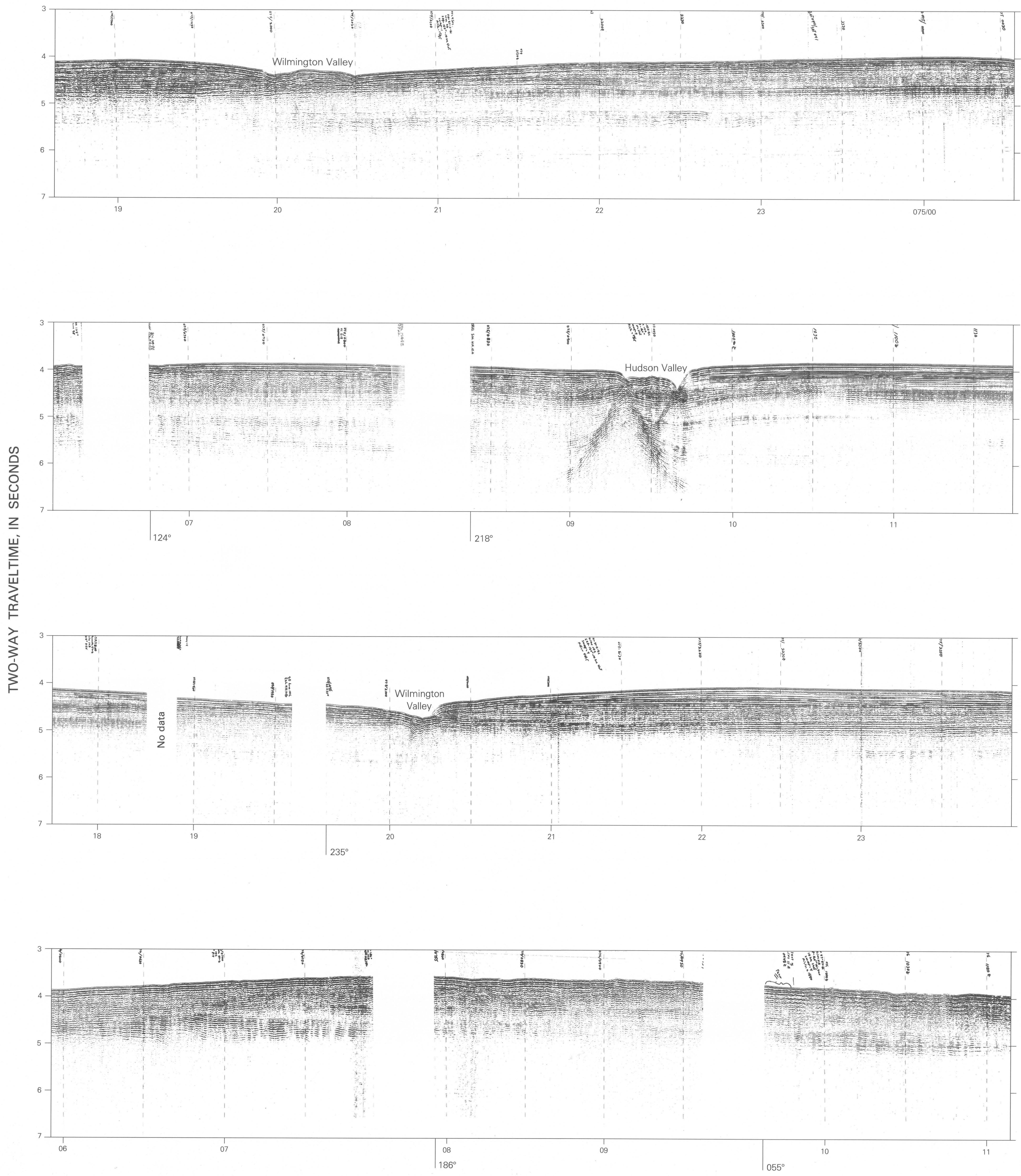

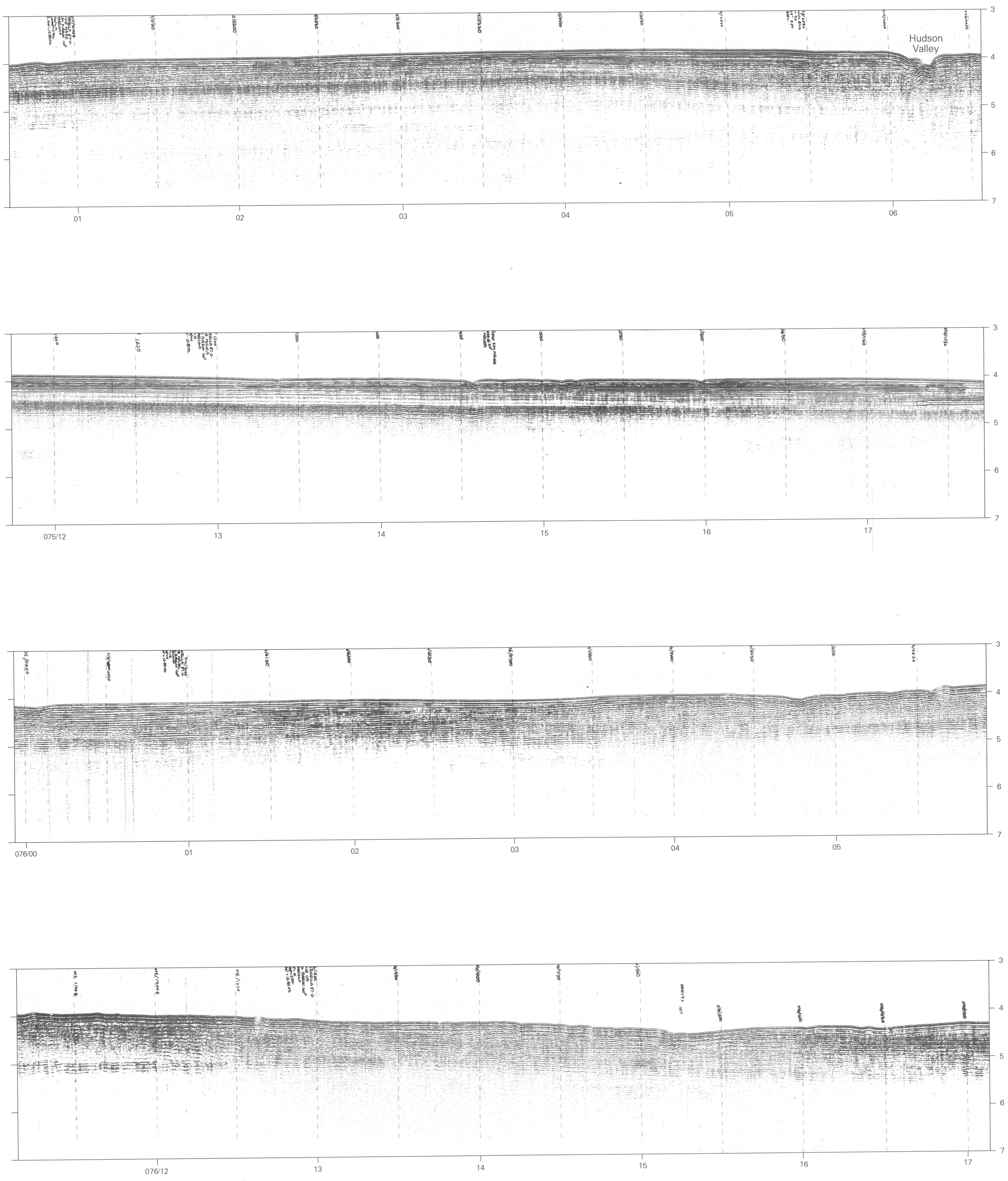

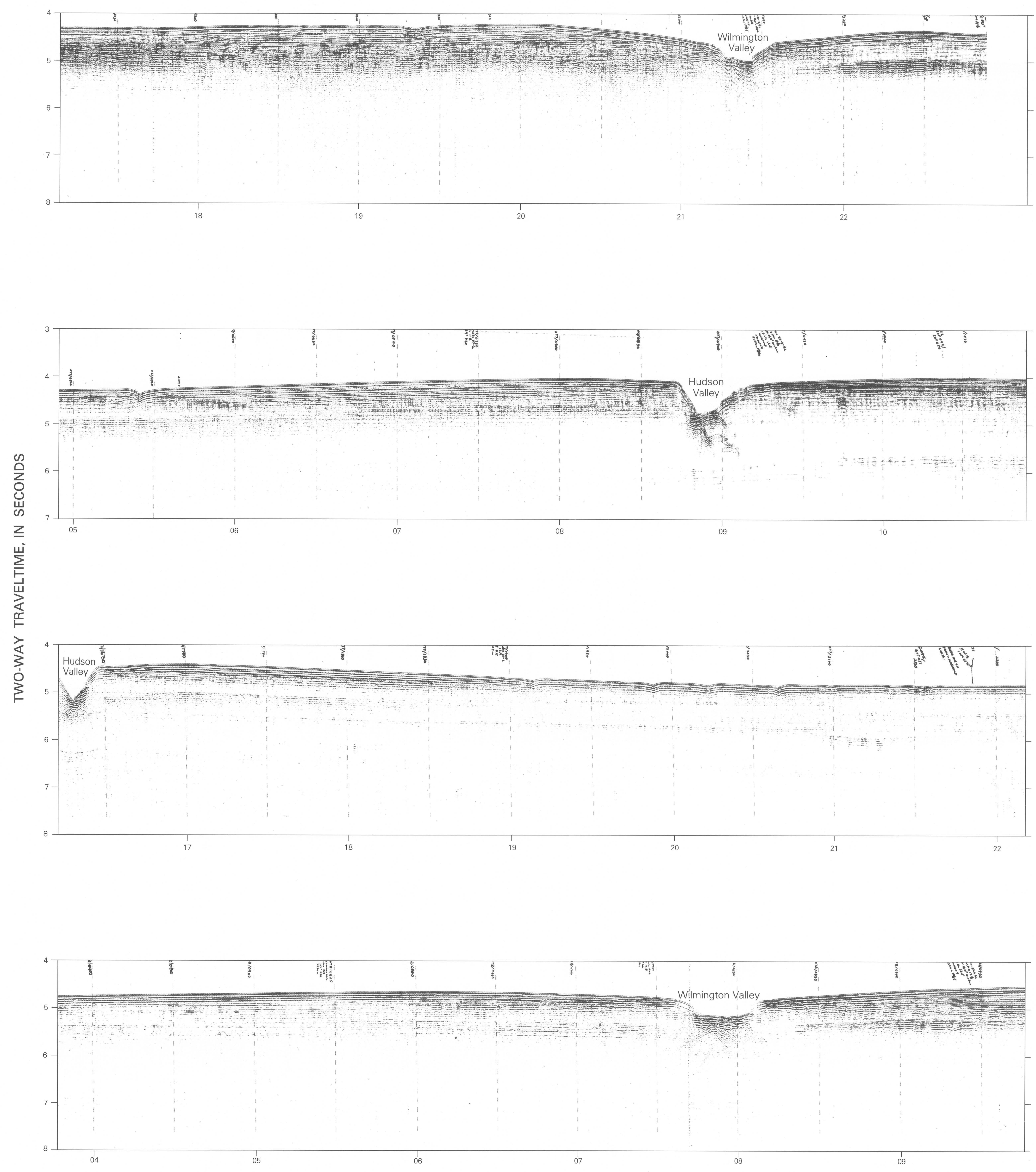

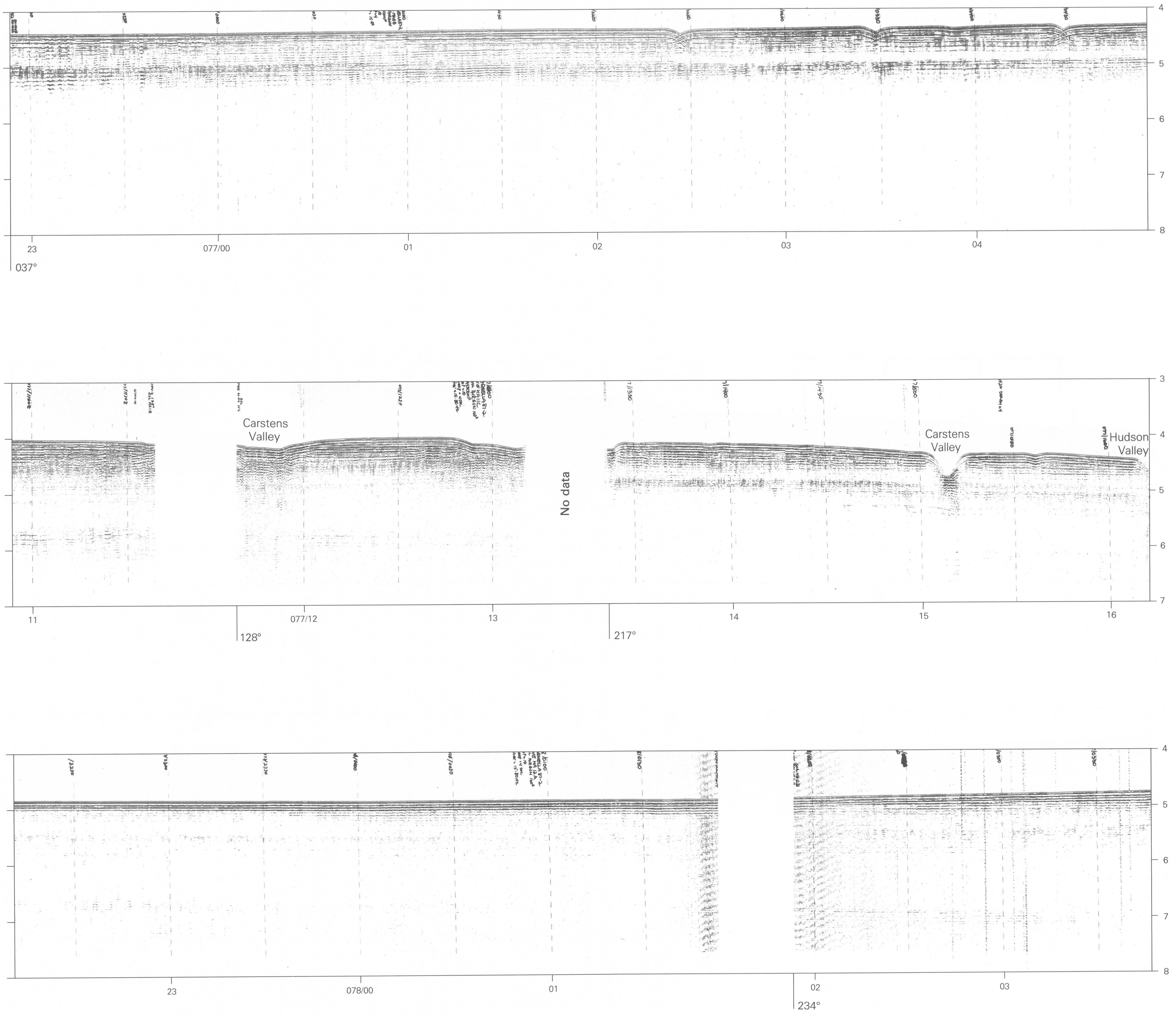

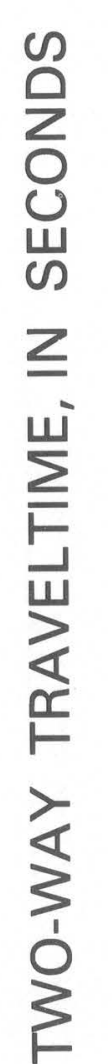

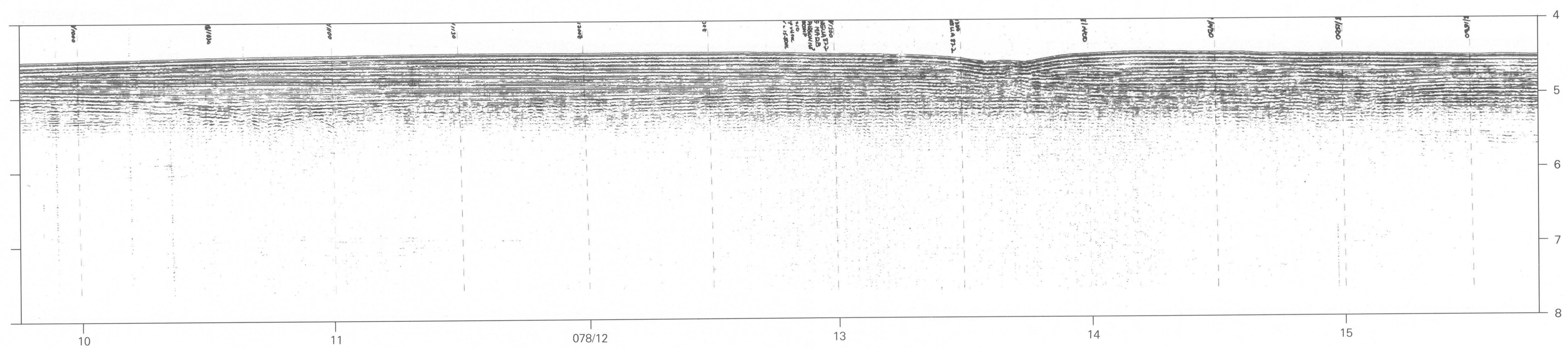



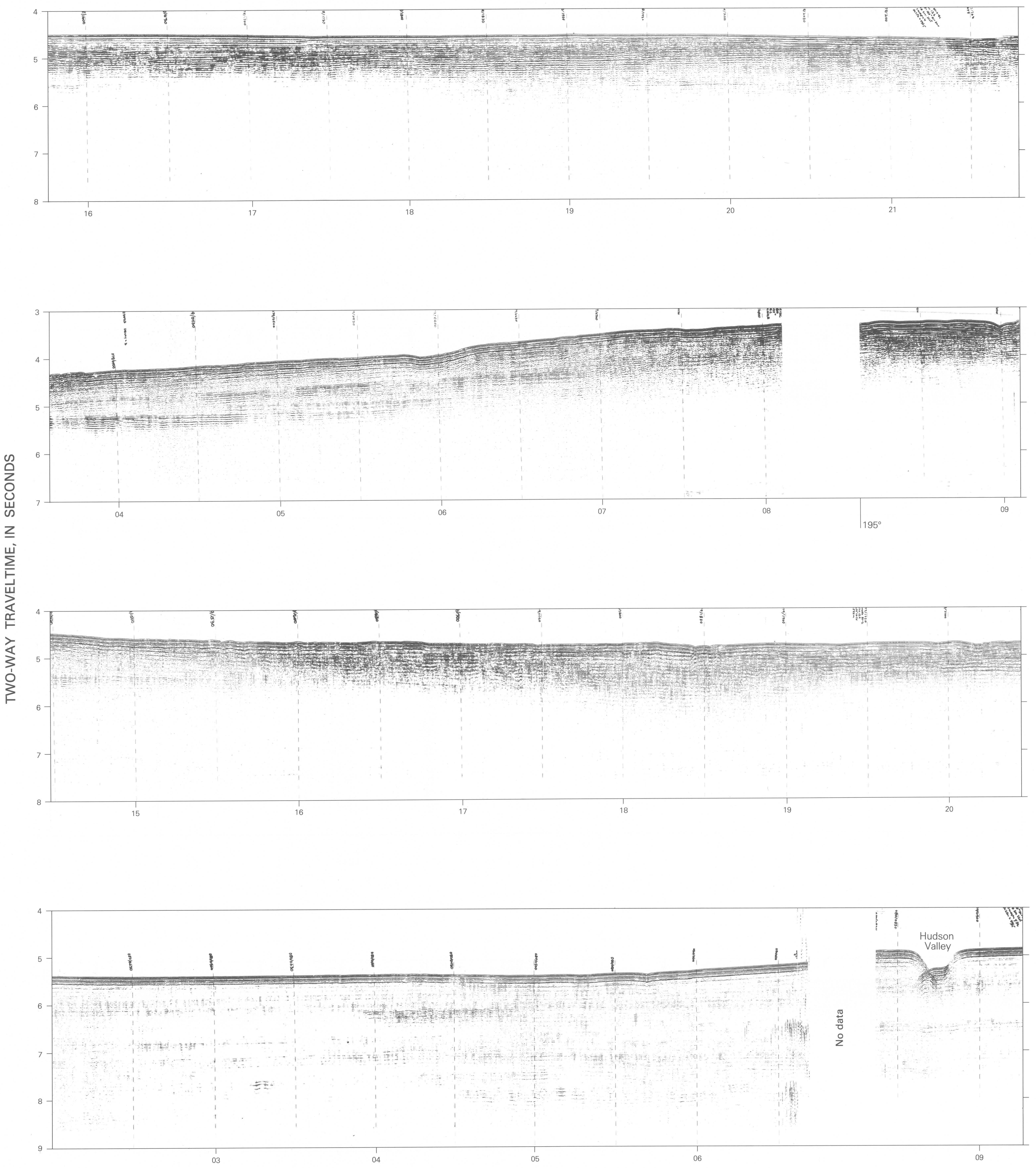

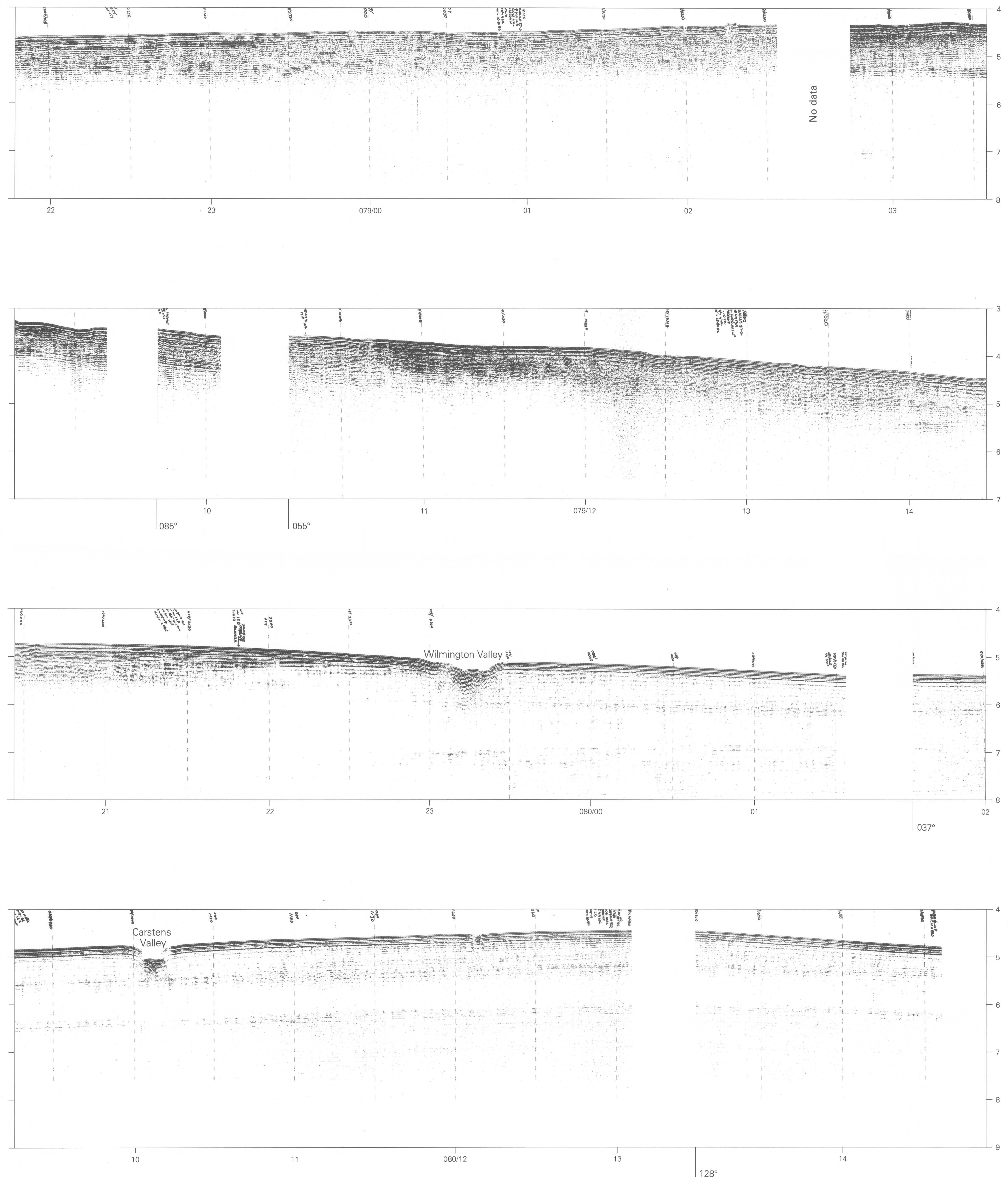

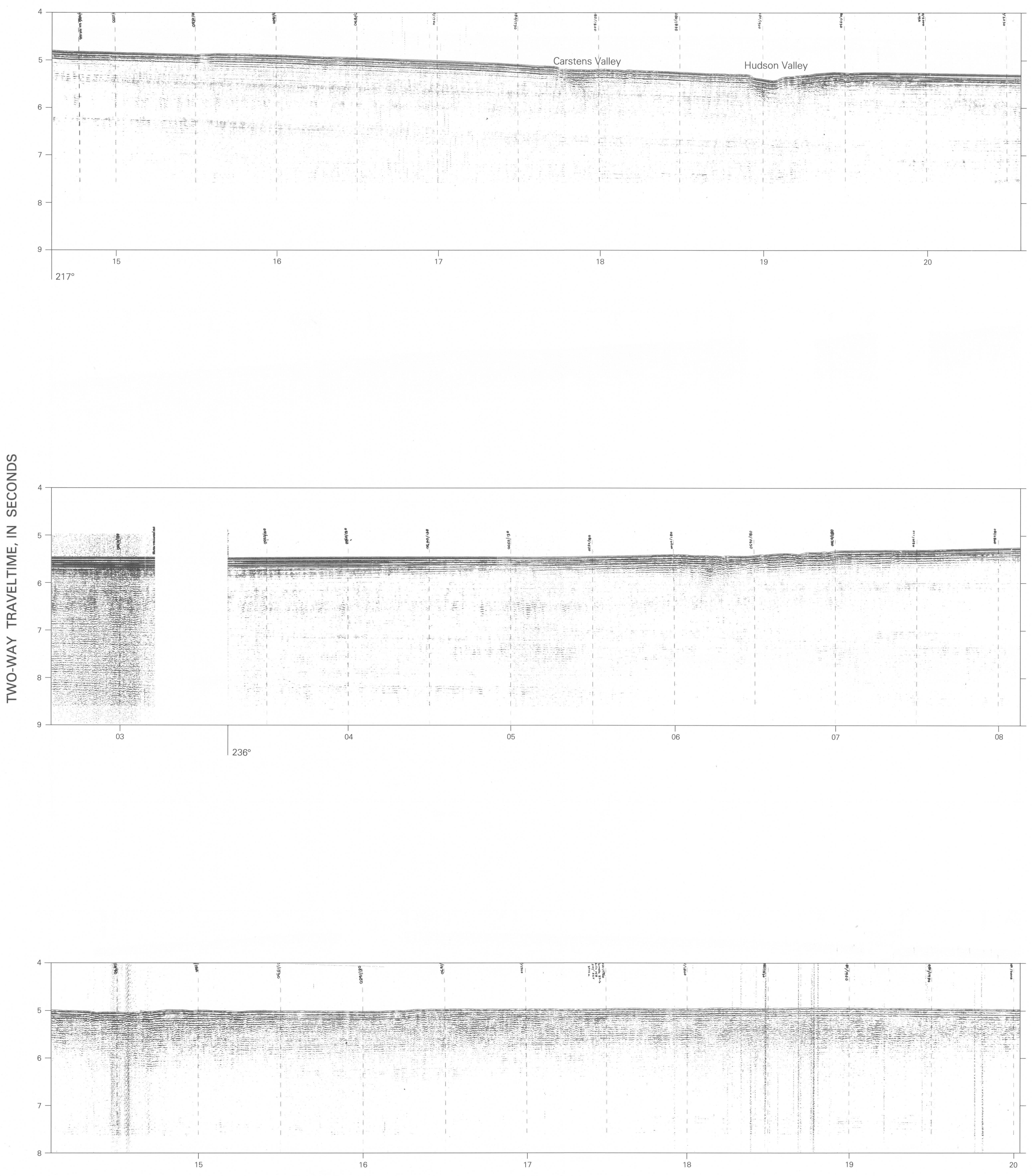

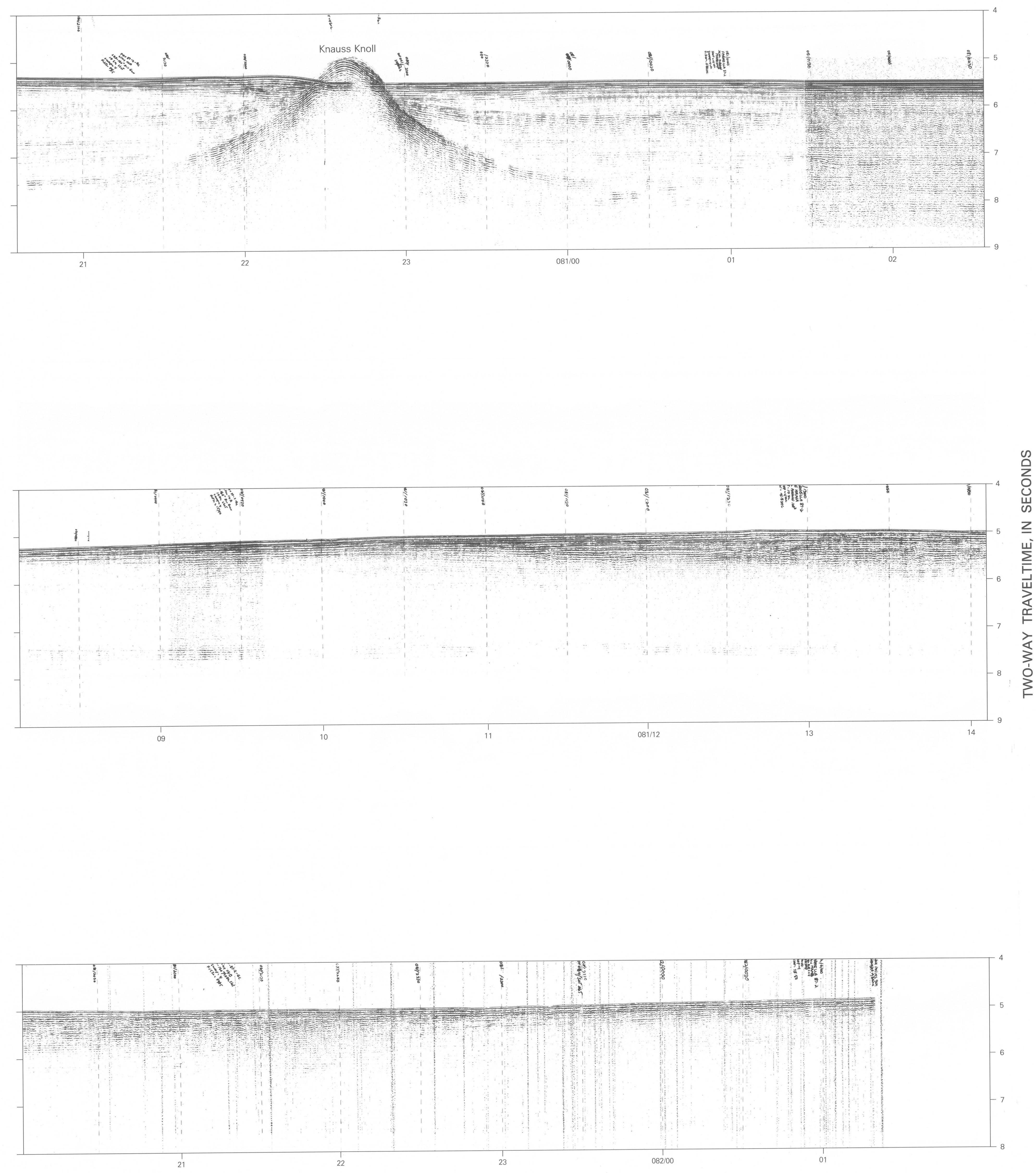

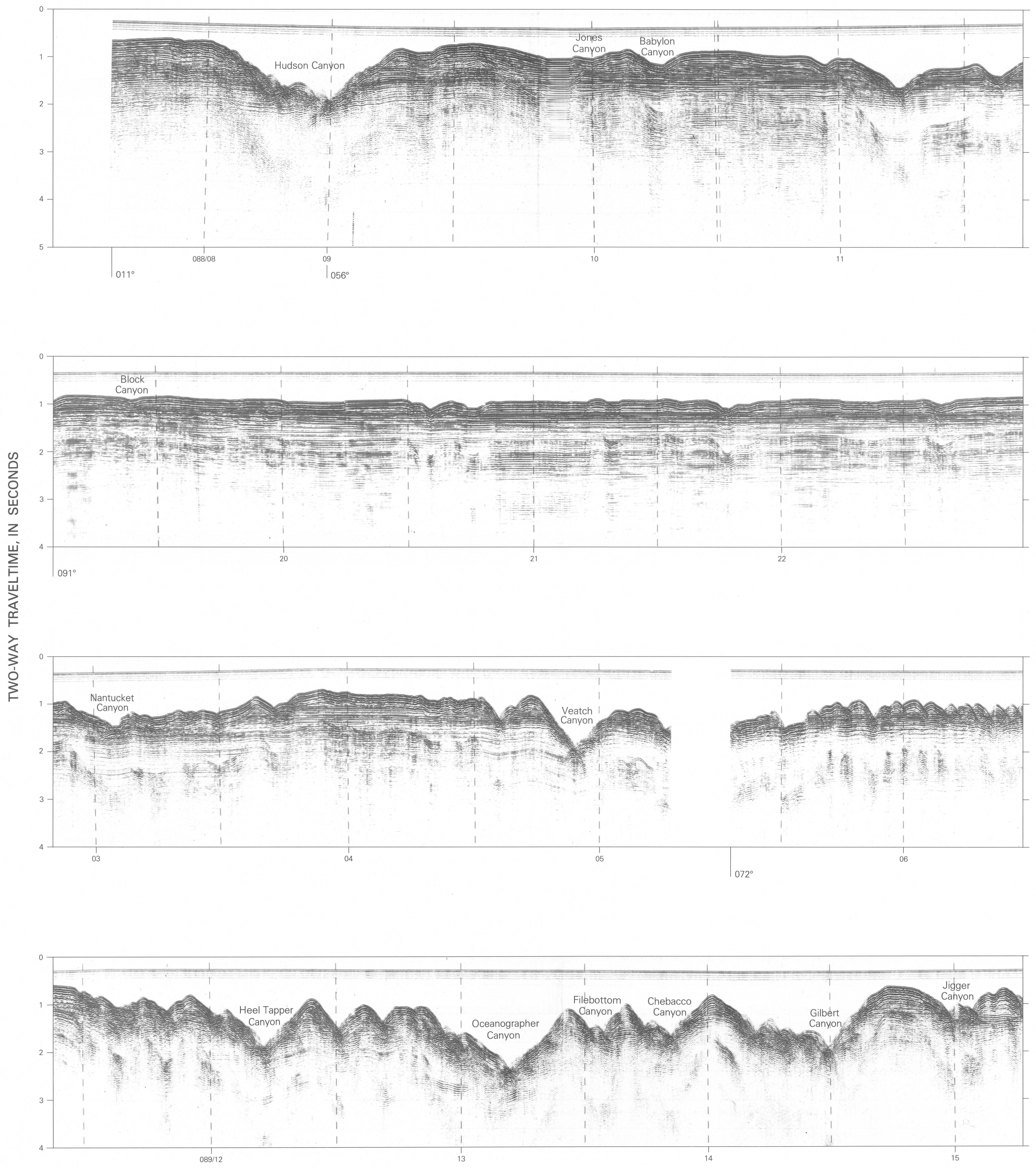

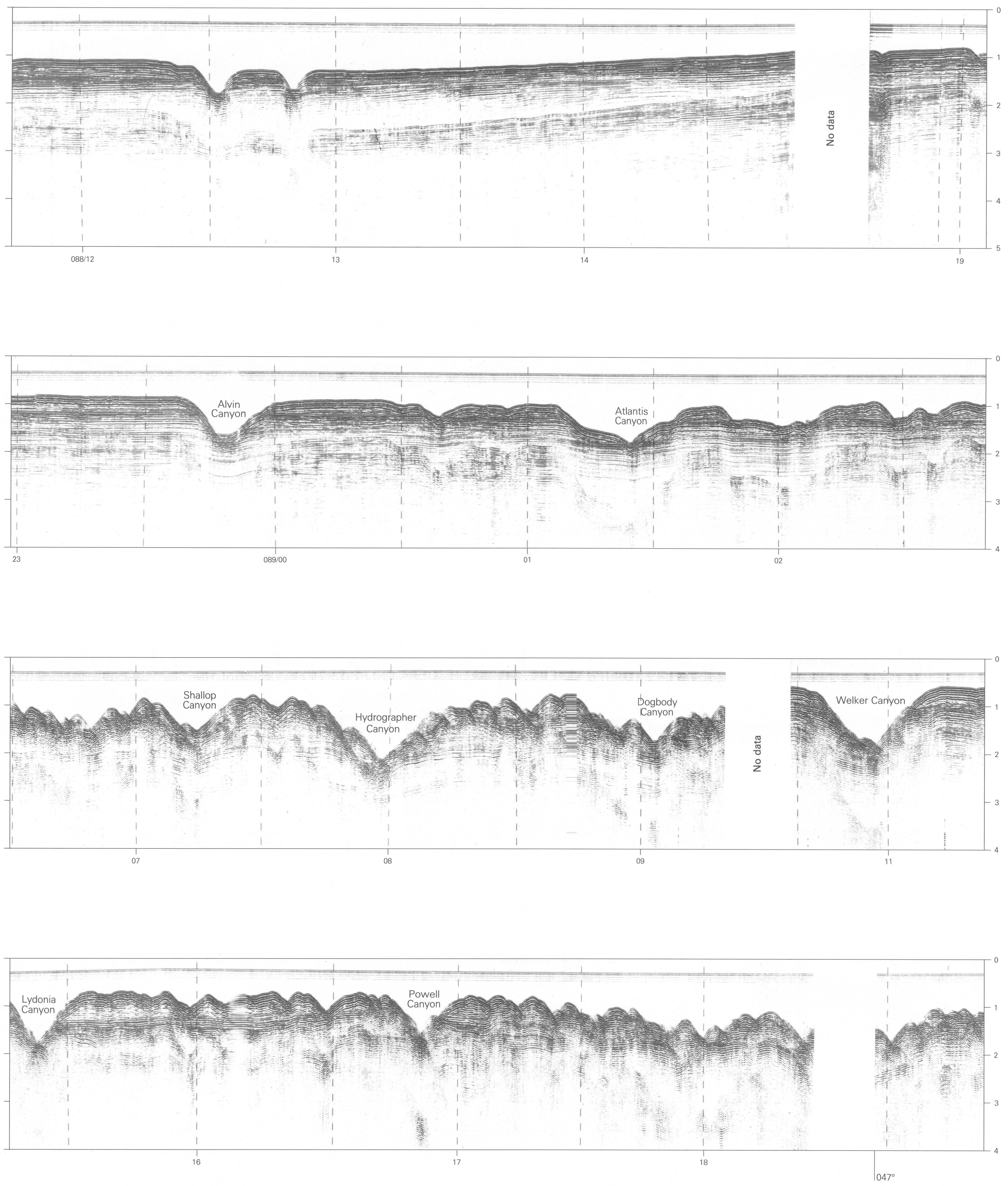

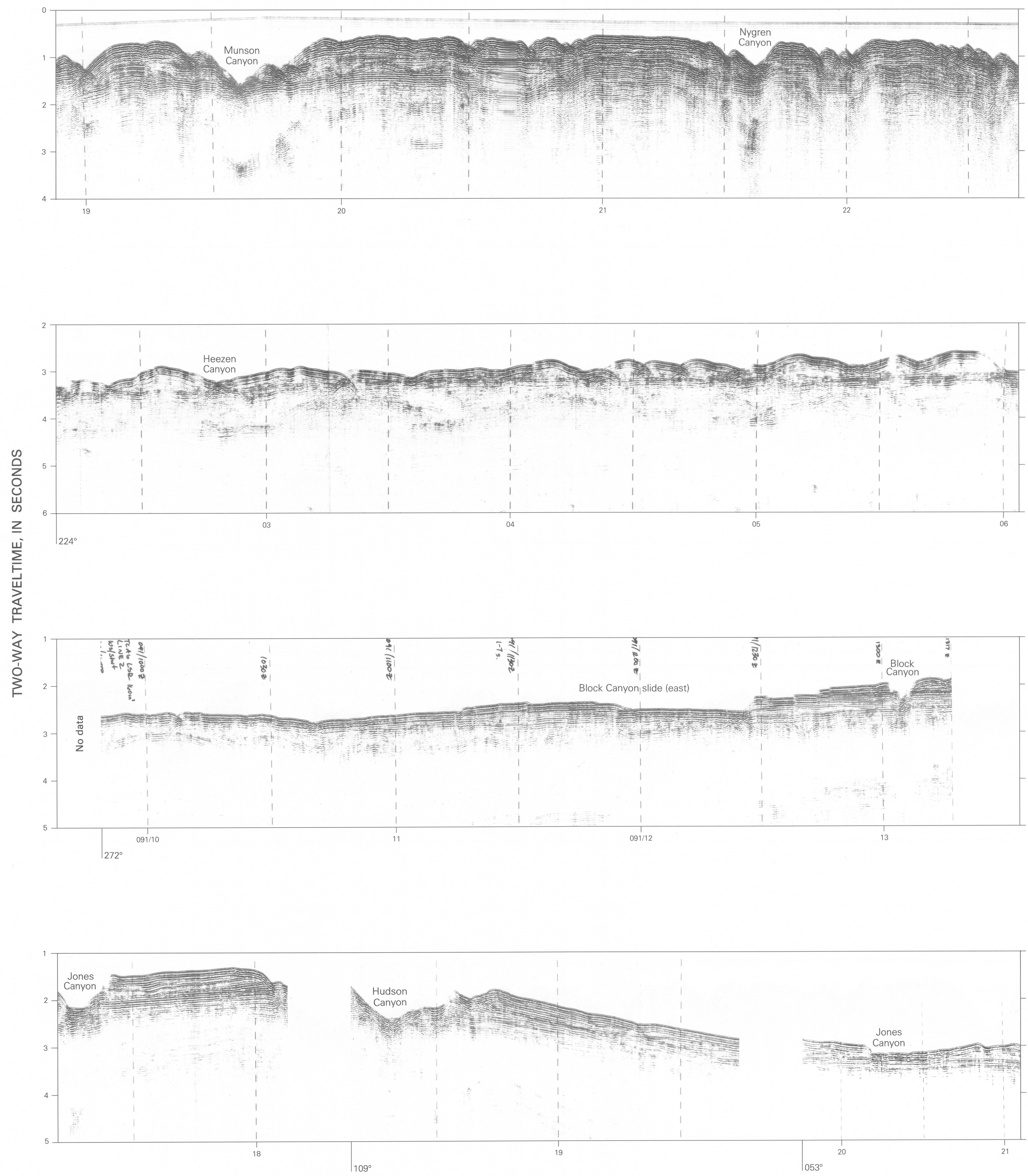

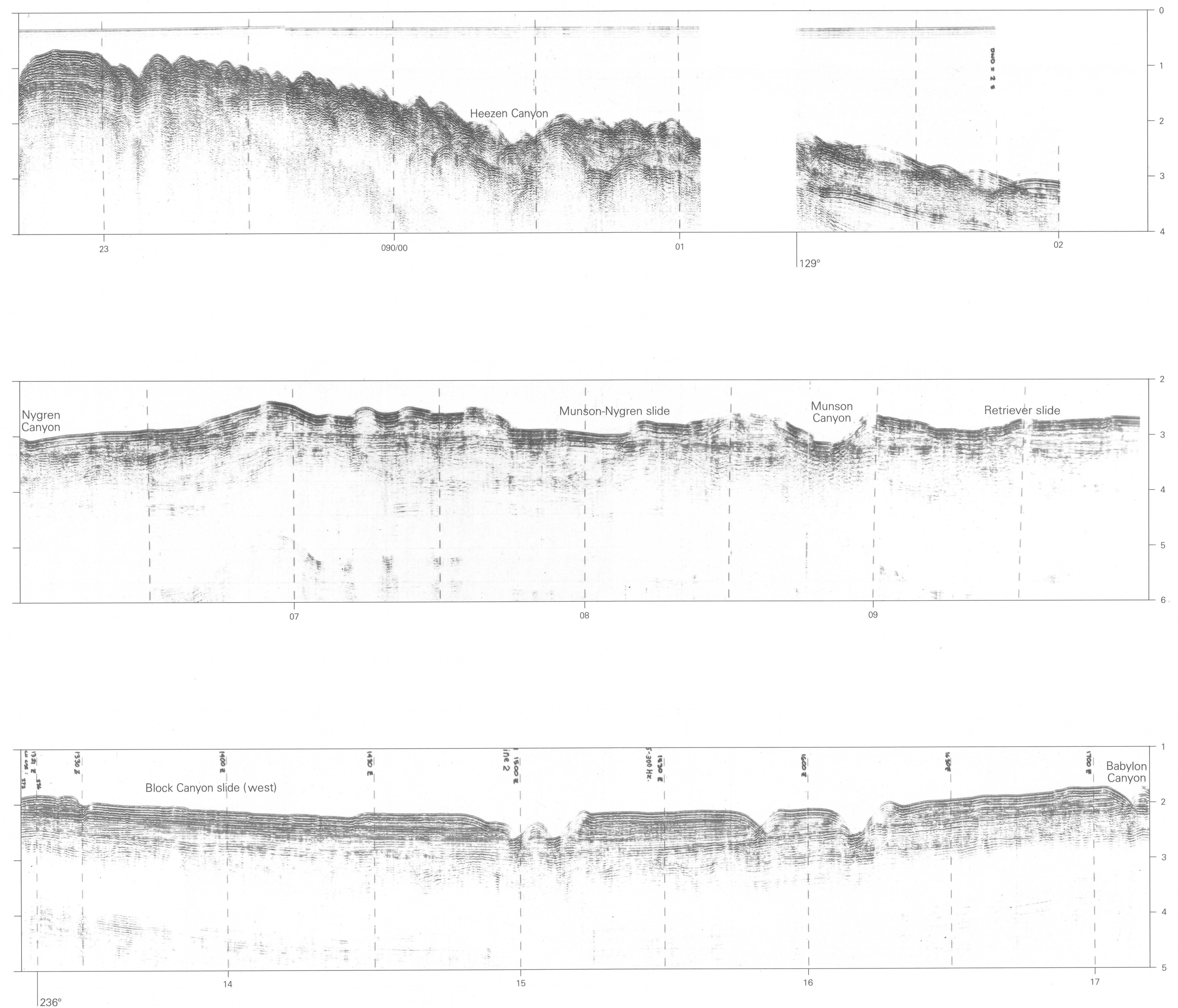

\section{$\eta$}

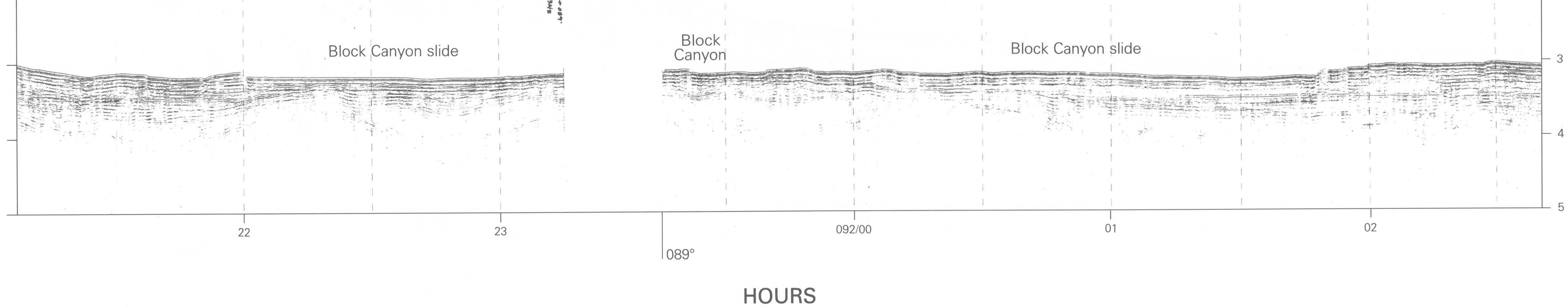



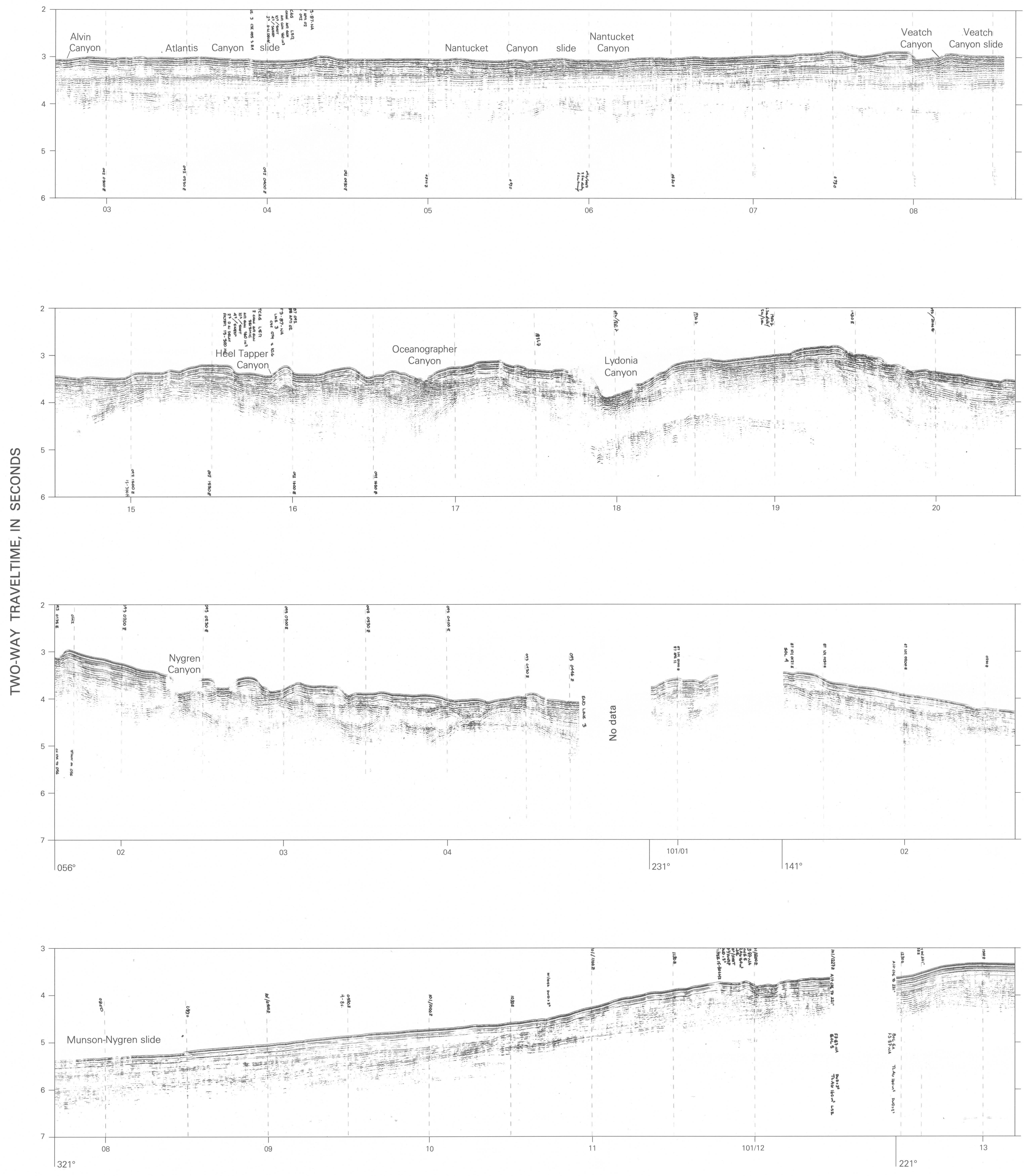

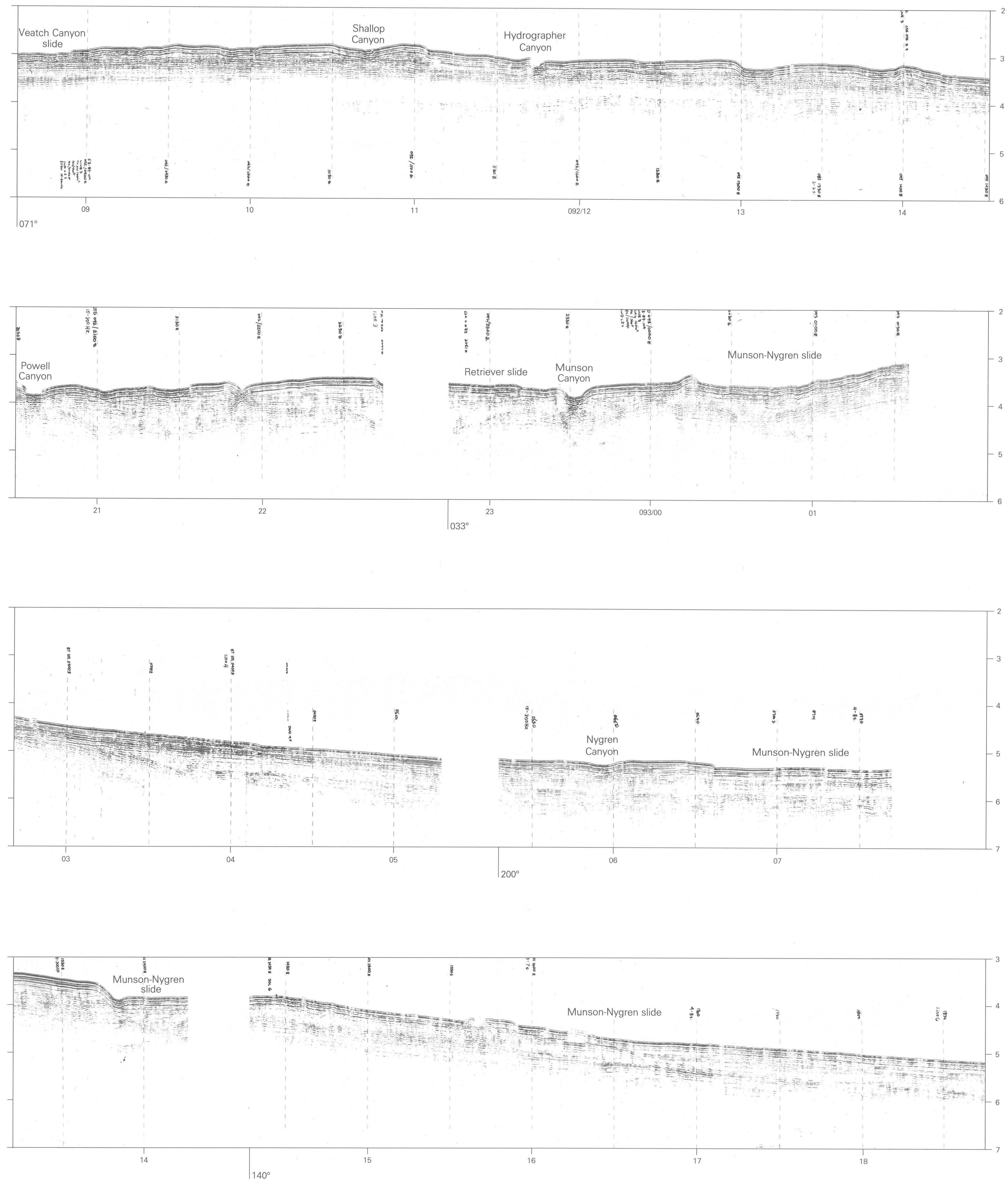

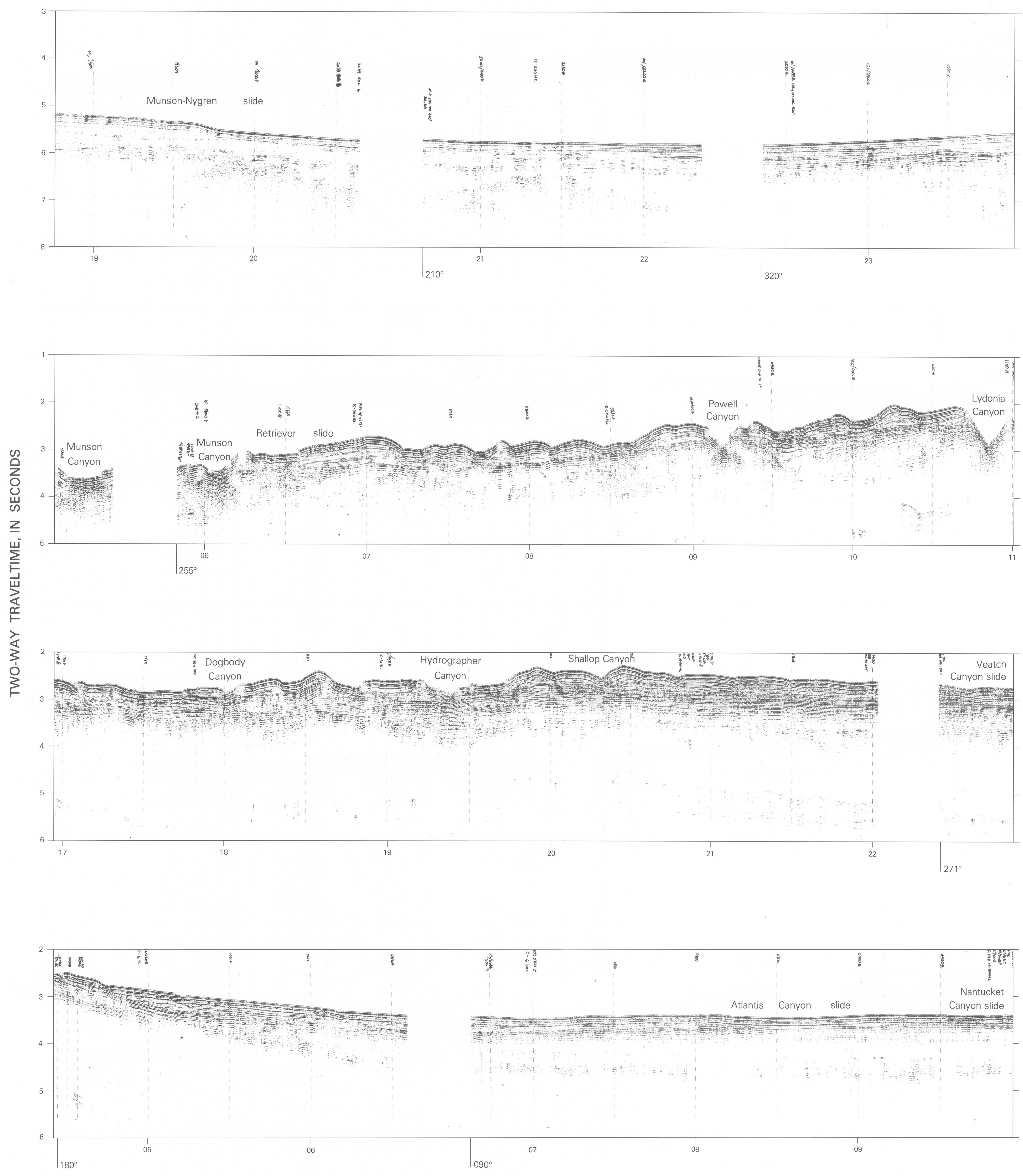

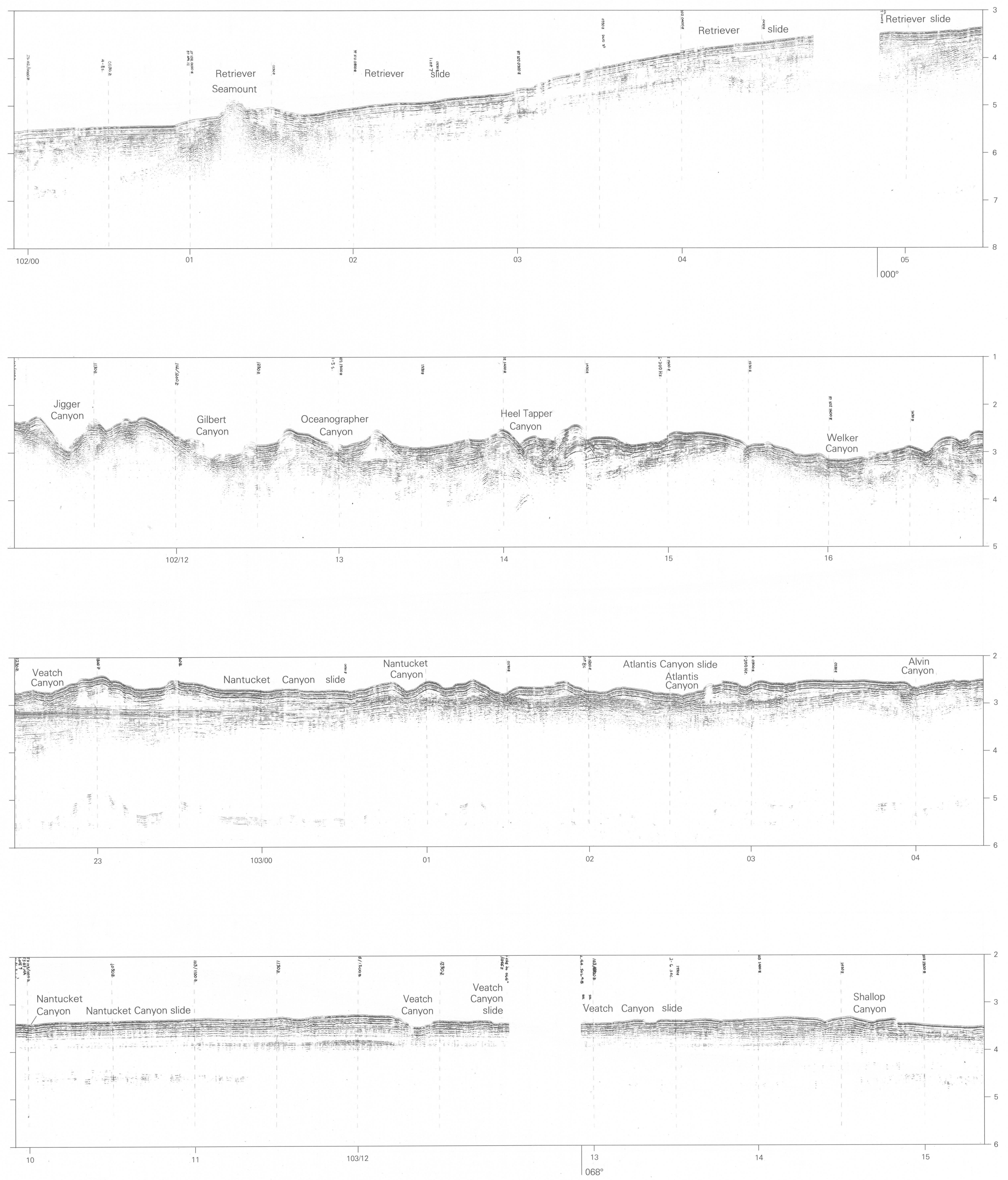
DEPARTMENT OF THE INTERIOR

USS. GEOLOGICAL SURVEY
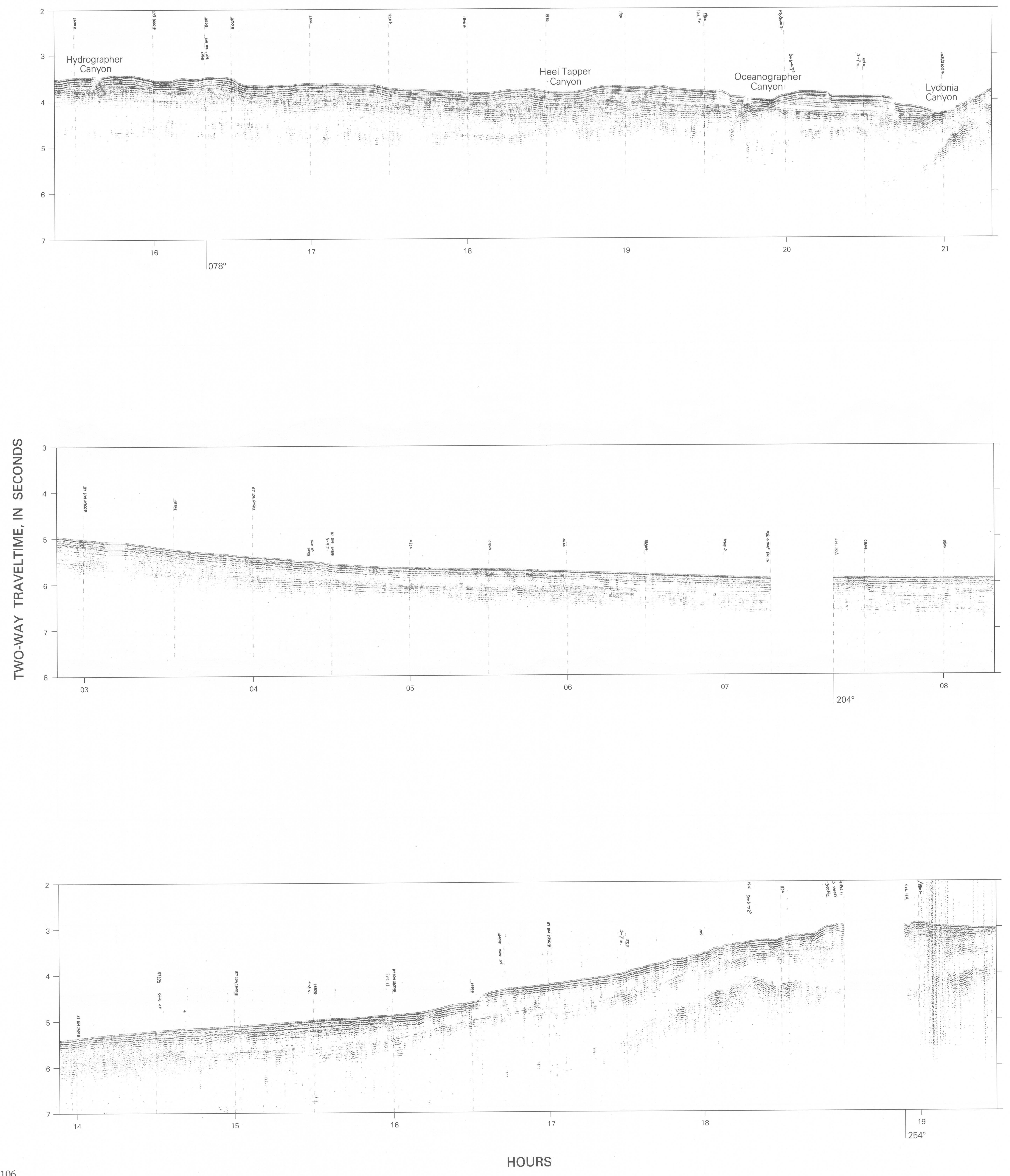

106 

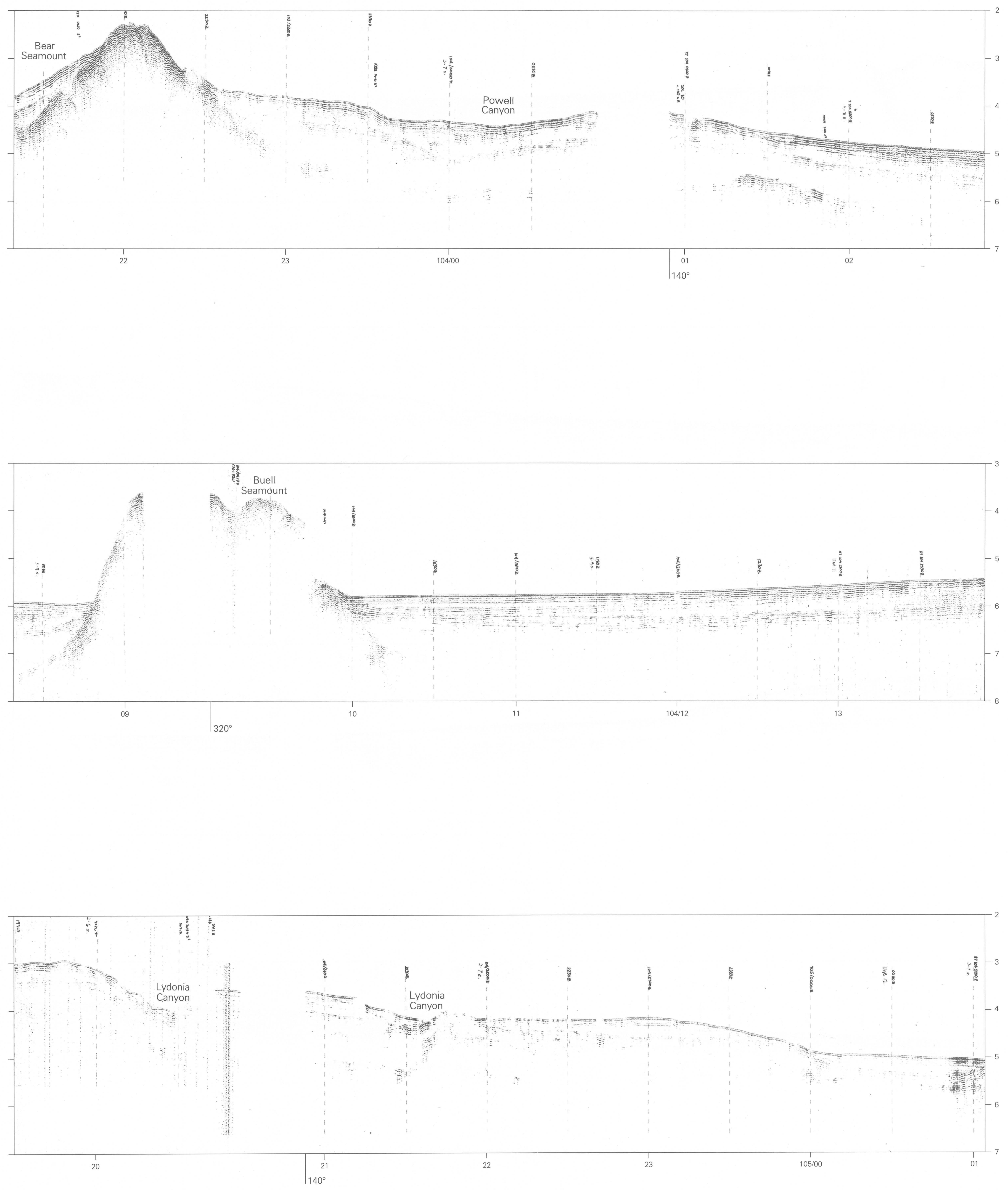

HOURS 
DEPARTMENT OF THE INTERIOR

U.S. GEOLOGICAL SURVEY
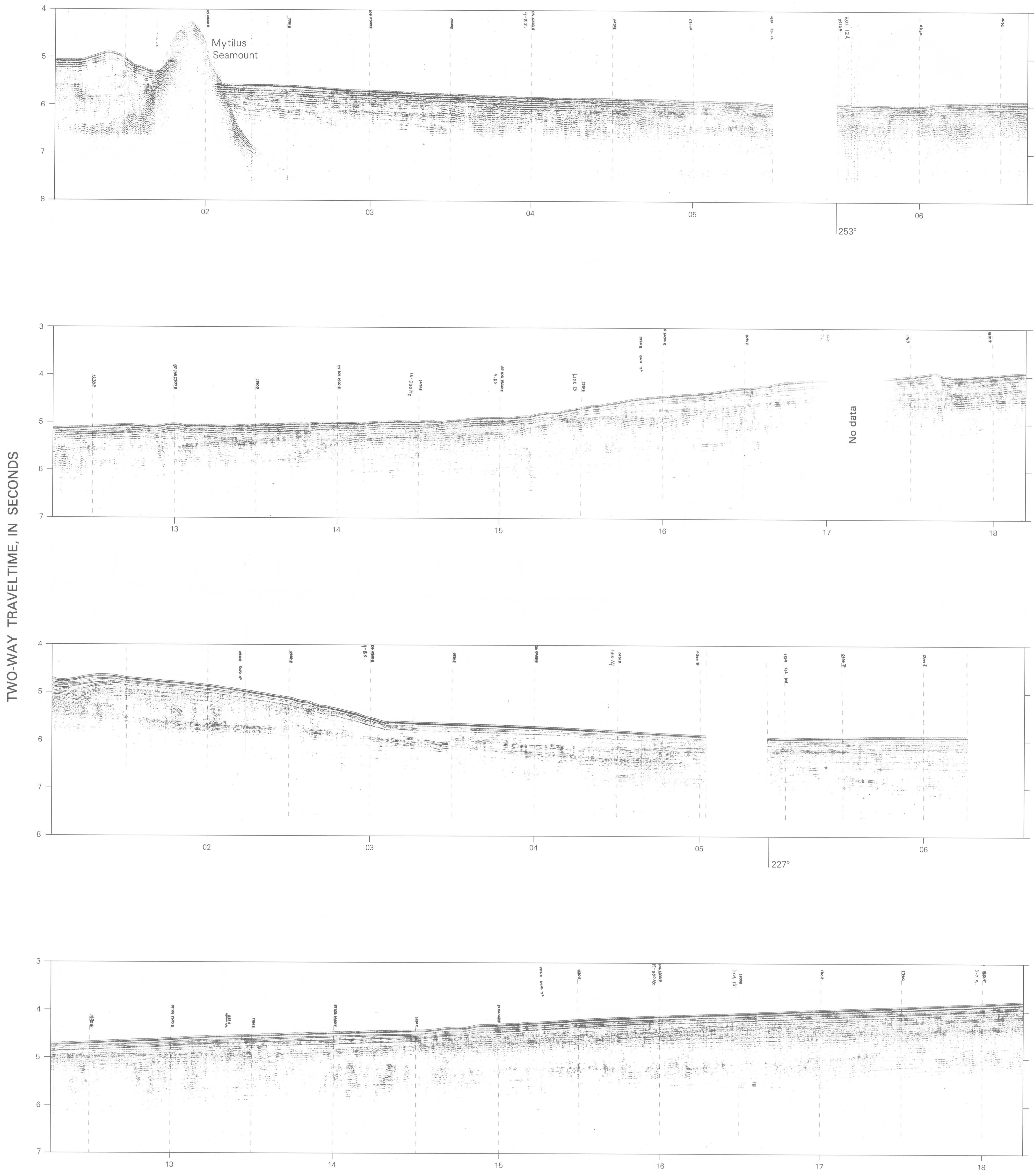

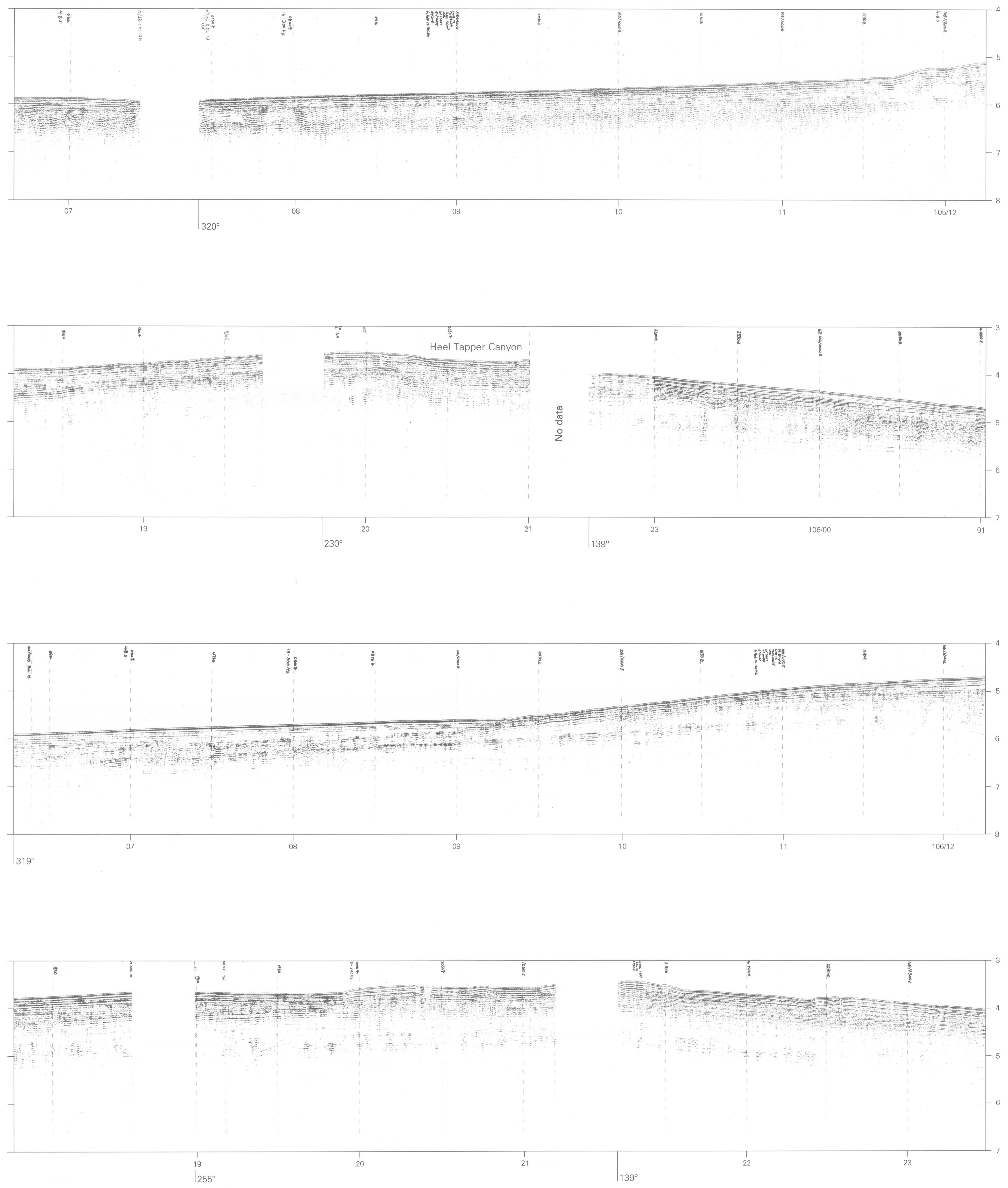

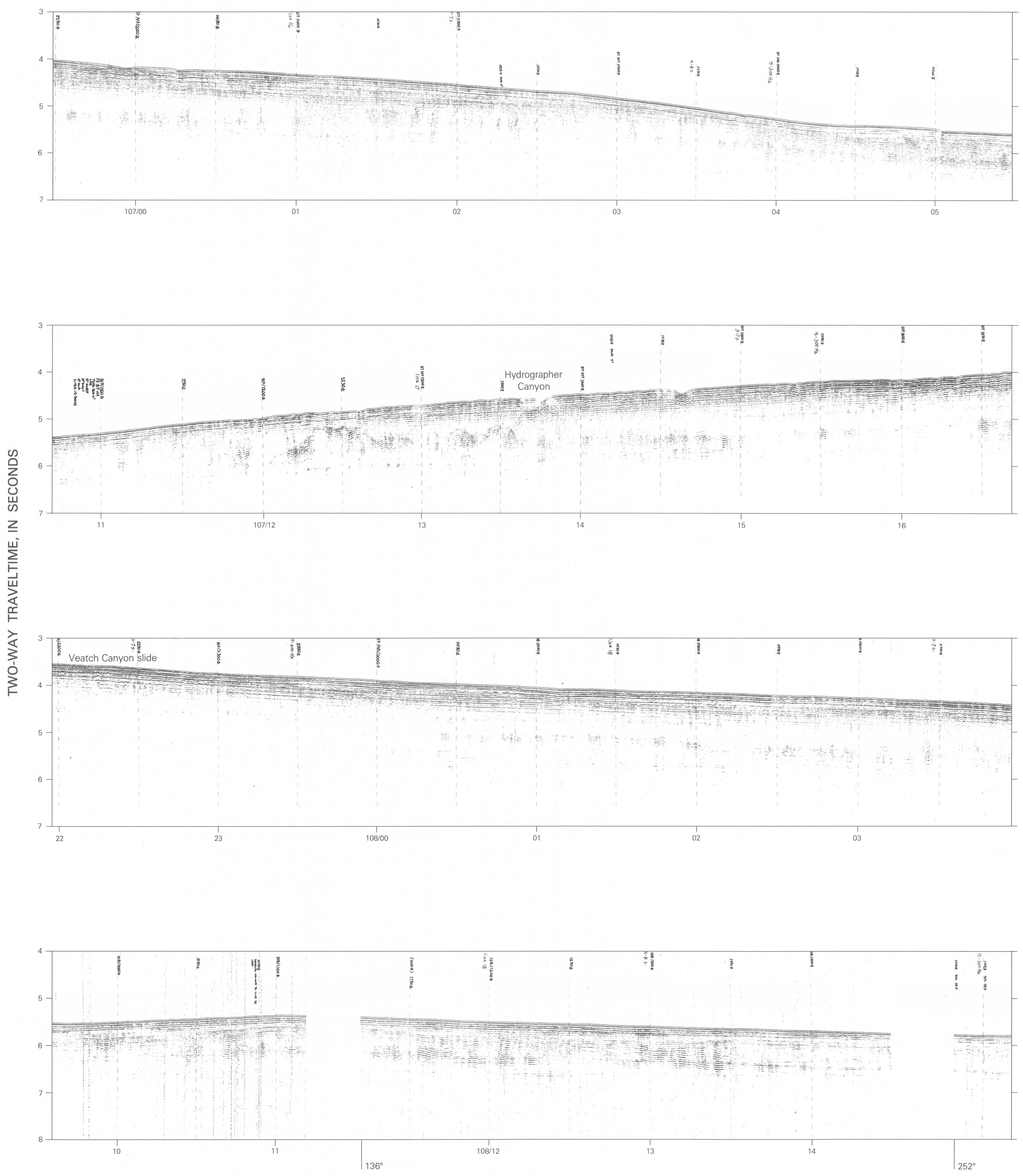

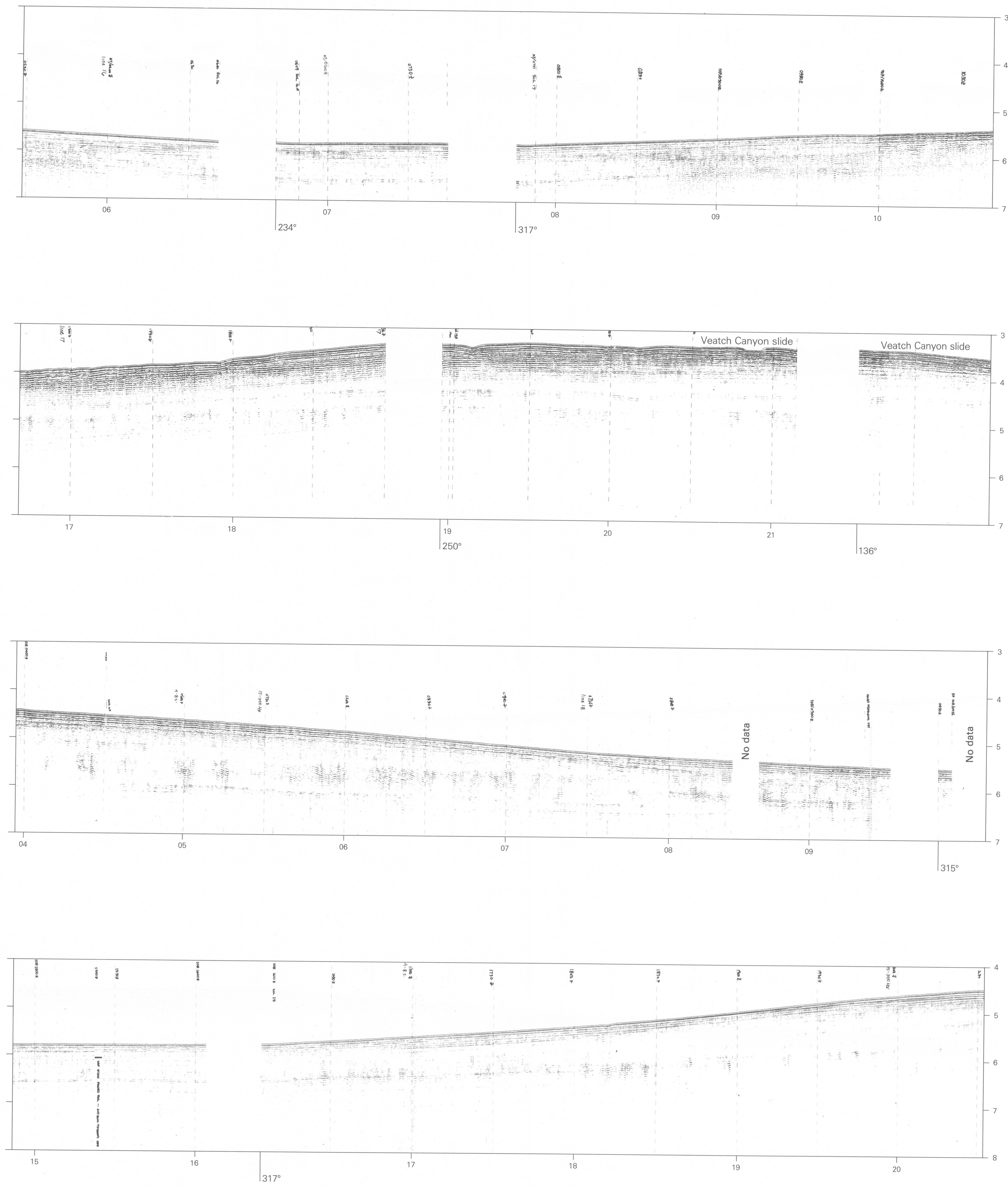
DEPARTMENT OF THE INTERIOR

U.S. GEOLOGICAL SURVEY
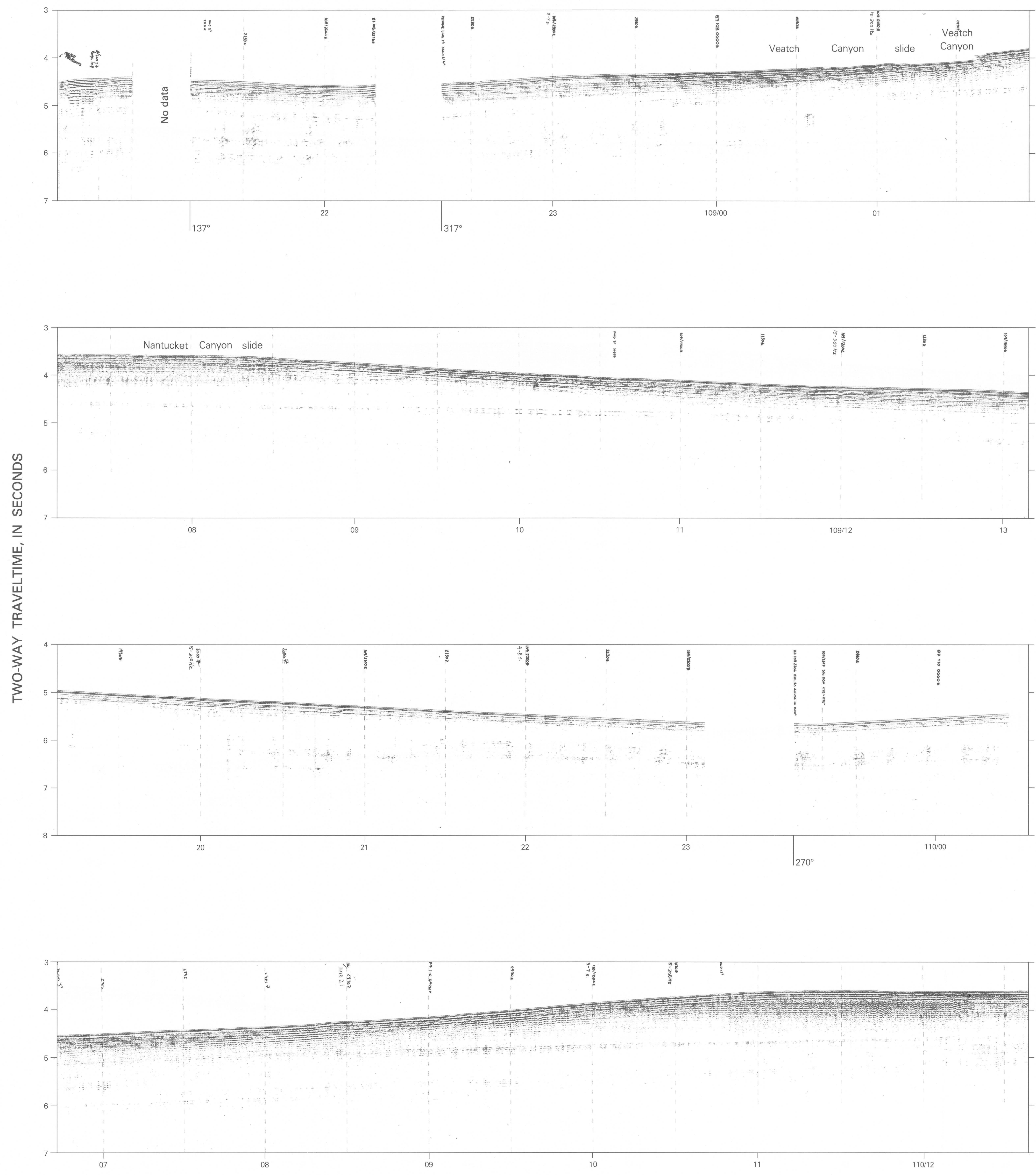

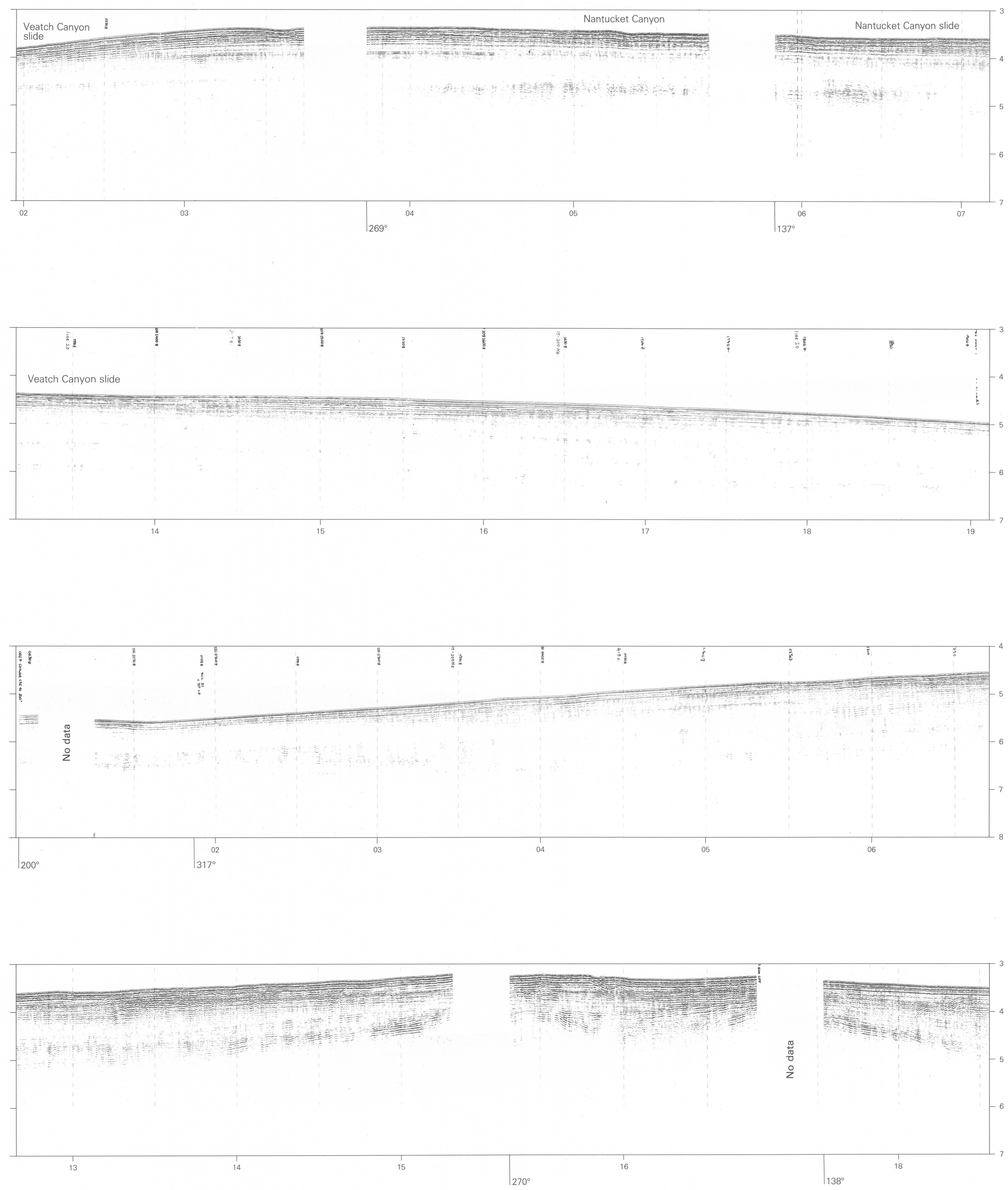

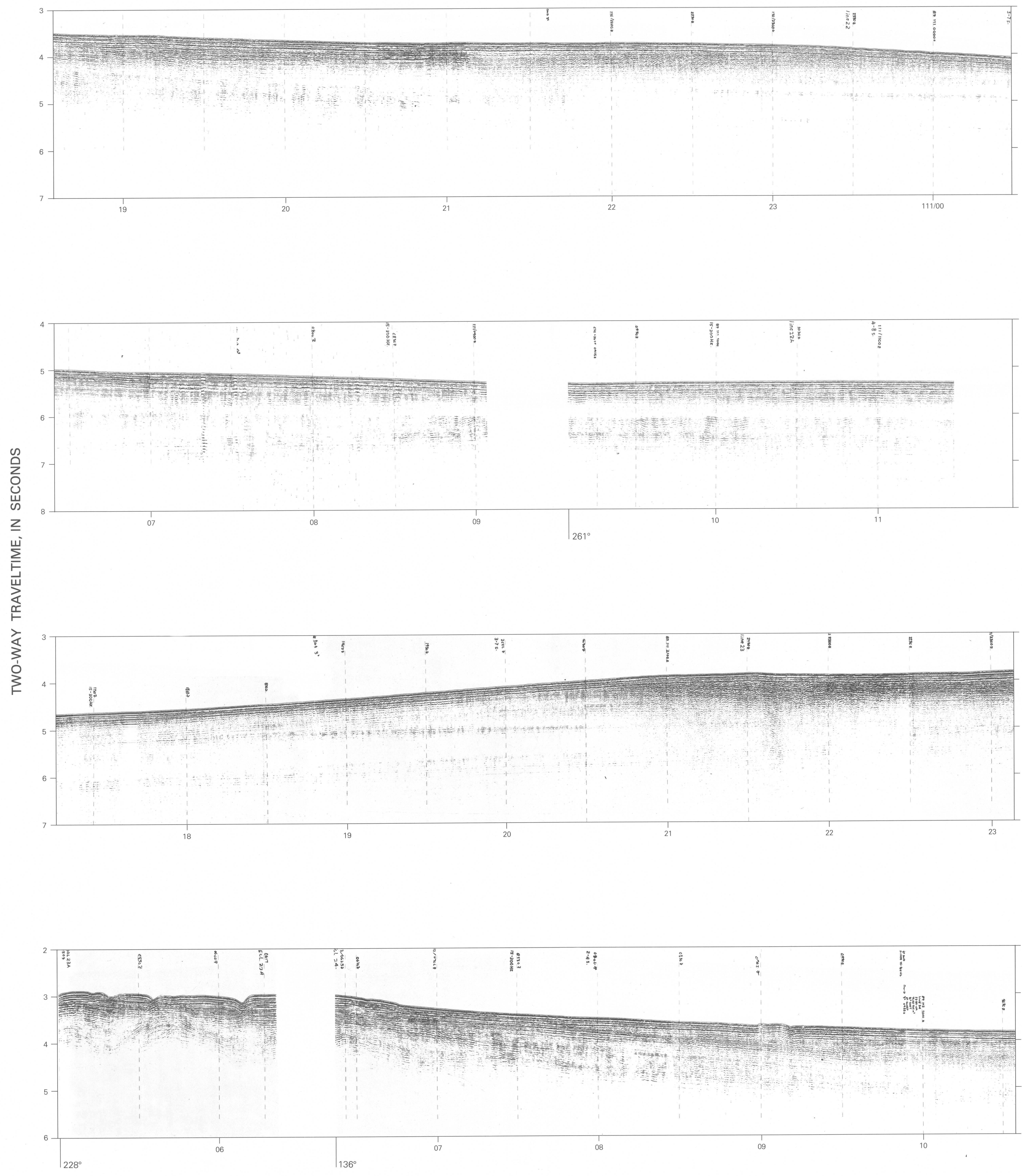

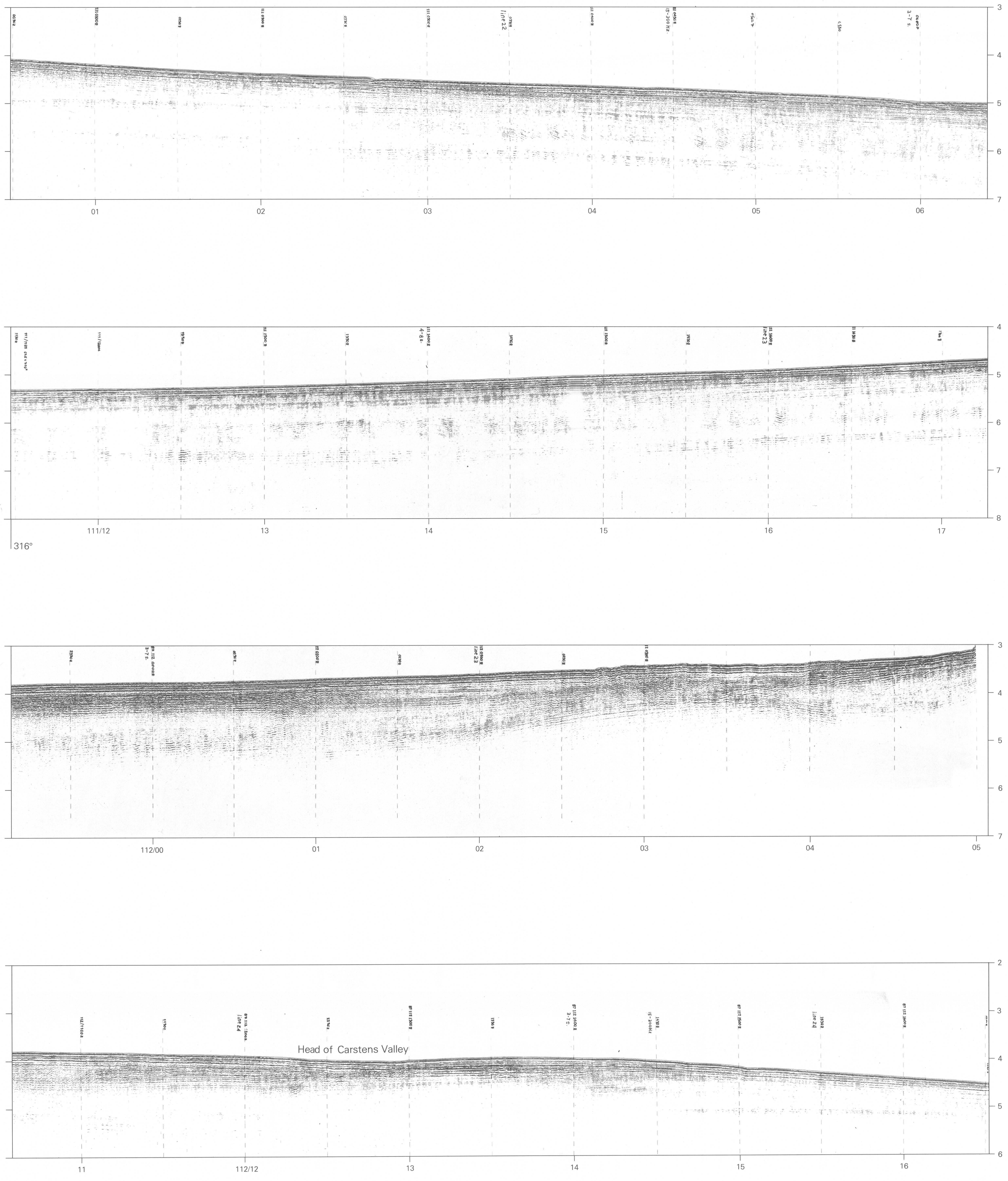

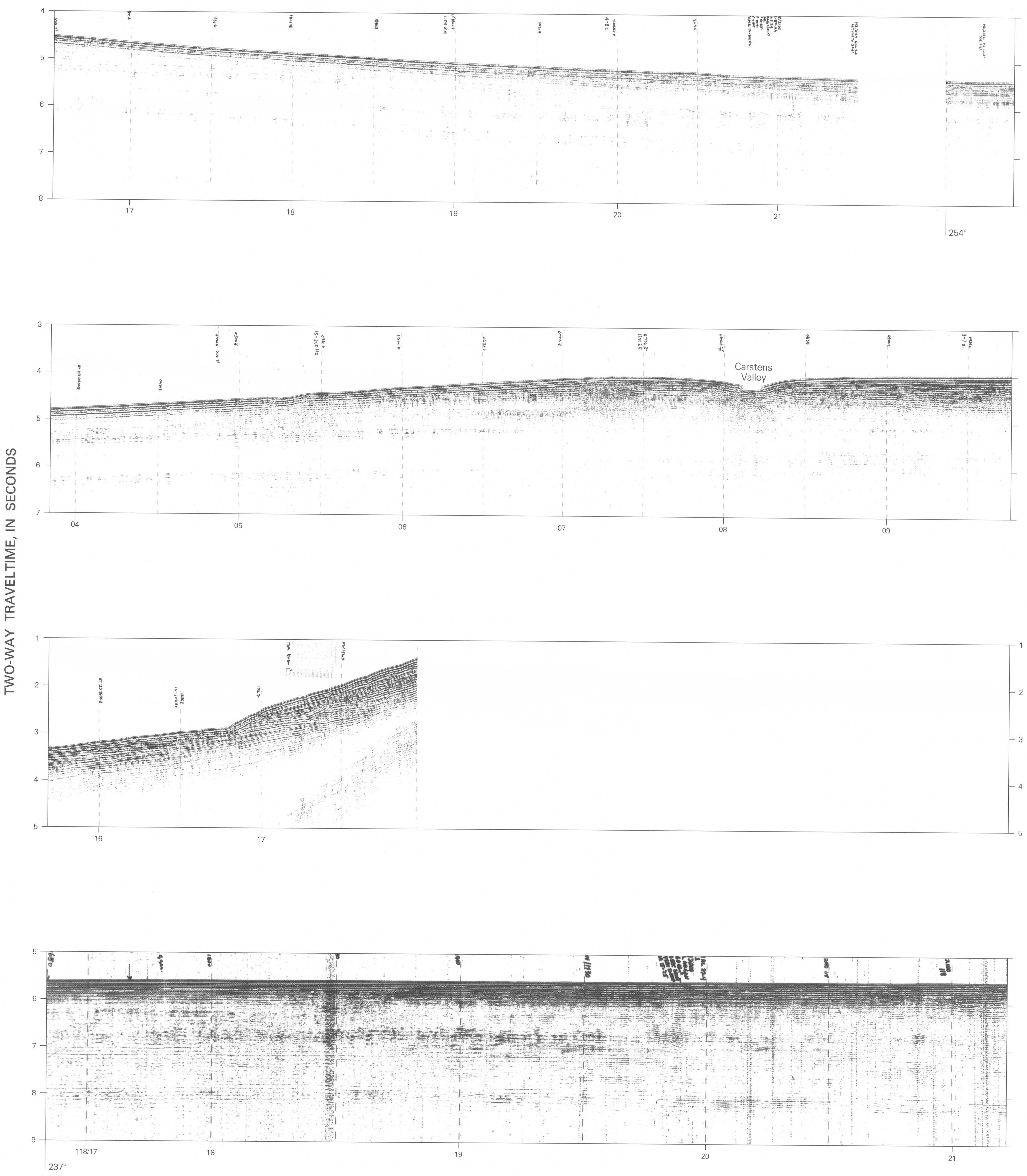

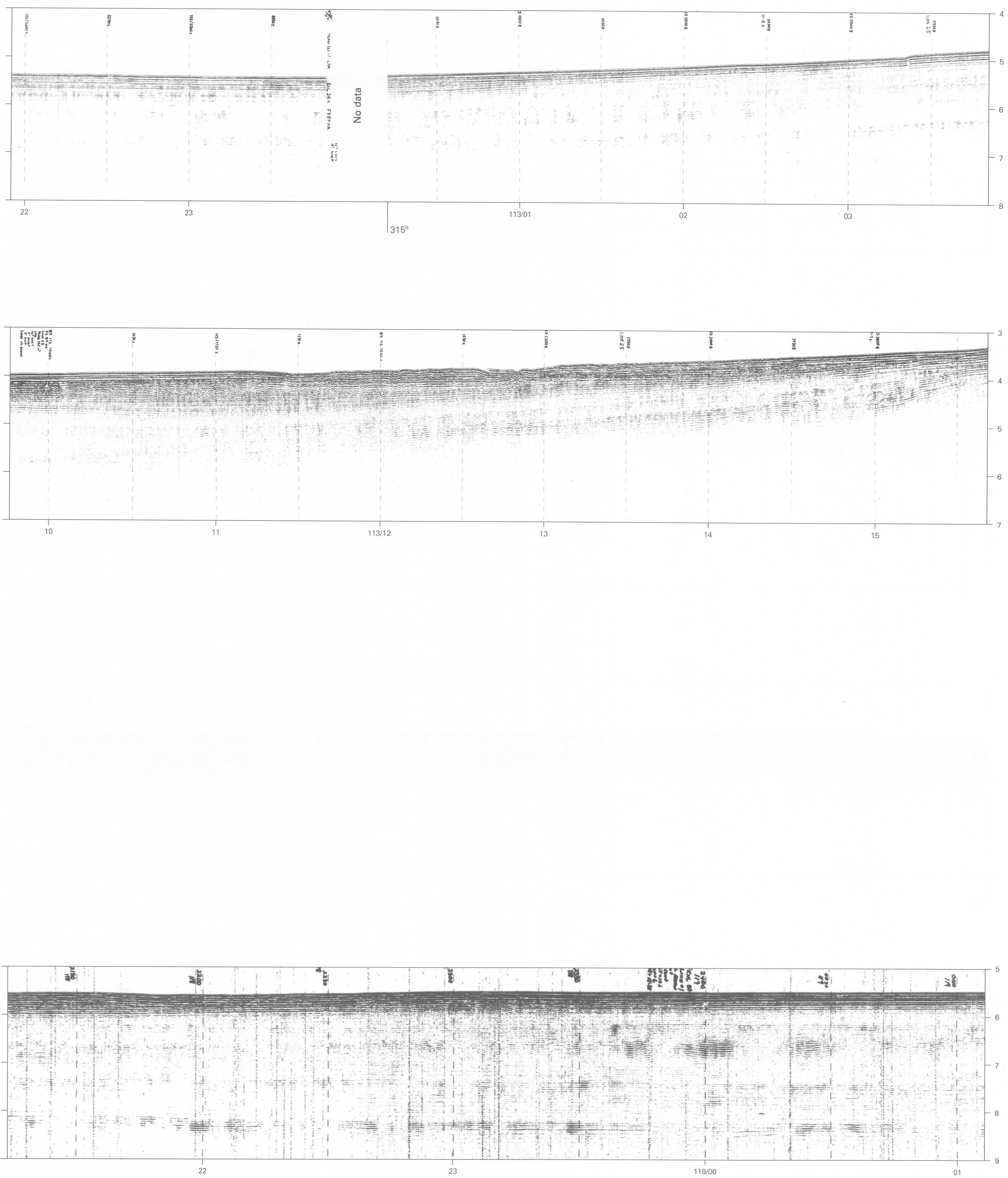

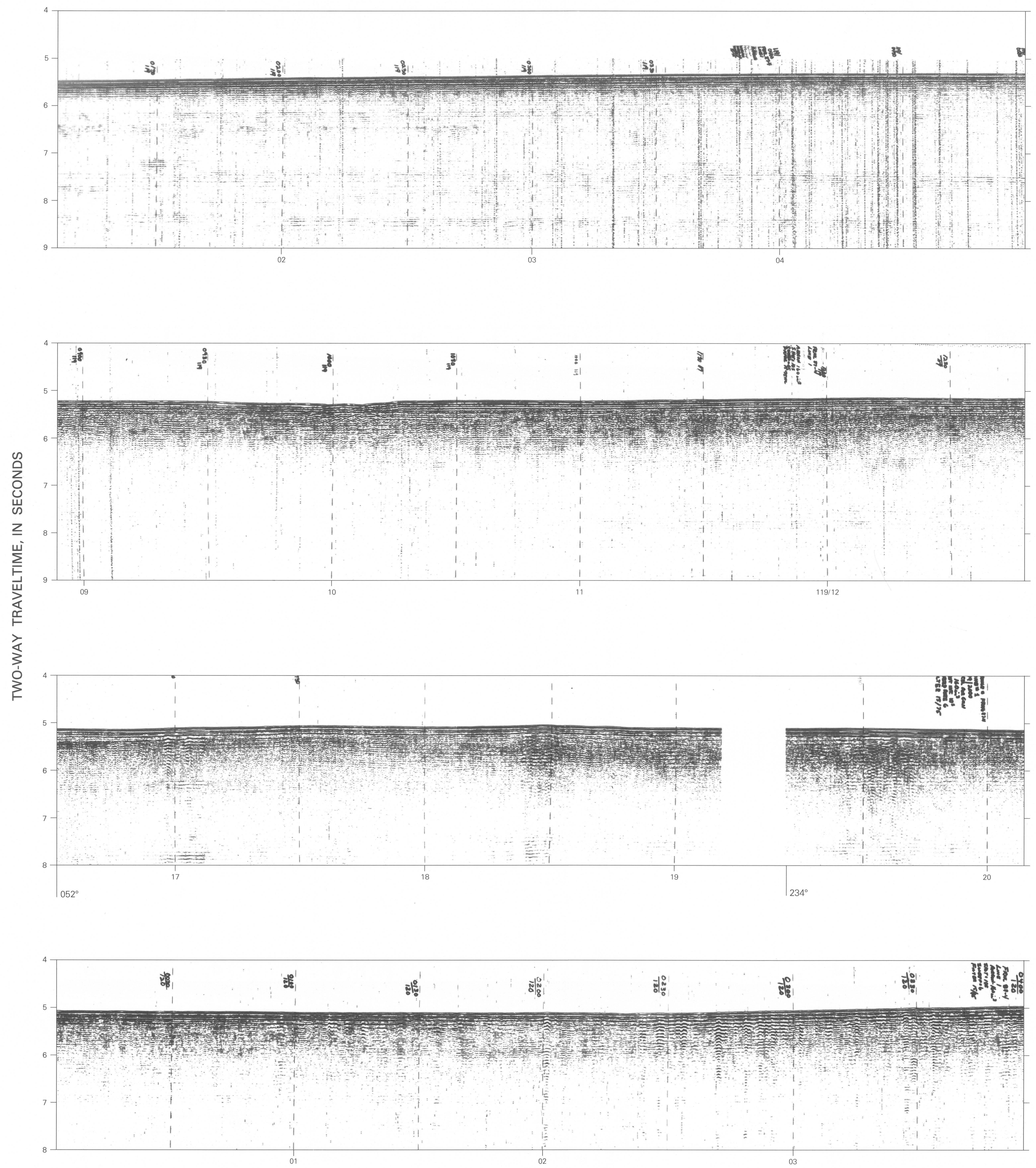

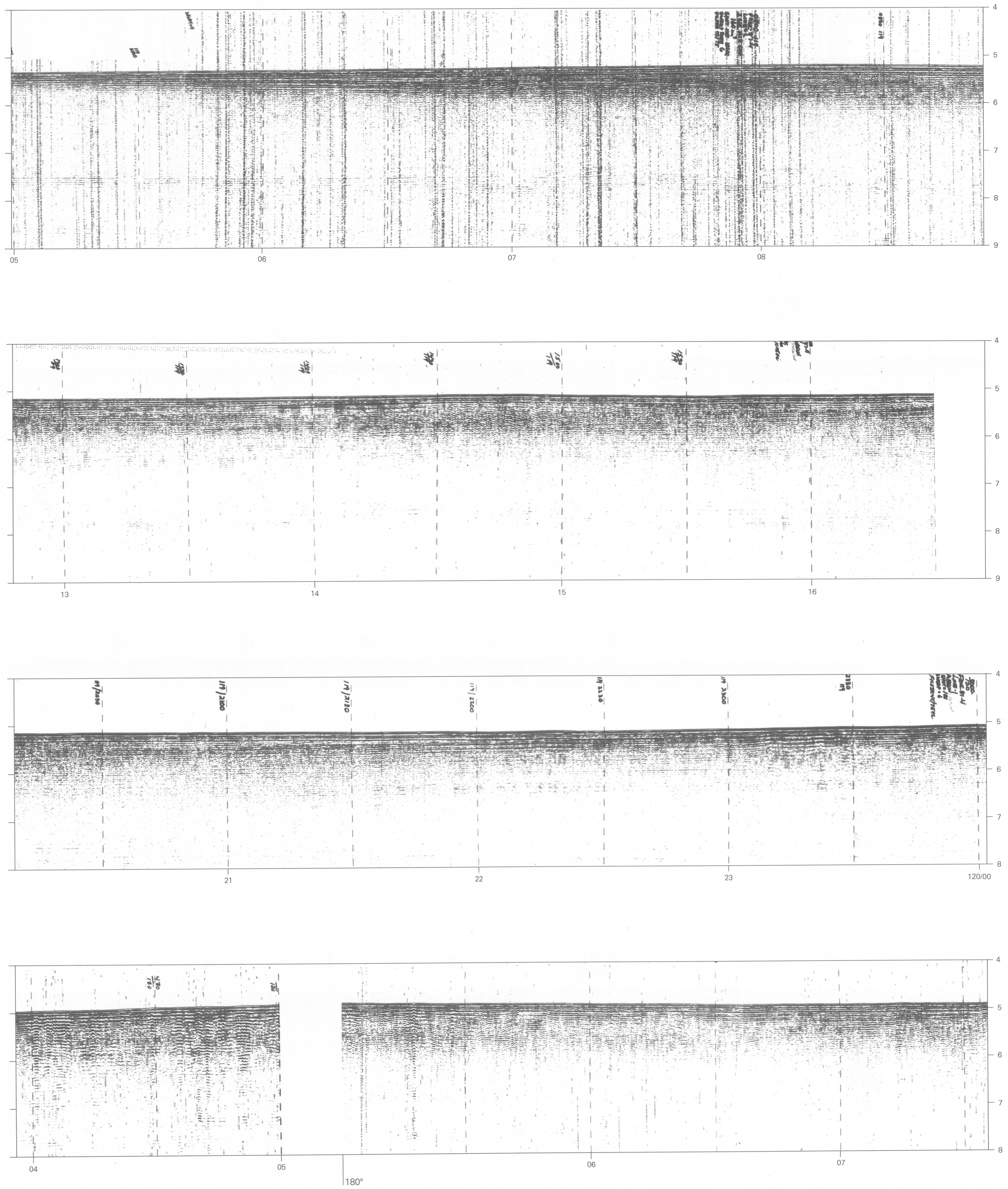

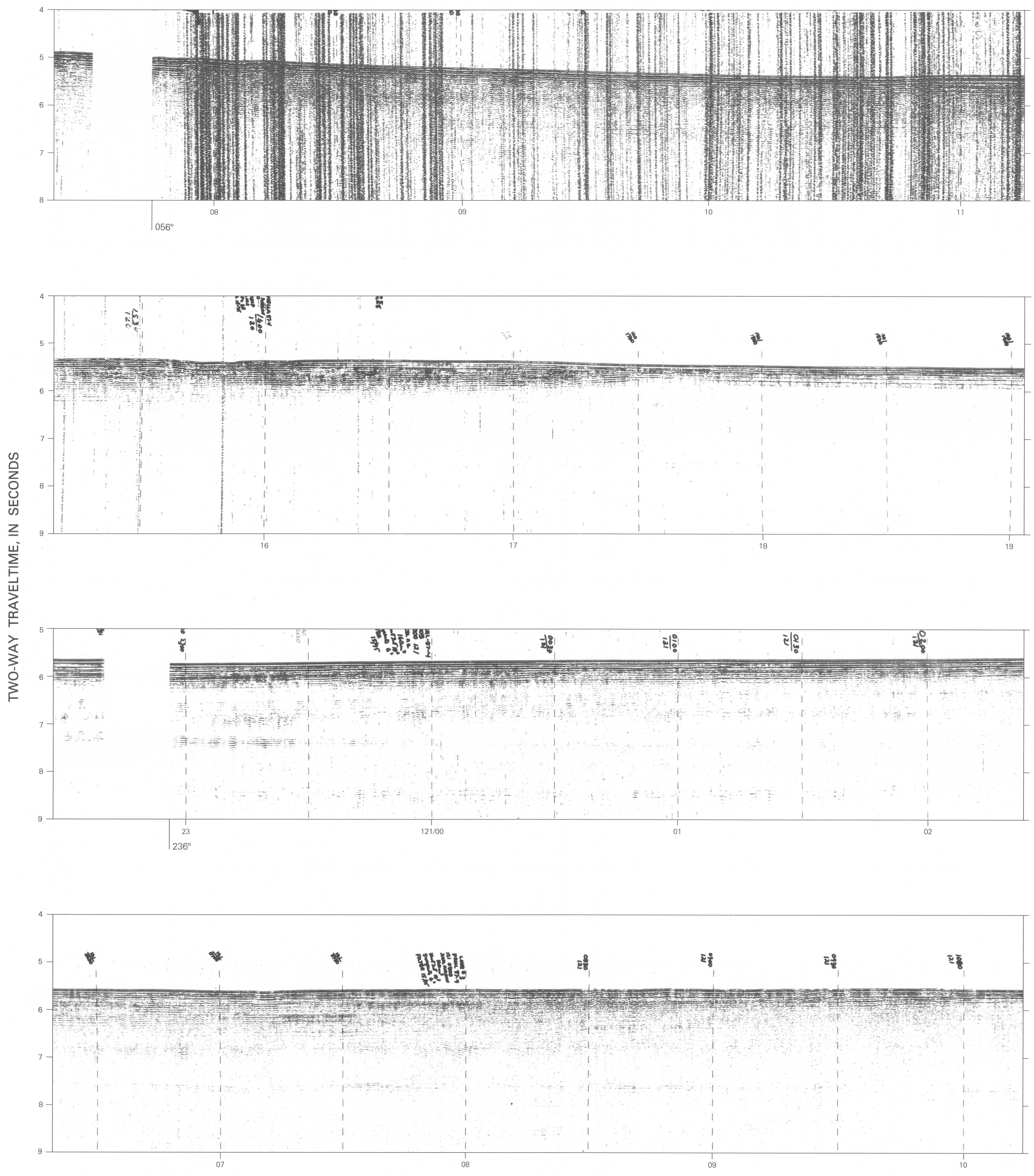

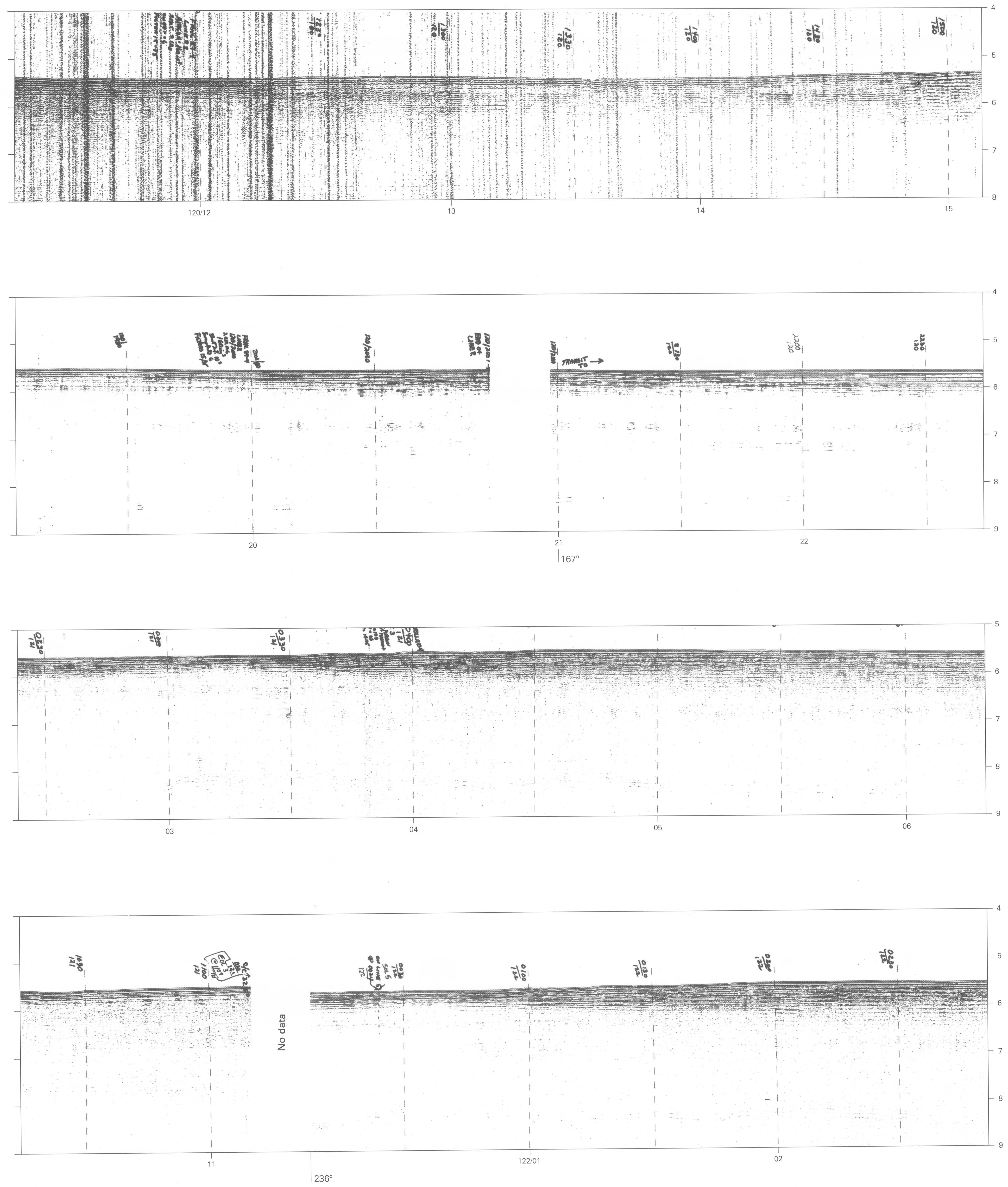

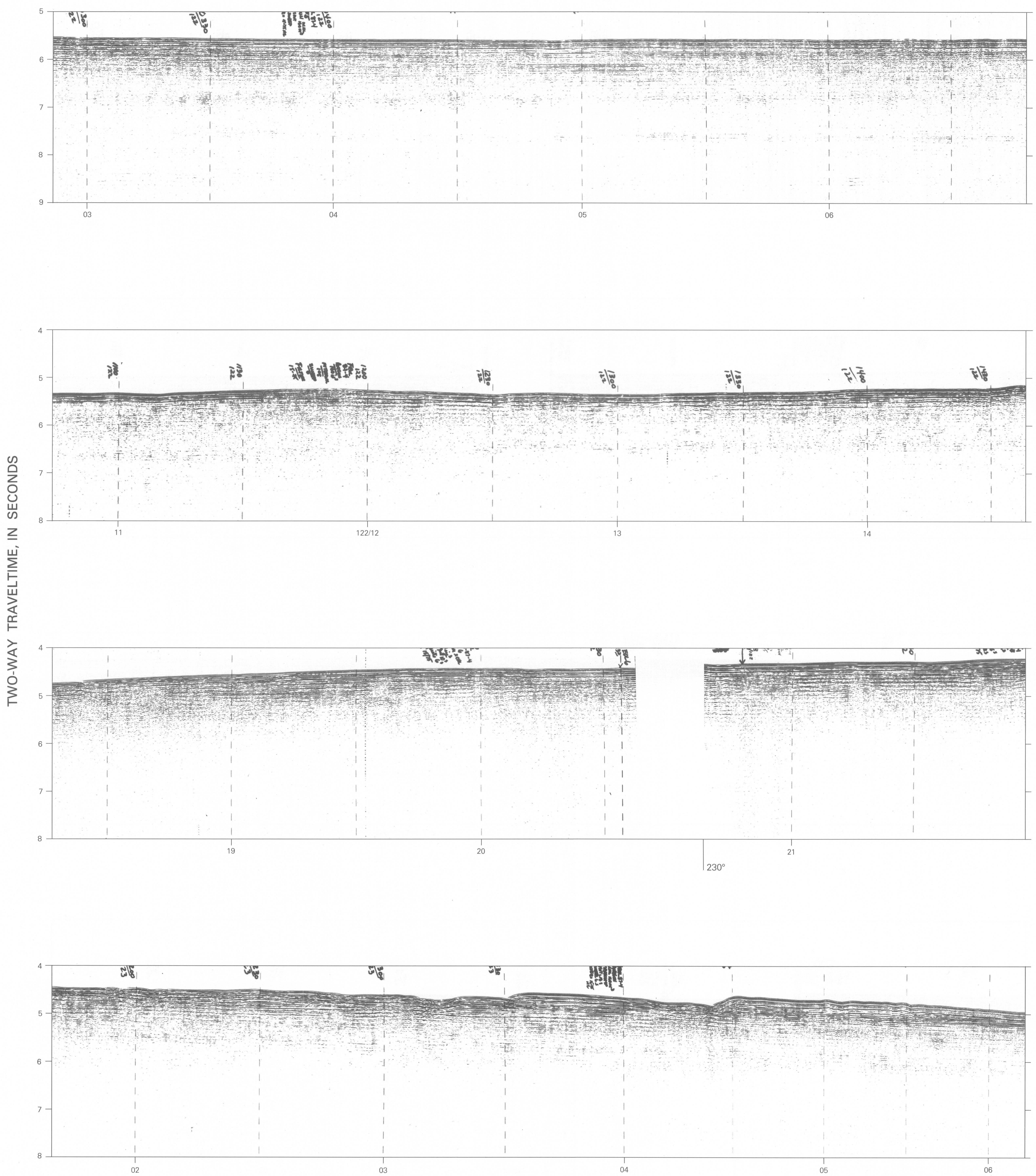

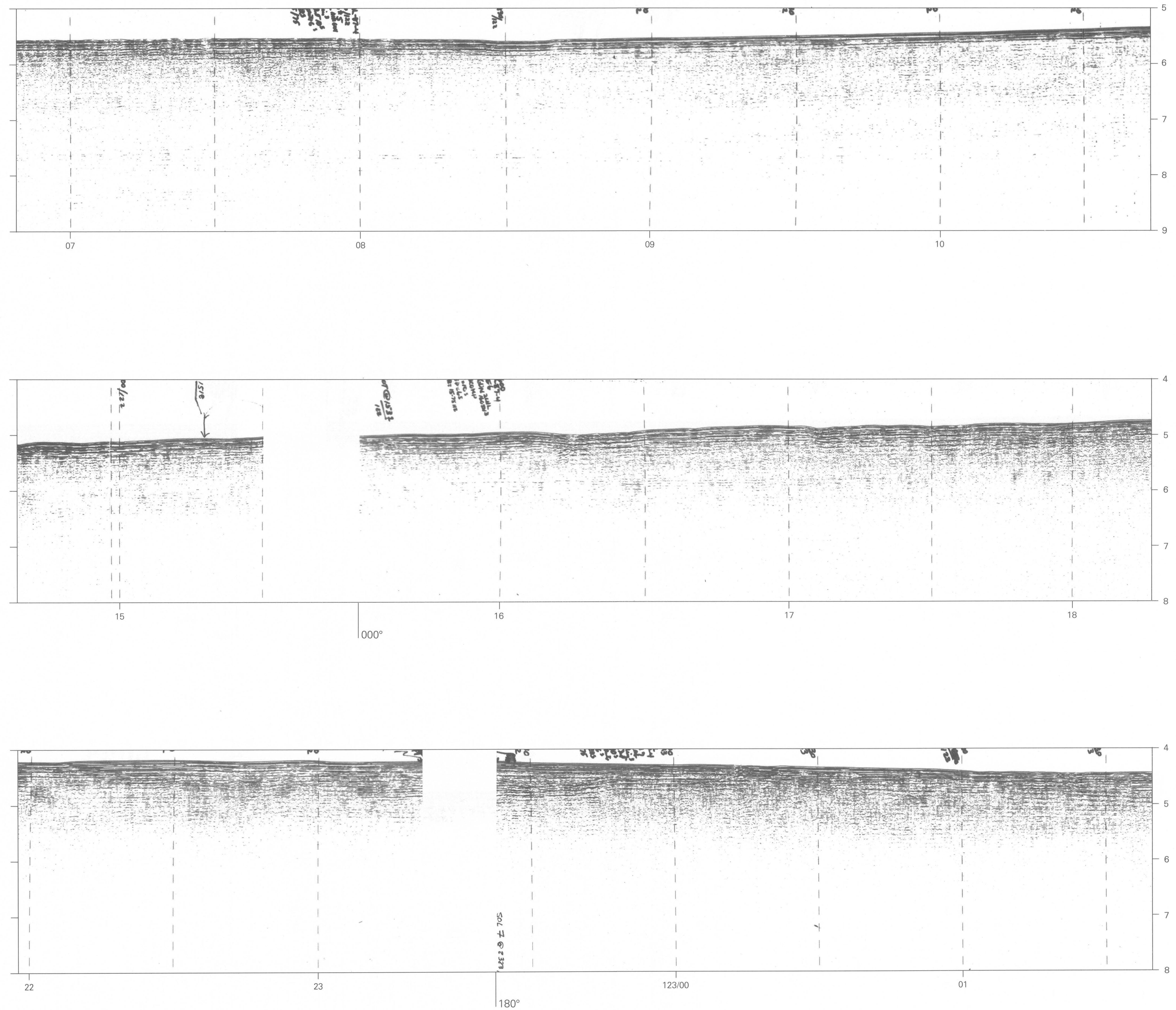

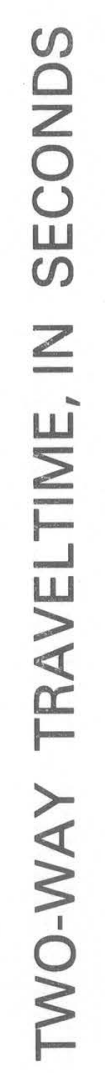

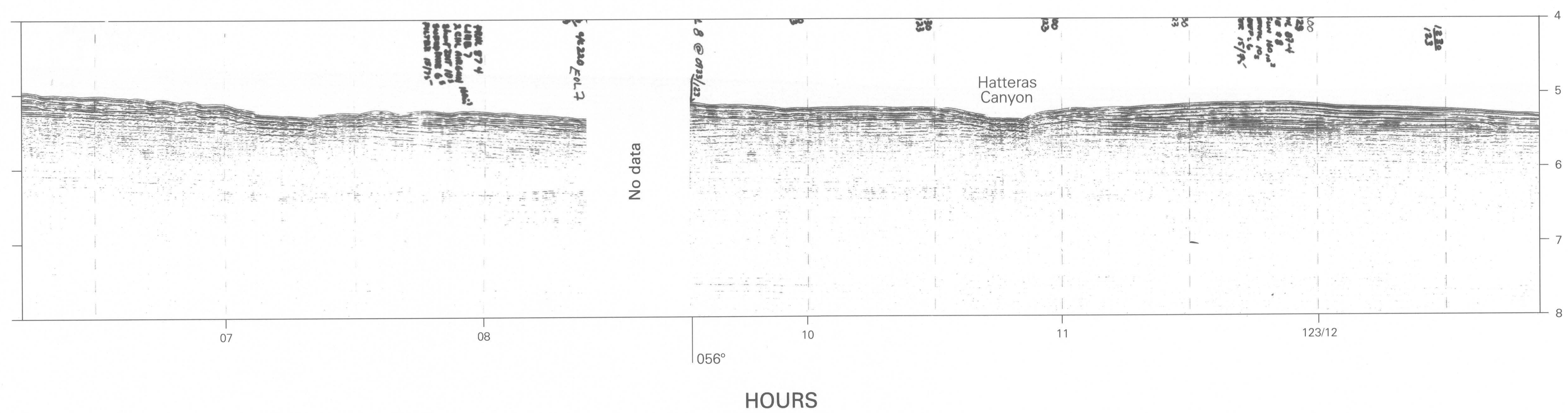

123 

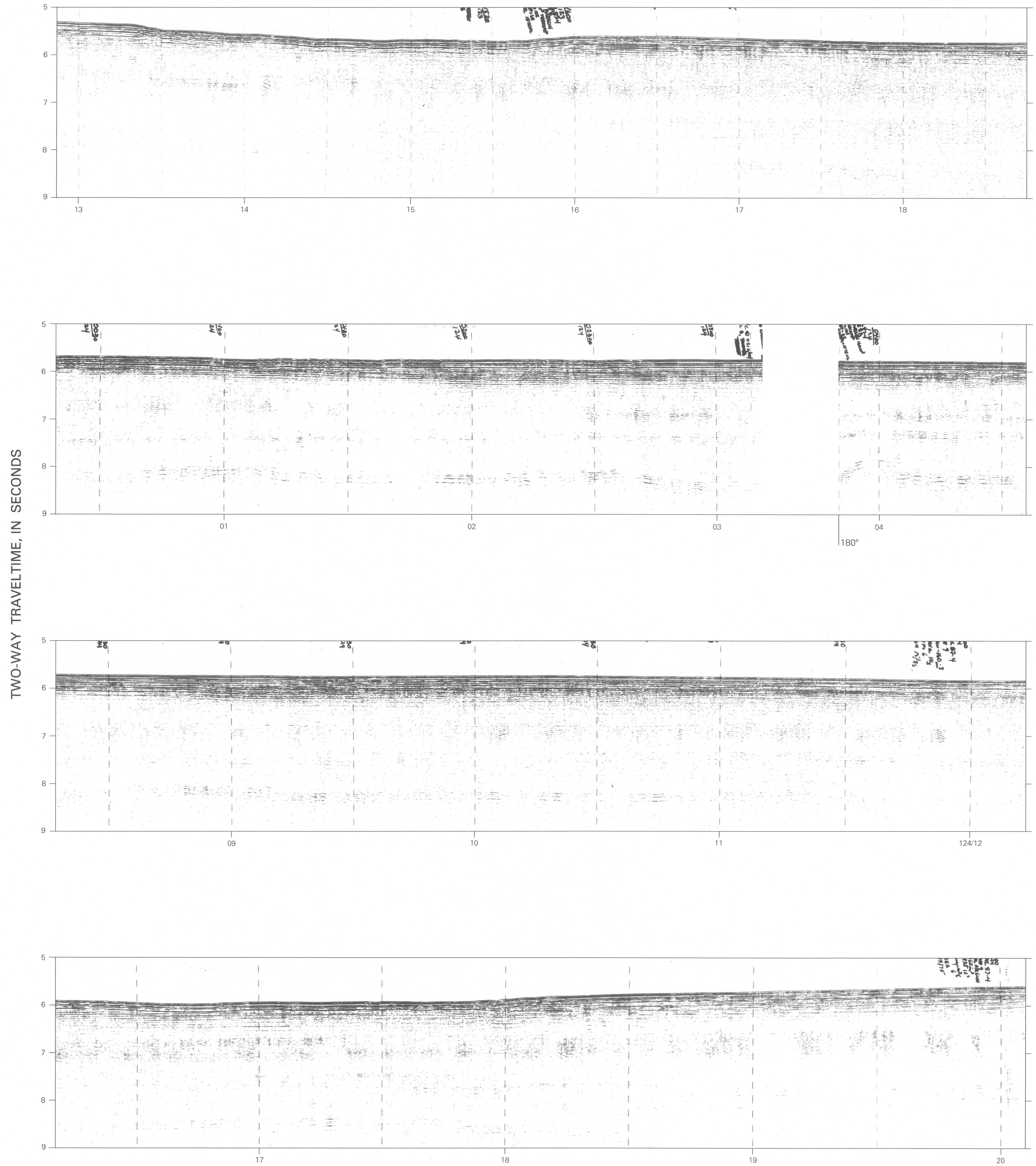

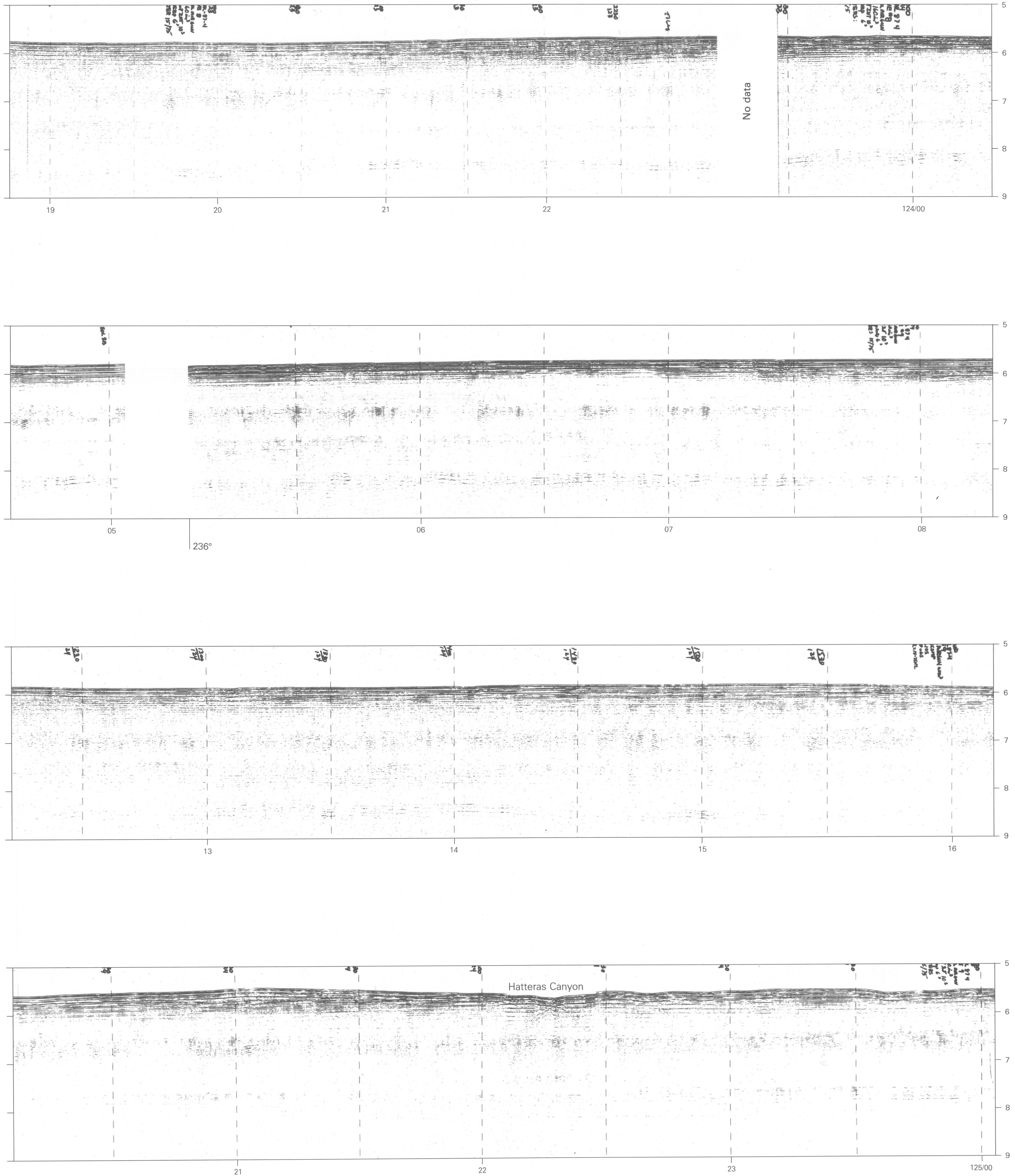

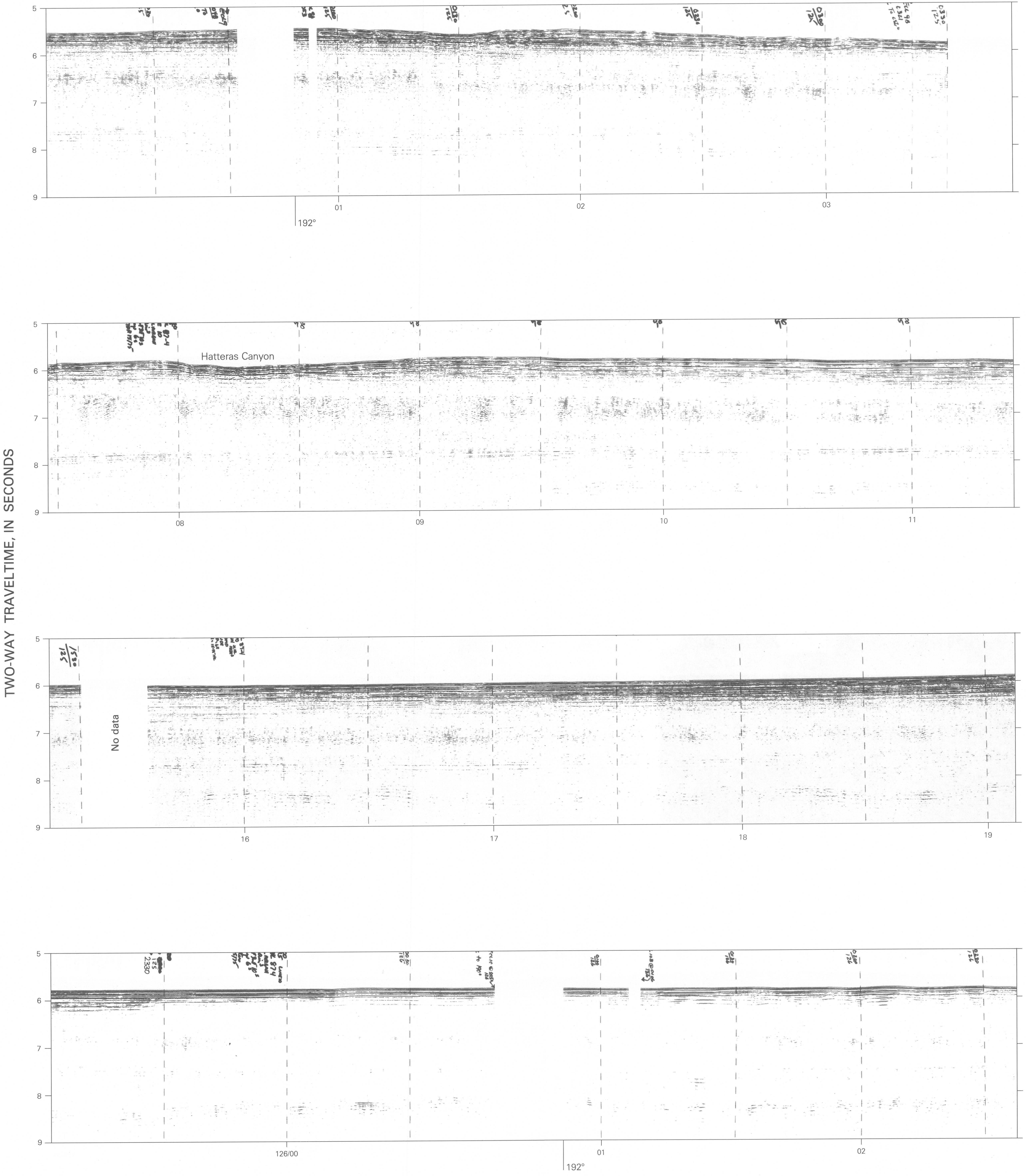

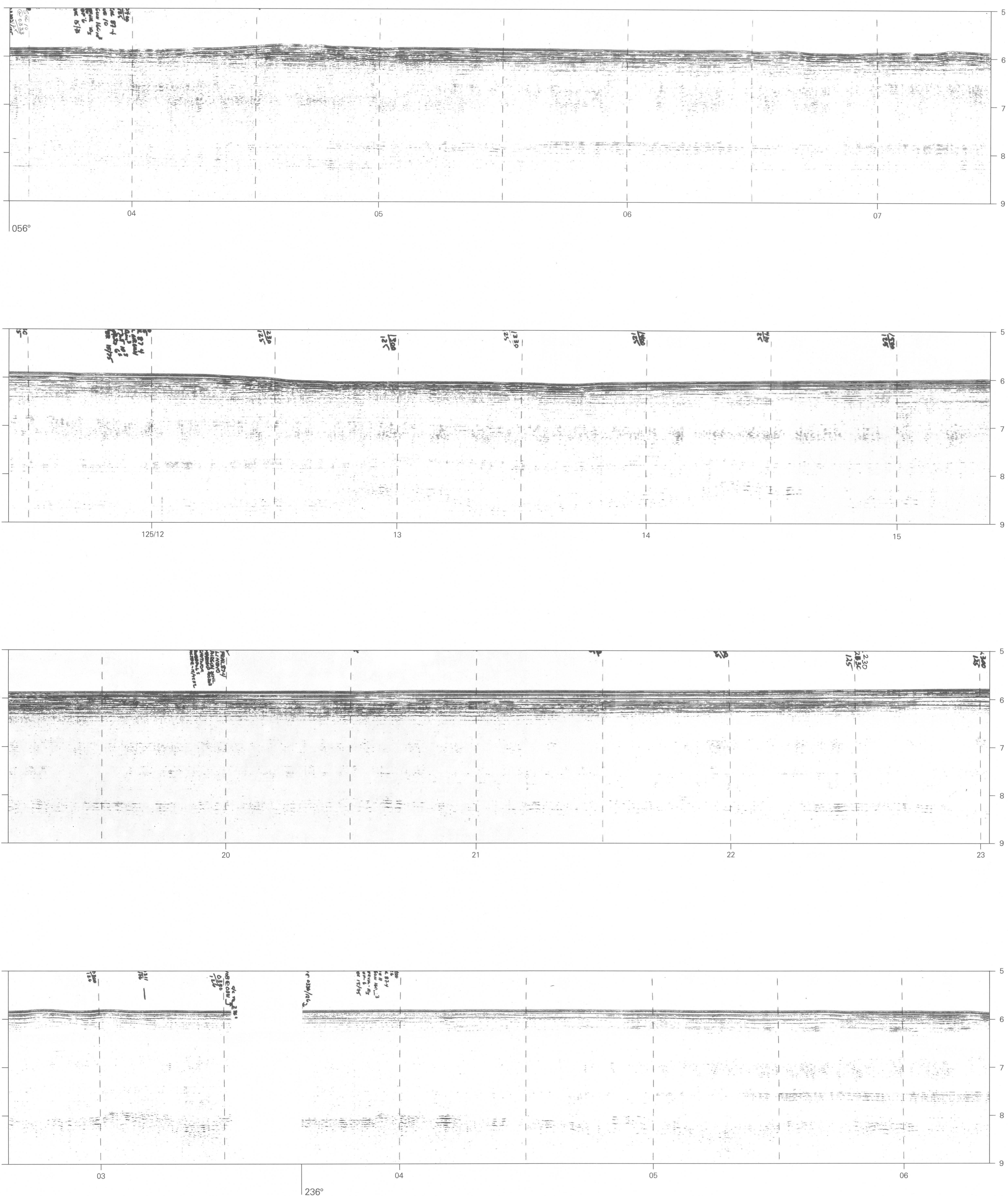

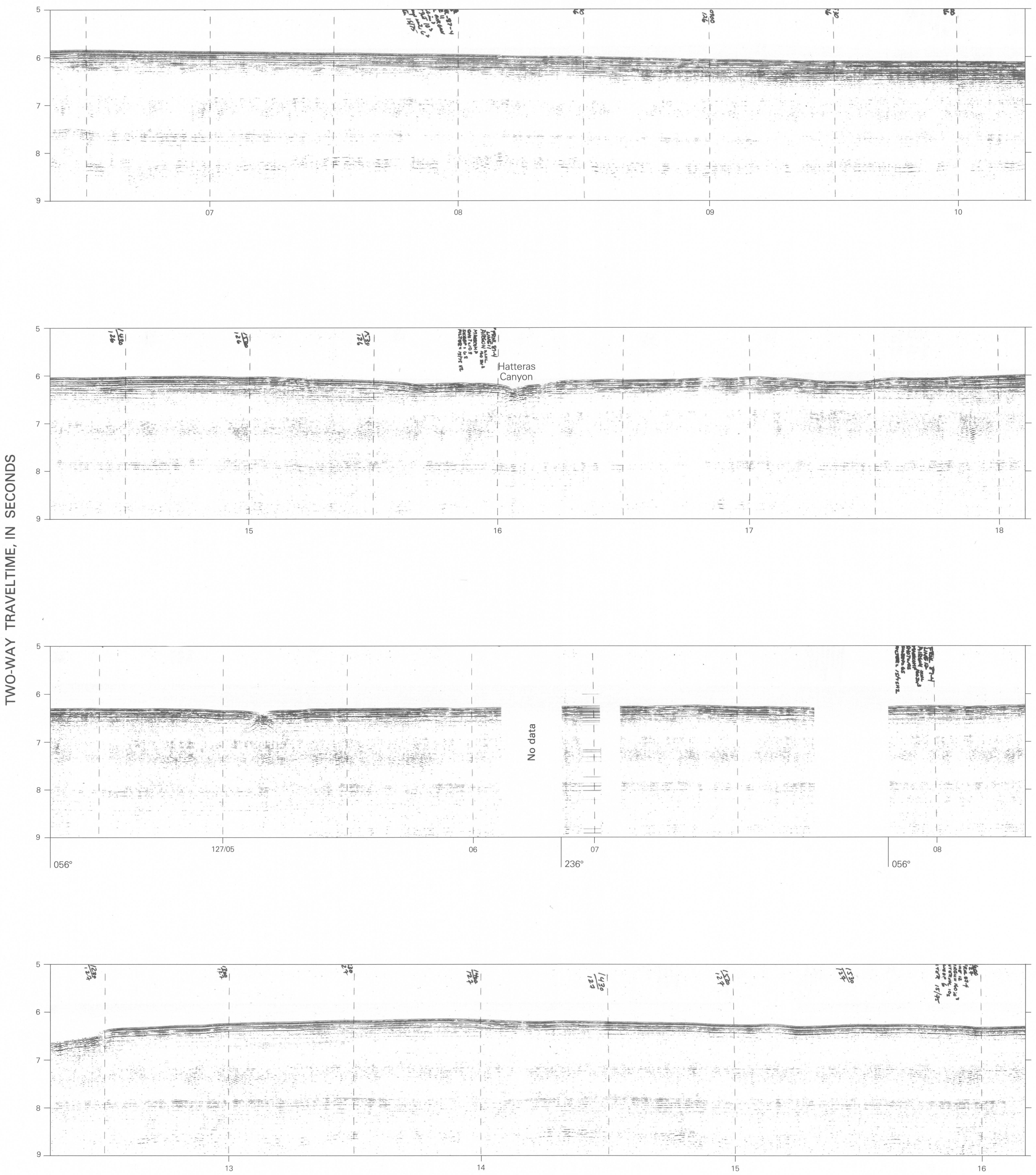

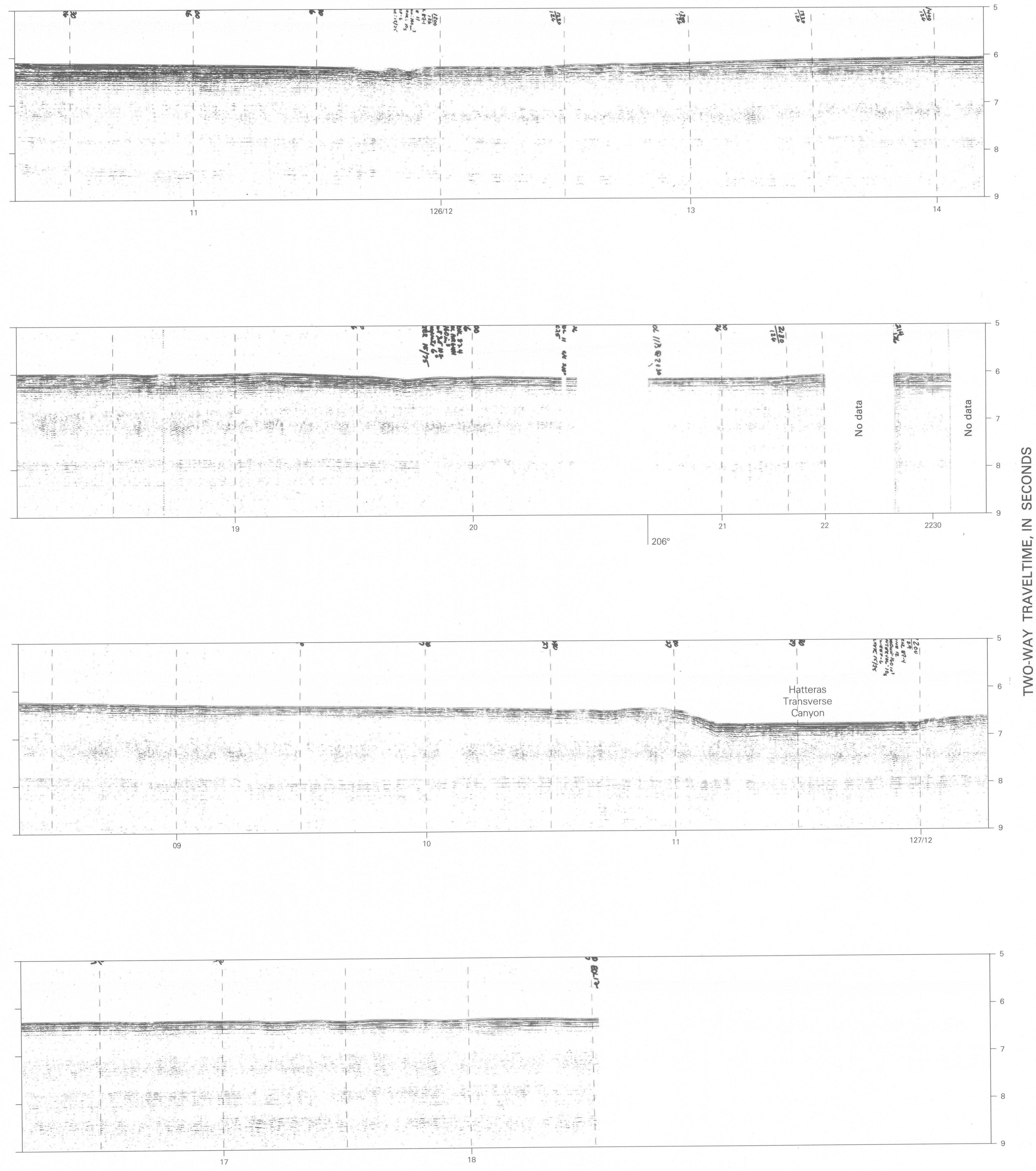

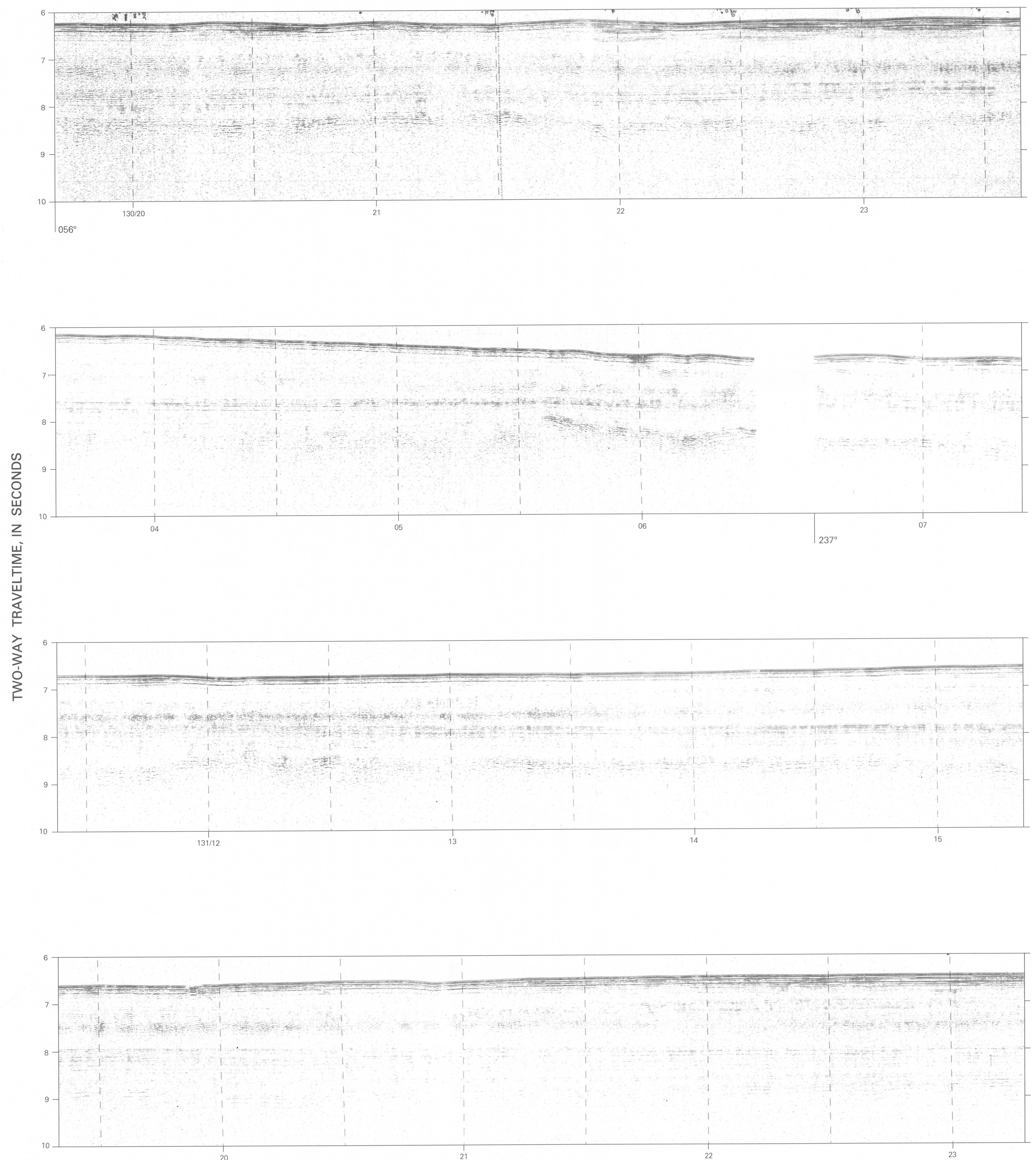

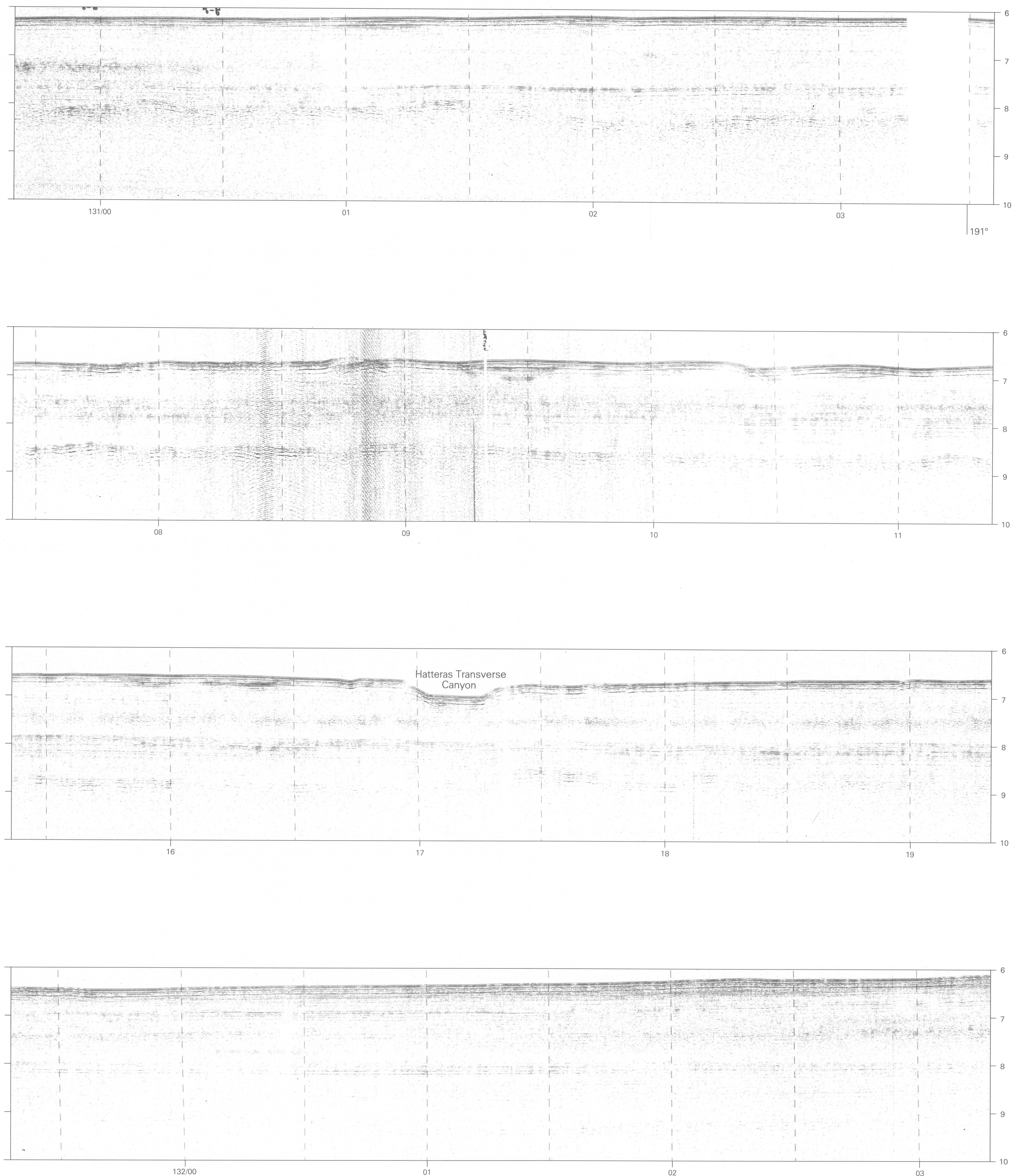

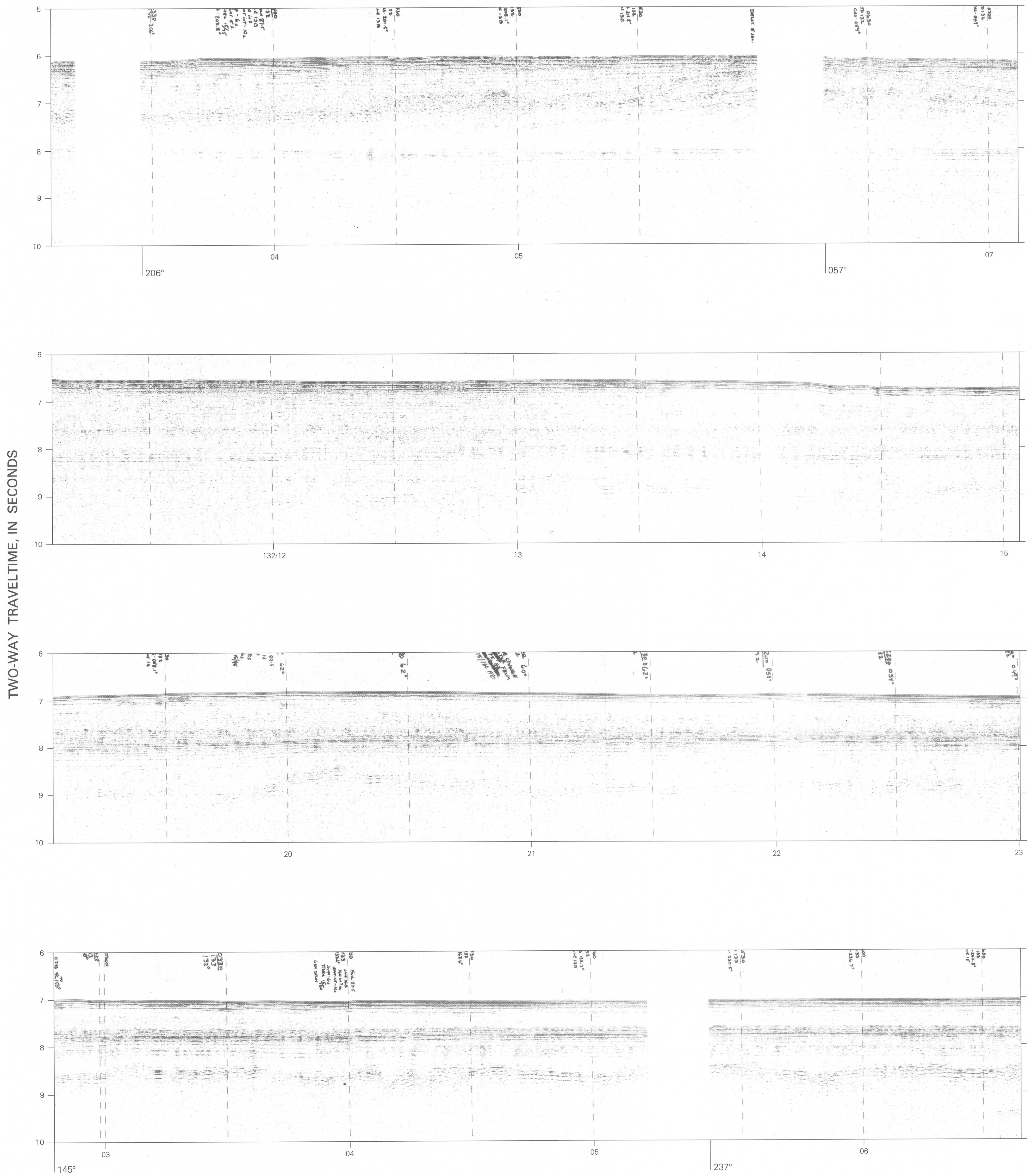

HOURS 

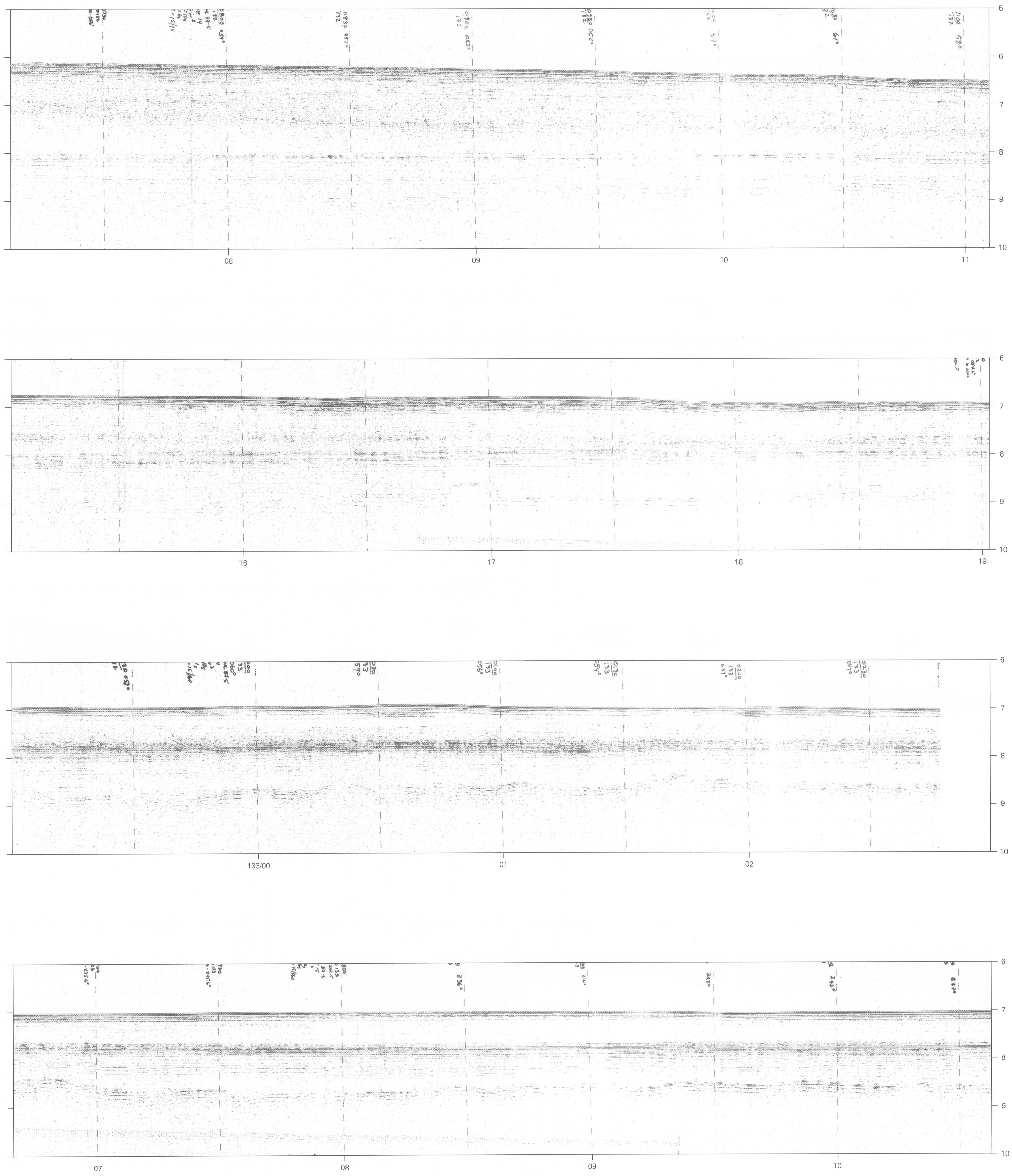

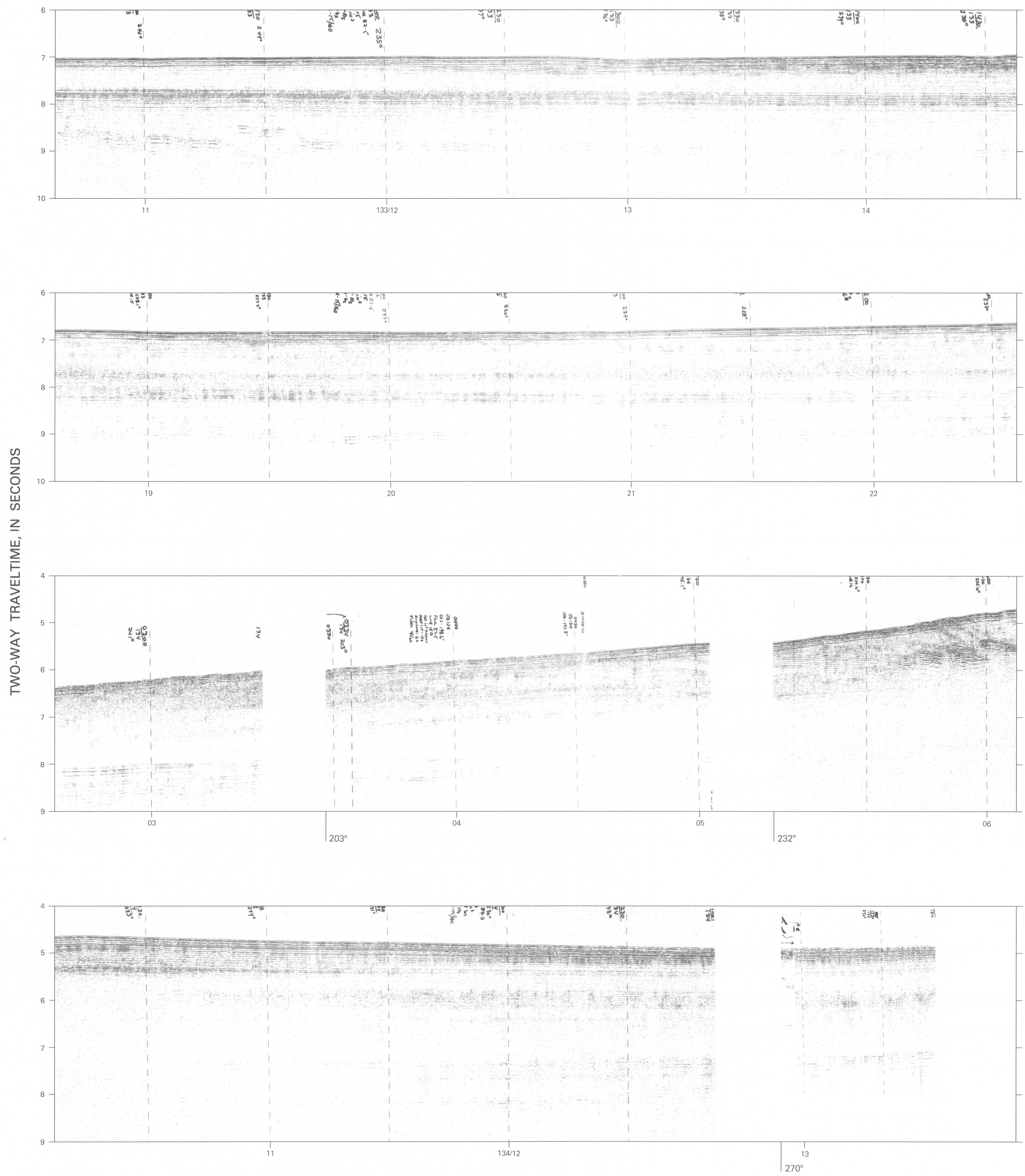

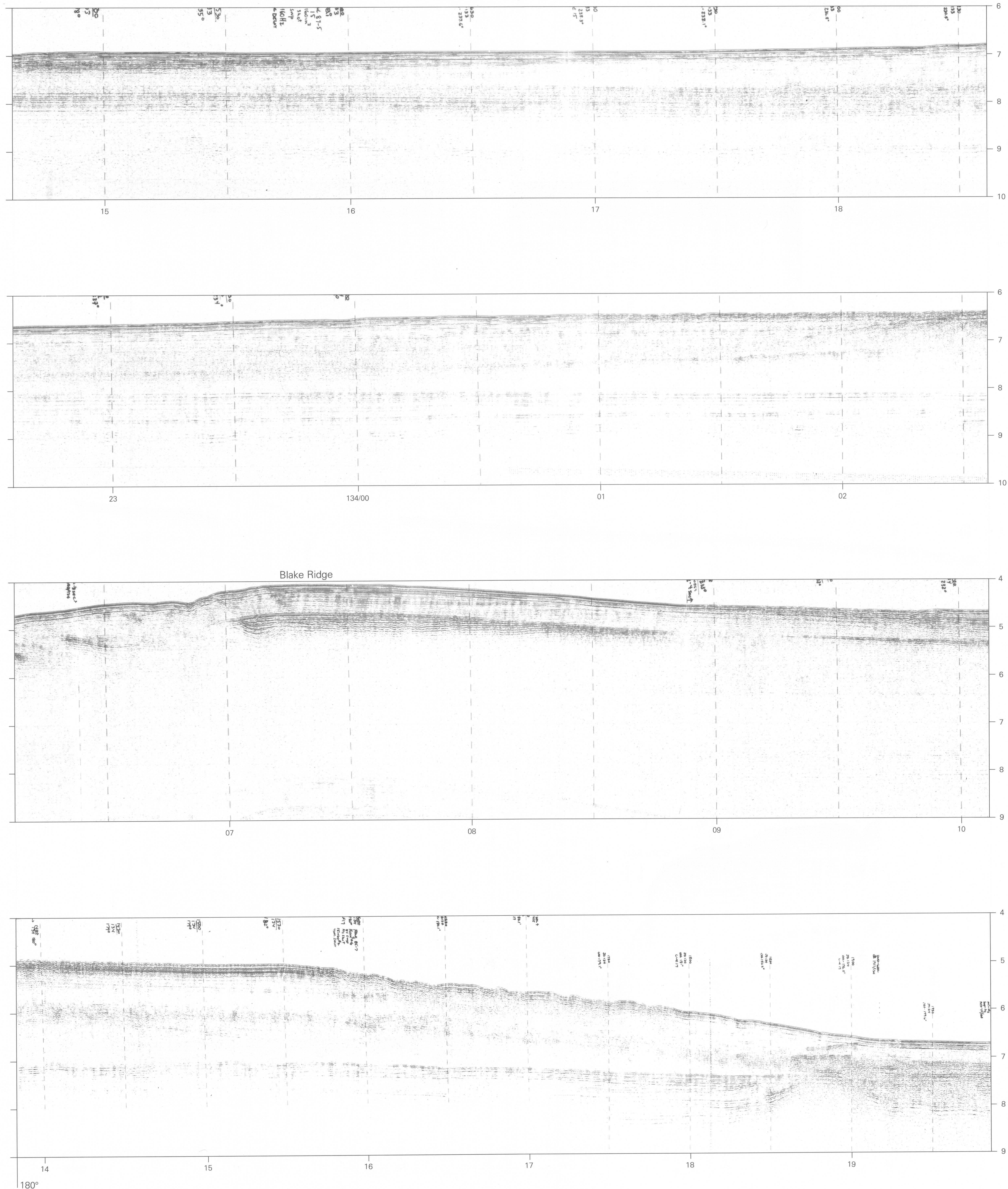

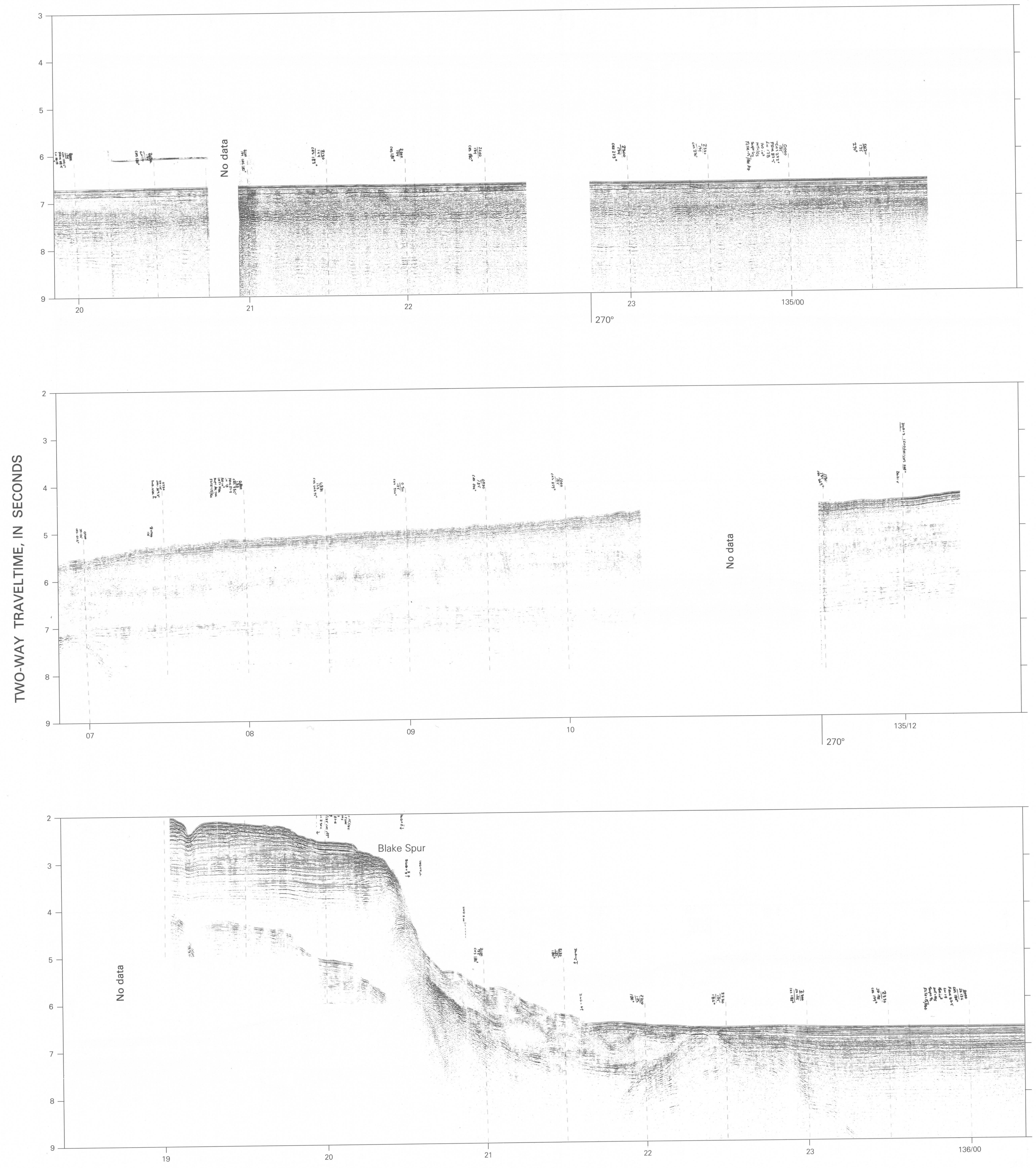

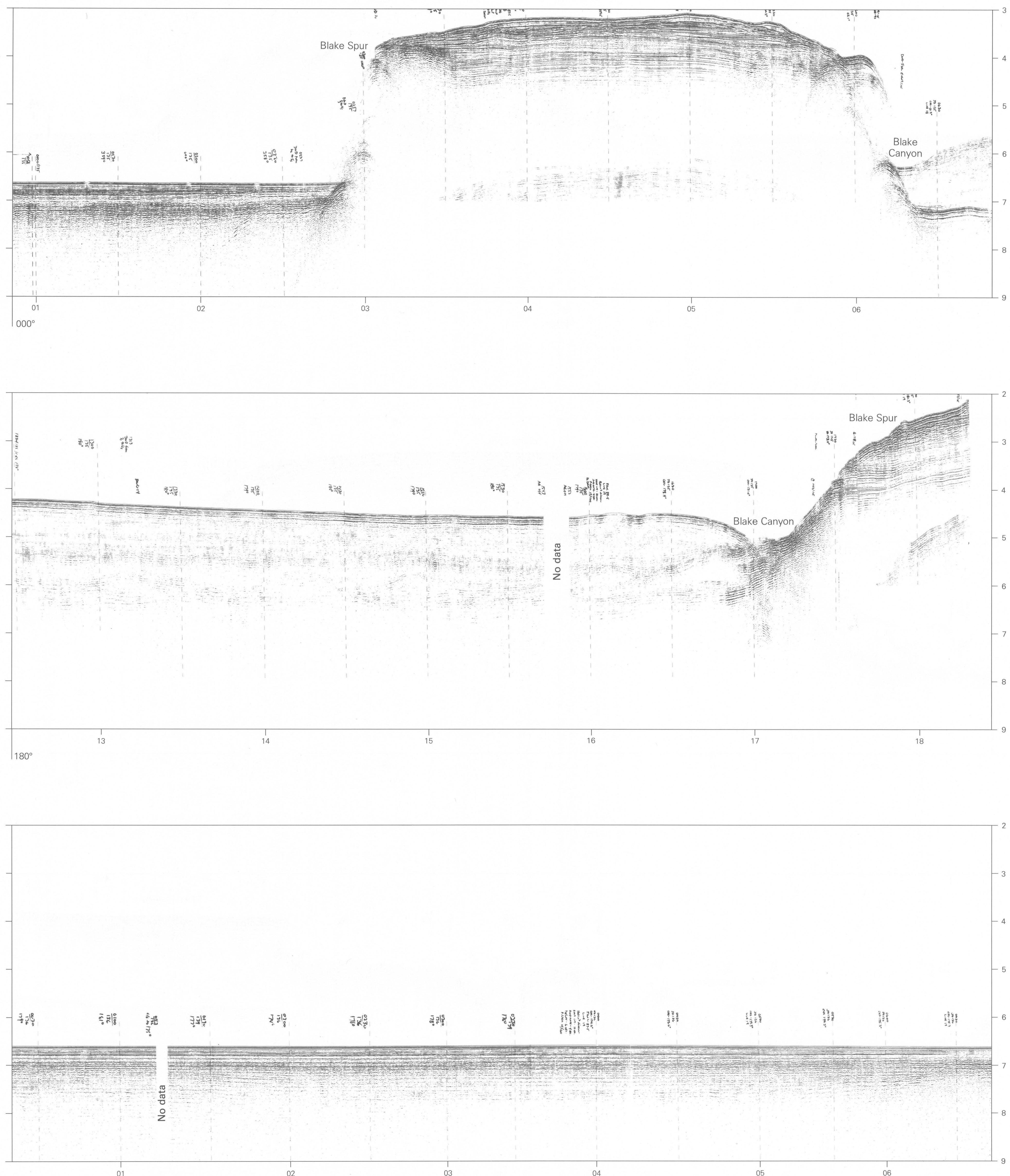

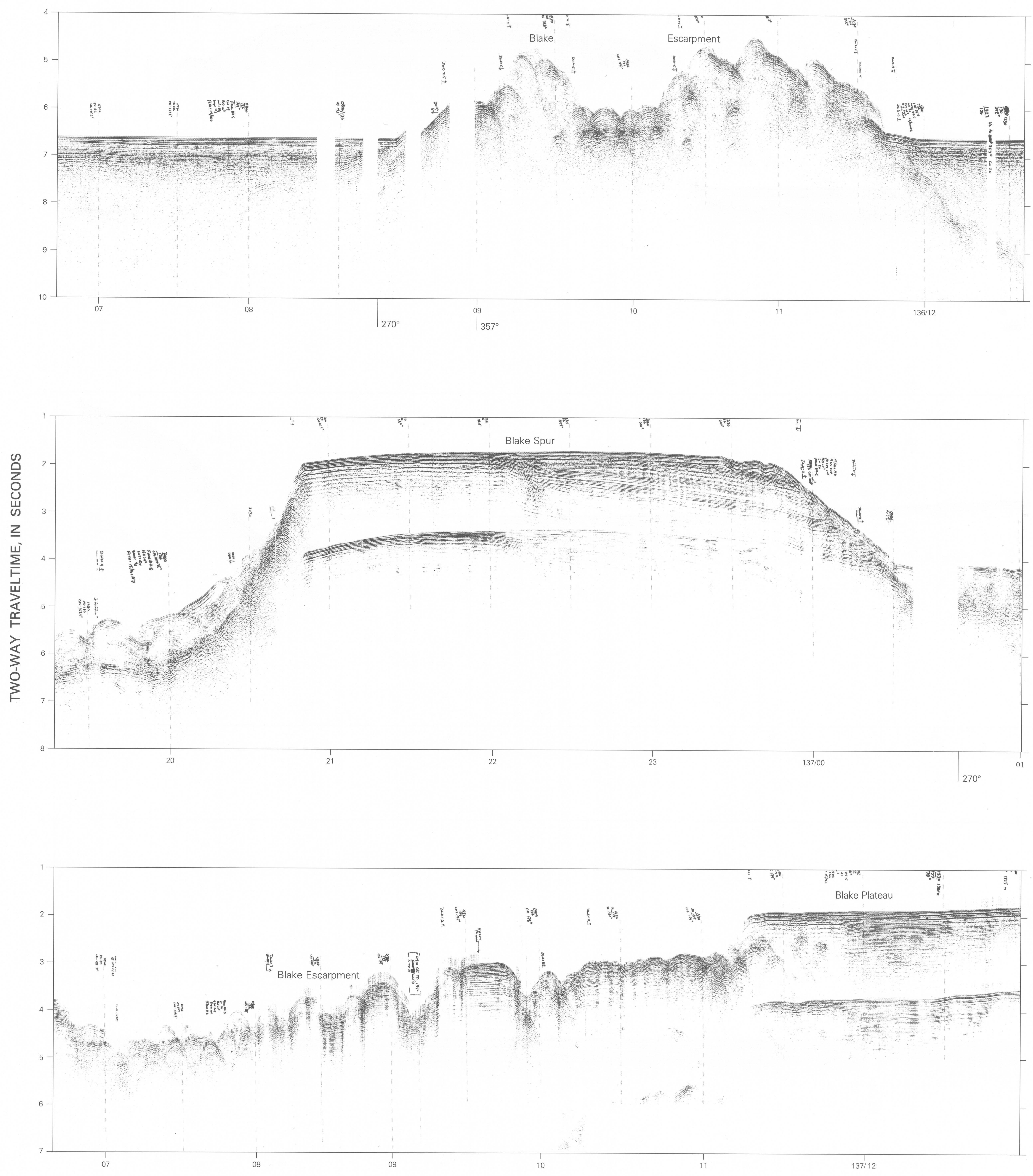

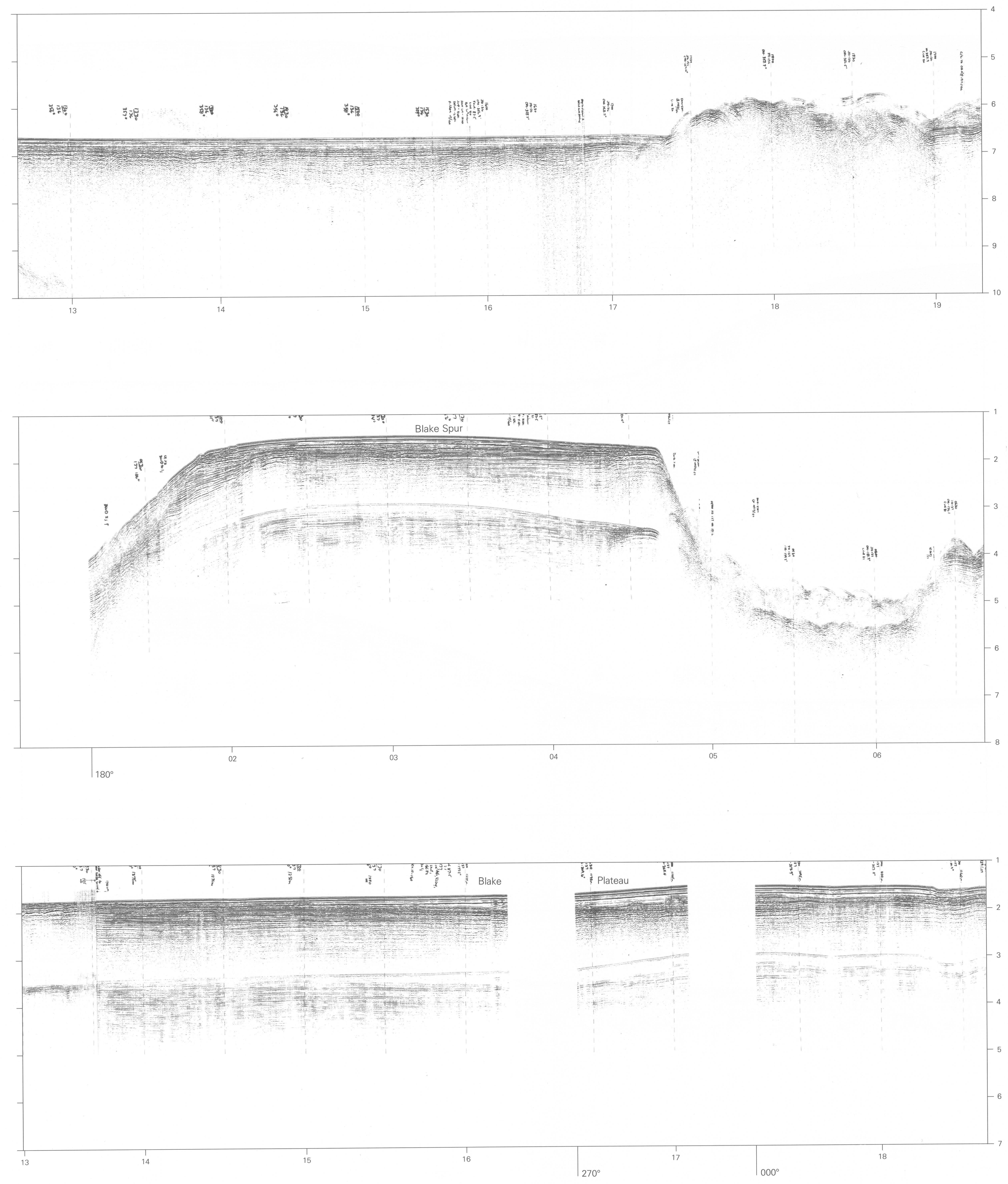

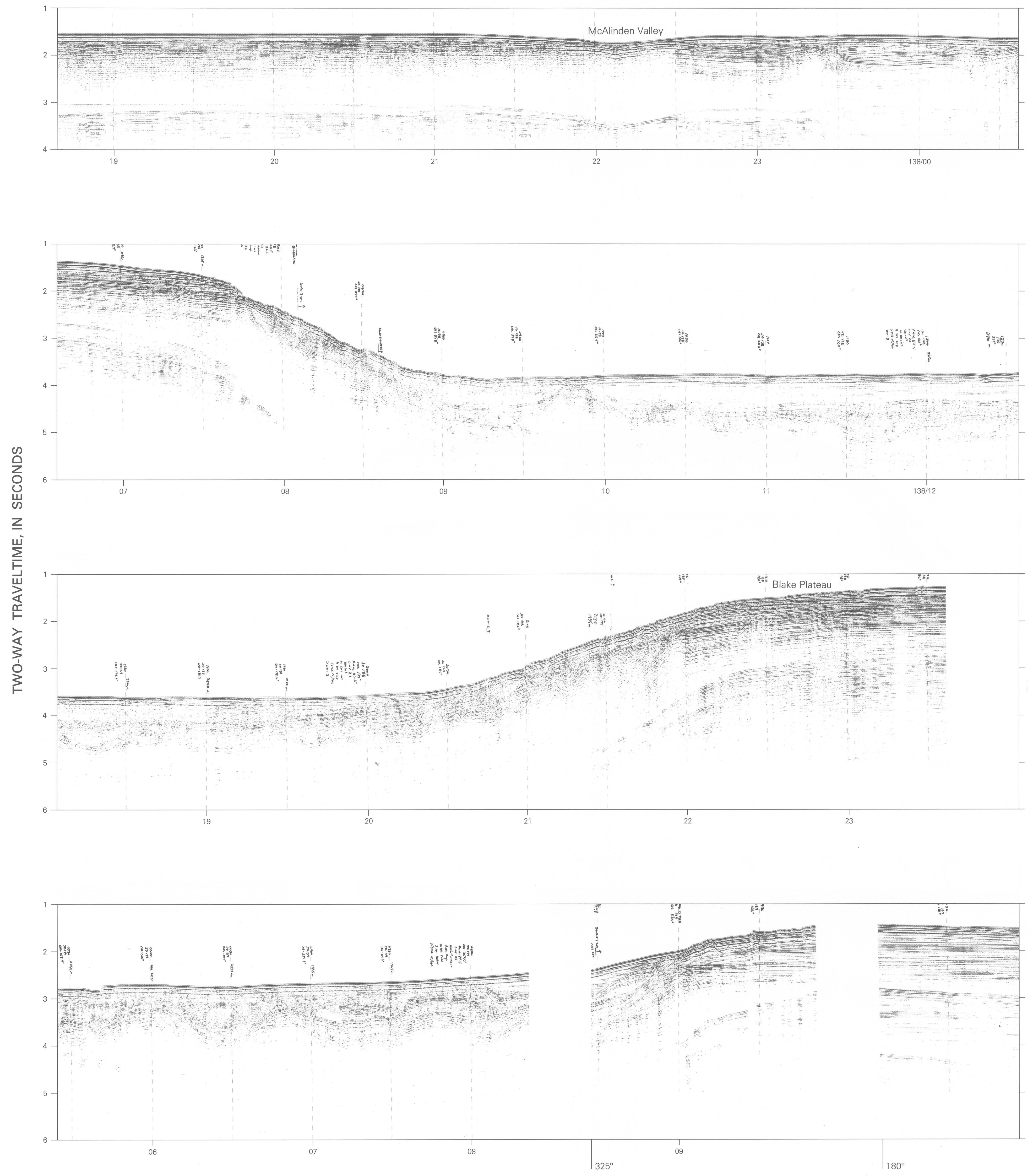

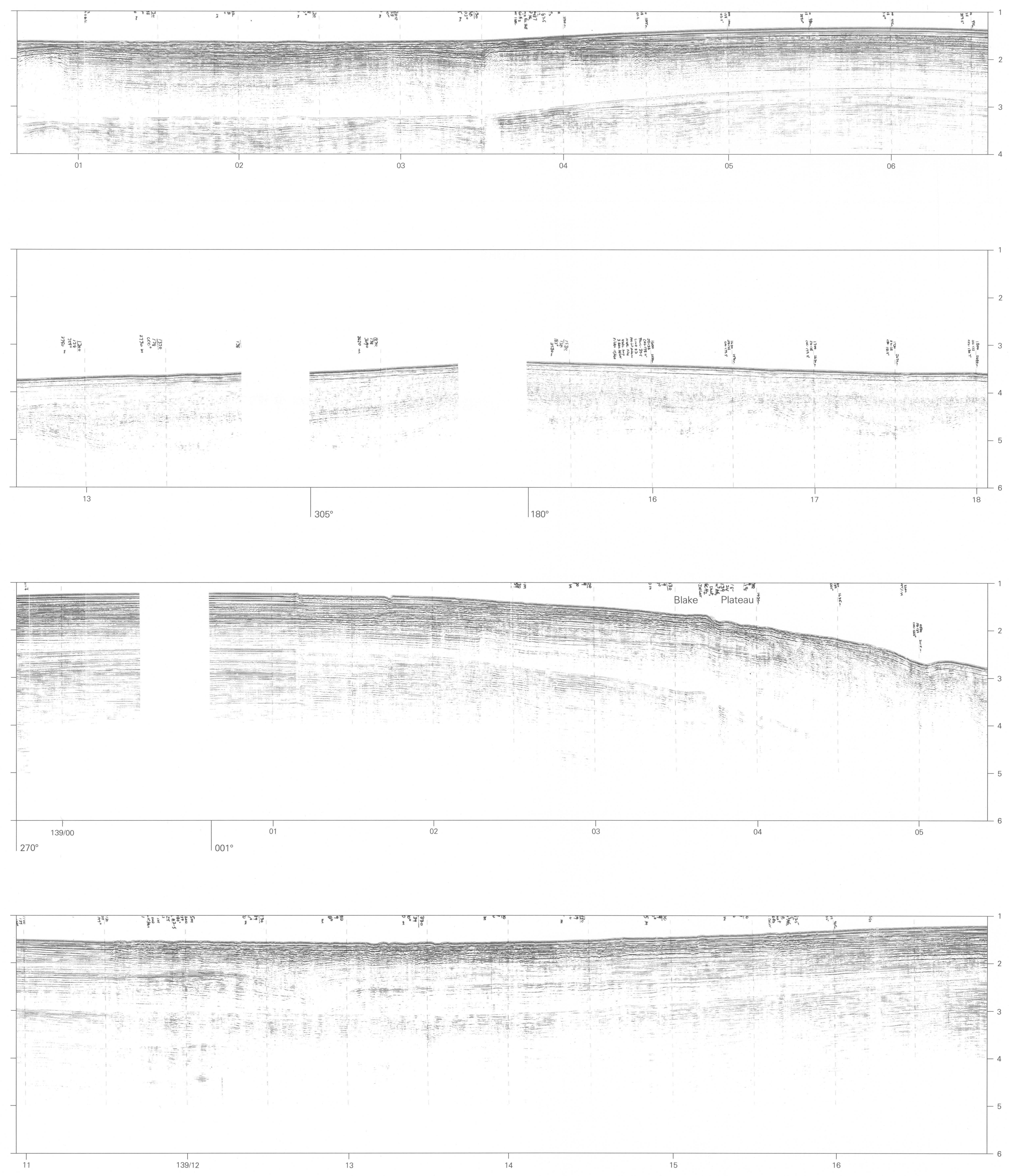
MAGNETIC-ANOMALY

AND BATHYMETRY PROFILES 

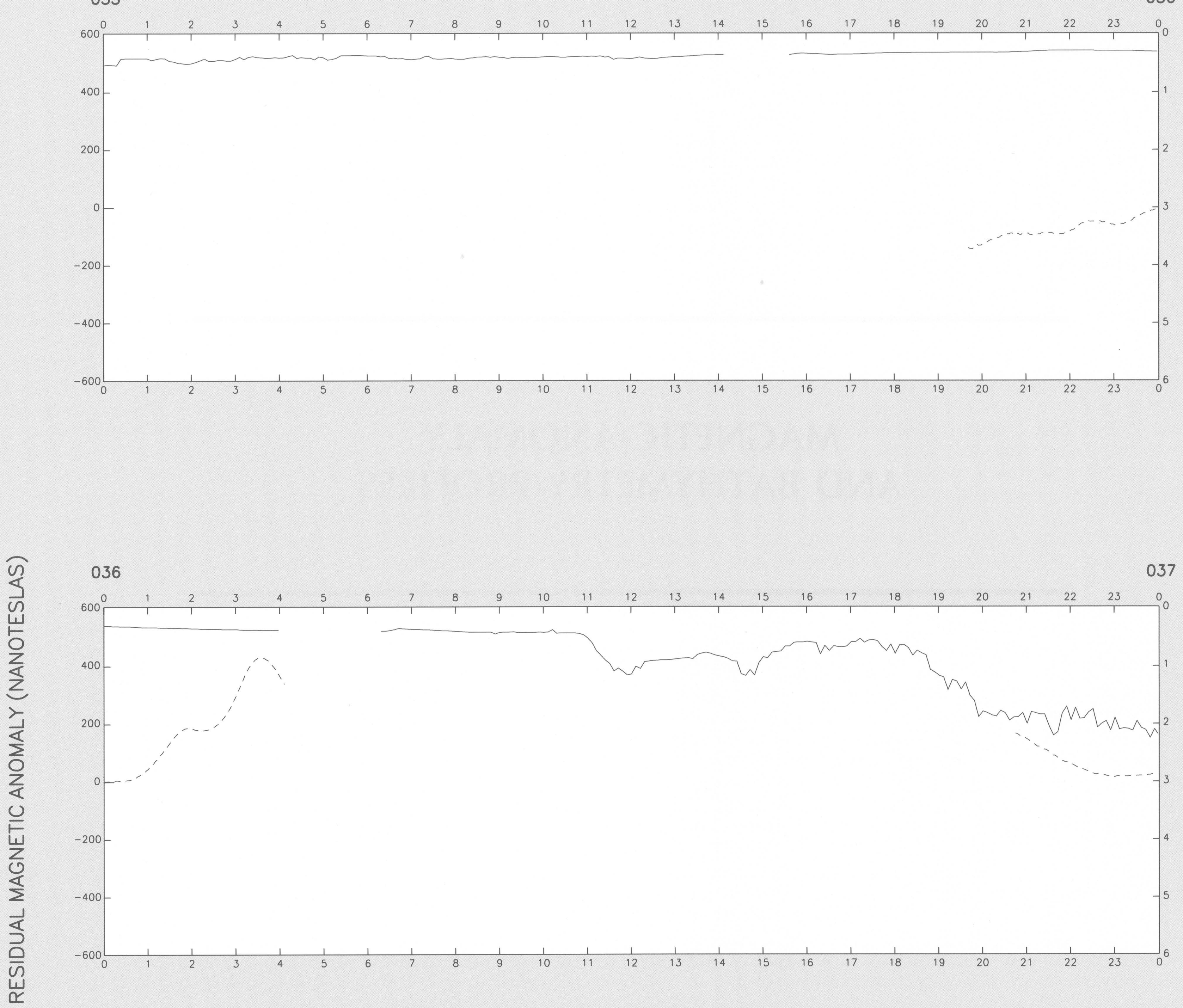

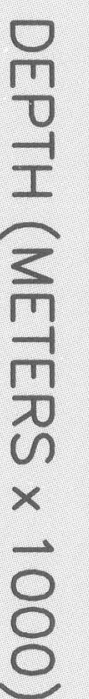

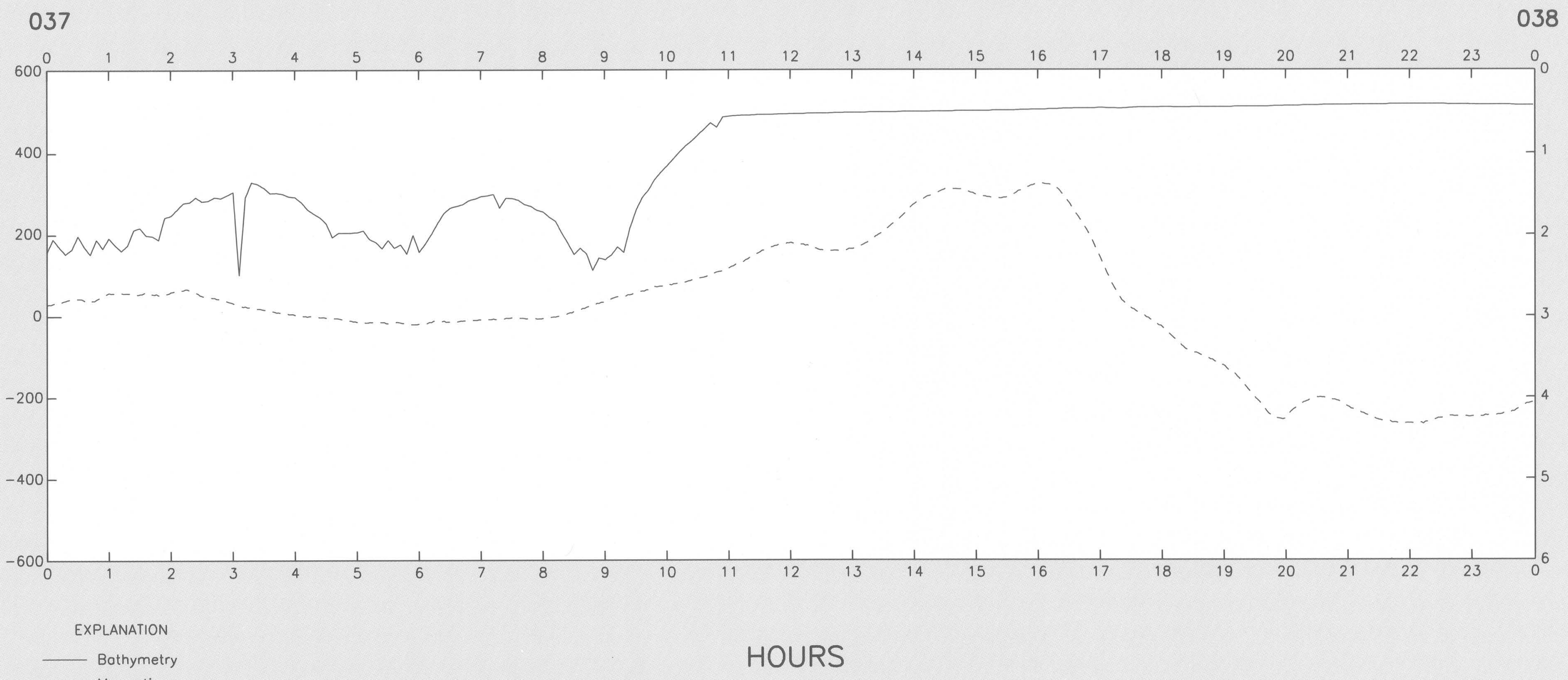


DAY 038-041

038

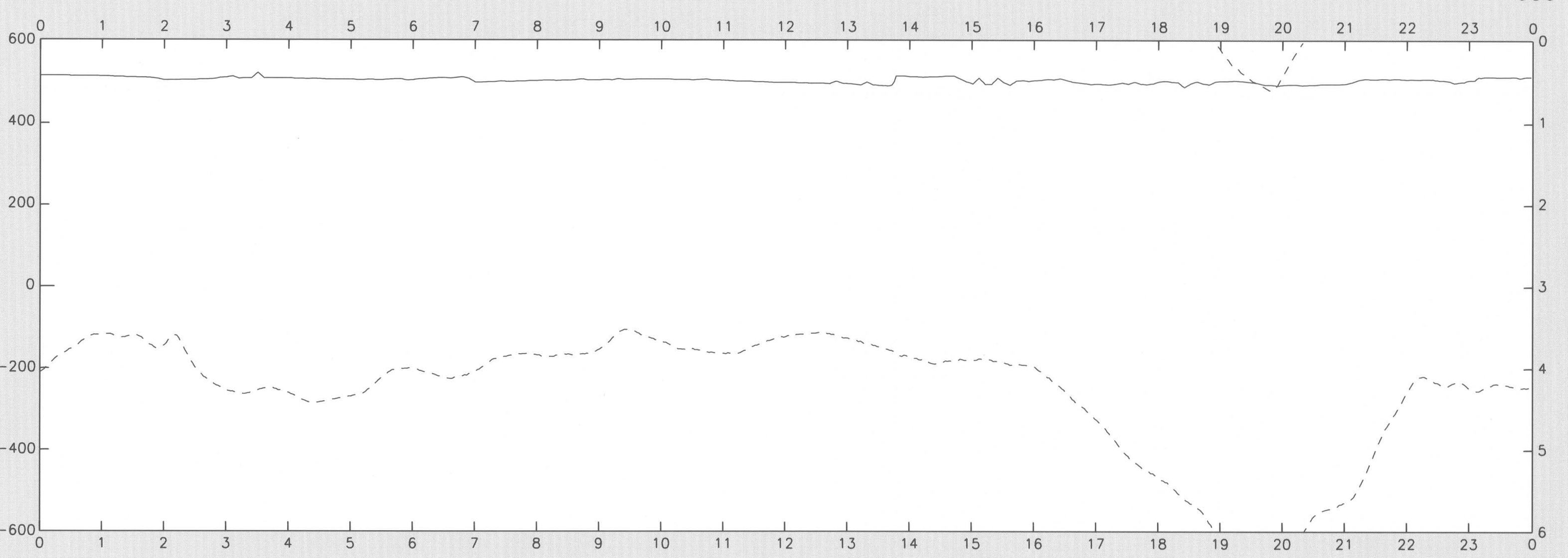

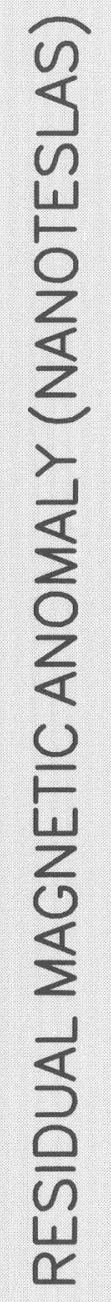
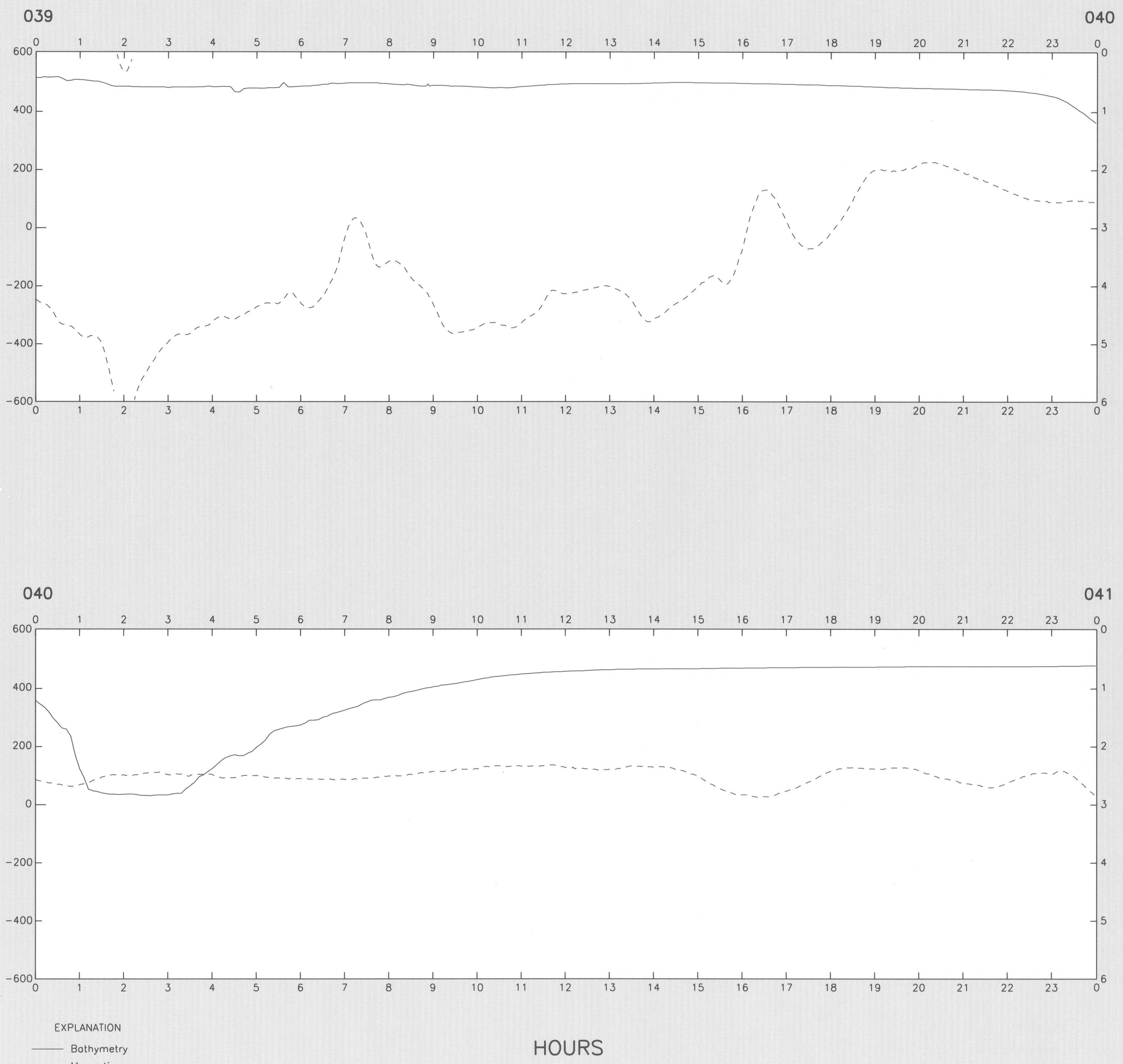
DAY 041-044
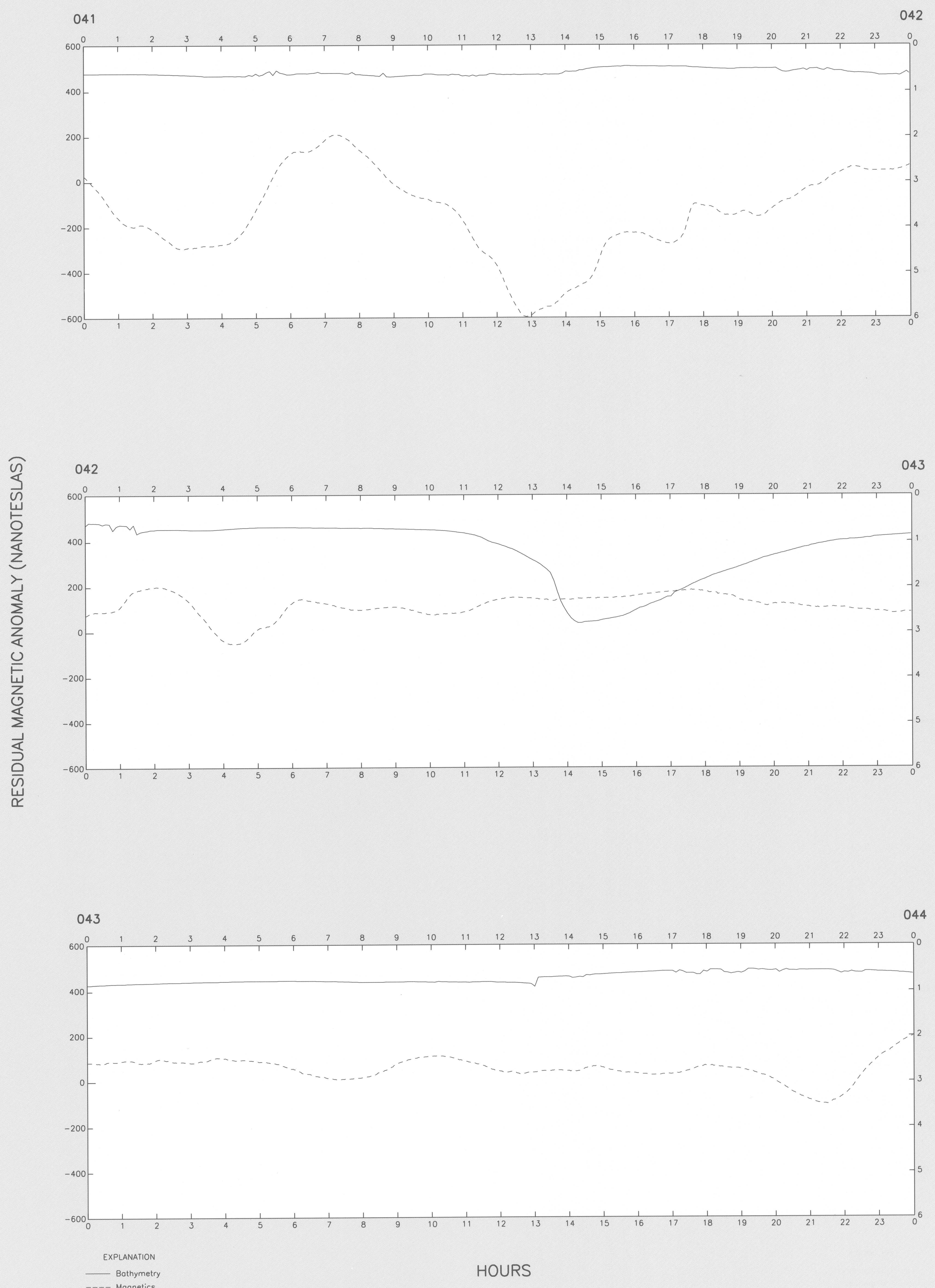
DAY 044-047

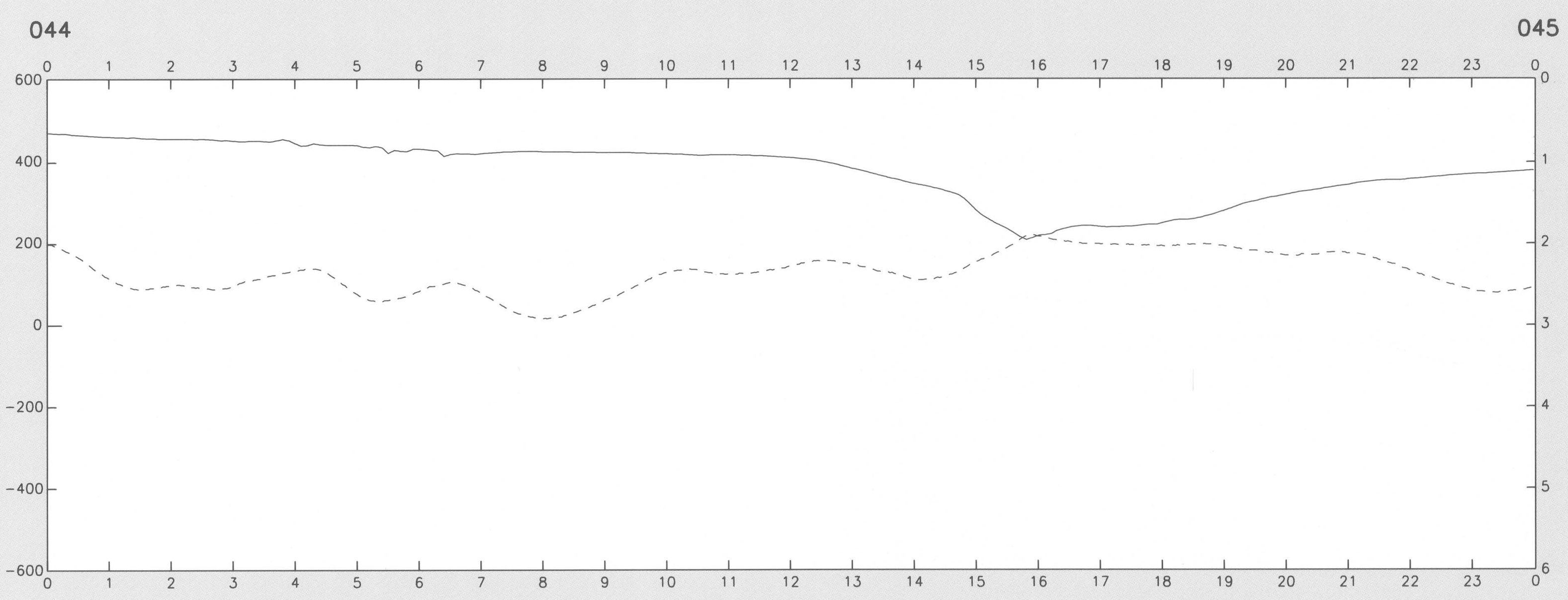

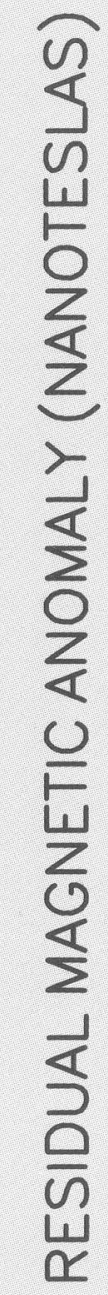

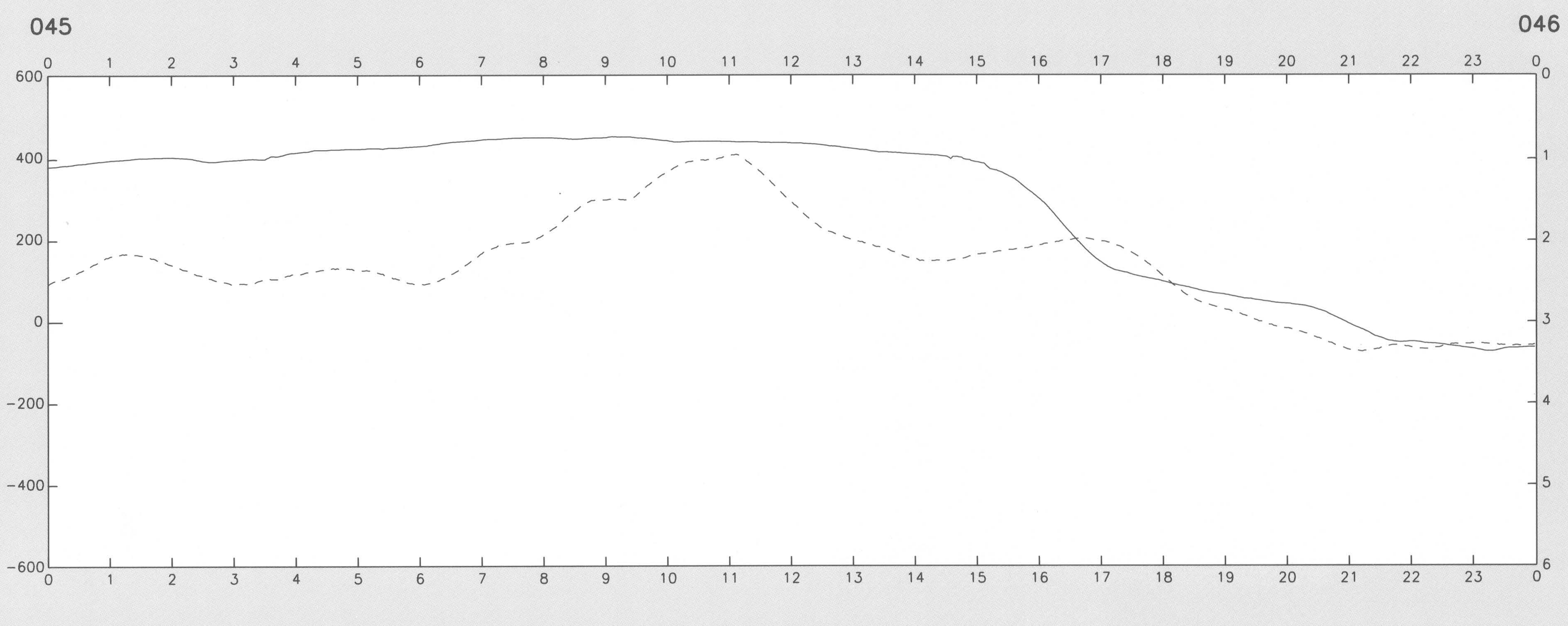

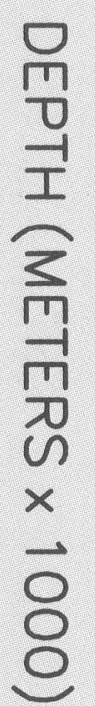

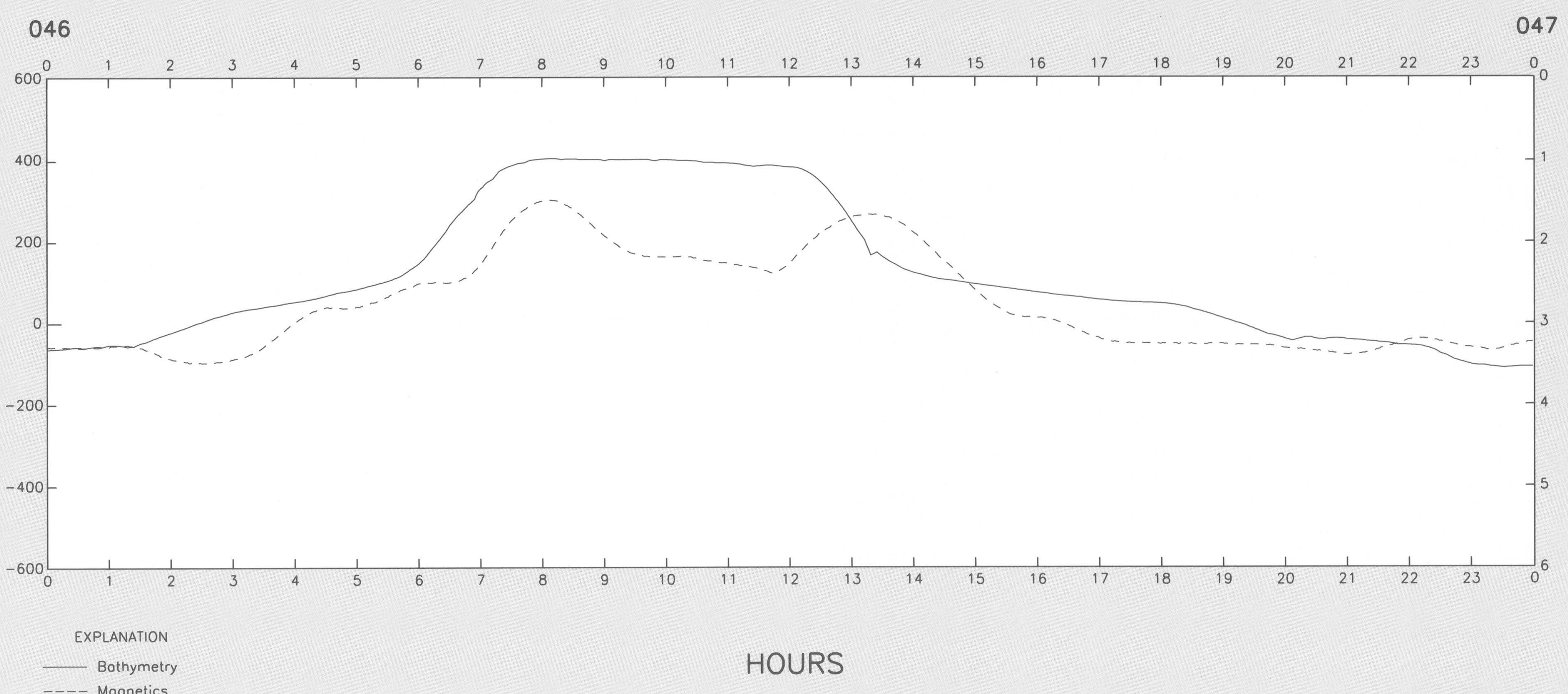



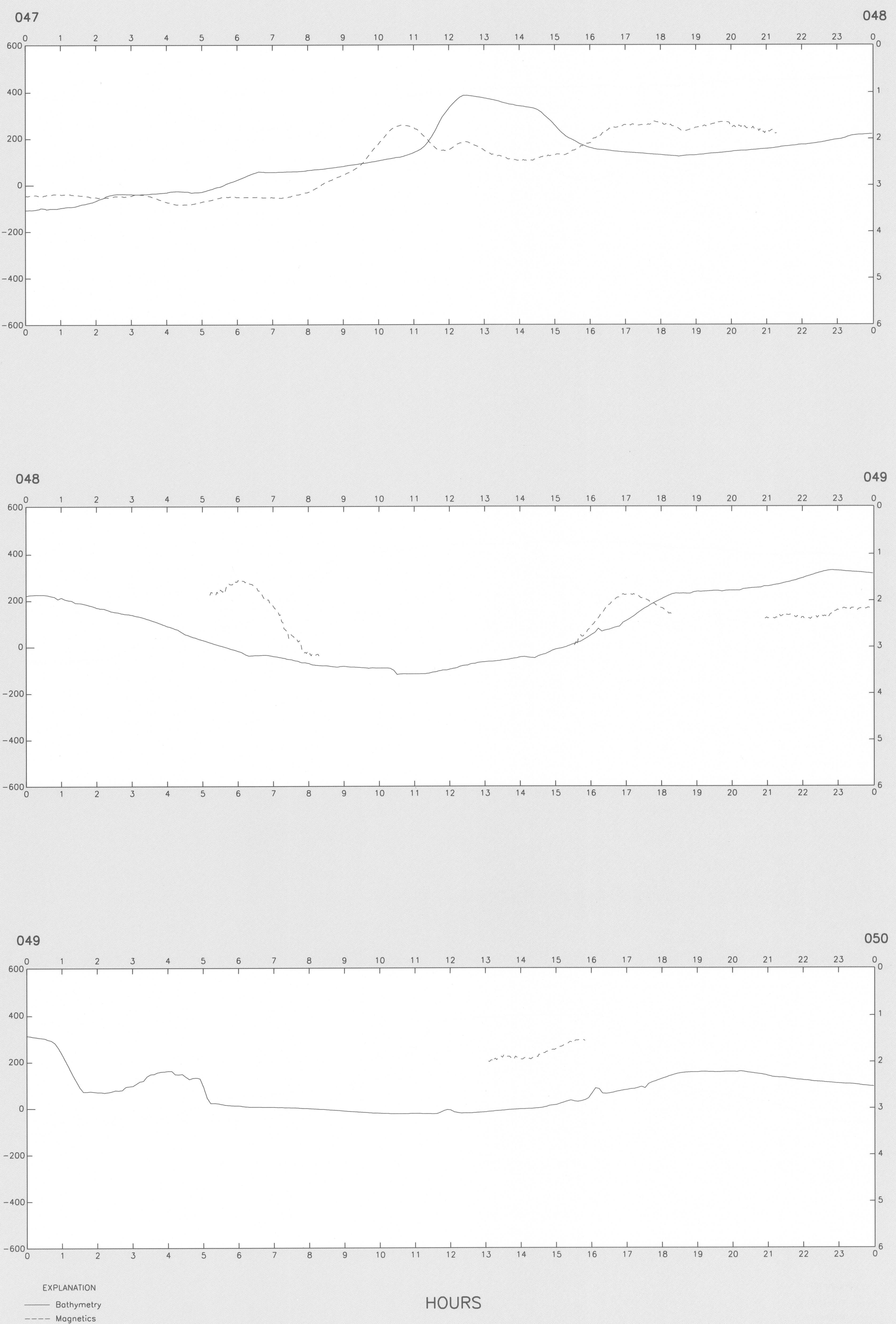


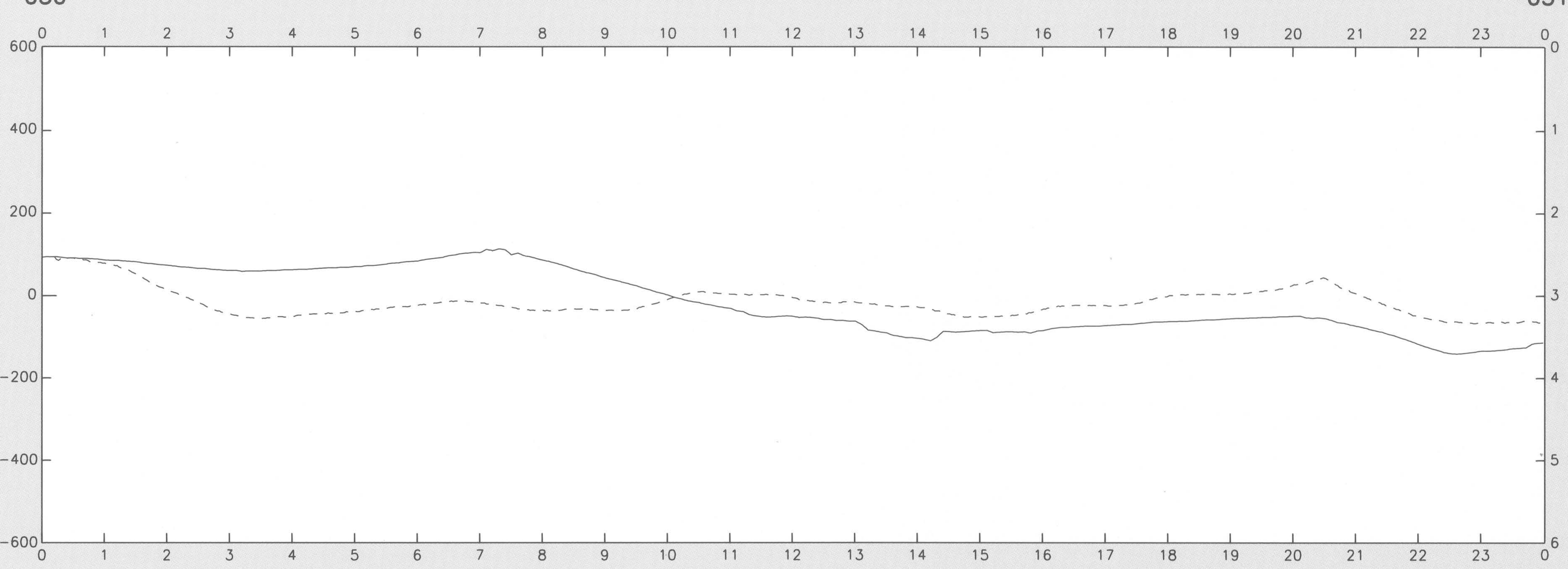

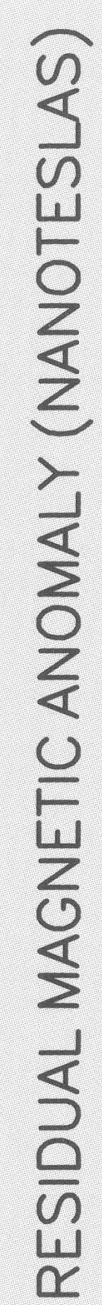
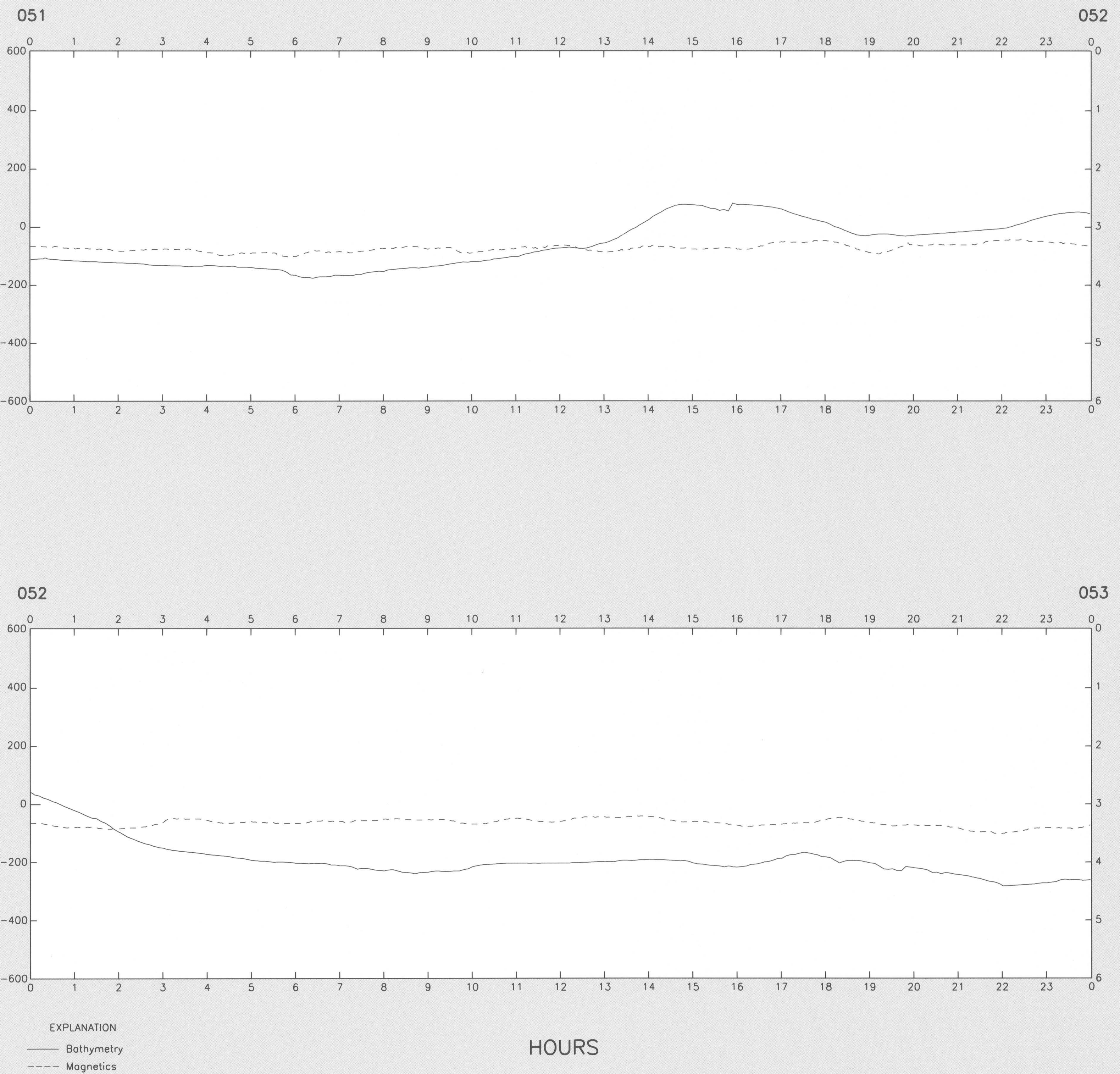
DAY 053-055, 056-057
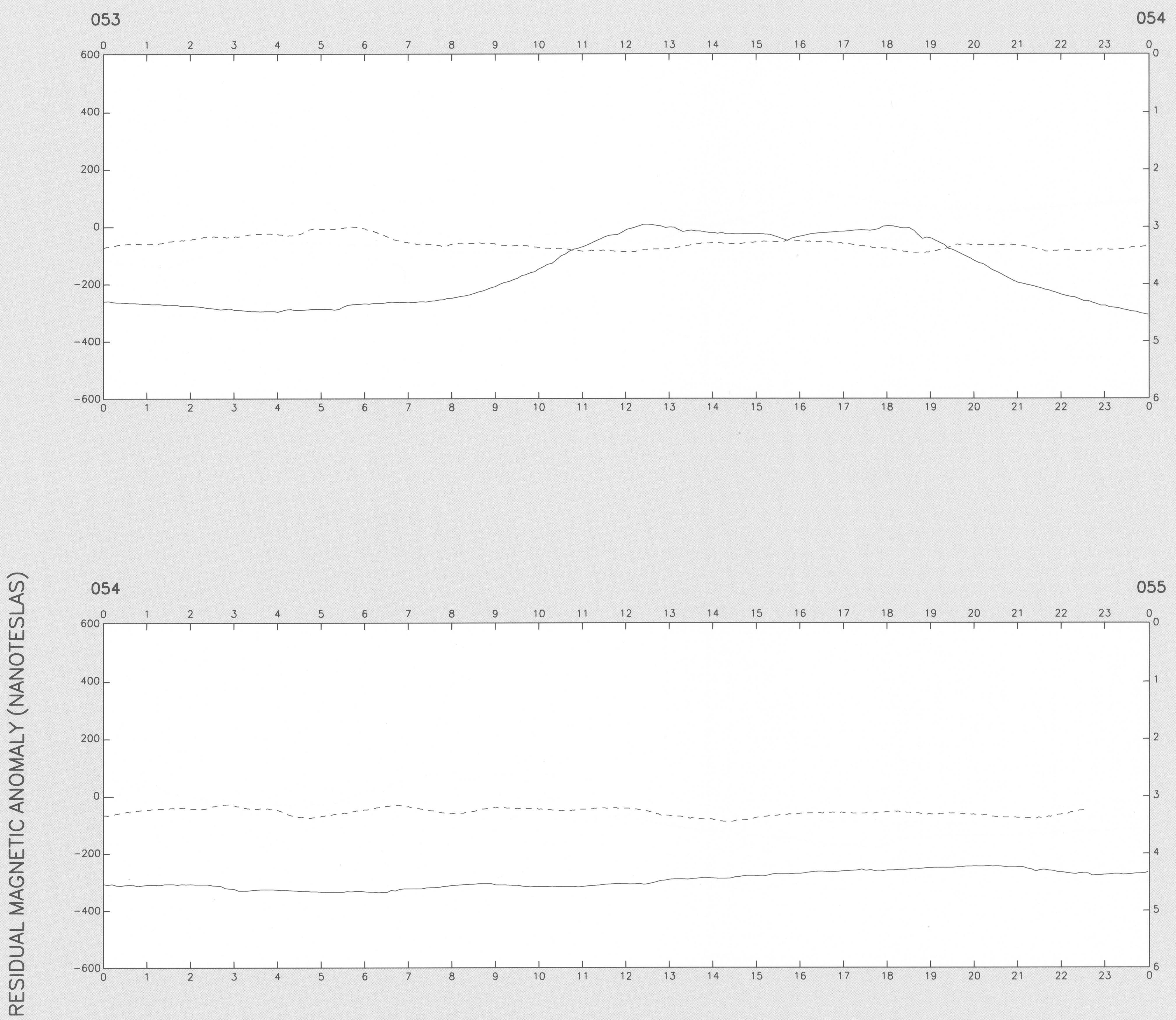

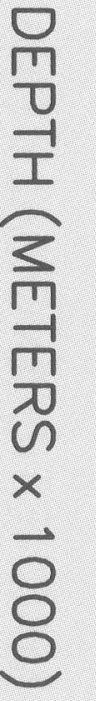

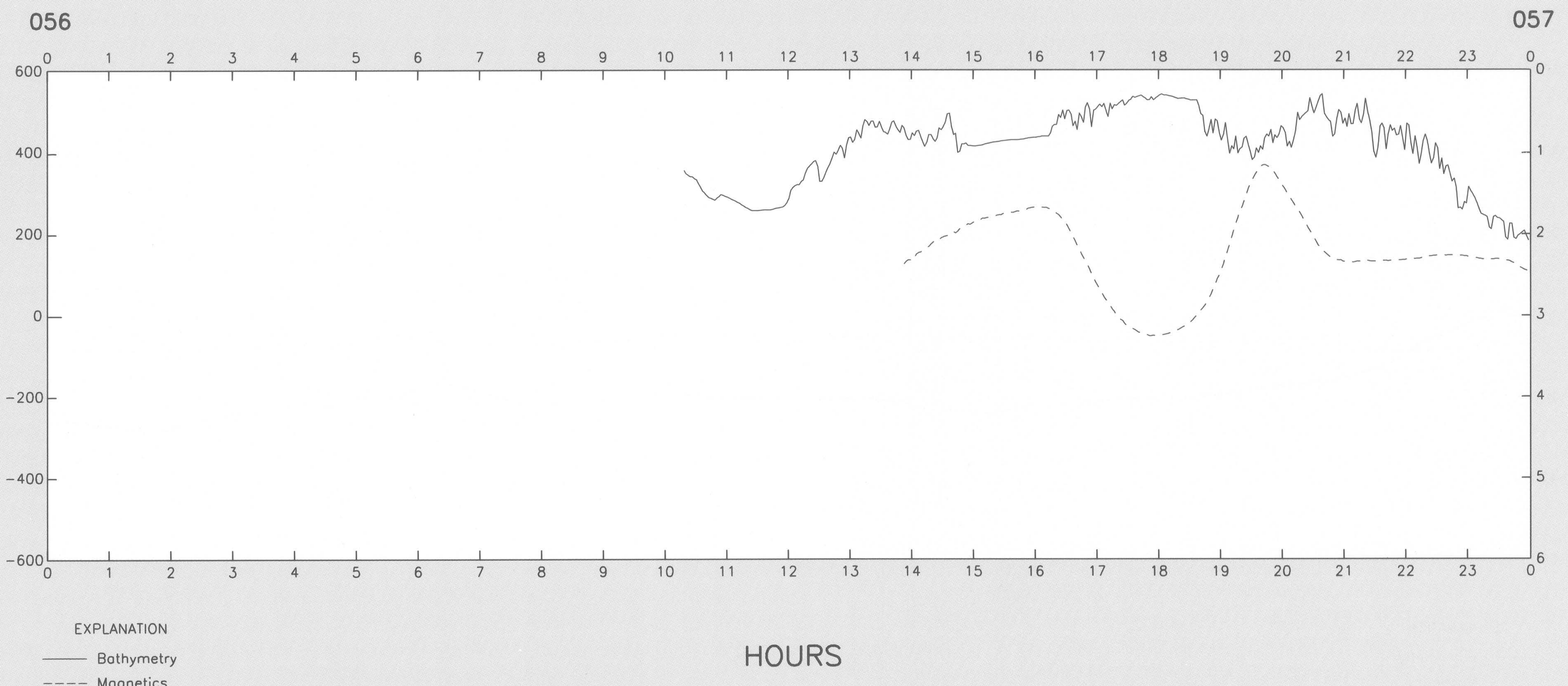




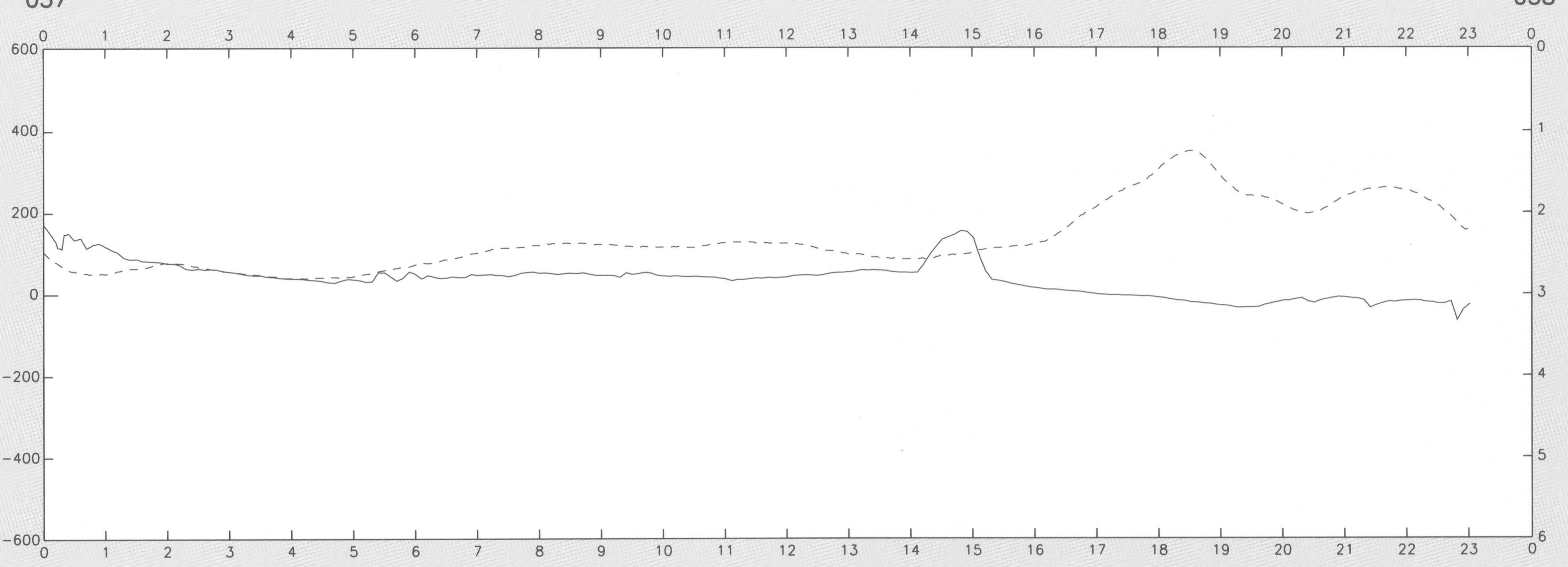

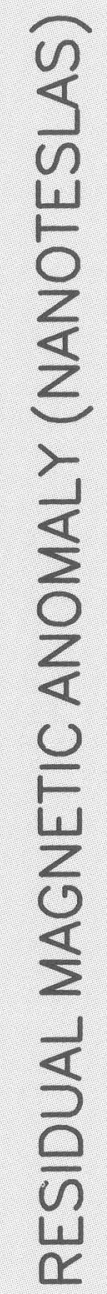

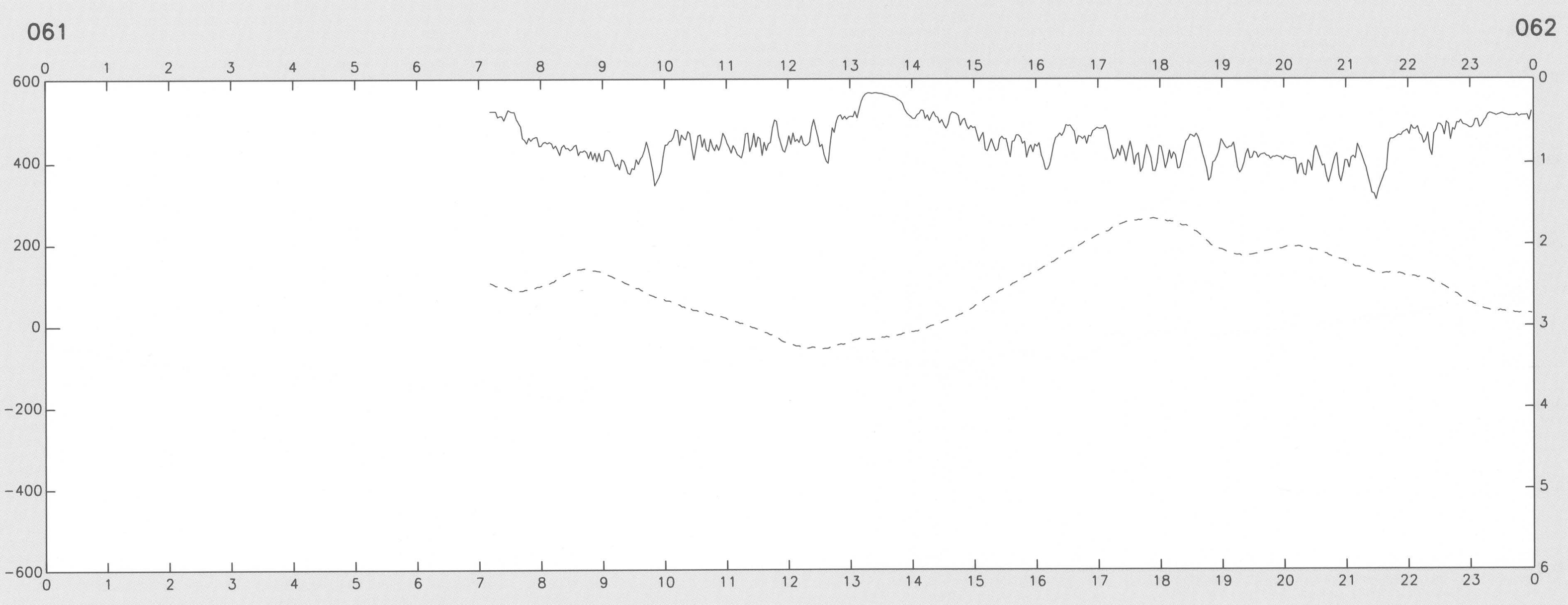

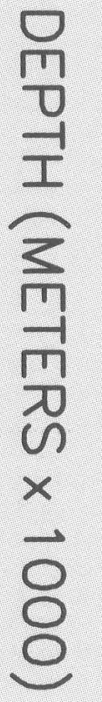

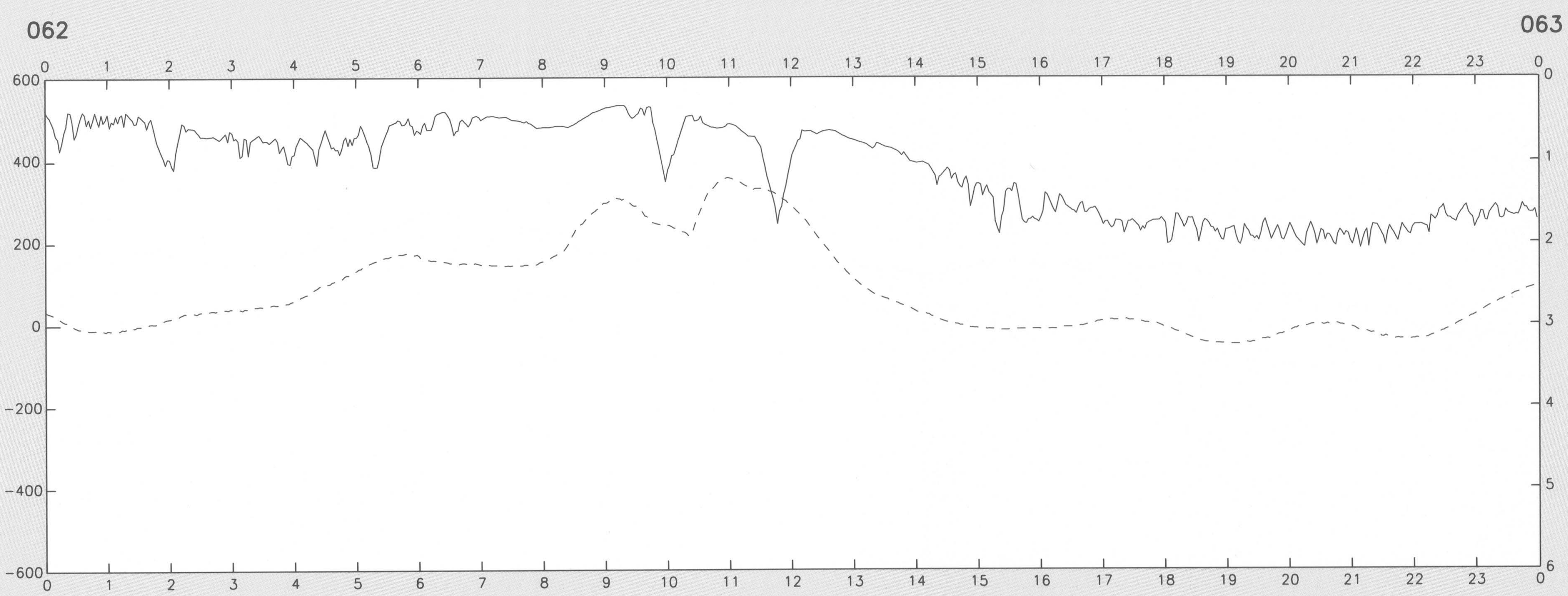

EXPLANATION
Bathymetry

HOURS 
DAY 063-066

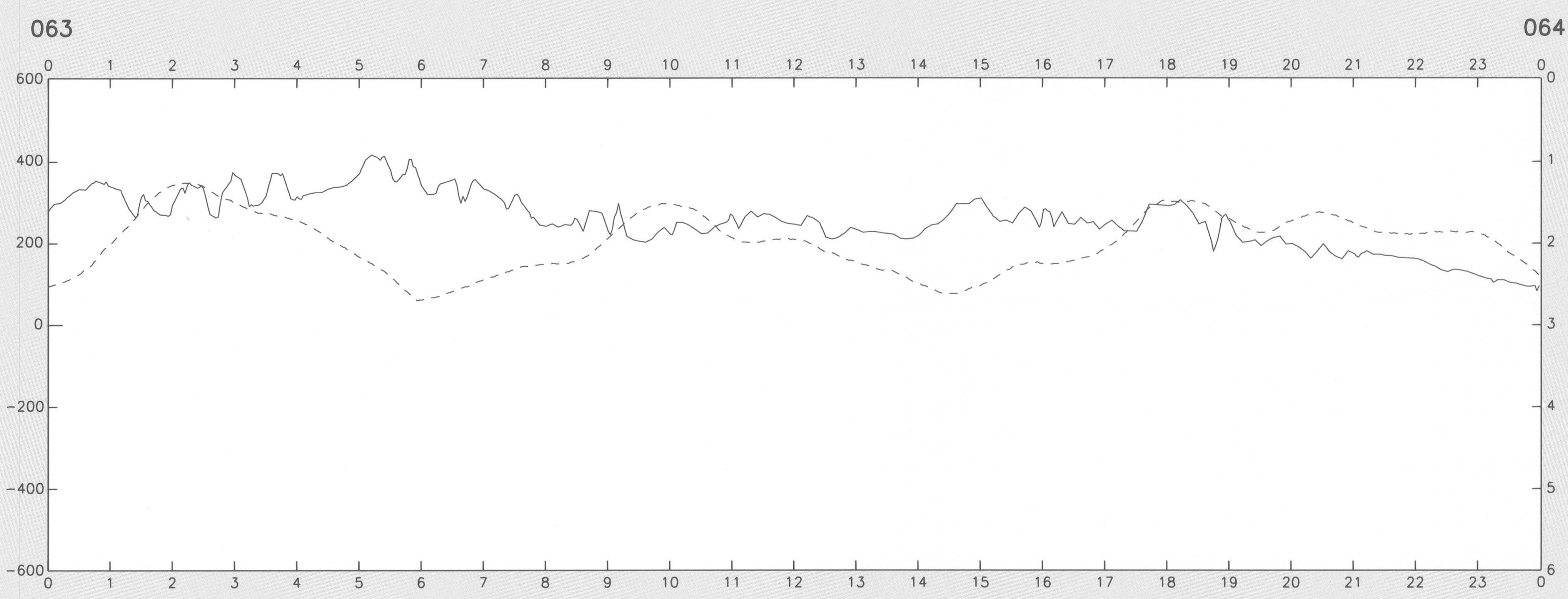

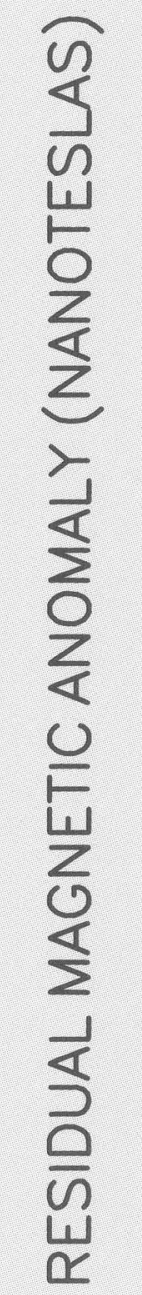

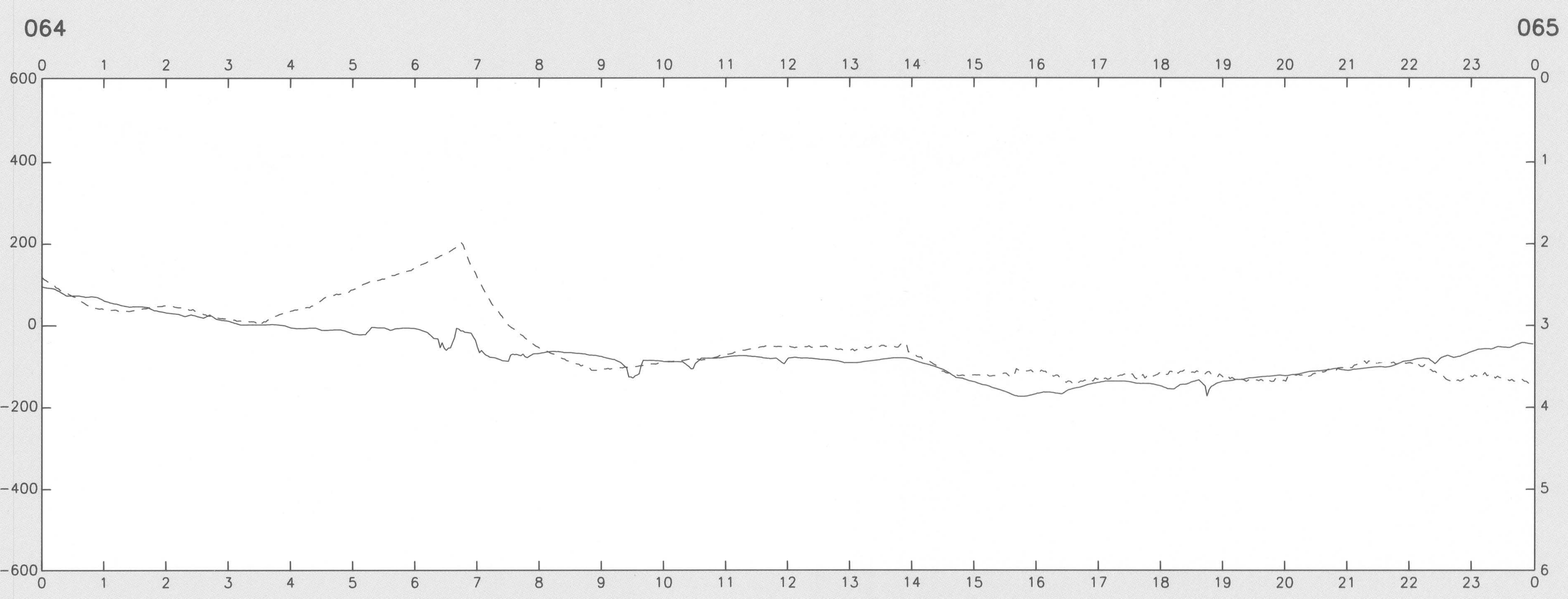

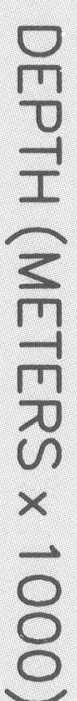

065

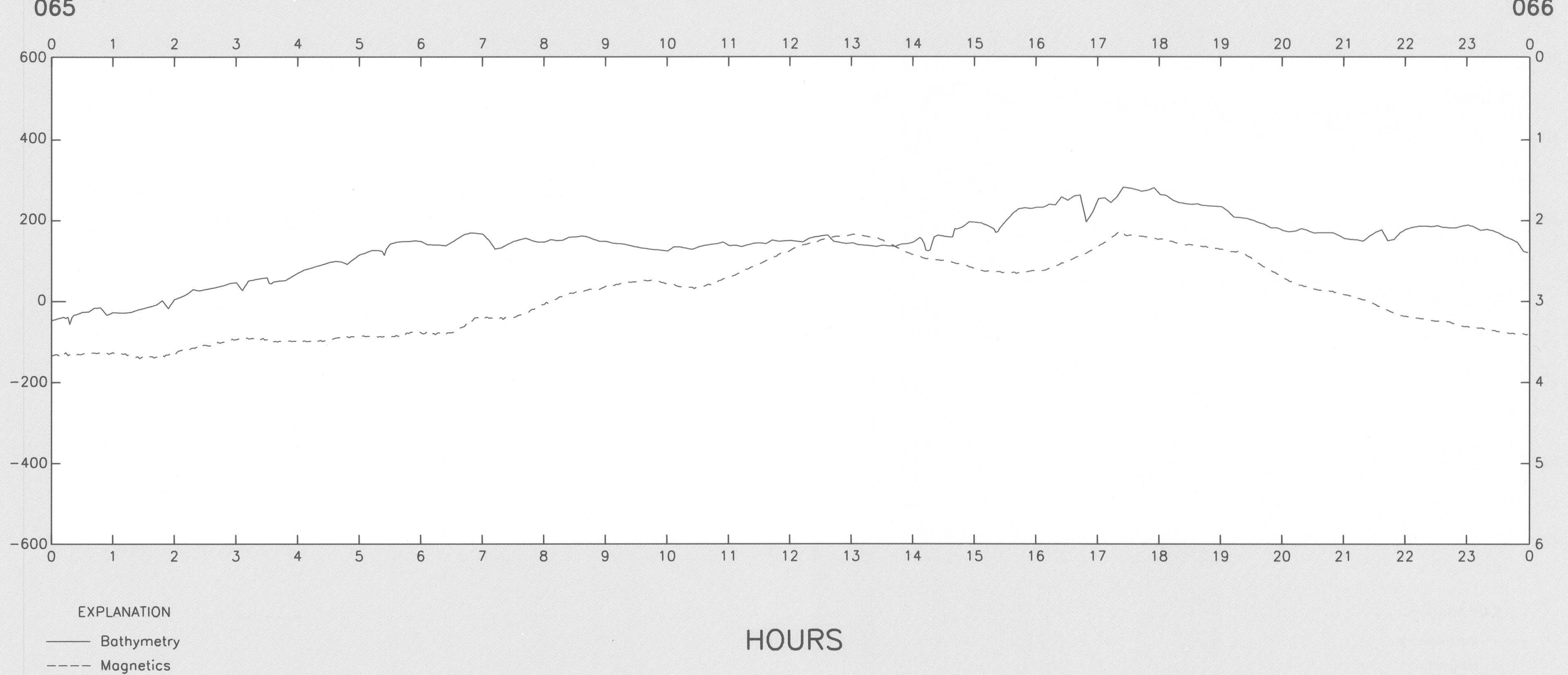



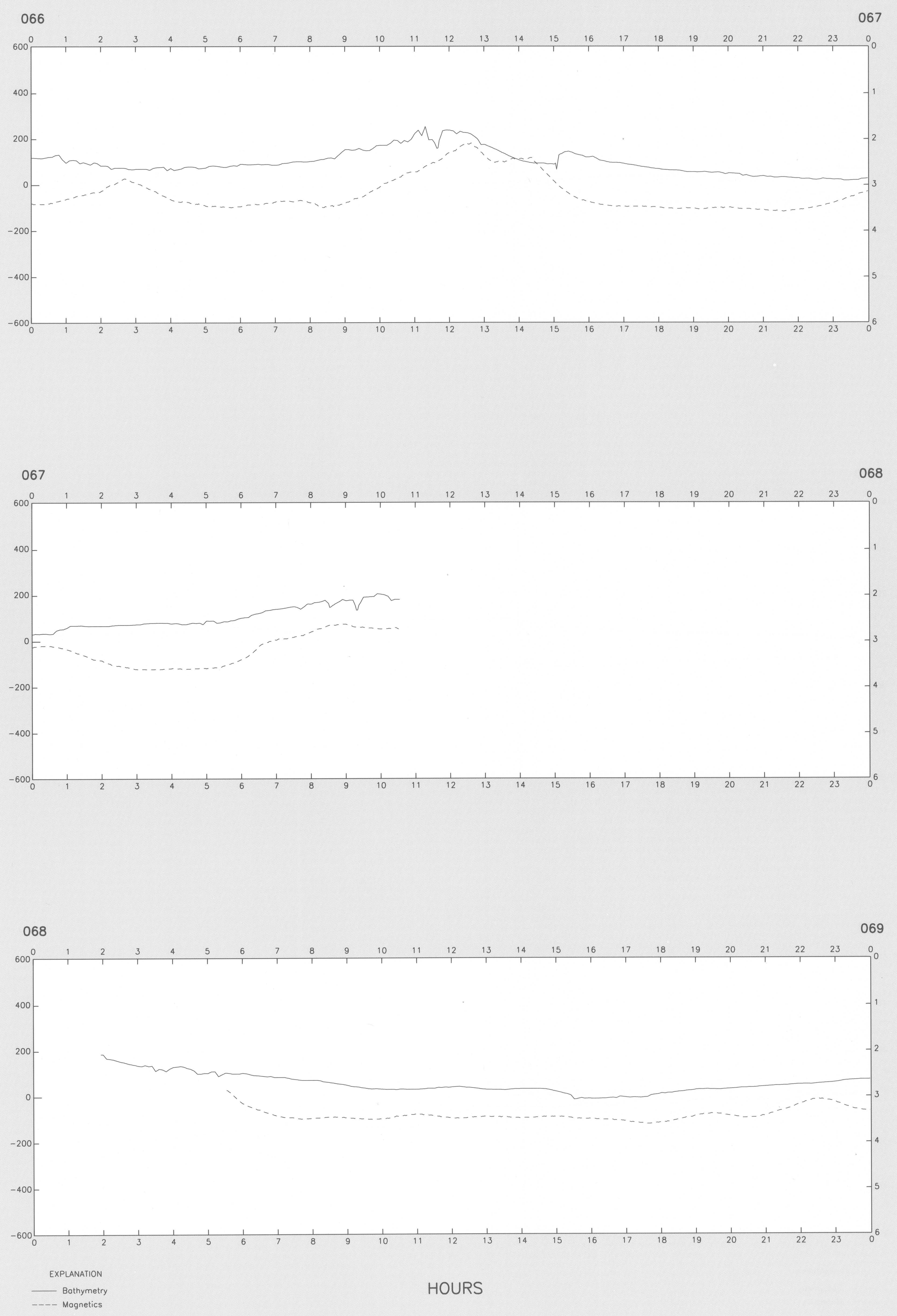

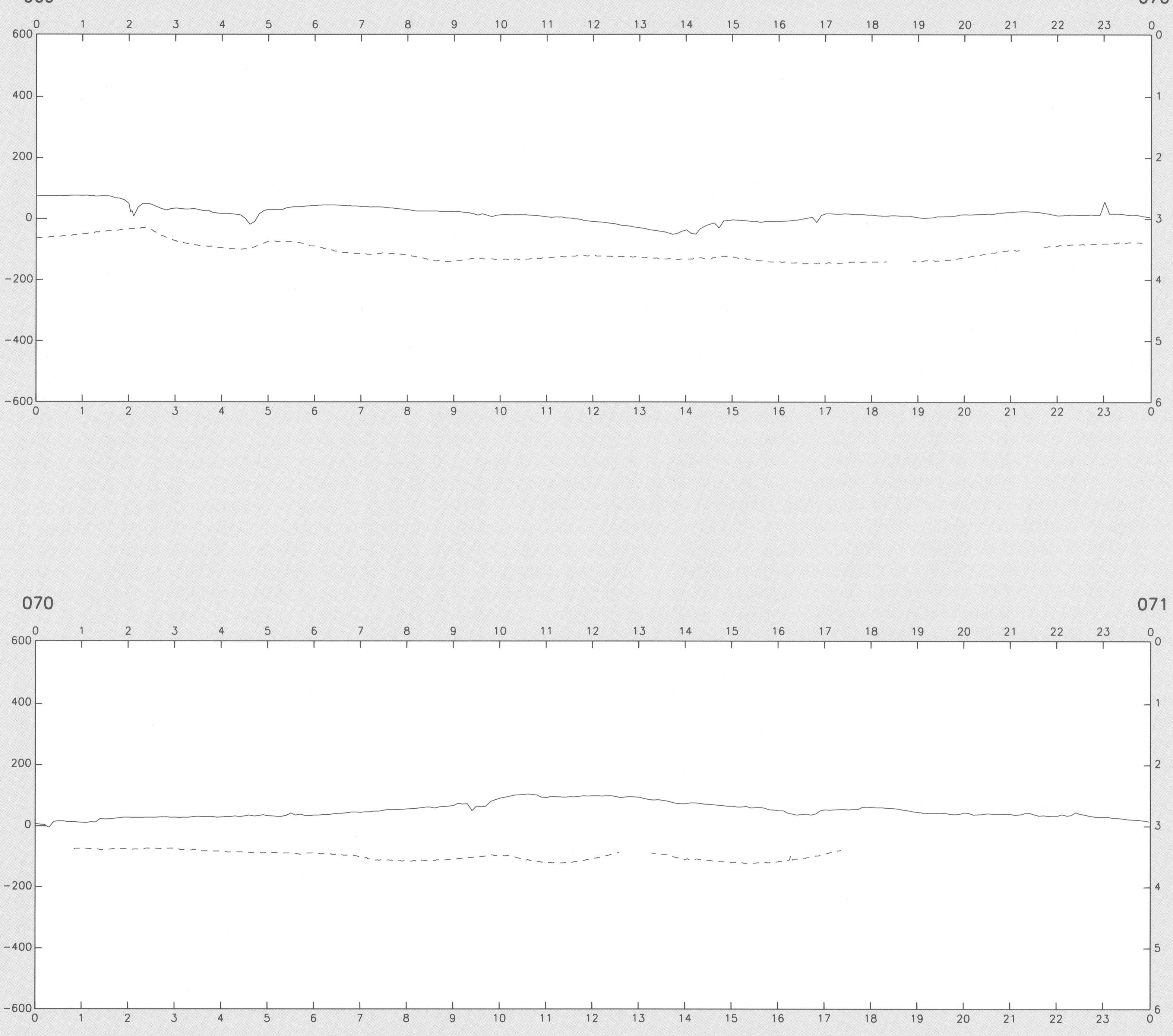

07

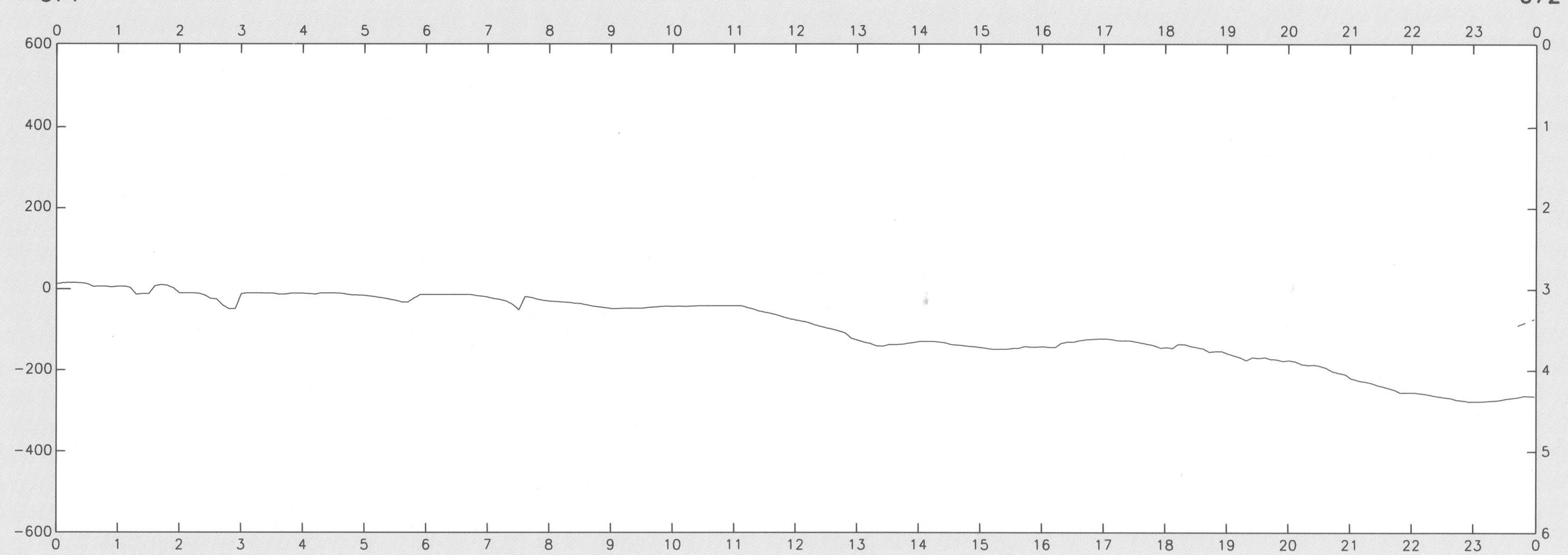

EXPLANATION

- Bathymetry
_--- Magnetics

HOURS 
DAY 072-075
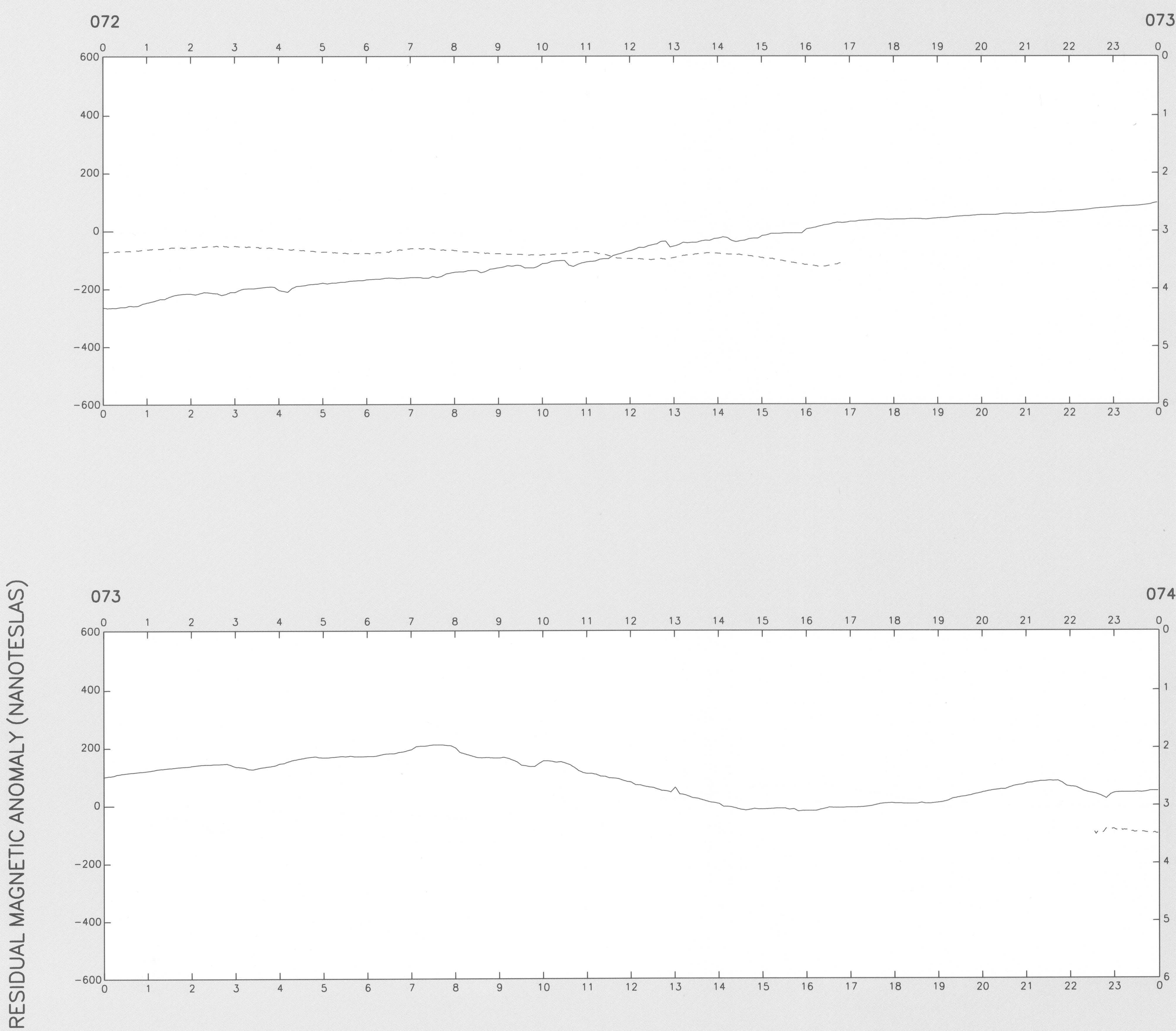

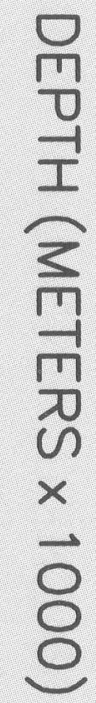

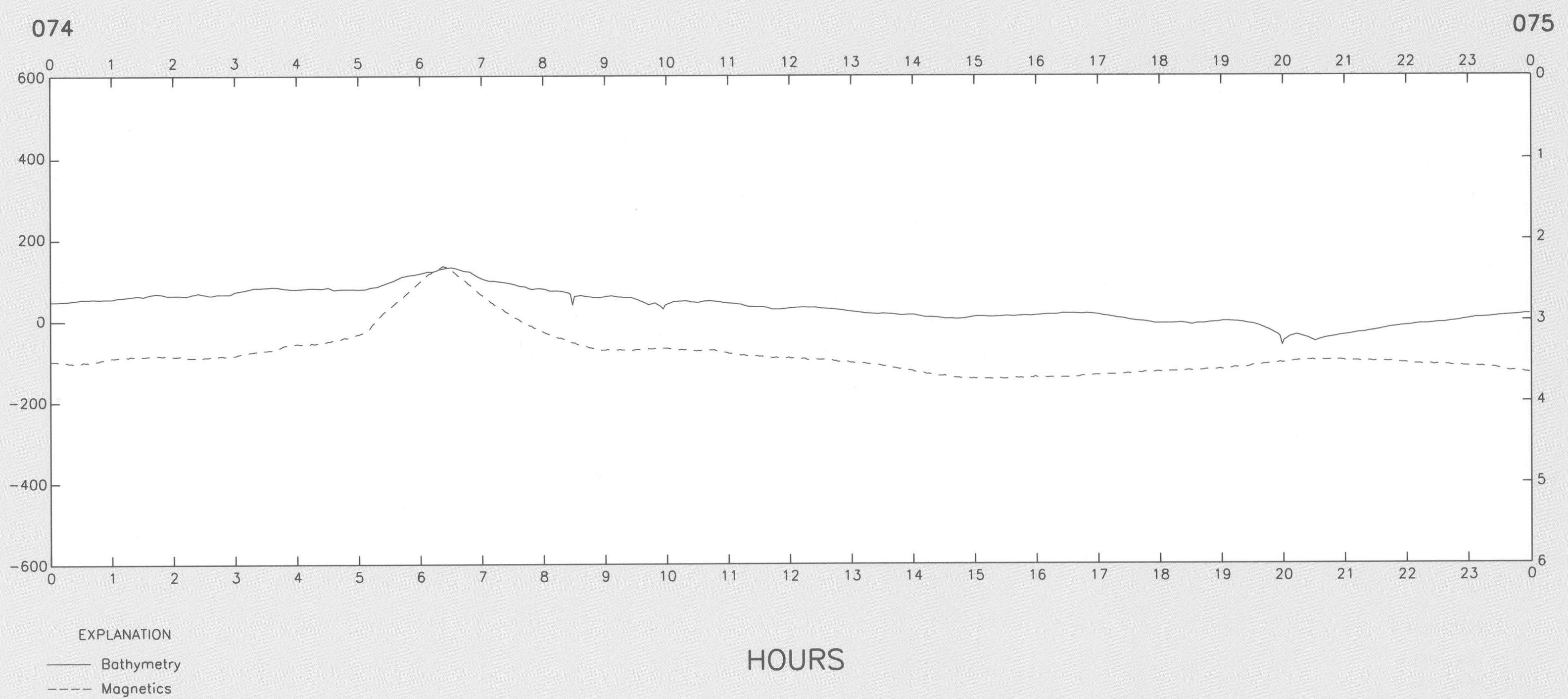


DAY 075-078
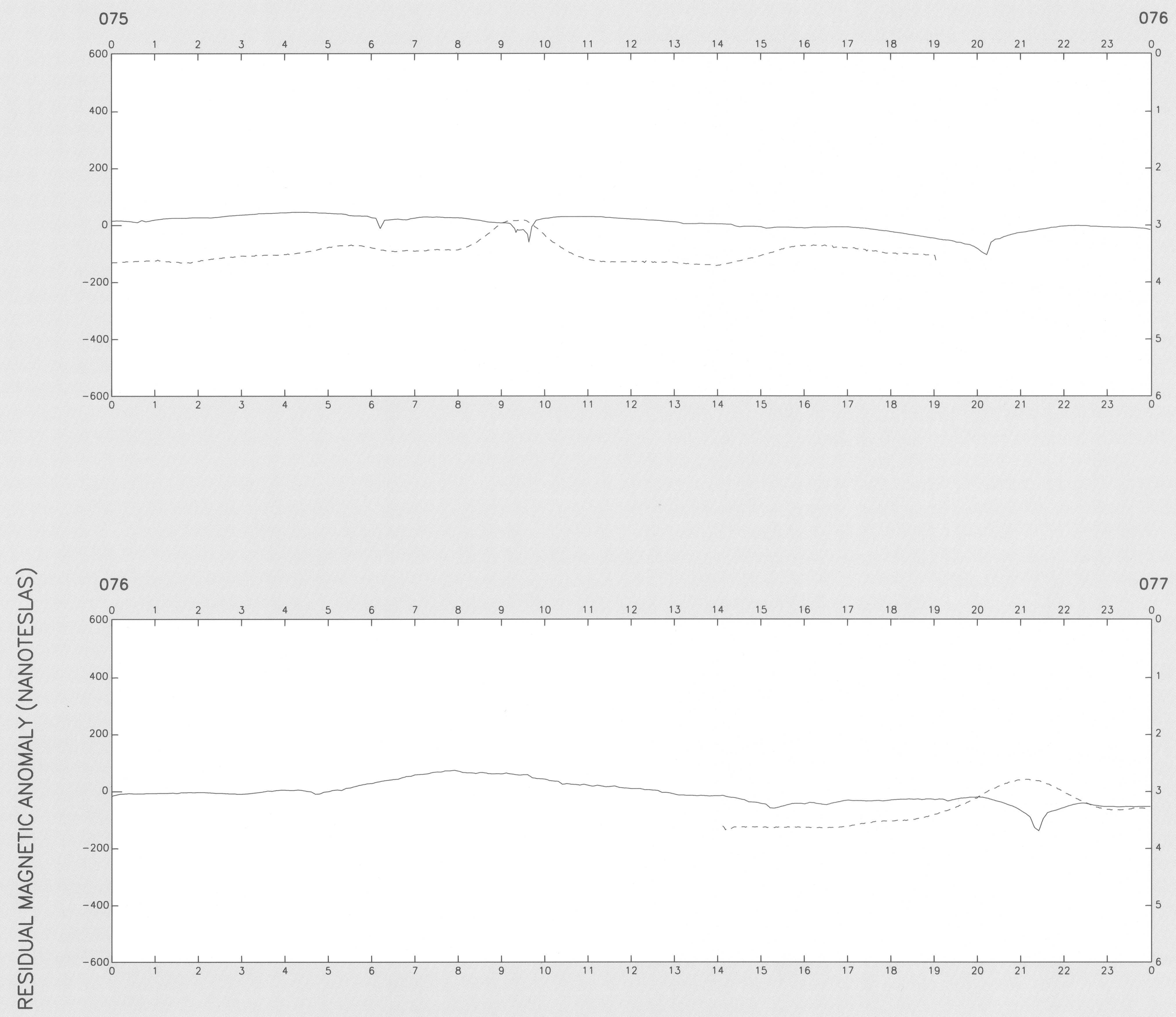

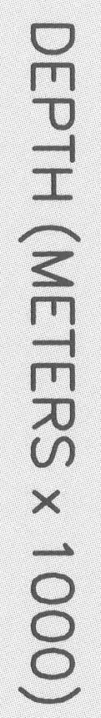

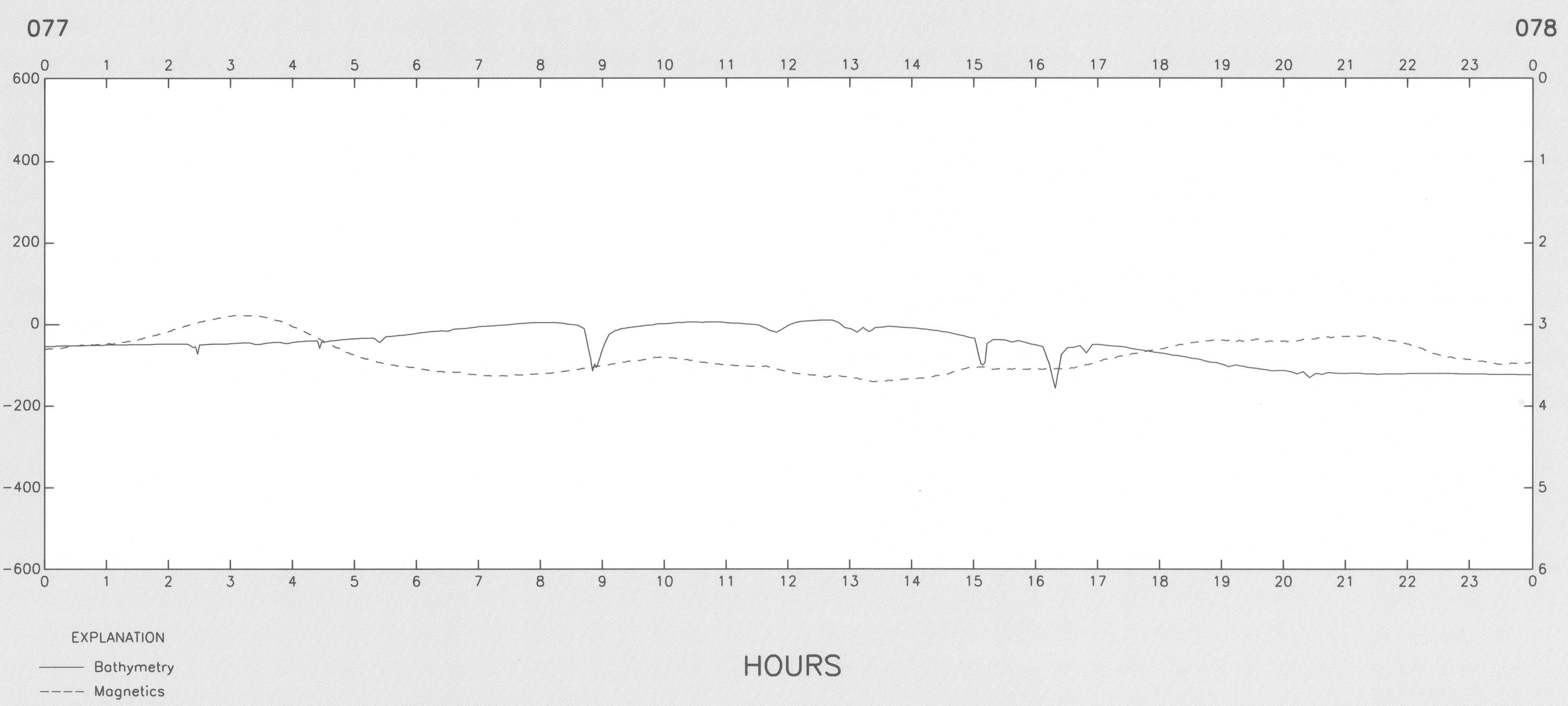


DAY 078-081

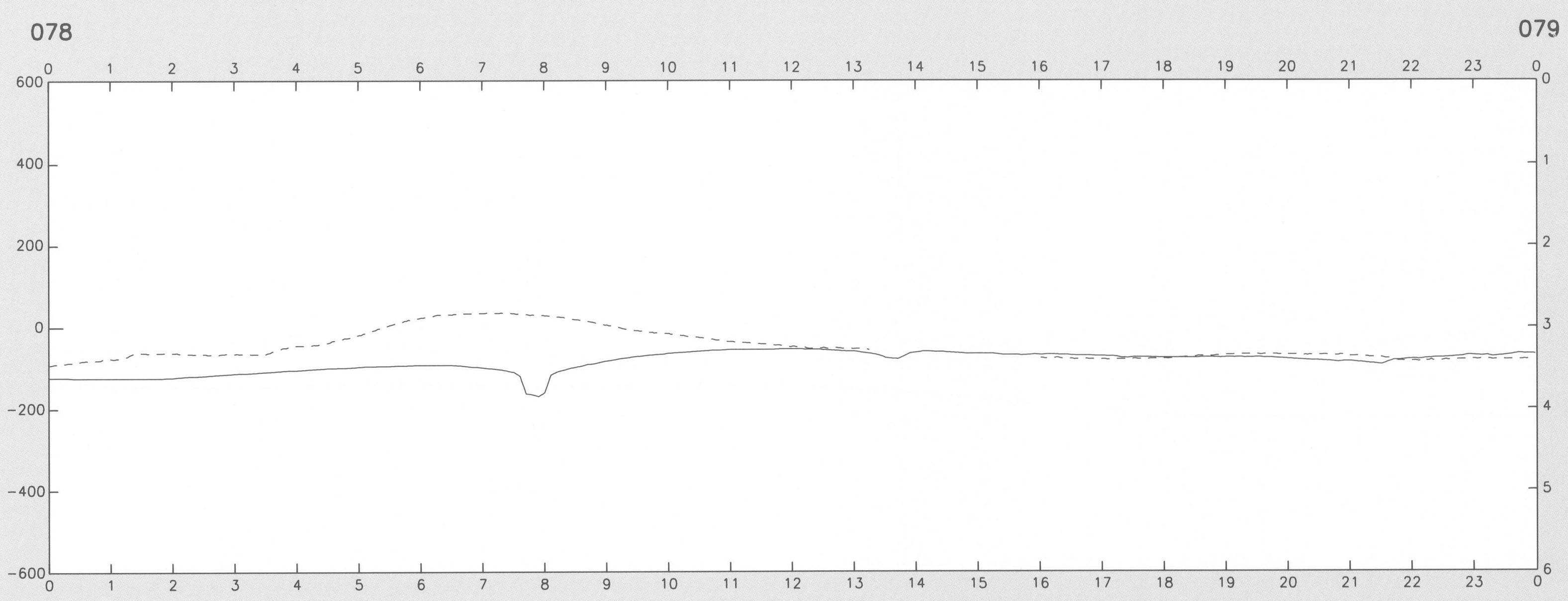

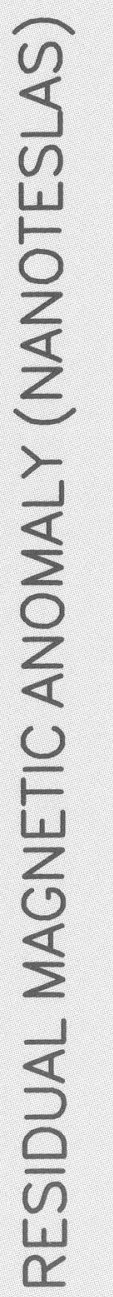

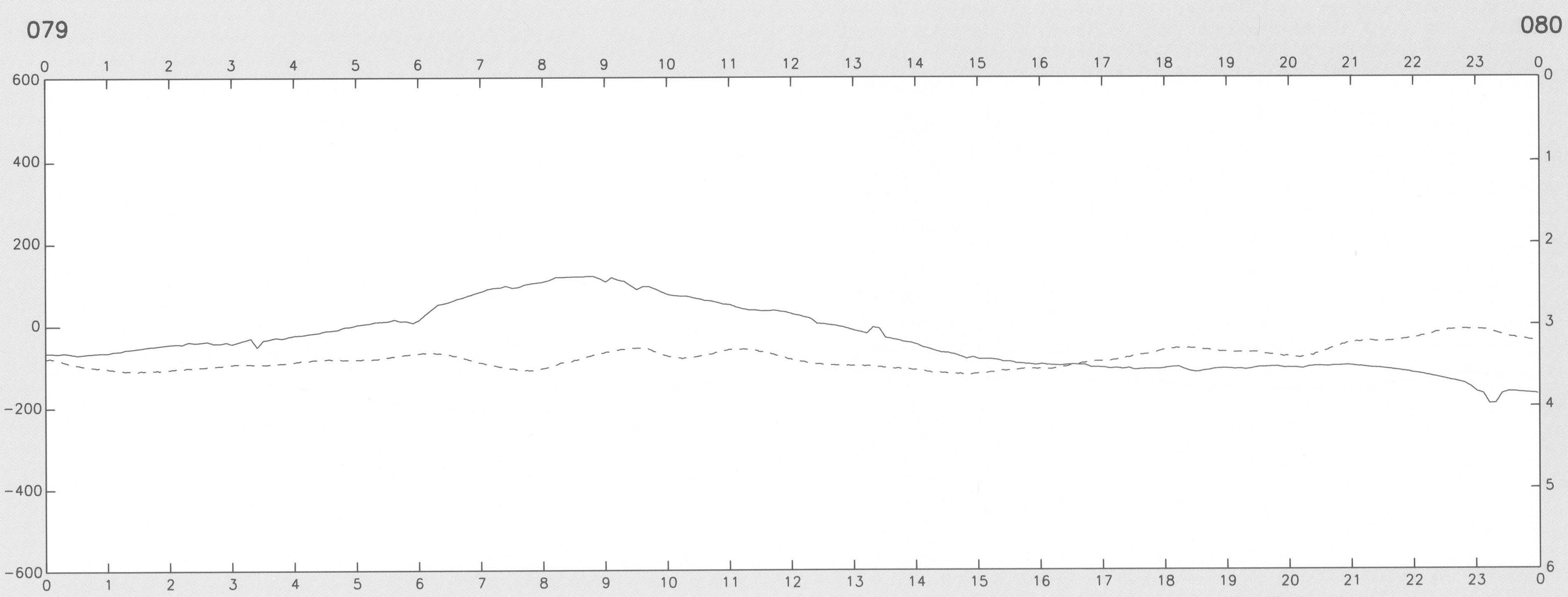

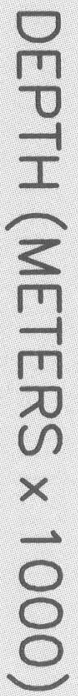

080

081

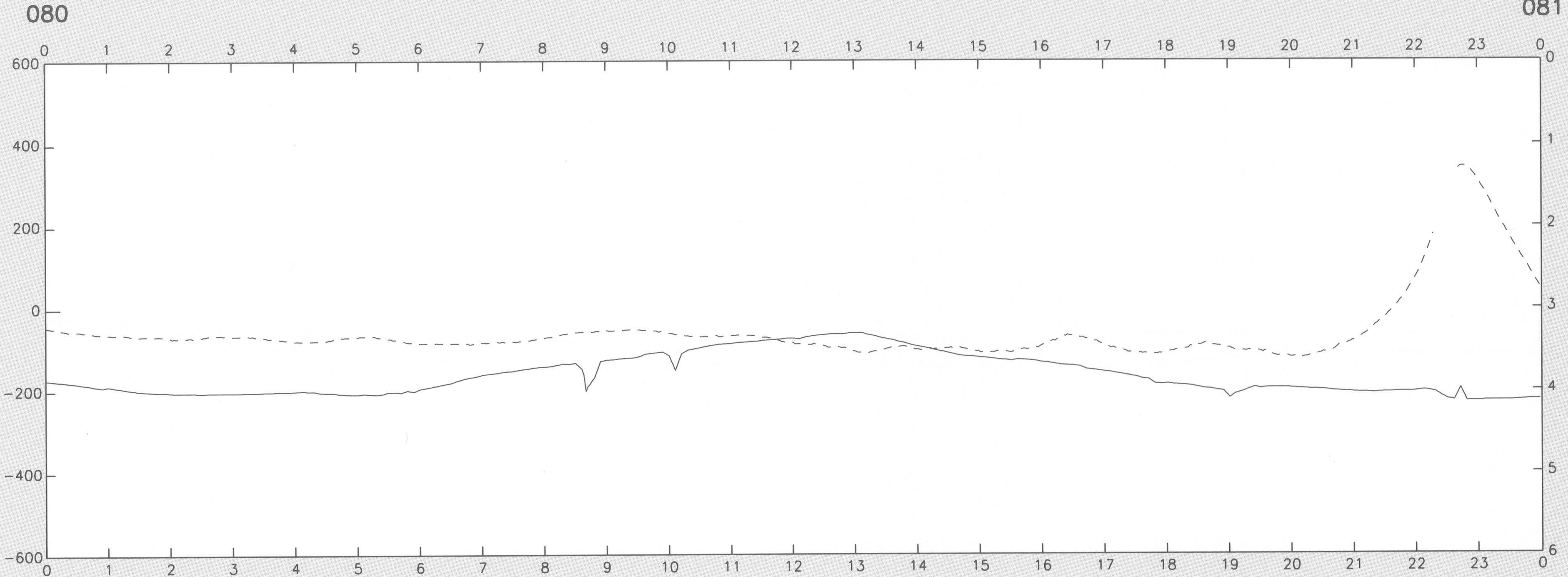

EXPLANATION 


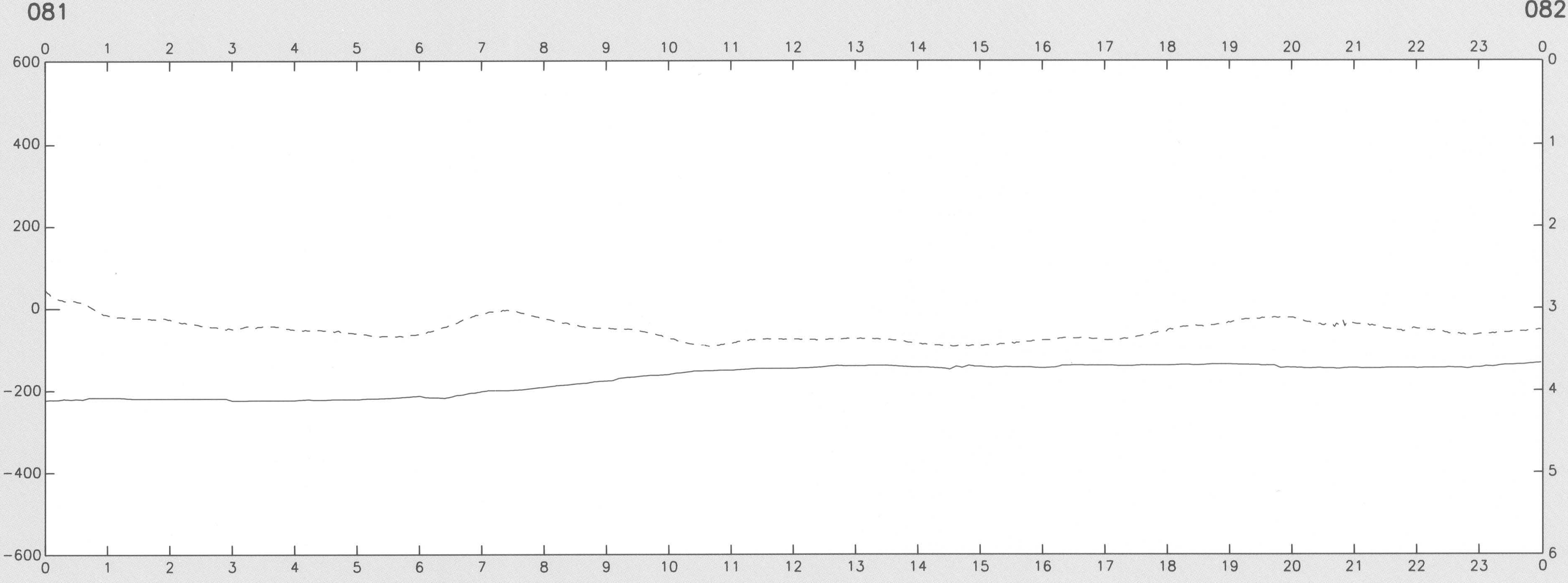

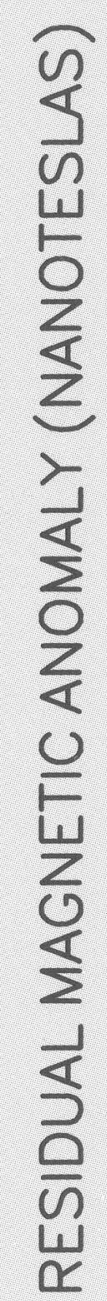

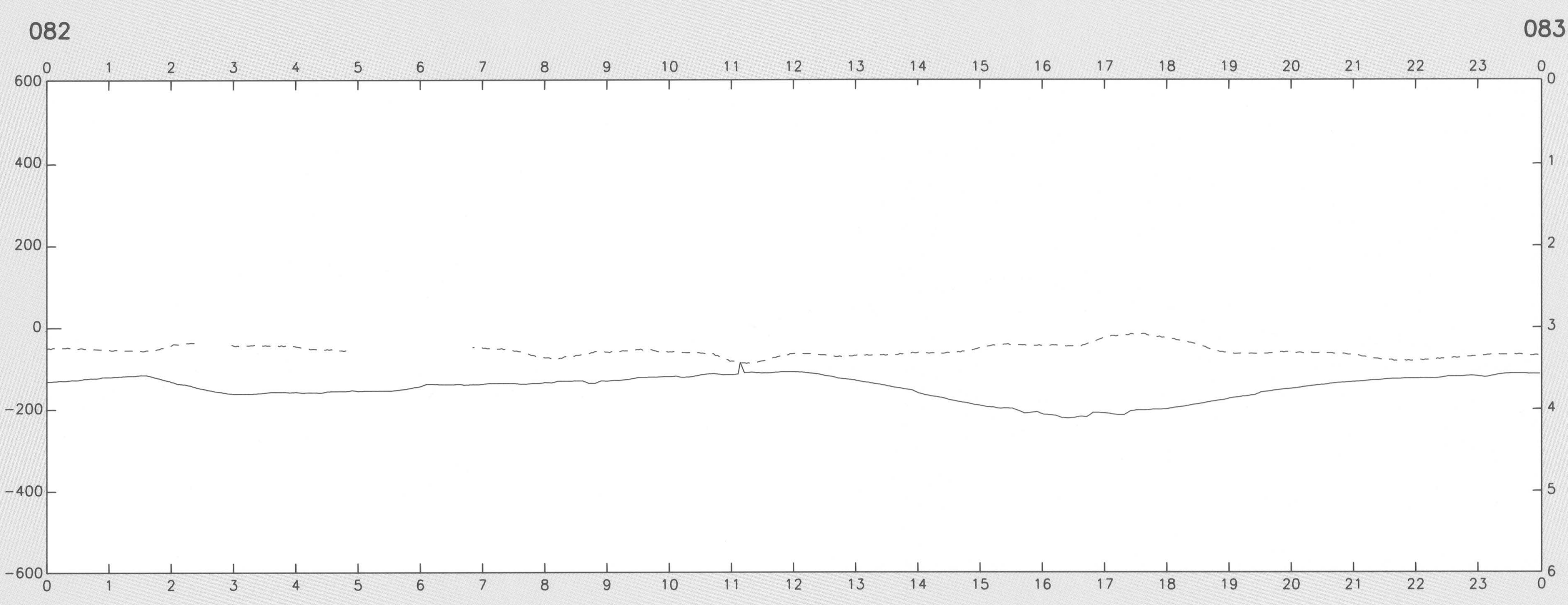

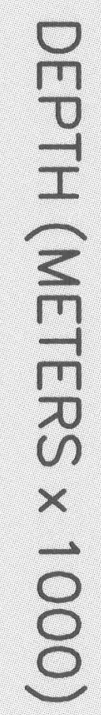

083

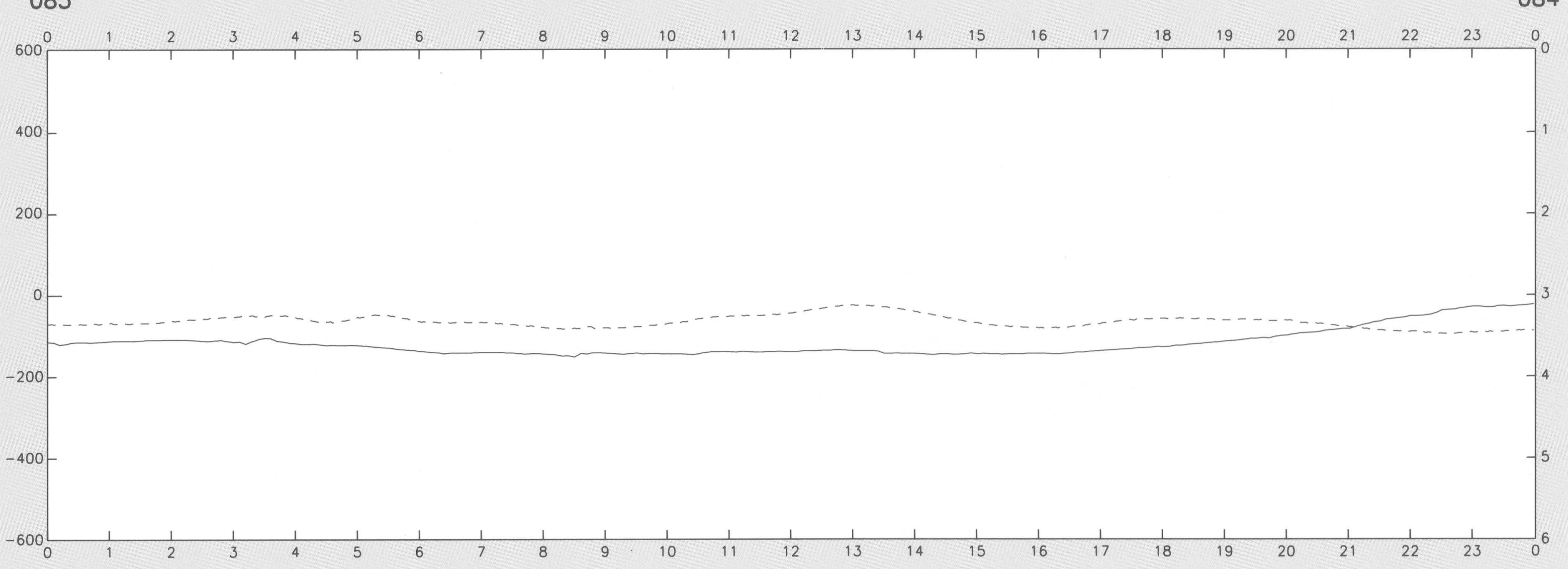


DAY 088-091
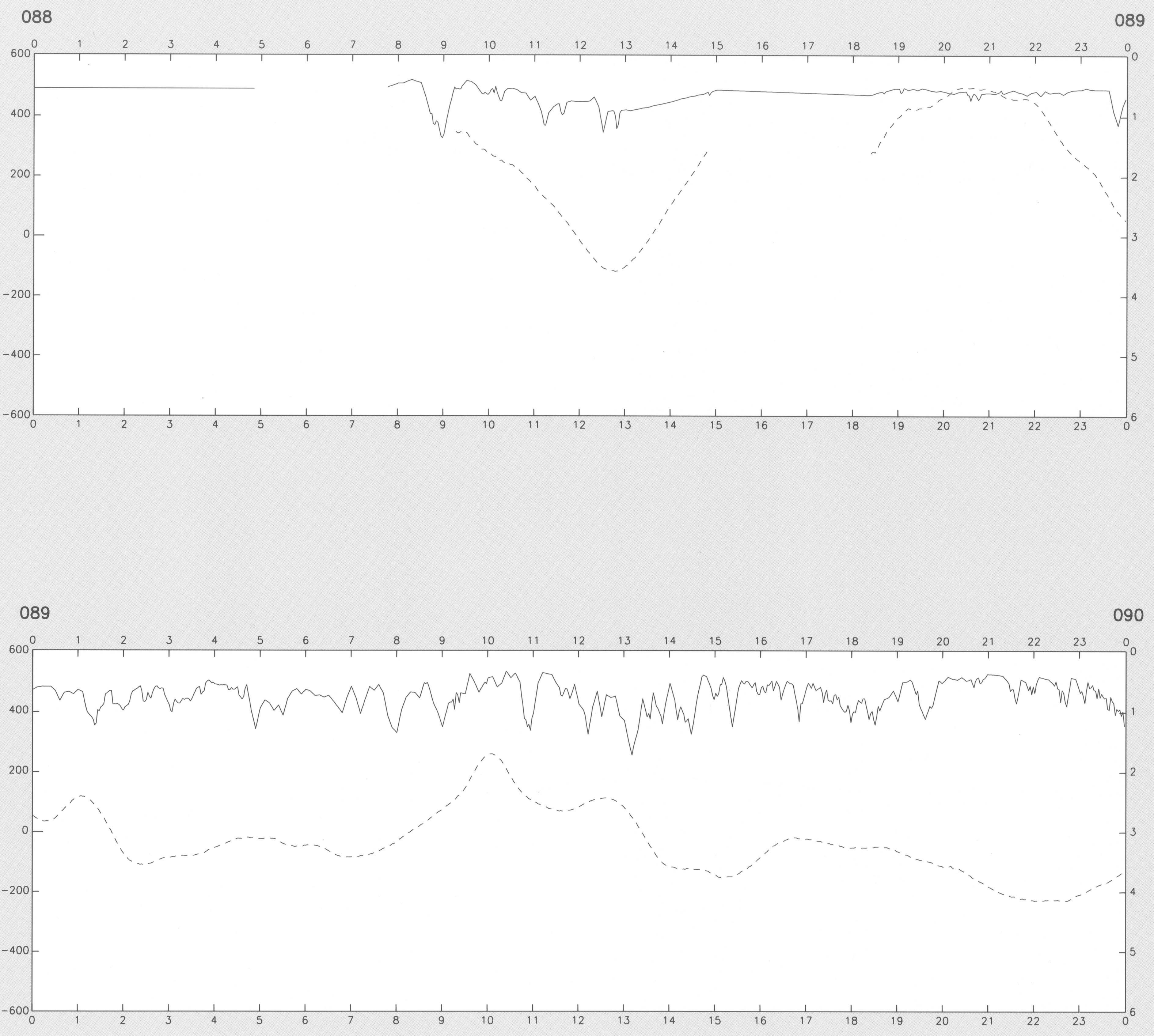

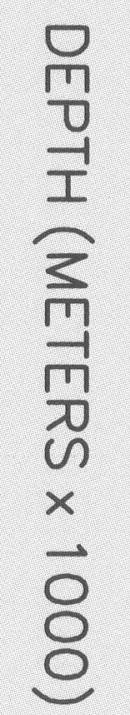

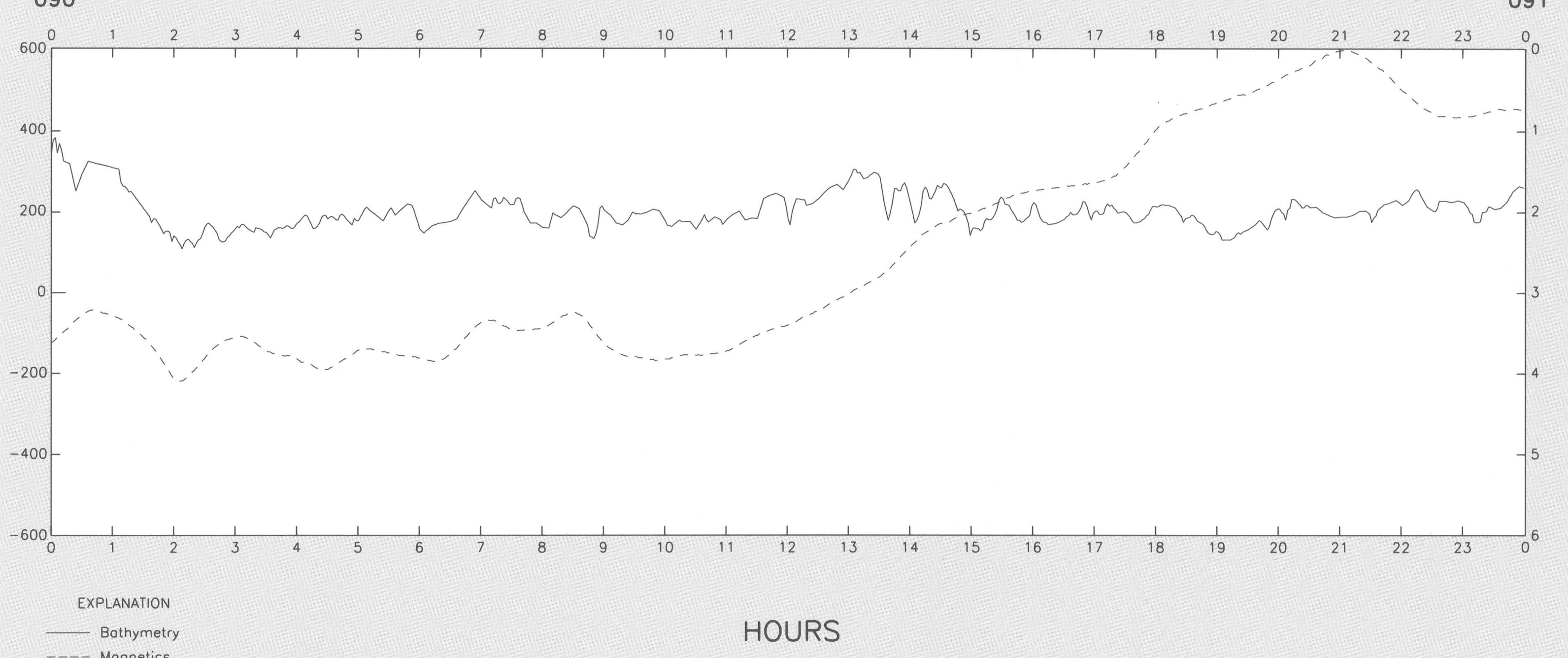



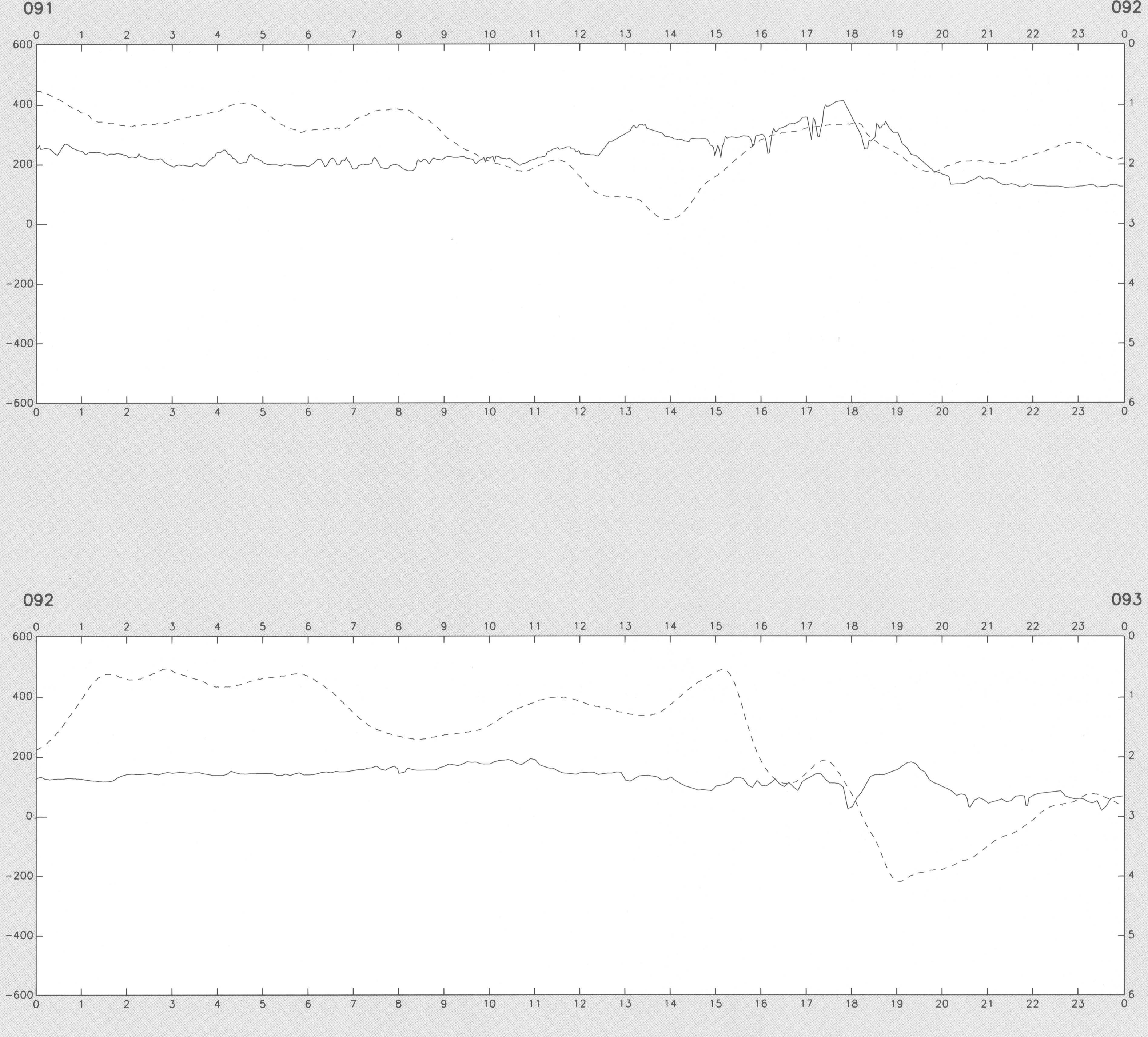

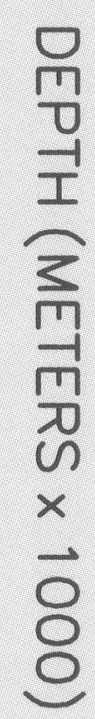

093

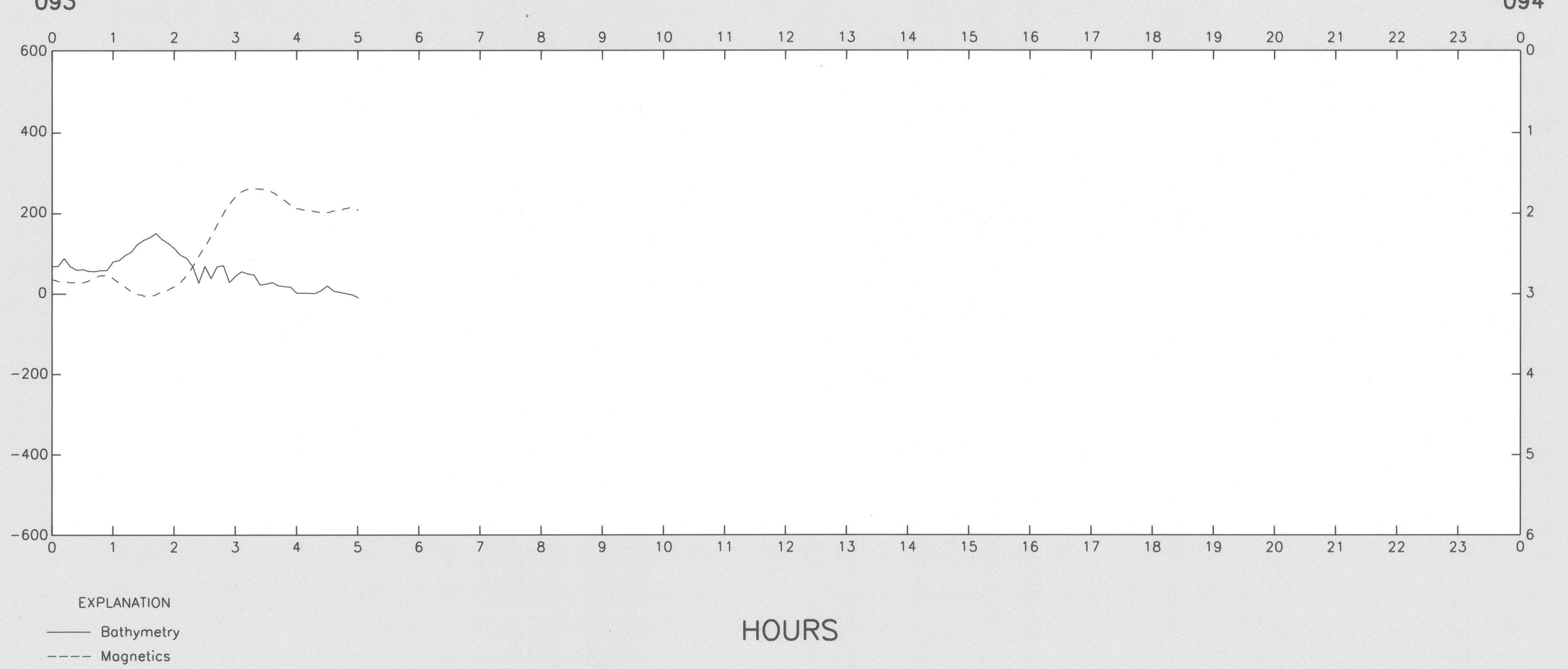



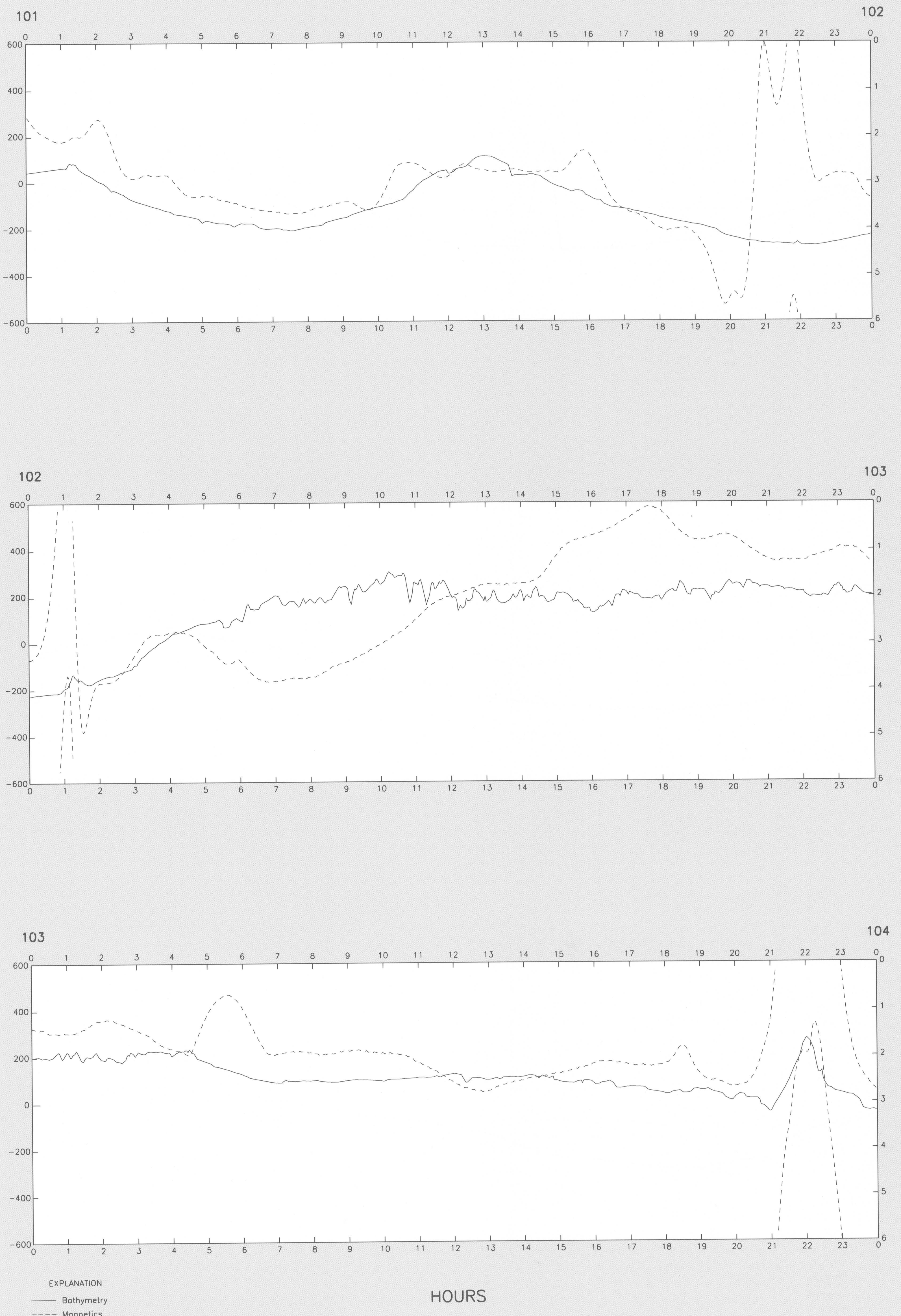
DAY 104-107
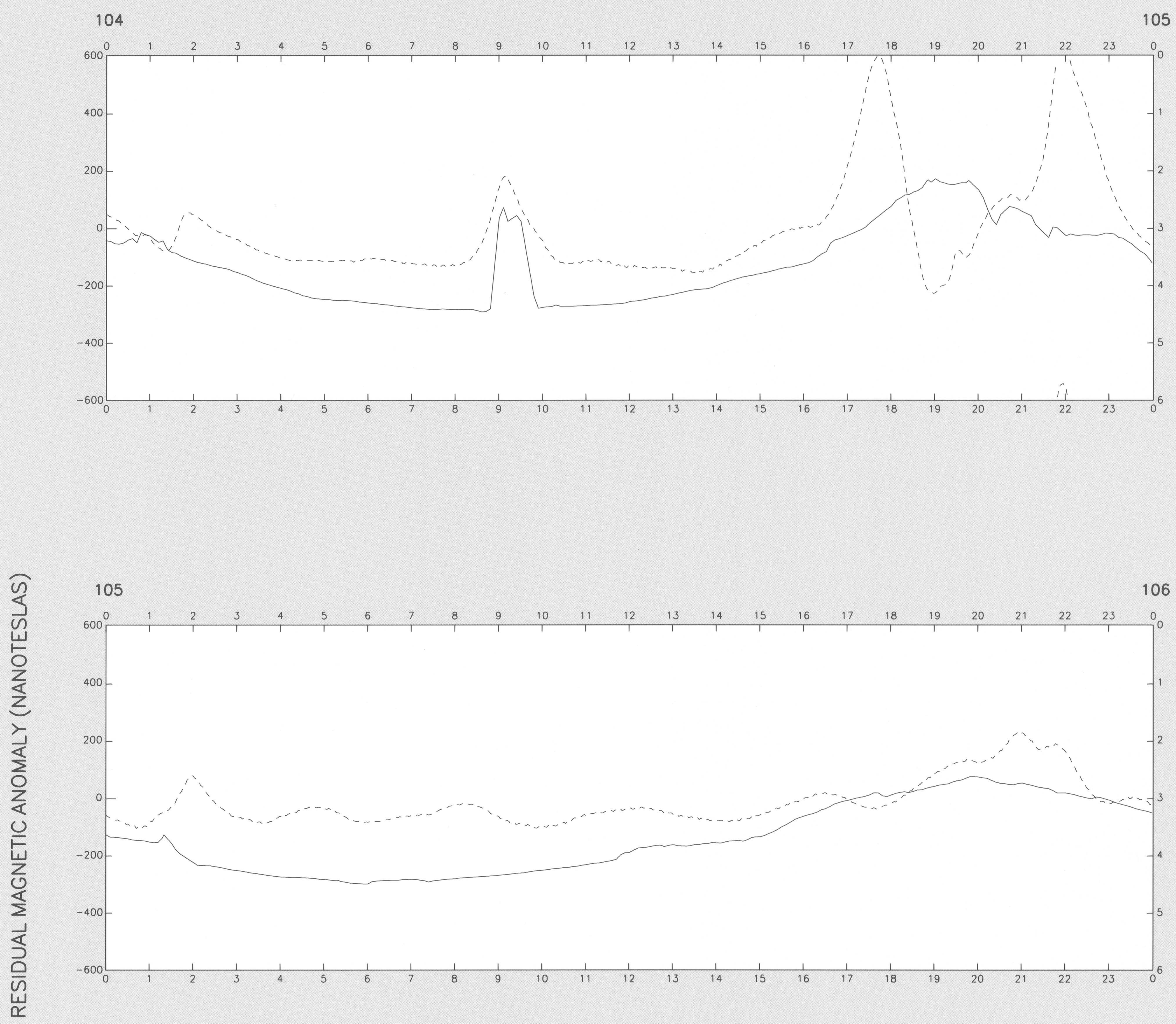

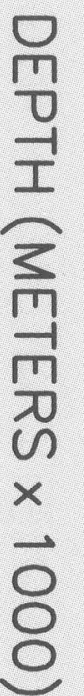

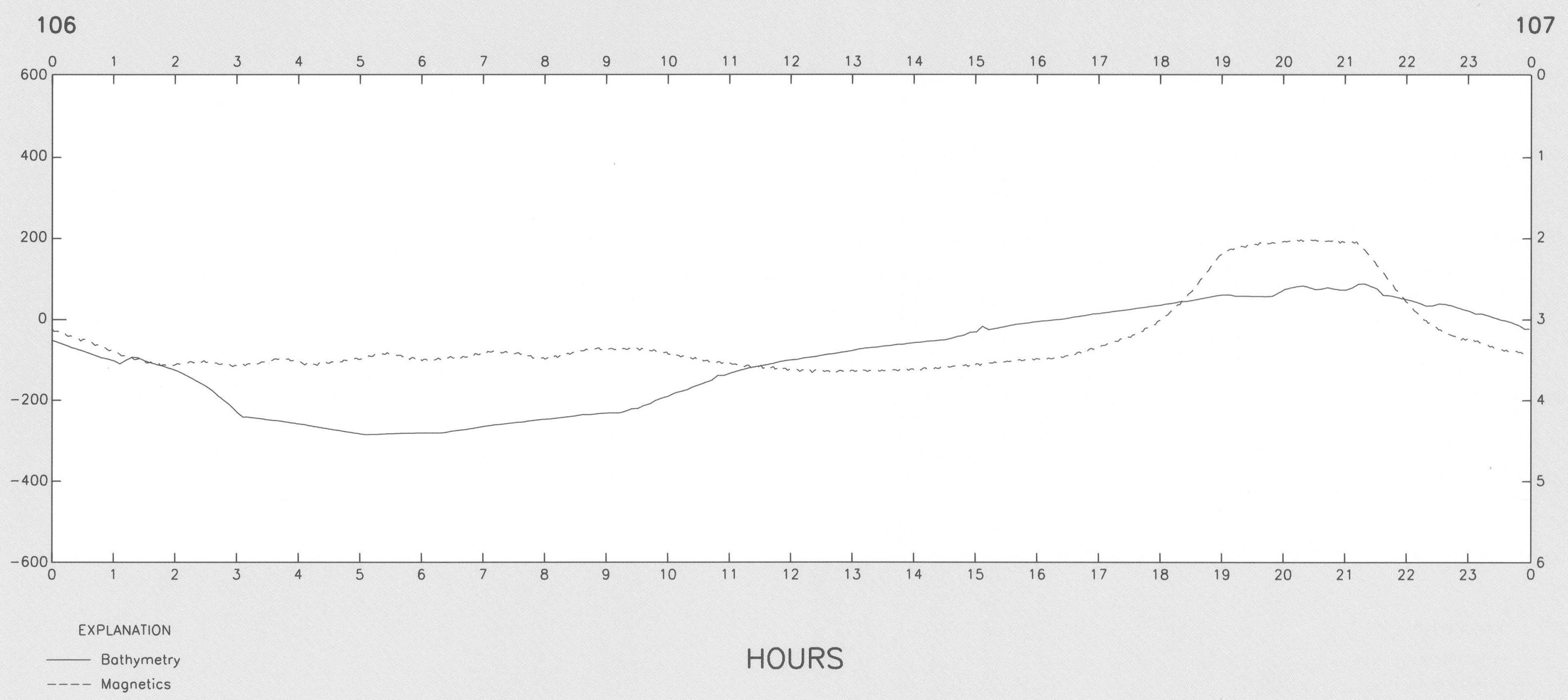


DAY $107-109,110-111$
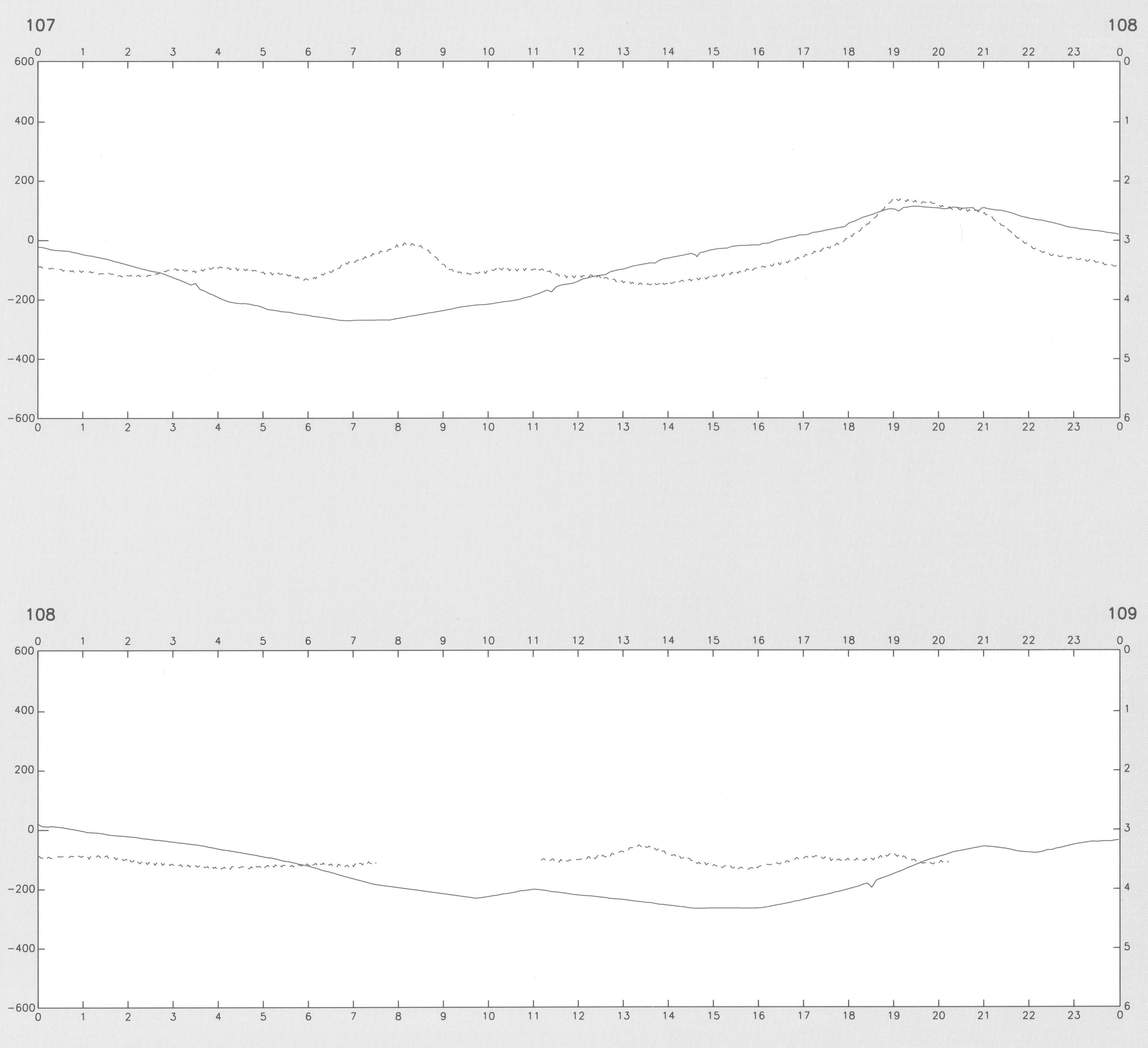

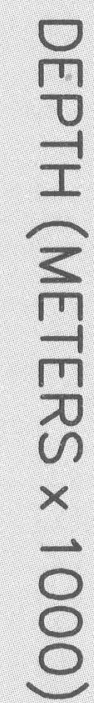

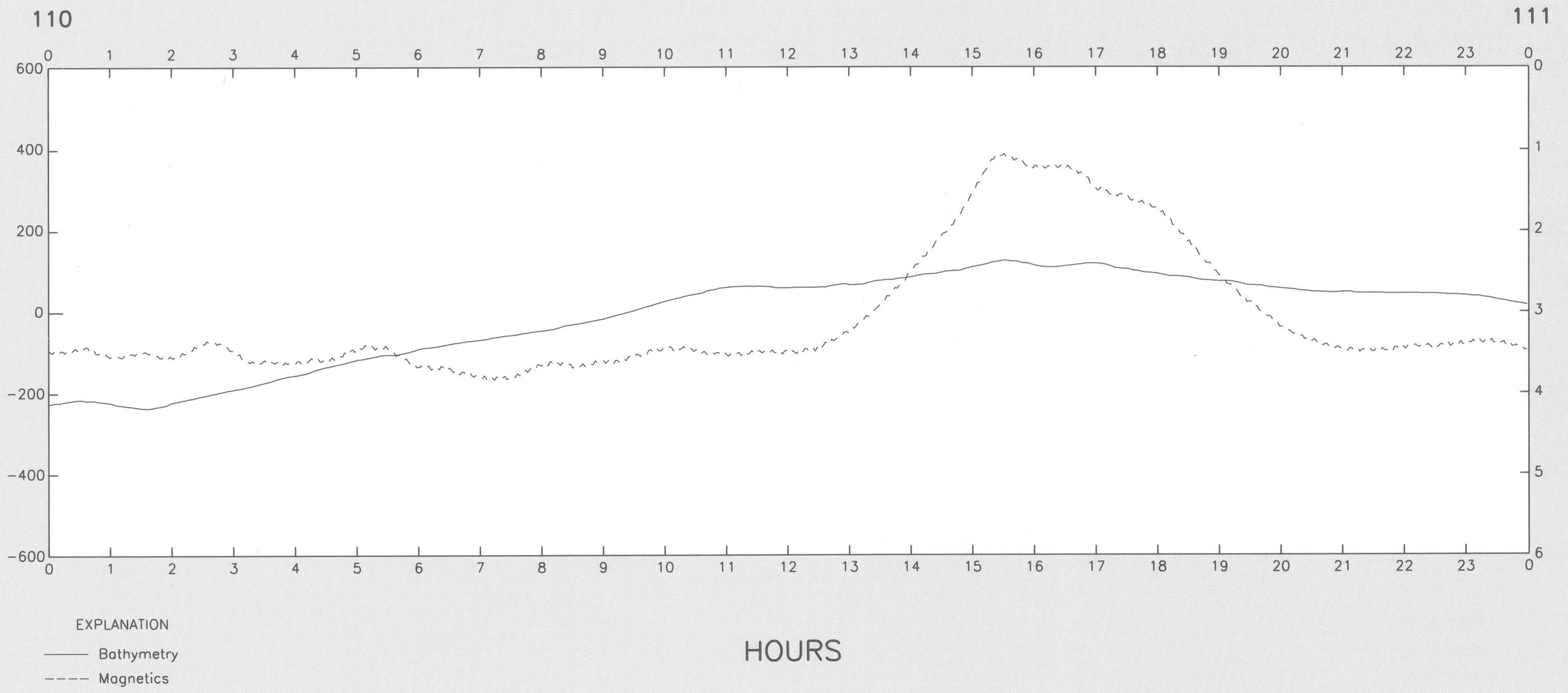


DAY $111-114$

111

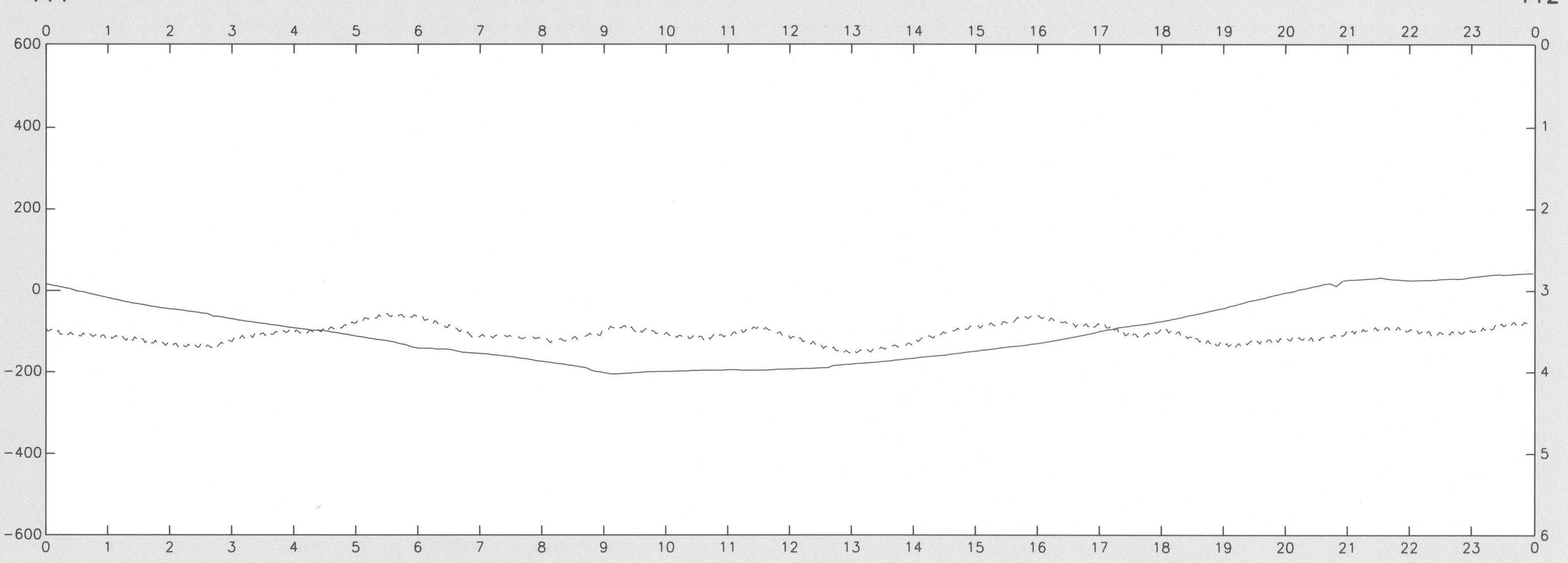

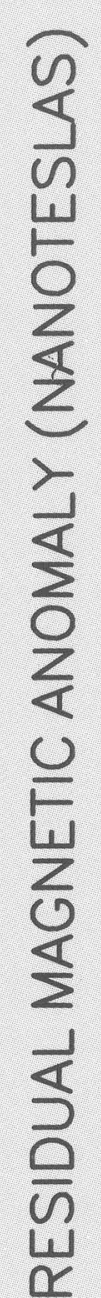

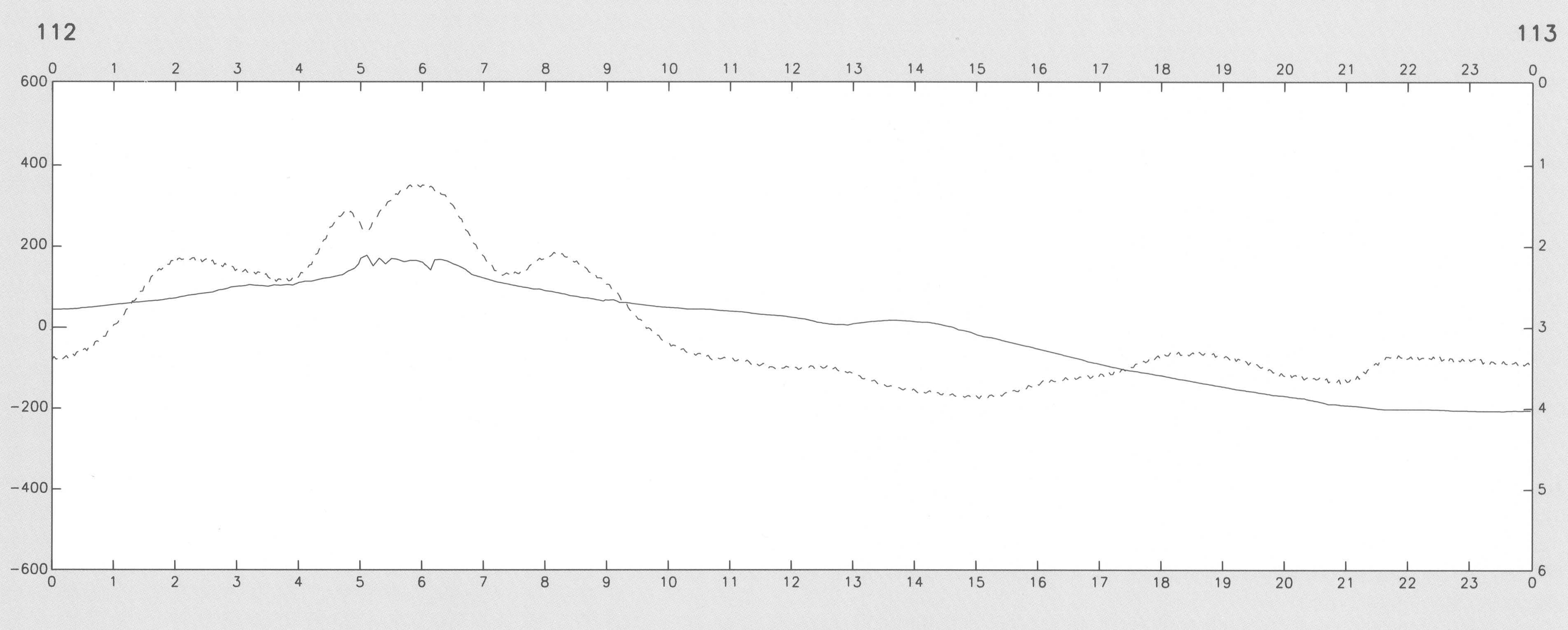

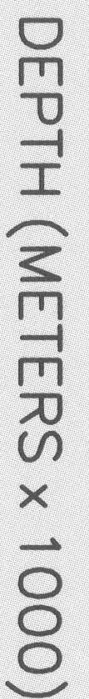

113

114

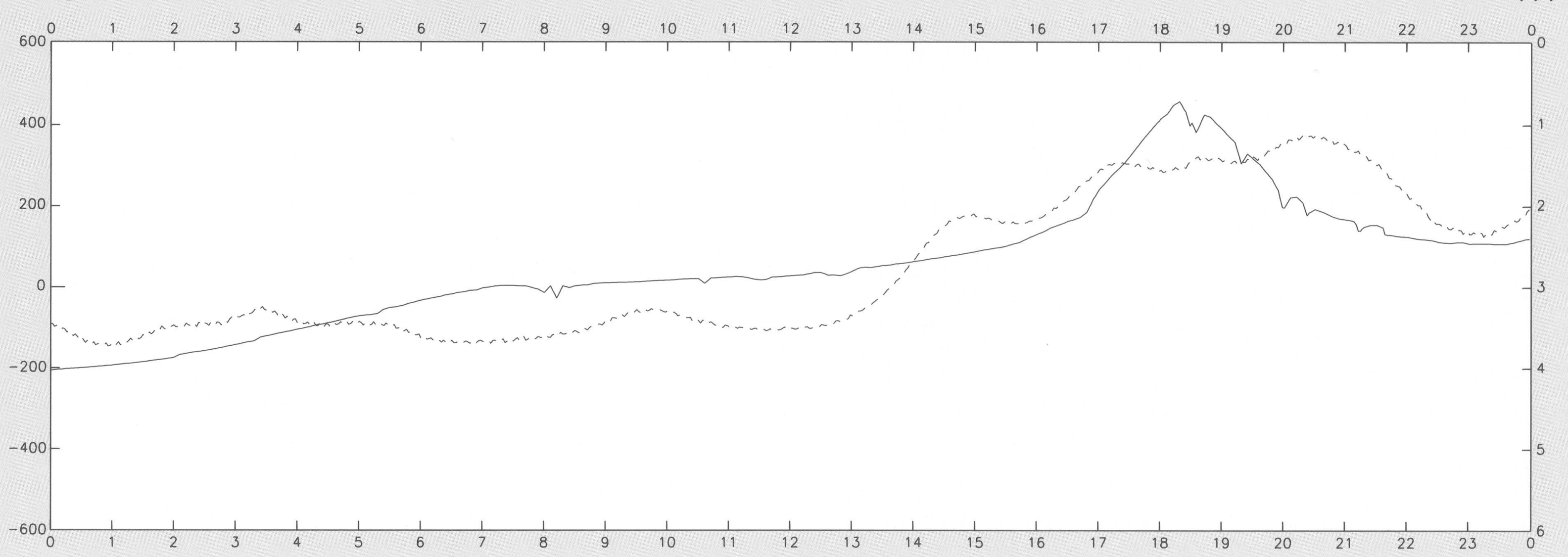

EXPLANATION

- Bathymetry

HOURS 
DAY $114-115,118-120$
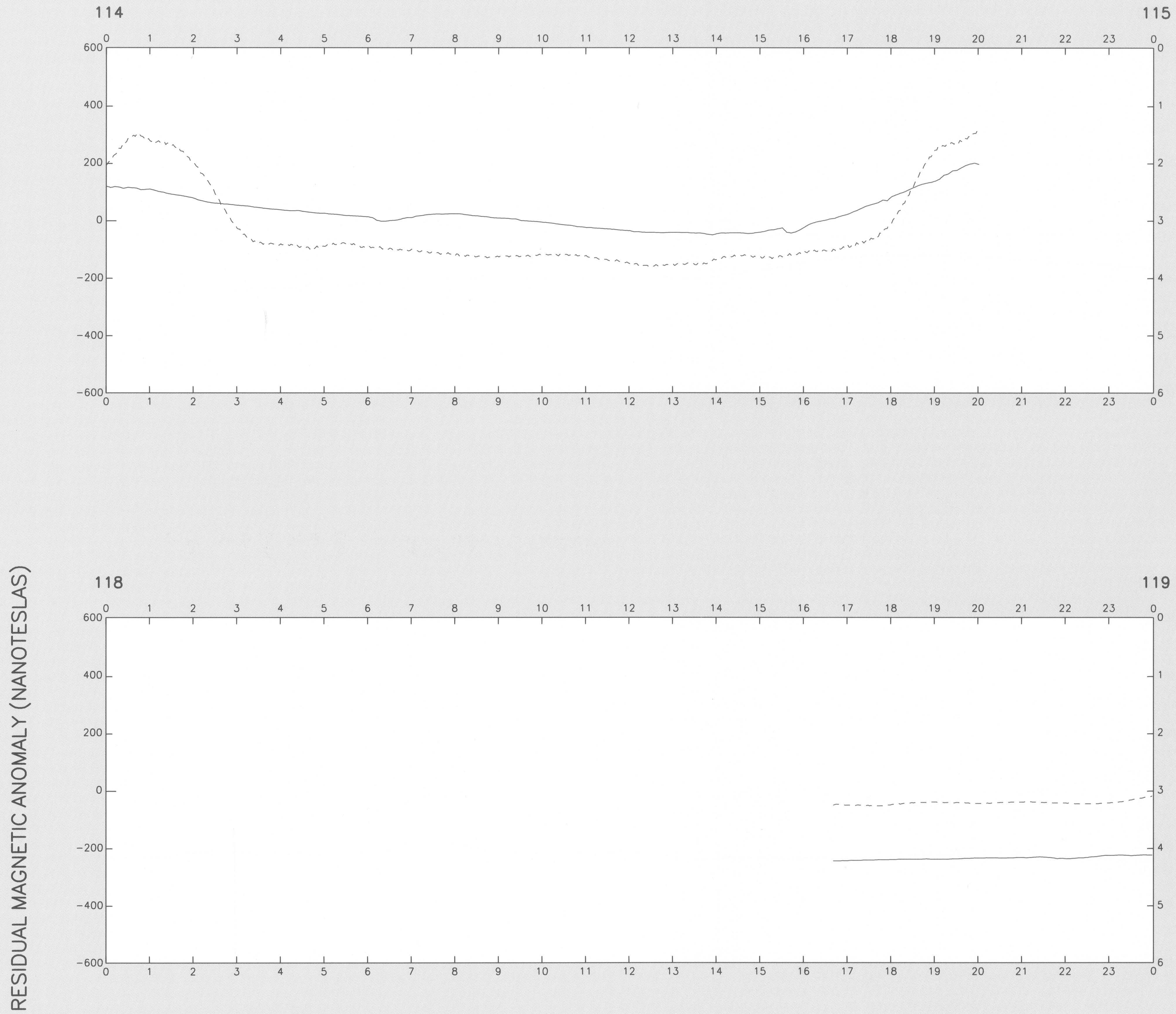

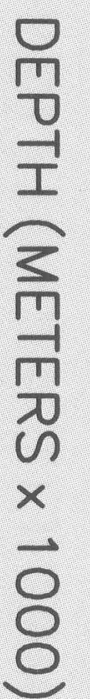

119

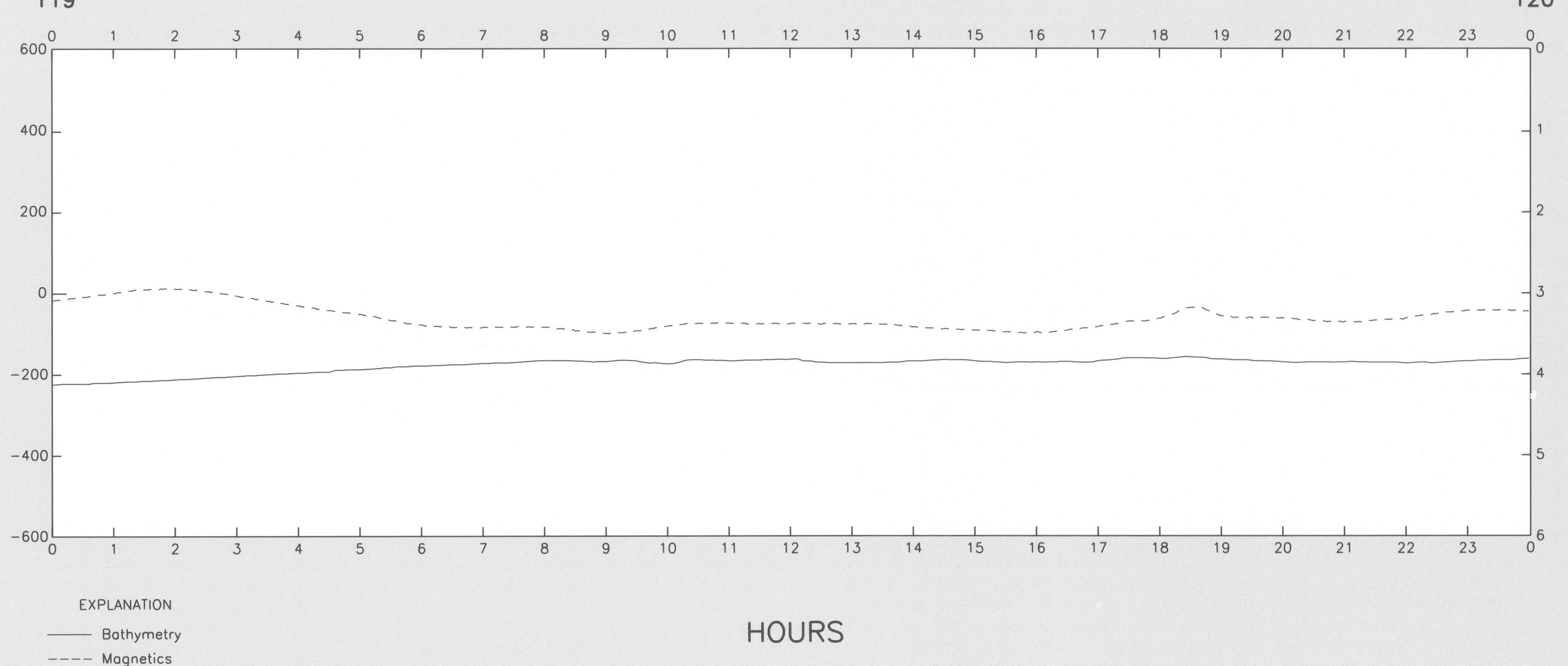


DAY $120-123$

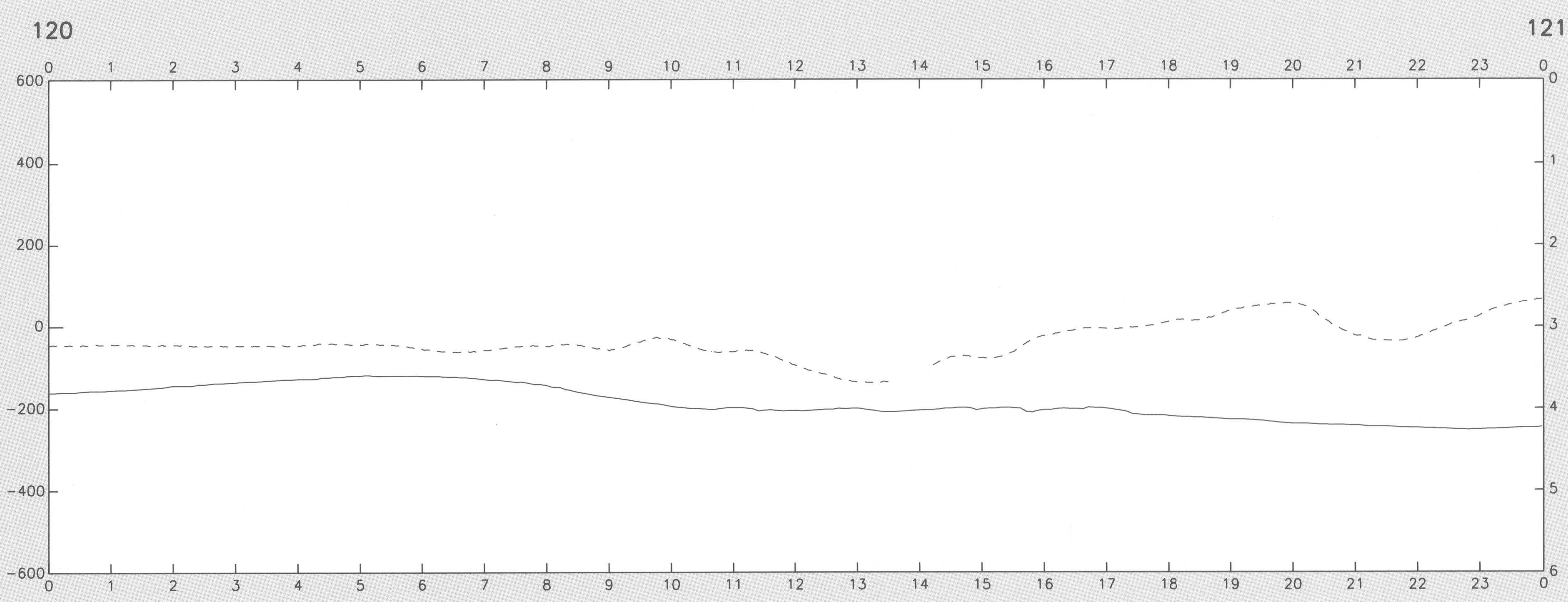

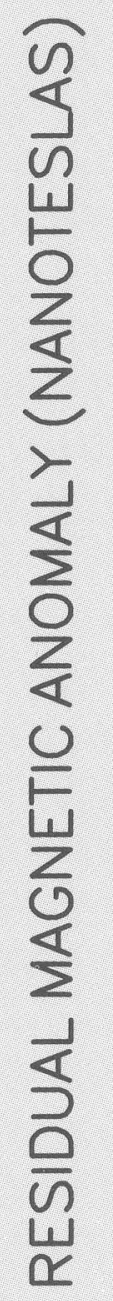

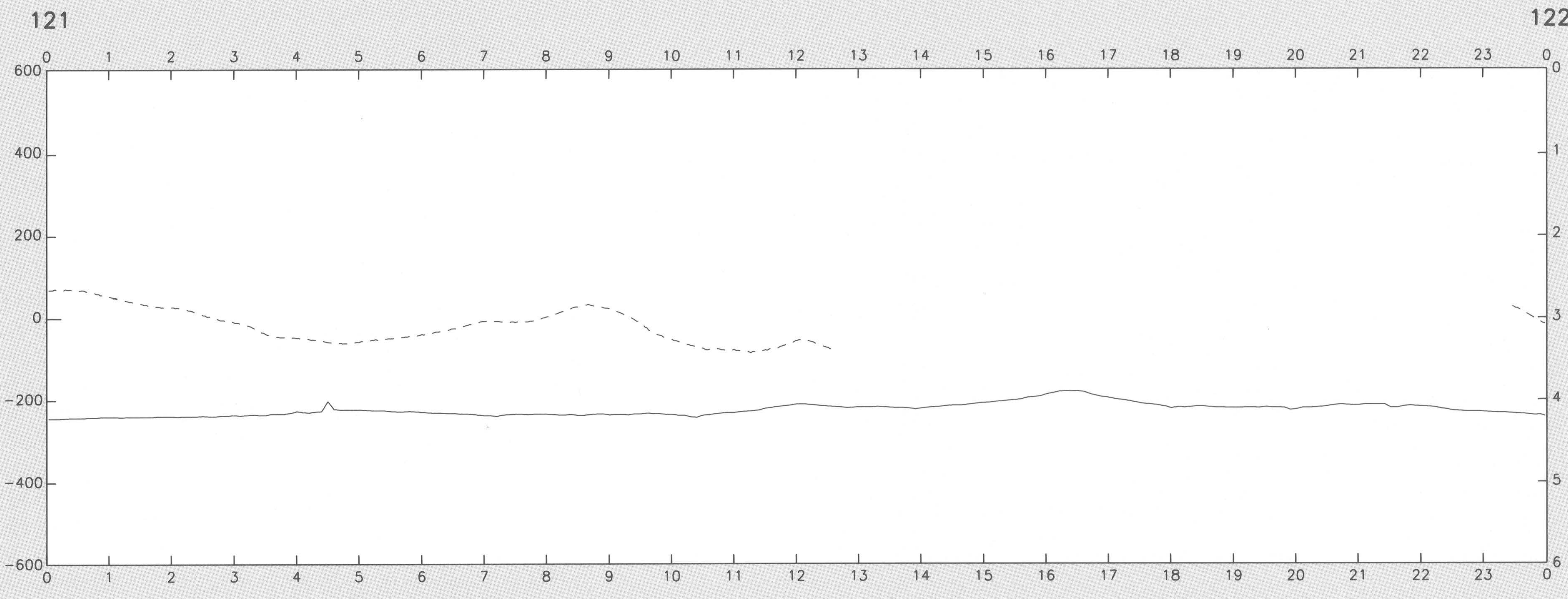

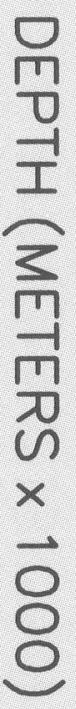

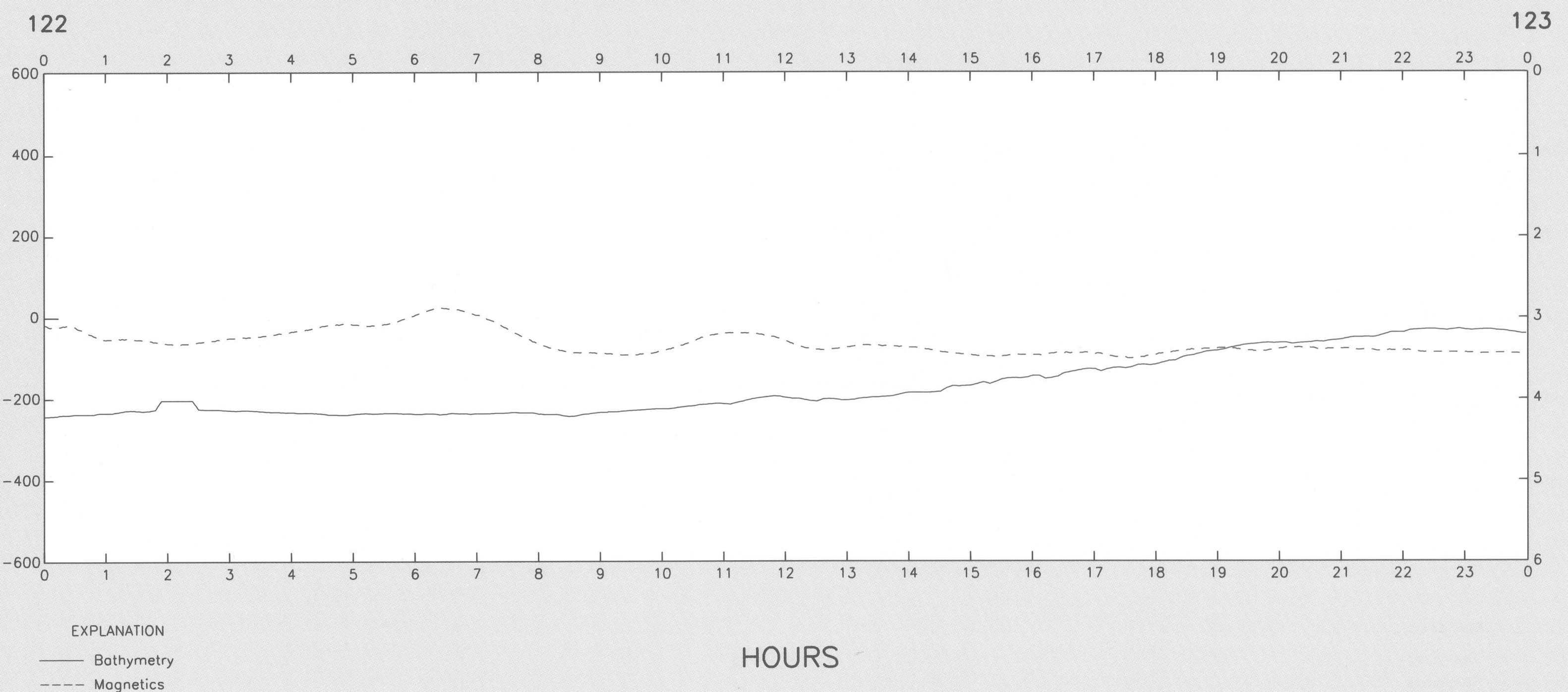


DAY $123-126$
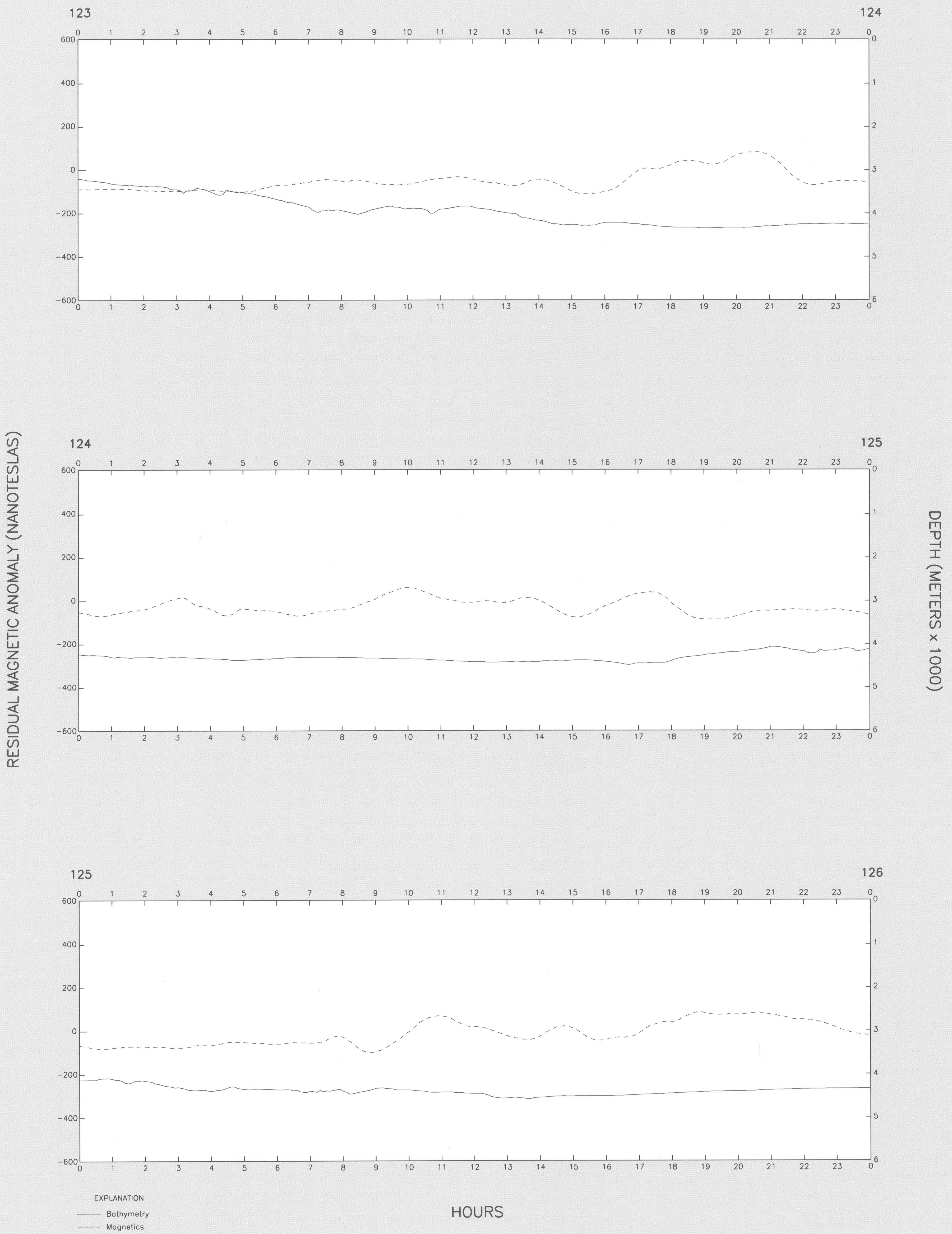
DAY $126-128,130-131$
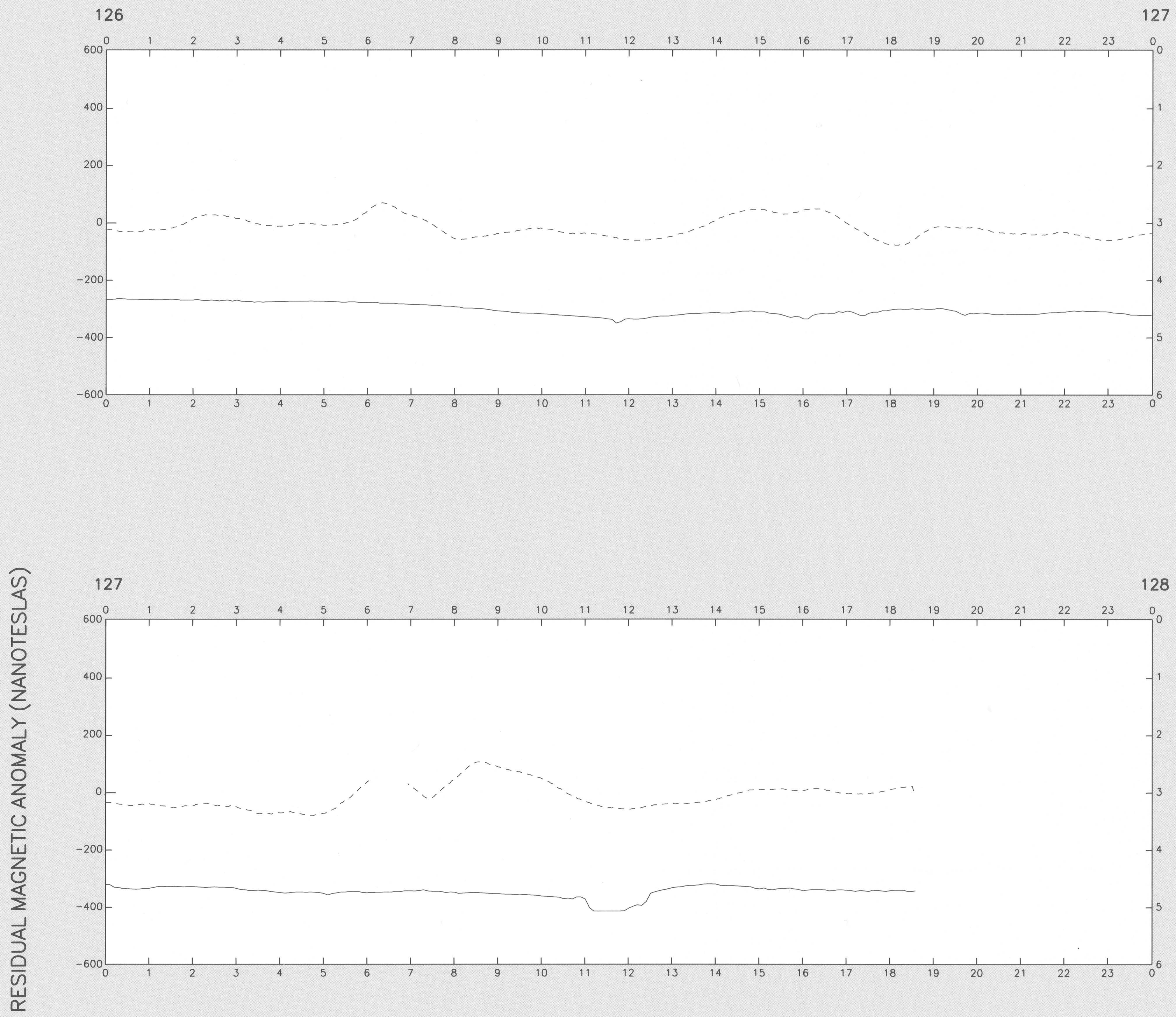

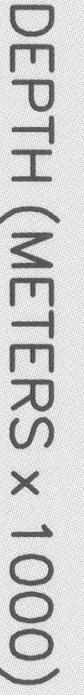

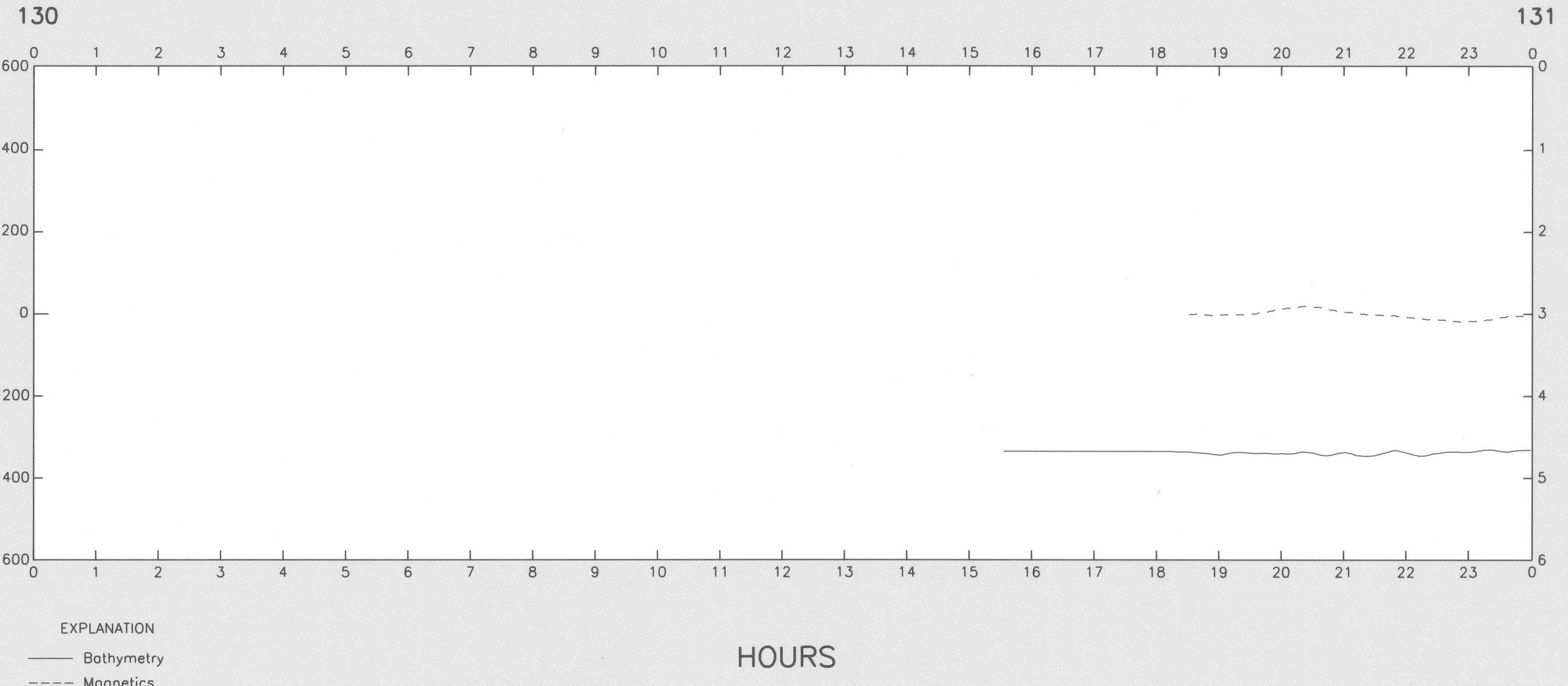


DAY 131-134
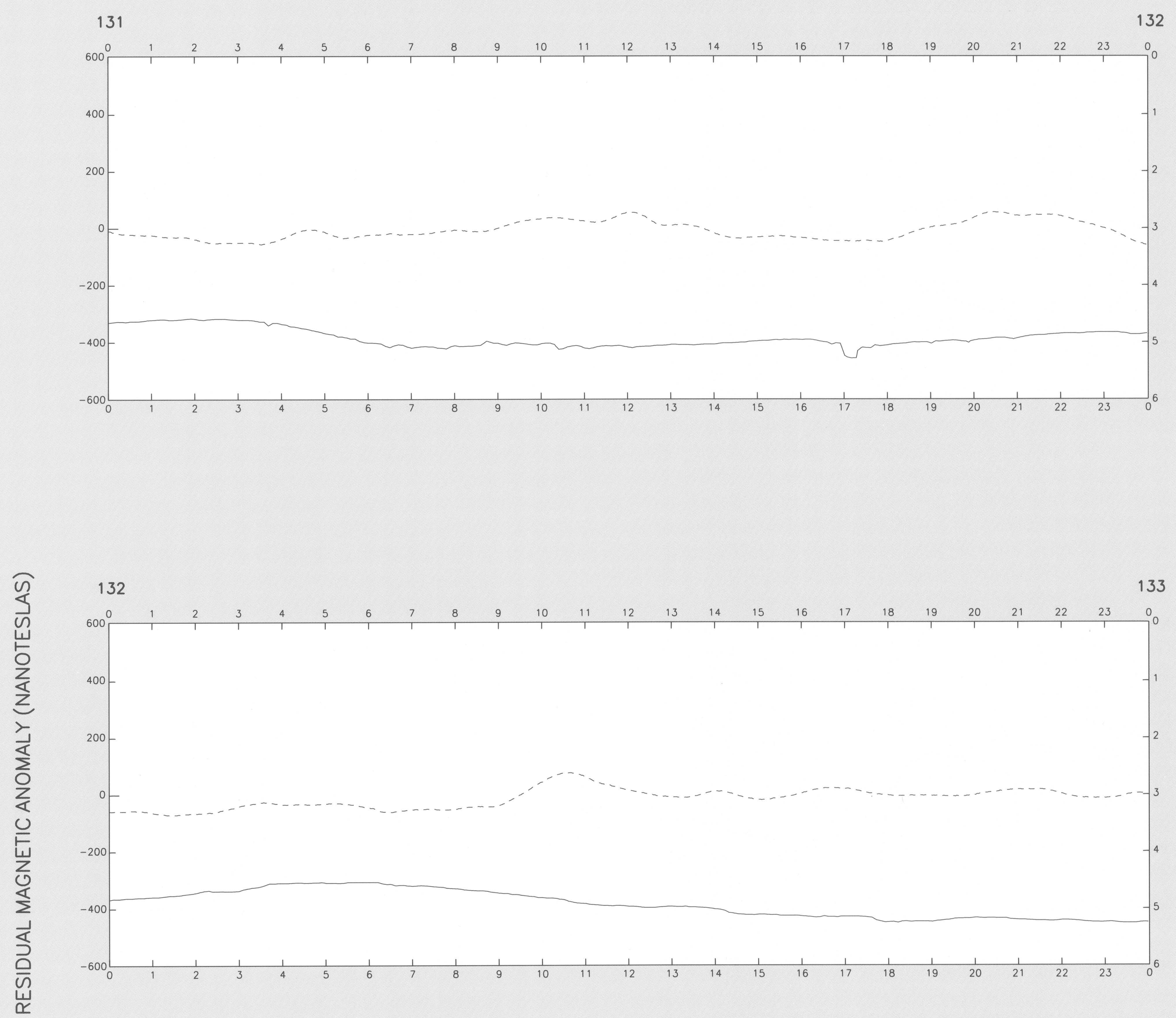

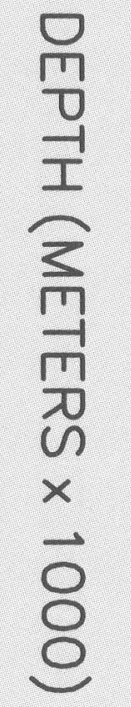

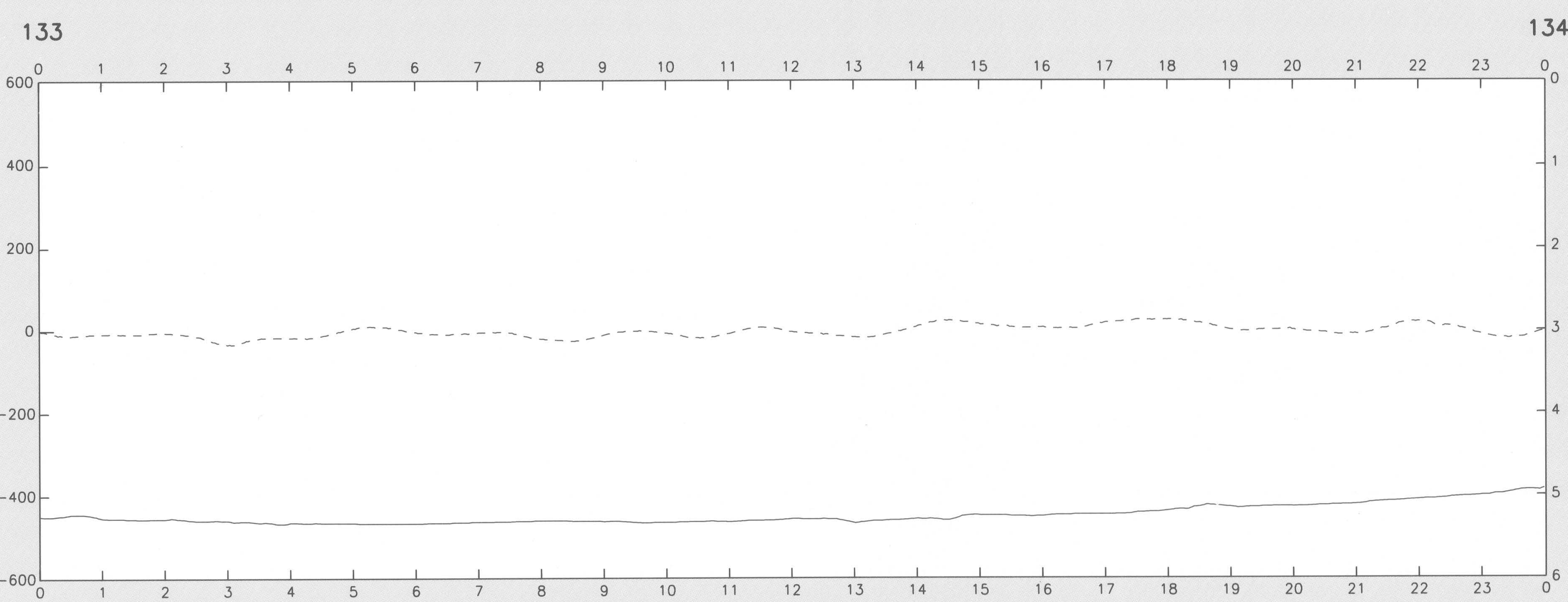




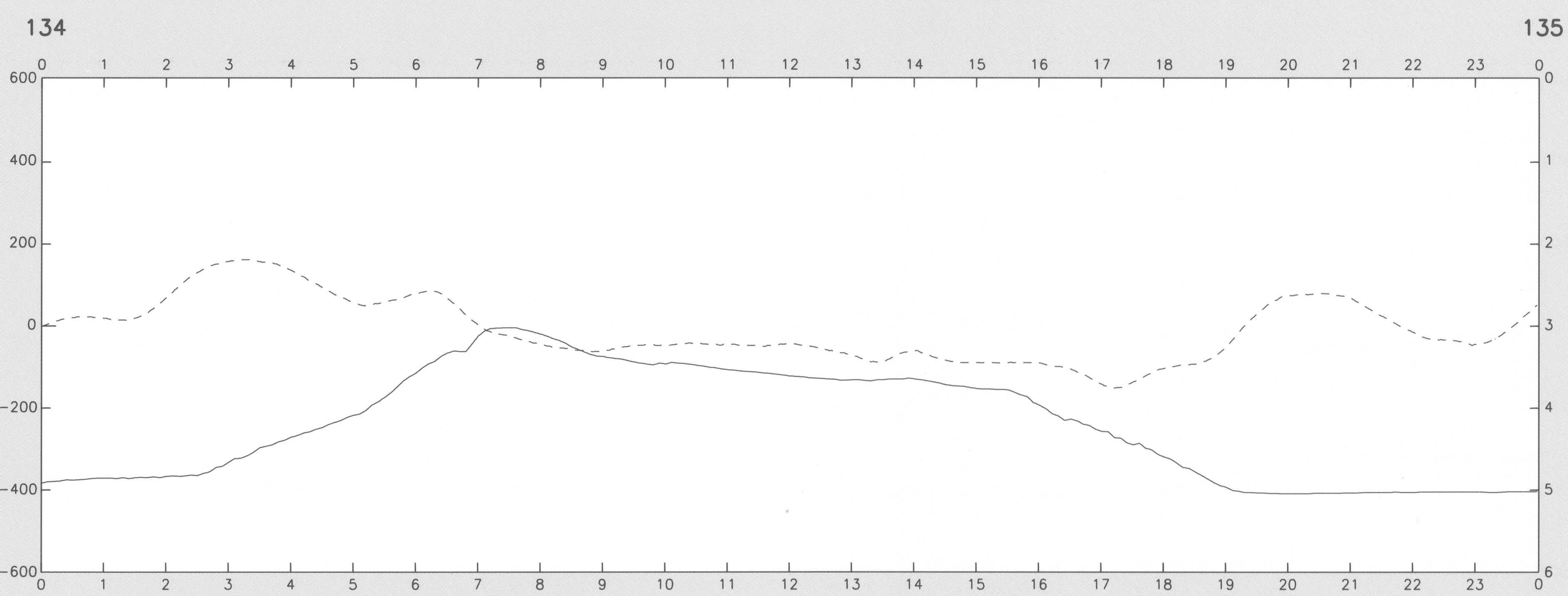

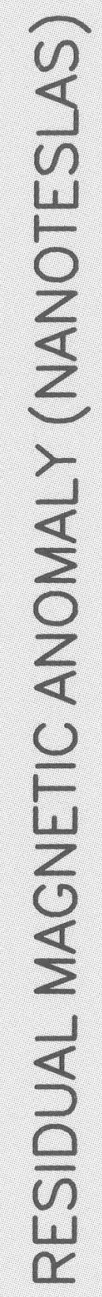

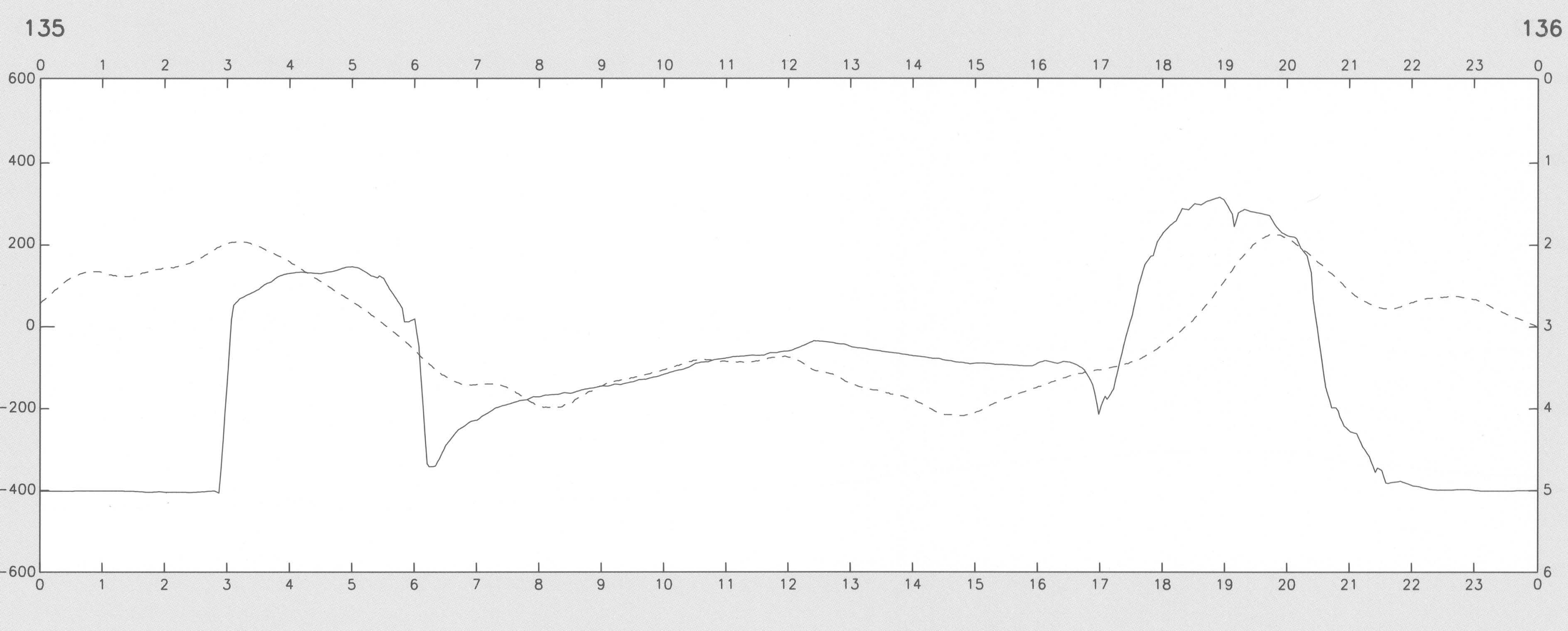

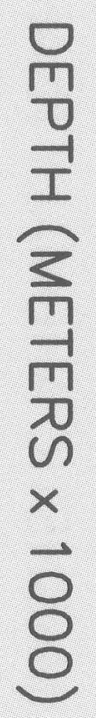

136

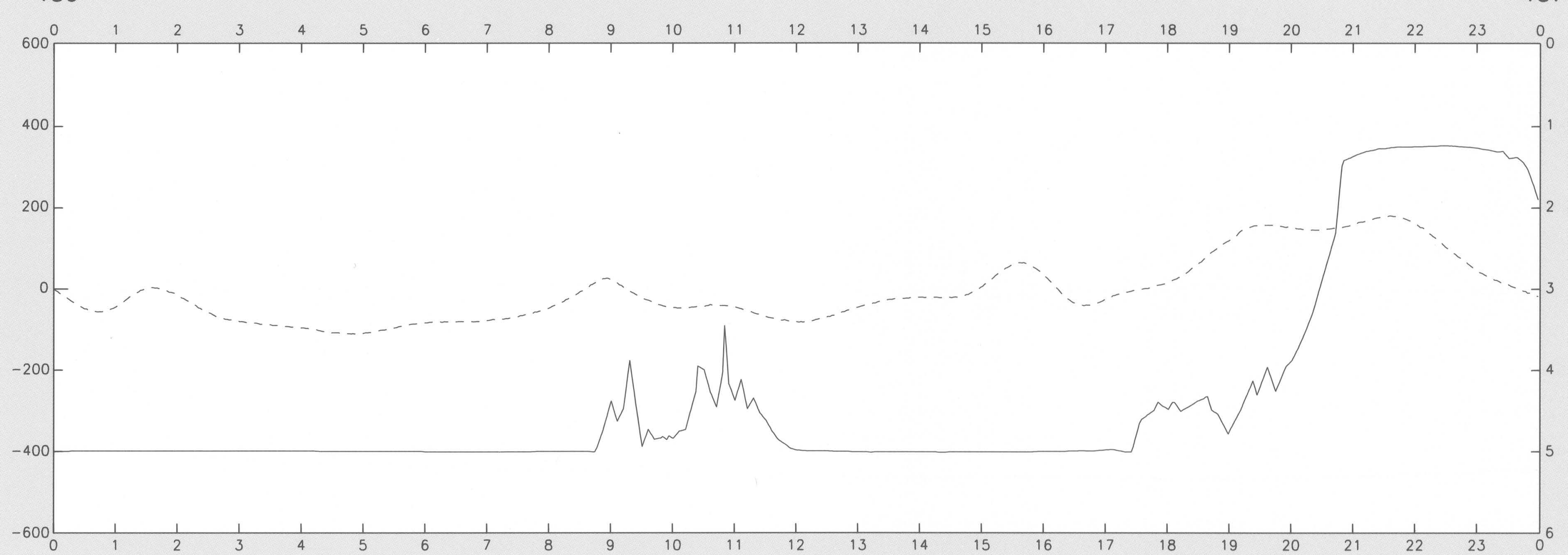

EXPLANATION 
DAY $137-140$

137
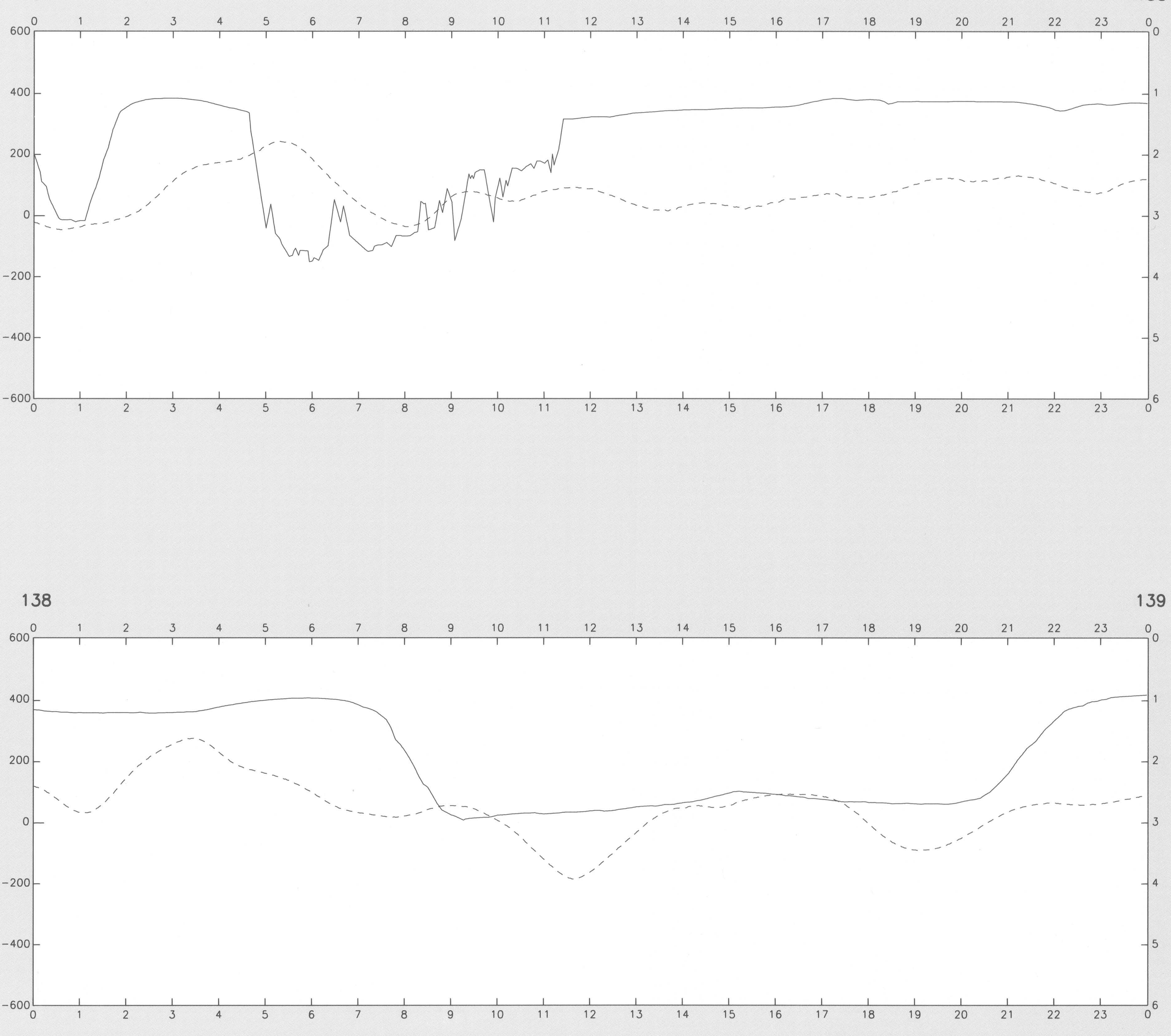

139

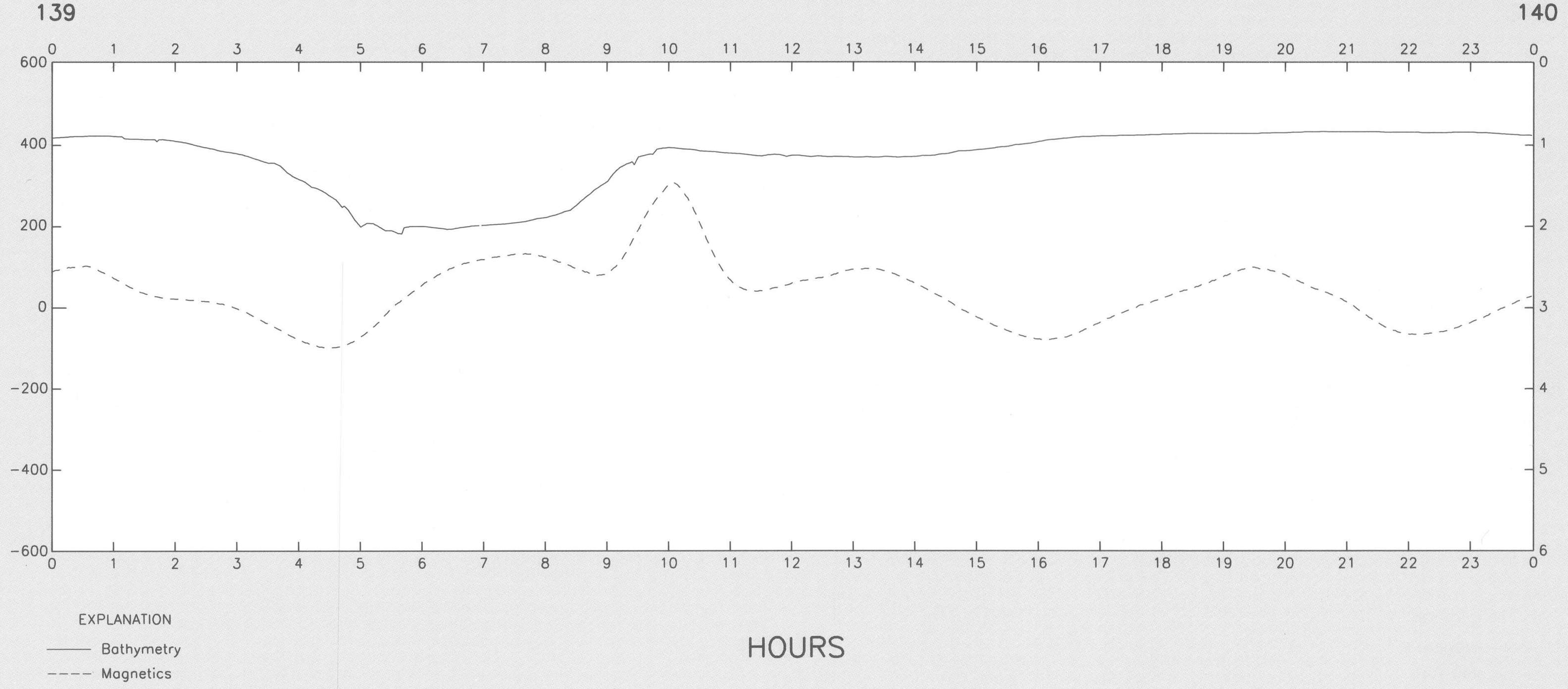


DAY $140-143$

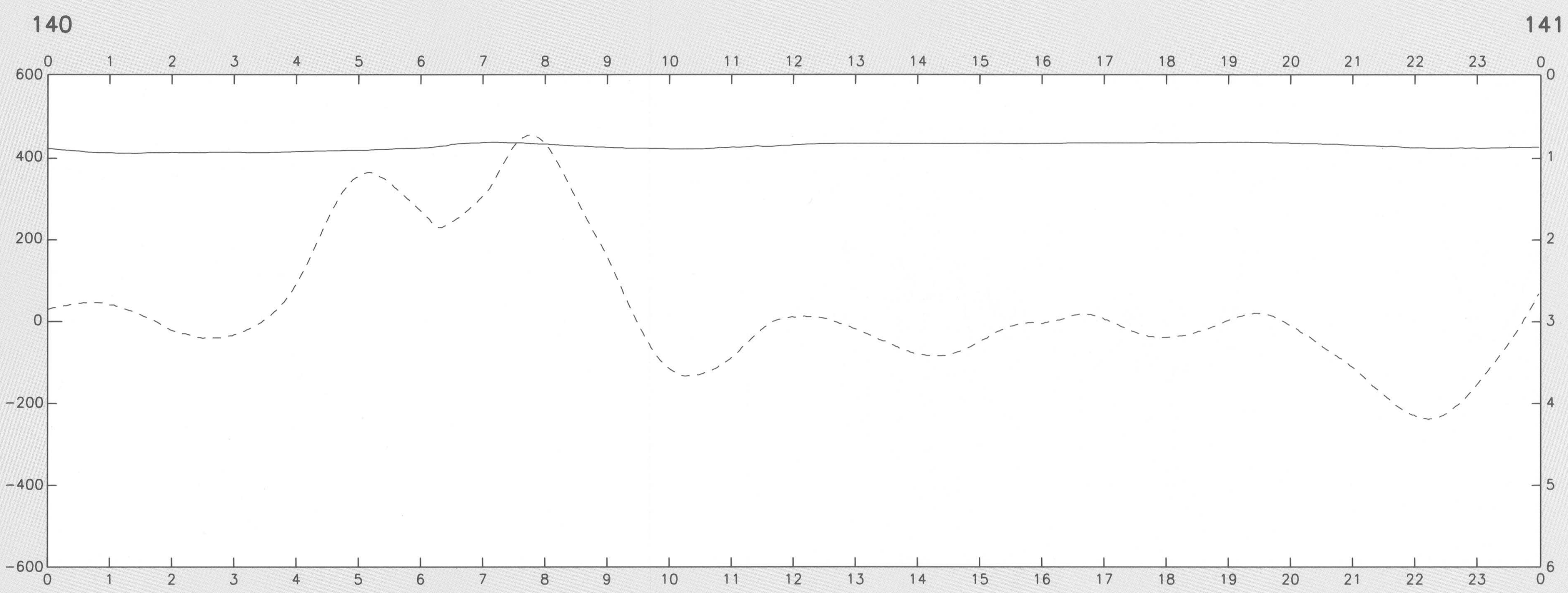

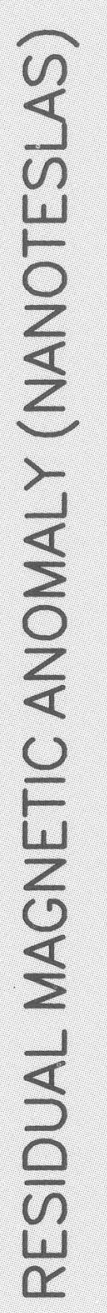
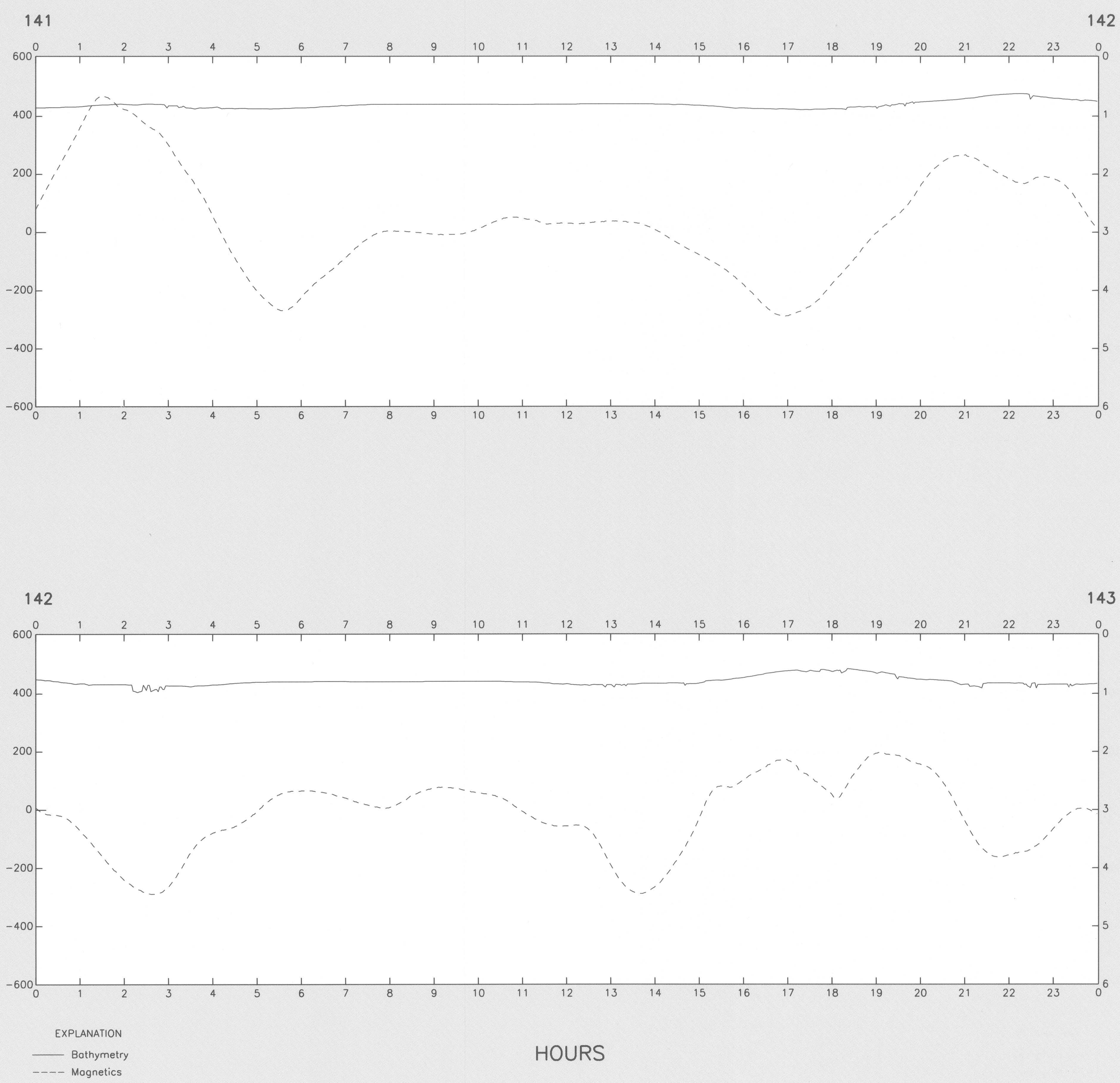
DAY $143-146$

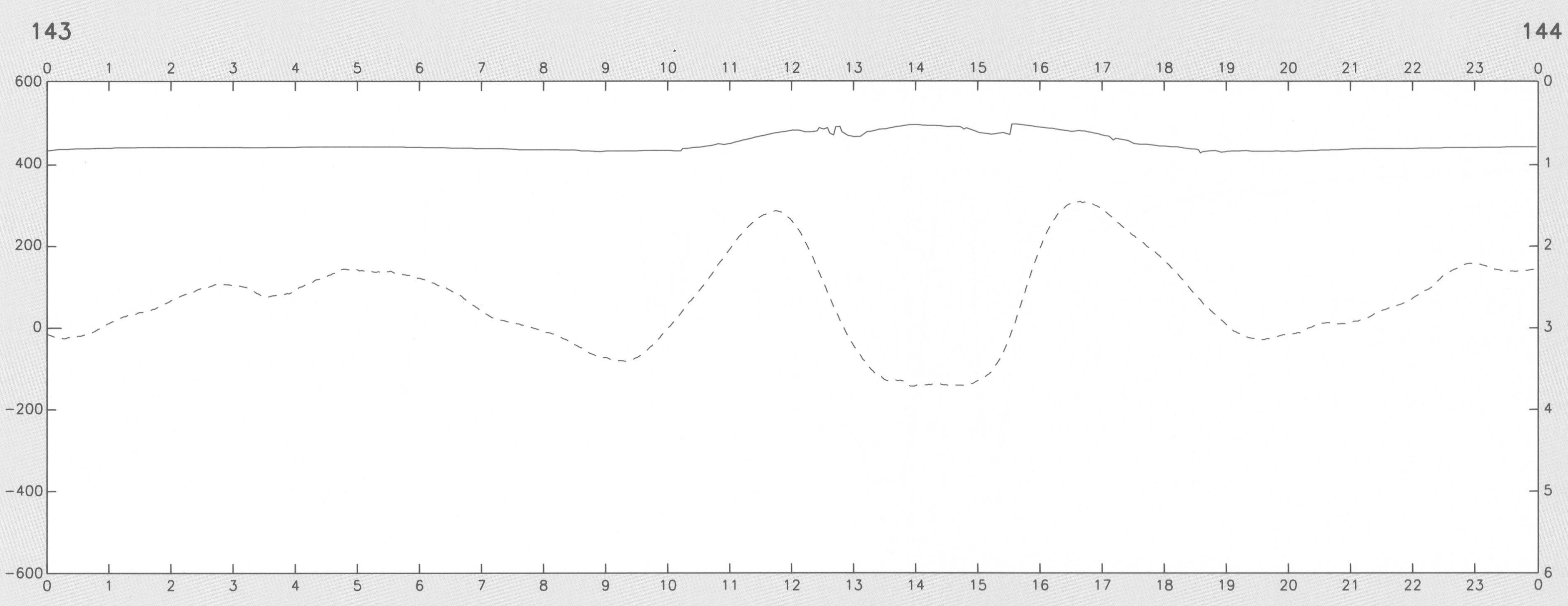

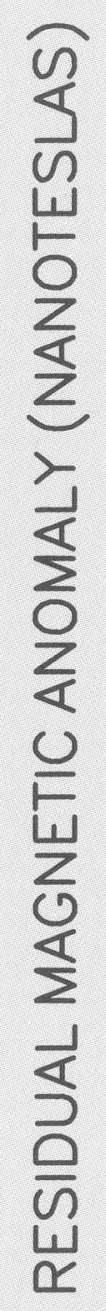

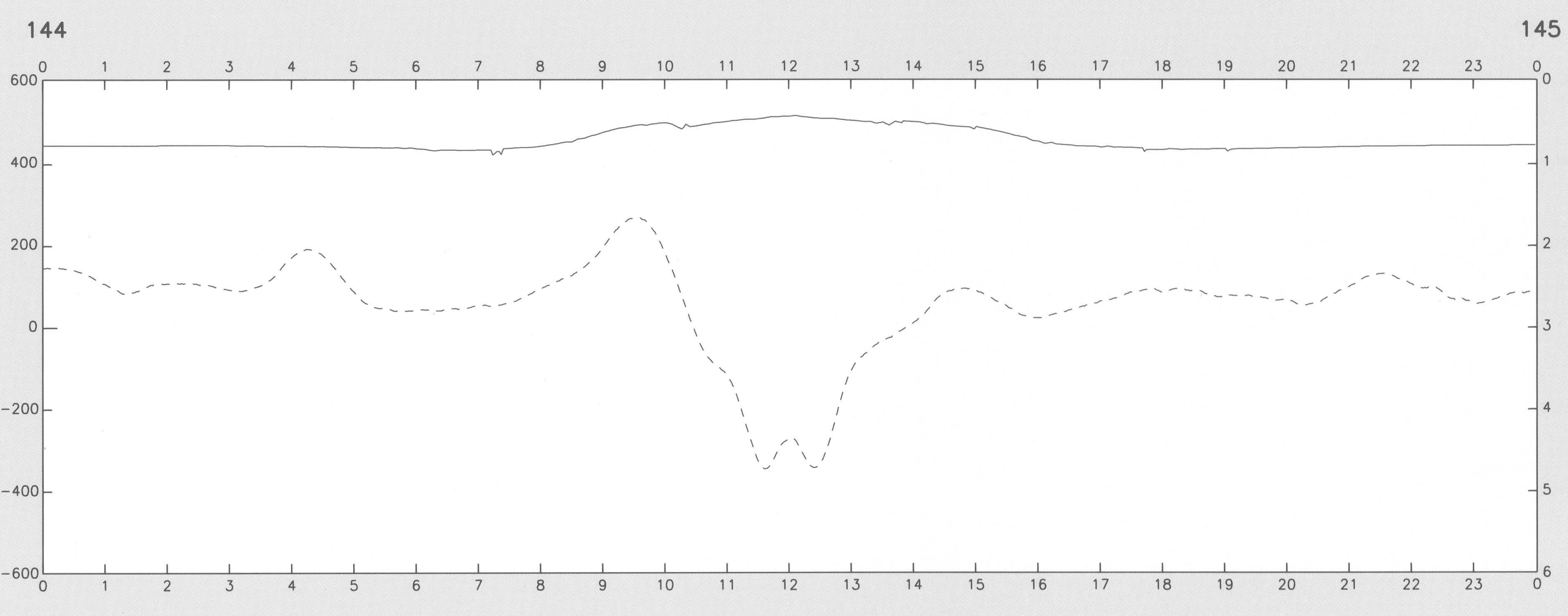

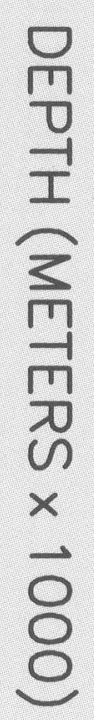

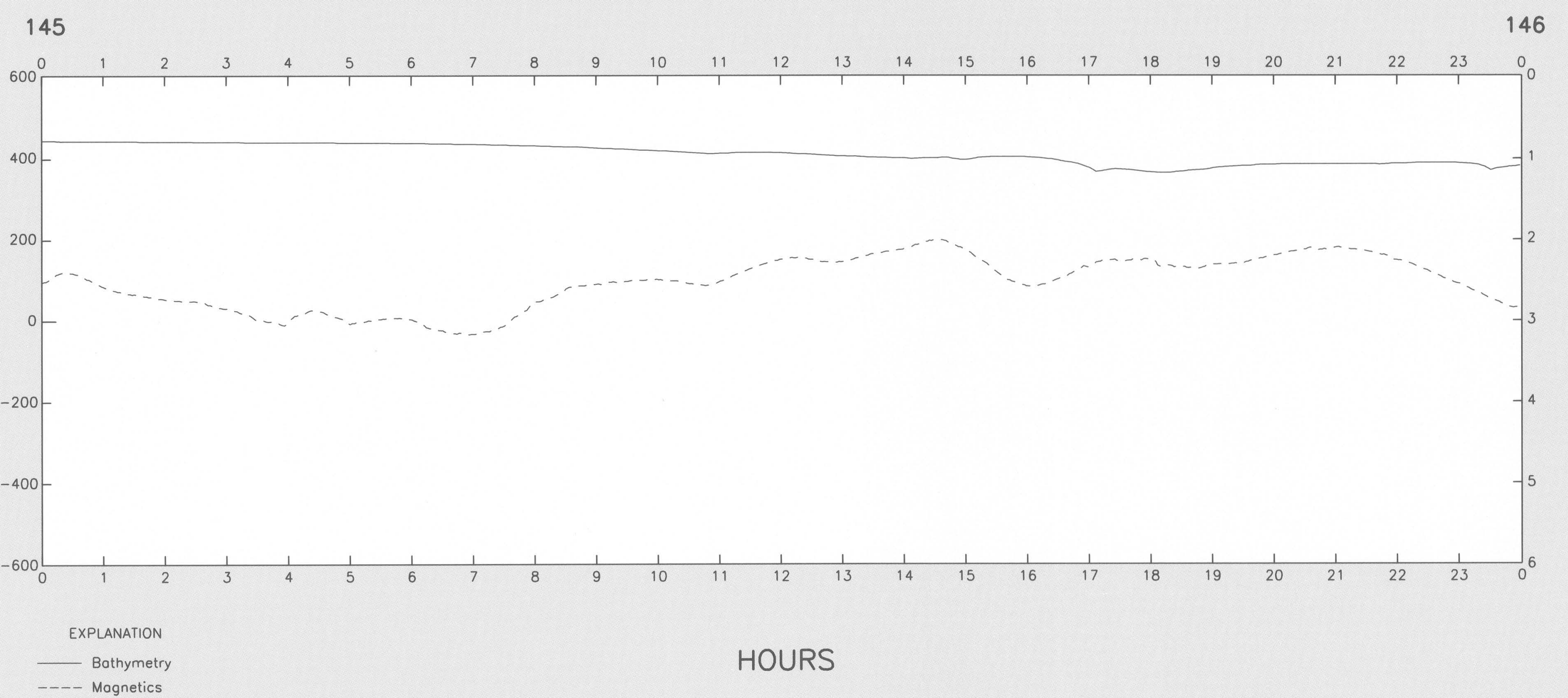




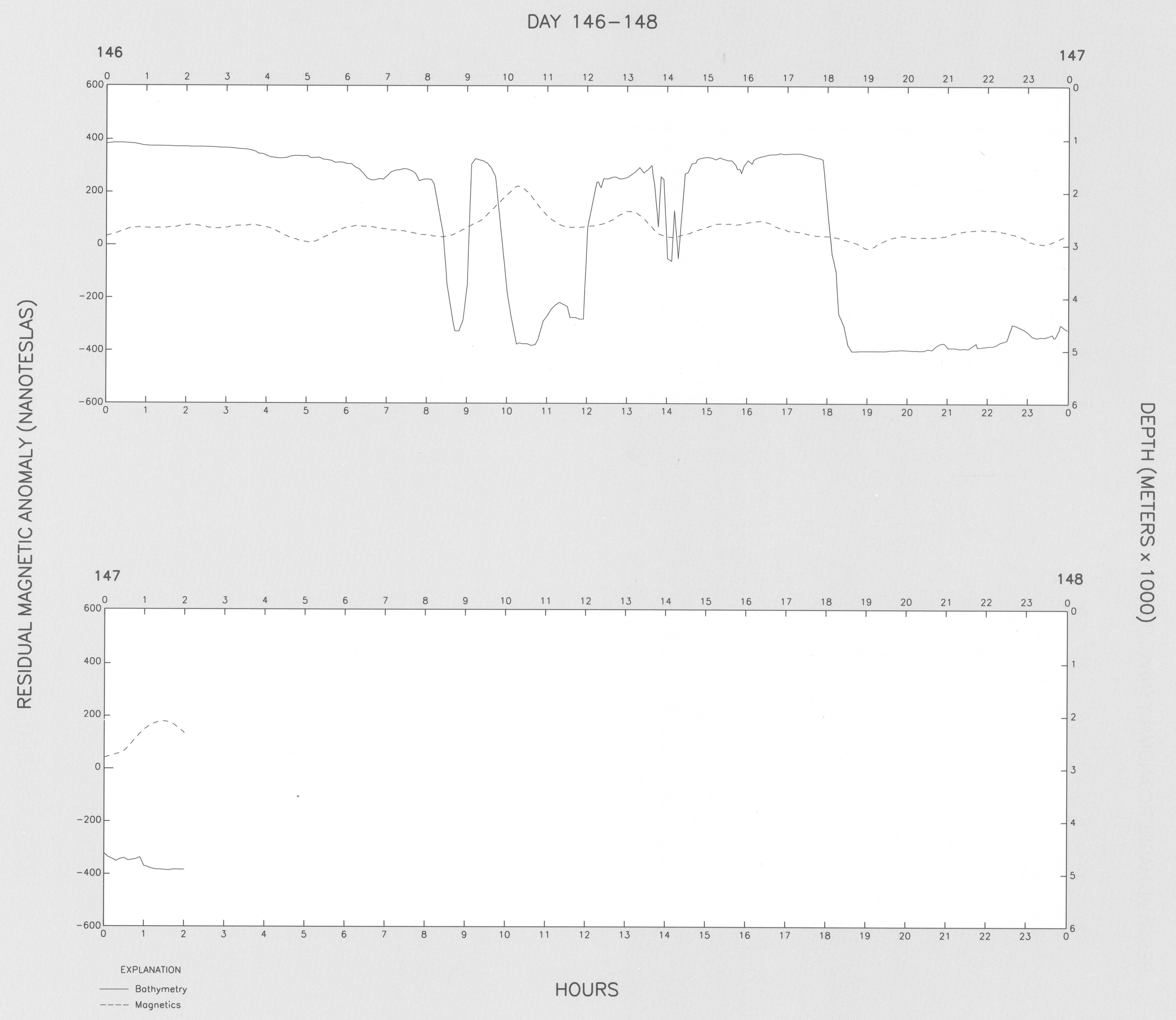

